MINISTRY OF EDUCATION AND SCIENCE OF UKRAINE KYIV NATIONAL UNIVERSITY OF TECHNOLOGIES AND DESIGN INTERNATIONAL SOCIETY OF ELECTROCHEMISTRY

\title{
PROMISING MATERIALS AND PROCESSES IN TECHNICAL ELECTROCHEMISTRY
}

Monograph

The Monograph was recommended for publication by the Scientific Council of Kyiv National University of Technologies \& Design 


\section{UDC 621.35(477) \\ BBC 24.57 \\ P26}

Monograph has been recommended by the Scientific Council of Kyiv National University of Technologies and Design (KNUTD) for the wide range of lectors, scientists, PhD students, holders of a master's degree and students of Universities, engineers and technicians of various electrochemical enterprises.

(Protocol No 8 of 27.04.2016)

\section{Editor's Board:}

V. Z. Barsukov - Prof.Dr., head of department for KNUTD, ISE member;.

Yu. V. Borysenko - PhD, senior lecturer for KNUTD;

O. I. Buket - PhD, senior lecturer for National Technical University of Ukraine "Kyiv Polytechnic Institute", ISE Regional representative for Ukraine;

V. G. Khomenko - PhD, Postdoc for KNUTD.

\section{Reviewers:}

O. V. Linyucheva - Prof.Dr., head of department for National Technical University of Ukraine "Kyiv Polytechnic Institute", ISE member;

O. A. Pud - Prof.Dr., head of department for Institute of Bioorganic Chemistry and Petrochemistry of the National Academy of Sciences of Ukraine, ISE member.

P26 Promising Materials and Processes in Technical Electrochemistry: Monograph / V.Z. Barsukov, Yu.V. Borysenko, O.I. Buket, V.G. Khomenko; editor-in-chief V.Z. Barsukov. Kyiv.: KNUTD, - 284 pages.

ISBN

The promising materials and processes have been considered in such directions of technical electrochemistry as electrochemical power sources, electroplating, corrosion protection, electrochemical sensors, modern electrochemical and related technologies. A state of art in these directions of electrochemistry determines substantially a progress in general development of science and technologies of $\mathrm{XXI}$ century and promotes to creation of essentially new types of production and technologies. Monograph has been recommended for scientists, lectors, PhD students, engineers and technicians.

\section{UDC 621.35(477)}

BBC 24.57

ISBN

(C) V. Z. Barsukov, Yu. V. Borysenko,

O. I. Buket, V. G. Khomenko, 2016

(C) KNUTD, 2016 


\section{МIНICTЕРСТВО ОСВІТИ I НАУКИ УКРАЇНИ \\ КИЇВСЬКИЙ НАЦІОНАЛЬНИЙ УНІВЕРСИТЕТ ТЕХНОЛОГІЙ ТА ДИЗАЙНУ \\ МІЖНАРОДНЕ ЕЛЕКТРОХІМІЧНЕ ТОВАРИСТВО}

\section{ПЕРСПЕКТИВНІ МАТЕРІАЛИ ТА ПРОЦЕСИ В ТЕХНІЧНІЙ ЕЛЕКТРОХІМІЇ}

Монографрія

\section{Рекомендовано Вченою радою}

Київського національного університету технологій та дизайну 


\section{УДК 621.35(477)}

\section{ББК 24.57}

П 26

Рекомендовано Вченою радою Київського національного університету технологій та дизайну для широкого кола викладачів, науковців, аспірантів, магістрів та студентів профрільних вищих навчальних закладів, інженерно-технічних працівників електрохімічних виробництв

(Протокол № 8 від 27.04.2016)

Колектив укладачів:

В. З. Барсуков - д-р хім. наук, проф., зав. кафедри КНУТД; член МЕТ; Ю. В. Борисенко - канд. техн. наук, доцент КНУТД;

О. А. Букет - канд. техн. наук, доцент НТУУ «КПІ», регіональний представник МЕТ від України;

В. Г. Хоменко - канд. теХн. наук, докторант КНУТД

\section{Рецензенти:}

О. В. Лінючева - д-р техн. наук, профр. зав. кафедри НТУУ «КПІ», член MET;

О. А. Пуд - д-р хім. наук, проф., зав. відділом ІБОНХ НАНУ, член МЕТ

П 26 Перспективні матеріали та процеси в технічній електрохімії: монограсрія / В. 3. Барсуков, Ю. В. Борисенко, О. А. Букет, В. Г. Хоменко; за заг. ред. В. 3. Барсукова. - К.: КНУТД, 2016. - 284 с.

ISBN

Розглянуті перспективні матеріали та процеси в таких напрямках розвитку технічної електрохімії, як електрохімічні джерела струму, гальванотехніка, захист від корозії, електрохімічні сенсори, сучасні електрохімічні та споріднені технології. Стан досліджень в цих напрямках електрохімії визначає в значній ступені прогрес в загальному розвитку науки і техніки XXI сторіччя і сприяє створенню суттєво нових типів продукції та технологій. Для викладачів, науковців, аспірантів, студентів профрільних ВНЗ, інженерно-технічних працівників електрохімічних виробництв.

УДК 621.35(477)

ББК 24.57

ISBN

(C) В. 3. Барсуков, Ю. В.Борисенко, О. А. Букет, В. Г. Хоменко, 2016

(C) КНУТД, 2016 


\section{CONTENT}

INTRODUCTION

15

COLLECTIVE MONOGRAPH AUTHORS

Part 1. ELECTROCHEMICAL POWER SOURCES

1.1 THE INFLUENCE OF GRAPHITE MATERIALS ON POWER PERFORMANCE OF LITHIUM-ION CAPACITORS

KHOMENKO V., BARSUKOV V., MAKYEYEVA I., CHERNYSH O.

1.2 THE EFFECT OF NANOPOROUS ELECTRODE COMPOSITION ON SUPERCAPACITOR PERFORMANCE DROBNYI D.

1.3 ELECTROCHEMICAL PROPERTIES OF $\mathrm{LiMn}_{2} \mathrm{O}_{4}$

SURFACE-MODIFIED WITH LiNi $0.5 \mathrm{Mn}_{1.5} \mathrm{O}_{4}$

POTAPENKO A.V.

1.4 COMPARATIVE ELECTROCHEMICAL CHARACTERISTICS OF

PURE AND ALUMINUM-DOPED LiMn $\mathrm{O}_{4}$ CATHODE MATERIALS FOR LITHIUM-ION BATTERIES

KOSILOV V.V., KRAVETS YU.A.

1.5 EFFECT OF THE ELECTROLYTE COMPOSITION ON THE ELECHTROCHEMICAL PROPERTIES OF BOTH NATURAL AND SYNTETIC GRAPHITE MATERIALS MODIEFIED BY 2Co(+3)$\mathrm{Ni}(+2)$ COMPLEXES WITH AMINOALCOHOLS ZUL'FIGAROV A.O., POTASKALOV V.A., ANDRIIKO A.A.

1.6 ELECTROLYTES FOR SUPERCAPACITORS BASED ON 48 DIMETHYL SULFOXIDE AND TETRAALKYLAMMONIUM SALTS MILOVANOVA O.I., GROMADSKYI D.G., PUSHIK O.B.

1.7 BINARY ELECTROLYTES FOR IMPROVING PYRITE CATHODE PERFORMANCE SIROSH V.A.

1.8 THE EFFECT OF TEPERATURE ON THE CHARACTERISTICS OF $\mathrm{MO}_{2} \mathrm{~S}_{3}$-ELECTRODE I ELECTROLYTE OF LiACCUMULATORS KIRSANOVA I.V., APOSTOLOVA R.D., BASKEVICH A.S.

1.9 THE EFFECT OF $\mathrm{TiO}_{2}$ OXIDE ON THE DISCHARGE CAPACITY OF FeS IN Li-ACCUMU-LATORS GLADUN V.A., APOSTOLOVA R.D., MARKEVICN A.V., SHEMBEL E.M. 
1.10 IMPROVEMENT OF FeS CHARACTERISTICS IN Li-

ACCUMULATORS BY ELECTROCHEMICAL CODEPOSITION WITH $\mathrm{SiO}_{2}$

MACIYEVSKYI N.A., APOSTOLOVA R.D., SAVCHENKO M.O., PIESKOV R.P., POLISCHUK YU.V.

1.11 HIGH-RATE LiMn ${ }_{2} \mathrm{O}_{4}$ CATHODE MATERIAL FOR Li-ION

BATTERIES SYNTHESIZED BY MICROWAVE-ASSISTED CITRATE METHOD

SHMATOK YU.V., POTAPENKO A.V.

$1.12 \mathrm{LiFePO}_{4}$ AS AN ELECTRODE MATERIAL FOR

LITHIUM-ION BATTERIES

MUKHIN V.V., SUSLOV M.M., POTAPENKO A.V.

1.13 QUANTUM-CHEMICAL MODELING THE MECHANISMS OF

OXYGEN REDUCTION REACTION FOR NON-PLATINUM

CATALYSTS

SENYK I.V., KHOMENKO V.G., KATASHINSKII A.S.,

BARSUKOV V.Z.

1.14 ELECTROCHEMICALLY $\mathrm{NH}_{4}{ }^{+}$-DOPED MANGANESE DIOXIDE WITH $\alpha-\mathrm{MnO}_{2}$ PHASE COMPONENT AS A PROSPECTIVE OXYGEN ELECTROREDUCTION ELECTRODE ZUDINA L.V., SOKOLSKY G.V., BOLDYREV E.I.

1.15 ELECTROCHEMICAL IMPEDANCE OF AN ALKALI Mn-Zn BATTERY AT VARIOUS TEMPERATURES

BOYCHUK A.V., POTAPENKO AI.V.

\section{Part 2. ELECTRODEPOSITION}

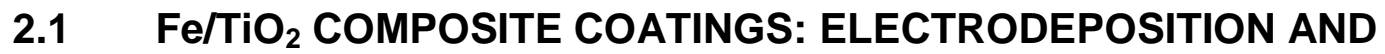
APPLICATION FOR PHOTO-CATALYTIC DYE DEGRADATION TSURKAN A.V., VASIL'EVA E.A., PROTSENKO V.S., DANILOV F.I.

2.2 HARD AND DECORATIVE NI-P COATINGS

ELECTRODEPOSITED FROM THE METHANESULFONATE ELECTROLYTE

ZHIGALOVA A.A., SKNAR Y.E., SKNAR I.V.

2.3 ELECTRODEPOSITION AND PROPERTIES OF NICKEL COATINGS AND FOIL REINFORCED WITH ALUMINA OVCHARENKO O. A., SAKHNENKO N. D., VED' M. V.

2.4 IONIZATION OF NICKEL IN NICKEL TARTRATE ELECTROLYTES

ANTSIKHOVICH I.V., CHERNIK A.A. 
2.5 GALVANOCHEMICAL FORMATION OF A MULTICOMPONENT

ALLOY BASED ON COBALT AND REFRACTORY METALS

HAPON YU.K., NENASTINA T.O., SAKHNENKO N.D., VED' M.V.

2.6 COMPOSITE COATINGS NICKEL - CARBON MATERIAL

COATINGS

BERVICKAJA O. S., POLISHCHUK YU.V.

Part 3. CORROSION PROTECTION

3.1 CORROSION-ELECTROCHEMICAL PROPERTIES OF COBALT-

MOLYBDENUM-ZIRCONIUM DEPOSITS

KOZIAR M. A., SLAVKOVA M. A., SAKHNENKO N. D., VED' M. V.

3.2 CORROSION RESISTANCE COMPARISON OF CONVERSION

COATINGS IN SALT FOG CHAMBER

AKULICH N.E., CHERNIK A.A., LOS A.I.

3.3 CORROSION PROTECTION OF AMC ALLOY IN ALKALINE

MEDIUMS BY SODIUM ORTHOVANADATE

KHARITONOV D.S., KURILO I.I., ZHARSKY I.M.

3.4 ELECTROCHEMICAL BEHAVIOR OF THE Fe/Fe ${ }_{3} \mathrm{O}_{4} / \mathrm{C} / \mathrm{NaCl}$

SYSTEM. KRAVCHENKO O.V., PERSHINA K.D.

3.5 MODELING A MECHANISM FOR INHIBITING ACID CORROSION OF STEEL BY MULTIFUNCTIONAL PYRIDINE SALTS WITH CARBONYL GROUPS

POGREBOVA I.S., PILIPENKO T.N., KOTSIUBA E.S.

3.6 INFLUENCE OF THE STATE OF THE B1341T ALUMINIUM 152 ALLOY OF THE AI - Mg - Cu - Si SYSTEM ON RESISTANCE AGAINST INTERGRANULAR CORROSION NURIACHMETOVA M.M., NYRKOVA L.I., LABUR T.M., BORYSENKO YU.V.

3.7 DEVELOPMENT OF METHODS FOR THE FORMATION OF PASSIVATION LAYERS ON ALUMINUM AND ITS ALLOYS KLIMOVA E.A.,KESHIN A.V., CHERNIK A.A., ZHYILINSKI V.V.

\section{Part 4. ELECTROCHEMICAL SENSORS}

4.1 CATHODIC REDUCTION OF NITROGEN DIOXIDE BY MEDIATOR CATALYSIS

POLYANICHKO O.O., BUKET O.I.

4.2 THE EFFECT OF THE NUMBER OF ELECTRODE COUPLES ON THE SENSITIVITY OF ELECTROCHEMICAL SENSORS OF ATMOSPHERIC CORROSION RATE OSADCHUK S.A., NYRKOVA L.I., MELNICHUK S.L. 
4.3 CHLORINE EMISSION MONITORING IN THE COPPER

ELECTROWINNING PROCESS FROM LEACH SOLUTIONS OF

CARBONATE ORES

USHCHAPOVSKYI D.YU., LINYUICHEV O.G., TSYMBALIUK A.S.

4.4 A CARBON DIOXIDE GENERATOR FOR CALIBRATION OF ELECTROCHEMICAL SENSORS

MATVEEV O.M., MAZANKA V.M., KOSOHIN O.V.

4.5 ELECTROCHEMICAL FORMATION OF ORDERED

182

STRUCTURES OF ALUMINUM OXIDE FOR THE ELECTRONIC INDUSTRY

EGOROVA YU.A., CHERNIK A.A., ZHARSKIY I.M.

4.6 THE CHEMICAL SYNTHESIS OF NANOSTRUCTURED SYSTEMS WITH CHEMOSENSITIVITY PROPERTIES

PYANKO A.V., ZHYLINSKI V.V., GOROH G.G.

4.7 ELECTROCHEMICAL FORMATION OF NANOSTRUCTURED ALUMINUM COATING

PISMENSKAYA A.S., CHERNIK A.A., ZHYLINSKI V.V.,

BOGOMAZOVA N. V.

Part 5. MODERN ELECTROCHEMICAL AND RELATED

193

TECHNOLOGIES

5.1 ANODIC GROWTH OF NANOPOROUS TIN OXIDE LAYERS IN ACIDIC ELECTROLYTES.

ZARASKA L., GAWLAK K., KRZYSIK A., JASKUŁA M.

5.2 THE INFLUENCE OF IONIC DOPANTS ON INITIAL STAGES OF

LEAD DIOXIDE ELECTROCRYSTALLI-ZATION

SHMYCHKOVA O., LUK'YANENKO T., VELICHENKO A.

5.3 THE EFFECT OF WATER ADDITION ON PHYSICOCHEMICAL PROPERTIES OF ELECTROCHEMICAL SYSTEMS BASED ON DEEP EUTECTIC SOLVENTS

BOBROVA L.S., SHAIDEROV D.A., KITYK A.A., PROTSENKO V.S., DANILOV F.I.

5.4 THE KINETICS OF WATER TRANSFER THROUGH CATION EXCHANGE MEMBRANES

B. PAVLOV, G. TULSKIY

5.5 WHEY ELECTRODIALYSIS USING ORGANIC-INORGANIC MEMBRANES

ZMIEVSKII YU.G., ROZHDESTVENSKA L.M., ZAKHAROV V.V., DZYAZKO YU.S., MYRONCHUK V.G. 

COMPOSITES WITH COPPER NANORODS ADDITIVES

SHPAK YU.V, DRAGAN D.R., SENYK I.V., BARSUKOV V.Z.

5.7 SMART WINDOWS: CATION INTERNAL AND ANION EXTERNAL ACTIVATION FOR ELECTROCHROMIC FILMS OF NICKEL

HYDROXIDE KOTOK V.A., MALAHOVA E.V. , KOVALENKO V.L., BARAMZIN M.N., KOVALENKO P.V.

5.8 GAS BUBBLE SIZE PREDICTION IN CONCENTRATED

ALKALINE SOLUTIONS USING THE THEORY OF PLANAR NUCLEUS

ATAPIN A.G., NEFEDOV V.G.

5.9 THE EFFECT OF DEHYDRATION OF MANGANESE NITRATE ON

THE QUALITY OF MANGANESE DIOXIDE COATING ON TITANIUM ANODES

BUTENKO O.S., BUKET O.I.

5.10 ELECTROLYTE EFFECT ON THE LECTROCHEMICAL PROPERTIES OF POLY(3-METHYLTHIOPHENE) THIN FILMS KOZLOVA T.B., MOTRONYUK T.I., SYDOROV D.O.

5.11 KINETICS OF ANODIC PROCESSES IN ACETIC ACID 245

SOLUTIONS BILOUS T.A., TULSKY G.G.

5.12 ELECTROCHEMICAL DISINFECTION OF WATER WITH A NATURAL CONTENT OF SALTS

E.B.BASHMAKOV, V.B.BAYRACHNYI, DIAB HASSAN

5.13 ELECTROCATALYTIC ACTIVITY OF COMPOSITE MATERIALS $\mathrm{PbO}_{2}-\mathrm{TiO}_{2}$ DEPOSITED FROM SUSPENSION ELECTROLYTES KNYSH V.A., VELICHENKO A. B.

5.14 USING ELECTROCHEMICAL METHODS FOR DETERMINING 260 THE DEGREE OF DEACETYLATION OF CHITOSAN SLIS A.A., REDKA K.V., SOLODOVNIK T.V.

5.15 THE INFLUENCE OF CONDUCTIVE FILLERS ON PROPERTIES OF POLYETHYLENE-BASED COMPOSITIONS KURIPTYA Y., NOVAK D., SAVCHENKO B., PLAVAN V.

5.16 BIOIMPEDANCE ANALYSIS OF THE HUMAN BODY: HISTORY, 270 CLASSIFICATION , BIOPHYSICAL FUNDAMENTALS OF THE METHOD.

CHEREVACH Ya.F., BORYSENKO Yu.V.

5.17 BIOELECTRIC POTENTIALS: MECHANISMS OF EMERGENCE AND FUNCTIONING; BIOLOGICAL ROLE PATLUN D.V., KISLOVA O.V. 
3MICT

ВСТУП

АВТОРИ КОЛЕКТИВНЇ МОНОГРАФІЇ

Розділ 1. ХІМІЧНІ ДЖЕРЕЛА СТРУМУ

1.1 ВПЛИВ ГРАФІТОВИХ МАТЕРІАЛІВ НА ЕЛЕКТРИЧНІ

ХАРАКТЕРИСТИКИ ЛІТІЙ-ІОННИХ КОНДЕНСАТОРІВ

ХОМЕНКО В.Г., БАРСУКОВ В.З., МАКЄЄВА І.С., ЧЕРНИШ О.В.

1.2 ВПЛИВ СКЛАДУ НАНОПОРИСТИХ ЕЛЕКТРОДІВ НА ХАРАКТЕРИСТИКИ СУПЕРКОНДЕНСАТОРІВ ДРОБНИЙ Д.М.

1.3 ЕЛЕКТРОХІМІЧНІ ВЛАСТИВОСТІ $\mathrm{LiMn}_{2} \mathrm{O}_{4}$, ПОВЕРХНЕВОМОДИФІКОВАНОГО LiNi ${ }_{0.5} \mathrm{Mn}_{1.5} \mathrm{O}_{4}$ ПОТАПЕНКО Г.В.

1.4 ПОРІВНЯННЯ ЕЛЕКТРОХІМІЧНИХ ХАРАКТЕРИСТИК ЧИСТОГО ТА ДОПОВАНОГО АЛЮМІНІЕМ КАТОДНОГО МАТЕРІАЛУ LiMn ${ }_{2} \mathrm{O}_{4}$ ДЛЯ ЛІТІЙ-ІОННИХ ДЖЕРЕЛ СТРУМУ КОСІЛОВ В. В., КРАВЕЦЬ Ю.А.

1.5 ВПЛИВ СКЛАДУ ЕЛЕКТРОЛІТУ НА ЕЛЕКТРОХІМІЧНІ

ВЛАСТИВОСТІ ПРИРОДНИХ ТА СИНТЕТИЧНИХ ГРАФІТОВИХ МАТЕРІАЛІВ, МОДИФІКОВАНИХ КОМПЛЕКСАМИ 2СО(+3)$\mathrm{Ni}(+2) 3$ AMIHОСПИРТАМИ ЗУЛЬФІГАРОВ А.О., ПОТАСКАЛОВ В.А., АНДРІЙКО О.О.

1.6 ЕЛЕКТРОЛІТИ ДЛЯ СУПЕРКОНДЕНСАТОРІВ НА ОСНОВІ ДИМЕТИЛСУЛЬФОКСИДУ ТА ТЕТРААЛКІЛ-АМОНІЄВИХ СОЛЕЙ

МІЛОВАНОВА О.І., ГРОМАДСЬКИЙ Д.Г., ПУШИК О.Б.

1.7 БІНАРНІ ЕЛЕКТРОЛІТИ ДЛЯ ПІДВИЩЕННЯ

ПРОДУКТИВНОСТІ ПІРИТОВОГО КАТОДУ

CIPOШ B.A.

1.8 ХАРАКТЕРИСТИКИ $\mathrm{MO}_{2} \mathrm{~S}_{3}$ ЕЛЕКТРОД / ЕЛЕКТРОЛІТ Li -АКУМУЛЯТОРА В ЗАЛЕЖНОСТІ ВІД ТЕМПЕРАТУРИ КІРСАНОВА І.В., АПОСТОЛОВА Р.Д., БАСКЕВИЧ О.С.

1.9 ВПЛИВ $\mathrm{TiO}_{2}$ НА ПІДВИЩЕННЯ РОЗРЯДНОЇ ЄMНОСТІ FeS У ЛІТІЄВОМУ АКУМУЛЯТОРІ ГЛАДУН В.А., АПОСТОЛОВА Р.Д., МАРКЕВИЧ О.В., ШЕМБЕЛЬ О.М.

1.10 ПОЛІПШЕННЯ ХАРАКТЕРИСТИК FeS B Li-AKУМУЛЯ-TOPI ЕЛЕКТРОХІМІЧНИМ СПІВОСАДЖЕННЯМ $3 \mathrm{SiO}_{2}$ МАЦІЄВСЬКИЙ Н.А., АПОСТОЛОВА Р.Д. , САВЧЕНКО М.О., ПЕСКОВ Р.П., ПОЛІЩУК Ю.В. 
1.11 СИНТЕЗОВАНИЙ МІКРОХВИЛЬОВИМ ЦИТРАТНИМ

МЕТОДОМ LiMn ${ }_{2} \mathrm{O}_{4}$ ЯК КАТОДНИЙ МАТЕРІАЛ ДЛЯ ЛІА

ВИСОКОЇ ПОТУЖНОСТІ ШМАТОК Ю.В., ПОТАПЕНКО Г.В.

1.12 LiFePO $_{4}$ ЯК ЕЛЕКТРОДНИЙ МАТЕРІАЛ ДЛЯ ЛІТІЙ-ІОННИХ ДЖЕРЕЛ СТРУМУ

МУХІН В.В., СУСЛОВ М.М., ПОТАПЕНКО Г.В.

1.13 КВАНТОВО-ХІМІЧНЕ МОДЕЛЮВАННЯ МЕХАНІЗМІВ РЕАКЦІЙ ВІДНОВЛЕННЯ КИСНЮ НА НЕПЛАТИНОВИХ

КАТАЛІЗАТОРАХ СЕНИК І.В., ХОМЕНКО В.Г., КАТАШИНСЬКИЙ А.С., БАРСУКОВ В.3.

1.14 ЕЛЕКТРОХІМІЧНО $\mathrm{NH}_{4}^{+}$-ДОПОВАНИЙ МАНГАН (IV) ОКСИД 3 $\alpha-\mathrm{MnO}_{2}$ ФАЗОВОЮ КОМПОНЕНТОЮ ЯК ПЕРСПЕКТИВНИЙ ЕЛЕКТРОД ЕЛЕКТРОВІДНОВЛЕННЯ КИСНЮ

ЗУДІНА Л.В., СОКОЛЬСЬКИЙ Г.В., БОЛДИРЄВ Є.І.

1.15 ЕЛЕКТРОХІМІЧНИЙ ІМПЕДАНС ЛУЖНОГО Mn-Zn ЕЛЕМЕНТА ПРИ РІЗНИХ ТЕМПЕРАТУРАХ

БОЙЧУК О.В., ПОТАПЕНКО О.В.

\section{Розділ 2. ГАЛЬВАНОТЕХНІКА}

$2.1 \mathrm{Fe} \mathrm{TiO}_{2}$ КОМПОЗИЦІЙНІ ПОКРИТТЯ: ЕЛЕКТРО-ОСАДЖЕННЯ ТА ВИКОРИСТАННЯ ДЛЯ ФОТО-КАТАЛІТИЧНОГО РОЗКЛАДАННЯ БАРВНИКІВ ЦУРКАН А.В., ВАСИЛЬЄВА О.О., ПРОЦЕНКО В.С., ДАНИЛОВ $\Phi . \breve{.}$.

2.2 ТВЕРДІ ТА ДЕКОРАТИВНІ ПОКРИТТЯ Ni-P, ЕЛЕКТРООСАДЖЕНІ ІЗ МЕТИЛСУЛЬФОНАТНОГО ЕЛЕКТРОЛІТУ

ЖИГАЛОВА О.О., СКНАР Ю.Є., СКНАР І.В.

2.3 ЕЛЕКТРООСАДЖЕННЯ ТА ВЛАСТИВОСТІ НІКЕЛЕВИХ ПОКРИВІВ І ФОЛЬГ, АРМОВАНИХ ОКСИДОМ АЛЮМІНІЮ ОВЧАРЕНКО О.О., САХНЕНКО М.Д., ВЕДЬ М.В.

2.4 ІОНІЗАЦІЯ НІКЕЛЮ В ТАРТРАТНИХ ЕЛЕКТРОЛІТАХ НІКЕЛЮВАННЯ

АНТІХОВИЧ І.В., ЧЕРНІК О.О.

2.5 ГАЛЬВАНОХІМІЧНЕ ФОРМУВАННЯ БАГАТОКОМПО-

НЕНТНОГО СПЛАВУ НА ОСНОВІ КОБАЛЬТА ТА

ТУГОПЛАВКИХ МЕТАЛІВ. ГАПОН Ю.К., НЕНАСТІНА Т.О., САХНЕНКО М.Д., ВЕДЬ М.В.

2.6 КОМПОЗИЦІЙНІ ПОКРИТТЯ НІКЕЛЬ - ВУГЛЕЦЕВИЙ МАТЕРІАЛ БЕРВИЦЬКА О.С., ПОЛІЩУК Ю.В. 
3.1 КОРОЗІЙНО-ЕЛЕКТРОХІМІЧНІ ВЛАСТИВОСТІ ПОКРИТТІВ

КОБАЛЬТ-МОЛІБДЕН-ЦИРКОНІЙ

КОЗЯР М. О., СЛАВКОВА М. О., САХНЕНКО М. Д, ВЕДЬ М. В.

3.2 ПОРІВНЯННЯ КОРОЗІЙНОЇ СТІЙКОСТІ КОНВЕРСІЙНИХ

ПОКРИТТІВ У КАМЕРІ СОЛЬОВОГО ТУМАНУ

АКУЛІЧ Н.Є., ЧЕРНІК О.О., ЛОСЬ А. І.

3.3 АНТИКОРОЗІЙНИЙ ЗАХИСТ СПЛАВУ АМЦ У ЛУЖНИХ

СЕРЕДОВИЩАХ ОРТОВАНАДАТОМ НАТРІЮ

ХАРИТОНОВ Д.С., КУРИЛО І.І., ЖАРСЬКИЙ І.М.

3.4 ЕЛЕКТРОХІМІЧНА ПОВЕДІНКА СИСТЕМИ $\mathrm{Fe} / \mathrm{Fe}_{3} \mathrm{O}_{4} / \mathrm{C} / \mathrm{NaCl}$.

КРАВЧЕНКО О.В., ПЕРШИНА К.Д.

3.5 МОДЕЛЮВАННЯ МЕХАНІЗМУ ІНГІБУВАННЯ КИСЛОТ-НОЇ

КОРОЗІЇ СТАЛЕЙ ПОЛІФУНКЦІОНАЛЬНИМИ

ПІРИДИНОВИМИ СОЛЯМИ 3 КАРБОНІЛВМІСНИМИ ГРУПАМИ

ПОГРЕБОВА І.С., ПИЛИПЕНКО Т.Н., КОЦЮБА О.С.

3.6 ВПЛИВ СТАНУ АЛЮМІНІЄВОГО СПЛАВУ В1341Т СИСТЕМИ Al-Mg-Cu-Si HA CTІЙКІСТЬ ПРОТИ МІЖКРИСТАЛІТНОÏ KOPO3III

НУРІАХМЕТОВА М.М., НИРКОВА Л.І., ЛАБУР Т.М., БОРИСЕНКО Ю.В.

3.7 РОЗРОБКА МЕТОДИКИ НАНЕСЕННЯ ПАСИВАЦІЙНИХ ШАРІВ НА АЛЮМИНІЙ ТА ЙОГО СПЛАВИ

КЛІМОВА О.А., КЕШИН А.В., ЧЕРНІК О.О., ЖИЛІНСЬКИЙ В.В.

\section{PоздіЛ 4. ЕЛЕКТРОХІМІЧНI СЕНСОРИ}

4.1 МЕДІАТОРНИЙ КАТАЛІЗ КАТОДНОГО ВІДНОВЛЕННЯ ДІОКСИДУ АЗОТУ

ПОЛЯНІЧКО О.О., БУКЕТ О.І.

4.2 ВПЛИВ КІЛЬКОСТІ ЕЛЕКТРОДНИХ ПАР НА ЧУТЛИВІСТЬ ЕЛЕКТРОХІМІЧНИХ ДАТЧИКІВ ШВИДКОСТІ АТМОСФЕРНОÏ KOPO3IÏ

ОСАДЧУК С.О., НИРКОВА Л.І., МЕЛЬНИЧУК С.Л.

4.3 МОНІТОРИНГ ВИКИДІВ ХЛОРУ ПРИ

ЕЛЕКТРОЕКСТРАКЦІЙНОМУ ОТРИМАННІ МІДІ 3 РОЗЧИНІВ ВИЛУГОВУВАННЯ КАРБОНАТНИХ РУД

УЩАПОВСЬКИЙ Д.Ю., ЛІНЮЧЕВ О.Г., ЦИМБАЛЮК А.С. 
4.4 ГЕНЕРАТОР ДІОКСИДУ ВУГЛЕЦЮ ДЛЯ КАЛІБРУВАННЯ

ЕЛЕКТРОХІМІЧНИХ СЕНСОРІВ

МАТВЄЄВ О. М., МАЗАНКА В.М., КОСОГІН О.В.

4.5 ЕЛЕКТРОХІМІЧНЕ ФОРМУВАННЯ ВПОРЯДКОВАНИХ 182 СТРУКТУР ОКСИДУ АЛЮМІНІЮ ДЛЯ ЕЛЕКТРОННОЇ ПРОМИСЛОВОСТІ ЄГОРОВА Ю.А., ЧЕРНІК О.О., ЖАРСЬКИЙ І.М.

4.6 ХІМІЧНИЙ СИНТЕЗ НАНОТСТРУКТУРОВАНИХ СИСТЕМ 3 185 ХЕМОЧУТЛИВИМИ ВЛАСТИВОСТЯМИ

ПЯНКО А.В., ЖИЛІНСЬКИЙ В.В., ГОРОХ Г.Г.

4.7 ЕЛЕКТРОХІМІЧНЕ ФОРМУВАННЯ 189 НАНОСТРУКТУРОВАНОГО АЛЮМІНІЄВОГО ПОКРИТТЯ ПИСЬМЕНСЬКА О.С., ЧЕРНІК О.О., ЖИЛІНСЬКИЙ В.В., БОГОМАЗОВА Н.В.

\section{РОздіЛ 5. СУЧАСНІ ЕЛЕКТРОХІМІЧНІ ТА СПОРІДНЕНІ} TЕХНОЛОГIII

5.1 АНОДНЕ ФОРМУВАННЯ НАНОПОРИСТИХ ШАРІВ ОКСИДУ 194 ОЛОВА В КИСЛИХ ЕЛЕКТРОЛІТАХ

ЗАРАЗКА Л. , ГАВЛАК К., КРЖИСІК А., ЯСКУЛА М.

5.2 В ВЛИВ ІОННИХ ДОБАВОК НА ПОЧАТКОВІ СТАДІЇ 199 ЕЛЕКТРОКРИСТАЛІЗАЦІЇ ПЛЮМБУМ ДІОКСИДУ ШМИЧКОВА О. Б., ЛУКЬЯНЕНКО Т. В., ВЕЛІЧЕНКО О. Б.

5.3 ВПЛИВ ДОБАВОК ВОДИ НА ФІЗИКО-ХІМІЧНІ ВЛАСТИВОСТІ ЕЛЕКТРОХІМІЧНИХ СИСТЕМ НА ОСНОВІ ГЛИБОКОЕВТЕКТИЧНИХ РОЗЧИННИКІВ БОБРОВА Л.С., ШАЙДЕРОВ Д.А., КІТИК А.А., ПРОЦЕНКО В.С., ДАНИЛОВ Ф.Й.

5.4 КІНЕТИКА ПЕРЕНОСУ ВОДИ ЧЕРЕЗ КАТІОНООБМІННІ 209 МЕМБРАНИ

ПАВЛОВ В., ТУЛЬСЬКИЙ Г.Г.

5.5 ЕЛЕКТРОДІАЛІЗ МОЛОЧНОЇ СИРОВАТКИ І3 ЗАСТОСУВАННЯМ ОРГАНО-НЕОРГАНІЧНИХ МЕМБРАН. ЗМІЄВСЬКИЙ Ю.Г., РОЖДЕСТВЕНСЬКА Л.М., ЗАХАРОВ В.В., ДЗЯЗЬКО Ю.С., МИРОНЧУК В.Г.

5.6
ЕЛЕКТРОМАГНІТНІ
ВТРАТИ
B
КОМПОЗИТАХ ВУГЛЕЦЫ/ПОЛІМЕР 3 ДОМІШКАМИ НАНО-СТЕРЖНІВ МІДІ ШПАК Ю.В., ДРАГАН Д.Р., СЕНИК І.В., БАРСУКОВ В.З.

219 
5.7 PОЗУМНI ВІКНА: КАТІОННА ВНУТРІШНЯ ТА АНІОННА ЗОВНІШНЯ АКТИВАЦІЯ ЕЛЕКТРОХРОМНИХ ПЛІВОК ГІДРОКСИДУ НІКЕЛЮ КОТОК В.А., МАЛАХОВА К.В. КОВАЛЕНКО В.Л., БАРАМЗІН М.М.

5.8 ПРОГНОЗУВАННЯ РОЗМІРІВ ГАЗОВИХ БУЛЬБАШОК У КОНЦЕНТРОВАНИХ ЛУЖНИХ РОЗЧИНАХ ЗА ДОПОМОГОЮ ТЕОРІЇ ПЛОСКОГО ЗАРОДКУ

АТАПІН А. Г., НЕФЕДОВ В. Г.

5.9 ВПЛИВ ПРОЦЕСУ ДЕГІДРАТАЦІЇ НІТРАТУ МАНГАНУ НА 234 ЯКІСТЬ ДІОКСИДНО-МАНГАНОВОГО ПОКРИТТЯ ТИТАНОВИХ АНОДІВ БУТЕНКО О.С, БУКЕТ О.І.

5.10 ВПЛИВ ПРИРОДИ ЕЛЕКТРОЛІТУ НА ЕЛЕКТРОХІМІЧНІ ВЛАСТИВОСТІ ТОНКИХ ПЛІВОК ПОЛІ (З-ЕТИЛТІОФЕНУ) 239 КОЗЛОВА Т.Б., МОТРОНЮК Т.І., СИДОРОВ Д.О.

5.11 КІНЕТИКА АНОДНИХ ПРОЦЕСІВ В РОЗЧИНАХ ОЦТОВОЇ КИСЛОТИ БІЛОУС Т.А., ТУЛЬСЬКИЙ Г.Г.

5.12 ЕЛЕКТРОХІМІЧНЕ ЗНЕЗАРАЖУВАННЯ ВОДИ 3 249 ПРИРОДНИМ СОЛЕВМІСТОМ

БАШМАКОВ Є.Б., БАЙРАЧНЫЙ В.Б., ДІАБ ХАССАН

5.13 ЕЛЕКТРОКАТАЛІТИЧНА АКТИВНІСТЬ КОМПОЗИ-ЦІЙНИХ 255 МАТЕРІАЛІВ $\mathrm{PbO}_{2}-\mathrm{TIO}_{2}$, ОСАДЖЕНИХ І3 СУСПЕНЗІЙНИХ ЕЛЕКТРОЛІТІВ

КНИШ В.О., ВЕЛІЧЕНКО О.Б.

5.14 ВИКОРИСТАННЯ ЕЛЕКТРОХІМІЧНИХ МЕТОДІВ ДЛЯ ВИЗНАЧЕННЯ СТУПЕНЯ ДЕАЦЕТИЛЮВАННЯ ХІТОЗАНУ СЛІСЬ А.А., РЕДЬКА К.В., СОЛОДОВНІК Т.В.

5.15 ВПЛИВ ВМІСТУ СТРУМОПРОВІДНИХ НАПОВНЮВАЧІВ НА 265 ВЛАСТИВОСТІ ПОЛІЕТИЛЕНОВИХ КОМПОЗИЦІЙ КУРИПТЯ Я.А., НОВАК Д.С., САВЧЕНКО Б.М., ПЛАВАН В.П.

5.16 БІОІМПЕДАНСНИЙ АНАЛІЗ СКЛАДУ ТІЛА ЛЮДИНИ: ІСТОРІЯ, КЛАСИФИКАЦІЯ ТА БІОФІЗИЧНІ ОСНОВИ МЕТОДУ ЧЕРЕВАЧ Я.Ф., БОРИСЕНКО Ю.В.

5.17 БІОЕЛЕКТРИЧНІ ПОТЕНЦІАЛИ: МЕХАНІЗМ ВИНИКНЕННЯ ТА ФУНКЦІОНУВАННЯ; БІОЛОГІЧНА РОЛЬ ПАТЛУН Д.В., КИСЛОВА О.В. 


\section{INTRODUCTION}

Under the auspices and sponsorship of the International Society of Electrochemistry (ISE) the "ISE Satellite Student Regional Symposium on Electrochemistry - 1st ISE Regional Student Meeting in Ukraine" was held in May, 2016 in Kyiv.

Such an important to Ukraine scientific event has initiated the preparation of this collective monograph, which considers the modern problems and promising ways for their solving in the following directions of Technical Electrochemistry: Electrochemical power sources (part 1), Electroplating (part 2), Corrosion protection (part 3), Electrochemical sensors (part 4), Modern electrochemical and related technologies (part 5).

The state of art in the above mentioned directions of Technical Electrochemistry determines substantially the progress in general development of science and technologies of the XXI century and just now promotes creation of essentially new types of equipment and technologies.

As examples, including those described in this monograph, it is possible to note the following developments: materials for effective lithium-ion accumulators and hybrid supercapacitors for electrical vehicles; non-platinum catalysts for fuel cells, which could be useful for eco-friendly "hydrogen power engineering"; electrochemical sensors for spike monitoring toxic substances; effective coatings which can protect metals against corrosion as well as people and electronic equipment against unfavorable effects of electromagnetic radiation; electrochemical technologies for synthesis of nanowires and nanorods; electrochromic materials for "smart windows", which could regulate the amount of light and heat inside premises, etc.

At the next page there is the list of all 129 authors of this collective monograph in alphabetical order. The papers written by these authors are shown in parentheses according the Content.

The monograph could be useful for a wide range of lecturers, scientists, post-graduates, holders of a master's degree and students of Universities, engineers and technicians of various electrochemical enterprises.

Prof.Dr. V. Barsukov 


\section{ВСТУП}

В травні 2016 року під еаідою та при спонсорській підтримці Міжнародного Електрохімічного Товариства (МЕТ) в Києві був проведений Регіональний сателітний студентський симпозіум MET з електрохімії - Перший Регіональний студентський симпозіум МЕT в Україні.

Ця важлива для України наукова подія ініціювала підготовку даної колективної монографії̈, в якій розглянуті сучасні проблеми i перспективні шляхи їх вирішення в таких напрямках розвитку технічної електрохімії, як хімічні джерела струму (розділ 1), гальванотехніка (розділ 2), захист металів від корозії (розділ 3), електрохімічні сенсори (розділ 4), сучасні електрохімічні та споріднені технології (розділ 5).

Стан наукових досліджень у вказаних напрямках технічної електрохімії в значній мірі обумовлює прогрес в загальному розвитку науки і технологій XXI сторіччя і уже зараз сприяє появі принципово-нових видів техніки і технологій.

В якості прикладів, які знайшли відображення в тому числі і в uій монографрії, можна навести розробку матеріалів для ефрективних літій-іонних акумуляторов та суперконденсаторів електромобільного призначення; неплатинових каталізаторів для паливних елементів, що сприяють розвитку екологічно-чистої «водневої» енергетики; електрохімічних сенсорів для моніторингу викиду токсичних речовин, ефрективних покриттів, здатних захистити метали від корозії, а людину та електронне обладнання - від шкідливого впливу електромагнітного випромінювання; розробку електрохімічних технологій отримання нановолокон та наностержнів; електрохромних матеріалів для «розумних» вікон, що здатні регулювати кількість світла та тепла в приміщенні; та ін.

На наступній сторінці наведений список всіх 129 авторів цієї колективної монографрії у відповідності до англійського алфавіту. В дужках вказані підготовлені ними статmі (підрозділи) монографії заідно з шифрами, які вказані в Змісті.

Монографрія може бути корисною для широкого кола викладачів, науковців, аспірантів, магістрів та студентів профрільних вищих навчальних закладів, інженерно-технічних працівників різноманітних електрохімічних виробництв. 


\section{COLLECTIVE MONOGRAPH AUTHORS}

\section{АВТОРИ \\ КОЛЕКТИВНЇ МОНОГРАФІЇ}

Surname

AKULICH N.E.

ANDRIIKO A.A.

ANTSIKHOVICH I.V.

APOSTOLOVA R.D.

ATAPIN A.G.

BARAMZIN M.N.

BARSUKOV V.Z.

BASHMAKOV E.B.

BASKEVICH A.S.

BAYRACHNYI V.B.

BERVICKAJA O.S.

BILOUS T.A.

BOBROVA L.S.

BOGOMAZOVA N. V.

BOLDYREV E.I.

BORYSENKO Yu.V.

BOYCHUK A.V.

BUKET O.I.

BUTENKO O.S.

CHEREVACH YA.F.

CHERNIK A.A.
Прізвище

АКУЛІЧ Н.Є.

АНДРІЙКО О.О.

АНТІХОВИЧ І.В.

АПОСТОЛОВА Р.Д.

АТАПІН А. Г.

БАРАMЗIH M.M.

БАРСУКОВ В.3.

БАШМАКОВ $€ . Б$.

БАСКЕВИЧ О.С.

БАЙРАЧНЫЙ В.Б.

БЕРВИЦЬКА О.С.

БІЛОУС Т.А.

БОБРОВА Л.С.

БОГОМАЗОВА Н.В.

БОЛДИРЕВ Є.І.

БОРИСЕНКО Ю.В.

БОЙЧУК О.В.

БУКЕТ O.I.

БУТЕНКО О.С.

ЧЕРЕВАЧ Я.Ф.

ЧЕРНIK O.O.
№ статті

3.2

1.5

2.4

$1.8 ; 1.9 ; 1.10$

5.8

5.7

$1.1 ; 1.13 ; 5.6$

5.12

1.8

5.12

2.6

5.11

5.3

4.7

1.14

$3.6 ; 5.16$

1.15

$4.1 ; 5.9$

5.9

5.16

$2.4 ; 3.2 ; 3.7 ; 4.5 ; 4.7$ 
CHERNYSH O.V.

DANILOV F.I.

DIAB HASSAN

DRAGAN D.R.

DROBNYI D.M.

DZYAZKO YU.S.

EGOROVA Yu.A.

GAWLAK K.

GLADUN V.A.

GOROH G.G.

GROMADSKYI D.G.

HAPON YU.K.

JASKUŁA M.

KATASHINSKII A.S.

KESHIN A.V.

KHARITONOV D.S.

KHOMENKO V.G.

KIRSANOVA I.V.

KISLOVA O.V.

KITYK A.A.

KLIMOVA E.A.

KNYSH V.A.

KOSILOV V.V.

KOSOHIN O.V.

KOTOK V.A.

KOTSIUBA E.S.

KOVALENKO P.V.

KOVALENKO V.L.

KOZIAR M. A.

KOZLOVA T.B.

KRAVCHENKO O.V.

KRAVETS YU.A.

KRZYSIK A.

KURILO I.I.

KURIPTYA Y.

LABUR T.M.

LINYUICHEV O.G.
ЧЕРНИШ О.В.

1.1

ДАНИЛОВ Ф.Й.

ДІАБ ХАССАН

ДРАГАН Д.Р.

ДРОБНИЙ Д.М.

ДЗЯЗЬКО Ю.С.

$2.1 ; 5.3$

5.12

5.6

1.2

5.5

ЄГОРОВА Ю.А.

4.5

ГАВЛАК К.

5.1

ГЛАДУН В.А.

1.9

ГОРОХ Г.Г.

4.6

ГРОМАДСЬКИЙ Д.Г.

1.6

ГАПОН Ю.К.

2.5

ЯСКУЛА М.

5.1

КАТАШИНСЬКИЙ А.С. $\quad 1.13$

КЕШИН А.В.

3.7

ХАРИТОНОВ Д.С.

3.3

ХОМЕНКО В.Г.

$1.1 ; 1.13$

KIPCAHOBA I.B.

1.8

КИСЛОВА О.В.

5.17

КІТИК А.А.

5.3

КЛІМОВА O.A.

3.7

КНИШ B.O.

5.13

КОСІЛОВ В. В.

1.4

КОСОГІН О.В.

4.4

КОTOK B.A.

5.7

КОЦЮБА О.С.

3.5

КОВАЛЕНКО П.В.

5.7

КОВАЛЕНКО В.Л.

5.7

КОЗЯР М. О.

3.1

КОЗЛОВА Т.Б.

5.10

КРАВЧЕНКО О.В.

3.4

KРАВЕЦЬ Ю.А.

1.4

КРЖИСІК А.

5.1

КУРИЛО І.І.

3.3

КУРИПТЯ Я.А.

5.15

ЛАБУР Т.М.

3.6

ЛІНЮЧЕВ О.Г. 
LOS A.I.

LUK'YANENKO T.

MACIYEVSKYI N.A.

MAKYEYEVA I.S.

MALAHOVA E.V.

MARKEVICN A.V.

MATVEEV O.M.

MAZANKA V.M.

MELNICHUK S.L.

MILOVANOVA O.I.

MOTRONYUK T.I.

MUKHIN V.V.

MYRONCHUK V.G.

NEFEDOV V.G.

NENASTINA T.O.

NOVAK D.S.

NURIACHMETOVA M.M.

NYRKOVA L.I.

OSADCHUK S.A.

OVCHARENKO O. A.

PATLUN D.V.

PAVLOV B.

PERSHINA K.D.

PIESKOV R.P.

PILIPENKO T.N.

PISMENSKAYA A.S.

PLAVAN V.P.

POGREBOVA I.S.

POLISCHUK YU.V.

POLYANICHKO O.O.

POTAPENKO A.V.

POTAPENKO AI.V.

POTASKALOV V.A.

PROTSENKO V.S.

PUSHIK O.B.

PYANKO A.V.

REDKA K.V.
ЛОСь A.I.

ЛУКЬЯНЕНКО Т.В.

5.2

МАЦІЄВСЬКИЙ Н.А.

1.10

МАКЄЄВА І.С.

1.1

МАЛАХОВА К.В.

5.7

МАРКЕВИЧ О.В.

1.9

MATBEЄB O.M.

4.4

MAЗАНКА B.M.

4.4

МЕЛЬНИЧУК С.Л.

4.2

МІЛОВАНОВА O.I.

1.6

МOTPOHЮК T.I.

5.10

MУXIH B.B.

1.12

МИРОНЧУК В.Г.

5.5

НЕФЕДОВ В. Г.

5.8

HEHACTIHA T.O.

2.5

НОВАК Д.С.,

5.15

3.6

НИРКОВА Л.І.

$3.6 ; 4.2$

ОСАДЧУК С.О.

4.2

ОВЧАРЕНКО О.О.

2.3

ПАТЛУН Д.В.

5.17

ПАВЛОВ В.

5.4

ПЕРШИНА К.Д.

3.4

ПЕСКОВ Р.П.

1.10

ПИЛИПЕНКО Т.Н.

3.5

ПИСЬМЕНСЬКА О.С.

4.7

ПЛАВАН В.П.

5.15

ПОГРЕБОВА І.С.

3.5

ПОЛІЩУК Ю.В.

$1.10 ; 2.6$

ПОЛЯНІЧКО О.О.

4.1

ПОТАПЕНКО Г.В.

ПОТАПЕНКО ОЛ.В.

$1.3 ; 1.11 ; 1.12$

1.15

ПОТАСКАЛОВ В.А.

1.5

ПРОЦЕНКО В.С.

$2.1 ; 5.3$

ПУШИК О.Б.

1.6

ПЯНКО А.В.

4.6

РЕДЬКА К.В. 
ROZHDESTVENSKA L.M. РОЖДЕСТВЕНСЬКА Л.M. $\mathbf{5 . 5}$

SAKHNENKO N. D.

SAVCHENKO M.O.

SAVCHENKO B. M.

SENYK I.V.

SHAIDEROV D.A.

SHEMBEL E.M.

SHMATOK YU.V.

SHMYCHKOVAO.

SHPAK Yu.V

SIROSH V.A.

SKNAR I.V.

SKNAR Y.E.

SLAVKOVA M. A.

SLIS A.A.

SOKOLSKY G.V.

SOLODOVNIK T.V.

SUSLOV M.M.

SYDOROV D.O.

TSURKAN A.V.

TSYMBALIUK A.S.

TULSKY G.G.

USHCHAPOVSKYI D.YU.

VASIL'EVA E.A.

VED' M. V.

VELICHENKO A. B.

ZARASKA L.

ZAKHAROV V.V.

ZHARSKIY I.M.

ZHIGALOVA A.A.

ZHYILINSKI V.V.

ZMIEVSKII YU.G.

ZUDINA L.V.

ZUL'FIGAROV A.O.
САХНЕНКО М.Д.

САВЧЕНКО M.O.

САВЧЕНКО Б.М.

СЕНИК I.В.

ШАЙДЕРОВ Д.А.

ШЕМБЕЛЬ О.М.

ШМАТОК Ю.В.

ШМИЧКОВА О. Б.

ШПАК Ю.В.

CIPOШ B.A.

CKHAP I.B.

СКНАР Ю.Є.

СЛАВКОВА М. О.

СЛІСь A.A.

СОКОЛЬСЬКИЙ Г.В.

СОЛОДОВНІК Т.В.

суслОВ М.М.

СИДОРОВ Д.О.

ЦУРКАН А.В.

ЦИМБАЛЮК А.С.

ТУЛЬСЬКИЙ Г.Г.

$2.3 ; 2.5 ; 3.1$

1.10

5.15

$1.13 ; 5.6$

5.3

1.9

1.11

5.2

5.6

1.7

2.2

2.2

3.1

5.14

1.14

5.14

1.12

5.10

2.1

4.3

$5.4 ; 5.11$

4.3

2.1

$2.3 ; 2.5 ; 3.1$

$5.2 ; 5.13$

5.1

5.5

$3.3 ; 4.5$

2.2

$3.7 ; 4.6 ; 4.7$

5.5

1.14

1.5 


\title{
Part 1 \\ ELECTROCHEMICAL POWER SOURCES
}

\author{
Розділ 1 \\ ХІМІЧНІ ДЖЕРЕЛА \\ CTPУMY
}




\title{
THE INFLUENCE OF GRAPHITE MATERIALS ON POWER PERFORMANCE OF LITHIUM-ION CAPACITORS
}

\author{
V. KHOMENKO, V. BARSUKOV, I. MAKYEYEVA, O. CHERNYSH \\ Kiev National University of Technologies \& Design \\ v.khomenko@i.ua
}

A well-designed lithium-ion capacitor (LIC) can reach higher energy and power density than traditional supercapacitors [1]. The research in the field of lithium-ion capacitors is focused on the development of systems with higher power and energy density and longer cycle life. For this purpose, in the last years, an intensive effort has been made to test many electrode materials for LIC. The anode materials have been transferred from the technologies of lithium-ion battery. Synthetic graphites, such as mesocarbon-microbead (MCMB) have been used commercially by many battery companies as anode materials in lithiumion batteries because they have shown a reversible electrochemical behavior and a low, flat potential curve for the lithium intercalation/deintercalation process [2]. However, the lower-cost natural graphite materials are of more interest. In the current work, the natural graphite materials with different physicochemical characteristics were considered for implementation in a lab cell.

Electrochemical performance of an LIC can be improved in several ways. A common approach is to try to find new materials with superior electrochemical properties. Minimizing the amount of inactive material (less weight impact) is another way to increase the specific energy and power in an LIC. The development of new smart designs and concepts that can add other values to the LIC is also a viable approach.

This work is to present the results of screening tests that were performed on a large number of low-cost materials. These materials were screened for their potential to have a positive impact on the highpower application. As part of this effort, we developed and employed a set of standard test protocols to evaluate all of the materials. Also, this work is dedicated to optimization of graphite electrodes in order to fulfill the requirements for use in an asymmetric supercapacitor such as LIC.

\section{Experimental}

Versatile electro-chemical testing of different anode materials was conducted in order to estimate their possible application for lithium-ion capacitors. Electrodes were composed of $89-91 \%$ of relevant-type graphite , $8 \%$ of the binder - polyvinyliden fluoride (PVDF) and 1-3\% of 
carbon percolators. Slurries for electrode casting were prepared from a mixture of the graphite and PVdF dissolved in 1-methyl-2-pyrrolidinone (NMP). They were spread onto a $\mathrm{Cu}$ foil with different thickness and dried under vacuum at $120^{\circ} \mathrm{C}$ for $12 \mathrm{~h}$. After drying, the electrodes were compressed by roll press. The thickness of active mass after rolling was varied within a wide range from 40 to $100 \mu \mathrm{m}$. The density of graphite layer was about $1.0-1.6 \mathrm{~g} / \mathrm{cm}^{3}$. The 2025 type of half-elements with lithium electrode were assembled using the electrodes with an operating area of $1,77 \mathrm{~cm}^{2}$. All these elements were assembled in the argon box (M Braun, USA) with a water content of $<1 \mathrm{ppm}$. Electrochemical investigations were performed using the multi-channel potentiostat/galvanostat VMP3 from Princeton Applied Research (UK). The electrochemical performance of materials was examined using a range of measurement techniques. Electrochemical cycling was used to establish capacity and power characteristics.

\section{Results and Discussion}

In this work, many kinds of carbonaceous materials were investigated in order to find the best materials. The common list of tested carbonaceous materials is presented in Table 1.

Table 1. Commercial types of carbonaceous materials

\begin{tabular}{|c|c|c|c|}
\hline Type of materials & Commercial grade & Country & Company \\
\hline \multirow[t]{2}{*}{ Natural graphite } & $\begin{array}{l}\text { SLC1512P, } \\
\text { SLC1520P, } \\
\text { SLC1520T, } \\
\text { SLA1518, } \\
\text { ABG1005 }\end{array}$ & USA & Superior Graphite Co. \\
\hline & LGN1212 & USA & $\begin{array}{c}\text { American Energy } \\
\text { Technologies Company }\end{array}$ \\
\hline \multirow[t]{3}{*}{$\begin{array}{c}\text { Synthetics } \\
\text { graphitic materials }\end{array}$} & $\begin{array}{c}\text { MCMB (TB-17), } \\
\text { MT-1 }\end{array}$ & USA & MTI \\
\hline & $\begin{array}{l}\text { KS6, SLP30, } \\
\text { SLP50 }\end{array}$ & Switzerland & Lonza (TIMICAL Group) \\
\hline & $\begin{array}{c}\text { LGS1228, LM1226, } \\
\text { LGS1211 }\end{array}$ & USA & $\begin{array}{c}\text { American Energy } \\
\text { Technologies Company }\end{array}$ \\
\hline Hard carbon & Carbotron-P & Japan & $\begin{array}{c}\text { Kureha Chemical Industry } \\
\text { Co. }\end{array}$ \\
\hline
\end{tabular}

All samples could be defined as spherical (for example, SLP30) or exfoliated (ABG 1005, KS6) types of graphite materials. The materials manufactured by Superior Graphite Co., USA (SLC1512P, SLC1520P, SLC1520T, SLA1518) were prepared from natural crystalline flake 
graphite obtained via flotation of graphite concentrate and purified by subjecting it to the uniform zone of heat treatment at temperatures above $2.500{ }^{\circ} \mathrm{C}$. The purified flake, in the subsequent stages of processing, was reduced in size by milling and classification technologies. As example, Fig. 1 shows SEM micrographs of graphite with prismatic and potato-shaped particles. The particles show only a small variation in shape. The sphericity of the potato- shaped particles is not such regular as that of mesocarbon micro- beads (MCMB) because the original natural graphite has a prismatic (flake-like) structure .

a)
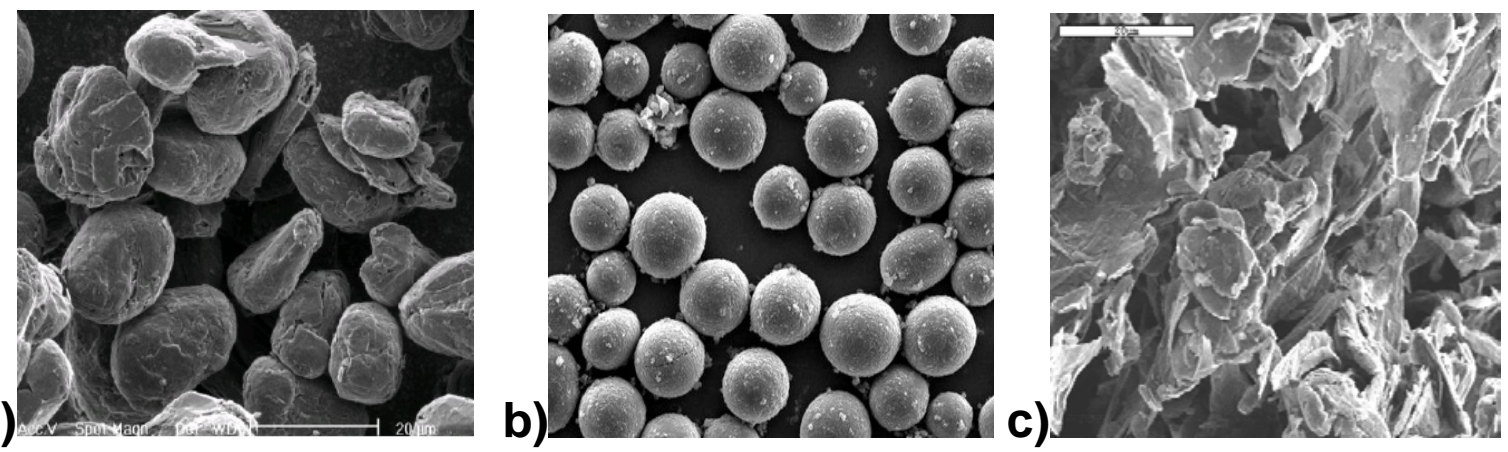

Figure 1. SEM micrographs of different- type graphite materials:

a) SLC1520P graphite; b) TB17 MCMB c) ABG 1005 graphite

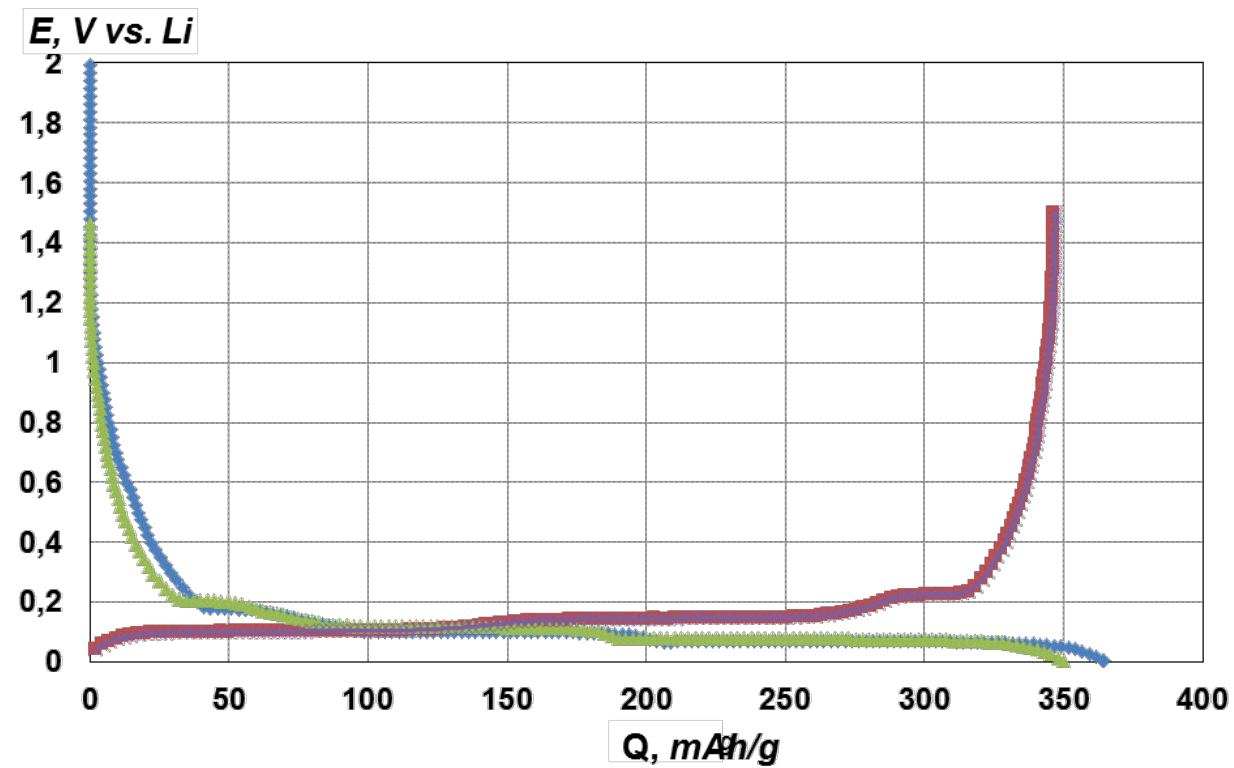

Figure 2. Charge and discharge profile of the half - element based on the reference SLC1520P graphite at the current density C/10

The electrochemical investigation of all anode materials was started with the first lithiation performed against metallic lithium. Fig. 2 shows initial charge/discharge curves for the SLK1520P graphite sample from Superior Graphite Co in the 2025 type half-elements. In the investigation, the coin cells were used for optimization of anode 
materials. The reversible capacity of SLC1520P graphite at the first cycle was of $\mathrm{Q} \sim 358 \mathrm{~mA} \cdot \mathrm{h} / \mathrm{g}$; this is quite close to the theoretical capacity. Irreversible loss of capacity at the first cycle came to $18 \mathrm{~mA} \cdot \mathrm{h} / \mathrm{g}$. The same test was done for different commercial types of carbonaceous materials. Some physical-chemical characteristics of selected samples are included in Table 2. Also, the values of reversible and irreversible capacity of all samples are presented in table 2. It is necessary to note that the lowest irreversible capacitance suggests the choice of Superior Graphite Co. Irreversible capacity is correlated to the surface area of a material, thus the more promising materials are the ones with a relatively low surface area and spherical or potato- shaped particles. For example, the SLC1512P has a lower specific surface area, thus a minimal irreversible capacity.

Table 2. Characteristics of anodes based on different types of graphite

\begin{tabular}{|c|c|c|c|c|c|}
\hline Carbon & Type of graphite & $\begin{array}{c}\text { Reversible } \\
\text { capacity, } \\
\text { mAh/g }\end{array}$ & $\begin{array}{l}\text { Irreversible } \\
\text { capacity, } \\
\text { mAh/g }\end{array}$ & $\begin{array}{c}\text { Particle } \\
\text { size, D } \\
50, \mu\end{array}$ & $\begin{array}{l}\text { BET } \\
\text { surface } \\
\text { area, } \\
\mathbf{m}^{2} / g\end{array}$ \\
\hline SLC1512P & $\begin{array}{l}\text { Surface coated } \\
\text { spheroidal natural } \\
\text { flake }\end{array}$ & 359 & 19 & 12,01 & 1,52 \\
\hline ABG1005 & $\begin{array}{l}\text { Expanded natural } \\
\text { flake }\end{array}$ & 327 & 106 & 6,5 & 16,5 \\
\hline KS6L & Synthetic graphite & 363 & 114 & 6 & 22 \\
\hline $\begin{array}{l}\text { TB17 } \\
\text { MCMB }\end{array}$ & $\begin{array}{l}\text { Artificial synthetic } \\
\text { materials }\end{array}$ & 309 & 25 & 26 & 0,86 \\
\hline SLP30 & $\begin{array}{l}\text { Highly crystalline } \\
\text { structure artificial } \\
\text { graphite }\end{array}$ & 358 & 50 & 32 & 7 \\
\hline SLC1520P & $\begin{array}{l}\text { Surface coated } \\
\text { spheroidal natural } \\
\text { flake graphite }\end{array}$ & 358 & 18 & 17,99 & 0,96 \\
\hline
\end{tabular}

It is well known that the reversible specific capacity decreases with increasing the current rate. In this work, selected graphite materials have been studied at various current densities in the cells using a $\mathrm{Li}$ metal counter electrode. Figure 3 shows discharge capability of graphite materials obtained as a function of discharge rate. Different graphite anodes were tested using the CR2025 coin half-cells. Discharge capability was determined at different $\mathrm{C}$-rates with a charge of $\mathrm{C} / 5$ in the voltage range: $0.001-1.50 \mathrm{~V}$ vs. $\mathrm{Li}$. 


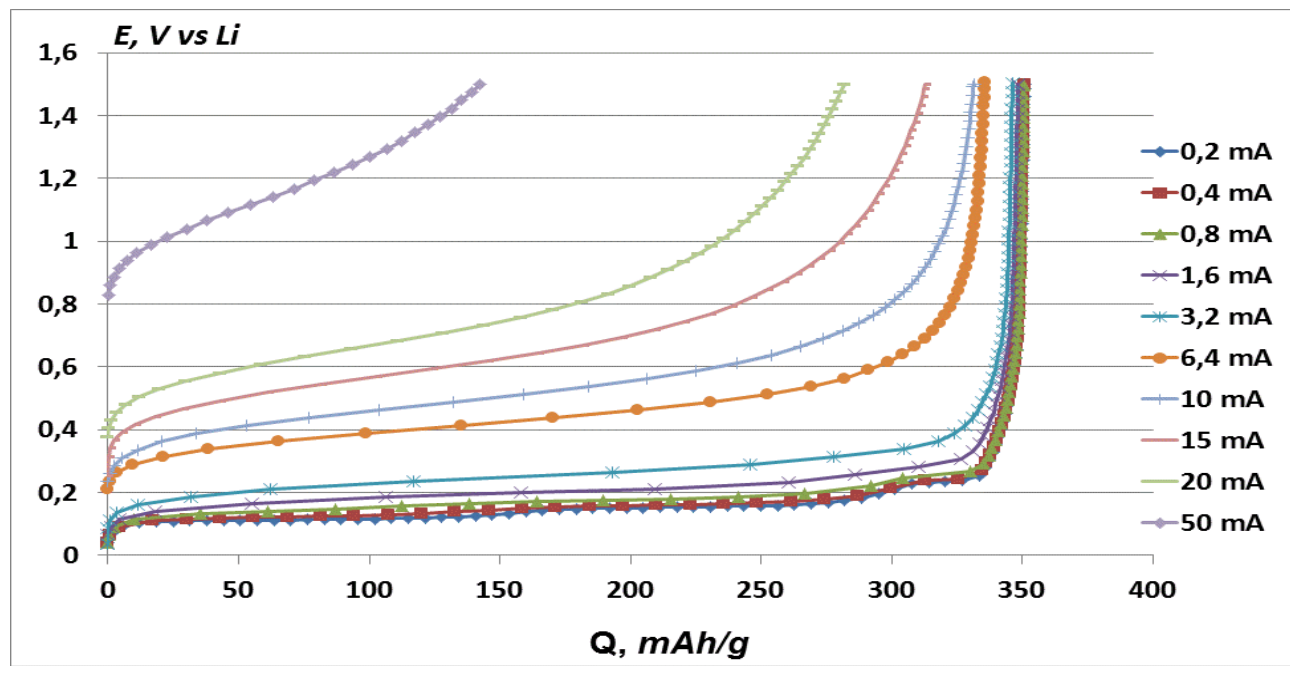

Figure 3. Discharge capability graphite materials SLP-30 at different C-rates with a charge of $\mathrm{C} / 5$ in the voltage range $0.001-1.50 \mathrm{~V} \mathrm{Vs}$. $\mathrm{Li}$

Such graphite materials as KS-6 and SLP-30 show more than $90 \%$ of capacity retention at $3 \mathrm{C}$ rate. However, high-rate capacity for the SLC1520P and MCMB (TB-17) graphite decreased. The other graphite materials presented in table 2 showed lower discharge capability than that of SLC1520 or MCMB. Therefore, such graphite materials as KS-6 and SLP-30 were selected for application in the LIC.

\section{Conclusions}

In this work different grades of carbonaceous materials were tested. Electrochemical high-rate and pulse measurements were applied to various types of graphite active materials for power-oriented lithium-ion capacitors. The results indicate the impact of graphite materials at highpower drain in real designed power devises. Surface coated spheroidal natural flake such as SLK1520P shows better electrochemical performance at low current density than other grades of graphite due to lower specific surface area. Nevertheless, these materials show some drawbacks regarding power performance. It was found that graphite KS-6 and SLP-30 from Timical shows the superior gravimetric capacity, density when high-current rates are used.

\section{References}

[1] Khomenko V. High-energy density graphite/AC capacitor in organic electrolyte/ V. Khomenko, E. Raymundo-Piñero, F. Béguin // Journal of Power Sources. - 2008. - Vol. 177. - P. 643-651

[2] Скундин А. М. Современное состояние и перспективы развития исследований литиевых аккумуляторов /Скундин А. М., Ефимов О.Н., Ярмоленко О.В. // Успехи химии, -2002. - Т. 71, -№4. $-379 \mathrm{c}$. 


\title{
THE EFFECT OF NANOPOROUS ELECTRODE COMPOSITION ON SUPERCAPACITOR PERFORMANCE
}

\author{
D. DROBNYI ${ }^{1,2}$ \\ ${ }^{1}$ Institute for sorption and problems of endoecology of National Academy \\ of Sciences of Ukraine \\ ${ }^{2}$ YUNASKO-UKRAINE LLC \\ ddrobny7773@gmail.com
}

Electrochemical double-layer capacitors (EDLC), otherwise known as supercapacitors or ultracapacitors, have become an integral part of various energy storage technologies, wherein EDLC low internal resistance is one of the key advantages, which predetermines the effectiveness of EDLC application in combined power supply units.

In this study the influence of different types of conductive additives in composite electrodes on supercapacitors performance has been investigated. Nano-porous activated carbon YP-80F (Kuraray, Japan) was selected as the active electrode material with appropriate pore size distribution between 1 and $5 \mathrm{~nm}$. Two types of conductive additives were used: low surface area carbon black (less than $100 \mathrm{~m}^{2} / \mathrm{g}$, Super P-Li, Timcal, Switzerland) and high surface area carbon black (SC2, Cabot, USA) with a specific surface area of about $1500 \mathrm{~m}^{2} / \mathrm{g}$. The electrodes were typically prepared by mixing the nanoporous activated carbon powder with conductive additive and PTFE suspension in water (SigmaAldrich). Galvanostatic charge-discharge cycling in the voltage range from $2.7 \mathrm{~V}$ to $1.35 \mathrm{~V}$ and current from $0.5 \mathrm{~A}$ to $3 \mathrm{~A}$ was used to measure the electrical parameters of EDLC prototypes. As a result, the use of $2 \%$ of Super P-Li leads to $7 \%$ decrease of internal resistance. Compared to Super P-Li, the SC2 conductive additive in amount of 20 mass $\%$ allows more than $20 \%$ increase in gravimetric capacitance at the same level of the internal resistance.

Electrical double-layer capacitors (EDLCs, also known as supercapacitors or ultracapacitors) are energy storage and power delivery devices with high power capability, high efficiency and long lifetime durability [1]. EDLCs are currently widely used in various energy storage technologies, wherein their low internal resistance and long cycle life are at an advantage (electric vehicles, energy recuperation modules, systems for uninterrupted power supply, fast recharging energy modules for high-power applications, wind energy, etc.) [2]. EDLC devices, which 
do not involve any mass or charge transfer through the electrodeelectrolyte interface, demonstrate much faster charge/discharge operations and longer cycle life as compared with conventional batteries. Therefore, EDLC devices can ensure a number of efficient power solutions that are mainly related to various backup systems to compensate short-term voltage surges or drops or with load leveling the batteries in various combined power sources.

The electrochemical performance of EDLCs depends on the pore structure, and high energy and power values can be achieved for high surface area materials, such as nano-porous carbon, which is an excellent active electrode material for EDLC due to its tremendous specific surface area, usually exceeding $1500 \mathrm{~m}^{2} / \mathrm{g}$ [3]. However, nanoporous carbon materials (typically powders) are not converted into final EDLC electrodes easily, and various types of binders are used to fabricate an electrode. Besides, low internal resistance can be one of key advantages of EDLC over all other types of energy storage devices since the efficiency and power capability are inversely proportional to internal resistance [4]. To increase the intrinsically low electrical conductivity of some nano-porous carbons, various types of conductive additives can also be added [5]. A high-performance composite electrode thus formed must demonstrate [6]:

- low ohmic resistance;

- good electrolyte accessibility and wettability;

- low contact resistance, stable interface with the current collector;

- high volumetric capacitance $\left(\mathrm{F} / \mathrm{cm}^{3}\right)$;

- chemical stability;

- low level of electrochemically active impurities;

- mechanical stability;

- the required "form factor", i. e. thickness, flexibility.

So, the particles of both activated carbon and conductive additive must be held together in a compact manner to ensure a high-density electrode with low ohmic resistance. This necessitates the use of a polymeric binder, which can maintain particle-to-particle contact, give the electrode mechanical integrity and provide stable, low-resistance bonding to a current collector. The binder must be inert toward the electrolyte, be stable at both negative and positive electrochemical potentials of the electrodes, be effective at low concentrations, and must not block more than a small fraction of the nano-porous carbon surface. A list of binders that meet these requirements and demonstrate good chemical and electrochemical stability include polytetrafluoroethylene (PTFE), polyvinylidenedifluoride (PVdF), polyvinyl alcohol (PVA), sodium carboxymethyl cellulose (CMC) and styrene-butadiene rubber (SBR) [7]. 
Compared to other listed binders, PTFE forms a network of fibrils instead of a polymer film. This results in a structure with good particle-to-particle contact and low internal resistance. Besides, the surface of carbon remains accessible for electrolyte ions, and the electrode does not become liophobic.

\section{Experimental}

Commercially available coconut shell derived activated carbon YP80F (Kuraray, Japan) was used as an electrode active material. Different types of conductive additives were used: low surface area (less than $100 \mathrm{~m}^{2} / \mathrm{g}$ ) carbon black (Super P-Li, Timcal, Switzerland) and high surface area carbon black (SC2, Cabot, USA) with a specific surface area of about $1500 \mathrm{~m}^{2} / \mathrm{g}$. The Super P-Li conductive additive was added to the active material in an amount of 2 mass $\%$ and 4 mass $\%$. In the case of SC2 carbon black, the mass fractions were as follows: 5\%, 10\% and $20 \%$ ('100\%' with respect to the total carbon mass with binder).

The electrodes were typically prepared by mixing the nano-porous activated carbon powder with conductive additive and PTFE suspension in water (Sigma-Aldrich) until a homogeneous mixture was obtained. The mixture was rolled to form sheets of 100 micron thick followed by cutting off the separate carbon electrodes. The active carbon electrodes thus obtained had their geometric surface area of $15 \mathrm{~cm}^{2}$ each and contained $7 \%$ of PTFE binder, (93-x)\% of activated nano-porous carbon and $\mathrm{x} \%$ of conductive additive, where $x=0 ; 2 ; 4 ; 5 ; 10 ; 20$ in compliance with conductive additive type. They were then applied onto electric-spark treated aluminum foil [8] used as a current collector of 20 micron thick and dried at $220{ }^{\circ} \mathrm{C}$ under vacuum for 8 hours. A couple of electrodes were then interleaved with a porous insulating sheet (separator) and placed into laminated aluminum shell. The prototypes thus fabricated were filled with 1.3 $\mathrm{M} \mathrm{Et}_{3} \mathrm{MeNBF}_{4}$ (TEMA) in acetonitrile and sealed. All the assembly operations were carried out in a dry box filled with argon.

Galvanostatic charge-discharge cycling in the voltage range from 2.7V to $1.35 \mathrm{~V}$ and current from $0.5 \mathrm{~A}$ to $3 \mathrm{~A}$ with the help of Arbin SCT 525 testing unit was used to measure the electrochemical parameters of EDLC prototypes.

\section{Results and Discussion}

The porous structure of selected activated carbon YP-80F has been studied from nitrogen adsorption/desorption isotherms at $77 \mathrm{~K}$ using a Nova 2200e Surface Area \& Pore Size Analyser (Quantachrome Instruments), and the results are illustrated in Figure 1. 


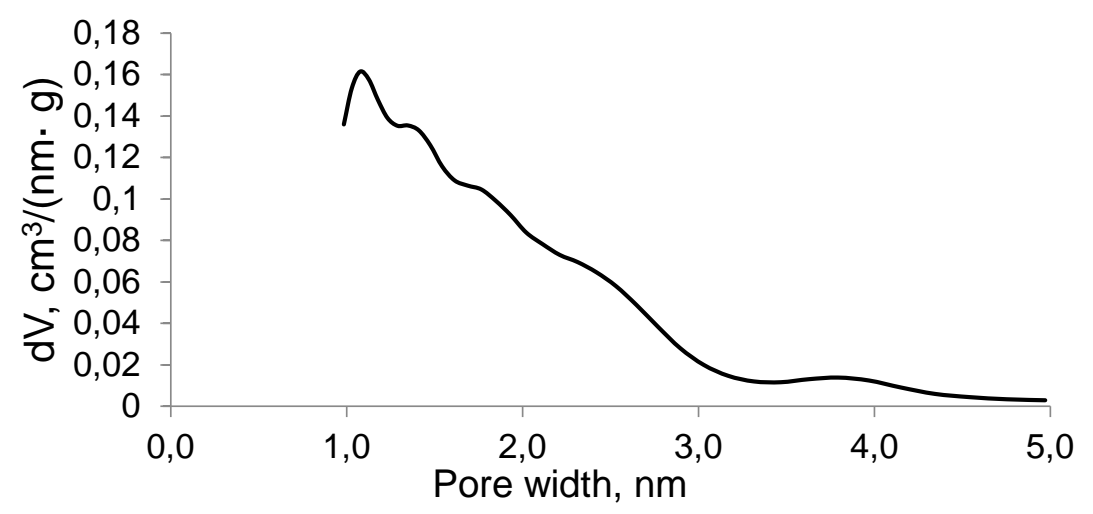

Figure 1. Pore size distribution obtained from nitrogen adsorption/desorption isotherms with the use of DFT calculations

This nano-porous carbon has its pore size in the range between 1 and 5 $\mathrm{nm}$ with a large portion concentrated between 1 and $3 \mathrm{~nm}$.

Testing results of EDLC prototypes with their electrodes fabricated either with the use of Super P-Li conductive additive or, for comparison purposes, with „pure” activated carbon electrodes (without any conductive additive), are listed in Table 1 below.

Table 1. Electrochemical parameters of EDLC with different content of Super P-Li conductive additive

\begin{tabular}{|c|c|c|c|c|c|}
\hline $\begin{array}{l}\text { Super } \\
\text { P-Li, } \\
\text { mass\% }\end{array}$ & $\begin{array}{c}\text { Electrode's } \\
\text { density, } \\
\text { g/cm }\end{array}$ & $\begin{array}{c}\text { Specific } \\
\text { capacitance, } \\
\text { F/g }\end{array}$ & $\begin{array}{c}\text { Volumetric } \\
\text { capacitanc } \\
\text { e, F/cm }\end{array}$ & $\begin{array}{c}\text { Specific } \\
\text { resistance, } \\
\text { Ohm-cm }\end{array}$ & $\begin{array}{c}\text { RC- } \\
\text { constant, } \\
\mathrm{s}^{-1}\end{array}$ \\
\hline 0 & 0,47 & 32,4 & 14,2 & 0,85 & 0,24 \\
\hline 2 & 0,5 & 30,5 & 14 & 0,79 & 0,22 \\
\hline 4 & 0,51 & 30,5 & 13,9 & 0,8 & 0,22 \\
\hline
\end{tabular}

As can be seen from this Table, addition of Super P-Li conductive additive in amount of 2 mass $\%$ allows to achieve $7 \%$ reduction of internal resistance. Further increase in the Super P-Li content does not reduce the resistance significantly. At the same time, an increase in Super P-Li content results in some decrease in volumetric capacitance due to lower specific surface area of the conductive additive.

Testing results of EDLC prototypes, whose electrodes were fabricated with SC2 conductive additive in comparison with „pure” activated carbon electrodes (without any conductive additive), are listed in Table 2 below. 
Table 2. Electrochemical parameters of EDLC with different content of conductive additive SC2

\begin{tabular}{|c|c|c|c|c|c|}
\hline $\begin{array}{c}\text { SC2, } \\
\text { mass } \\
\%\end{array}$ & $\begin{array}{c}\text { Electrode's } \\
\text { density, } \\
\text { g/cm }\end{array}$ & $\begin{array}{c}\text { Specific } \\
\text { capacitance, } \\
\text { F/g }\end{array}$ & $\begin{array}{c}\text { Volumetric } \\
\text { capacitance, } \\
\mathrm{F} / \mathrm{cm}^{3}\end{array}$ & $\begin{array}{c}\text { Specific } \\
\text { resistance, } \\
\text { Ohm } \cdot \mathrm{cm}^{2}\end{array}$ & $\begin{array}{c}\text { RC- } \\
\text { constant } \\
, \mathrm{s}^{-1}\end{array}$ \\
\hline 0 & 0,47 & 32,4 & 14,2 & 0,85 & 0,24 \\
\hline 5 & 0,49 & 32,4 & 14,0 & 0,82 & 0,23 \\
\hline 10 & 0,51 & 33,8 & 14,3 & 0,78 & 0,22 \\
\hline 20 & 0,52 & 39,7 & 15,1 & 0,78 & 0,23 \\
\hline
\end{tabular}

Gradual increase in SC2 content allows reaching the minimum of internal resistance at 10 mass\% of SC2. Further increase in the content of SC2 does not provide lower resistance, but significantly affects the gravimetric capacitance, which can be seen in Figure 2.

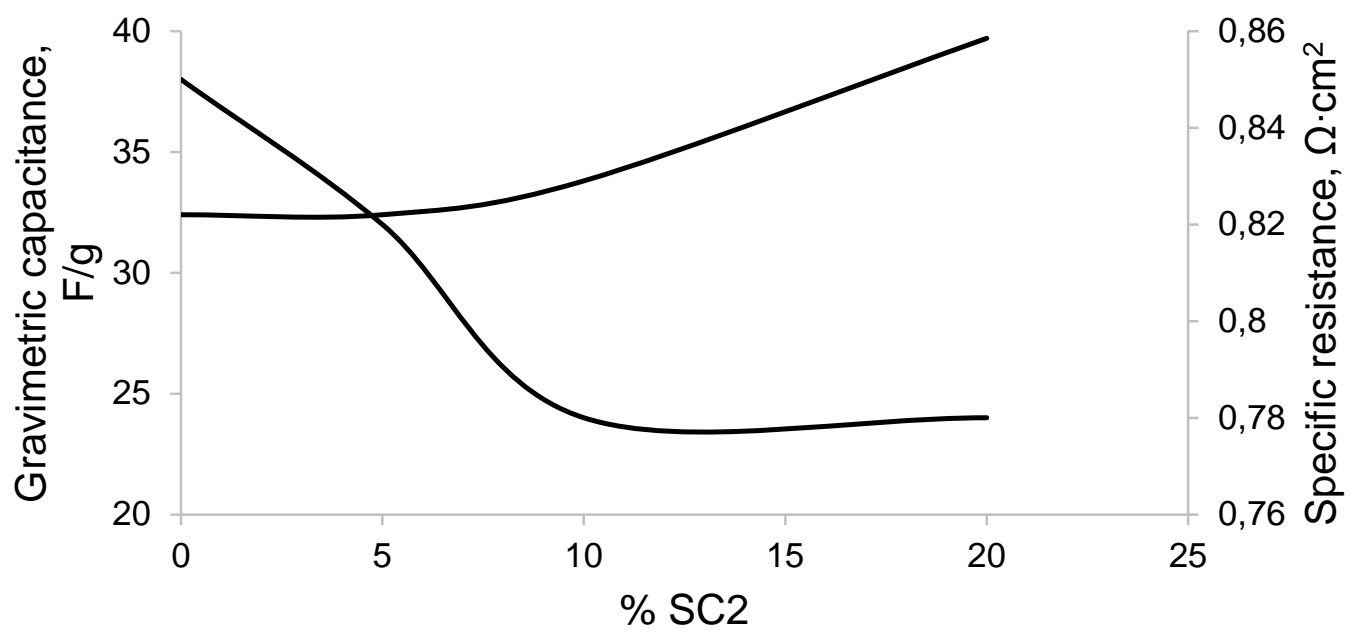

Figure 2. Dependence of EDLC specific parameters on SC2 content

In accordance with testing results, the use of SC2 conductive additive in amount of 20 mass\% allows more than 20\% increase in gravimetric capacitance of such composite electrodes.

\section{CONCLUSIONS}

The optimized ratio of various ingredients (nano-porous carbon, polymer binder and conductive additive) in composite EDLC electrodes enables one to improve the electrode's mechanical strength and EDLC performance significantly.

The use of conductive additive SC2 in amount of 20 mass\% besides reducing the internal resistance also increases gravimetric capacitance by $20 \%$. 


\section{References}

[1] Conway B. E. Electrochemical Supercapacitors: Scientific Fundamentals and Technological Applications, 1999. New-York: KluwerPlenum Press. http://dx.doi.org/10.1007/978-1-4757-3058-6

[2] Burke A. Ultracapacitors: why, how, and where is the technology. J. Power Sources, 2000, vol. 91, № 1. -P: 37-50.

[3] Pandolfo A.G., Hollenkamp A.F. Carbon properties and their role in supercapacitors. J. Power Sources, 2006, vol. 157, № 1. -P: 11-27.

[4] Maletin Y., Strelko V., Stryzhakova N. \& Drobny D. Carbon Based Electrochemical Double Layer Capacitors of Low Internal Resistance. Energy and Environment Research, 2013, vol. 3, № 2.

[5] Jäckela N., Weingartha D., Schreibera A., Krünera B., Zeigera M., Tolosaa A., Aslana M., Pressera V. Performance evaluation of conductive additives for activated carbon supercapacitors in organic electrolyte. Electrochimica Acta, vol. 191. -P: 284-298.

[6] D. Zuckerbrod, R. Sassa, M. Szabo, M. Mizenko, Performance of Carbon-PTFE Electrodes and PTFE Separators in Electrochemical Double Layer Capacitors (EDLCs).

http://www.gore.com/MungoBlobs/perf cn ptfe elect separ ators wp.pdf

[7] Lestriez B. Functions of polymers in composite electrodes of lithium ion batteries. Comptes Rendus Chimie, 2010, vol. 13, № 11. -P: 13411350.

[8] Maletin Y., Podmogilny S., Stryzhakova N., Mironova A., Danilin V., \& Maletin A. Electrochemical double layer capacitor, 2008. US Patent Appl №. 20080151472. 
UDC 544.6.076.324.4 + 544.016

\title{
ELECTROCHEMICAL PROPERTIES OF LiMn $\mathrm{O}_{4}$ SURFACE-MODIFIED WITH $\mathrm{LiNi}_{0.5} \mathrm{Mn}_{1.5} \mathrm{O}_{4}$
}

\author{
POTAPENKO A.V \\ Joint Department of Electrochemical Energy Systems, \\ 38a Vernadsky Blvd., Kiev 03680, Ukraine \\ avoloshka@ukr.net
}

Surface modified samples of $\mathrm{LiMn}_{2} \mathrm{O}_{4}$ coated with $\mathrm{LiNi}_{0.5} \mathrm{Mn}_{1.5} \mathrm{O}_{4}$ have been synthesized by a citric acid aided method and tested as a cathode material in sample lithium ion batteries. It has been been found that the surface layer of $\mathrm{LiNi}_{0.5} \mathrm{Mn}_{1.5} \mathrm{O}_{4}$ is easily permeable for $\mathrm{Li}^{+}$ions. The surface modified samples are able to endure current loads of $20 \mathrm{C}$ (2940 mAh/g) without degradation and after heavy-duty tests deliver the same specific capacity as before current loading.

The growing need in renewable energy storage is enhancing the research on new materials and the ways of their improvement. Nowadays, substituted lithium manganese spinels are used as cathode materials for rechargeable lithium ion batteries due to their low cost and high potential vs. $\mathrm{Li} / \mathrm{Li}^{+}$. These are promising for numerous applications, in spite of capacity fading upon cycling, which hinders their commercialization. In view of this fact, numerous methods of enhancing their properties have been suggested. One of them is based on the surface modification of the electrode material [1]. In this case, the composition of a solid layer formed on the surface of the mother material is changing, and less degradation of the electrode and electrolyte solution occurs.

In our recent papers, two types of lithium manganese spinels, $\mathrm{LiMn}_{2} \mathrm{O}_{4}$ and $\mathrm{LiNi}_{0.5} \mathrm{Mn}_{1.5} \mathrm{O}_{4}$, have been studied in one and the same electrolyte, viz. a $1 \mathrm{~mol} / \mathrm{L}$ solution of $\mathrm{LiPF}_{6}$ in a mixture of ethylene carbonate/dimethyl carbonate with a mass ratio of 1:1 [2-4]. It has been found that in spite of a considerably higher working potential range of the latter material, it is extremely stable on cycling even at high current loads.

Therefore, the aim of this work was to obtain the lithium manganese spinel coated with $\mathrm{LiNi}_{0.5} \mathrm{Mn}_{1.5} \mathrm{O}_{4}$. It might be helpful in achieving more efficient cycling of the electrode material due to the presence of a protective "shell" on the surface of the stoichiometric lithium manganese spinel. 


\section{Research Methodology}

Materials under investigation were synthesized by the citric acid aided procedure described in Refs. [5,6] using solutions of lithium nitrate, nickel (II) nitrate, manganese (II) nitrate, and citric acid (all of analytical grade) mixed in proper molar ratios. In order to modify their surfaces, a pyrolysed precursor of $\mathrm{LiMn}_{2} \mathrm{O}_{4}$ was soaked with the solution containing lithium, nickel, manganese nitrate, and citric acid, so as to obtain a layer of $\mathrm{LiNi}_{0.5} \mathrm{Mn}_{1.5} \mathrm{O}_{4}$ on its surface after pyrolysis. The mass ratio of $\mathrm{LiMn}_{2} \mathrm{O}_{4}$ and $\mathrm{LiNi}_{0.5} \mathrm{Mn}_{1.5} \mathrm{O}_{4}$ was adjusted to 1:0.1. The temperatures of pyrolysis and further annealing of pyrolysed samples were $400{ }^{\circ} \mathrm{C}$ and $700{ }^{\circ} \mathrm{C}$, respectively. For more details of the procedure see our Refs. [2-4].

Electrochemical measurements were performed in model CR2016 coin cells on a home-made automated electrochemical workstation using cyclic voltammetry (CV) and galvanostatic charge/discharge cycling methods. Cells with a lithium metal anode serving as a counter and reference electrode, a cathode made of the material in question, a Celgard 2500 separator membrane, and a $1 \mathrm{~mol} / \mathrm{L}$ solution of $\mathrm{LiPF}_{6}$ in a mixture of ethylene carbonate/dimethyl carbonate with the mass ratio of 1:1 were assembled in a dry glove box. The working electrodes were made of $82 \%$ of the material under consideration, $10 \%$ of a conducting additive and $8 \%$ of a poly(vinylidene difluoride) binder.

\section{Results and Discussion}

In Fig. 1, CV curves for neat $\mathrm{LiMn}_{2} \mathrm{O}_{4}, \mathrm{LiMn}_{2} \mathrm{O}_{4}$ modified with $\mathrm{LiNi}_{0.5} \mathrm{Mn}_{1.5} \mathrm{O}_{4}$, and neat $\mathrm{LiNi}_{0.5} \mathrm{Mn}_{1.5} \mathrm{O}_{4}$ are compared. The data for neat spinels well correspond to those published $[2,3]$. The surface modified material perfectly reproduces the features of the neat $\mathrm{LiMn}_{2} \mathrm{O}_{4}$. The presence of $\mathrm{LiNi}_{0.5} \mathrm{Mn}_{1.5} \mathrm{O}_{4}$ on the surface of the lithium manganese spinel is recognizable as reversible waves at potentials around 4.4-4.9 V.

Galvanostatic charge/discharge cycling data within the 3.5-4.5 V voltage range reveal that the surface modified samples behave like the samples of the neat $\mathrm{LiMn}_{2} \mathrm{O}_{4}$. This means that the surface layer of $\mathrm{LiNi}_{0.5} \mathrm{Mn}_{1.5} \mathrm{O}_{4}$ is easily permeable for $\mathrm{Li}^{+}$ions. Clearly, much work should be done in order to determine the role of the modifier and changes in the resistance of $\mathrm{LiMn}_{2} \mathrm{O}_{4}$ after covering with $\mathrm{LiNi}_{0.5} \mathrm{Mn}_{1.5} \mathrm{O}_{4}$. However, the dependence of capacity retention on the current load presented in Fig. 2 reveals that the surface modified samples are able to endure the current loads of $20 \mathrm{C}(2940 \mathrm{mAh} / \mathrm{g})$ without degradation and after heavy-duty tests deliver the same specific capacity as before current loading. 


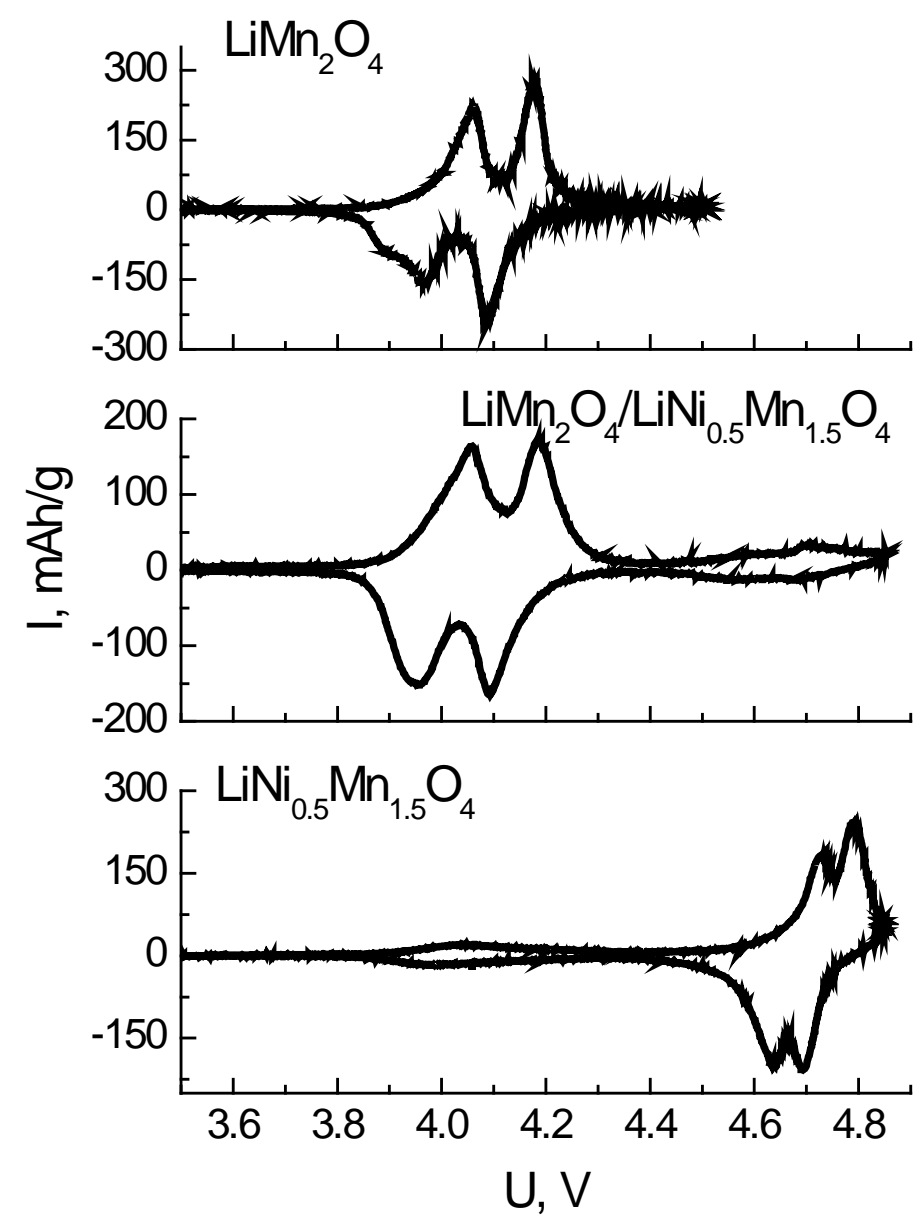

Figure 1. Cycling voltammograms for $\mathrm{LiMn}_{2} \mathrm{O}_{4}$, $\mathrm{LiNi}_{0.5} \mathrm{Mn}_{1.5} \mathrm{O}_{4}$, and surface modified sample $\mathrm{LiMn}_{2} \mathrm{O}_{4} / \mathrm{LiNi}_{0.5} \mathrm{Mn}_{1.5} \mathrm{O}_{4}$.

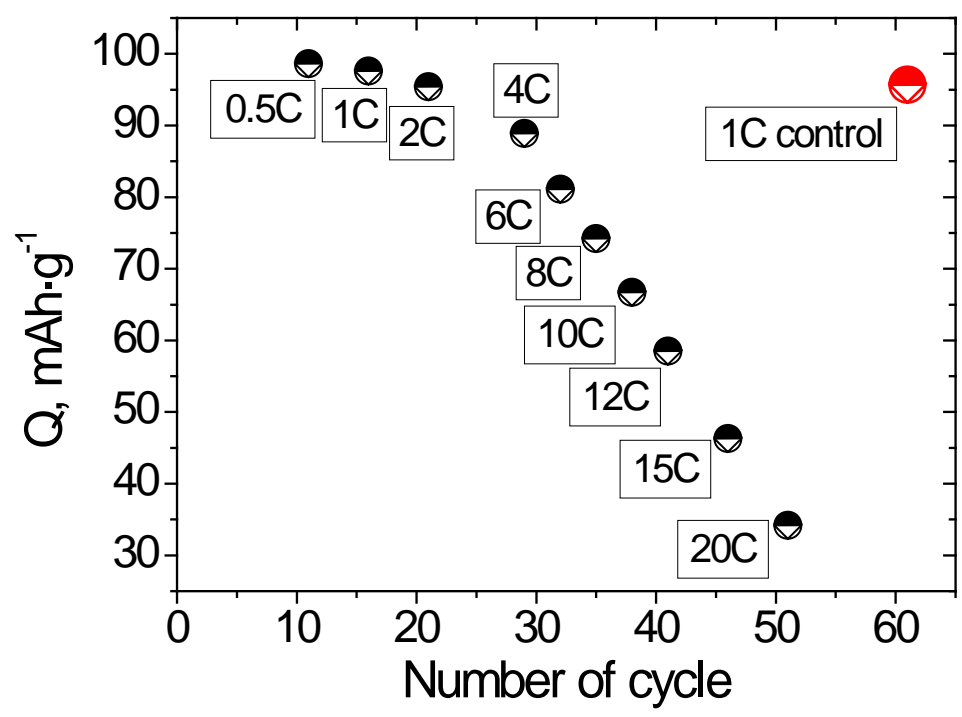

Figure 2. Dependence of discharge capacity on cycle number for the surface modified $\mathrm{LiMn}_{2} \mathrm{O}_{4} / \mathrm{LiNi}_{0.5} \mathrm{Mn}_{1.5} \mathrm{O}_{4}$ sample. Numbers in the figure mean current loads in $C$ units $(1 \mathrm{C}=147 \mathrm{mAh} / \mathrm{g})$ 


\section{Conclusions}

The surface modified samples of $\mathrm{LiMn}_{2} \mathrm{O}_{4}$ coated with $\mathrm{LiNi}{ }_{0.5} \mathrm{Mn}_{1.5} \mathrm{O}_{4}$ have been synthesized by a citric acid aided method. Electrochemical tests reveal that the surface layer of $\mathrm{LiNi}_{0.5} \mathrm{Mn}_{1.5} \mathrm{O}_{4}$ is easily permeable for $\mathrm{Li}^{+}$ions. The surface modified samples are able to endure the current loads of $20 \mathrm{C}(2940 \mathrm{mAh} / \mathrm{g})$ without degradation and after heavy-duty tests deliver the same specific capacity as before current loading.

\section{Acknowledgments}

The author is grateful to Dr. S.A. Kirillov for discussions, advice and comments.

\section{References}

[1] Z. Chen, Y. Qin, K. Amine, Y.-K. Sun, Role of surface coating on cathode materials for lithium-ion batteries, Journal of Materials Chemistry, 20, 7606-7612 (2010).

[2] A.V. Potapenko, S.I. Chernukhin, I.V. Romanova, K.Sh. Rabadanov, M.M. Gafurov, S.A. Kirillov, Citric acid aided synthesis, characterization, and high-rate electrochemical performance of $\mathrm{LiNi}_{0.5} \mathrm{Mn}_{1.5} \mathrm{O}_{4}$, Electrochimica Acta, 134, 444-449 (2013).

[3] A.V. Potapenko, S.I. Chernukhin, S.A. Kirillov, A new method of pretreatment of lithium manganese spinels and high-rate electrochemical performance of $\mathrm{Li}\left[\mathrm{Li} 0.033 \mathrm{Mn}_{1.967} \mathrm{O}_{4}\right.$. Materials for Renewable and Sustained Energy 3, 40-47 (2014).

[4] A.V. Potapenko, S.I. Chernukhin, I.V. Romanova, K.Sh. Rabadanov, M.M. Gafurov, S.A. Kirillov, High-rate Electrochemical Performance of Nanosized $\mathrm{LiNi}_{0.5} \mathrm{Mn}_{1.5} \mathrm{O}_{4}$, International conference «Nanomaterials: Application and Properties (NAP-2013)», Sumi, Ukraine, 2, 04NEA06 (4 pp) (2013).

[5] I.A. Farbun, I.V. Romanova, T.E. Terikovskaya, D.I. Dzanashvili, S. A. Kirillov, Complex formation in the course of synthesis of zinc oxide from citrate solutions, Russian Journal of Applied Chemistry, 80, 17731778 (2007).

[6] I.A. Farbun, I.V. Romanova, S.A. Kirillov, Optimal design of powdered nanosized oxides of high surface area and porosity using a citric acid aided route, with special reference to $\mathrm{ZnO}$, Journal of Sol-Gel Science and Technology, 68, 411-422 (2013). 


\title{
COMPARATIVE ELECTROCHEMICAL CHARACTERISTICS OF PURE AND ALUMINUM-DOPED $\mathrm{LiMn}_{2} \mathrm{O}_{4}$ CATHODE MATERIALS FOR LITHIUM-ION BATTERIES
}

\author{
V. KOSILOV, Y. KRAVETS \\ Joint Department of Electrochemical Energy Systems \\ 3s23p2@bigmir.net
}

In this paper, regularities of overstoichiometric lithiation of $\mathrm{LiMn}_{2} \mathrm{O}_{4}$ spinel samples of different origin have been established using the methods of galvanostatic (CCCV) and voltammetric cycling. Unlike individual $\mathrm{LiMn}_{2} \mathrm{O}_{4}$, the aluminum doped spinel reveals high stability after repeated overdischarge. In particular, individual $\mathrm{LiMn}_{2} \mathrm{O}_{4}$ does not tolerate even a few individual overdischarge cycles of the cathode below 3.0 V, whereas several overdischarge cycles are not critical for the aluminum doped spinel.

The lithium manganese spinel $\mathrm{LiMn}_{2} \mathrm{O}_{4}$ has been known since 1983 as a cathode material for lithium-ion batteries [1] and is the subject of numerous researches to this day $[2,3]$. The electrochemical intercalation/ deintercalation of lithium ions into/from the lattice of $\mathrm{LiMn}_{2} \mathrm{O}_{4}$ occurs at about $4 \mathrm{~V}$ according to eq. (1),

$$
\mathrm{LiMn}_{2} \mathrm{O}_{4} \leftrightarrow \mathrm{Li}_{1-x} \mathrm{Mn}_{2} \mathrm{O}_{4}+x \mathrm{Li}^{+}+x \mathrm{e}^{-} .
$$

The theoretical capacity of the spinel is $148 \mathrm{mAh} \cdot \mathrm{g}^{-1}$. In the composition ranges of $0 \leq x \leq 0.5$ and $0.5 \leq x \leq 1.0$, the reaction takes place in two stages, but the spinel keeps its cubic structure with the lattice parameter $a=8.248 \AA$. These stages can be well observed on galvanostatic curves, which consist of two separated flat regions, and on cyclic voltammetry curves having two typical peaks corresponding with the intercalation/ deintercalation of lithium ions. At the same time, when lithium ions are in excess, $x>1$ (overlithiation), the intercalation potential of lithium ions becomes $-2.9 \mathrm{~V}$ to $\mathrm{Li}^{\prime} \mathrm{Li}^{+}$, and the spinel structure experiences a tetragonal disorder with a small increase in the unit cell volume ( $a=8.007 \AA, c=9.274 \AA$ ) according to reaction (2):

$$
\mathrm{Li}+\mathrm{LiMn}_{2} \mathrm{O}_{4} \leftrightarrow 2 \mathrm{LiMnO}_{2}
$$

Furthermore, the Jahn-Teller effect contributes to this distortion. It can be observed during the accumulation of more than $50 \%$ of $\mathrm{Mn}^{3+}$ ions according to reaction (2) and results in the symmetry lowering of the structure [4]. Low cycling ability of lithium-ion batteries with $\mathrm{LiMn}_{2} \mathrm{O}_{4}$ cathodes, typical for reaction (2), is mainly due to the destruction of the cathode material because of its asymmetrical expansion/contraction 
upon charging/discharging [5]. One of the ways to improve electrochemical characteristics of the lithium-manganese spinel is the substitution of manganese ions and obtaining compounds of a $\mathrm{LiMe}_{1}$. ${ }_{x} \mathrm{Me}_{x} \mathrm{O}_{4}$ formula [6].

Reaction (2) can partly occur upon malfunctions in a battery operation, first of all, upon overdischarge. The effect of overdischarge (overlithiation) on the stoichiometric spinel $\mathrm{LiMn}_{2} \mathrm{O}_{4}$ prepared by different methods is well described [5]. In order to avoid overdischarge and the occurrence of reaction (2), charge-discharge cycling of doped spinels is conducted at discharge potentials above $3.0 \mathrm{~V}$ [7]. As lowering the charge/discharge voltage inevitably leads to overdischarge and overlithiation effects, the determination of the overlithiation mechanism and its role in various modifications of the lithium-manganese spinel is an important issue. Therefore the objectives of this research have been to establish the general pattern of overstoichiometric lithiation of $\mathrm{LiMn}_{2} \mathrm{O}_{4}$ and to study the effect of excess lithium intercalation on the following electrochemical behavior of manganese spinel in high voltage regions. From a practical point of view a long-term cycling of cathodes based on spinel materials in different potential ranges will allow to draw a conclusion about their stability to the overdischarge phenomena during exploitation of lithium-ion batteries.

\section{Materials and methods}

In this study, commercial samples of lithium-manganese spinel, viz., stoichiometric $\mathrm{LiMn}_{2} \mathrm{O}_{4}$ EQ-Lib-LMO by MTI (USA) and modified $\mathrm{LiMn}_{2} \mathrm{O}_{4}$ HPM-9051C by Toda Kogyo Corp. (Japan), containing $1.52 \%$ aluminum were used (Table 1).

Electrochemical studies were performed in sample button-type 2016 cells with lithium metal as a counter and reference electrode. A slurry was prepared by mixing the active material, Super P and SFG6 (Timcal) conductive additives, and a PVdF binder (Kureha \#1100) in $\mathrm{N}$-methylpyrrolidone (Sigma-Aldrich) with the "dry" component ratio of 80:7:5:8 in a high-speed mixer (IKA RW 20). The working electrode was made by coating the aluminum current collector with the slurry. The mass loading of the electrode was $4-5 \mathrm{mg} / \mathrm{cm}^{2}$; it was pressed to the thickness of $17-20 \mu \mathrm{m}$. A $1 \mathrm{M}$ solution of $\mathrm{LiPF}_{6}$ in a mixture of EC and DMC (1:1 by weight) was used as an electrolyte. The cells for cycling were assembled in an argon-filled glove box. Electrochemical experiments were conducted on a home-made automated electrochemical workstation using cycling voltammetry (CV) at the scan rate of $0.1 \mathrm{mV} / \mathrm{s}$ and galvanostatic cycling in $\mathrm{CC}$ and $\mathrm{CCCV}$ modes. The $146.7 \mathrm{~mA} / \mathrm{g}$ current numerically equal to the theoretical discharge capacity of the stoichiometric $\mathrm{LiMn}_{2} \mathrm{O}_{4}$ was taken as $1.0 \mathrm{C}$. 
Table 1. Physical and chemical characteristic of $\mathrm{LiMn}_{2} \mathrm{O}_{4}$

\begin{tabular}{|l|c|c|}
\hline & $\begin{array}{c}\mathrm{LiMn}_{2} \mathrm{O}_{4} \\
\text { MTI EQ-Lib-LMO (USA) }\end{array}$ & $\begin{array}{c}\mathrm{LiMn}_{2} \mathrm{O}_{4} \\
\text { Toda HPM-9051C(Japan) }\end{array}$ \\
\hline Working range & $3,4-4,5 \mathrm{~V}$ & $3,4-4,3 \mathrm{~V}$ \\
\hline Nominal capacity & $115 \mathrm{~mA} \cdot \mathrm{h} / \mathrm{g}$ & $96 \mathrm{~mA} \cdot \mathrm{h} / \mathrm{g}$ \\
\hline Particle size & $12 \mathrm{mkm}$ & $10 \mathrm{mkm}$ \\
\hline Specific surface & $0,4 \sim 1,0 \mathrm{~m}^{2} / \mathrm{g}$ & $0,51 \mathrm{~m}^{2} / \mathrm{g}$ \\
\hline
\end{tabular}

Before the main experiment, all samples underwent four formation cycles of galvanostatic charge/discharge cycling with a $0.1 \mathrm{C}$ current and three testing CV cycles with the scan rate of $0.1 \mathrm{mV} / \mathrm{s}$. Testing CV cycles in the typical range of potentials were conducted between series with different final discharge potentials.

\section{Results and Discussion}

In preliminary CV tests (Fig. $1 \mathrm{~A}, \mathrm{~B}$ ), characteristics of both electrode materials with the final intercalation potential of $1.5 \mathrm{~V}$ were obtained. First, electrode cycling in the standard range of potentials was conducted and typical CV characteristics (cycle 6) extensively described in literature [1-8] were acquired. The specific capacities of the stoichiometric spinel (MTI) and the aluminum-modified sample (Toda) are $115 \mathrm{~mA} \cdot \mathrm{h} / \mathrm{g}$ and 91 $\mathrm{mA} \cdot \mathrm{h} / \mathrm{g}$, respectively.

Then cycling in the lower potential range (2.4-3.5 V) was performed. There were obtained a peak in the cathode region and a reverse peak in the anode region at around $2.9 \mathrm{~V}$ (cycle 9), corresponding to the $\mathrm{Mn}^{4+} \leftrightarrow \mathrm{Mn}^{3+}$ red-ox reaction and to the transformation of the cubic phase to the tetragonal one [9]. Cycling in the 2.4-3.5 $\mathrm{V}$ range showed reverse capacity of about 80 and $46 \mathrm{~mA} \cdot \mathrm{h} / \mathrm{g}$ for the MTI and Toda samples, respectively. After this, the electrodes were cycled in the typical potential range (cycle 12). A small decrease in peak current (and, respectively, capacity) in the regular spinel and a nearly complete reproducing of the curve in the modified $\mathrm{LiMn}_{2} \mathrm{O}_{4}$, compared to cycle 3, were observed.
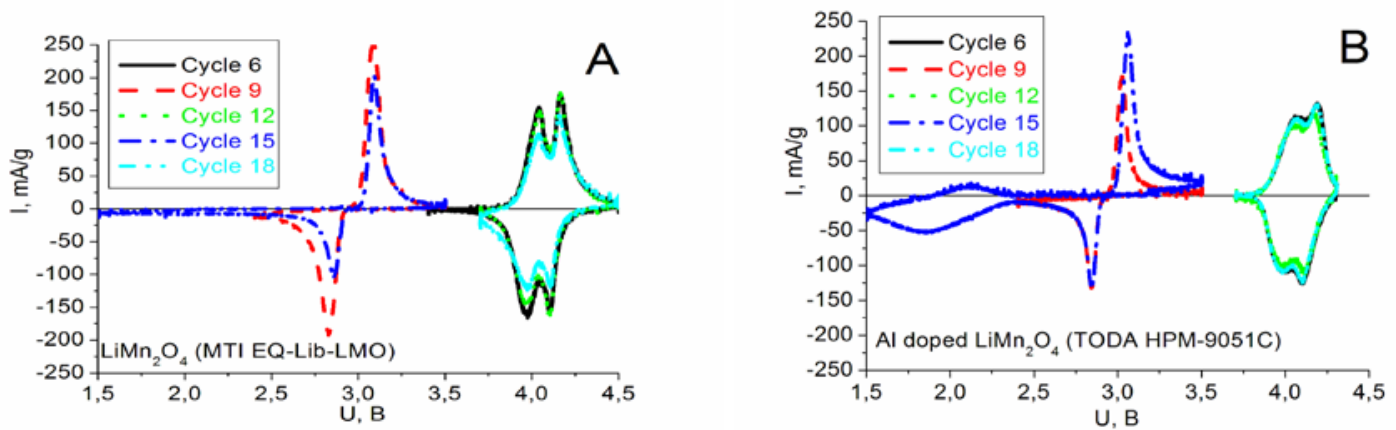

Figure 1. CV curves of $\mathrm{LiMn}_{2} \mathrm{O}_{4}$ by MTI (A) and Toda (B) upon cycling to 2.4 and $1.5 \mathrm{~V}$ 
Further, electrodes were cycled in the potential range of $1.5-3.5 \mathrm{~V}$ imitating a deep overdischarge. The treatment of the MTI material to 1.5 $\mathrm{V}$ (Fig. 1A, cycle 15) showed a practically full absence of processes in the $1.5-2.4 \mathrm{~V}$ potential range. At the same time, CV characteristics in the standard potential range demonstrated a considerable decrease in peak current values (cycle 18) with a decrease in specific capacity to 94 $\mathrm{mA} \cdot \mathrm{h} / \mathrm{g}$.

A deeper intercalation to $1.5 \mathrm{~V}$ (Fig.1 B, cycle 13) showed a capacity up to $110-115 \mathrm{~mA} \cdot \mathrm{h} / \mathrm{g}$, with a wave at about $2.0 \mathrm{~V}$, which disappears on the following cycles (curve 15). Interestingly, returning to the cycling potential range of $2.4 \mathrm{~V}-3.5 \mathrm{~V}$ gave a twofold increase in capacity, from 46 to $94 \mathrm{~mA} \cdot \mathrm{h} / \mathrm{g}$. Test CV curves obtained in the higher-voltage region before and after the low-voltage treatment (curves 12 and 18), showed a minor decrease in specific capacity without the change of the curve shapes. This capacity drop can be explained, most likely, by the increase in the electrode resistance because of the growth of passive films during multiple cycles in the low-voltage range. The effect of increasing peak currents and specific capacity in the intercalation/deintercalation process in the potential region around $3.0 \mathrm{~V}$ after treatment until $1.5 \mathrm{~V}$ is presumably related to the structure features of the lithium-manganese spinel doped with aluminum, and requires additional physical, chemical and electrochemical investigations.

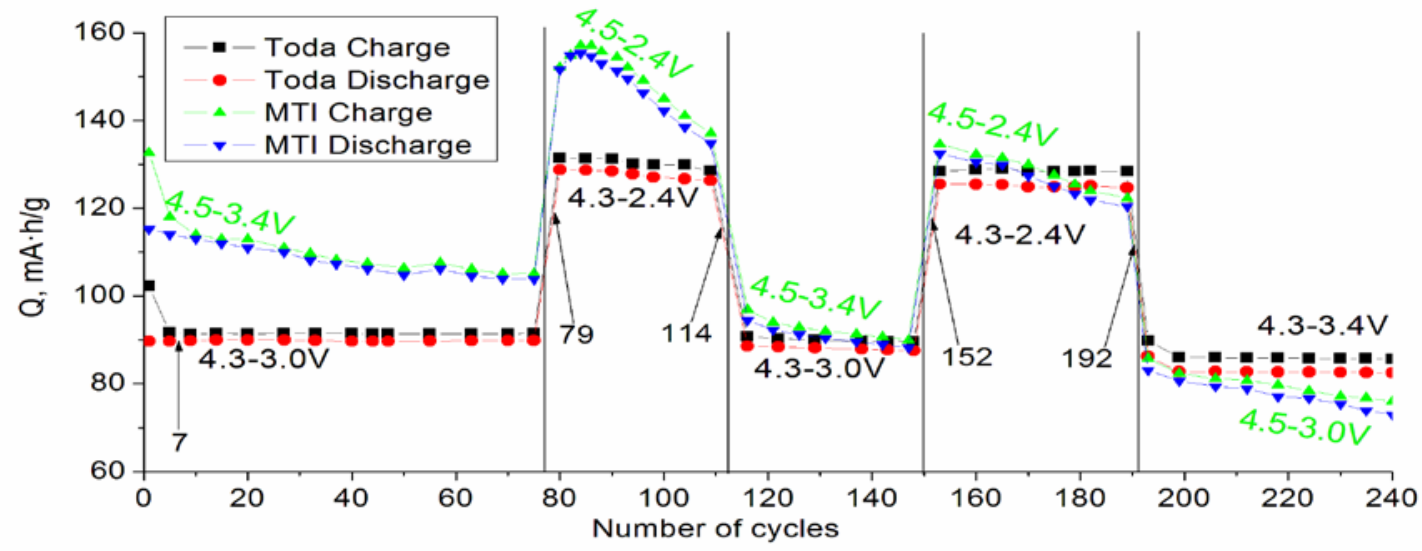

Figure 2. Dependence of specific capacity in the lithium intercalation-deintercalation processes in $\mathrm{LiMn}_{2} \mathrm{O}_{4}$ by $\mathrm{MTI}(A)$ and Toda (B) during long-term cycling in different ranges of potentials. Numbered arrows refer to the number of the cycle in test $\mathrm{CV}$ measurements

As a next step, a long-term resource cycling of MTI and Toda samples at standard working ranges (see Table 1) and with overdischarge to $2.4 \mathrm{~V}$ (Fig.2) was made. Cycling was held in the CCCV regime: charging with a $1.0 \mathrm{C}$ current, surcharging to $0.1 \mathrm{C}$, and discharging at $1.0 \mathrm{C}$. Between these regimes, $\mathrm{CV}$ measurements were carried out at a scan rate of $0.1 \mathrm{mV} / \mathrm{s}$ (Fig. $3 \mathrm{~A}, \mathrm{~B}$ ). 
As can be observed from Fig. 2, cycling of $\mathrm{LiMn}_{2} \mathrm{O}_{4}(\mathrm{MTI})$ to $3.4 \mathrm{~V}$ exhibits a decrease in specific capacity values, which equal to 105 $\mathrm{mA} \cdot \mathrm{h} / \mathrm{g}$ after 75 cycles, whereas $\mathrm{LiMn}_{2} \mathrm{O}_{4}$ (Toda) holds a higher stability of electrochemical characteristics. The value of specific capacity while cycling in the standard range of potentials (4.3-3.0 V) during 75 cycles remains constant and is of about $90 \mathrm{~mA} \cdot \mathrm{h} / \mathrm{g}$.

As shown in Fig.2, decreasing the cycling voltage to $2.4 \mathrm{~V}$ (cycles 80-109) shows an increase in the specific capacity of $\mathrm{LiMn}_{2} \mathrm{O}_{4}$ (MTI) to $155 \mathrm{~mA} \cdot \mathrm{h} / \mathrm{g}$ with the following rapid decline to $135 \mathrm{~mA} \cdot \mathrm{h} / \mathrm{g}$. For $\mathrm{LiMn}_{2} \mathrm{O}_{4}$ (Toda), widening the working potential range leads to smaller changes in specific capacity.

Returning to the 4.5-3.4 $\mathrm{V}$ cycling window (cycles 115-147) for $\mathrm{LiMn}_{2} \mathrm{O}_{4}(\mathrm{MTI})$ reveals a decrease in capacity compared to the starting cycling from 105 to $95 \mathrm{~mA} \cdot \mathrm{h} / \mathrm{g}$ and to a further capacity decline with the speed of $0.17 \mathrm{~mA} \cdot \mathrm{h} / \mathrm{g}$ per cycle. On the contrary, $\mathrm{LiMn}_{2} \mathrm{O}_{4}$ (Toda) in the standard cycling window restores its initial characteristics. Further cycling to lowest possible potentials (cycles 153-189) and within recommended potentials (cycles 193-240) supports the trend obtained.

$\mathrm{CV}$ measurements in the standard potential range conducted after each series of the resource cycling are shown in Fig. $3 \mathrm{~A}, \mathrm{~B}$. It is evident that after cycling $\mathrm{LiMn}_{2} \mathrm{O}_{4}(\mathrm{MTI})$ to the final potential of $2.4 \mathrm{~V}$ a fast decrease in the peak current and current slope is observed. Fig. 4 reveals that the specific capacity values and the Coulomb efficiency of lithium intercalation/deintercalation are also decreasing.
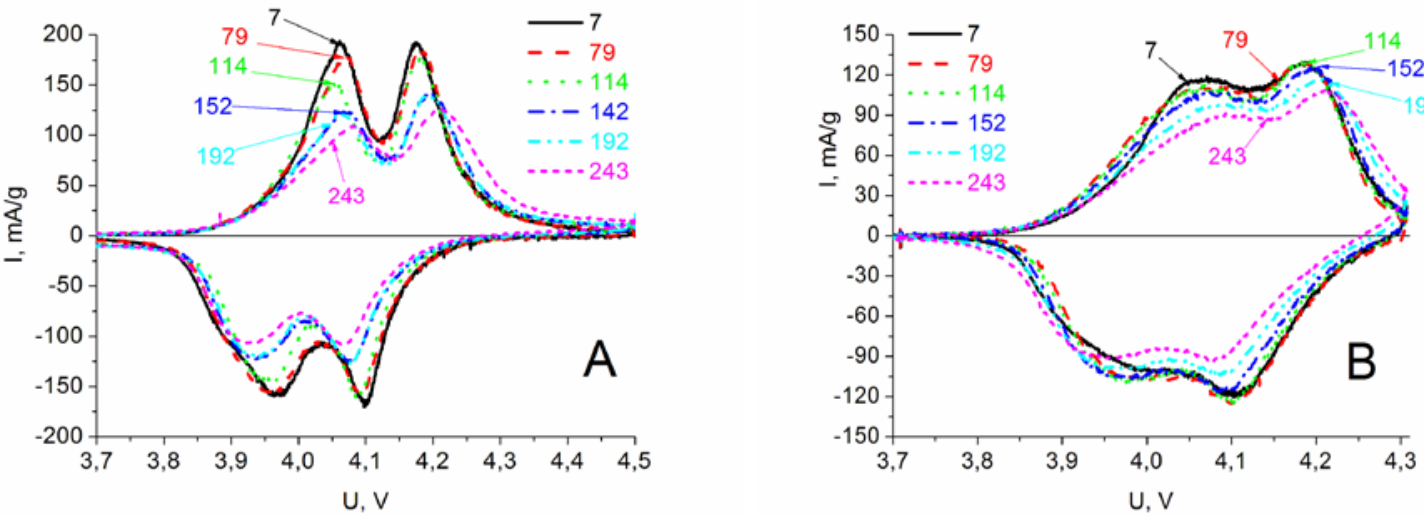

Figure 3. $\mathrm{CVs}$ of $\mathrm{LiMn}_{2} \mathrm{O}_{4}$ by $\mathrm{MTI}(\mathrm{A})$ and Toda (B) on long-term cycling to different potentials according to conditions denoted in Fig.2.

CV characteristics of $\mathrm{LiMn}_{2} \mathrm{O}_{4}$ (Toda) (Fig. 3 B) confirm conclusions regarding the dependence of capacity on cycle number. During more than 240 cycles, the shape of the CV curves remains constant. A decrease in the peak current and the current slope are observed since 190 cycles. At the same time, a decrease in the specific capacity and Coulomb efficiency is noticed. 


\section{Conclusions}

Simulation of deep overdischarge during 240 cycles shows a high stability of the aluminum doped lithium-manganese spinel compared with the stoichiometric sample. From a practical point of view it can be stated that commercial $\mathrm{LiMn}_{2} \mathrm{O}_{4}(\mathrm{MTI})$ as a cathode material in lithium-ion batteries does not tolerate even a few overdischarge cycles at $3.0 \mathrm{~V}$. On the contrary, the application of lowered discharge potentials to the aluminum doped $\mathrm{LiMn}_{2} \mathrm{O}_{4}$ (Toda) is not critical for its successful operation.

\section{Acknowledgments}

The authors are grateful to Mr S.I. Chernukhin for assistance and to Dr. S.A. Kirillov for discussions and comments.

\section{References}

[1] Thackeray M.M., David W.I.F., Bruce P.G., Goodenough J.B., Lithium insertion into manganese spinels, Mater. Res. Bull., 18, 461-472 (1983).

[2] Whittingham M.S., Lithium batteries and cathode materials, Chem. Rev., 104, 4271-4301 (2004).

[3] Park O.K., Cho Y., Lee S., Yoo H-C., Song H-K., Cho J. Who will drive electric vehicles, olivine or spinel?, Energy Environ. Sci., 4, 16211633, (2011).

[4] Yamada A., Lattice instability in $\mathrm{Li}\left(\mathrm{Li}_{x} \mathrm{Mn}_{2-x}\right) \mathrm{O}_{4}$, J. Solid State Chem., 122, 160-165 (1996).

[5] Winter M., Besenhard J.O., Spahr M.E., Novak P., Insertion electrode materials for rechargeable lithium batteries, Adv. Mater. 10, 725-763 (1998).

[6] Ohzuku T., Takeda S., Iwanaga M., Solid-state redox potentials for $\mathrm{Li}\left[\mathrm{Me}_{1 / 2} \mathrm{Mn}_{3 / 2}\right] \mathrm{O}_{4}$ (Me: 3d-transition metal) having spinel-framework structures: a series of 5 volt materials for advanced lithium-ion batteries, J. Power Sources, 81, 90-94 (1999).

[7] Strobel P., Ibarra Palos A., Anne M. Structural, magnetic and lithium insertion properties of spinel-tipe $\mathrm{Li}_{2} \mathrm{Mn}_{3} \mathrm{MO}_{8}$ oxides $(\mathrm{M}=\mathrm{Mg}$, Co, $\mathrm{Ni}, \mathrm{Cu}$ ), J. Materials Chem., 10, 429-436 (2000).

[8] Xu H., Cheng B., Xu E., Xu L., Yang J., Qian Y., Investigations of high rate capability and high temperature performance for nano-sized porous $\mathrm{LiAl}_{x} \mathrm{Mn}_{2-\mathrm{x}} \mathrm{O}_{4}(\mathrm{x}=0,0.05,0.1,0.15)$ cathode material, Int. J. Electrochem. Sci., 7, 11917 - 11929 (2012).

[9] Potapenko A.V., Kirillov S.A., Lithium manganese spinel materials for high-rate electrochemical applications, J. Energy Chem., 23, 543-558 (2014). 


\title{
EFFECT OF THE ELECTROLYTE COMPOSITION ON THE ELECHTROCHEMICAL PROPERTIES OF BOTH NATURAL AND SYNTETIC GRAPHITE MATERIALS MODIEFIED BY 2Co(+3)-Ni(+2) COMPLEXES WITH AMINOALCOHOLS
}

\author{
ZUL'FIGAROV A.O., POTASKALOV V.A., ANDRIIKO A.A. \\ National Technical University of Ukraine "Kyiv Polytechnic Institute" \\ sars2007@ukr.net
}

The method of preparation and properties of the carbon materials modified by polynuclear complex compound 2Co-Ni with aminoalcohols have been used. As the graphite substrate used natural and synthetic origin. Were formed lithium ion electrochemical current sources with electrolytes based on lithium perchlorate and LiPF $_{6}$. The combination of electrolyte and graphite certain origins helps to reduce cost in the manufacture of lithium ion elements along with improving their specific electrochemical characteristics.

Presently, synthetic or artificial graphites are the main materials for the negative electrodes of commercial Li-ion batteries. In order to improve the electrochemical properties of these materials (capacity, cycleability), various methods of their modification are currently under development. Among them, grafting of the heterometal trinuclear complexes of $2 \mathrm{Me}(+3)-\mathrm{Me}(+2)$, in particular, $2 \mathrm{Co}(+3)-\mathrm{Ni}(+2)$, with aminoalcohols, followed by pyrolysis in an inert atmosphere, proved to be very efficient $[1,2]$.

The aim of this work was to find out how the composition of the aprotic organic electrolyte affects the properties of modified graphites of different origin (either synthetic or natural).

\section{Research Methodology}

Chemical purity grade cobalt $\mathrm{Co}\left(\mathrm{NO}_{3}\right)_{2}{ }^{*} 6 \mathrm{H}_{2} \mathrm{O}$ and nickel $\mathrm{Ni}\left(\mathrm{NO}_{3}\right)_{2}{ }^{\star} 6 \mathrm{H}_{2} \mathrm{O}$ nitrates, potassium hydroxide $\mathrm{KOH}$, monoaminoethanol $(\mathrm{HEtm})$, diaminoethanol $\left(\mathrm{H}_{2}\right.$ Detm $)$ and triaminoethanol $\left(\mathrm{H}_{3} \mathrm{Tetm}\right)$ and isopropanol were used for the synthesis of $2 \mathrm{Co}-\mathrm{Ni}$ complexes. The syntheses were performed in two steps.

First, the inner complex $\mathrm{Co}(+3)$ compounds with each aminoalcohol were obtained. For this, the solutions of cobalt nitrate and potassium hydroxide in isopropanol were prepared. Further on, an overstoichiometric excess of the aminoalcohol was added to the cobalt nitrate solution (molar ratios $\mathrm{Co}\left(\mathrm{NO}_{3}\right)_{2} / \mathrm{HEtm}, \mathrm{Co}\left(\mathrm{NO}_{3}\right)_{2} / \mathrm{H}_{2}$ Detm and 
$\mathrm{Co}\left(\mathrm{NO}_{3}\right)_{2} / \mathrm{H}_{3}$ Tetm were equal to $1 / 4,1 / 4$ and $1 / 2.2$ accordingly), and after that, the potassium hydroxide solution was added. The mixture stayed at room temperature for $30 \mathrm{~min}$, and formed potassium nitrate crystals were filtered out. The filtrate solution was aerated for 2-3 hours by means of a compressor. After that, the solution was aged for 3 days.

The chemical reactions (1), (3) and (5) correspond to the formation of the inner complex compounds with HEtm, $\mathrm{H}_{2}$ Detm and $\mathrm{H}_{3}$ Tetm accordingly.

The second step was the synthesis of trinuclear complex. It was performed as follows. The nickel nitrate was dissolved in isopropanol at $50-60^{\circ} \mathrm{C}$, cooled down to the room temperature and added to the previously prepared solution of the inner complex compound at constant stirring. Thus obtained, the mixture was aged for 3 days.

The chemical reactions (2), (4) and (6) correspond to the formation of trinuclear complexes with HEtm, $\mathrm{H}_{2}$ Detm and $\mathrm{H}_{3}$ Tetm accordingly.

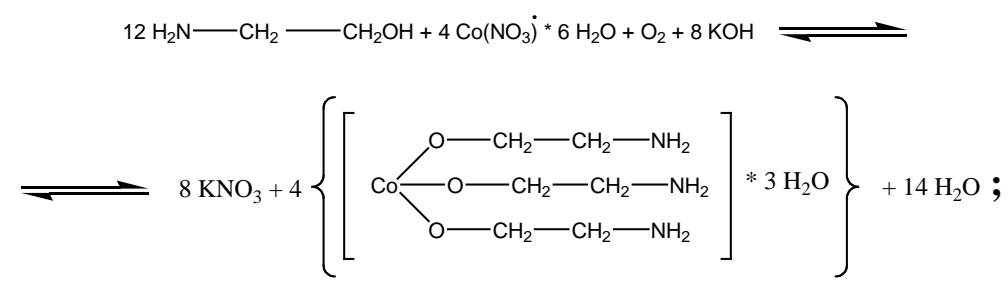

$\mathrm{Ni}\left(\mathrm{NO}_{3}\right)_{2} * 6 \mathrm{H}_{2} \mathrm{O}+2\left\{\left[\mathrm{Co}(\mathrm{Etm})_{3}\right] * 3 \mathrm{H}_{2} \mathrm{O} \longrightarrow \mathrm{Ni}\left[\mathrm{Co}(\mathrm{Etm})_{3}\right]_{2}\left(\mathrm{NO}_{3}\right)_{2}+12 \mathrm{H}_{2} \mathrm{O}\right.$

$8 \mathrm{NH} \mathrm{CH}_{2}-\mathrm{CH}_{2} \mathrm{OH}+4 \mathrm{Co}\left(\mathrm{NO}_{3}\right)_{2} * 6 \mathrm{H}_{2} \mathrm{O}+\mathrm{O}_{2}+8 \mathrm{KOH} \rightleftharpoons$

$\rightleftharpoons 8 \mathrm{KNO}_{3}+33 \mathrm{H}_{2} \mathrm{O}+4\left\{\left[\begin{array}{c}\mathrm{Co}-\mathrm{O}-\mathrm{CH}_{2}-\mathrm{CH}_{2}-\mathrm{CH}_{2}-\mathrm{CH}_{2}^{\mathrm{NH}} \\ \mathrm{O}-\mathrm{CH}_{2}-\mathrm{CH}_{2}-{ }^{\mathrm{NH}} \\ \mathrm{HO}-\mathrm{CH}_{2}-\mathrm{CH}_{2}\end{array}\right] * \mathrm{H}_{2} \mathrm{O}\right\} ;$

$\mathrm{Ni}\left(\mathrm{NO}_{3}\right)_{2} * 6 \mathrm{H}_{2} \mathrm{O}+2[\mathrm{Co}($ Detm * Hdetm $)] * \mathrm{H}_{2} \mathrm{O} \longrightarrow\left\{\mathrm{Ni}[\mathrm{Co}(\text { Detm * Hdetm })]_{2}\right\}\left(\mathrm{NO}_{3}\right)_{2}+8 \mathrm{H}_{2} \mathrm{O}$.

$8 \mathrm{~N}=\mathrm{CH}_{2}-\mathrm{CH}_{2}-\mathrm{CH}_{2}-\mathrm{OH}+4 \mathrm{Co}\left(\mathrm{NO}_{3}\right)_{2} * 6 \mathrm{H}_{2} \mathrm{O}+8 \mathrm{KOH}+\mathrm{O}_{2}=$

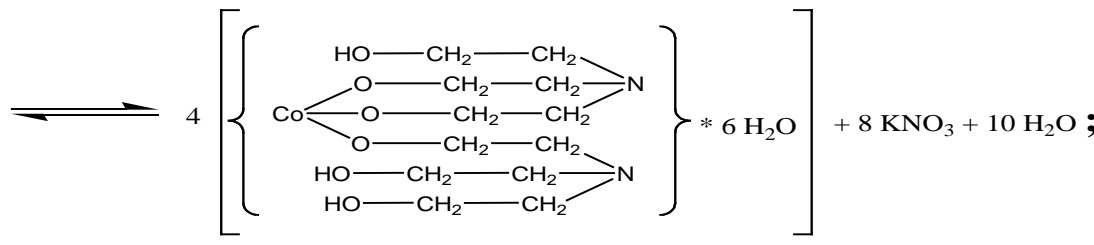

$\mathrm{Ni}\left(\mathrm{NO}_{3}\right)_{2} * 6 \mathrm{H}_{2} \mathrm{O}+2\left\{\left[\mathrm{Co}\left(\mathrm{H}_{2}\right.\right.\right.$ tetm $*$ Htetm $\left.\left.)\right] * 6 \mathrm{H}_{2} \mathrm{O}\right\} \longrightarrow$

$\longrightarrow\left\{\mathrm{Ni}\left[\mathrm{Co}\left(\mathrm{H}_{2} \mathrm{tetm} * \mathrm{Htetm}\right)\right]_{2}\right\}\left(\mathrm{NO}_{3}\right)_{2}+18 \mathrm{H}_{2} \mathrm{O}$. 
Two types of graphite materials were chosen for the investigation synthetic LBG-73 (Superior Graphite Company, USA), and natural GP-1 (Ukraine). Their modification was performed by adsorption from isopropanol solution $(0.05 \mathrm{~mol}$ of the complex per $1 \mathrm{~g}$ of graphite) with subsequent pyrolysis in high purity argon atmosphere. Adsorption time was 2 days. After that the material was filtered and dried at room temperature. The pyrolysis was carried out at $500^{\circ} \mathrm{C}, 550^{\circ} \mathrm{C}$ and $650^{\circ} \mathrm{C}$ for mono- di- and triaminoethanol complexes accordingly during 1 hour.

Investigation of the electrochemical properties of the modified graphite materials was performed in button 2016 size mock-up cells with Li counter-electrode. Two types of the electrolytes were tested - with lithium perchlorate $\mathrm{LiClO}_{4}$ and lithium fluorophosphate $\mathrm{LiPF}_{6}$. The salts were dissolved in equimolar mixture of ethylencarbonate (EC) and dimethylcarbonate (DMC). The assembled cells were tested in galvanostatic conditions using the 8-channel computer governed equipment.

\section{Results and Discussions}

The electrochemical behavior of natural and synthetic graphites in the perchlorate electrolyte is shown in Fig1 and Fig2.

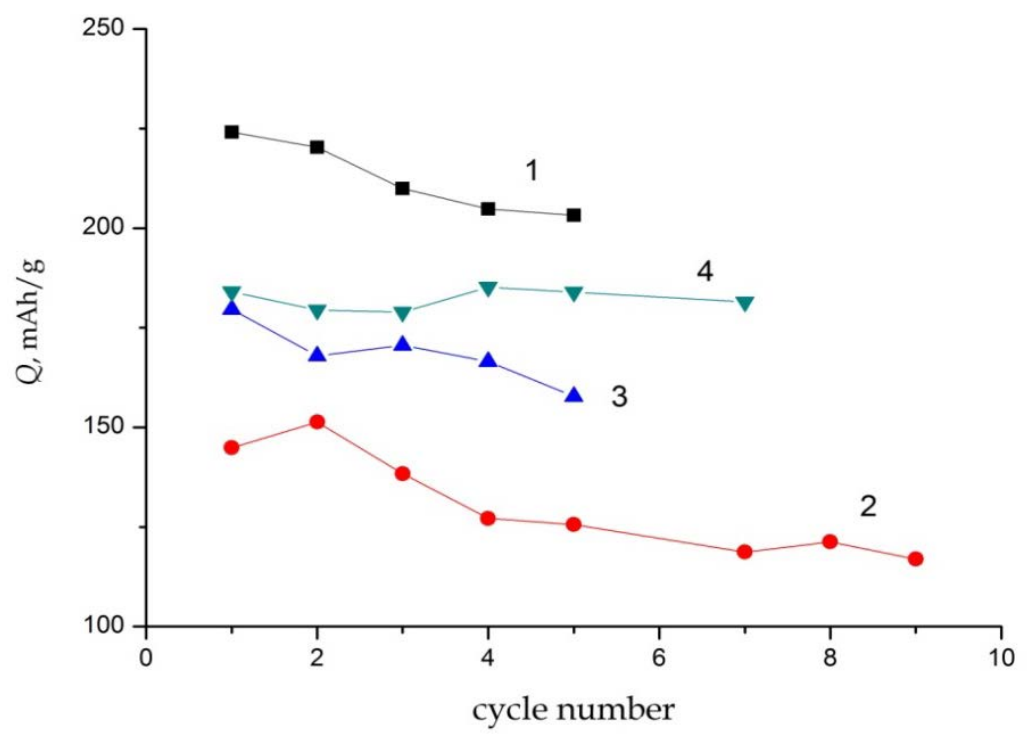

Figure 1. Specific discharge capacities vs. cycle number for natural graphite in perchlorate electrolyte:

1 - original, 2 - modified by monoaminoethanol, 3 - modified by diaminoethanol and 4 - modified by triaminoethanol pyrolysis products. Current load $10 \mathrm{~mA} / \mathrm{g}$ 


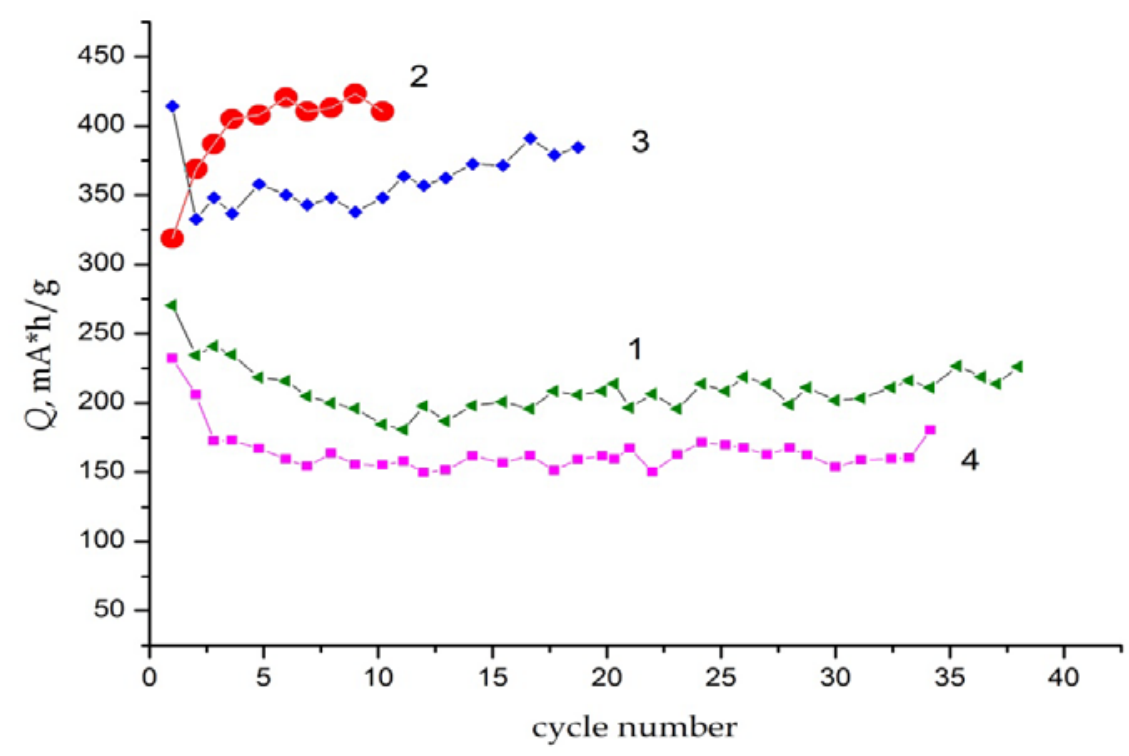

Figure 2. Specific discharge capacities vs. cycle number for synthetic graphite LBG-73 in perchlorate electrolyte:

1 - original, 2 - modified by monoaminoethanol, 3 - modified by diaminoethanol and 4 - modified by triaminoethanol pyrolysis products. Current load $10 \mathrm{~mA} / \mathrm{g}$

As follows from Fig1, no catalytic effect is observed for the modified samples of natural graphite in the perchlorate electrolyte. Meanwhile, the modification effect is quite pronounced for the artificial graphite.

The results of the modification is much better in case of hexafluorophosphate electrolyte, Fig3 and Fig4.

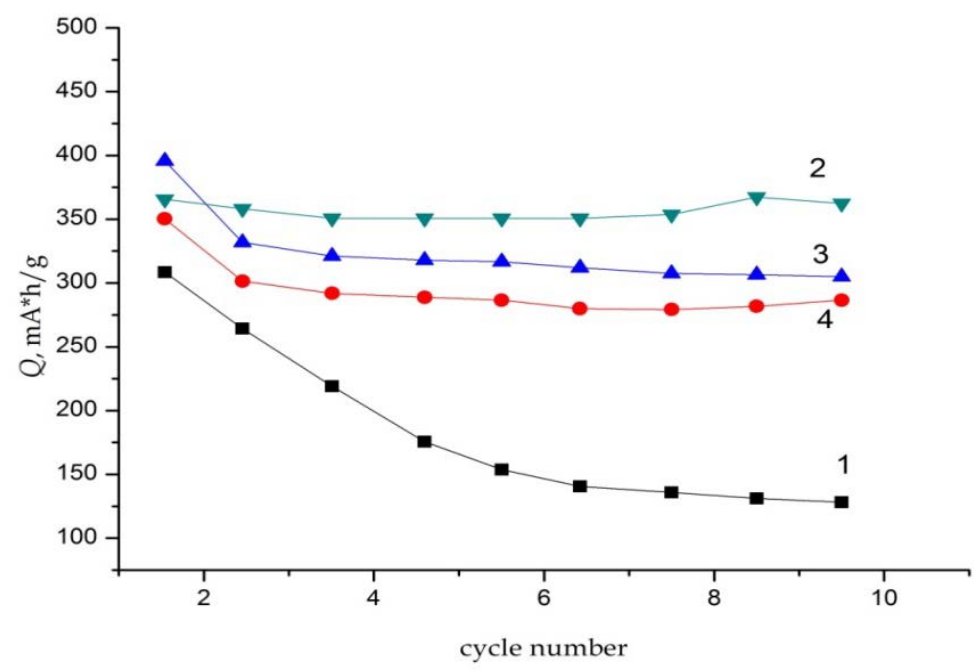

Figure 3. Specific discharge capacities vs. cycle number for natural graphite in hexafluorophosphate electrolyte: 1 - original, 2 - modified by monoaminoethanol, 3 modified by diaminoethanol and 4 - modified by triaminoethanol pyrolysis products.

Current load $10 \mathrm{~mA} / \mathrm{g}$ 


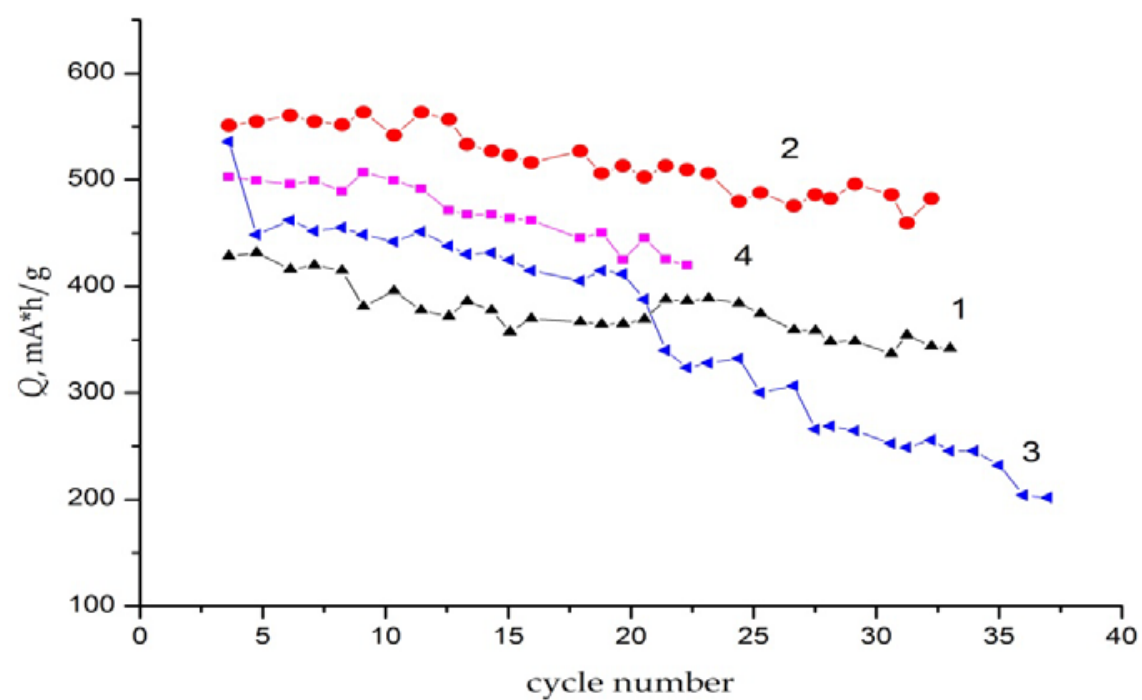

Figure 4. Specific discharge capacities vs. cycle number for synthetic graphite LBG-73 in hexafluorophosphate electrolyte: 1 - original, 2 - modified by monoaminoethanol, 3 - modified by diaminoethanol and 4 - modified by triaminoethanol pyrolysis products. Current load $10 \mathrm{~mA} / \mathrm{g}$

One can see that the electrochemical behavior of both natural and synthetic graphite can be significantly improved by means of the modification by monoaminoethanol pyrolysis products.

\section{Conclusions}

The effect of modification depends not only on the type of ligand and pyrolysis temperature, but on the type of the graphite and electrolyte as well. It was found that the catalytic effect is absent for the natural graphite in perchlorate electrolyte. Practically, modified natural graphite (which is cheaper) can be used in combination with hexafluorophosphate electrolyte. On the other hand, the cheaper and more environmentally friendly perchlorate electrolyte can be successfully used for the cells with the synthetic graphite.

\section{References}

[1] Андрийко А.А., Потаскалов В.А., Крюкова Е.А, Зульфигаров А.О. и др.. Модификация углеродных материалов отрицательного электрода литиевых аккумуляторов продуктами пиролиза комплексов 3d-металов с этаноламинами // Электрохимическая энергетика. - 2005. - том 5, №3. - с.169-175.

[2] Андрійко О.О., Потаскалов В.А., Зульфрігаров А.О. та інші Електрокаталітичні властивості продуктів піролізу гетерометальних триядерних комплексів $\mathrm{Ni}-2 \mathrm{Co} 3$ етаноламіном у реакції електрохімічної інтеркаляції літію в графріт // Науковий вісник Чернівецького університету. - 2008. - Вип. 399-400. - с. 80. 


\title{
ELECTROLYTES FOR SUPERCAPACITORS BASED ON DIMETHYL SULFOXIDE AND TETRAALKYLAMMONIUM SALTS
}

\author{
MILOVANOVA O.I., GROMADSKYI D.G., PUSHIK O.B. \\ Joint Department of Electrochemical Energy Systems \\ 38A, Vernadsky Ave, 03680 Kyiv, Ukraine \\ mylovanovaolya@gmail.com
}

Solutions based on dimethyl sulfoxide (DMSO) and tetraalkylammonium salts were studied as electrolytes for supercapacitors. The specific conductivity and potential range of electrochemical stability for DMSO solutions were obtained, and galvanostatic studies of supercapacitors with these electrolytes were carried out.

Supercapacitors (or electrochemical double-layer capacitors, EDLCs) belong to the category of energy storage systems with high specific power and are widely used in industry (e.g. in hybrid electric vehicles, customer electronics, etc.) [1]. The operation principle of $p$ supercapacitors is based on charging-discharging the electric doublelayer by adsorption/desorption of electrolyte components on the surface and inside a porous electrode [2]. As electrolytes for EDLCs, aqueous, non-aqueous solutions and ionic liquids are used [3], and solutions of tetraalkylammonium $\left(\mathrm{R}_{4} \mathrm{~N}^{+}\right)$salts in organic solvents are widely employed [1-5]. Their main benefit is a wide potential range at relatively high current densities providing hundreds thousands of charge/discharge cycles. A significant disadvantage of EDLCs is their low specific capacitance compared to the 'classical' energy storage devices, i.e. batteries.

Important factors defining the characteristics of a supercapacitor are the composition and properties of electrolyte solutions, namely their electrochemical window, thermal stability and conductivity. The widest class of electrolytes for EDLCs is presented by solutions based on acetonitrile, propylene carbonate, as well as other aprotic solvents and their mixtures [1-3]. Organic solvents employed in supercapacitors, methyl cyanide ( $s$ acetonitrile) on the first place, are far from being safe and pose environmental and health problems. This circumstance calls for the replacement of these solvents by environmentally friendly, non-toxic analogues, and dimethyl sulfoxide (DMSO) is a prospective candidate to satisfy such demands. 
Electrolytes based on DMSO are not widely used in lithium batteries and supercapacitors. This is due to the structure features of DMSO, first of all, to the presence of $S=O$ bond affecting interactions between the solvent and electrode materials. As a result of such interaction, the potential range of electrochemical stability is significantly reduced, and this is an issue for a number of composite electrode materials. The impact of adding DMSO on physico-chemical properties of electrolytes is described in Ref. [6]. It should be noted that characteristics of EDLCs with electrolytes based on DMSO and $\mathrm{R}_{4} \mathrm{~N}^{+}$salts are not presented in the literature. However, these electrolytes have a relatively low cost and allow for operating with a high concentration of the salt in their composition. Therefore, we aimed at filling this gap in the current work via a detailed study of DMSO-based solutions with various $\mathrm{R}_{4} \mathrm{~N}^{+}$salts as electrolytes for supercapacitors.

\section{Experimental}

In this study, tetraethylammonium tetrafluoroborate $\left(\mathrm{Et}_{4} \mathrm{NBF}_{4}\right)$ and bis(oxalato)borate $\left(\mathrm{Et}_{4} \mathrm{NBOB}\right)$, tetramethylammonium bis(oxalato)borate ( $\left.\mathrm{Me}_{4} \mathrm{NBOB}\right)$, and bis(salicylato)borate ( $\mathrm{Me}_{4} \mathrm{NBSB}$ ) were used. $\mathrm{Me}_{4} \mathrm{NBOB}$ and $\mathrm{Et}_{4} \mathrm{NBOB}$ were obtained by means of microwave synthesis according to Ref. [7].

Electrochemical measurements of carbon-based EDLCs with electrolytes were carried out in coin cells of 2016 type. All operations with electrolytes and cell assembling were performed in a glove box. The specific conductivity of solutions was determined from electrode impedance curves obtained by means of a Z-2000 impedancemeter (Elins, Russia) at the frequency range of $1-100 \mathrm{kHz}$. Measurements were carried out in the temperature range of $-10-+70^{\circ} \mathrm{C}$ in thermoplastic glass cells with flat parallel electrodes. A P-30 potentiostat (Elins, Russia) was used to determine the potential range of the electrochemical stability of electrolytes and to record cyclic voltammetric curves for EDLCs. Galvanostatic cycling for supercapacitor cells was performed by a TIONIT testing equipment (Ukraine).

\section{Results and Discussion}

Polytherms of the specific conductivity (In $k-1 / T)$ for electrolytes with a concentration of $0.7 \mathrm{~mol} / \mathrm{kg}$ of salts are presented in Fig. $1 \mathrm{a}$. These dependences are almost the same for the $\mathrm{Me}_{4} \mathrm{NBOB}, \mathrm{Et}_{4} \mathrm{NBOB}$ and $\mathrm{Et}_{4} \mathrm{NBF}_{4}$, whereas the $\mathrm{Me}_{4} \mathrm{NBSB}$-based solution has significantly lower specific conductivity than other ones due to big differences in the size of bis(salicylato)borate, bis(oxalato)borate and tetrafluoroborate. A sharp decrease in the specific conductivity in the temperature range of $5 \ldots 7^{\circ} \mathrm{C}$ is caused by the freezing of solution, which can be observed 
visually. The freezing point of the solution is $\mathrm{ca} .10^{\circ} \mathrm{C}$ lower than for pure DMSO $\left(19^{\circ} \mathrm{C}\right)$.

The polytherms of specific conductivity for the $\mathrm{Me}_{4} \mathrm{NBOB}$ solutions with various salt concentrations $(0.2-2.0 \mathrm{~mol} / \mathrm{kg})$ are linear in Arrhenius coordinates (Fig. 1b). The temperature of the liquid-solid transition decreases with increasing the salt concentration. For instance, such temperature for the solution of $0.2 \mathrm{~mol} / \mathrm{kg}$ concentration is about $14{ }^{\circ} \mathrm{C}$, that is $5^{\circ} \mathrm{C}$ lower than for pure DMSO, while for the solution of 1.4 $\mathrm{mol} / \mathrm{kg}$ concentration the temperature decrease is $18.5^{\circ} \mathrm{C}$.
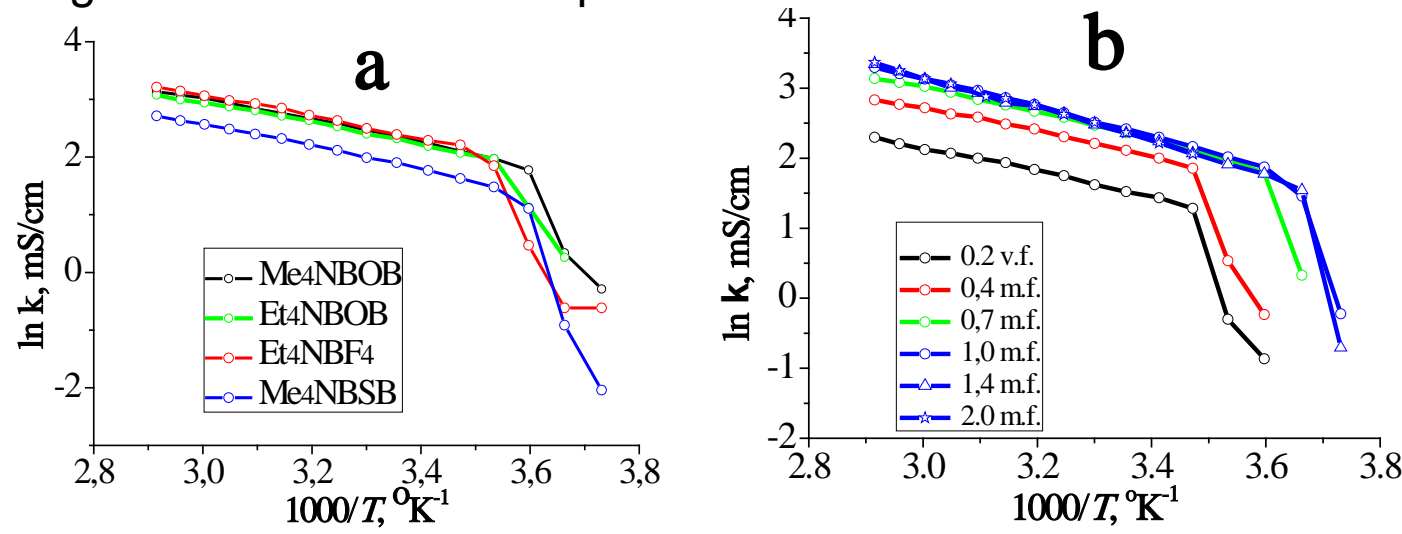

Figure 1. Polytherms of specific conductivity: (a) solutions containing $0.7 \mathrm{~mol} / \mathrm{kg}$ of salts; (b) solutions of $\mathrm{Me}_{4} \mathrm{NBOB}$ containing different salt concentrations

Fig. 2a shows cyclic voltammograms of $\mathrm{Me}_{4} \mathrm{~N}^{+}$-containing solutions in various aprotic solvents recorded on a platinum electrode. According to the data obtained the potential range of electrochemical stability is about 2.8-3.0 $\mathrm{V}$ for all electrolytes. Thus, it can be assumed that the voltage of the adsorption-desorption process will be of similar value. It is noteworthy that this potential range for acetonitrile and propylene carbonate solutions is nonsymmetrical and moves to the anodic region by nearly $500 \mathrm{mV}$ unlike DMSO-based solutions, which have almost the same values of oxidation/reduction potentials.
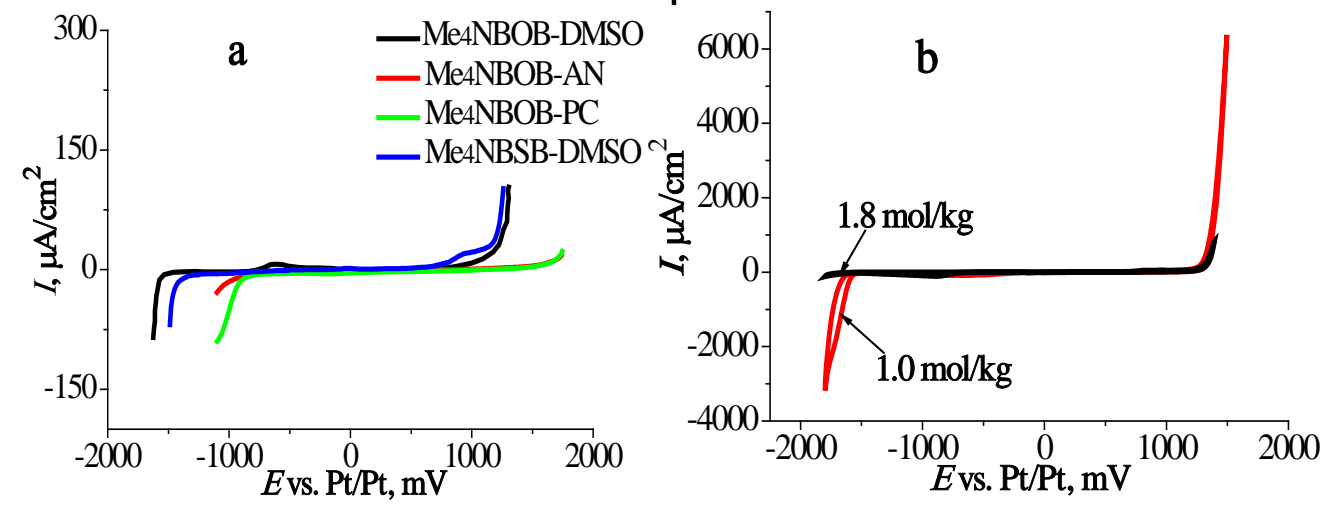

Figure 2. Cyclic voltammograms of (a) $\mathrm{Me}_{4} \mathrm{~N}^{+}$-containing solutions in various aprotic solvents of $0.7 \mathrm{~mol} / \mathrm{kg}$ salt concentration and (b) Cyclic voltagramms of the $\mathrm{Me}_{4} \mathrm{NBOB}-\mathrm{DMSO}$ solutions of various salt concentrations. Pt electrode, $5 \mathrm{mV} / \mathrm{s}$ scan rate 
As all DMSO-based electrolytes regardless of their cationic and anionic composition demonstrate a similar electrochemical behavior it may be suggested that this feature is determined by the properties of DMSO, namely its electrochemical stability in the anodic region. The increase of the salt concentration up to $1.8 \mathrm{~mol} / \mathrm{kg}$ has a little effect on the width of the electrochemical window (Fig. 2b).

Galvanostatic charge-discharge curves registered at different voltages (from $0.9 \mathrm{~V}$ to $1.9 \mathrm{~V}$ ) for EDLCs based on $\mathrm{Me}_{4} \mathrm{NBOB}-\mathrm{DMSO}$ and $\mathrm{Et}_{4} \mathrm{NBF}_{4}-\mathrm{DMSO}$ electrolytes with $0.7 \mathrm{~mol} / \mathrm{kg}$ and $1 \mathrm{~mol} / \mathrm{kg}$ salt concentration, respectively, are presented in Fig. 3. As in the case of voltammograms, increasing voltage above $1.5 \mathrm{~V}$ leads to the change of an almost ideal triangular view of the galvanostatic curves, while at higher voltages these curves are distorted due to faradaic processes.
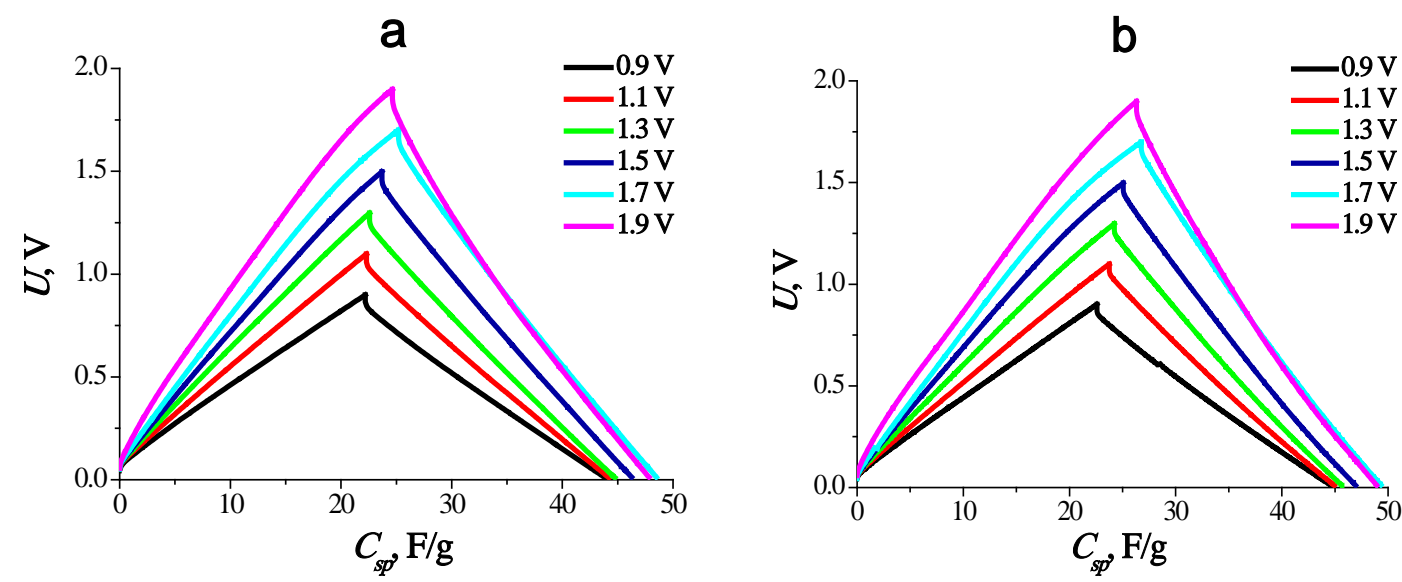

Figure 3. Galvanostatic charging-discharging curves for EDLCs at different cycling voltages: (a) $0.7 \mathrm{~mol} / \mathrm{kg} \mathrm{Me}{ }_{4} \mathrm{NBOB}-\mathrm{DMSO}$ electrolyte; (b) $1.0 \mathrm{~mol} / \mathrm{kg} \mathrm{Et}_{4} \mathrm{NBF}_{4}$ DMSO electrolyte. $1 \mathrm{~mA} / \mathrm{cm}^{2}$ current density

A decrease in specific capacitance with the cycle number during galvanostatic charge-discharge to $1.9 \mathrm{~V}$ for EDLCs with $\mathrm{Me}_{4} \mathrm{BOB}-$ DMSO and $\mathrm{Et}_{4} \mathrm{NBF}_{4}-\mathrm{DMSO}$ electrolytes is shown in Fig. 4. Increasing the cycling current leads to stabilization of the capacitance value.

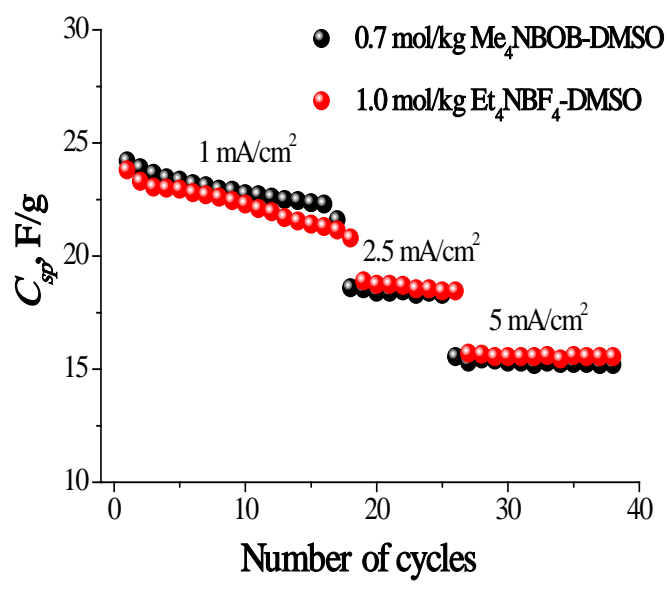

Figure 4. Dependences of specific capacitance for EDLCs with NoritDLC-Supra electrodes on cycle number and current density 


\section{Conclusions}

The specific conductivity and potential range of electrochemical stability for DMSO of tetraalkylammonium salts solutions were obtained, and galvanostatic studies of supercapacitors with these electrolytes were carried out. Based on these data it could be concluded that DMSO based electrolytes might serve as an environmentally benign alternative to common acetonitryle solutions employed in commercial supercapacitors.

\section{Acknowledgments}

The authors are grateful to Dr. N.I. Globa for collaboration and discussions, and to Dr. S.A. Kirillov for reading the manuscript and comments.

\section{References}

[1] Ruch P.W., Cericola D., Foelske A., Kotz R., Wokaun A. Aging of electrochemical double layer capacitors with acetonitrile-based electrolyte at elevated voltages. Electrochimica Acta, 55, 4412-4420 (2010).

[2] Ruch P.W., Cericola D., Foelske A., Kotz R., Wokaun A. A comparison of the aging of electrochemical double layer capacitors with acetonitrile and propylene carbonate-based electrolytes at elevated voltages. Electrochimica Acta, 55, 2352-2357 (2010).

[3] Zhang Z., Lai Y., Li J., Liu Y. Electrochemical behavior of wound supercapacitors with propylene carbonate and acetonitrile based nonaqueous electrolytes. Journal of Central South University of Technology, 16, 247-252 (2009)

[4] Brandt A., Isken P.,.Lex-Balducci A, Balducci A. Adiponitrile-based electrochemical double layer capacitor. Journal of Power Sources, 204, 213-219 (2012)

[5] Yoo H.D., Jang J.H., Ryu J.H., Park Y., Oh S.M. Impedance analysis of porous carbon electrodes to predict rate capability of electric double-layer capacitors. Journal of Power Sources, 267, 411-420 (2014) [6] Maca J., Frk M., Sedtarikova M. Properties of electrolytes for Li ion batteries with higher fire safety in Proc. Int. Conference on Renewable Energies and Power Quality (ICREPQ'13), Bilbao, Spain, March 20-22, 2013

[7] Глоба Н.І., Присяжний В.Д., Діамант В.А., Потапенко О.В. Синтез біс(оксалато)борату літію. Пат. України №90234 А200908093 UA, C2 МПК (2009) C07F5/00. Заявл. 03.08.2009; Опубл. 12.04.2010. Бюл. №7. - 8c 
УДК 541.136; 541.6.018.42-16

\title{
BINARY ELECTROLYTES FOR IMPROVING PYRITE CATHODE PERFORMANCE
}

\author{
SIROSH V.A. \\ Joint Department of Electrochemical Energy Systems NAS of Ukraine \\ SiroshVitalik@ukr.net
}

The aim of this study was improvement of the cycle life of $\mathrm{Li} / \mathrm{FeS}_{2}$ cells through modification of solid electrolyte interface (SEI) by using electrolytes based on binary mixtures of lithium salts, one of which is lithium bis(oxalato)borate (LiBOB). Analysis of the results of the research in the $1,3-2,6 \mathrm{~V}$ operating voltage range showed a significant effect of the concentration ratio of lithium salts on the specific capacity of $\mathrm{FeS}_{2}$ cathode and its stability upon galvanostatic cycling at room temperature. It was found that the highest cyclic stability of $\mathrm{FeS}_{2}$ electrode could be achieved by using electrolytes based on lithium triflate with 2-5 wt.\% of LiBOB and lithium perchlorate with $10 \mathrm{wt} . \%$ of LiBOB.

\section{БІНАРНІ ЕЛЕКТРОЛІТИ ДЛЯ ПІДВИЩЕННЯ ПРОДУКТИВНОСТІ ПІРИТОВОГО КАТОДУ}

CIPOШ B.A.

Міжвідомче відділення електрохімічної енергетики НАН

України; SiroshVitalik@ukr.net

Метою роботи $є$ покращення електрохімічних характеристик $\mathrm{Li} / \mathrm{FeS}_{2}$ системи шляхом використання електролітів на основі бінарних сумішей солей літію, однією з яких $є$ біс(оксалато)борат літію (LiBOB). Аналіз результатів дослідження у діапазоні напруги 1,3-2,6 В показав суттєвий вплив співвідношення літієвих солей на питому ємність $\mathrm{FeS}_{2}$ катоду та її стабільність в процесі циклування при кімнатній температурі. Встановлено, що підвищена стабільність при циклуванні $\mathrm{FeS}_{2}$ електроду може бути отримана при застосуванні електролітів на основі $1 \mathrm{M}$ розчину трифлату літію із Bмістом LiBOB 2-5 \%мac. та $1 \mathrm{M}$ розчину перхлорату літію при концентрації LiBOB 10 \%мас.

Створення високопотужних джерел струму для задоволення потреб різних галузей промисловості стимулює пошук та розробку нових електродних матеріалів 3 підвищенними питомими 
характеристиками. В якості перспективних катодних матеріалів значну увагу привертають сульфіди металів, зокрема, $\mathrm{TiS}_{2}$, CuS, NiS i $\mathrm{FeS}_{2}$ через їх низьку вартість та високі питомі характеристики [1]. Поміж вказаних сполук, дисульфід заліза або пірит $\left(\mathrm{FeS}_{2}\right)$ має одні 3 найвищих теоретичних значень питомої ємності (0,89 А·год/г) та питомої енергії (1304 Вт/кг або 2500 Вт/дм³). Крім того, пірит є досить розповсюдженим, дешевим та екологічно безпечним матеріалом [1,2]. Проте, незважаючи на комерціалізацію первинних літійпіритових джерел струму (Energizer) [2], використання $\mathrm{FeS}_{2}$ в якості позитивного електроду вторинних батарей ускладнено через низьку здатність піриту до перезарядження за кімнатних температур.

За роботами [3,4], процес електрохімічного відновлення природного піриту протікає згідно реакцій:

$$
\begin{aligned}
\mathrm{FeS}_{2}+2 \mathrm{Li}^{+} & \rightarrow \mathrm{Li}_{2} \mathrm{FeS}_{2} \\
\mathrm{Li}_{2} \mathrm{FeS}_{2}+2 \mathrm{Li}^{+} & \rightarrow \mathrm{Fe}+2 \mathrm{Li}_{2} \mathrm{~S}
\end{aligned}
$$

Процес заряду є стадійним і його схема може бути подана як:

$$
\begin{gathered}
\mathrm{Fe}+\mathrm{Li}_{2} \mathrm{~S} \rightarrow \mathrm{FeS}+2 \mathrm{Li}^{+} \\
\mathrm{Li}_{2} \mathrm{~S} \rightarrow 1 / 8 \mathrm{~S}_{8}+2 \mathrm{Li}^{+}
\end{gathered}
$$

За аналогією $3 \mathrm{Li} / \mathrm{S}$ батареями 3 неводним рідким електролітом, електрохімічне окиснення $\mathrm{Li}_{2} \mathrm{~S}$ [4] проходить через серію полісульфідів літію $\left(\mathrm{Li}_{2} \mathrm{~S}_{n}, 2 \leq n \leq 8\right)$ як проміжних продуктів, здатних розчинятися в неводному електроліті при $n \geq 4$, що призводить до протікання паразитних побічних реакцій з літієвим анодом та зміною складу катоду. Отже, Li/FeS 2 батареї мають проблеми, подібні до тих, що відбуваються в Li/S комірках [4].

В цій роботі нами зроблено спробу усунути ці проблеми i підвищити продуктивність $\mathrm{Li}_{\text {/FeS }}$-системи шляхом використання бінарної суміші солей, одна з яких $€$ біс(оксалато)боратом літію (LiBOB). Останній за рахунок розкладу в області катодних потенціалів здатен змінювати природу твердоелектролітної плівки (TEП), що може призводити, за певних концентрацій LiBOB, до збільшення ефективності роботи $\mathrm{FeS}_{2}$-катоду. В роботі визначено концентраційний вплив LiBOB на питомі характеристики $\mathrm{FeS}_{2}$ в процесі гальваностатичного циклування.

\section{Методологія досліджень}

Для приготування розчинів електролітів в якості основної солі використовували трифтторметансульфонат літію, LiTf («Aldrich», 96\%) та перхлорат літію, $\mathrm{LiClO}_{4}$ («Синбіаз», >98\%), які попередньо сушили у вакуумі протягом 6 годин за температури $130{ }^{\circ} \mathrm{C}$ та $160{ }^{\circ} \mathrm{C}$, відповідно. Біс(оксалато)борат літію (LiBOB) отримували згідно роботи [5]. Електроліти (концентрація 1 моль/л) готували шляхом розчинення наважки окремої солі або кількох солей в бінарній суміші 
пропіленкарбонату (PC, «Sigma-Aldrich», 99,7\%) і дигліму (DG,

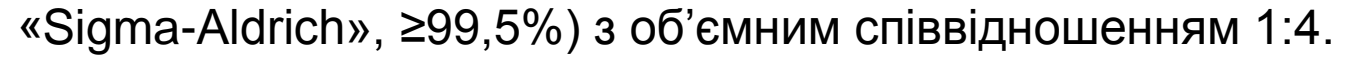

Катодну масу готували із суміші природного піриту $\left(\mathrm{FeS}_{2}\right.$, фрракція <40 мкм), електропровідної домішки (карбонізована сажа) та сполучника (тефлон марки Ф42Л), взятих у масовому співвідношенні 50:35:15. Маса активного матеріалу $\left(\mathrm{FeS}_{2}\right)$ в складі катоду становила близько $2,0 \div 2,5 \mathrm{Mr} / \mathrm{cm}^{2}$.

Для електрохімічних досліджень використовували макетні зразки елементів дискової конструкції в габаритах 2016 з літієвим противоелектродом товщиною 0,8 мм. Шар із мікропористої поліпропіленової плівки ПОРП-А («УФІМ», Росія) товщиною 30 мкм використаний як сепаратор. Питомі характеристики $\mathrm{Li}^{\prime} \mathrm{FeS}_{2}$-комірок визначали методом гальваностатичного циклування 3 використанням заряд-розрядних пристроїв типу УЗР 0,03-10 («Бустер», Росія) за температури $25 \pm 1{ }^{\circ} \mathrm{C}$.

\section{Результати та їх обговорення}

Як у випадку літій-сірчаних комірок [6], введення до складу електроліту незначної кількості біс(оксалато)борату літію (LiBOB) може позитивно впливати і на роботу $\mathrm{Li} / \mathrm{FeS} \mathrm{S}_{2}$ електрохімічної системи. Як відзначено в роботі [6], в присутності LiBOB за рахунок утворення ТЕП на поверхні сірчаного електроду вдається значно скоротити міграцію полісульфідів літію. Це суттєво підвищує кулонівську ефективність та стабільність при циклуванні Li/S пари.

Циклування $\mathrm{Li} / \mathrm{FeS}_{2}$-комірок проводили в діапазоні потенціалів 1,3-2,6 В за густини струму 0,2 $\mathrm{mA} / \mathrm{cm}^{2}$. Використання струму відносно високої густини і кінцевої напруги розрядження 1,3 В уможливлює більш ефективне відстеження залежності питомої ємності $\mathrm{FeS}_{2}$-електрода від складу електроліту.

Результати, наведені на рис. 1(а,б), свідчать, що питома ємність $\mathrm{FeS}_{2}$-катода в досліджуваному діапазоні потенціалів у всіх електролітах нижча за теоретичну та істотно залежить від природи аніона солі літію. За умов напруги в кінці розряду 1,3 В коефіцієнт використання $\mathrm{FeS}_{2}$ складає не більше $40 \%$.

На рис. 1а представлені залежності зміни питомої ємності $\mathrm{Li}_{\text {/FeS }}$ комірок від номеру циклу в електролітах на основі LiTf 3 різним вмістом LiBOB. Аналіз отриманих кривих показує суттєву відмінність у значеннях питомої ємності при використанні LiBOBвмісних електролітів на перших розрядних циклах, що може бути пов'язано з особливостями формування TEП на поверхні $\mathrm{FeS}_{2}$. Слід також відмітити, що при концентрації LiBOB у межах від 2 до 10 мас.\% залежність питомої ємності від номера циклу у досліджуваних електролітах має схожий характер і проходить через певний 
максимум. Така залежність може свідчити про зменшення загального опору електрохімічної системи в ході циклування, що призводить до підвищення напруги розряду i, як результат - до збільшення питомої ємності. Найбільш ефективним для LiTfелектролітів виявляється вміст LiBOB 2:5 \%мac. Питома ємність Li/FeS 2 -системи при цьому в залежності від співвідношення LiTfLiBOB становить від 408 до 344 мА·год/г на 1-му циклі і до 10-го циклу стабілізується на рівні 364 і 359 мА·год/г, відповідно.
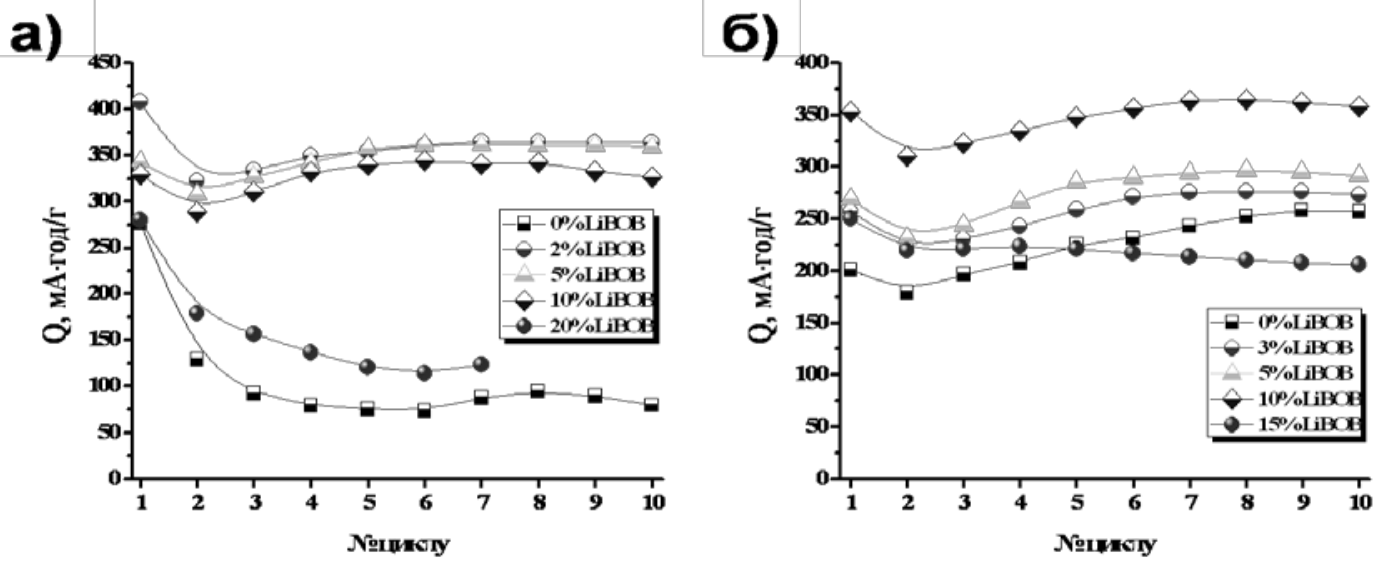

Puc. 1. Вплив вмісту LiBOB (\%мac.) в електролітах на залежність питомої ємності Li/FeS 2 комірок від номера циклу та природи аніона фонової солі: а) LiTf; б) $\mathrm{LiClO}_{4}$.

Залежності питомої ємності від номера циклу, отримані при гальваностатичному циклуванні $\mathrm{Li}^{\prime} \mathrm{FeS}_{2}$-комірок в $\mathrm{LiClO}_{4}$ - $\mathrm{LiBOB}$ електролітах наведені на рис. 1б. Згідно наведених кривих, при використанні розчинів перхлорату літію впродовж 10 циклів спостерігається підвищення питомої ємності майже для всіх зразків, аналогічно до розчинів LiTf-LiBOB з низьким вмістом останнього. Також слід відмітити наявність на наведених кривих більш вираженого максимуму питомої ємності, на відміну від розчинів трифллату літію. Найвищі питомі характеристики та ефективність циклування були отримані в електроліті, що містив LiBOB в кількості 10 \%мас. Величина питомої ємності при цьому складала 353 мА·год/г на 1-му циклі і 358 мА·год/г на 10-му циклі, відповідно.

\section{Висновки}

Проведено дослідження електрохімічної поведінки $\mathrm{Li} / \mathrm{FeS}_{2}$ системи в режимі гальваностатичного циклування з електролітами різного складу при кімнатній температурі. Проаналізовано зміну питомих характеристик піритового електроду під час перших 10-ти циклів зарядження/розрядження в залежності від співвідношення солей LiTf-LiBOB та $\mathrm{LiClO}_{4}$-LiBOB в складі електроліту. Аналіз результатів засвідчив, що природа аніону основної літієвої солі 
впливає на величину питомої ємності $\mathrm{FeS}_{2}$-катоду. Це може бути обумовлено утворенням ТЕП, фрормування якої відбувається за участю всіх компонентів електроліту, в тому числі, при значній ролі LiBOB у цьому процесі. Природа ТЕП наряду 3 опором в міжелектродному просторі та в об'ємі сепаратору визначає опір електродної системи, що в результаті відбивається на величині розрядної напруги i, таким чином, визначає величину питомої ємності, одержуваної у процесі циклування в заданому інтервалі напруги. Показано, що величина питомої ємності Li/FeS ${ }_{2}$-системи у процесі гальваностатичного циклування може бути збільшена введенням до складу електроліту незначної кількості біс(оксалато)борату літію. Встановлено, що найвищу стабільність при циклуванні $\mathrm{FeS}_{2}$-електроду вдається досягнути при використанні електролітів на основі солі трифлату літію з кількістю LiBOB в межах $2 \div 5$ \%мас., тоді як для розчинів 3 перхлоратом літію найкращий результат спостерігається при вмісті LiBOB 10 \%мac.

\section{Подяки}

Автор вдячний к.т.н. Н.І. Глобі за допомогу в проведенні досліджень і обговорення результатів, а також д.Х.н. С.О. Кириллову за зауваження.

\section{Перелік посилань}

[1] Choi Y.J., Kim N.W., Kim K.W., Cho K.K., Cho G.B., Ahn H.J., Ahn J.H., Ryu K.S., Gu H.B. Electrochemical properties of nickel-precipitated pyrite as cathode active material for lithium/pyrite cell // J. Alloys and Compounds. - 2009. - Vol. 485, No.1. - P. 462-466.

[2] Shao-Horn Y., Horn Q.C. Chemical, structural and electrochemical comparison of natural and synthetic $\mathrm{FeS}_{2}$ pyrite in lithium cells // Electrochim. Acta. - 2001. - Vol. 46. - P. 2613-2621.

[3] Takada K., Kitami Y., Inada T., Kajiyama A., Kouguchi M., Kondo S., Watanabe M., Tabuchi M. Electrochemical reduction of $\mathrm{Li}_{2} \mathrm{FeS}_{2}$ in solid electrolyte // J. Electrochem. Soc. - 2001. - Vol. 148, No.10. - P. A1085-A1090.

[4] Zhang S.S. The redox mechanism of $\mathrm{FeS}_{2}$ in non-aqueous electrolytes for lithium and sodium batteries // J. Mater. Chem. A. - 2015. - Vol. 3. - P. 7689-7694.

[5] Пат. 90234 Україна, МПК C07F 5/00. Синтез біс-(оксалато)борату літію / Н.І. Глоба, В.Д. Присяжний, В.А. Діамант, О.В. Потапенко. - № а200908093; заявл. 03.08.2009; опубл. 12.04.2010, Бюл. № 7. - 4 с.

[6] Xiong S., Kai X., Hong X., Diao Y. Effect of LiBOB as additive on electrochemical properties of lithium-sulfur batteries // Ionics. - 2012. Vol. 18, No.3. - P. 249-254. 


\title{
THE EFFECT OF TEMPERATURE ON CHARACTERISTICS OF $\mathrm{MO}_{2} \mathrm{~S}_{3}$-ELECTRODE / ELECTROLYTE OF Li-ACCUMULATOR
}

\author{
KIRSANOVA I.V., APOSTOLOVA R.D., BASKEVICH A.S. \\ SHEl «Ukrainian State University of Chemical Technology» \\ shembel@onil.dp.ua
}

In this work, changes in impedance spectra of $\mathrm{Mo}_{2} \mathrm{~S}_{3}$, electrochemically deposed on aluminum and discharged in $\mathrm{Li}$ accumulator, with temperature have been analyzed. The character of changes with temperature (273-332K) have been determined for the parameters ( $\mathrm{R}$ - ohmic resistance, $\mathrm{W}$ - diffusion impedance, and CPE constant phase element) which determine electrode processes related to overcoming the energy of charge- and mass- transfer as well as impedance behavior. It was shown that effective transformation of $\mathrm{Mo}_{2} \mathrm{~S}_{3}$ in a lithium accumulator could be provided only in the 298-307K temperature range.

\section{ХАРАКТЕРИСТИКИ $\mathrm{MO}_{2} \mathrm{~S}_{3}$ ЕЛЕКТРОД / ЕЛЕКТРОЛІТ Lі-АКУМУЛЯТОРА В ЗАЛЕЖНОСТІ ВІД ТЕМПЕРАТУРИ}

\author{
КІРСАНОВА І.В., АПОСТОЛОВА Р.Д., БАСКЕВИЧ О.С. \\ ДВНЗ «Український державний хіміко-технологічний \\ університеm»; shembel@onil.dp.ua
}

Проаналізована еволюція імпедансних спектрів із зміною температури електрохімічно одержаного на алюмінії сульфріду $\mathrm{Mo}_{2} \mathrm{~S}_{3}$, розрядженого в літієвому акумуляторі. Визначено зміну за температурою (273-332K) складових параметрів еквівалентної електричної схеми годографрів імпедансу досліджуваної системи: R (омічного опору), W (дифузійного імпедансу) та СРЕ (елемента постійної фрази), які відображають параметри електродних процесів, пов'язаних з подоланням енергії перенесення зарядів та маси, а також 3 імпедансною поведінкою. Визначено, що забезпечення ефективного перетворення сульфріду $\mathrm{Mo}_{2} \mathrm{~S}_{3}$ в літієвому акумуляторі може бути гарантовано лише при температурах 298-307К.

Електрохімічно синтезовані молібден-сульфідні сполуки нанометрової шкали можуть знайти широке застосування в літієвих акумуляторах [1]. Вони показують кращі розрядні характеристики, 
ніж їх нанометрові аналоги, отримані за іншими методами. Визначальним параметром розрядної ємності Мо-сульфідів у літієвому акумуляторі є температура. При охолодженні та нагріванні розрядна ємність $\mathrm{Mo}_{2} \mathrm{~S}_{3}$ в редокс-реакції з літієм знижується в порівнянні з такою при (298-303К). В даній роботі визначено температурну область ефективного перетворення електрохімічно синтезованого $\mathrm{Mo}_{2} \mathrm{~S}_{3}$ в редокс-реакції з літієм.

\section{Методологія досліджень}

Мо-сульфіди синтезовано відновленням розчинів $\mathrm{Na}_{2} \mathrm{MoO}_{4}$ $\left(0,08 \div 0,14\right.$ моль·л $\left.{ }^{-1}\right), \mathrm{Na}_{2} \mathrm{~S}_{2} \mathrm{O}_{3}\left(0,010 \div 0,012\right.$ моль $\left.\pi^{-1}\right)$ на алюмінієвій

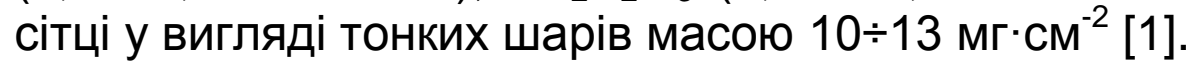

Імпеданс системи $\mathrm{Mo}_{2} \mathrm{~S}_{3}$ електрод (1) / 1 моль·л ${ }^{-1} \mathrm{LiClO}_{4}$, ПК, ДМЕ / $\mathrm{Mo}_{2} \mathrm{~S}_{3}$ електрод (2) вимірювали за допомогою аналітичного радіометра VoltaLab PJZ 301 при накладенні електричного сигналу

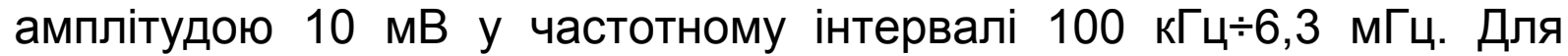
аналізу спектрів використовували програму ZView (Version 2.1b).

\section{Результати та їх обговорення}

За даними рентгенофазового аналізу у складі тонкошарового електроду налічується $\mathrm{Mo}_{2} \mathrm{~S}_{3}$ моноклінної сінгонії (просторова група $\mathrm{P} 2_{1} / \mathrm{m}$ [81-2031]) за наявністю домішок сульфідів $\mathrm{Co}_{4} \mathrm{~S}_{3}, \mathrm{Co}_{3} \mathrm{~S}_{4}$.

Імпедансні характеристики в залежності від температури визначено з електродами, розрядженими в літієвому акумуляторі до 1,1 В. Потенціал електроду без струму $\left(E_{0}\right)$ стабілізується на значенні 1,32 В, який відповідає хімічній формулі $\mathrm{Li}_{x} \mathrm{Mo}_{2} \mathrm{~S}_{3}$. Для аналізу годографів імпедансу досліджуваної системи підібрано еквівалентні електричні схеми та установлено значення параметрів елементів схеми при температурах 273, 298, 307, 319, 332К.

$\mathrm{Ha}$ рис. 1 показано годограф імпедансу системи $\mathrm{Mo}_{2} \mathrm{~S}_{3}$ / 1 моль $\pi^{-1} \mathrm{LiClO}_{4}$, ПК, ДМЕ / $\mathrm{Mo}_{2} \mathrm{~S}_{3}$ при Т=307К та еквівалентна електрична схема годографу імпедансу системи.

Імпеданс системи зростає з пониженням температури як в високочастотній, так і в лінійній ділянках годографу (рис.2).

Проведено аналіз залежності складових параметрів імпедансу від температури: (R) - омічного опору, (CPE) - елементу здвигу постійної фази, (W) - дифузійного імпедансу, виходячи 3 теоретичних основ імпедансної спектроскопії [2].

Елемент СРЕ може відображати експоненційний розподіл параметрів електрохімічної реакції, пов'язаної 3 подоланням енергетичного бар'єру при перенесенні зарядів та маси, а також імпедансну поведінку, викликану фрактальністю поверхневої структури. 


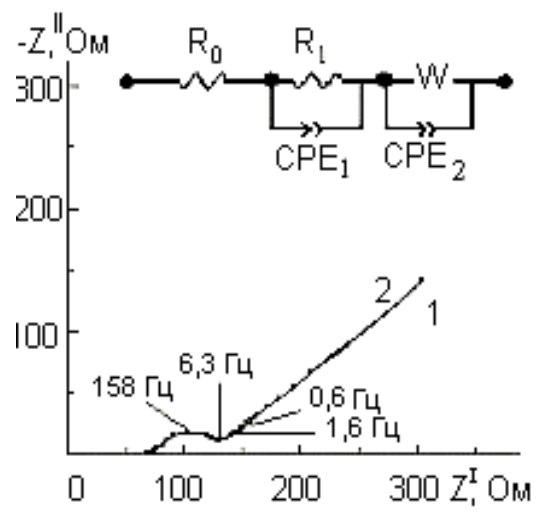

Puc. 1. Годографр імпедансу досліджуваної системи:

1 - експериментальний,

2 - аналоговий;

та еквівалентна схема. $T=307 \%$.
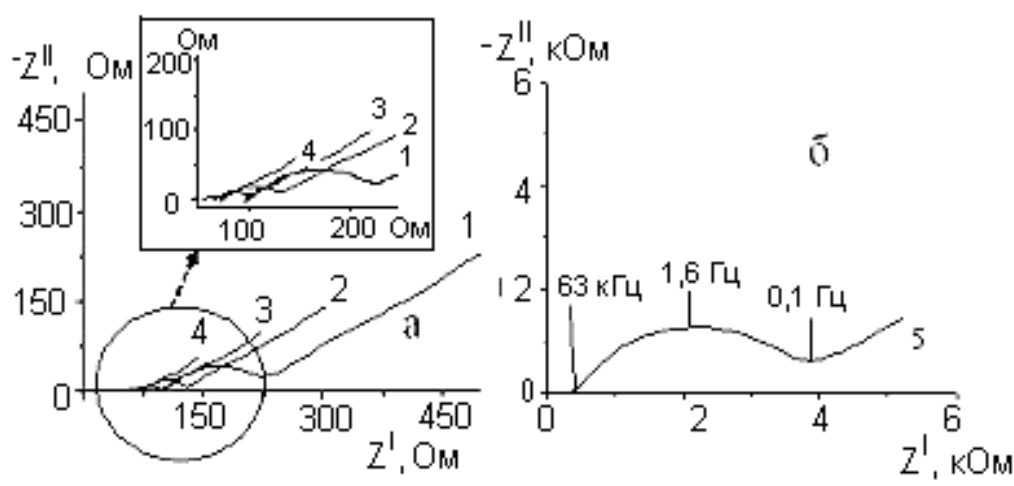

Puc. 2. Годографри імпедансу досліджуваної системи в залежності від T K: а) 1 - 298, 2 - 307, 3 - 319, 4 - 332; вставка - збільшений масштаб; б) 5 - 273.

Імпеданс СРЕ визначається параметрами $\mathrm{CPE}_{\mathrm{P}}$ та $\mathrm{CPE}_{\mathrm{T}}(1)$ :

$$
\mathrm{Z}_{\mathrm{CPE}}=\mathrm{CPE}_{\mathrm{T}} \cdot(\gamma \cdot \omega)^{-\mathrm{CPE}_{\mathrm{P}}} \text {. }
$$

Параметр $\mathrm{CPE}_{\mathrm{P}}=\mathrm{n}$ - коефріцієнт фррактальності поверхні, який встановлює тип частотного розподілу параметрів C, W, R. Він моделює ідеальний або деформований дифузійний імпеданс при $\mathrm{n}=0,5 \pm \varepsilon ;$ чистий або спотворений резистор при $\mathrm{n}=0 \pm \varepsilon$; псевдоємність при $\mathrm{n}=0,5 \div 1,0$. Параметр СРЕ $\mathrm{T}_{\mathrm{T}}$ - псевдоємність.

Елемент імпедансу Варбурга визначається як (2):

$$
\mathrm{Z}_{\mathrm{W}}=\mathrm{W}_{\mathrm{R}} \frac{(\text { cth } \cdot \gamma \cdot \omega \cdot)^{\mathrm{W}_{\mathrm{p}}}}{\left(\gamma \cdot \mathrm{W}_{\mathrm{T}} \cdot \omega\right)^{\mathrm{W}_{\mathrm{p}}}},
$$

де $\gamma=\sqrt{-1}, \omega$ - кругова частота; $W_{R}$ - омічний опір; $W_{T}=I^{2} / D_{L i}$, I - дифузійна довжина, $D_{\mathrm{Li}}$ - коефріцієнт дифузії іонів літію;

$\mathrm{W}_{\mathrm{p}}=\mathrm{n}-$ коефріцієнт фррактальності поверхні.

При аналізі виявлено, що зміна визначених 9 параметрів годографрів імпедансу при підвищенні температури від 298 до 323К 
відбувається відмінно від закономірності, яка виявлена в температурному перебігу від 298 до 273К (Рис. 3).

Простежується закономірність: параметри $\mathrm{CPE}_{1 \mathrm{~T}}, \mathrm{CPE}_{2 \mathrm{~T}}, \mathrm{~W}_{\mathrm{T}}$, $\mathrm{CPE}_{1 \mathrm{p}}, \mathrm{CPE}_{2 \mathrm{p}}, \mathrm{W}_{\mathrm{p}}$ мало змінюються за температурою в межах 298-307К. Екстремальні зміни параметрів спостерігаються при охолодженні (273К) та при нагріванні, починаючи з температури 319К (рис.3,б; рис.3,в).

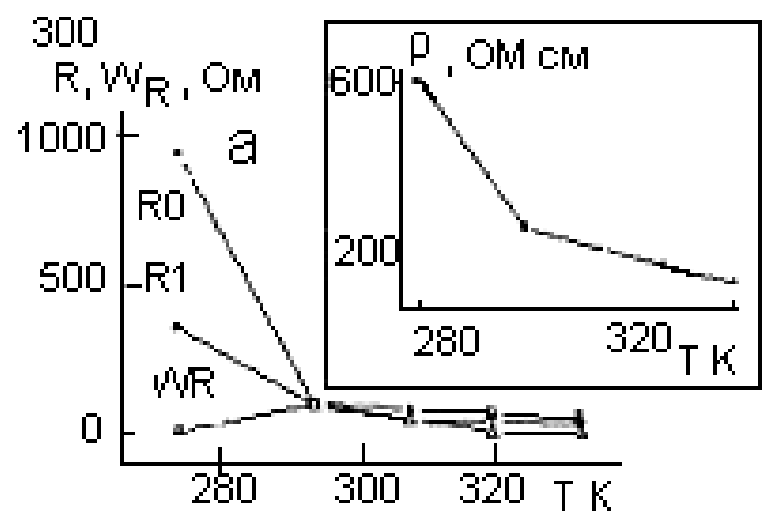

CPEp, Wp
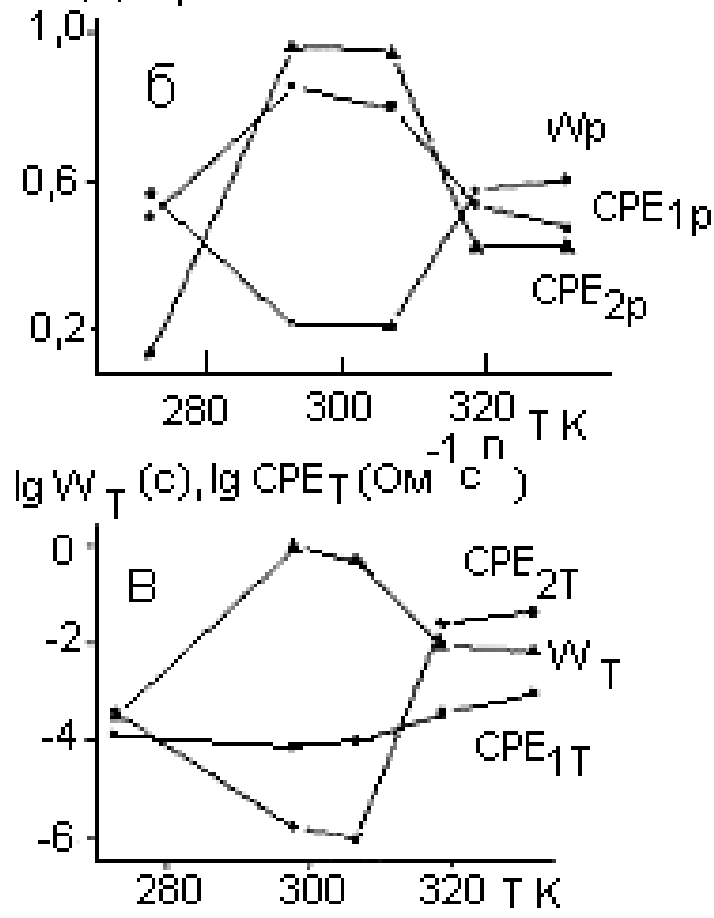

Puс.3. Параметри модельної схеми в функції температури (T K).

У значеннях параметрів омічного опору (рис. 3, а) спостерігається різкий перебіг при охолодженні від 298 до 273К.

Залежність $\mathrm{R}_{0}$ від температури корелює 3 температурною залежністю опору електроліту 1 моль $\boldsymbol{r}^{-1} \mathrm{LiClO}_{4}$, ПК, ДМЕ в свободному просторі $\rho$ (Рис. 3, а - вставка). Ареніусівська 
залежність провідності $\mathrm{R}_{0}$ спостерігається в межах 298-332K і порушується при 273К. Це свідчить про зміну механізмів процесу подолання опору $\mathrm{R}_{0}$ в означених температурних інтервалах.

Елемент $\mathrm{R}_{1} / \mathrm{CPE}_{1}$ представляється як опір перенесення зарядів $\mathrm{R}_{1}$ (електроліт / поверхнева плівка / $\mathrm{Mo}_{2} \mathrm{~S}_{3}$ ), зашунтований елементом постійної фрази $\mathrm{CPE}_{1}$, який враховує неоднорідність ємності, обумовлену фарадеївським процесом та геометричною поверхнею. В макросистемі опір $\mathrm{R}_{1}$ - ефективна величина, яка $\epsilon$ функцією міграції/дифузії зарядів/маси в електроліті поруватого простору $\mathrm{Mo}_{2} \mathrm{~S}_{3}$, провідності $\mathrm{Mo}_{2} \mathrm{~S}_{3}$ та контактного омічного опору між частинками $\mathrm{Mo}_{2} \mathrm{~S}_{3}$.

B підтримку температурного ефекту провідності $\mathrm{Mo}_{2} \mathrm{~S}_{3}$ на значення $\mathrm{R}_{1}$ свідчать дані, згідно 3 якими електропровідність сульфріду $\mathrm{Mo}_{2} \mathrm{~S}_{3}$ знижується від $10^{-3}$ до $10^{-5} \mathrm{C} \cdot \mathrm{cm}^{-1}$ при охолодженні від 373 до 273К [3].

Згідно $з$ кривими залежності $\mathrm{CPE}_{1 \mathrm{P}}$ та $\mathrm{CPE}_{2 \mathrm{P}}$ від температури (Рис. 3, б) тип контролю електродного процесу в межах 273-332К змінюється неодноразово. Стабільність параметрів спостерігається лише при 298, 307К. Розбіжність в типах контролю можна пояснити стабільністю електродного процесу в температурному перебігу (298307К) та пошкодженням його за межами цих температур. При нагріві посилюється активність $\mathrm{Mo}_{2} \mathrm{~S}_{3}$ в окисненні електроліту. Відомо також про підвищення хімічної нестійкості $\mathrm{Mo}_{2} \mathrm{~S}_{3}{ }_{3}$ підвищенням температури.

Означена нестабільність електродного процесу супроводжується перебудовою поверхневої морфології та можливими змінами в структурі $\mathrm{Mo}_{2} \mathrm{~S}_{3}$ і поверхневої плівки. Про це свідчить зростання псевдоємності $\mathrm{CPE}_{1 т}$ майже на порядок та більш значне зростання $\mathrm{CPE}_{2 \mathrm{~T}}$ при перебігу температури від 307 до $332 \mathrm{~K}$ (рис. 3, в). Визначене зростання можна пов'язати зі зниженням гомогенності морфології поверхні за рахунок розчинення плівки, зниженням товщини поверхневої плівки на $\mathrm{Mo}_{2} \mathrm{~S}_{3}$, в підтримку чого

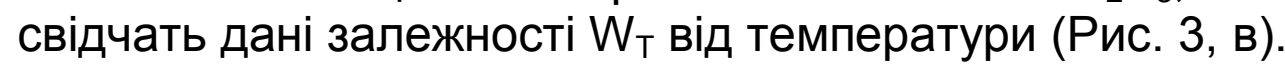

При зниженні температури від 298 до 273К визначальними параметрами перетворення в досліджуваній системі стає омічний опір - опір перенесення зарядів через межу електроліт / електрод, пов'язаний з опором перенесення зарядів через міжсразні поверхні електроліт / поверхнева плівка та поверхнева плівка / $\mathrm{Mo}_{2} \mathrm{~S}_{3}$ / струмовий колектор, 3 опором міграції зарядів в електроліті поруватого простору сульфідної матриці, опором перенесення зарядів в твердотільній матриці, 3 контактним опором між частинками твердотільної матриці. 


\section{Висновки}

Проведено аналіз визначених 9 параметрів еквівалентної схеми годографрів імпедансу $\mathrm{Mo}_{2} \mathrm{~S}_{3}$ в контакті 3 електролітом 1 моль-л ${ }^{-1}$ $\mathrm{LiClO}_{4}$, ПК, ДМЕ в температурному інтервалі 273-332К, які відображають характеристики окремих стадій електродного процесу взаємодії з літієм, пов'язаних з подоланням енергії перенесення зарядів та маси, а також з імпедансною поведінкою, викликаною фррактальністю поверхневої структури. Низькотемпературний ефект імпедансу електроду $\mathrm{Mo}_{2} \mathrm{~S}_{3}$ в контакті з електролітом визначається в найбільшій мірі підвищенням опору перенесення зарядів $\left(\mathrm{R}_{1}\right)$. Певну роль при зниженні температури до 273К відіграють зниження провідності електроліту в поруватому просторі $\mathrm{Mo}_{2} \mathrm{~S}_{3}$ та провідности активної речовини. При температурі 319K та вище порушується стійкість електроліту 1 моль л $^{-1} \mathrm{LiClO}_{4}$, ПК, ДМЕ в контакті $3 \mathrm{Mo}_{2} \mathrm{~S}_{3}$. На підставі отриманих результатів можна розраховувати на ефективне перетворення $\mathrm{Mo}_{2} \mathrm{~S}_{3}$ в літієвому акумуляторі 3 електролітом 1 моль:л ${ }^{-1} \mathrm{LiClO}_{4}$, ПК, ДМЕ лише В інтервалі температур 298-307К. Для підвищення кулонівської ефективності перетворення мікроакумулятору $\mathrm{Mo}_{2} \mathrm{~S}_{3} / \mathrm{Li}$ в широкому температурному інтервалі необхідно оптимізувати склад електроліту шляхом додавання домішок в електроліт або підібрання придатних апротонних розчинників та літієвої солі.

\section{Перелік посилань:}

[1] Шембель Е.М., Апостолова Р.Д., Тысячный В.П., Кирсанова И.В. // Электрохимия. - 2005. - Т. 41. - № 12. - С. 1465-1475.

[2] Электрохимический импеданс. Стойнов 3.Б., Графов Б.М., Савова-Стойнова Б., Елкин В.В., Наука, М., 1991. - 331 с.

[3] Перов Э.П., Мощенская Н.В. // Изв. Алтайск. гос. универс. 2002. - №25 (3). - C. 33-36. 
УДК 544.643-621.357

\section{THE EFFECT OF $\mathrm{TIO}_{2}$ OXIDE ON THE DISCHARGE CAPACITY OF FeS IN Li-ACCUMULATORS}

GLADUN V.A., APOSTOLOVA R.D., MARKEVICN A.V., SHEMBEL E.M. SHEI "Ukrainian State University of Chemical Technology shembel@onil.dp.ua

Thin-layer FeS electrodes and the same electrodes based on compositions of $\mathrm{FeS}$ with $\mathrm{TiO}_{2}$ were synthesized onto the cathode in aqueous electrolytes. Aglomerates of micrometer-size $\mathrm{TiO}_{2}$ consisting of smaller particles were visible on the surface of the composite deposits in optic microscope. The discharge capacity of the thin-layer $\left(\mathrm{FeS}, \mathrm{TiO}_{2}\right)$ compositions in a lithium accumulator prototype in the 2.8$1.1 \mathrm{~V}$ voltage range exceeds that for the FeS analog by $50-53 \%$.

\section{ВЛИЯНИЕ $\mathrm{TiO}_{2}$ НА ПОВЫШЕНИЕ РАЗРЯДНОЙ ЕМКОСТИ FeS В ЛИТИЕВОМ АККУМУЛЯТОРЕ}

ГЛАДУН В.А., АПОСТОЛОВА Р.Д., МАРКЕВИЧ А. В., ШЕМБЕЛЬ Е.М. ГВУЗ "Украинский государственный химикотехнологический университет; shembel@onil.dp.ua

Тонкослойные FeS-электроды и такие же электроды на основе композиций FeS с оксидом $\mathrm{TiO}_{2}$ были синтезированы на катоде из водных электролитов. В изображениях поверхности осадков в оптическом микроскопе были видны агломераты включенного $\mathrm{TiO}_{2}$ микрометрового уровня, состоящие из более мелких частиц. Разрядная емкость композиций $\left(\mathrm{FeS}, \mathrm{TiO}_{2}\right)$ в макетном литиевом аккумуляторе в ряду напряжения 2,8-1,1 В превышает таковую FeS-аналога на 53 \%.

В связи с интенсивным техническим прогрессом в области электронных миниатюрных устройств повышаются требования к характеристикам необходимых для них литиевых микроаккумуляторов по энергоемкости, стоимости, экологической безопасности. Тонкослойные FeS-электроды, полученные электрохимически из водных растворов, соответствуют многим предъявляемым повышенным требованиям, обеспечивая разрядную емкость в литиевом аккумуляторе 400-500 мА ч $\mathrm{r}^{-1}$ и в отрицательных электродах литий-ионной системы - 400-550 мА ч $\mathrm{r}^{-1}$ [1]. Улучшению электрических характеристик FeS в данной работе способствовало соосаждение с нанометровым $\mathrm{TiO}_{2}$. 


\section{Методология исследований}

FeS синтезировали электрохимически из раствора, $\Gamma \cdot r^{-1}$ : $\mathrm{FeSO}_{4} \cdot 7 \mathrm{H}_{2} \mathrm{O}-13 ; \mathrm{Na}_{2} \mathrm{~S}_{2} \mathrm{O}_{3} \cdot 5 \mathrm{H}_{2} \mathrm{O}-5$. pH 4,5-5,0; $\mathrm{i}_{\text {katod }}=1,5-3,0 \mathrm{~mA} \cdot \mathrm{cm}^{-2}$. Осаждение вели с принудительным перемешиванием электролита. Как добавку использовали титан-диоксид A-HR с тетрагональной сингонией анатаз с размером зерна 50 нм производства Huntsman Corporation. Осадки получали на нержавеющей стали, на поверхности которой снижается адгезия активного материала при повышении температуры. Поэтому осадки сушили при температуре $60^{\circ} \mathrm{C}$, которая не является оптимальной для получения самой высокой удельной разрядной емкости FeS. Tем не менее, выбранная температура позволяет провести сравнительную оценку эфффекта добавки $\mathrm{TiO}_{2}$ на разрядные характеристики $\mathrm{FeS}$.

Структуру полученных осадков определяли с помощью рентгенофазового анализа на установке ДРОН-2.0 в $\mathrm{Cu}_{-} \mathrm{K}_{\alpha}$ излучении с использованием монокристалла LiF в интервале $2 \theta=5$ $\div 85$ градусов.

Морфологию поверхности синтезированного материала определяли в оптическом микроскопе МБС-2.

Синтезированные образцы тестировали в литиевом дисковом источнике тока в габаритах 2016 с электролитом: диметоксиэтан (ДМЭ), диоксолан (ДОЛ), 1 моль $\cdot{ }^{-1} \mathrm{LiBF}_{4}$.

Для изготовления композитных намазных электродов на основе коммерческого $\mathrm{TiO}_{2}$ использована масса состава,\%: $\mathrm{TiO}_{2}-70$; ацетиленовая сажа - 20; связующее Ф4-Д - 10. Массу запрессовывали на сетку из стали 18Н12Х9Т.

Гальваностатические разрядно-зарядные характеристики получены на испытательном стенде с программным обеспечением.

\section{Результаты и их обсуждение}

В соответствии с данными рентгенофазового анализа в осадках, полученных из электролита без добавки $\mathrm{TiO}_{2}$, образуется FeS с гексагональной сингонией [80-1029].

На разрядной кривой FeS первого цикла имеются две площадки напряжения со средним значением 1,7 и 1,4 В. Емкость первого цикла (515 мA ч $\left.\mathrm{r}^{-1}\right)$ приближается к значению теоретической емкости FeS (560 мA ч $\mathrm{r}^{-1}$ ). В следующем цикле потеря разрядной емкости составляет 49,5\%. С повышением плотности разрядного тока разрядная емкость снижается (рис.1а). 

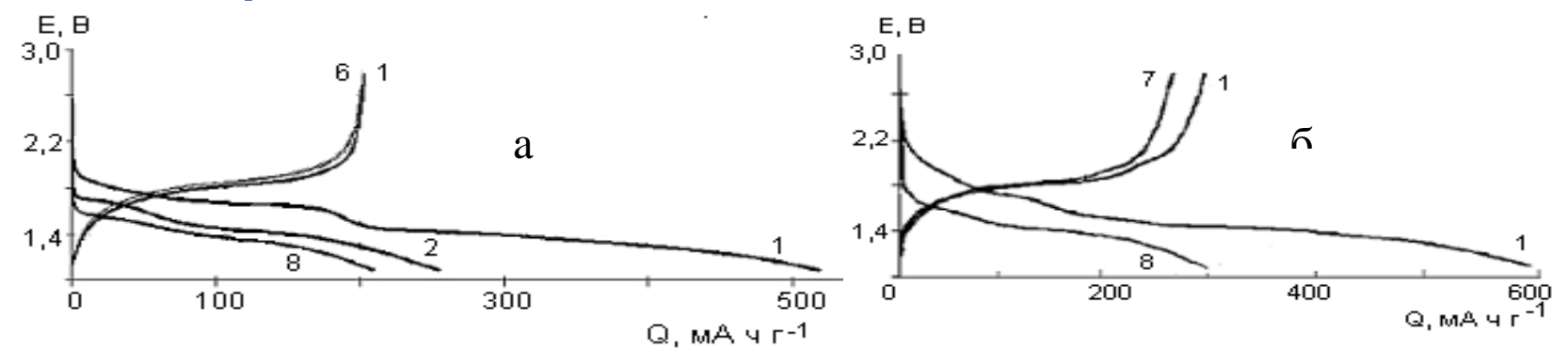

Puc.1. Разрядно-зарядные кривые Li-аккумулятора на основе:

a) $\mathrm{FeS}$, б) композиции $\mathrm{FeS}, \mathrm{TiO}_{2} . i_{\text {разр}}, \mathrm{MA} \mathrm{CM}^{-2}: 0,05$ (1,2 циклы); 0,17(8 цикл)

В осадках, синтезированных из суспензии $\mathrm{TiO}_{2}$ в электролите осаждения $\mathrm{FeS}$, наряду c $\mathrm{FeS}$ идентифицирован $\mathrm{TiO}_{2}$-анатаз (782486) - рис. 2. На дифрактограмме осадка, кроме рефлексов $\mathrm{FeS}$, $\mathrm{TiO}_{2}$, наблюдаются рефлексы дифракционного отражения основы (Fe).

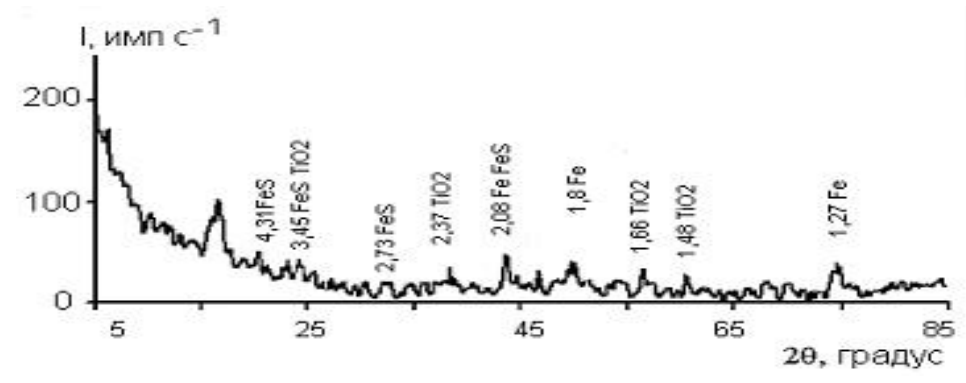

Рuс.2.Рентгеновская дифрактограмма осадка, полученного из суспензии $\mathrm{TiO}_{2}$ в электролите осаждения $\mathrm{FeS}$

На микрофотографиях поверхности осадков видны светлые включения, представляющие агломераты $\mathrm{TiO}_{2}$ микрометрового уровня на темном фроне FeS (рис. 3).
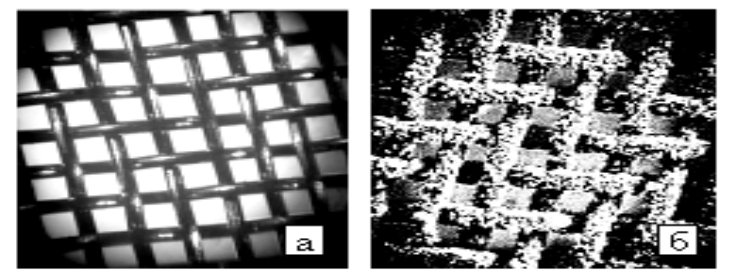

Puc.3. Изображение поверхности основы-нержавеющей стали (а) и осадка композита $\mathrm{FeS}, \mathrm{TiO}_{2}$ (б) в микроскопе МБС-2 при увеличении 87,5

Из хорошо известных структурных модификаций титан-диоксида (анатаз, рутил, брукит) в литиевых источниках тока наиболее исследован и применяется анатаз. В положительных электродах литиевого аккумулятора его разрядное напряжение выше, чем $\mathrm{TiO}_{2}$ рутила приблизительно на 0,4 В.

Нанометровый $\mathrm{TiO}_{2}$ представляется перспективным материалом для положительных [3], а также отрицательных электродов литийионных батарей в паре с положительным электродом $\left(\mathrm{LiNi}_{0,5} \mathrm{Mn}_{1,5} \mathrm{O}_{4}\right)$, разрядное напряжение которого находится около $5 \mathrm{~B}$ [4]. Разрядное напряжение такого ЛИА - около 3 В и тем самым решается проблема безопасности литий-ионной батареи, связанная с коротким замыканием литиевыми дендритами. В коммерческих 
ЛИА используется графит в отрицательных электродах, работающих в ЛИА в основном при потенциале 0,1 В относительно $\mathrm{Li} / \mathrm{Li}^{+}$-электрода, близком к потенциалу осаждения лития. При неконтролируемых условиях возможно осаждение лития на графите, не исключающее короткого замыкания в ЛИА.

Разрядно-зарядные характеристики нанометрового $\mathrm{TiO}_{2}$, используемого в данной работе, приведены на рис. 4.

На разрядной кривой при меньшей плотности тока (рис. 4 а) имеются две горизонтальные площадки напряжения (E, B), которые на основании литературных данных можно отнести к $\mathrm{TiO}_{2}$ (анатаз) с $\mathrm{E}_{\text {средн }}=1,75 \mathrm{~B}$ и к $\mathrm{TiO}_{2}$ (рутил) $с \mathrm{E}_{\text {средн }}=1,35$ В. Судя по разрядным характеристикам, в составе порошка $\mathrm{TiO}_{2}$ (анатаз) имеется примесь $\mathrm{TiO}_{2}$ (рутила). Разрядная емкость электрода приближается к 150 мА ч $\Gamma^{-1}$ при меньшей плотности тока и снижается при ее повышении до 55 мА ч г ${ }^{-1}$ (рис. 4 б).

Разрядные характеристики композита $\mathrm{FeS}, \mathrm{TiO}_{2}$ (рис.1 а) в литиевом аккумуляторе улучшены по сравнению с таковыми $\mathrm{FeS}$ (рис. 1 б). Разрядная емкость композита $\mathrm{FeS}, \mathrm{TiO}_{2}$ на $53 \%$ выше, чем таковая FeS на 8-ом цикле при циклировании в интервале напряжения 2,8-1,1 B.

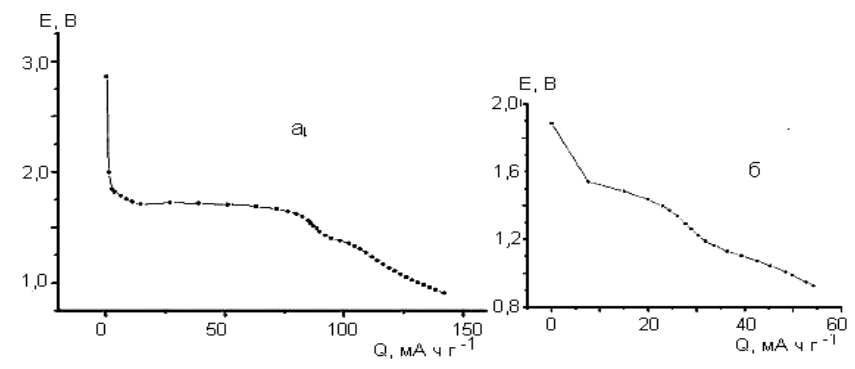

Puc.4. Разрядные характеристики $\mathrm{TiO}_{2}$ (масса 19,9 ме $\mathrm{CM}^{-2}$ ), используемого для синтеза (FeS, $\mathrm{TiO}_{2}$ ). іразр, $_{\text {ра }} \mathrm{CM}^{-2}:$ a) 0,$5 ;$ б). 4,0. Электролит: пропиленкарбонат, диметоксиэтан, 1 моль $\cdot \pi^{-1} \mathrm{LiClO}_{4}$

\section{Выводы}

Полученные электрохимически в тонких слоях композиции FeS с $\mathrm{TiO}_{2}$ массой $1,5-1,7$ мг $\mathrm{cm}^{-2}$ в литиевом макетном аккумуляторе показали улучшенные разрядные характеристики по сравнению с аналогом FeS. Разрядная емкость композиции увеличилась по сравнению с таковой аналога на 50-53 \%. Необходима оптимизация состава композиции $\mathrm{FeS}, \mathrm{TiO}_{2}$ в дальнейшем для повышения разрядной емкости.

\section{Литература}

[1] Apostolova R.D., Kolomoyets O.V., Shembel E.M. // Surface Engin. Appl. Electrochem. - 2011. - V. 47. - №5. - P. 465-470.

[2] Hu Y.S., Kienle L., Guo Y.G., Maier J. // Advanc. Mater. - 2006. V. 18. - P. 1421-1426.

[3] Armstrong G., Armstrong A., Bruce P., Reale P., Scrosati B. // Advanc. Mater. - 2006. - V. 18. - P. 2597-2600. 


\title{
IMPROVEMENT OF FeS CHARACTERISTICS IN Li-ACCUMULATORS BY ELECTROCHEMICAL CODEPOSITION WITH $\mathrm{SiO}_{2}$
}

\author{
MACIYEVSKYI N.A., APOSTOLOVA R.D., SAVCHENKO M.O., \\ PIESKOV R.P., POLISCHUK Yu.V. \\ SHEl "Ukrainian State University of Chemical Technology" \\ shembel@onil.dp.ua
}

Comparison of discharge characteristics of electrochemically synthesized $\mathrm{FeS}$ and its compositions with $\mathrm{SiO}_{2}$ in lithium accumulator was carried out. The inclusion of $\mathrm{SiO}_{2}$ in $\mathrm{FeS}$ deposit was confirmed by $X$-ray data and galvanostatic discharge-charge cycling. The discharge capacity of thin-layer $\left(\mathrm{FeS}, \mathrm{SiO}_{2}\right)$ compositions showed an increase of $50-55 \%$ in comparison with that of thin-layer FeS in a model lithium accumulator in the 2.8-1.1 V voltage range. On determining the possibility of using the thin-layer compositions in the negative electrodes of lithium-ion systems an increase of discharge capacity was established in $2.80-0.01 \mathrm{~V}$ potential range vs. $\mathrm{Li} / \mathrm{Li}^{+}$.

\section{УЛУЧШЕНИЕ ХАРАКТЕРИСТИК FeS В Lі-АККУМУЛЯТОРЕ ЭЛЕКТРОХИМИЧЕСКИМ СООСАЖДЕНИЕМ С $\mathrm{SiO}_{2}$}

\section{МАЦИЕВСКИЙ Н.А., АПОСТОЛОВА Р.Д. , САВЧЕНКО М.О., ПЕСКОВ Р.П., ПОЛИЩУК Ю.В.}

ГВУЗ “Украинский государственный химико-технологический университет"; shembel@onil.dp.ua

Проведено сравнение разрядных характеристик в макетном литиевом аккумуляторе электрохимически синтезированного FeS и его композиции с $\mathrm{SiO}_{2}$. Включение $\mathrm{SiO}_{2}$ в осадок $\mathrm{FeS}$ подтверждено данными рентгенофразового анализа и гальваностатического разрядно-зарядного циклирования. Разрядная емкость тонкослойных композиций $\left(\mathrm{FeS}, \mathrm{SiO}_{2}\right)$ выросла на $50-55 \%$ по сравнению с таковой тонкослойного сульфида FeS в макетном литиевом аккумуляторе в интервале напряжения 2,8-1,1 B, а также при 2,80-0,05 В относительно Li/Li ${ }^{+}$-электрода для установления возможности ее использования в отрицательных электродах Lі-ионной системы.

Тонкослойные 
основе хорошо зарекомендовали себя в макетном Li-аккумуляторе при разряде до 1,1 В [1], но их нельзя использовать в отрицательных электродах литий-ионных батарей, работающих в области потенциалов электрохимической активности алюминия в реакции с литием. Осаждение М-сульфидов для этих электродов осуществляют на сетке из стали (18Н12X9T). Повысить эфрфективность преобразования М-сульфидов на стальной сетке в литиевом Li-аккумуляторе можно, включая электрохимически частицы графита в осадок М-сульфидов [2]. При осаждении М-сульфидов на пластине из стали $18 \mathrm{H} 12$ Х9Т не удается достигнуть прочного сцепления осадка с подложкой, обеспечивающего стабильную разрядную емкость аккумулятора.

Необходимы новые способы повышения эффрективности преобразования М-сульфидов в редокс-реакции с литием, один из которых предложен в данной работе. Получен положительный эфрфект в макетном Li-аккумуляторе с композитным электродом $\mathrm{FeS}, \mathrm{SiO}_{2}$, синтезированным электрохимически.

\section{Методология исследований}

FeS синтезирован на катоде из водного раствора, содержащего, г.л ${ }^{-1}: \mathrm{FeSO}_{4} \cdot 7 \mathrm{H}_{2} \mathrm{O}-13 ; \mathrm{Na}_{2} \mathrm{~S}_{2} \mathrm{O}_{3} \cdot 5 \mathrm{H}_{2} \mathrm{O}-5 ; \mathrm{pH} 4,5-5,0$ при принудительном перемешивании (180 об/мин). Нанометровый $\mathrm{SiO}_{2}$ добавляли в раствор в количестве $2 г \cdot r^{-1}$. $\mathrm{i}_{\text {катод }}=1,5-3,0 \mathrm{~mA} \cdot \mathrm{cm}^{-2}$, $\mathrm{t}_{\text {электр }}=(17-19)^{\circ} \mathrm{C}$.

$\mathrm{SiO}_{2}$ аморфной модификации получен по методу осаждения серной кислотой (с размерами зерна 10-16 нм, удельной поверхностью по азоту $202 \mathrm{~m}^{2} \cdot \Gamma^{-1}$, массовой долей влаги 6,2\%).

Электрохимические характеристики сульфидных материалов определяли в модельном Li-аккумуляторе в габаритах ХИТ 2016 с

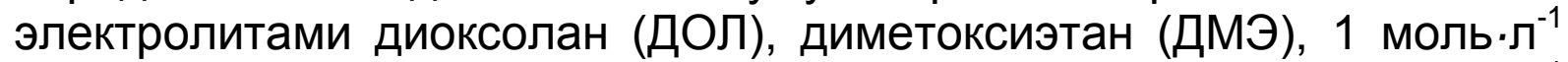
$\mathrm{LiBF}_{4}$ или диметилкарбонат (ДМК), этиленкарбонат (ЭК), 1 моль: ${ }^{-1}$ $\mathrm{LiClO}_{4}$ в гальваническом разрядно-зарядном циклировании.

\section{Результаты и их обсуждение}

По данным рентгенофазового анализа в осадке, полученном из электролита без $\mathrm{SiO}_{2}$, идентифицирован $\mathrm{FeS}$ с гексагональной сингонией (80-1029), из суспензии $\mathrm{SiO}_{2}$ в электролите осаждения наряду с FeS обнаружен $\mathrm{SiO}_{2}$ с гексагональной сингонией (82-0511). Частицы $\mathrm{SiO}_{2}$ включаются в осадок в виде агломератов микрометрового размера, состоящих из субмикронных частиц.

Обратимая емкость FeS в Li-аккумуляторе составляет 160-170 мА.ч·r ${ }^{-1}$ на 8-м цикле при плотности тока 0,17 мА.см ${ }^{-2}$ (рис.1 а), 
композита $\left(\mathrm{FeS}, \mathrm{SiO}_{2}\right)$ - 290-300 мA.4. $\mathrm{r}^{-1}$ (рис.1 б), что на 50-55\% выше разрядной емкости FeS.

Разрядная емкость $\left(\mathrm{FeS}, \mathrm{SiO}_{2}\right)$ с той же массой 1,65 мг· $\mathrm{cm}^{-2} \cdot$ при циклировании в ряду 2,80-0,01 B, установленная для определения возможности использования в отрицательных электродах Li-ионной системы, стабилизируется на уровне 500 мА.ч·r ${ }^{-1}$ после 15 циклов (рис.2).

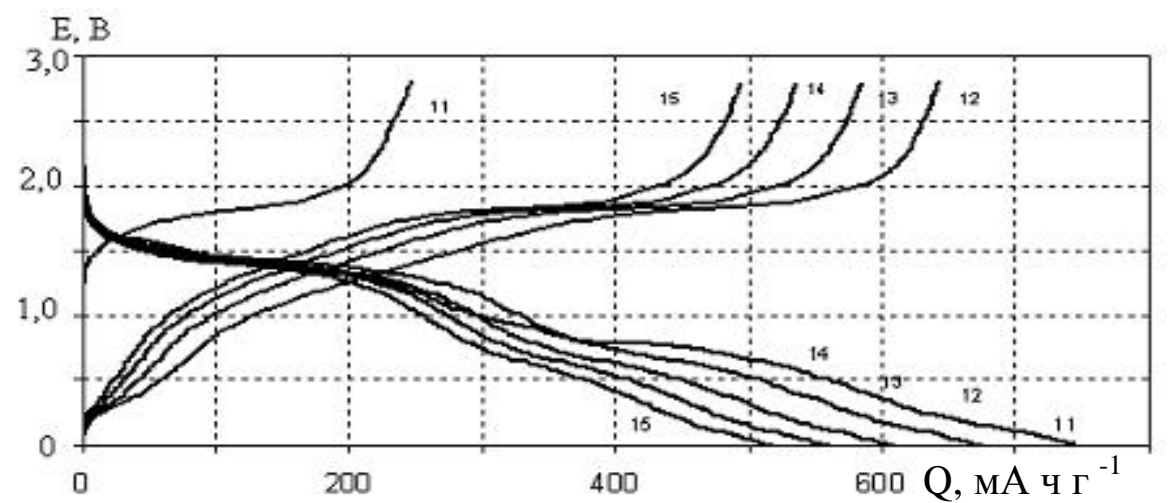

Puc. 2. Разряднозарядные кривые $\left(\mathrm{FeS}, \mathrm{SiO}_{2}\right)$ в Liаккумуляторе (1115 циклы). Электролит ДОЛ, ПК, $1 \mathrm{M} \mathrm{LiBF}_{4}$. $i_{\text {разр }}=0,30 \mathrm{MA} \cdot \mathrm{CM}^{-2}$

B макете на основе $\mathrm{FeS}, \mathrm{SiO}_{2}$ c массой 7,00 мг· $\mathrm{cm}^{-2}$ зарядное напряжение при циклировании выходит на уровень 1,7-1,8 В относительно лития (рис.3) и не поднимается до 2,8 В, как на (рис.2).

При длительном заряжении обратимая разрядная емкость (кривые 2, 3) равная $500 \mathrm{MA} \cdot 4 \cdot \mathrm{r}^{-1}$ составляет 45\% от зарядной емкости. Профриль разрядных кривых 2,3 аналогичен профилю, характерному для FeS. Признаков наличия площадки напряжения $\mathrm{SiO}_{2}$ вблизи 0,2 В на разрядных кривых 2,3 не наблюдается. Однако после кратковременного заряжения (рис.3, кривая 4; рис.4) FeS практически не образуется при литировании, но выявляется площадка напряжения вблизи $0,2 \mathrm{~B}$, присущая $\mathrm{SiO}_{2}$. В последующем 5-ом цикле происходят изменения в разрядной кривой, как показано на рис.5.

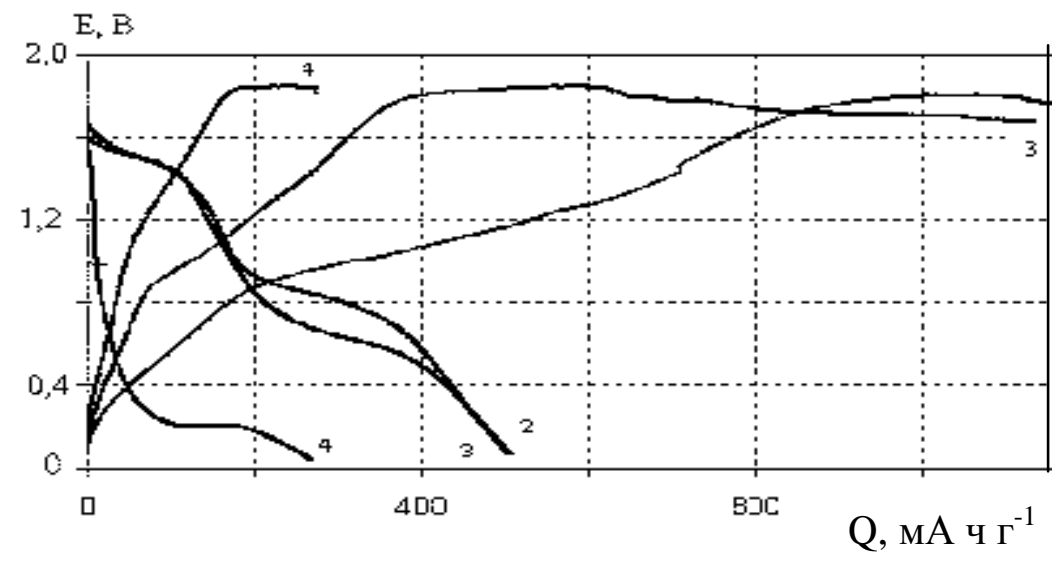

Puc. 3. Разряднозарядные кривые $\left(\mathrm{FeS}, \mathrm{SiO}_{2}\right)$ в $\mathrm{Li}-$ аккумуляторе (2-4 циклы). Электролит ЭК, ДМК, $1 \mathrm{M} \mathrm{LiClO}_{4}$. $i_{3}=0,03 \mathrm{MA} \cdot \mathrm{CM}^{-2}$, $i_{\text {разр }}=0,30 \mathrm{MA} \cdot \mathrm{CM}^{-2}$ 


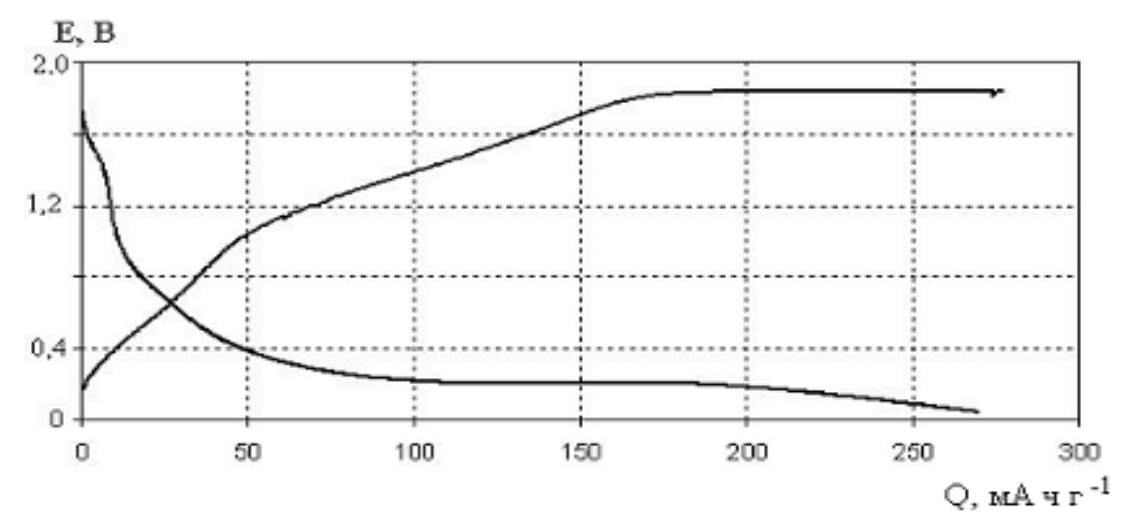

Puc. 4. Разрядно-зарядная кривая композита $\left(\mathrm{FeS}, \mathrm{SiO}_{2}\right)$ в литиевом аккумуляторе, представленная на Puс. 3 (кривая 4)

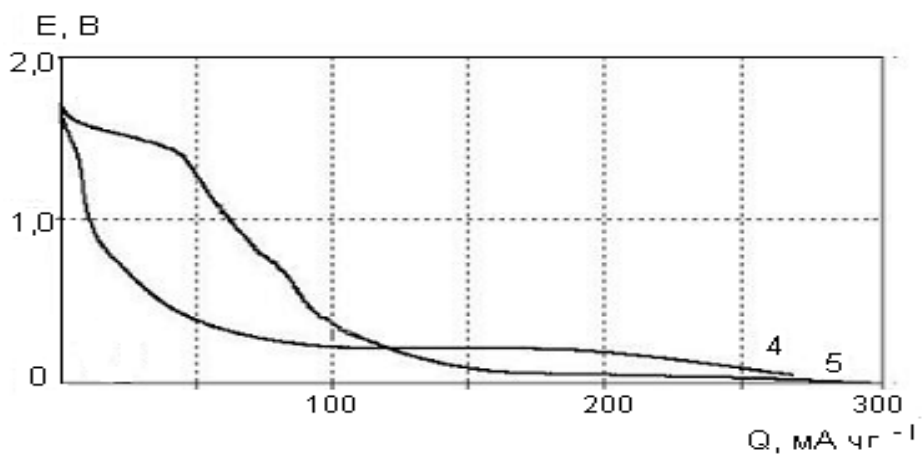

Рuc. 5. Разрядные кривые образиа (FeS, $\left.\mathrm{SiO}_{2}\right)$ в литиевом аккумуляторе в зависимости от длительности заряжения $(\tau)$ при напряжении $E=1,7$ B.

$\mathrm{SiO}_{2}$ исследуют в отрицательных электродах ЛИА. Мнения о возможности использования его в качестве активного электродного материала разделяются на явно противоположные - от инертности в реакции с литием и термодинамической несостоятельности реакции $\mathrm{SiO}_{2}$ с литием [3] до экспериментальных доказательств его восстановления литием с образованием ионопроводящего силиката $\mathrm{Li}_{4} \mathrm{SiO}_{4}$ и $\mathrm{Li}_{2} \mathrm{O}$ [4], а также реализации разрядной емкости $400 \mathrm{MA} \cdot 4 \cdot r^{-1}$ коммерческим $\mathrm{SiO}_{2}$ [5]. Показано, что ортосиликат лития $\mathrm{Li}_{4} \mathrm{SiO}_{4}$ при взаимодействии с апротонным литий-содержащим электролитом ЛИА переходит в плохо проводящий $\mathrm{Li}_{2} \mathrm{SiO}_{3}$.

Представленные результаты свидетельствуют о включении $\mathrm{SiO}_{2}$ в процессе электрохимического синтеза $\mathrm{FeS}$ в его тонкий слой, электрохимической активности $\mathrm{SiO}_{2}$ в реакции с литием (наличие разрядной кривой с горизонтальной площадкой напряжения вблизи 0,2 B) и о благотворном влиянии на разрядные характеристики FeS в литиевом аккумуляторе.

Представленные изменения разрядных кривых 4, 5 (рис. 3-5) могут быть связаны с выше указанными превращениями силикатов. Наряду с этим, проявляется эффрект электрохимического преобразования FeS на реакцию литирования вблизи 0,2 В. Для выявления указанных эффектов при 0,2 В, а также при 1,7-1,8 В в процессе делитирования необходимы дальнейшие исследования. 
Следует сказать при этом, что в данной работе температура сушки FeS была выбрана как компромисная. Она ограничена величиной $60^{\circ} \mathrm{C}$ из-за снижения адгезии $\mathrm{FeS}$ к нержавеющей стали с повышением температуры, приводящей к снижению разрядной емкости в ЛИА, тогда как повышение температуры повышает разрядную емкость $\mathrm{FeS}$. В исследуемом $\mathrm{SiO}_{2}$, высушенном при $60^{\circ} \mathrm{C}$, не удаляется вся влага. Это отрицательно отражается на разрядных характеристиках $\mathrm{SiO}_{2}$ в неводной среде. Наличие площадки напряжения при 1,7-1,8 В при делитировании композита $\left(\mathrm{FeS}, \mathrm{SiO}_{2}\right)$ с массой 7,00 мг. $\mathrm{cm}^{-2}$ и отсутствием еe при делитировании образцов с массой 1,65 мг. $\mathrm{cm}^{-2}$ можно объяснить влиянием влаги. В случае образца с малой массой привносимая с ним влага в макетный аккумулятор допустима и не влияет на его зарядную характеристику, но с повышением массы композита и количества влаги в нем достигается критическая величина, оказывающая отрицательное воздействие на преобразование исследуемой системы.

\section{Выводы}

При осаждении на катоде тонкослойного FeS в присутствии $\mathrm{SiO}_{2}$, синтезированного осаждением серной кислотой, получена композиция $\left(\mathrm{FeS}, \mathrm{SiO}_{2}\right)$, разрядная емкость которой выше таковой FeS-аналога на 50-55 \%. Получены свидетельства электрохимической активности $\mathrm{SiO}_{2}$ в редокс-реакции с литием.

\section{Литература}

[1] Нагирный В.М., Апостолова Р.Д., Шембель Е.М. Синтез и электрохимические характеристики электролитических металлооксидных и металло-сульфидных соединений для литиевых аккумуляторов. Днепропетровск: Изд-во ГВУЗ УДХТУ, 2008. 260 с.

[2] Apostolova R.D., Kolomoyets O.V., Shembel' E.M. // Surface Engin. Appl. Electrochem. - 2011. - V. 47. - №5. - P. 465-470.

[3] Saint J., Morcrette M., Larcher D., Laffont L., Beattie S., Peres J. P., Talaga D., Couzi M., Tarascon J.-M. // Advanc. Function. Mater. - 2007. - vol. 17. - № 11. - P. 1765-1774.

[4] Xun S., Song X., Wang L., Grass M. E., Liu Z., Battaglia V. S., Liua G. // J. Electrochem. Soc. - 2011. - vol. 158. - № 12. - P. A1260A1266.

[5] Gao B., Sinha S., Fleming L., Zhou O. // Advanc. Mater. - 2001. vol. 11. - № 11. - P. 816-819. 


\title{
HIGH-RATE LiMn ${ }_{2} \mathrm{O}_{4}$ CATHODE MATERIAL FOR Li-ION BATTERIES SYNTHESIZED BY MICROWAVE-ASSISTED CITRATE METHOD
}

\author{
SHMATOK YU.V., POTAPENKO A.V. \\ Joint Department of Electrochemical Energy Systems, \\ 38a Vernadsky Blvd., Kiev 03680, Ukraine, yu.shmatok@gmail.com
}

Spinel $\mathrm{LiMn}_{2} \mathrm{O}_{4}$ cathode materials of high-rate electrochemical performance were successfully synthesized using a microwave-assisted citrate technique. The influence of synthesis conditions on structural and morphological characteristics of the materials obtained were investigated by X-ray diffraction (XRD) and scanning electron microscopy (SEM). The synthesized spinels deliver specific capacity up to $97 \mathrm{mAh} / \mathrm{g}$ at the $0.5 \mathrm{C}$ rate and demonstrate excellent cyclability and high-rate capability up to $40 \mathrm{C}$.

In the technology of materials for lithium ion batteries (LIBS), considerable attention is paid to transition from micro- to nanosized electrode materials, which is associated with necessity to obtain higher specific characteristics during long cycling and high-rate operation [1, 2]. It is of special importance in terms of the energy required by powerful consumers such as electric vehicles.

Spinel $\mathrm{LiMn}_{2} \mathrm{O}_{4}$ is a promising cathode material for using in such LIBs $[1,2]$. The choice of the optimal $\mathrm{LiMn}_{2} \mathrm{O}_{4}$ synthesis conditions is a significant factor for achieving high electrochemical characteristics of synthesized materials.

Using microwave (MW) irradiation for the synthesis of electrode materials becomes more and more popular [3]. On the first place, this is related to high speed and energy efficiency of such a process. The minimization of the duration of heating allows for obtaining nanosized materials.

In this work, MW heating coupled with the citrate synthesis method was employed for the synthesis of $\mathrm{LiMn}_{2} \mathrm{O}_{4}$. The influence of the duration of MW stage on structural and morphological characteristics of the materials obtained was investigated. The suitability of this method for the synthesis of $\mathrm{LiMn}_{2} \mathrm{O}_{4}$ for the high-rate LIBs was shown.

\section{Research Methodology}

Solutions of lithium nitrate, manganese nitrate and citric acid of 0.5 $2 \mathrm{M}$ concentrations mixed in the molar ratio of $1: 2: 6$ according to the procedure described in Refs. [4-6], were used to prepare $\mathrm{LiMn}_{2} \mathrm{O}_{4}$. 
For MW synthesis, consumer Saturn ST-MW7154 and LG MS1949W microwave ovens were used operating at $2.45 \mathrm{GHz}$ frequency with maximum output power of $700 \mathrm{~W}$. The mixture of solutions in a quantity of $20-30 \mathrm{ml}$ was placed in MW oven and irradiated at a power of 120-600 W for 30-35 min. The precursor obtained was ground and then subjected to heating in the MW oven for 15-20 min at maximal operating power. After that the power was reduced to $420 \mathrm{~W}$ and the process was continued. The temperature was measured with an infrared contactless UT303A pyrometer after switching the oven off. Then $\mathrm{LiMn}_{2} \mathrm{O}_{4}$ samples were annealed at $700{ }^{\circ} \mathrm{C}$ for $24 \mathrm{~h}$ with constant heating and cooling rates equal to 5 and $2{ }^{\circ} \mathrm{C} / \mathrm{min}$, respectively.

The particle size and morphology were characterized by means of scanning electron microscopy (JSM 6700F, JEOL, Japan). The phase composition and structural parameters were studied using X-ray diffraction on a DRON UM1 diffractometer with CoKa radiation.

Electrochemical investigations were performed in CR2016 coin cells with $\mathrm{Li}$ anode on a home-made automated workstation. The cathode slurry consisting of $80.6 \%$ of the working material $\left(\mathrm{LiMn}_{2} \mathrm{O}_{4}\right), 11.4 \%$ of a conducting additive and $8 \%$ of a poly(vinylidene difluoride) binder was coated on an aluminum foil with a doctor blade. Celgard 2500 was employed as a separator. The $1 \mathrm{M}$ solution of $\mathrm{LiPF}_{6}$ in a mixture of ethylene carbonate and dimethyl carbonate taken in the 1:1 mass ratio was used as an electrolyte. Galvanostatic investigations were performed in the 3.4-4.5 $\mathrm{V}$ potential range at different current densities expressed in $\mathrm{C}$ values $(1 \mathrm{C}=148 \mathrm{~mA} / \mathrm{g})$.

\section{Results and Discussion}

The X-ray diffraction patterns of $\mathrm{LiMn}_{2} \mathrm{O}_{4}$ samples obtained at various duration of $\mathrm{MW}$ pyrolysis are shown in Fig.1. All samples are well-formed crystalline $\mathrm{LiMn}_{2} \mathrm{O}_{4}$ phases (JCPDS 35-0782) regardless of MW exposure duration as indicated by respective peaks. Any impurities in synthesized samples have not been detected. The morphology of the synthesized $\mathrm{LiMn}_{2} \mathrm{O}_{4}$ samples is shown in Fig. 2.

Shortening of the thermal treatment by the use of MW pyrolysis allows at this stage for getting weakly agglomerated particles with the average size of less than $50 \mathrm{~nm}$ (Fig. 2a). Further annealing during $24 \mathrm{~h}$ at $700{ }^{\circ} \mathrm{C}$ leads to expected enlargement of particles; their average sizes increase to $50-60 \mathrm{~nm}$ (Fig. 2b). There is a marked growth in the particle size of spinel to $60-80 \mathrm{~nm}$ with increasing of exposure of MW pyrolysis to 2 (Fig. 2c) and 4 (Fig. 2d) min, which is associated with a higher rate of crystal growth, that occurs during $\mathrm{MW}$ heating. Nevertheless, all synthesized $\mathrm{LiMn}_{2} \mathrm{O}_{4}$ samples remain weakly agglomerated, which is important in terms of obtaining high electrochemical performances. 


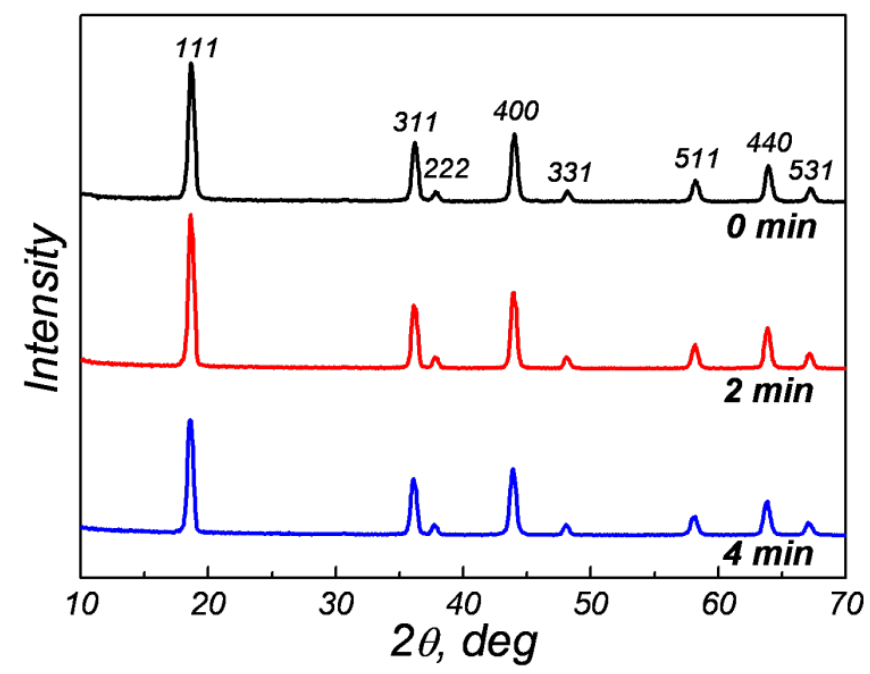

Figure 1. XRD patterns of samples obtained at various duration of MW pyrolysis.
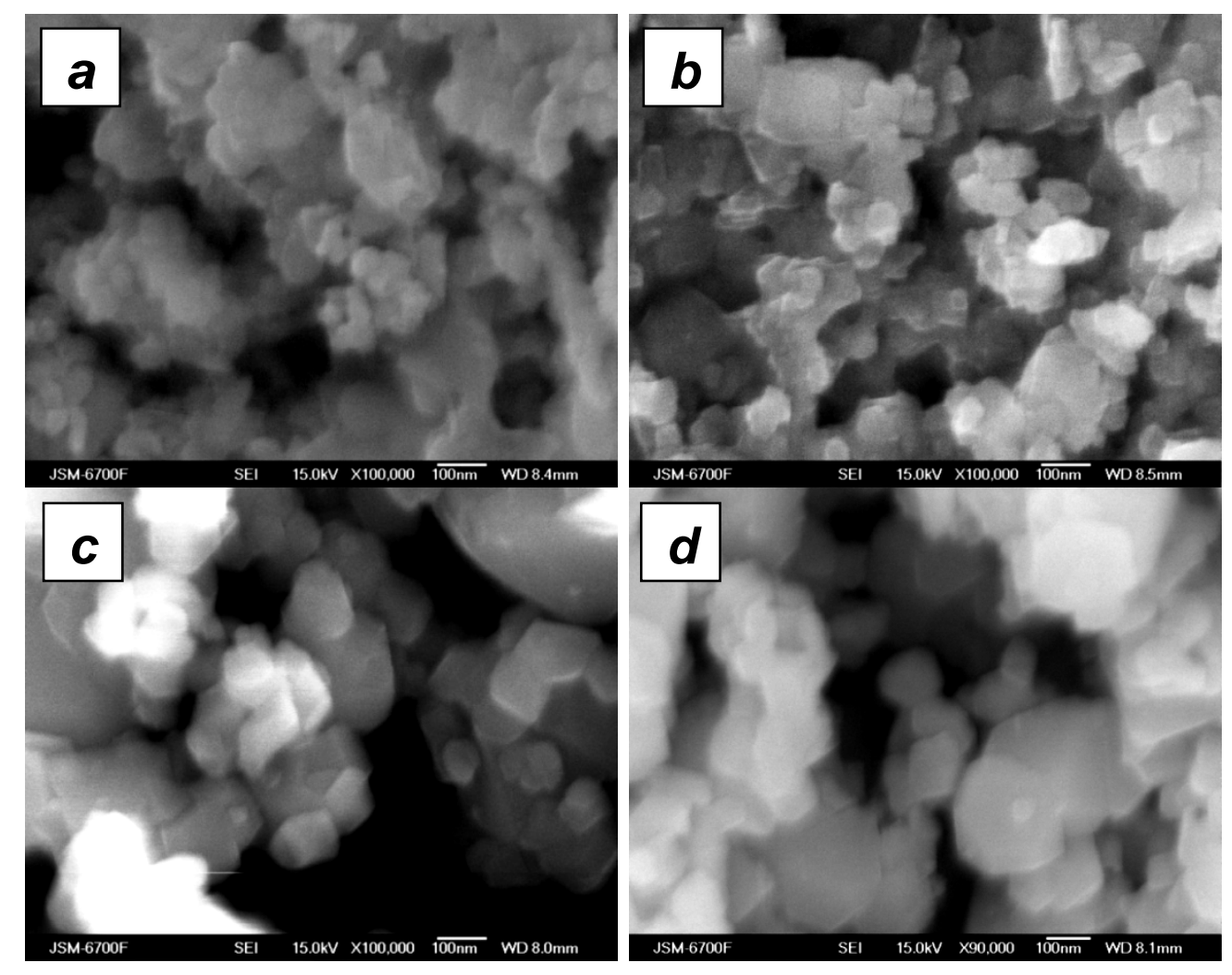

Figure 2. SEM images of $\mathrm{LiMn}_{2} \mathrm{O}_{4}$ samples (a) MW treated for 15-20 min at $700 \mathrm{~W}$; (b) same as (a) + annealing for $24 \mathrm{~h}$; (c) same as (a) + MW treatment for 2 min at $420 \mathrm{~W}+$ annealing for $24 \mathrm{~h}$; (d) same as (a) + MW treatment for 4 min at $420 \mathrm{~W}+$ annealing for $24 \mathrm{~h}$. 

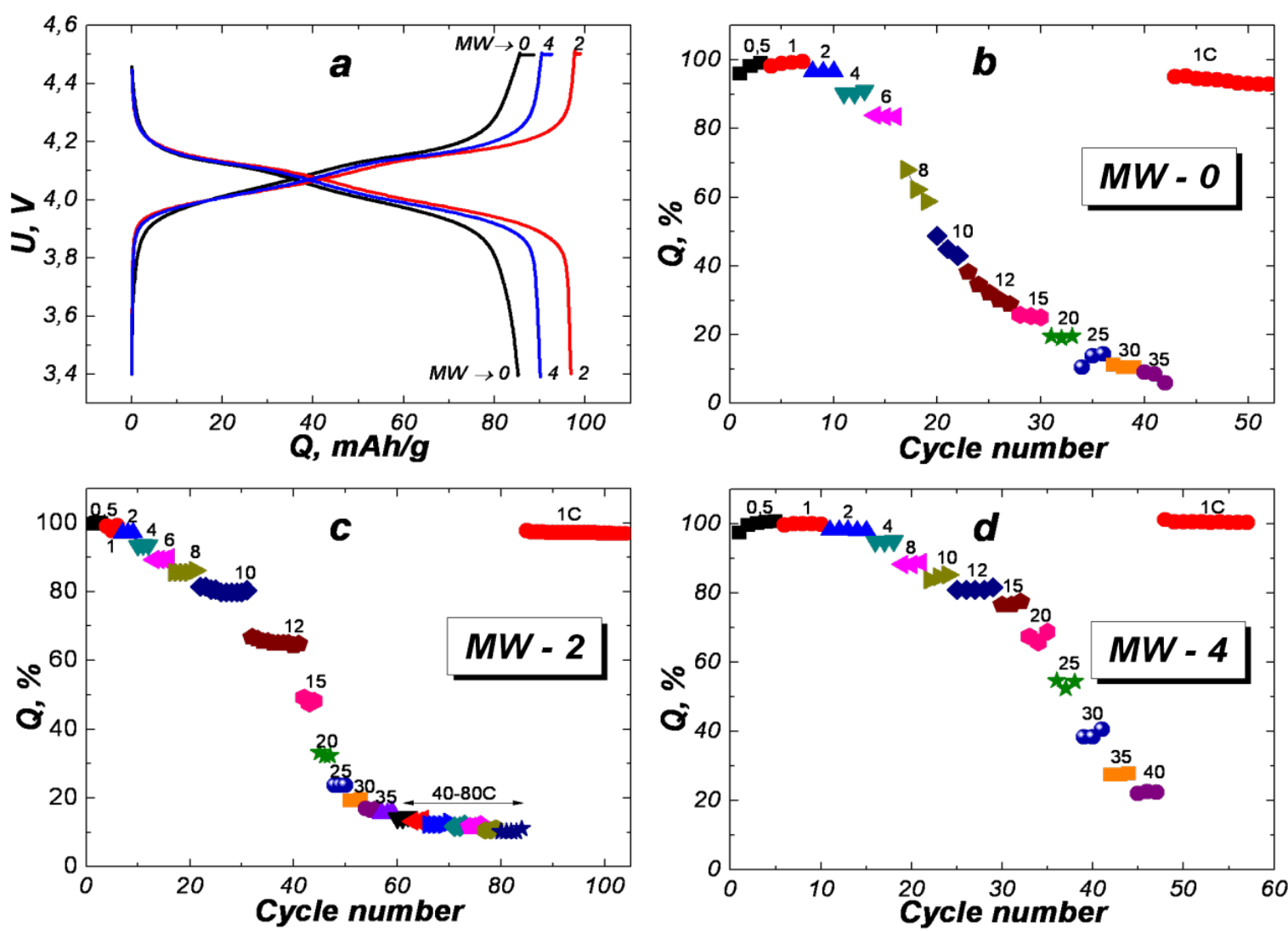

Figure 3. Galvanostatic curves of the $\mathrm{Li} \| \mathrm{LiMn}_{2} \mathrm{O}_{4}$ cells on the third charge-discharge cycles at $0.5 \mathrm{C}$ rate (a) and $(b-d)$ dependences of the discharge capacity on cycle number at various current rates (charge rate of $1 \mathrm{C}$ with a trickle charge at $0.1 \mathrm{C}$ ).

Numeric values mean discharge current densities in $C$ units

Fig. 3a shows the galvanostatic curves of the $\mathrm{Li} \| \mathrm{LiMn} \mathrm{O}_{4}$ cells on the third charge-discharge cycle at the minimal current load of $0.5 \mathrm{C}$. The specific discharge capacities obtained are quite low and their values are 85, 97 and $90 \mathrm{mAh} / \mathrm{g}$ for $\mathrm{LiMn}_{2} \mathrm{O}_{4}$ samples with $\mathrm{MW}$ duration of $0,2,4$ min, respectively. However, the synthesized spinels demonstrate quite good high-rate capabilities, and the best among them is the sample with MW duration of 4 min (Fig. 3d). Its specific capacity at the $25 \mathrm{C}$ rate is more than $50 \%$ of its initial value, and upon the maximum discharge current of $40 \mathrm{C}$, the capacity equals to $22 \%$.

In addition, during control cycling at the $1 \mathrm{C}$ current rate, this spinel demonstrate $100 \%$ of initial specific capacity. This indicates on absence of degradation of the electrode materal and shows prospects for its application in high-power LIBs. 


\section{Conclusions}

In the present paper, $\mathrm{LiMn}_{2} \mathrm{O}_{4}$ has been synthesized by using a microwave-assisted citrate method. It is shown that variation of the MW heating duration allows for obtaining $\mathrm{LiMn}_{2} \mathrm{O}_{4}$ of controllable dispersion with average particle size from $50 \mathrm{~nm}$. Investigations of electrochemical characteristics show that in spite of quite low specific capacities not exceeding $97 \mathrm{mAh} / \mathrm{g}$, the materials in question are able to sustain high current loads (up to $40 \mathrm{C}$ ) without degradation, which makes them promising for possible use in LIBs of new generation.

\section{Acknowledgments}

Thanks are due to Dr. S.A. Kirillov for discussions and advice.

\section{References}

[1] Aricò A.S., Bruce P., Scrosati B., Tarascon J.M., Schalkwijk W. Nanostructured materials for advanced energy conversion and storage devices. Nature Materials, 4, 366-377 (2005).

[2] Myung S.-T., Amine K., Sun Y.-K. Nanostructured cathode materials for rechargeable lithium batteries. Journal of Power Sources, 283, 219-236 (2015).

[3] Balaji S., Mutharasu D., Subramanian N. S., Ramanathan K. A review on microwave synthesis of electrode materials for lithium-ion batteries. Ionics, 15, 765-777 (2009).

[4] Потапенко А.В., Чернухин С.И., Романова И.В., Кириллов С.А. Физико-химические и электрохимические свойства наноразмерного $\mathrm{Li}\left[\mathrm{Li}_{0,033} \mathrm{Mn}_{1,967}\right] \mathrm{O}_{4}$. Хімія, фрізика та технологія поверхні. 2, 175-181 (2011).

[5] Potapenko A.V., Chernukhin S.I., Kirillov S.A. A new method of pretreatment of lithium manganese spinels and high-rate electrochemical performance of $\mathrm{Li}\left[\mathrm{Li}_{0.033} \mathrm{Mn}_{1.967}\right] \mathrm{O}_{4}$. Materials for Renewable and Sustained Energy 3, 40-47 (2014).

[6] Farbun I.A., Romanova I.V., Kirillov S.A. Optimal design of powdered nanosized oxides of high surface area and porosity using a citric acid aided route, with special reference to ZnO. Journal of Sol-Gel Science and Technology.68, 411-422 (2013). 
UDC 544.6.076.324.4 + 544.016

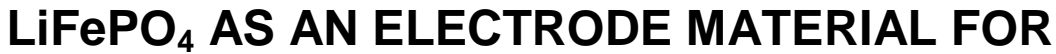 LITHIUM-ION BATTERIES
}

\author{
MUKHIN V.V ${ }^{1}$, SUSLOV M.M ${ }^{1}$, POTAPENKO A.V ${ }^{2}$, \\ ${ }^{1}$ Kyiv National University of Technologies and Design, Kiev \\ ${ }^{2}$ Joint Department of Electrochemical Energy Systems, Kiev \\ avoloshka@ukr.net
}

Lithium iron phosphate (LFP) samples have been synthesized by a solid-state method from $\mathrm{Li}_{2} \mathrm{CO}_{3},\left(\mathrm{NH}_{4}\right)_{2} \mathrm{HPO}_{4}$, and $\mathrm{FeC}_{2} \mathrm{O}_{4} \cdot 2 \mathrm{H}_{2} \mathrm{O}$ in the presence of citric acid monohydrate as a source of carbon. It has been shown that LFP samples have initial capacity of $130 \mathrm{mAh} \cdot \mathrm{g}^{-1}$ at a current rate of $0.6 C$.

There is an increasing claim for applications of electrochemical energy systems in energy storage, transportation and portable electronics, and a lot of electrode materials for lithium ion batteries have been created during last thirty years. Lithium ion phosphate (LFP) has been recommended as a cathode material in 1997 [1]. Since then, different methods of obtaining LFP have been used. This material has specific advantages and disadvantages. High theoretical capacity (170 mAh. $g^{-1}$ ), thermal stability (up to $80{ }^{\circ} \mathrm{C}$ ), high potential of charge/discharge (3.4V vs $\mathrm{Li}^{+} / \mathrm{Li}$ ) and a number of charge/discharge cycles (2000-8000) have been considered as advantages. Low electronic conductivity at the room temperature $\left(10^{-9} \mathrm{~S} \cdot \mathrm{cm}^{-1}\right)$ and coefficient of diffusion $\left(1.8 \cdot 10^{-14} \mathrm{CM}^{2} \cdot \mathrm{c}^{-1}\right)$ can be estimated as disadvantages [2]. The properties of LFP obtained by different methods are summarized in Table 1 . The highest discharge rates and capacities have been achieved for samples obtained by means of a rheological method. Spray pyrolysis and microwave synthesis give good results, particularly $59 \mathrm{mAh} \cdot \mathrm{g}^{-1}$ at the scanning rate of $20 \mathrm{C}$.

In this paper, LFP has been synthesized by the traditional solidstate method in the presence of citric acid monohydrate as a source of carbon, so as to ensure a conductive coverage of the LFP particles. The data on morphology and electrochemical properties of the sample obtained are presented and discussed. 
Table 1. Physical-chemical and electrochemical characteristics of electrode materials obtained by different methods.

\begin{tabular}{|c|c|c|c|c|}
\hline $\begin{array}{l}\text { Method of } \\
\text { synthesis }\end{array}$ & $\begin{array}{l}\text { Precursors, } \\
\text { carbon source }\end{array}$ & $\begin{array}{l}\text { Temperature, } \\
\text { atmosphere, } \\
\text { regime of cycling }\end{array}$ & $\begin{array}{l}\text { Discharge } \\
\text { capacity } \\
\mathrm{mAh} \cdot \mathrm{g}^{-1}\end{array}$ & Ref. \\
\hline Rheological & $\begin{array}{c}\mathrm{H}_{3} \mathrm{PO}_{4} \\
\mathrm{FeSO} \\
\mathrm{LiOH} \cdot 7 \mathrm{H}_{2} \mathrm{O} \\
\text { starch }\end{array}$ & $\begin{array}{c}600^{\circ} \mathrm{C} \text { (inert } \\
\text { atmosphere), } \\
2.0-4.4 \mathrm{~V} \\
0.2-30 \mathrm{C}\end{array}$ & $157-72$ & [3] \\
\hline Rheological & $\begin{array}{c}\mathrm{H}_{3} \mathrm{PO}_{4}, \\
\mathrm{FeSO} \\
\mathrm{LiOH} \cdot 7 \mathrm{H}_{2} \mathrm{O}, \mathrm{H}_{2} \mathrm{O}_{2} \\
\text { stearic acid }\end{array}$ & $\begin{array}{c}600^{\circ} \mathrm{C} \text { (inert } \\
\text { atmosphere), } \\
2.0-4.4 \mathrm{~V} \\
0.5-30 \mathrm{C}\end{array}$ & 160-93 & {$[4]$} \\
\hline Spray pyrolysis & $\begin{array}{c}\mathrm{Li}_{2} \mathrm{CO}_{3} \\
\mathrm{Fe}\left(\mathrm{NO}_{3}\right)_{3} \cdot 9 \mathrm{H}_{2} \mathrm{O} \\
\mathrm{NH}_{4} \mathrm{H}_{2} \mathrm{PO}_{4} \\
\text { citric acid }\end{array}$ & $\begin{array}{c}700^{\circ} \mathrm{C} \text { (inert } \\
\text { atmosphere), } \\
2.0-4.2 \mathrm{~V} \\
0.1-20 \mathrm{C}\end{array}$ & 159-60 & {$[5]$} \\
\hline $\begin{array}{l}\text { Combined spray } \\
\text { pyrolysis + "wet" } \\
\text { treatment in a ball } \\
\text { mill }\end{array}$ & $\begin{array}{c}\mathrm{Li}(\mathrm{HCOO}) \cdot \mathrm{H}_{2} \mathrm{O} \\
\mathrm{FeCl}_{2} \cdot 4 \mathrm{H}_{2} \mathrm{O} \\
\mathrm{H}_{3} \mathrm{PO}_{4}\end{array}$ & $\begin{array}{l}500^{\circ} \mathrm{C} \\
600{ }^{\circ} \mathrm{C} \\
700^{\circ} \mathrm{C} \\
800{ }^{\circ} \mathrm{C}\end{array}$ & $\begin{array}{l}160-15 \\
150-75 \\
145-35 \\
130-25\end{array}$ & [6] \\
\hline & & $\begin{array}{c}\left(\mathrm{N}_{2}+3 \% \mathrm{H}_{2}\right), 2.5- \\
4.5 \mathrm{~V} \\
0.1-20 \mathrm{C}\end{array}$ & & \\
\hline Microwave heating & $\begin{array}{c}\mathrm{CH}_{3} \mathrm{COOLi} \cdot 2 \mathrm{H}_{2} \mathrm{O} \\
\mathrm{FeSO}_{4}, \mathrm{H}_{3} \mathrm{PO}_{4} \\
\text { citric acid, } \\
\text { polyethylene } \\
\text { glycol }\end{array}$ & $\begin{array}{l}400 \mathrm{BT} \\
2.7-4.2 \mathrm{~V} \\
0.2-20 \mathrm{C}\end{array}$ & $152-59$ & [7] \\
\hline
\end{tabular}

\section{Research Methodology}

$\mathrm{Li}_{2} \mathrm{CO}_{3},\left(\mathrm{NH}_{4}\right)_{2} \mathrm{HPO}_{4}, \mathrm{FeC}_{2} \mathrm{O}_{4} \cdot 2 \mathrm{H}_{2} \mathrm{O}$ and citric acid monohydrate in respective amounts were mixed in a ball mill for 15-20 min. Pyrolysis and thermal treatment of the mixture were performed at $400{ }^{\circ} \mathrm{C}$ and $700{ }^{\circ} \mathrm{C}$ respectively. Working electrodes were made of $85 \%$ of the material under consideration, $7 \%$ of a conducting additive (carbon black) and $8 \%$ of a poly(vinylidene difluoride) binder. The slurry was homogenized by an ultrasonic disperser. It was needed for grinding the particles of the material and carbon black. After the removal of the solvent under an IR 
radiator the quantity of LFP in a dried remainder was of $8-10 \mathrm{mg} \cdot \mathrm{cm}^{-2}$. The electrodes were rolled so as to decrease the thickness of the layer from $110-90$ to $20-30 \mu \mathrm{m}$.

Electrochemical measurements were performed in model CR2016 coin cells on a home-made automated electrochemical workstation using cyclic voltammetry (CV) and galvanostatic charge/discharge cycling methods.

\section{Results and Discussion}

Cyclic voltammetry demonstrates intercalation/deintercalation peaks at 2.5-4.2 V. Galvanostatic tests reveal that the material obtained has discharge capacity of $130 \mathrm{mAh} \cdot \mathrm{g}^{-1}$ and $90 \mathrm{mAh} \cdot \mathrm{g}^{-1}$ at the current rates of $0.6 \mathrm{C}$ and $2 \mathrm{C}$, respectively (Fig. 1). Such a low value of discharge capacity may be due to the fact that the decomposition process is not finished at the temperature chosen for annealing. As follows from micrographs (Fig. 2), the remnants of citric acid are not burnt completely.

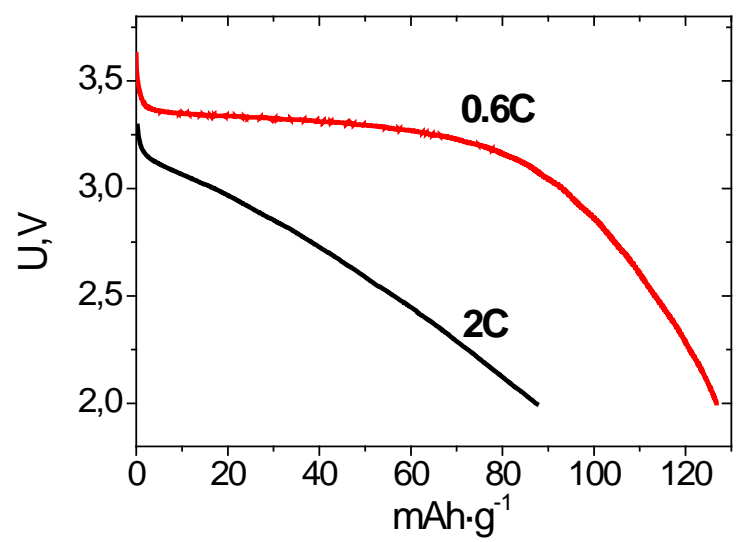

Figure 1. Discharge capacities of LFP samples at different current rates

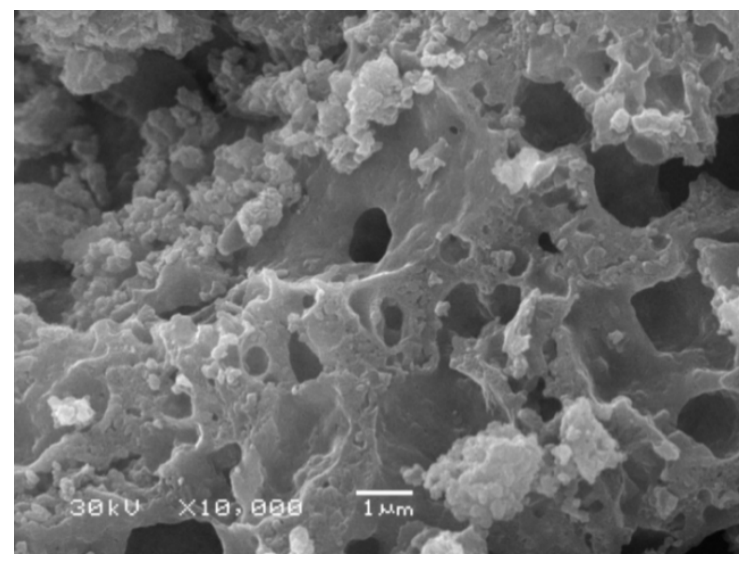

Figure 2. A micrograph of LFP samples 


\section{Conclusions}

Lithium iron phosphate (LFP) samples synthesized by a solid-state method demonstrate initial capacity of $130 \mathrm{mAh} \cdot \mathrm{g}^{-1}$ at a current rate of $0.6 \mathrm{C}$ and discharge capacity of $90 \mathrm{mAh} \cdot \mathrm{g}^{-1}$ at a current rate of $2 \mathrm{C}$.

\section{References}

[1] A.K. Padhi, K.S. Nanjundaswamy, J.B. Goodenough, Phosphoolivines as positive-electrode materials for rechargeable lithium batteries, Journal of electrochemical society, 144, 1188-1194 (1997).

[2] J. W. Fergus. Recent developments in cathode materials for lithium ion batteries, Journal of Power Sources,195, 939-954 (2010).

[3] Y. Huang, H. Ren, Sh. Yin, Y. Wang, Z. Peng, Y. Zhou, Synthesis of $\mathrm{LiFePO}_{4} / \mathrm{C}$ composite with high-rate performance by starch sol assisted rheological phase method, Journal of Power Sources, 195, 610-613 (2010).

[4] Y. Huang, H. Ren, Z. Peng, Y. Zhou, Synthesis of $\mathrm{LiFePO}_{4} / \mathrm{carbon}$ composite from nano-FePO ${ }_{4}$ by a novel stearic acid assisted rheological phase method, Electrochimica Acta, 55, 311-315 (2009).

[5] F. Yu, J. Zhang, Y. Yang, G. Song, Preparation and characterization of mesoporous $\mathrm{LiFePO}_{4} / \mathrm{C}$ microsphere by spray drying assisted template method, Journal of Power Sources, 189, 794-797 (2009)

[6] M. Konarova, I. Taniguchi, Physical and electrochemical properties of $\mathrm{LiFePO}_{4}$ nanoparticles synthesized by a combination of spray pyrolysis with wet ball-milling, Journal of Power Sources, 194, 10291035 (2009).

[7] Y. Zhang, H. Feng, X. Wu, L. Wang, A. Zhang, T. Xia, H. Dong, M. Liu, One-step microwave synthesis and characterization of carbonmodified nanocrystalline $\mathrm{LiFePO}_{4}$, Electrochimica Acta, 54, 3206-3210 (2009). 
УДК 544.476

QUANTUM-CHEMICAL MODELING THE MECHANISMS OF OXYGEN REDUCTION REACTION FOR NON-PLATINUM CATALYSTS

SENYK I.V., KHOMENKO V.G., KATASHINSKII A.S., BARSUKOV V.Z. Kyiv National University of Technologies and Design;

v-barsukov@i.ua

Quantum-chemical modeling of the oxygen reduction reaction (ORR) has been fulfilled for the following groups of non-platinum catalysts: conducting polymers (CPs), transition metal oxides (TMOs) and transition metal spinels (TMSs). In accordance with rotating disc electrode experiments the "effective" number of electrons for ORR counts ca 2.0 for CPs, 2.8 - 3.4 for TMOs and 3.6 - 3.7 for TMSs. Theoretical interpretation of these experimental results has been done due to the ORR modeling for these catalysts. It was shown that the nature of catalysts and specifically the adsorption energy of catalysts for hydrogen peroxide plays a decisive role in the mechanism of ORR.

\section{КВАНТОВО-ХІМІЧНЕ МОДЕЛЮВАННЯ МЕХАНІЗМІВ РЕАКЦІЙ ВІДНОВЛЕННЯ КИСНЮ НА НЕПЛАТИНОВИХ КАТАЛІЗАТОРАХ}

СЕНИК І.В., ХОМЕНКО В.Г., КАТАШИНСЬКИЙ А.С., БАРСУКОВ В.3. Київський національний університет технологій та дизайну, v-barsukov@i.ua

Виконано квантово-хімічне моделювання реакцій відновлення кисню (РВК) на наступних групах неплатинових каталізаторів: струмопровідні полімери (СП), оксиди перехідних металів (ОПМ) та шпінелі перехідних металів (ШПМ). У відповідності до результатів експериментів на дисковому електроді, що обертається, «ефективна» кількість електронів нараховує приблизно 2,0 для СП, 2,8-3,4 для ОПМ та 3,6-3,7 для ШПМ. Дана теоретична інтерпретація експериментальним результатам завдяки моделюванню РВК на таких каталізаторах. Показано, що вирішальну роль в механізмі РВК грає природа каталізатора i, зокрема, енергія адсорбції каталізатора до пероксиду водню.

Реакція відновлення кисню (РВК) на неплатинових каталізаторах має величезне значення для створення недорогих та ефрективних метал-повітряних батарей, паливних елементів, газових сенсорів. 
В літературі [1] описані «класичні» уявлення про можливості відновлення кисню на оксидних каталізаторах по 2-х або 4-х електронному механізмам

в кислому середовищі:

$$
\begin{array}{ll}
\mathrm{O}_{2}+2 \mathrm{H}^{+}+2 \mathrm{e}^{-}=\mathrm{H}_{2} \mathrm{O}_{2} ; & \mathrm{E}_{0}=0,67 \mathrm{~B} \\
\mathrm{H}_{2} \mathrm{O}_{2}+2 \mathrm{H}^{+}+2 \mathrm{e}^{-}=2 \mathrm{H}_{2} \mathrm{O} ; & \mathrm{E}_{0}=1,77 \mathrm{~B}
\end{array}
$$

в лужному середовищі:

$$
\begin{array}{ll}
\mathrm{O}_{2}+\mathrm{H}_{2} \mathrm{O}+2 \mathrm{e}^{-}=\mathrm{HO}^{2-}+\mathrm{OH}^{-} ; & \mathrm{E}_{0}=-0,065 \mathrm{~B} \\
\mathrm{HO}^{2-}+\mathrm{H}_{2} \mathrm{O}+2 \mathrm{e}^{-}=3 \mathrm{OH}^{-} ; & \mathrm{E}_{0}=+0,867 \mathrm{~B}
\end{array}
$$

Дослідження нашої наукової групи дозволили виявити певну каталітичну активність до РВК в наступних групах каталізаторів: струмопровідні полімери (СП) [2], оксиди перехідних металів (ОПМ) та шпінелі перехідних металів (ШПМ) [3]. Експерименти, виконані на дисковому електроді, що обертається, дозволили визначити «ефективну» кількість електронів "n" в РВК, яка склала n=2,0 для СП (поліанілін, поліпіррол), n=2,8-3,4 для ОПМ (CoOx, NiOx) та n=3,6-3,7 для ШПМ $\left(\mathrm{MnCO}_{2} \mathrm{O}_{4}, \mathrm{NiCO}_{2} \mathrm{O}_{4}\right)$ [3].

Виникає необхідність пояснити механізм РВК в таких системах (особливо при «проміжних» значеннях $2<\mathrm{n}<4$ ).

\section{Методологія досліджень}

Виконані ab initio квантовохімічні розрахунки електронної структури молекулярних кластерів та адсорбційних комплексів, які моделюють фізичну та хімічну адсорбцію молекулярного кисню на поверхні складних оксидів (шпінелей) нікелю-кобальту та залізакобальту. Квантовохімічні розрахунки виконано з використанням фрормалізму самоузгодженого поля МО ЛКАО Хартрі-Фока-Рутана в 6-31 базисі функцій Гауса.

\section{Результати та їх обговорення}

Квантово-хімічні розрахунки дозволяють виконати оптимізацію геометричних параметрів адсорбційних комплексів «кисеньполіпіррол» та «кисень-поліанілін» за критерієм мінімуму енергії та встановити, що найбільш вірогідними можуть бути структури, наведені на рис. 1. В присутності протонів електроліту, які швидко приєднуються до атомів кисню з утворенням пероксиду водню, вказані комплекси легко руйнуються, $\mathrm{H}_{2} \mathrm{O}_{2}$ десорбується завдяки відносно малої енергії зв'язку з СП і подальший процес відновлення кисню припиняється. 
(a)

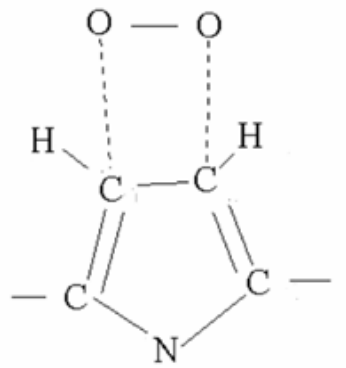

(б)

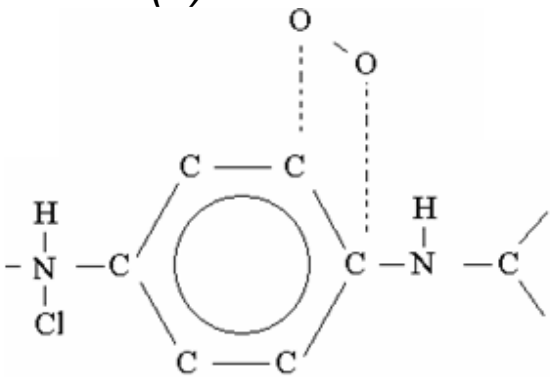

Puc. 1. Найбільш вірогідні структури комплексів СП з киснем для поліпіррола (а) та поліаніліна (б)

Таким чином, в адсорбційних комплексах «кисень-поліпіррол» та «кисень-поліанілін» кисень відновлюється за класичним 2електронним механізмом (до пероксиду водню).

В оксидах та шпінелях перехідних металів РВК протікає за більш складним механізмом.

В кристалах шпінелей нікелю-кобальту, мангану-кобальту та заліза-кобальту катіони нікелю, мангану та заліза заповнюють тетраедричні, а кобальту - октаедричні позиції (рис. 2). Елементарні комірки таких шпінелем складаються з 32 аніонів кисню, 16 катіонів кобальту і 8-ми катіонів нікелю (або відповідно мангану, заліза) [4].

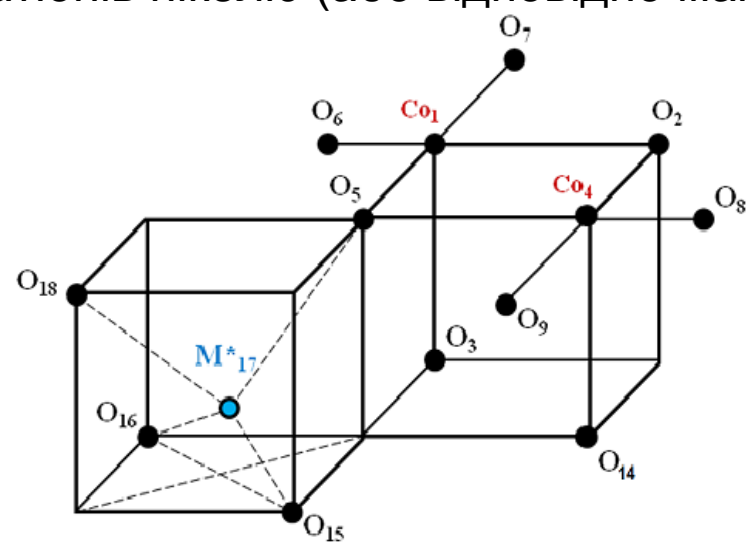

Puc. 2. Спрощена модель молекулярного кластера, де $\mathrm{M}^{*}$ - атоми металів $\mathrm{Ni}, \mathrm{Mn}$ або $\mathrm{Fe}$

Розрахунки показують, що в процесі адсорбції по донорноакцепторному механізму адсорбовані молекули входять в першу координаційну сореру центра адсорбції, що викликає збільшення координаційного числа. Збільшення координаційного числа центра адсорбції може викликати деформацію координаційної ссрери центра адсорбції та зміщення атомів.

Енергія адсобціонного зв'язку $\Delta$ Еадс обчислювалася як різниця повної енергії адсорбційного комплекса Еак і суми енергій кластера Екл і адсорбата Еад:

$$
\Delta \text { Еадс }=\text { Еак }-(\text { Екл }+ \text { Еад). }
$$


3 наведенного слідує, що молекула пероксиду водню може утворитися на поверхні каталізатора в результаті поетапного приєднання до хемосорбованої молекули кисню 2- х протонів і 2-х електронів (Рис. За).

При малих значеннях енергії зв'язку між поверхнею каталізатора i утвореною молекулою пероксиду остання десорбується і процес відновлення кисню закінчується. При відсутності десорбції (тобто у випадку великих значень енергій зв'язку) адсорбований пероксид відновлюється до води (Рис. 3б) внаслідок поетапного приєднання до молекули пероксиду 2- $\mathrm{x}$ протонів і 2-х електронів.

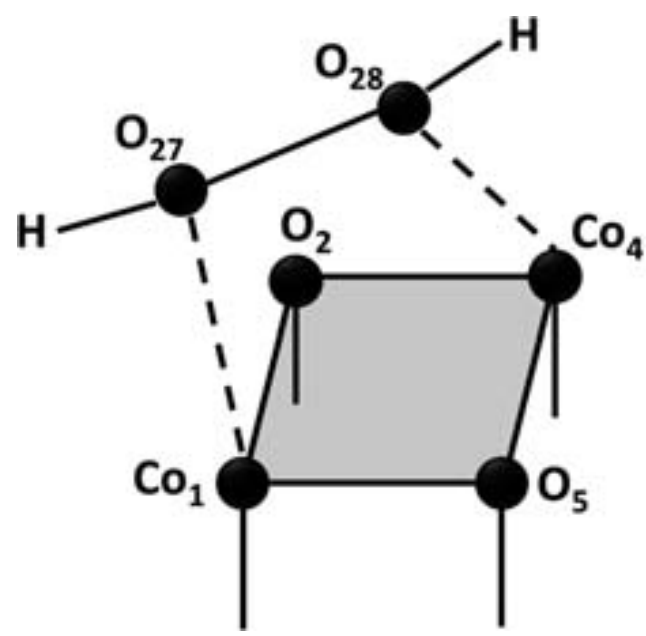

(a)

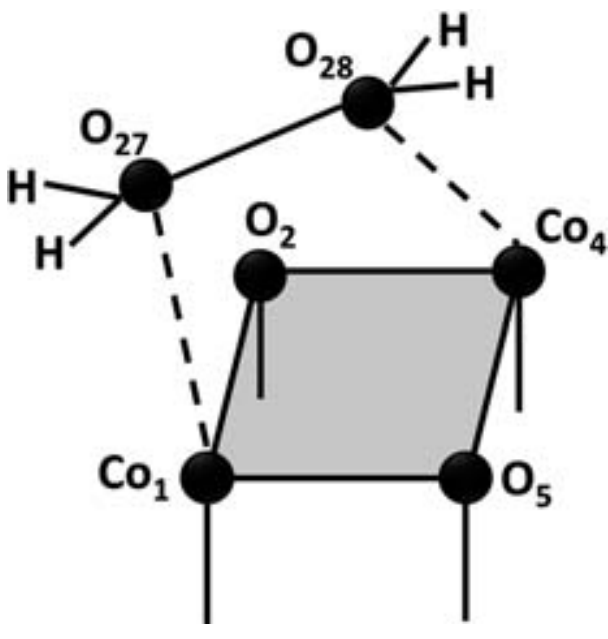

(б)

Puc. 3. Схема утворення молекул пероксиду водню (а) та води (б) на поверхні молекулярних кластерів

Квантово-хімічні розрахунки дають детальну кількісну картину всіх утворених в таких реакціях структур.

\section{Висновки}

1. Установлено, що на поверхні шпінелей можуть утворюватися стабільні адсорбційні комплекси атомів кисню та його сполук, в яких, під впливом адсорбатів, відбувається перерозподіл електронної густини між силовими центрами та деформація поверхні каталізатора.

2. Показано, що основною причиною активації хемосорбованої молекули кисню $€$ зміщення на молекулу кисню електронної густини 3 поверхні каталізатора. Адсорбована молекула кисню у стані фрізичної адсорбції проявляє донорні властивості по відношенню до шпінелі, що є причиною її стабілізації. При фрізичній адсорбції в приповерхневому просторі збільшується концентрація молекул атмосферного кисню, в результаті чого зростає частота зіткнень 
молекул кисню з активними центрами поверхні та прискорюється процес хемосорбції. Внаслідок взаємодії між адсорбатами й шпінеллю змінюються адсорбційні та каталітичні властивості поверхні каталізатора.

3. Величина енергії адсорбції пероксиду водню безпосередньо впливає на механізм відновлення кисню: при малих значеннях цієї енергії кисень відновлюється по 2-х електронному механізму, після чого новоутворена молекула десорбується. При великих значеннях енергії адсорбції пергідролю відновлення кисню відбувається по 4-х електронному механізму до води. Отже, в середньому це може відповідати ефективному значенню $n \sim 3,7$ на поверхні шпінелей із більшим зміщенням в бік 4-х електронного процесу, що відповідає експериментальному значенню.

\section{Подяка}

Автори вдячні Міністерству освіти та науки за підтримку цих досліджень в межах держбюджетної тематики.

\section{Перелік посилань}

[1] Тарасевич М.P. Электрокатализ реакции восстановления кислорода на окисных катализаторах / М.P. Тарасевич, Е.И. Хрущева, Н.А. Шумилова // Итоги науки и техники. - М., 1978. - Т. 13. - C. 47-88.

[2] Khomenko V., Barsukov V., Katashinskii A.. The catalytic activity of conducting polymers toward oxygen reduction I/ Electrochim. Acta, 2005. - v. 50, - pp. 1675-1683.

[3] Khomenko V.G., Lykhnytskyi K.V., Barsukov V.Z. Oxygen reduction at the surface of polymer/carbon and polymer/carbon/spinel catalysts in aqueous solutions // Electrochimica Acta, - 2013. - v. 104, - pp. 391-399.

[4] Каташинський А.С., Лихницький К. В., Хоменко В.Г., Барсуков В.3. Квантово-хімічне моделювання адсорбції молекулярного кисню та його сполук на поверхні кристалічного оксиду кобальта // Вісник КНУТД. - 2014. -№ 3. - С. 125-135. 


\title{
ELECTROCHEMICALLY $\mathrm{NH}_{4}{ }^{+}$-DOPED MANGANESE DIOXIDE WITH $\alpha-\mathrm{MnO}_{2}$ PHASE COMPONENT AS A PROMISING OXYGEN ELECTROREDUCTION ELECTRODE
}

\author{
ZUDINAL.V. ${ }^{\text {a) }}$, SOKOLSKY G.V. ${ }^{\text {a) }}$, BOLDYREV E.I. ${ }^{\text {b) }}$ \\ ${ }^{a}$ National University of Food Technologies, Kyiv, Ukraine \\ ${ }^{b}$ V.I. Vernadsky Institute of General and Inorganic Chemistry of \\ NASU, Kyiv, Ukraine; gvsokol@rambler.ru
}

a- $\mathrm{MnO}_{2}$ with hollandite structure type is considered to be the most effective oxygen electrocatalyst. It has been demonstrated that manganese dioxide samples doped with ammonium cations possess promising properties for different types of lithium-air batteries. The measured earlier high catalytic activity of $\mathrm{H}_{2} \mathrm{O}_{2}$ decomposition on $\mathrm{NH}_{4}{ }^{+}-$ doped manganese dioxide [1] caused our interest to further in-depth research. Thin films were electrodeposited using the following electrolyte composition: $1 \mathrm{M} \mathrm{MnSO}_{4} ; 0,1 \mathrm{HF} ; 0,75 \mathrm{M}\left(\mathrm{NH}_{4}\right)_{2} \mathrm{SO}_{4}$ with current density3$4 \mathrm{MA} / \mathrm{cm}^{2}$ and temperature was $15-20^{\circ} \mathrm{C}$ or $90-95^{\circ} \mathrm{C}$. The current density $100 \mathrm{MA} / \mathrm{cm}^{2}$ was applied to obtain powders. $\mathrm{NH}_{4}{ }^{+}$-Doping or $\left(\mathrm{NH}_{4}\right)_{2} \mathrm{SO}_{4}$ additive to a fluorine containing electrolyte of manganese dioxide in electrocrystallisation acts as a template of hollandite-structure channels in samples. There is a template effect of other indifferent ions (alkali, alkaline earth metals) on the structure ordering in the electrocrystallisation process, which was demonstrated in our earlier publications. An increase in the content of $\alpha-\mathrm{MnO}_{2}$ phase component and the crystallite size of this phase is shown in this work as a result of increasing the temperature of electrodeposition up to $90-95^{\circ} \mathrm{C}$. To prove this hypothesis, the simulations of XRD patterns by the Rietveld refinement method using PowderCell v. 2.3 package were realized. XRD patterns were registered on MoK $\alpha$-irradiation to improve signal/noise ratio. Diffuse peaks of XRD patterns were successfully interpreted by the Rietveld refinement as a set of phase components detected in samples with sizes of crystallites lower than XRD detection limit (about $5 \mathrm{~nm}$ ). 


\title{
ЕЛЕКТРОХІМІЧНО $\mathrm{NH}_{4}{ }^{+}$-ДОПОВАНИЙ МАНГАН (IV) ОКСИД 3 $\alpha-\mathrm{MnO}_{2}$ ФАЗОВОЮ КОМПОНЕНТОЮ ЯК ПЕРСПЕКТИВНИЙ ЕЛЕКТРОД ЕЛЕКТРОВІДНОВЛЕННЯ КИСНЮ
}

\author{
ЗУДІНА Л.В., СОКОЛЬСЬКИЙ Г.В. ${ }^{\text {a) }}$, БОЛДИРєВ Є.І. ${ }^{\text {b) }}$

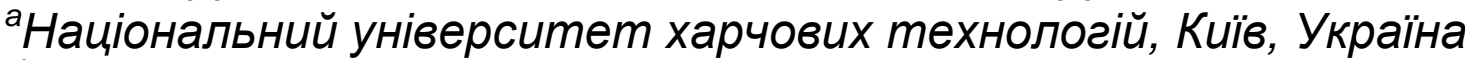 \\ ${ }^{b}$ Iнститут загальної та неорганічної хімії НАНУ, Київ, Україна \\ gvsokol@rambler.ru
}

Оксидна система мангану (IV) відрізняється різноманіттям поліморфних тунельних видозмін 3 унікальними молекулярноситовими та електрокаталітичними властивостями [2] та $\epsilon$ інтенсивно досліджуваною у пошуці електрокаталізаторів Liповітряних акумуляторів (ЛПА). Поліморф $\alpha-\mathrm{MnO}_{2}$ (структурний тип голандиту) вважається найбільш активним та містить $(2 \times 2)$ та $(1 \times 1)$ тунелі поєднаних спільними гранями ланцюгів подвійних $\mathrm{MnO}_{6}$ октаедрів [3]. ЛПА $€$ перспективними щодо введення у практику системою з густиною енергії (5200 Вт г кг ${ }^{-1}$ в 5-10 разів більшою за сучасні літій-іонні акумулятори (ЛІА) [4]. Однак не вирішено низку проблем практичного застосування ЛПА: низька стабільність електроліту та оберненість циклів, повільна кінетика кисню.

Використовуючи $\alpha-\mathrm{MnO}_{2}$ нанодріт в якості каталізатора,P. Bruce та співавтори [3] вперше одержали зразки 3 ємністю катода 3000 мА.г. $r^{-1}$ протягом 10 циклів. Показано, що $\mathrm{MnO}_{2}$ нанодроти демонструють вищу каталітичну активність, ніж об'ємні стани $\mathrm{MnO}_{2}$ в $\alpha$ - та $\beta$-орормах. S. Suib зі співавторами [4] порівнювали каталітичну активність $\alpha-\mathrm{MnO}_{2}$ у водних та органічних електролітах. Інша стратегія з підвищення електрокаталітичної активності - катіонне допування наночастинок $\mathrm{MnO}_{x}$

Нами розроблено методологію електрокристалізації функціональних матеріалів оксидної системи мангану(IV), де інструментом фрункціоналізації $€$ введення добавок катіонів в електроліт анодного осадження 3 фрлуорвмісних електролітів (електролітичне катіонне допування). Раніше нами було встановлено високу активність допованого катіонами амонію манган(IV) оксиду у реакції розкладу проміжного продукту електровідновлення кисню - гідроген пероксиду [1]. Отже, метою даного дослідження $\epsilon$ розглянути перспективи застосування електролітично допованих катіоном амонію оксидів мангану(IV) як електрокаталізаторів кисневого електроду ЛПА. 


\section{Методологія досліджень}

Плівки манган (IV) оксиду отримували 3 фрлуоровмісних електролітів [5] шляхом анодного осадження на платиновий диск в гальваностатичних умовах з електроліту такого складу: $1 \mathrm{M} \mathrm{MnSO}_{4}$; 0,1 HF; 0,75M $\left(\mathrm{NH}_{4}\right)_{2} \mathrm{SO}_{4}$ при густині струму 3-4 мA/см² та температурі $15-20^{\circ} \mathrm{C}$ та $90-95^{\circ} \mathrm{C}$. Порошкові зразки одержували за тих самих умов за виключенням густини струму, що складала $100 \mathrm{~mA} / \mathrm{cm}^{2}$. Анодом була платинова пластина з 10 разів більшою площею ніж катод.

Загальний вміст мангану у зразках визначали атомноабсорбційною спектроскопією. Дослідження 3 рентгенівської дифракції виконували на приладах серії ДРОН із Мо $K_{\alpha}$ випромінюванням та комп'ютерним інтерфейсом. Повнопрофрільний аналіз рентгенограм синтезованих порошкових зразків виконували методом Рітвельда за допомогою комп'ютерних програм PowderCellfor Windows v 2.3 [6].

\section{Результати та їх обговорення}

Електрокристалізовані зразки 3 електролітів 3 добавками катіонів висушували до постійної ваги при $120{ }^{\circ} \mathrm{C}$ та проводили хімічний аналіз за зазначеними вище методиками. Потім реєстрували рентгенограми зразків та здійснювали їх повнопрофрільний аналіз із використанням програмного забезпечення Powder Cell.

Нами встановлено значний вміст рентгеноаморфної компоненти в зразках, одержаних методом електрокристалізації. Як виявилося, не дуже вдалим з точки зору величини співвідношення сигнал/шум $€$ вибір мідного аноду для реєстрації рентгенограм. Водночас дифракційні дані в широкому діапазоні кутів розсіювання ( 2 нм$^{-1}$ i вище) можна отримати за допомогою рентгенівських променів 3 малою довжиною хвилі, тобто більш високих енергій. Такі рентгенівські промені можуть бути отримані на рентгенівських трубках 3 Мо (енергія 17 кеВ) анодом. Енергія CuK випромінювання складає всього близько 8 кеВ [7]. Рентгенограми, одержані на молібденовому випромінюванні, відрізнялись кращим співвідношенням сигнал/шум, а також більш чітко вираженою дифузною компонентою. Нами було встановлено, що дифузна компонента найкраще описується як нанокристалічна складова від основних фраз, використаних у рентгенівських дослідженнях 3 розміром кристалітів 1-3 нм (Рис.).

Порівняльний аналіз результатів моделювання рентгенограм показує підвищений вміст рамсделітної фрази до $40 \%$ (об.) за умов синтезу при кімнатній температурі $\left(25^{\circ} \mathrm{C}\right)$ та найменший розмір кристалітів цієї фрази порівняно із зразком, одержаним при $90{ }^{\circ} \mathrm{C}$. 
Збільшення внеску крупнокристалічної компоненти голандиту розміром 6,78 нм і переважною орієнтацією кристалітів (310), а також наноголандитної складової $€$ характерним при нагріванні електроліту (Табл.).

За нашими даними [8], внесок голандитної компоненти зростає за вищої температури внаслідок темплатної дії катіонів амонію. Дана інтерпретація пояснює більшу активність у каталітичному розкладі $\mathrm{H}_{2} \mathrm{O}_{2}$ зразка, одержаного при $90{ }^{\circ} \mathrm{C}$ (константа швидкості 2,2.10-4 проти $1,7 \cdot 10^{-4} \mathrm{c}^{-1}$ для $25^{\circ} \mathrm{C}$ зразка [4]) за рахунок збільшення вмісту $\alpha-\mathrm{MnO}_{2}$ [2-3]. Слід відмітити аналогічну активність цих зразків, випробуваних у макетах ХДС цинк-повітря [9].

\section{Висновки}

Серед інших матеріалів $\alpha-\mathrm{MnO}_{2}$ вважається одним з найбільш активних електрокаталізаторів кисню. Нами показано, що доповані катіонами амонію електрокристалізованіi 3 фрлуорвмісних електролітів зразки манґан(IV) оксиду містять $\alpha-\mathrm{MnO}_{2}$ фразову компоненту та $\epsilon$ перспективними катодними матеріалами літійповітряних батарей різних типів на підставі повно профільного аналізу рентгенограм та даними каталітичної активності розкладу гідроген пероксиду. Подальші випробовування будуть здійснені найближчим часом.

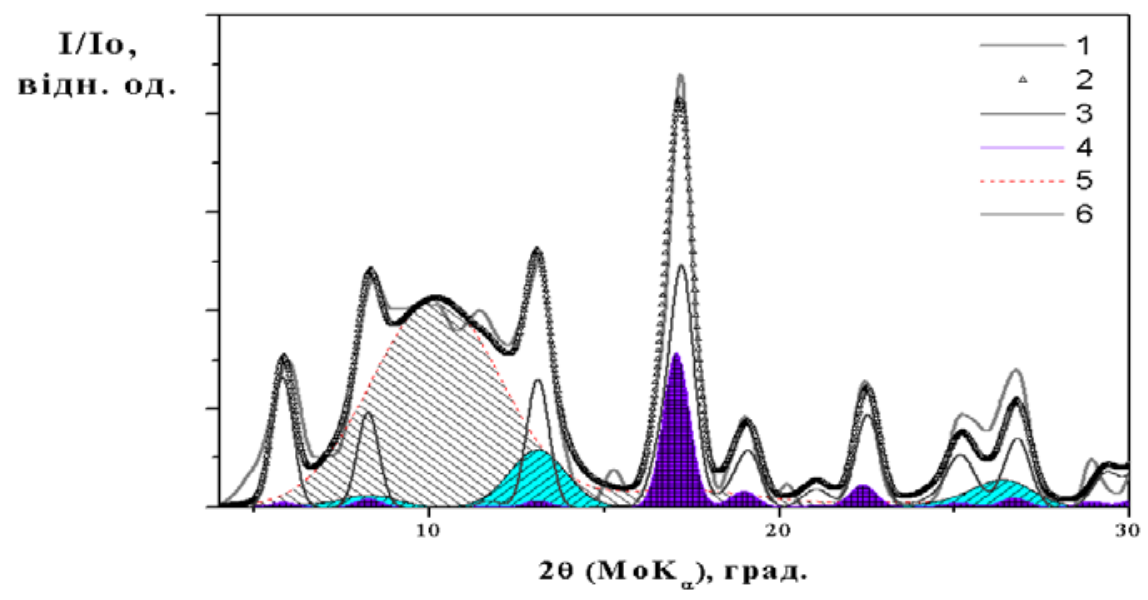

Рис. Фазові компоненти рентгенограми допованого електролітично $1,5 \mathrm{M} \mathrm{NH}_{4}{ }^{+}$-іонами при $25^{\circ} \mathrm{C}$ порошкового зразка манґан(IV) оксиду (Mо $K_{\alpha}{ }^{-}$ випромінювання, заштриховані області відповідають напіваморфрним компонентам нанорозмірних фраз голандиту та рамсделіту):

1 - експериментальна рентгенограма; 2 - сумарна теоретична рентеенограма; 3 - голандит; 4 - голандит з переважною орієнтацією кристалітів за Марч-Доллас (121); 5 - напіваморфрна нанорозмірна компонента рамсделіту з (110) за Марч-Доллас; 6 - напіваморфна нанорозмірна компонента голандиту з (310) за Марч-Доллас 
Табл. Фазовий склад (\% (об.)) та розміри (d, нм), електроосаджених при 25 та $90^{\circ} \mathrm{C}$ у присутності 1,5M $\left(\mathrm{NH}_{4}\right)_{2} \mathrm{SO}_{4}$ зразків манґан(IV) оксиду за результатами моделювання рентгенограм кристалітів програмою PowderCell v.2.3.

\begin{tabular}{|c|c|c|c|}
\hline \multirow{2}{*}{\multicolumn{2}{|c|}{$\begin{array}{c}\text { Фазовий склад, \% (об.), розміри } \\
\text { кристалітів (нм) }\end{array}$}} & \multicolumn{2}{|c|}{ Температура електроліту, ${ }^{\circ} \mathrm{C}$} \\
\hline & & 25 & 90 \\
\hline \multirow{2}{*}{ Голандита-MnO 2 (310)* } & \% (об.) & 46,7 & 59,3 \\
\hline & $\mathrm{d}, \mathrm{HM}$ & 6,7 & 6,8 \\
\hline \multirow{2}{*}{ Голандит $\alpha-\mathrm{MnO}_{2}(121)^{*}$} & $\%$ (об.) & 10,3 & - \\
\hline & d, HM & 5,5 & \\
\hline \multirow{2}{*}{ Наноголандит $\alpha-\mathrm{MnO}_{2},(200)^{*}$} & \% (об.) & 4,7 & 16,9 \\
\hline & $\mathrm{d}, \mathrm{HM}$ & 2,5 & 1,9 \\
\hline \multirow{2}{*}{ рамсделіт, ү-MnO 2} & \% (об.) & - & 19,5 \\
\hline & $\mathrm{d}, \mathrm{HM}$ & - & 4,5 \\
\hline \multirow{2}{*}{ Нанорамсделіт(110)* } & \% (об.) & 38,3 & 4,39 \\
\hline & $\mathrm{d}, \mathrm{HM}$ & 1,1 & 1,2 \\
\hline \multicolumn{2}{|l|}{$R_{p}$} & 22,7 & 27,09 \\
\hline \multicolumn{2}{|l|}{$\mathrm{R}_{\exp }$} & 9,64 & 10,61 \\
\hline
\end{tabular}

*переважна орієнтація кристалітів за Марч-Доллас, (hkl)

\section{Перелік посилань}

[1] N. D. Ivanova, E. I. Boldyrev, S. V. Ivanov, G. V. Sokol'skii, and I. S. Makeeva // Russian Journal of Applied Chemistry. - 2002. - 75, No. 6. - P. 935-938.

[2] R.Cao , J.-S.Lee, M. Liu , and J.Cho // Adv.Energy Mater. — 2012 - 2. - P. 816-829.

[3] A. Debart, A. J. Paterson, J. Bao, P. G. Bruce //Angew. Chem. Int. Ed.-2008. - 47. - P. 4521-4524.

[4] E. M. Benbow, S. P. Kelly, L. Zhao, J. W. Reutenauer, S. L. Suib // J.Phys. Chem. C. - 2011. - 115. P. 22009-22017.

[5] Ivanova N. D. etal. Making manganese dioxide from fluorinebearing electrolytes //Zhurn. Prikl. Khimii. - 1998. - V. 71, No 7. - P. 121123.

[6] http://www.iucr.ac.uk, programmed by Werner Kraus \& Gert Nolze (BAM Berlin), Federal Institute for Materials Researchand Testing, Lab. BAM-I.33: X-Ray Structure and Phase Analysis.

[7] V. Petkov. // Mat. Today. - 2008. - 11, N11. - P. 29-38.

[8] G. V. Sokolsky, S. V. Ivanov, E. I. Boldyrev, N. D. Ivanova, T. F. Lobunets //Solid State Phenomena. -2015. - 230. - P. 85-92.

[9] Иванова Н.Д., Болдырев Е.И., Сокольский Г.В. // Укр. хим. журнал. 1997. — т. 63, № 12. — С. 55-57. 
УДК 544.6.018

\title{
ELECTROCHEMICAL IMPEDANCE OF AN ALKALI Mn-Zn BATTERY AT VARIOUS TEMPERATURES
}

\author{
BOYCHUK A.V. ${ }^{1}$, POTAPENKO AI.V. ${ }^{2}$ \\ ${ }^{1}$ Kyiv National University of Technologies and Design, Kiev \\ ${ }^{2}$ Joint Department of Electrochemical Energy Systems, Kiev \\ hiking@ukr.net
}

\begin{abstract}
Electrochemical behavior of a $\mathrm{Mn}$ - $\mathrm{Zn}$ battery upon varying temperature was studied by electrochemical impedance spectroscopy. An equivalent circuit was proposed enabling one to numerically estimate the irreversible degradation of the battery. Analysis shows that on rising the temperature above $50{ }^{\circ} \mathrm{C}$ the corrosion rate of the anode material increases resulting in an increase in the inner resistance and decrease in the capacity of the battery.
\end{abstract}

\section{ЭЛЕКТРОХИМИЧЕСКИЙ ИМПЕДАНС ЩЕЛОЧНОГО Mn-Zn ЭЛЕМЕНТА ПРИ РАЗЛИЧНЫХ ТЕМПЕРАТУРАХ}

\author{
БОЙЧУК А.В. ${ }^{1}$, ПОТАПЕНКО Ал.В. ${ }^{2}$ \\ Киевский национальный университет технологий и дизайна ${ }^{1}$ \\ Міжвідомче відділення електрохімічної енергетики НАН України ${ }^{2}$ \\ hiking@ukr.net
}

Марганцево-цинковый гальванический элемент является первичным химическим источником тока, в котором в качестве катода используется диоксид марганца, анода - порошок цинка, а в качестве электролита - раствор щёлочи, обычно гидроксида калия [1]. Для определения технического состояния таких систем необходимо изучить ряд параметров данных элементов, таких как напряжение элемента под нагрузкой, внутреннее сопротивление, отдаваемая емкость и изменение названных характеристик в зависимости от условий хранения, в частности от температуры. Современные методы контроля обеспечивают получение необходимых параметров только при полной или частичной деградации источников тока, что является недопустимым в случае использования первичных систем [2]. 
Применение методов неразрушающего контроля для оценки состояния первичных элементов и сформулировало цель настоящей работы - исследовать влияние температуры и степени разряда на электрохимические характеристики щелочного марганец-цинкового гальванического элемента методом спектроскопии электрохимического импеданса (СЭИ).

\section{Методология исследований}

В качестве исследуемых гальванических элементов применялись коммерческие источники питания фрирмы Duracell (США) в габаритах LR03 с номинальным напряжением 1,5 B. Измерения спектров электрохимического импеданса проводили в диапазоне температур 15 ч $80^{\circ} \mathrm{C}$, контролируемых при помощи термостата. Ошибка измерения температуры составляла $\pm 0,5^{\circ} \mathrm{C}$. Перед каждым измерением элементы выдерживались при заданной температуре не менее 40 мин. Съемку спектров проводили на электрохимическом модуле Autolab-30 модели PGSTAT302N Metrohm Autolab, оснащенном модулем FRA (Frequency Response Analyzer) в интервале частот $10^{-2}$ ч $10^{6}$ Гц. Управление модулем осуществляли при помощи программы Autolab 4.9 по стандартной процедуре с последующей обработкой в пакете Zview 2.0.

\section{Результаты и обсуждение}

В результате испытаний методом СЭИ установлено влияние температуры на вид и параметры спектра испытуемых элементов при сохранении его номинального напряжения разомкнутой цепи 1,5 В (рис. 1). Во всех случаях спектры импеданса представляют собой в высоко- и среднечастотной области спектра неправильную полуокружность с центром ниже оси абсцисс, а в низкочастотной области - линейный участок с различными углами наклона. Кроме того, в высокочастотной области присутствует участок «сопротивления индуктивности» $\left(\mathrm{L}_{1}, \mathrm{R}_{2}\right)$, который объясняется конструкционными особенностями источника питания и не связан с протекающими в нем химическими процессами. Полученные спектры удается удовлетворительно моделировать с помощью электрической эквивалентной схемы (ЭЭС), представленной на рис. 2. Средние значения расчетных элементов ЭЭС и ошибки при их вычислении в ходе термического воздействия на источник тока представлены в табл. 1. 

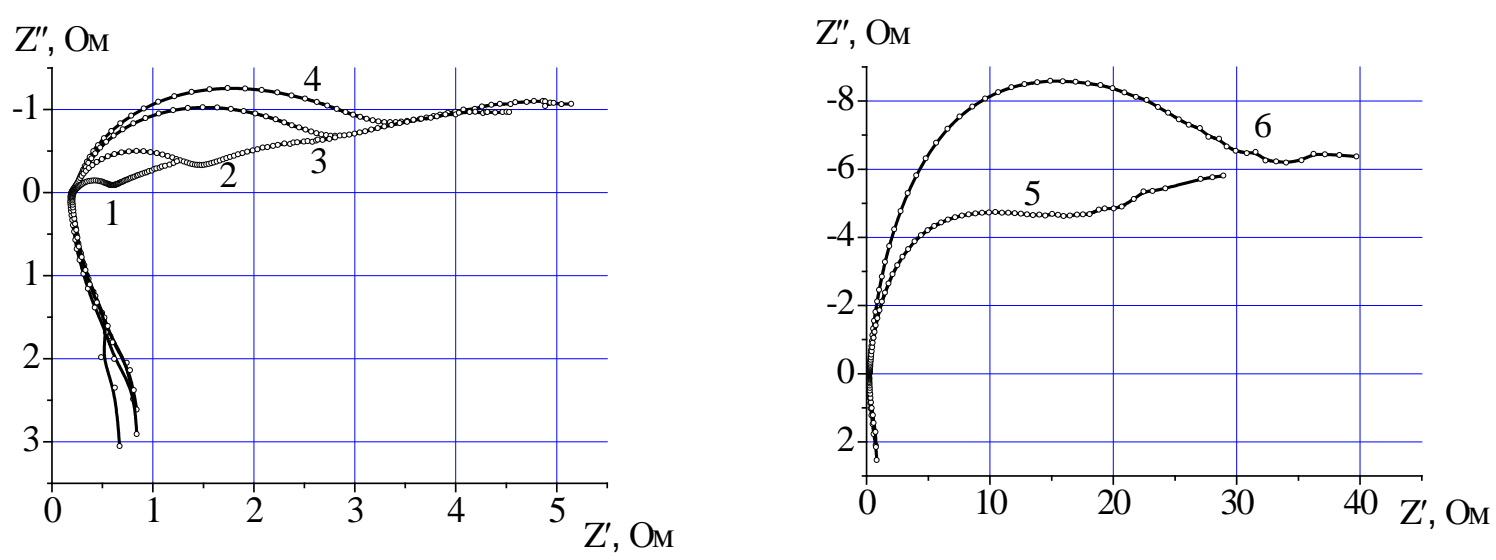

Puc.1. Диаграммы Найквиста для щелочного марганец-цинкового элемента при различных температурах: $1-15^{\circ} \mathrm{C} ; 2-30^{\circ} \mathrm{C} ; 3-40^{\circ} \mathrm{C} ; 4-50^{\circ} \mathrm{C} ; 5-60$ ${ }^{\circ} \mathrm{C} ; 6-80{ }^{\circ} \mathrm{C}$.

Таблица 1. Средние значения расчетных элементов ЭЭС при термическом воздействии на источник тока

\begin{tabular}{|c|c|c|}
\hline Элемент ЭЭС & Значение, Ом & Ошибка, $\%$ \\
\hline $\mathrm{R}_{1}$ & 0,82 & 1,17 \\
\hline $\mathrm{L}_{1}$ & $3,58 \cdot 10^{-7}$ & $3,83 \cdot 10^{-9}$ \\
\hline $\mathrm{R}_{2}$ & 4,72 & 3,22 \\
\hline $\mathrm{CPE}_{2}-\mathrm{T}$ & 0,25 & 2,9 \\
\hline $\mathrm{CPE}_{2}-\mathrm{P}$ & 0,85 & 2,8 \\
\hline $\mathrm{C}_{2}$ & 0,0023 & 4,06 \\
\hline $\mathrm{R}_{3}$ & 0,84 & 2,69 \\
\hline
\end{tabular}

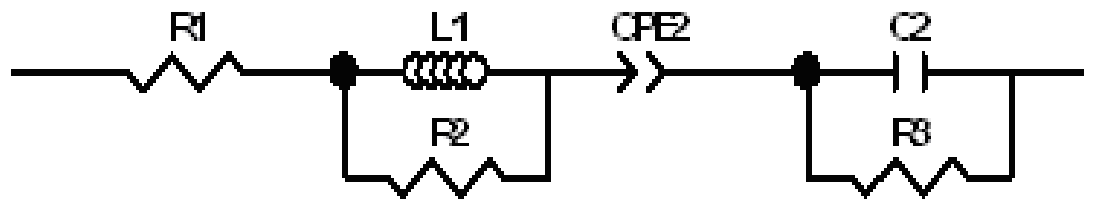

Puc.2. Электрическая эквивалентная схема щелочного марганец-цинкового гальванического элемента.

При анализе полученных результатов по сопротивлениям $\mathrm{R}_{1}$ и $\mathrm{R}_{3}$ в ЭЭС была обнаружена зависимость (рис. 3), в которой $\mathrm{R}_{1}$ (сопротивление электролита в порах сепаратора и электродного материала) практически не изменяется с изменением температуры. Величина сопротивления $\mathrm{R}_{3}$ (сопротивление пассивной пленки на поверхности активного материала) возрастает в несколько раз с одновременным падением емкости шунтированного конденсатора на несколько порядков (с 1,4 Ф/г до 0,005 Ф/г). Значительное изменение сопротивления $\mathrm{R}_{3}$ при температурах выше $50{ }^{\circ} \mathrm{C}$ может 
свидетельствовать как об увеличении скорости коррозии цинкового порошка, так и о деградации катодного материала вследствие растворения $\mathrm{MnO}_{2}$, которое впоследствии приводит к заметному снижению напряжения источника тока и уменьшению его емкости [3-5].

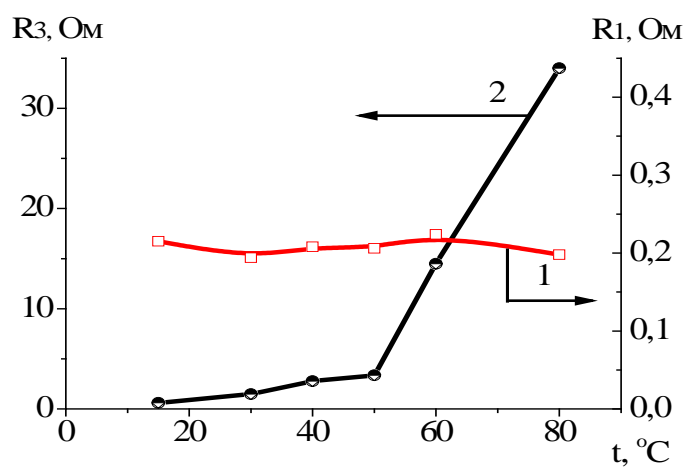

Рис.3. Изменение сопротивле-ния электролита в порах сепаратора (1) и сопротивление пассивной пленки на поверхности активного материала (2)

\section{Выводы}

Методом СЭИ исследованы коммерческие образцы первичных щелочных марганцево-цинковых элементов. Предложена модельная ЭЭС, позволяющая численно оценивать необратимую деградацию элемента по значению сопротивления, шунтирующего емкость двойного электрического слоя. Показано, что с повышением температуры увеличивается скорость коррозии цинкового порошка, которая резко возрастает при температурах выше $50{ }^{\circ} \mathrm{C}$ и приводит к заметному снижению напряжения источника тока и уменьшению его емкости.

\section{Литература}

[1] DURACELL®Alkaline Batteries. Section 3: Composition/ Information on ingredients//GMEL \#.- 2002.-9-EU.P. 1 - 6

[2] R.Koch, A. Jossen, R. Kuhn. Implementation of continuous online diagnostic methods in battery packs// SGBM/- 2014 - 1st Singapore Battery Meeting - 27/28 of February .9.- P.12.

[3] M. Freitas, V. Pegoretti, M. Pietre, Recycling manganese from spent $\mathrm{Zn}-\mathrm{MnO}_{2}$ primary batteries// Journal of Power Sources.- 2007.164.- P. 947-952.

[4] Y. M. Baba Ismail, H. Haliman, A. A. Mohamad. Hydroponics polymer gels for $\mathrm{Zn}-\mathrm{MnO}_{2}$ alkaline batteries//Int. J. Electrochem. Sci.2012.- 7.-P. $3555-3566$.

[5] Mankea and J. Banhart. In situ investigation of the discharge of alkaline $\mathrm{Zn}-\mathrm{MnO} 2$ batteries with synchrotron $\mathrm{x}$-ray and neutron tomographies// Applied Physics Letters.-2007.- 90.-P. 214102-1 214102-3. 


\title{
Part 2 \\ ELECTROPLATING
}

\author{
Розділ 2 \\ ГАЛЬВАНОТЕХНІКА
}




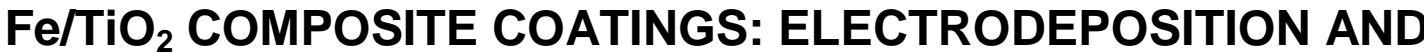 APPLICATION FOR PHOTO-CATALYTIC DYE DEGRADATION
}

\author{
TSURKAN A.V., VASIL'EVA E.A., PROTSENKO V.S., DANILOV F.I. \\ Ukrainian State University of Chemical Technology \\ annatsurkan@ukr.net
}

The electrodeposition of iron-titania composite coatings from a methanesulfonate plating bath is studied in this work. The $\mathrm{TiO}_{2}$ content in deposits is shown to increase with increasing titania concentration in suspension electrolyte and decreasing cathode current density. The kinetics of composite $\mathrm{Fe} / \mathrm{TiO}_{2}$ electrodeposition obeys the model proposed by Guglielmi. The photo-catalytic activity of synthesized $\mathrm{Fe} / \mathrm{TiO}_{2}$ composite electrochemical coatings was estimated in the model reaction of decomposition of Methyl Orange dye in an alkaline solution. The use of the $\mathrm{Fe} / \mathrm{TiO}_{2}$ composite electroplated films as a photo-catalyst allows accelerating the decomposition of Methyl Orange dye in aqueous media under the action of UV radiation.

Developing novel catalytic materials for the decontamination of wastewaters containing various organic pollutants is an important task of modern chemistry and chemical engineering [1]. In this context, $\mathrm{TiO}_{2}$ may be considered as the most efficient and environmentally friendly photo-catalyst, and it has been widely used for photo-degradation of various pollutants [2]. In particular, titania is very effective in photocatalytic decomposition of various organic dyes in wastewaters [3]. In this respect, one of unsolved problems is the development of convenient supports for the $\mathrm{TiO}_{2}$ photo-catalyst, because the use of powdered titania for wastewater treatment involves evident implementation impediments. We think that the electrodeposition of composite coatings in which $\mathrm{TiO}_{2}$ particles are uniformly distributed in a metal matrix allows successfully solving the problem concerned [4].

From our point of view, composite coatings containing $\mathrm{TiO}_{2}$ particles entrapped into electrodeposited iron matrix attract considerable attention, because Fe and its compounds are particularly cheap, available and lowtoxic. In this study we used methanesulfonate plating baths for iron matrix electrodeposition [4-6]. Methanesulfonate plating baths based on methanesulfonic acid $\mathrm{CH}_{3} \mathrm{SO}_{3} \mathrm{H}$ (MSA) are known to be an attractive alternative to ordinary electroplating baths because MSA is regarded as a "green acid" due to its environmental advantages [7]. 


\section{Research Methodology}

All solutions were prepared using double distilled water and reagent grade chemicals. Iron (II) methanesulfonate was synthesized by the procedure reported in detail elsewhere [7]. The $\mathrm{pH}$ value of the plating bath was controlled through a common potentiometric method and adjusted to the required value by adding either $\mathrm{Na}_{2} \mathrm{CO}_{3}$ or MSA solutions. To obtain composite coatings, a weighed portion of $\mathrm{TiO}_{2}$ nanopowder (Degussa P 25, Evonik; the average particle size $25 \mathrm{~nm}$ ) was introduced into the electroplating bath. Before electrodeposition, the plating bath was stirred for $1 \mathrm{~h}$ by mechanical agitator and then ultrasonically treated with a UZDN-A ultrasonic disperser to reach uniform distribution of colloidal particles in the bath. The electrodeposition of $\mathrm{Fe} / \mathrm{TiO}_{2}$ composite coatings was performed under the conditions of a continuous bath agitation with a magnetic stirrer (ca. 60 rev $\mathrm{min}^{-1}$ ).

Electrodeposition was performed at a steady current density in a usual thermostated glass cell $(298 \mathrm{~K})$ for $20 \mathrm{~min}$. Iron-titania films were deposited on the mild steel plates fixed in a plastic holder. Prior to each experiment, the sample surface was treated with magnesium oxide, etched for several minutes in 1:1 (vol.) $\mathrm{HCl}$ solution and then thoroughly rinsed with double distilled water. The electrolysis was carried out with anodes made from mild steel.

The photo-catalytic properties of the $\mathrm{Fe} / \mathrm{TiO}_{2}$ composites were evaluated by studying the kinetics of decomposition of Methyl Orange (MO) dye under the action of UV radiation in an aqueous alkali solution $(0.1 \mathrm{M} \mathrm{NaOH})$. A UV lamp with the effective spectral range of 180 to 275 $\mathrm{nm}$ was used. The lamp was arranged over the MO solution at a distance of $10 \mathrm{~cm}$ from its surface. In the course of photo-catalytic decomposition, the $\mathrm{MO}$ solution was continuously stirred with a magnetic stirrer. The MO concentration was determined photo-metrically. Steel plates with the electrodeposited $\mathrm{Fe} / \mathrm{TiO}_{2}$ coating were fixed at a depth of $2 \mathrm{~mm}$ in the solution parallel to its surface (at an angle of $90^{\circ}$ to the UV beam).

\section{Results and Discussion}

Fig. 1 shows that the amount of the $\mathrm{TiO}_{2}$ particles in the coatings increases with an increase in titania concentrations in the electrolyte and with a decrease in the current density.

According to this concept, the particles inclusion in the metallic matrix occurs in two consecutive steps of adsorption. The model involves Langmuir adsorption of particles. In the first step, called a "loose adsorption", the ion-coated particles are reversibly adsorbed on the cathode surface and yield a high degree of coverage. The second step is 
a "strong adsorption" of particles. The reduction of metal ions adsorbed on the particles creates the circumstances of an irreversible strong adsorption. Further, the particles are engulfed by the overgrowing of a metallic matrix.

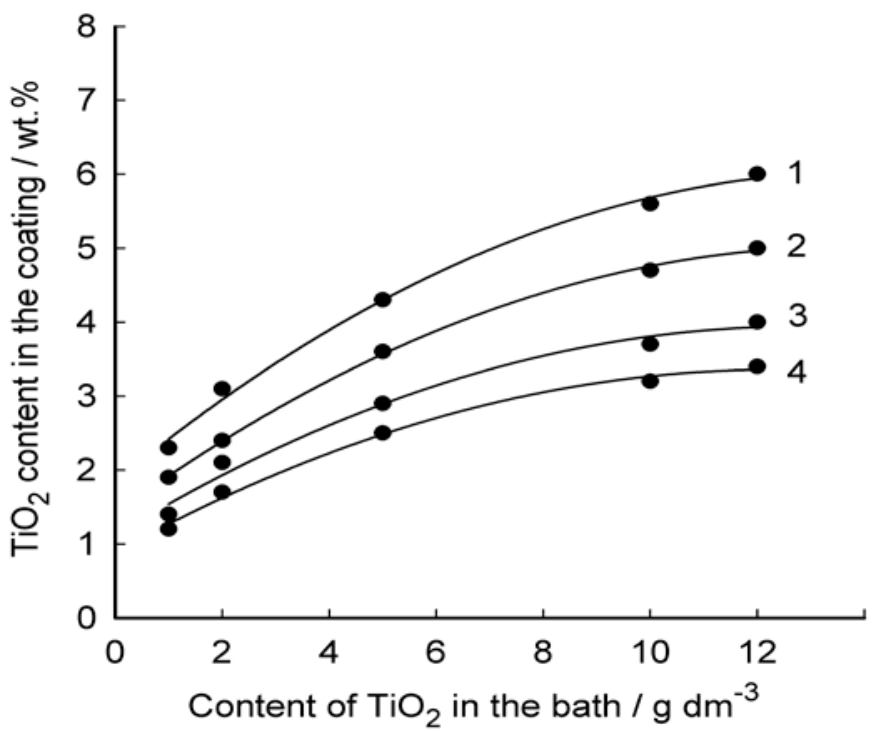

Figure 1. Effect of titania concentration in the bath on $\mathrm{TiO}_{2}$ in coatings at various current densities, $A d m^{-2}$ : (1) 5, (2) 10 , (3) 15 , (4) 20

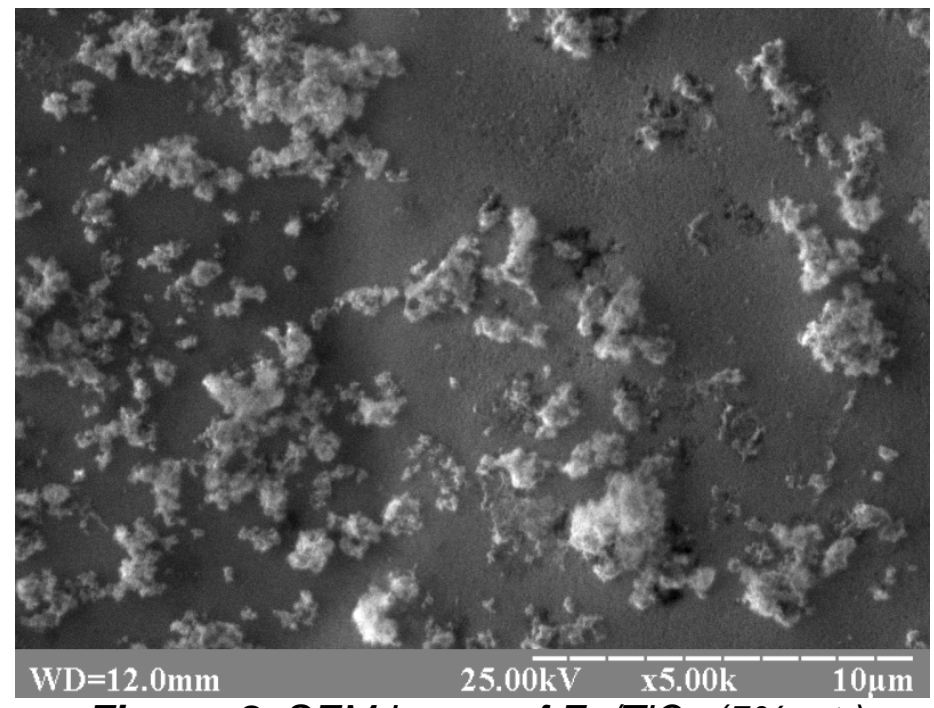

Figure 2. SEM image of $\mathrm{Fe} / \mathrm{TiO}_{2}$ (5\% wt.) coating electrodeposited from methanesulfonate bath at $10 \mathrm{~A} \mathrm{dm}^{-2}$

SEM images of $\mathrm{Fe} / \mathrm{TiO}_{2}$ coating deposited from methanesulfonate baths show that the surface contains flakelike particles of agglomerated $\mathrm{TiO}_{2}$ with an average size of about several micrometers (Fig. 2). The EDS analysis revealed that the surface areas corresponding to flakelike particles in SEM photos consist essentially of titanium and oxygen in a ratio practically equal to the stoichiometric composition of $\mathrm{TiO}_{2}$. This means that the aggregation of $\mathrm{TiO}_{2}$ nano-powder occurs in methanesulfonate solutions. These findings are fully conformed by the results of sedimentometric analysis. The coarsening of the particles results in their enhanced sedimentation and subsequent phase separation. This is why the electrochemical synthesis of the $\mathrm{Fe} / \mathrm{TiO}_{2}$ composites was carried out under the conditions of a continuous bath agitation with a magnetic stirrer. 


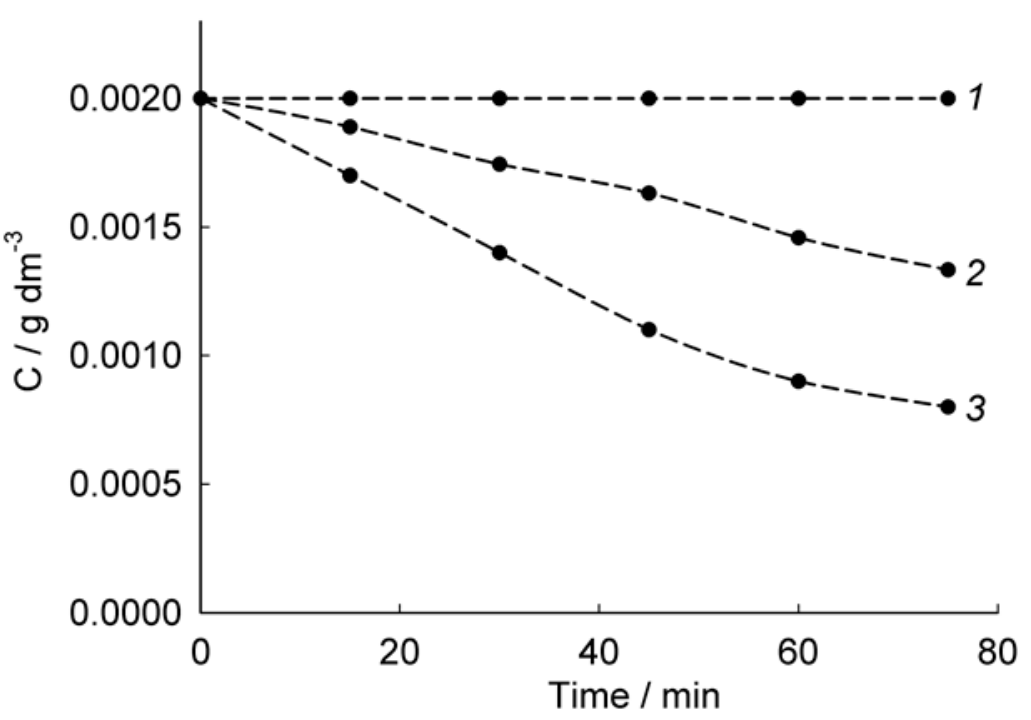

Figure 3. Time dependences of MO concentration (1) in the dark, (2) under UV irradiation without catalyst, and (3) under UV irradiation in the presence of $\mathrm{Fe} / \mathrm{TiO}_{2}$ catalyst (10\% wt. $\left.\mathrm{TiO}_{2}\right)$

The catalytic activity of $\mathrm{Fe} / \mathrm{TiO}_{2} \quad$ composite electrochemical coatings was evaluated in this study in the model reaction of decomposition of $\mathrm{MO}$ dye in alkaline solution [9]. Without the action of UV irradiation, Methyl Orange dye does not undergo spontaneous decomposition (Fig. 3). The photocatalytic decomposition of the dye under the action of UV radiation is appreciably accelerated in the presence of a catalyst, $\mathrm{Fe} / \mathrm{TiO}_{2}$ catalyst. It was stated that the kinetic curves plotted in the coordinates "logarithm of MO concentration versus time" are straight lines, this suggests the pseudo-first reaction order. The formal rate constants were shown to be 0.0054 and $0.0135 \mathrm{~min}^{-1}$ for the photocatalytic decomposition without catalyst and in the presence of the iron/titania catalyst, respectively.

According to the modern notion of the mechanism of the photocatalytic action of titania in the dye decomposition [9], the following processes occur on the $\mathrm{TiO}_{2}$ surface under the action of UV radiation in a medium containing dissolved atmospheric oxygen:

$$
\begin{aligned}
& \mathrm{Fe}-\mathrm{TiO}_{2} \stackrel{h v}{\longrightarrow} \mathrm{Fe}-\mathrm{TiO}_{2}\left(e^{-}+h^{+}\right), \\
& h^{+}+\mathrm{OH}_{a d}^{-} \rightarrow \mathrm{OH}_{a d}, \\
& h^{+}+\mathrm{H}_{2} \mathrm{O}_{a d} \rightarrow \mathrm{OH}_{a d}+\mathrm{H}^{+}, \\
& e^{-}+\mathrm{O}_{2} \rightarrow \mathrm{O}_{2}^{-},
\end{aligned}
$$

where $h^{+}$are positively charged holes generated on the catalyst surface.

The MO molecules decompose under the action of the generated hydroxyl radicals forming $\mathrm{CO}_{2}$ and $\mathrm{H}_{2} \mathrm{O}$ as final decomposition products [9]. 


\section{Conclusions}

1. $\mathrm{Fe} / \mathrm{TiO}_{2}$ composite coatings can be synthesized by electrodeposition method from an environmentally friendly methanesulfonate iron plating bath containing titania nano-powder. The content of $\mathrm{TiO}_{2}$ particles in the coatings is shown to increase with increasing titania concentrations in the electrolyte and decreasing the cathodic current density.

2. The use of the $\mathrm{Fe} / \mathrm{TiO}_{2}$ composite electroplated coating as the catalyst allows accelerating the decomposition of Methyl Orange in aqueous solution under the action of UV radiation. Thus, these photocatalysts seem to be promising in waste-water treatment processes.

\section{References}

[1] Brillas E., Martínez-Huitleb C.A., Decontamination of wastewaters containing synthetic organic dyes by electrochemical methods. An updated review, Appl. Catal. B: Environ., 166-167, 603-643, (2015).

[2] Chen X., Mao S.S., Titanium dioxide nanomaterials: synthesis, properties, modifications, and applications, Chem. Rev., 107, 2891-2959, (2007).

[3] Lachheb H., Puzenat E., Houas A., Ksibi M., Elaloui E., Guillard C., Herrmann J.-M., Photocatalytic degradation of various types of dyes (Alizarin S, Crocein Orange G, Methyl Red, Congo Red, Methylene Blue) in water by UV-irradiated titania, Appl. Catal. B: Environ., 39, 75-90, (2002).

[4] Protsenko V.S., Vasil'eva E.A., Smenova I.V., Danilov F.I. Electrodeposition of iron/titania composite coatings from methanesulfonate electrolyte, Russ. J. Appl. Chem., 87, 283-288, (2014). [5] Protsenko V.S., Vasil'eva E.A., Smenova I.V., Baskevich A.S., Danilenko I.A., Konstantinova T.E., Danilov F.I., Electrodeposition of Fe and composite $\mathrm{Fe} / \mathrm{ZrO}_{2}$ coatings from a methanesulfonate bath, Surf. Eng. Appl. Electrochem., 51, 65-75, (2015).

[6] Danilov F.I., Tsurkan A.V., Vasil'eva E.A., Protsenko V.S., Electrocatalytic activity of composite $\mathrm{Fe} / \mathrm{TiO}_{2}$ electrodeposits for hydrogen evolution reaction in alkaline solutions, Int. J. Hydrogen Energy, in press, doi: 10.1016/j.ijhydene.2016.02.112.

[7] Gernon M.D., Wu M., Buszta T., Janney P., Environmental benefits of methanesulfonic acid: comparative properties and advantages, Green Chem., 1, 127-140, (1999).

[8] Guglielmi N., Kinetics of the deposition of inert particles from electrolytic baths, J. Electrochem. Soc., 119, 1009-1012, (1972).

[9] Sonawane R.S., Kale B.B., Dongare M.K., Preparation and photocatalytic activity of $\mathrm{Fe}-\mathrm{TiO}_{2}$ thin films prepared by sol-gel dip coatings, Mater. Chem. Phys., 85, 52-57, (2004). 


\title{
HARD AND DECORATIVE Ni-P COATINGS ELECTRODEPOSITED FROM THE METHANESULFONATE ELECTROLYTE
}

\author{
ZHIGALOVA A.A., SKNAR Y.E., SKNAR I.V. \\ Ukrainian State University of Chemical Technology, Dnepropetrovsk, \\ Ukraine; zhigalova1028@gmail.com
}

The regularities of electrodeposition $\mathrm{Ni}-\mathrm{P}$ coatings from the methanesulfonate and sulfate electrolytes were investigated. As a phosphorus-containing component we used sodium hypophosphite. It has been shown that increasing concentration of sodium hypophosphite in electrolytes leads to an increase in phosphorus content in the coatings. Increasing the electrodeposition current density of current density leads to reduction of phosphorus content in the coatings.

Cathodic voltamperograms were taken for the methanesulfonate and sulfate electrolytes. Addition of sodium hypophosphite to the electrolyte leads to a shift of the total voltamperogram in the region of positive potential. It was established that boric acid in the methanesulfonate electrolyte reduces the difference in nickel and nickel-phosphorus discharge overvoltage.

Hard and decorative Ni-P coatings are characterized by high internal stresses. The internal stresses increase with increasing concentration of sodium hypophosphite in electrolytes. Nickel-phosphorus coatings are characterized by high values of microhardness. The highest values of the microhardness of coatings are observed at a concentration of sodium hypophosphite $0,12 \mathrm{~mol} / \mathrm{l}$. The microhardness of the coatings obtained from the methanesulfonate electrolyte is higher than that of the coatings obtained from the sulfate electrolyte. The extent of nickel-phosphorus coatings brightness deposited from the methanesulfonate electrolyte reaches $20 \%$ and slightly lower in the case of the sulfate electrolyte. Results suggest that the physical-chemical properties of the coatings obtained from the methanesulfonate electrolyte higher in comparison with coatings obtained from the sulfate electrolyte.

Nickel-based coatings have a very valuable physical-chemical, mechanical and magnetic properties. For this reason, researchers are paying particular attention to the study of the electrochemical coatings based on $\mathrm{Ni}$ [1]. Considering this one of the most promising material is a nickel-phosphorus alloy. Ni-P coatings are characterized by high values of microhardness, wear resistance, increased protective and magnetic properties [2, 3]. To obtain high-quality coatings Ni-P alloy is necessary 
to establish patterns between the various factors electrodeposition coating process, their structure and properties.

\section{Experimental procedure}

In this work, we added to the electrolytes sodium hypophosphite in an amount of $0 ; 0.03 ; 0.05 ; 0.07 ; 0.12 \mathrm{~mol} / \mathrm{l}$. Electrodeposition of Ni-P alloys was performed at $\mathrm{pH}, \mathrm{T}=333 \mathrm{~K}$ and at current densities 2, 3, 5, 7 $\mathrm{A} / \mathrm{dm}^{2}$ for each concentration of sodium hypophosphite. Phosphorus content in Ni-P coatings deposited from the methanesulfonate and sulfate electrolytes was determined by a photocolorimetric method. In the study of the kinetics of the Ni-P coatings electrodeposition was used polarization curves analysis method. Internal stresses are defined by a flexible cathode method [4]. The brightness degree of Ni-P coatings measured relatively silver mirror using a photoelectric gloss meter. Microhardness determined using $\mathrm{PMH}-3$ device.

\section{Results and Discussion}

Increasing the concentration of sodium hypophosphite in electrolytes increases the phosphorus content in the coatings. It is found that the phosphorus content does not differ in the coatings deposited from the methanesulfonate and sulfate electrolytes (figure 1). At a current density $2 \mathrm{~A} / \mathrm{dm}^{2}$ at a concentration of $0,03 \mathrm{~mol} / \mathrm{l}$ sodium hypophosphite in the electrolyte can be observed incorporation of phosphorus in an amount of $4.7 \%$ by weight in the coatings obtained from the methanesulfonate electrolyte and $4.5 \%$ by weight in the coatings deposited from the sulfate electrolyte. Further increase concentration $\mathrm{NaH}_{2} \mathrm{PO}_{2}$ to $0,12 \mathrm{~mol} / \mathrm{l}$ phosphorus content increases in deposits less. On the content of phosphorus in the coatings affected by current density of electrodeposition. Increasing the current density leads to a reduction of phosphorus content in the coatings.

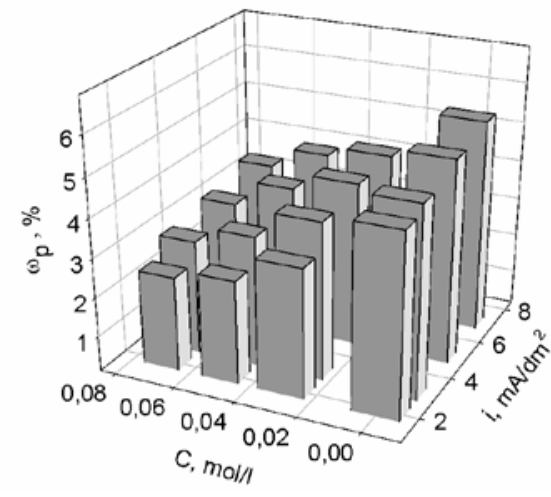

a

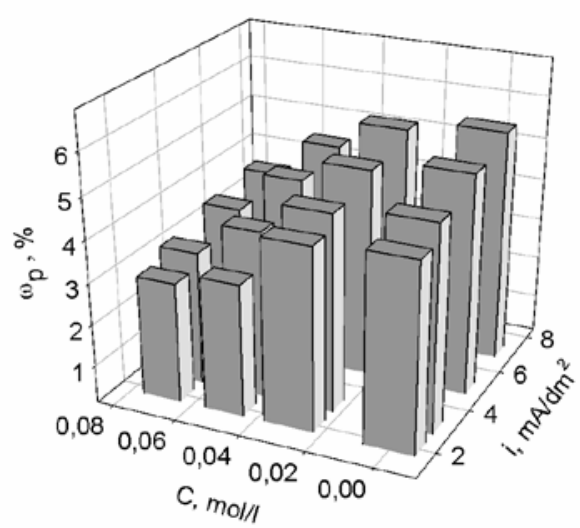

b

Figure 1. The phosphorus content in the Ni-P coatings deposited from the methanesulfonate (a) and sulfate (b) electrolytes 
We have found that the overvoltage of nickel electrodeposition from methanesulfonate electrolyte is $100 \mathrm{mV}$ lower than in the case of the sulfate electrolyte. (figure 2).

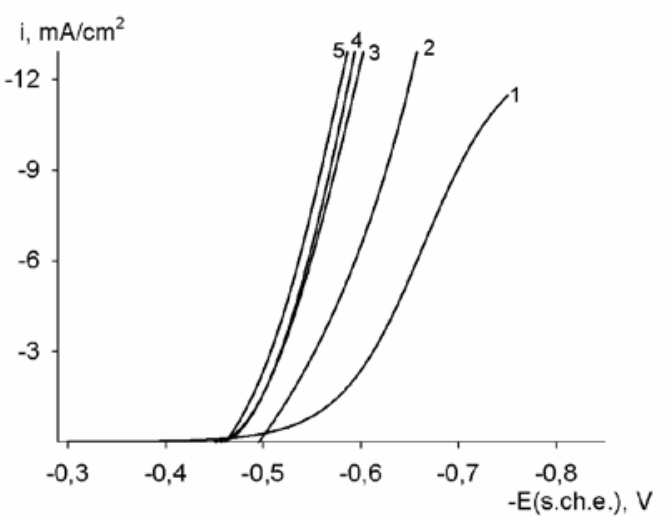

a

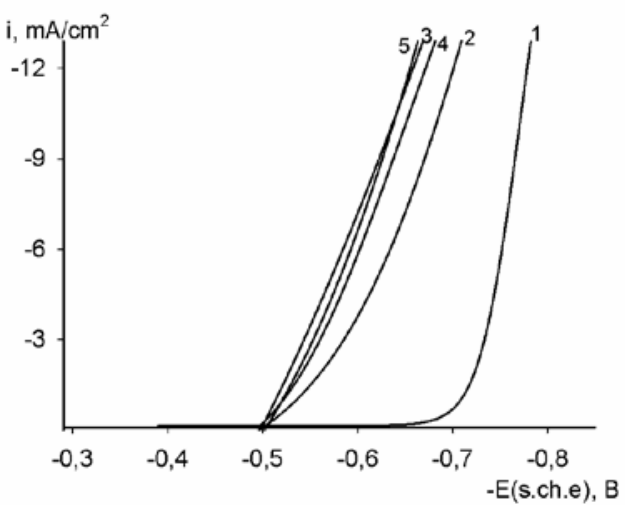

b

Figure 2. The cathodic voltamperograms obtained in the methanesulfonate (a) and sulfate (b) electrolytes at the presence of sodium hypophosphite, mol/l: 1 - 0; 2 0,$03 ; 3-0,05 ; 4-0,07 ; 5-0,12$.

Introduction of the sodium hypophosphite in the electrolyte leads to a shift depending on the voltamperogram towards positive potentials. Increasing the concentration of sodium hypophosphite in the electrolyte is more than $0,05 \mathrm{~mol} / \mathrm{l}$ had little effect on the course of the polarization dependencies. It was found that boric acid reduces the difference in discharge overvoltage for nickel and nickel-phosphorus alloys obtained from the methanesulfonate electrolyte (figure 3).

The nickel-phosphorus alloys deposited from the methanesulfonate electrolyte characterized by high values of internal stresses. Internal stresses increase with increasing concentration of sodium hypophosphite in the electrolyte. Obviously, this is due to structural changes in the crystal lattice of coatings. A similar effect was observed when using the sulfate electrolyte.

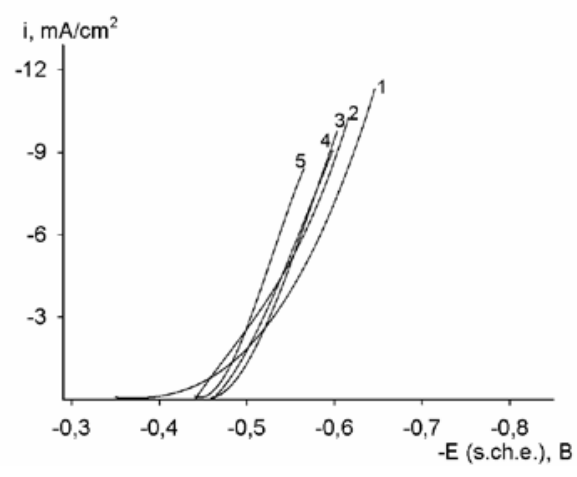

a

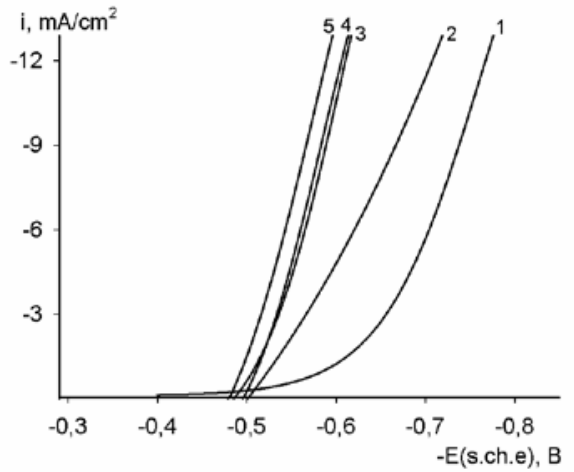

b

Figure 3. The cathodic voltamperograms obtained in the methanesulfonate (a) and sulfate (b) electrolytes at the presence of $0,7 \mathrm{~mol} / \mathrm{l}$ boric acid and sodium hypophosphite, mol/l: $1-0 ; 2-0,03 ; 3-0,05 ; 4-0,07 ; 5-0,12$. 
The brightness degree of Ni-P coatings deposited from the methanesulfonate electrolyte reaches $20 \%$ and slightly lower in the case of the sulfate electrolyte (figure 4). The highest values of the brightness degree correspond low current density. It may be due to the decrease of phosphorus content in Ni-P coatings at higher current density.

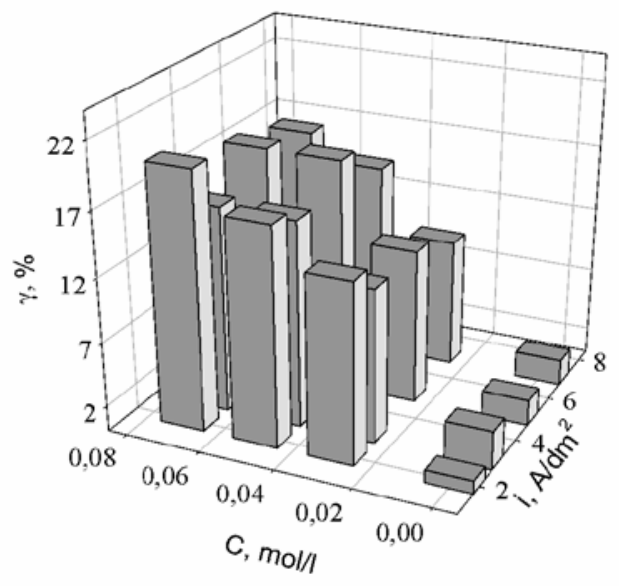

a

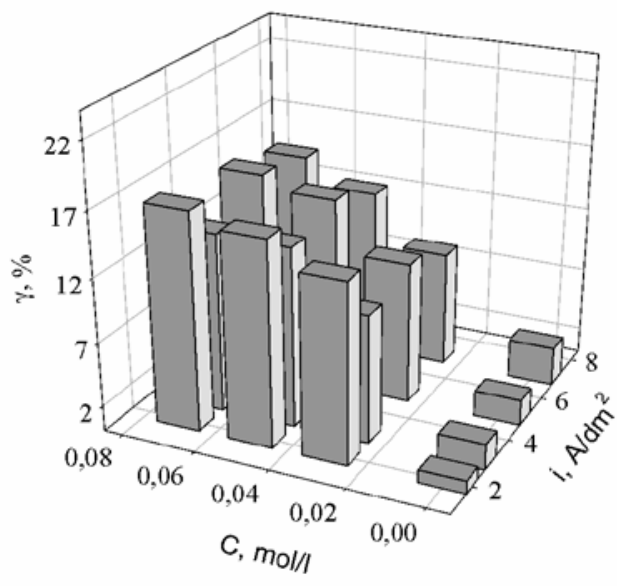

b

Figure 4. The brightness degree in the Ni-P coatings deposited from the methanesulfonate (a) and sulfate (b) electrolytes

Nickel-phosphorus coatings have high microhardness (figure 5). Microhardness increase with increasing concentration of sodium hypophosphite in the electrolytes. Microhardness of coatings deposited from methanesulfonate electrolyte exceeds the microhardness of coatings deposited from the sulfate electrolyte.

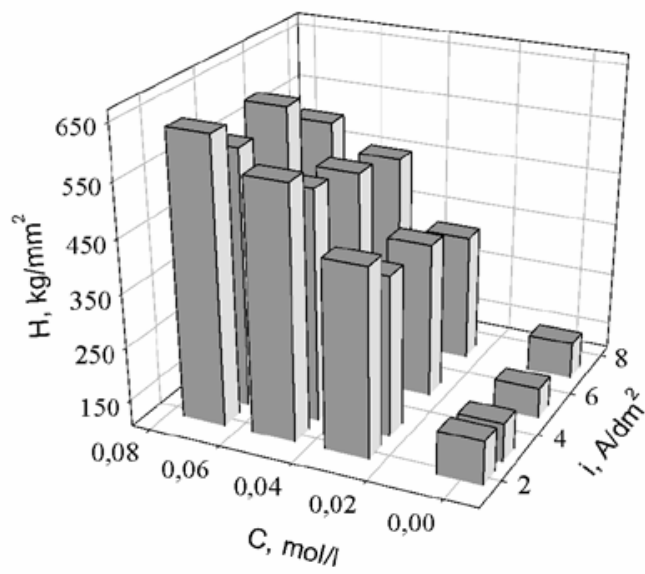

a

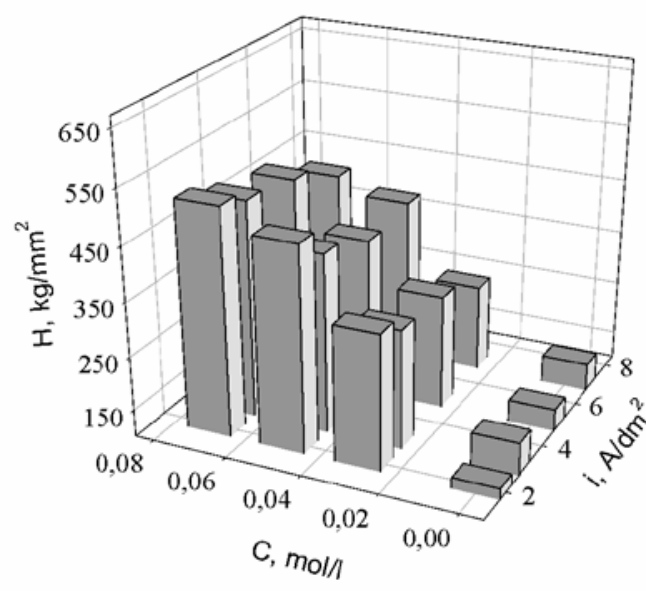

b

Figure 5. Microhardness of the Ni-P coatings deposited from the methanesulfonate (a) and sulfate (b) electrolytes 


\section{Conclusions}

It is established that the nickel-phosphorus alloys deposited from the methanesulfonate and sulfate electrolytes under identical conditions similar in composition. According to the kinetics research rate of electroreduction of the nickel ions(II) at the presence of sodium hypophosphite in the electrolyte increases. Similar dependences are obtained for the sulfate electrolyte. The addition of boric acid to the methanesulfonate electrolyte reduces the differences in the kinetics of the Ni-P and nickel electrodeposition. In the sulfate electrolyte such effect is not observed. Ni-P coatings deposited from the methanesulfonate electrolyte have higher physical-chemical properties than coatings deposited from the sulfate electrolyte.

\section{Reference}

[1] Djokic Stojan S. Electrodeposition of amorphous alloys based on the iron group of metals. // J. Electrochem. Soc., 1999, vol.146, pp.18241828

[2] Revesz A., Lendvai J., Loranth J., Padar J., Bakonyi I. Nanocrystallization studies of an electroless plated $\mathrm{Ni}-\mathrm{P}$ amorphous alloy. //J. Electrochem. Soc., 2001, vol.148, pp. 715-720.

[3] Thomas M. Harris, Quoc D. Dang. The mechanism of phosphorus incorporation during the electrodeposition of nickel-phosphorus alloys. //J. Electrochem. Soc., 1993, vol.140, pp. 81-83.

[4] Shmelev N.M. The controller of works in electroplating. Metallurgy, Moscow, 1966. 175 p. 


\title{
ELECTRODEPOSITION AND PROPERTIES OF NICKEL COATINGS AND FOIL REINFORCED WITH ALUMINA
}

\author{
OVCHARENKO O. A., SAKHNENKO N. D., VED' M. V. \\ National Technical University "Kharkiv Polytechnic Institute" \\ olgaovcharenko@kpi.kharkov.ua
}

The results of the electrochemical formation of composite coatings and foil based on nickel reinforced with nanoscale alumina are reported. Nickel based foil reinforced with the variable dispersion alumina phase content and adhesive composite coatings were deposited from nickel sulphamate electrolytes on polished steel substrates. The chemical topdown principle method is used for commercial $\mathrm{Al}_{2} \mathrm{O}_{3}$ dispergation. The hydrosole of alumina was received by dispersion of the high-temperature $\mathrm{Y}-\mathrm{Al}_{2} \mathrm{O}_{3}$ in water solution at $\mathrm{pH}>13$ with the following elutriation of unreal solution. The influence of the alumina concentration in the electrolyte on the physic-mechanical properties of reinforced foil is established. Inclusion of reinforcing phase particles into the Ni matrix leads to a decrease in the grain size. The topography of the surface and crosssectional profile of composites are studied by scanning probe AFM microscope and their influence on the properties of materials is established. The surface of synthesized $\mathrm{Ni}-\mathrm{Al}_{2} \mathrm{O}_{3}$ composites is well developed, but the composite electrolytic coatings are more roughness, crystalline, characterized by a wide range of grain sizes within the same scan compared with a foil. The content of alumina 1,5 at.\% (in terms of metal) in foil and composite coatings enhances microhardness, tensile strength and yield point of the material twice compared to monometallic systems.

In recent years, new technology development and their facility creation require materials with unique functional characteristics. One of the most advanced research vectors is the synthesis of composite coatings and foils based on metal matrix with the second phase inclusions [1]. As second phase dopants there are used oxides, carbides, silicides, borides, nitrides and other. The achieved composites combine both the properties of the metal and the dispersed phase. They have higher corrosion resistance, micro-hardness, improved durability and heat resistance. In practical terms the important properties of the composite coatings and foils are defined with the nature of the dispersed phase. As long as the improvement of the composite materials performance index is tighten with the combination of two different-nature 
materials, it is necessary to use those materials which have the enough strong interaction with the metal matrix [2]. That is why it is an increasing interest in using the metal oxides (Aluminum, Zirconium etc.) as second phase materials [3]. The choice of alumina is based on its essential physico-mechanical properties, as follows, the improved hardness, crushing stress and high resistance to corrosion and cupping. More than that - the alumina is a low-cost material, which does not lead to critical rise of the self-cost [4].

Improved physico-mechanical properties without changing the metal crystal lattice are possible when adding less amount of strengthening phase. The new class of composite materials, meeting the same requirements, came up recently, and it is based on usage of sintered alumina, zircon dioxide and others, which size is about 1-100 $\mathrm{nm}$ [5]. The wide application of the nickel coatings is based on valuable properties, such as atmosphere corrosion resistance in alkali media and some of the acids. That's why they are used for improvement of steel chemical resistance in operating conditions, including under pressure and aggressive media influence. At the same time the specified coating are strained and fragile enough making it difficult to obtain a nickel foil and restricts electroforming [6]. These points are the base for major interest in composite electrolytic coatings (CEC) and foils development basing on nickel reinforced with nano-sized alumina.

\section{Research Methodology}

Nickel based foil reinforced with the variable dispersion alumina phase content was deposited on polished stainless steel AISI 304 substrates. Adhesive composite coatings with the same composition were settled on steel 20 [7]. Both types of deposits were deposited from nickel sulphamate electrolytes [8] of the following composition, $\mathrm{g} \cdot \mathrm{dm}^{-3}$ : nickel sulphamate 80-320; nickel chloride 7-20; boron hydroxide 25-40 with variable concentration of dispersion phase. The content of the second phase was within 1 до $2.5 \mathrm{~g} \cdot \mathrm{dm}^{-3}$ in electrolyte solution.

Electrolytes were prepared of the certified reactive «pure grade» mark on the distilled water. The regulated power supply B5-47 was used for electrolysis, performed with current density $2-3 \mathrm{~A} \cdot \mathrm{dm}^{-2}$ at the temperature of $20-25^{\circ} \mathrm{C}$ during $30-40 \mathrm{~min}$. The thickness of the received composites was $30-50 \mu \mathrm{m}$.

Physic-mechanical tests of the $\mathrm{Ni}-\mathrm{Al}_{2} \mathrm{O}_{3}$ foils - mirco-thickness, yield point $\sigma_{\mathrm{T}}$, tensile strength $\sigma_{п р}$, were held at room-temperature using mechanical testing machine TIRAtest-2300 with the scanning speed of $0.36 \mathrm{~mm} \cdot \mathrm{min}^{-1}$.

The chemical composition of the coatings was analyzed by X-ray photoelectron spectroscopy with an INCA Energy 350 energy-dispersive 
spectrometer; the X-rays were excited by exposure of the samples to a beam of $15 \mathrm{keV}$ electrons. The surface morphology of the coatings was studied with a Zeiss EVO 40XVP scanning electron microscope (SEM). The surface roughness was evaluated by the contact method on $10 \times 10 \times 2 \mathrm{~mm}$ samples with an NT-206 scanning probe AFM microscope (lateral and vertical resolutions 2 and $0.2 \mathrm{~nm}$, respectively; $1024 \times 1024$ scanning matrix, CSC cantilever B as probe, probe tip radius $10 \mathrm{~nm}$ ).

\section{Results and Discussion}

The hydrosole of alumina was received by dispersion of the hightemperature $\mathrm{y}-\mathrm{Al}_{2} \mathrm{O}_{3}$ in water solution at $\mathrm{pH}>13$ during 10-30 min with the following elutriation of unreal solution. Dispersion of the alumina particles achieves by partially dissolving amphoteric $\mathrm{Al}_{2} \mathrm{O}_{3}$ forming $\left[\mathrm{Al}(\mathrm{OH})_{4}\right]^{-}$. The last are adsorbed on $\mathrm{Al}_{2} \mathrm{O}_{3}$ surface defining the charge of colloid particle:

$$
\left\{\mathrm{m}\left(\mathrm{Al}_{2} \mathrm{O}_{3}\right) \cdot \mathrm{n}\left[\mathrm{Al}\left(\mathrm{OH}_{4}\right)\right]^{-} \cdot(\mathrm{n}-\mathrm{x}) \mathrm{Na}^{+} \cdot \mathrm{yH} \mathrm{H}_{2} \mathrm{O}\right\}^{\mathrm{x}} \text {. }
$$

The stability of colloids is based on the presence of complexes $\left[\mathrm{Al}(\mathrm{OH})_{4}\right]^{-}$, which are more effective charge determine ions with the stability constant $K_{s}=3,2 \cdot 10^{32}$. The dispersion particles move to the cathode due to adsorption of $\mathrm{Ni}^{2+}$ on their surface. The particles holding on cathode initiate the nucleation in the points of contact with its surface stimulating the covering of these particles with the metal [9-11].

Analysis of the synthesized composite foils strength characteristic showed that while increasing the amount of alumina in electrolyte 0.25$1.5 \mathrm{~g} \cdot \mathrm{dm}^{-3}$ the microhardness increases in the range $1800-2900 \mathrm{MPa}$, yield point $\sigma_{\mathrm{T}}$ rises up to $150-980 \mathrm{MPa}$, tensile strength reaches 550$1200 \mathrm{MPa}$ with the minor flexibility decrease. The reason of that is the incorporation into the $\mathrm{Ni}$ matrix adding into the main matrix the of $\mathrm{Al}_{2} \mathrm{O}_{3}$ nano-particles which are reliable restraint to dislocation moving. That is common to explain mechanism of reinforcement by Orován (rounding of the second phase particles by dislocations) [12].

The surface of synthesized $\mathrm{Ni}-\mathrm{Al}_{2} \mathrm{O}_{3}$ composites is well developed, but the CEC (Fig. 1 a) are more roughness, crystalline, characterized by a wide range of grain sizes within the same scan compared with a foil (Fig. 1 b). It should also be noted that $\mathrm{Al}_{2} \mathrm{O}_{3}$ nano-particles tend to coalescence and formation of conglomerates. Profile intersection of crystallites between markers 1 and 2 shows that the grain size of CEC is 50-300 nm, while the foil - 180-200 nm. The difference between peaks and valleys of CEC relief distributes irregularly over the cross section and varies within 10-300 nm unlike evenly distributed difference of 100 $\mathrm{nm}$ to foil. 

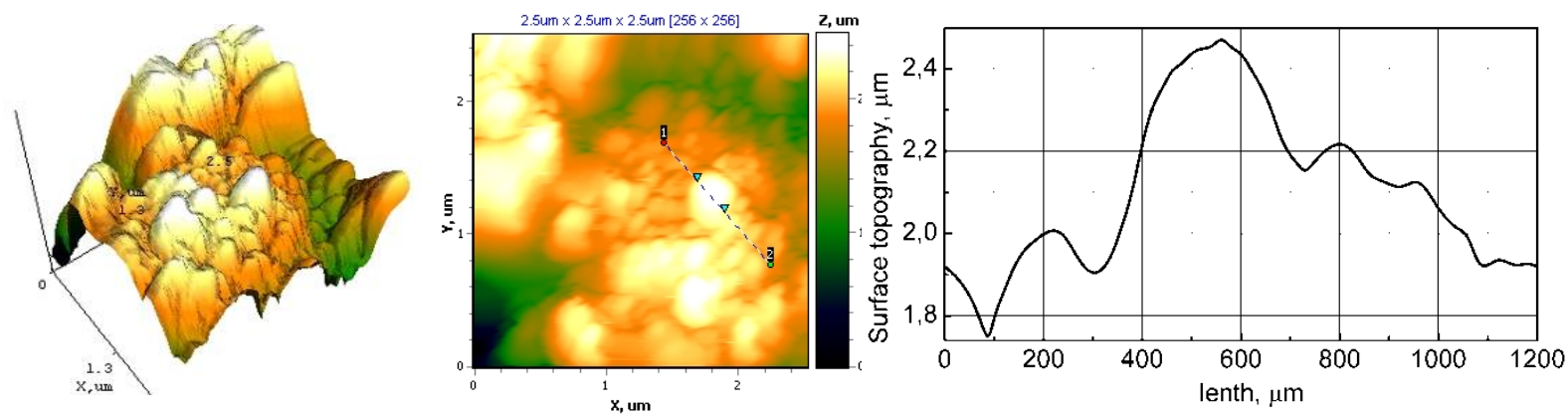

a
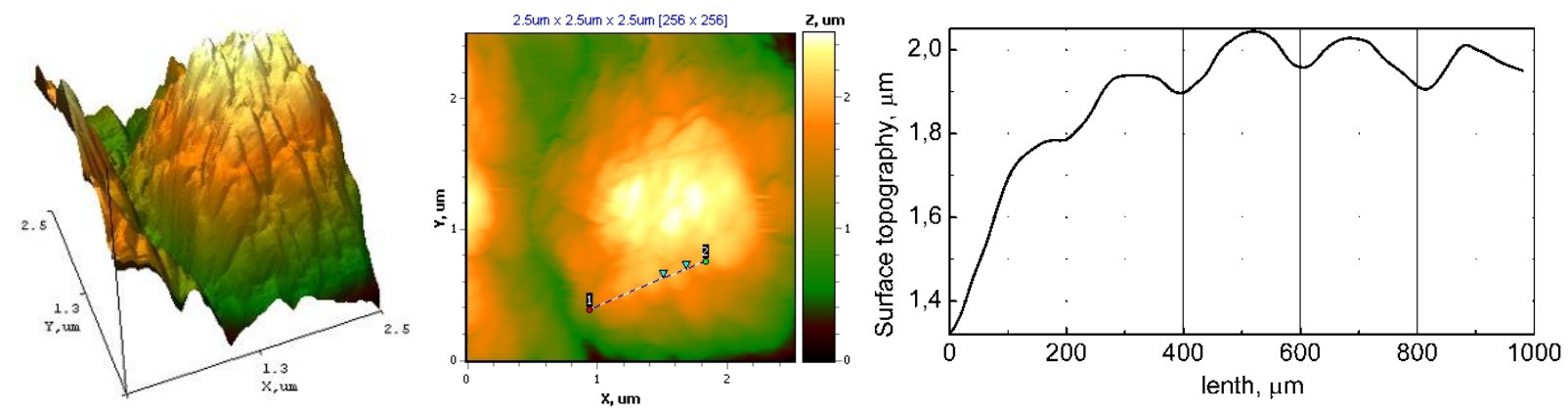

$b$

Figure 1. $3 D$ and $2 D$ surface maps and cross section profile between markers 1-2 for $\mathrm{Ni}-\mathrm{Al}_{2} \mathrm{O}_{3} \mathrm{CEC}$ (a) and foil (b) with $\mathrm{Al}_{2} \mathrm{O}_{3}$ content 1,5 at.\% (in terms of metal).

Scanning area $2,5 \times 2,5 \mu \mathrm{m}$

The incorporation of the aluminum oxide nano-sized particles to the metal matrix leads to the metal crystallites size decreasing, which affects its mechanical properties. Decrease in crystallite size promotes grain boundaries increasing following by improving the mechanical characteristics of the material such as hardness [13, 14].

\section{Conclusions}

1. The compact fine-grained pore-free composite coatings, based on nickel matrix reinforced with the nano-sized alumina are electro deposited from sulphamate nickel bath containing chemically dispersed high-temperate oxide $\mathrm{Y}-\mathrm{Al}_{2} \mathrm{O}_{3}$.

2. The incorporation of nanoscale reinforcing phase particles $\mathrm{Al}_{2} \mathrm{O}_{3}$ in Ni matrix reduces grain size and improving the mechanical properties of composites. The content of alumina 1,5 at.\% (in terms of metal) in foil and CEC enhances microhardness, tensile strength and yield point of the material twice compared to monometallic systems. 


\section{References}

[1] Кобаяси Н., Введение в нанотехнологию, [пер. с японск. А.В. Хачоян], БИНОМ. Лаборатория знаний, 2008.

[2] Ханника Р., Хилл А., Наноструктурные материалы, [пер. с англ. А. А. Шустикова], Техносфрера, 2009.

[3] Sakhnenko M.D., Ovcharenko O.O., Ved' M.V., Lyabuk S.I., Physicomechanical Properties of $\mathrm{Cu}-\mathrm{Al}_{2} \mathrm{O}_{3}$ Electroplating Compositions , Materials science, Vol. 50, No. 5, pp. 646-652, (2015).

[4] Сергеев Г.Б. Нанохимия, Книжный дом университет, 2007.

[5] Сехов И.Н., Жабреев В.А., Марголин В.И., Проблемы нанотехнологии в современном материаловедении, Физика и химия стекла. Т. 29, № 2, С. 241 - 255, (2003).

[6] Вячеславов П.М., Промышленная гальванопластика, Машиностроение, 1986.

[7] Sakhnenko N. D., Ovcharenko O. A., Ved' M. V., Electrochemical Synthesis of Nickel-Based Composite Materials Modified with Nanosized Aluminum Oxide, Russian Journal of Applied Chemistry, Vol. 88, № 2, pp. 267-271, (2015).

[8] Сайфуллин Р.С. Неорганические композиционные материалы, Химия, 1983.

[9] Protsenko V.S., Vasil'eva E.A., Smenova I.V., Danilov F.I., Electrodeposition of iron/titania composite coatings from methanesulfonate electrolyte, Russian Journal of Applied Chemistry, vol. 87, № 3, pp. 283-288, (2014).

[10] Sakhnenko N. D., Ovcharenko O. A., Ved' M. V. Electrodeposition and Physicomechanical Properties of Coatings and Foil of Copper Reinforced with Nanosize Aluminum Oxide, Russian Journal of Applied Chemistry, Vol. 87, № 5, pp. 596-600. 2014.

[11] Адамсон А., Физическая химия поверхностей, Мир, 1979.

[12] N. Sakhnenko, O. Ovcharenko, M. Ved. Copper (nickel) based composite coatings reinforced with nanosized oxides, Functional Materials, Vol.22, № 1, pp.105-109, (2015).

[13] Солнцев Ю.П. Материаловедение, Химиздат, 2004.

[14] Портной К.И., Бабич Б.Н., Светлов И.Л.. Композиционные материалы на никелевой основе, Металлургия, 1979. 
УДК 544.642:544.6.018.4

\title{
IONIZATION OF NICKEL IN NICKEL TARTRATE ELECTROLYTES
}

\author{
ANTSIKHOVICH I.V., CHERNIK A.A. \\ Belarusian State Technological University \\ antihovich.irina@gmail.com
}

The effect of various factors (current density, the concentration of electrolyte components) on the current efficiency, nickel oxidation and basic electrokinetic parameters has been studied. It has been revealed that nickel ionization process must be conducted at a temperature of 50 ${ }^{\circ} \mathrm{C}$ and current densities of up to $0,4 \mathrm{~A} / \mathrm{cm}^{2}$. Lowering the temperature to $20{ }^{\circ} \mathrm{C}$ leads to decreasing the anodic current efficiency by $20-30 \%$. The depth of nickel oxidation in tartrate electrolyte ranges from $3,7 \cdot 10^{-4}$ to $5 \cdot 10^{-6} \mathrm{~cm}$. The composition of electrolyte solution and the temperature have a significant impact on the value of oxidation depth. The limiting stage of dissolving nickel is electrochemical one.

\section{ИОНИЗАЦИЯ НИКЕЛЯ В ТАРТРАТНЫХ ЭЛЕКТРОЛИТАХ НИКЕЛИРОВАНИЯ}

\author{
АНТИХОВИЧ И.В., ЧЕРНИК А.А.
}

Белорусский государственный технологический университет antihovich.irina@gmail.com

Изучение влияния различных фракторов (плотности тока, концентрации комонентов электролита) на выход по току, глубину окисления никеля и основные электрокинетические параметры позволило установить, что процесс ионизации никеля необходимо осуществлять при температуре $50{ }^{\circ} \mathrm{C}$ и плотностях тока до $0,4 \mathrm{~A} / \mathrm{cm}^{2}$. Понижение температуры до $20^{\circ} \mathrm{C}$ приводит к уменьшению анодного выхода по току на 20-30 \%. Глубина окисления никеля в тартратных электролитах колеблется в диапазоне от $3,7 \cdot 10^{-4}$ до $5 \cdot 10^{-6} \mathrm{~cm}$. Состав раствора и температура электролита оказывают значительное влияние на величину глубины окисления. Лимитирующая стадия растворения никеля - электрохимическая. 
Основными

направлениями

развития

технологии электрохимического осаждения никелевого покрытия является поиск экологичных составов, обладающих высокой буферной емкостью и улучшенными эксплуатационными свойствами [1]. Стабильность электролита никелирования зависит от особенностей катодного осаждения и растворения никелевых анодов, которые склонны к пассивации, вследствие чего их растворение протекает при значительной анодной поляризации. Пассивация анодов является крайне нежелательным процессом, так как в процессе электроосаждения происходит обеднение электролита по никелю [2, 3].

Цель работы - изучить кинетические особенности ионизации никеля в тартратном электролите никелирования.

Концентрация $\mathrm{Ni}^{2+}$ в электролите варьировалась в диапазоне 0,25-1,35 моль/дм ${ }^{3}$, тартрат Na-K (tart ${ }^{2-}$ ) 0,05-0,9 моль/дм ${ }^{3}$, значение $\mathrm{pH}$ поддерживалось $\mathrm{pH}$-метром $\mathrm{pH}-150$ на уровне 2-3. Необходимое значение $\mathrm{pH}$ электролитов устанавливали концентрированной $\mathrm{H}_{2} \mathrm{SO}_{4}$ или $\mathrm{NaOH}$.

\section{Методология исследований}

Электрохимические исследования осуществляли с помощью потенциостата IPC-Pro-M в стандартной трехэлектродной ячейке ЯСЭ-2. Электрод сравнения - насыщенный хлоридсеребряный. Значения потенциалов пересчитывали в шкалу стандартного водородного электрода. Температура поддерживалась с помощью жидкостного термостата 5ОК-20/0.05-03 с точностью поддержания температуры $\pm 0,5^{\circ} \mathrm{C}$. Анодами служила никелевая лента толщиной 1,5 мм из металлургического никеля марки Н0. Величину выхода по току определяли гравиметрическим методом.

Для установления влияния концентрации электролита и температуры на процесс окисления никеля (изменение потенциала и выхода по току) использовалась эмпирическая модель. Математическое описание процессов осуществлялось в виде уравнения регрессии:

$$
y=b_{0}+b_{1} x_{1}+b_{2} x_{2}+b_{3} x_{3}
$$

где $\mathrm{x}_{1}, \mathrm{x}_{2}, \mathrm{x}_{3}$ - переменные, соответственно концентрация комплексообразующей и буферной добавки (сегнетовой соли), моль/дм ${ }^{3}$; концентрация никеля в пересчете на металл (смеси сульфрата и хлорида никеля), моль/дм ${ }^{3}$; температура, ${ }^{\circ} \mathrm{C} ; \mathrm{b}_{0}, \mathrm{~b}_{1}, \mathrm{~b}_{2}, \mathrm{~b}_{3}$ - коэффициенты модели, которые определяют на основании результатов эксперимента. 


\section{Результаты и их обсуждение}

Влияние концентрации тартрат-иона и никеля на анодные поляризационные кривые на никелевом электроде при температуре $20{ }^{\circ} \mathrm{C}$ представлено на рис. 1.

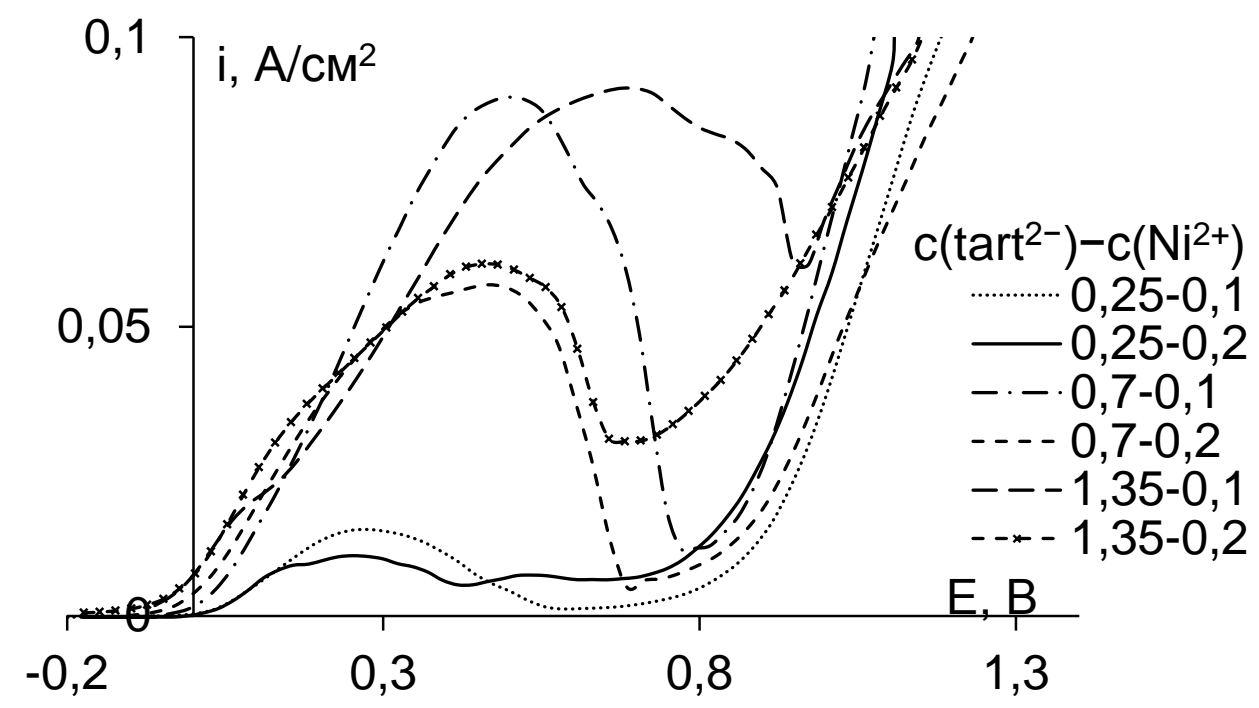

Puс. 1. Влияние концентрации тартрат-иона $\left(0,1 ; 0,2\right.$ моль/дм $\left.{ }^{3}\right)$ и никеля $\left(0,25 ; 0,7 ; 1,35\right.$ моль/дм $\left.{ }^{3}\right)$ на анодные поляризационные кривые на никелевом электроде при температуре $20^{\circ} \mathrm{C}$

Установлено, что увеличение концентрации тартратиона (рисунок 1) уменьшает пик окисления на $0,005 \mathrm{~A} / \mathrm{cm}^{2}$ при концентрации никеля 0,25 моль/дм ${ }^{3}$ и на $0,03 \mathrm{~A} / \mathrm{cm}^{2}$ при концентрациях никеля 0,7 и 1,35 моль/дм ${ }^{3}$, что способствует увеличению анодного выхода по току (табл. 1).

При увеличении температуры в электролите с низким содержанием никеля 0,25 моль/дм ${ }^{3}$ на анодной кривой наблюдается небольшой пик окисления в области потенциалов $\sim 0,1 \mathrm{~B}$ (таблица 2), что вероятно связано с образованием NiO, при этом анодная поляризация уменьшается на 0,5 В при увеличении температуры на $40{ }^{\circ} \mathrm{C}$ (с 30 до $70{ }^{\circ} \mathrm{C}$ ) при плотности тока $0,05 \mathrm{~A} / \mathrm{cm}^{2}$. При температуре $60-70^{\circ} \mathrm{C}$ пик окисления отсутствует. В более концентрированных составах пик окисления лежит в области 0,08-0,15 В и до плотности тока $0,05 \mathrm{~A} / \mathrm{cm}^{2}$, что вероятно связано с образованием оксида никеля более высокой валентности $-\mathrm{Ni}_{3} \mathrm{O}_{4}$.

Количество электричества, поглощенное электродом при поляризации до состояния полной пассивации и глубина окисления никеля, представлены в таблице 2. 
Таблица 1. Выход по току анодный ( $1,5 \%$ в в зависимости от плотности тока и состава сульфатно-хлоридно-тартратного электролита при температурах 20 и $50^{\circ} \mathrm{C}$

\begin{tabular}{|c|c|c|c|c|c|c|c|c|c|}
\hline \multirow{4}{*}{$\begin{array}{l}\mathrm{T}, \\
{ }^{\circ} \mathrm{C}\end{array}$} & \multirow{4}{*}{$\begin{array}{l}\text { Плот- } \\
\text { ность } \\
\text { тока, } \\
\text { А/см² }\end{array}$} & \multicolumn{8}{|c|}{$\mathrm{Ni}^{2+}$, моль/дм ${ }^{3}$} \\
\hline & & \multicolumn{2}{|c|}{0,25} & \multicolumn{3}{|c|}{0,7} & \multicolumn{3}{|c|}{1} \\
\hline & & \multicolumn{8}{|c|}{ tart $^{2-}$, моль/дм } \\
\hline & & 0,1 & 0,2 & 0,1 & 0,2 & 0,3 & 0,1 & 0,2 & 0,3 \\
\hline \multirow{4}{*}{20} & 0,04 & 63,6 & 78,4 & 71,9 & 79,1 & 78,4 & 78,4 & 69,4 & 78,4 \\
\hline & 0,08 & 68,2 & 71,6 & 73,1 & 83,2 & 80,1 & 75,0 & 75,6 & 76,7 \\
\hline & 0,28 & - & 59,9 & - & 81,3 & 74,0 & 76,0 & 36,1 & 74,5 \\
\hline & 0,4 & - & 40,2 & - & 80,7 & 49,4 & - & 64,2 & 54,9 \\
\hline \multirow{4}{*}{50} & 0,04 & 79,1 & 100,0 & 52,1 & 90,0 & 100,0 & 92,0 & 76,9 & 100,0 \\
\hline & 0,08 & 80,5 & 100,0 & 75,6 & 84,5 & 88,6 & 100,0 & 78,0 & 100,0 \\
\hline & 0,28 & - & 100,0 & - & 81,8 & 100,0 & 100,0 & 99,6 & 100,0 \\
\hline & 0,4 & - & 100,0 & - & 95,1 & 99,8 & 100,0 & 100,0 & 100,0 \\
\hline
\end{tabular}

Таблица 2. Токи и потенциалы пиков анодных поляризационных кривых и глубина окисления никеля

\begin{tabular}{|c|c|c|c|c|c|c|c|c|c|}
\hline \multirow{2}{*}{$\operatorname{tart}^{2}$} & \multicolumn{5}{|c|}{$\mathrm{Ni}^{2+} 0,25$ моль/дм ${ }^{3}$} & \multicolumn{4}{|c|}{$\mathrm{Ni}^{2+} 0,7$ моль/дм ${ }^{3}$} \\
\hline & $\begin{array}{l}\mathrm{T}^{\circ}{ }^{\circ} \\
\mathrm{C}\end{array}$ & $\begin{array}{c}\begin{array}{c}\text { Eeak, } \\
B\end{array} \\
\end{array}$ & $\begin{array}{c}\mathrm{i}_{\text {peak }} \\
\mathrm{A} / \mathrm{cm}^{2} \\
\end{array}$ & $\begin{array}{c}Q, \\
M A \cdot 4\end{array}$ & $\begin{array}{c}\delta \cdot 10^{5}, \\
\mathrm{CM}\end{array}$ & $\begin{array}{c}\text { Eeak, } \\
B\end{array}$ & \begin{tabular}{|c|}
$i_{\text {peak }}$, \\
$\mathrm{A} / \mathrm{cm}^{2}$ \\
\end{tabular} & $\begin{array}{c}, \\
M A \cdot 4\end{array}$ & $\begin{array}{c}\delta \cdot 10^{5}, \\
\mathrm{CM}\end{array}$ \\
\hline \multirow{4}{*}{0,2} & 20 & 0,245 & 0,010 & 0,163 & 2,01 & 0,471 & 0,057 & 1,467 & 18,13 \\
\hline & 30 & 0,129 & 0,009 & 0,210 & 2,60 & 0,202 & 0,027 & 0,399 & 4,93 \\
\hline & 40 & 0,143 & 0,005 & 0,059 & 0,73 & 0,351 & 0,053 & 1,351 & 16,69 \\
\hline & 50 & 0,162 & 0,013 & 0,124 & 1,53 & 0,137 & 0,010 & 0,122 & 1,51 \\
\hline & \multicolumn{5}{|c|}{$\mathrm{Ni}^{2+} 1$ моль/дм ${ }^{3}$} & \multicolumn{4}{|c|}{$\mathrm{Ni}^{2+} 1,35$ моль/дм ${ }^{3}$} \\
\hline \multirow{5}{*}{0,1} & 20 & 0,55 & 0008 & 3,019 & 37,31 & 0,674 & 0,091 & 1,644 & 20,31 \\
\hline & 30 & 0,331 & 0,065 & 1,347 & 16,64 & 0,518 & 0,064 & 1,218 & 15,06 \\
\hline & 40 & 0,139 & 0,019 & 0,257 & 3,18 & 0,231 & 0,058 & 1,192 & 14,73 \\
\hline & 50 & 0,148 & 0,038 & 0,465 & 5,75 & 0,283 & 0,070 & 1,627 & 20,11 \\
\hline & 55 & 0,169 & 0,042 & 0,317 & 3,81 & 0,154 & 0,018 & 0,162 & 2,01 \\
\hline \multirow{5}{*}{0,2} & 20 & 0,165 & 0,03 & 0,368 & 20,53 & 0,461 & 0,061 & 1,596 & 19,73 \\
\hline & 30 & 0,13 & 0,037 & 0,355 & 4,39 & - & - & - & - \\
\hline & 40 & 0,078 & 0,024 & 0,216 & 2,67 & 0,082 & 0,023 & 0,204 & 2,52 \\
\hline & 50 & 0,09 & 0,03 & 0,380 & 4,70 & 0,015 & 0,007 & 0,037 & 0,46 \\
\hline & 5 & 0,064 & 0,038 & 0,325 & 4,01 & 006 & 0,008 & 0,055 & 8 \\
\hline
\end{tabular}

Почти $100 \%$ анодный выход по току наблюдается в электролитах с высоким содержанием тартрат-иона $(0,2-$ 0,3 моль/дм $\left.{ }^{3}\right)$ и повышенных температурах (40-50 $\left.{ }^{\circ} \mathrm{C}\right)$. Поэтому для поддержания анода в рабочем состоянии, при использовании тартратных электролитов, необходимо сохранять соотношение площадей катода к аноду не менее 1:1,5. 
Глубина окисления никеля в тартратных электролитах колеблется в диапазоне от $3,7 \cdot 10^{-4}$ до $5 \cdot 10^{-6} \mathrm{~cm}$. Состав раствора и температура электролита оказывают значительное влияние на величину глубины окисления. Повышение температуры на $30^{\circ} \mathrm{C}$ уменьшает глубину окисления на порядок при концентрации никеля 1-1,35 моль/дм ${ }^{3}$ и тартрат-иона 0,1 моль/дм ${ }^{3}$, а также при концентрации никеля 0,7 моль/дм ${ }^{3}$ и тартрат-иона 0,2 моль/дм ${ }^{3}$ и на 2 порядка при концентрации никеля 1,35 моль/дм ${ }^{3}$ и тартрат-иона 0,2 моль/дм³

Полученные в таблице 2 данные были обработаны посредством линейного уравнения регрессии. Установлено, что увеличение концентрации никеля на 1 моль/дм ${ }^{3}$, температуры на $10^{\circ} \mathrm{C}$ и концентрации тартрат-иона на 0,1 моль/дм ${ }^{3}$ способствует увеличению анодного выхода по току на 8,7, 6,6 и 4,52\% соответственно. Увеличение плотности тока на $0,01 \mathrm{~A} / \mathrm{cm}^{2}$ вызывает уменьшение анодного выхода по току на $2 \%$.

Основные электрокинетические параметры для тартратных электролитов (ток обмена никеля, коэффрициенты $a \quad n \quad b$ ) определялись графическим методом из полулогарифмических поляризационных кривых. Установлено, что коэфффициент а изменяется незначительно от 0,1 до 0,29 В. Коэфффициент $b$ реакции ионизации никеля в уравнении Тафеля находится в интервале от 0,10 до 0,13 В, что свидетельствует о замедленности стадии переноса электрона. Ток обмена никеля в тартратных растворах составляет $2,9 \cdot 10^{-8}-2 \cdot 10^{-5} \mathrm{~A} / \mathrm{cm}^{2}$.

\section{Выводы}

Изучение влияния различных фракторов (плотности тока, концентрации комонентов электролита) на выход по току, глубину окисления никеля и основные электрокинетические параметры позволило установить, что процесс ионизации никеля необходимо осуществлять при температуре $50{ }^{\circ} \mathrm{C}$ и плотностях тока до $0,4 \mathrm{~A} / \mathrm{cm}^{2}$. Лимитирующая стадия растворения никеля - электрохимическая.

\section{Литература}

[1] Fumitaka, S. Nickel electropiating bath using malic acid as a substitute agent for boric acid / S. Fumitaka, K. Keisuke, N. Yuzuru, K. Koichi, S. Yuichi // Metal Finish. - V. 105, №12. - 2007. - P. 34-38, $59,60$.

[2] Мамаев, В.И. Никелирование: учебное пособие. Под ред. В. Н. Кудрявцева. - М.: РХТУ им. Д. И. Менделеева, 2014. - 192 с.

[3] Хейфец, В. Л.Электролиз никеля / В. Л. Хейфец, Т. В. Грань. М.: Металлургия, 1975. - 333 с. 


\title{
GALVANOCHEMICAL FORMATION OF A MULTICOMPONENT ALLOY BASED ON COBALT AND REFRACTORY METALS
}

\author{
HAPON YU.K., NENASTINA T.O.*, SAKHNENKO N.D., VED' M.V. \\ National Technical University «Kharkov Polytechnic Institute» \\ * Kharkov National Automobile and Highway University \\ hapon@kpi.kharkov.ua
}

Effects of major parameters of electrolysis on the composition and morphology of the cobalt-molybdenum-tungsten alloy from citratepyrophosphate and citrate-ammonium electrolytes have been analysed. It has been shown that the content of component metals in the Co-W-Mo alloy depends on the nature and composition of the electrolyte solution. The influence of electrolysis conditions and regime on the structure and morphology of cobalt alloys with refractory metals has been established. The elemental composition and morphology of the triple cobalt molybdenum - tungsten coatings have been determined with a scanning electron microscope.

\section{ГАЛЬВАНОХІМІЧНЕ ФОРМУВАННЯ БАГАТОКОМПОНЕНТНОГО СПЛАВУ НА ОСНОВІ КОБАЛЬТА ТА ТУГОПЛАВКИХ МЕТАЛІВ}

\author{
ГАПОН Ю.К., НЕНАСТІНА Т.О., САХНЕНКО М.Д., ВЕДЬ М.В. \\ Національний технічний університет „Харківський політехнічний \\ інституm" \\ *Харківький національний автомобільно-дорожній університет, \\ hapon@kpi.kharkov.ua
}

Проаналізовано вплив основних параметрів електролізу на склад та морфологію сплаву кобальт-молібден-вольфрам отриманого з цитратно-дифосфратного та цитратно-амоніачного електролітів. За допомогою сканівного електронного мікроскопу досліджено склад і морфологію потрійних покриттів. Було показано, що вміст компонентів в сплаві Co-W-Mо залежить від природи ліганда і співвідношення концентрацій сплавотвірних металів. Встановлено вплив густини струму, а також часу імпульсу та паузи на структуру і морфологію покриттів. 
В поточний час значну увагу науковців привертають сплави кобальту, підвищення функціональних властивостей яких досягають легуванням тугоплавкими металами, зокрема, вольфрамом і молібденом. Залежно від співвідношення компонентів таких сплавів їх властивості можуть значною мірою змінюватися: сплави з високим вмістом кобальту проявляють магнітні властивості і можуть бути використані в пристроях запису і зберігання інформації, сплави 3 високим вмістом молібдену і вольфраму мають високу твердість, хімічну та корозійну стійкість, їх можна використовувати для підвищення зносостійкості деталей машин, що працюють в агресивних середовищах і при високих температурах [1]. Значний вплив на стабільність електроліту, якість покриттів, морфологію поверхні та вихід за струмом має вибір лігандів і їх співвідношення в електроліті [2]. Для осадження бінарних сплавів вольфраму і молібдену 3 кобальтом частіше всього використовують розчини цитратних, хлоридно-цитратних, дифосфратних і дифосфратноцитратних комплексів, а введення до складу електроліту динатрієвої солі етилендіамінтетраоцтової кислоти (ЕДТА) сприяє збільшенню вмісту в сплаві тугоплавких компонентів [3].

Метою даної роботи є дослідження умов електроосадження покриттів сплавом Co-Mo-W з нетоксичних комплексних електролітів зі збереженням високого рівня функціональних властивостей, а також визначення їх елементного складу і морфології.

\section{Методологія досліджень}

Електроосаждення потрійного сплаву на основі кобальту 3 тугоплавкими металами проводили 3 полілігандних цитритнодифосфатного та цитратно-амоніачного електролітів постійним струмом $j=2 \ldots 8 \mathrm{~A} /$ дм $^{2}$ та уніполярним імпульсним струмом амплітудою $j=4 \ldots 20 \mathrm{~A}^{2}$ д $^{2}$ в діапазоні частот $f=19 \ldots 910$ Гц, тривалість імпульсу варіювали в межах $t_{\mathrm{i}}=2 \cdot 10^{-3} \ldots 2 \cdot 10^{-1} \mathrm{c}$, паузи $t_{п}=2 \cdot 10^{-2} \ldots 2 \cdot 10^{-1} \mathrm{c}$.

Імпульсні режими електроосадження здійснювали за допомогою потенціостату ПІ-50-1.1 з програматором ПР-8. Як розчинні аноди використовували кобальтові компланарні пластини. Розчини для осадження сплавів Co-Mo-W готували з аналітично чистих реактивів, які розчиняли в невеликій кількості дистильованої води, після чого розчини змішували в певній послідовності, ґрунтуючись на результатах дослідження іонних рівноваг. Покриття сплавами наносили на підкладки з міді (M0) і сталі (Ст.3).

Елементний склад i морфологію зразків аналізували за допомогою сканівного електронного мікроскопа ZEISS EVO 40XVP. Зображення поверхні зразків отримували завдяки реєстрації 
вторинних електронів (BSE) шляхом сканування електронного пучка по поверхні, що дозволяло 3 високою роздільною здатністю та контрастністю досліджувати топографрію (нерівності) поверхні.

\section{Результати та їх обговорення}

Результати дослідження впливу режимів електролізу на склад, структуру і морфологію поверхні електролітичних покриттів Сo-МоW, а також встановлення їх взаємозв'язку з фрізико-механічними i фрізико-хімічними властивостями синтезованих сплавів $€$ основою для фрормування рекомендацій щодо застосування матеріалів.

При дослідженні процесів нанесення покриттів сплавом Co-WМо $з$ полілігандних електролітів (таблиця 1) було виявлено ряд особливостей [4]. Так, якщо в ролі одного з лігандів використовувати цитрат-іон, а другого - дифосфат-іон або гідроксид амонію, то можна встановити наступне:

1. 3 цитратно-дифосфатного електроліту осаджуються покриття з більш високим вмістом молібдену.

2. При осадженні з цитратно-амоніачних розчинів вміст тугоплавких компонентів у сплаві практично однаковий (в діапазоні 10-18\%), але у разі використання імпульсного режиму вміст вольфраму різко збільшується.

Таблиця. Мікрофотографії та склад сплаву Co-Mo-W

\begin{tabular}{|c|c|c|c|c|}
\hline & \multicolumn{4}{|c|}{ Електроліти } \\
\hline & \multicolumn{2}{|c|}{ Цитратно-дифоссфатний (1) } & \multicolumn{2}{|c|}{ Цитратно-амоніачний (2) } \\
\hline & $\begin{array}{l}\text { Мікрофротографія } \\
\text { (х200) }\end{array}$ & $\begin{array}{l}\text { Склад, } \\
\text { Мас. \% }\end{array}$ & $\begin{array}{l}\text { Мікрофротографрія } \\
(\mathbf{2 0 0 )}\end{array}$ & $\begin{array}{l}\text { Склад, } \\
\text { Мас. \% }\end{array}$ \\
\hline$a$ & 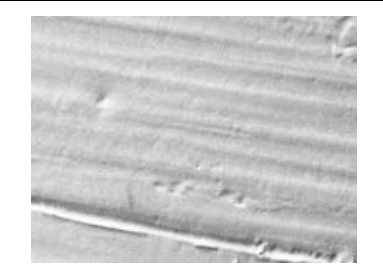 & $\begin{array}{c}\text { Co- } 64,6 \\
\text { Mo- } 24,1 \\
\text { W-1,8 }\end{array}$ & & $\begin{array}{c}\text { Co-63,3 } \\
\text { Mo- } 15,1 \\
\text { W-14,2 }\end{array}$ \\
\hline б & 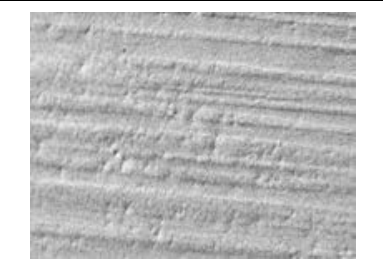 & $\begin{array}{c}\text { Co-53,9 } \\
\text { Mo- } 30,3 \\
\text { W-4,2 }\end{array}$ & & $\begin{array}{c}\text { Co-62,2 } \\
\text { Mo- } 12,7 \\
\text { W-17,4 }\end{array}$ \\
\hline B & 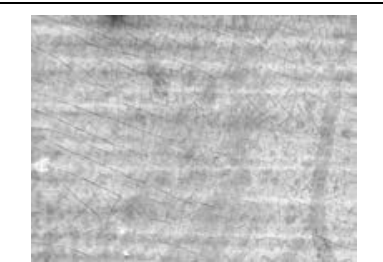 & $\begin{array}{c}\text { Co-52,6 } \\
\text { Mo- } 30,1 \\
\text { W-5,0 }\end{array}$ & & $\begin{array}{c}\text { Co-44,1 } \\
\text { Mo- } 11,2 \\
\text { W-27,8 }\end{array}$ \\
\hline
\end{tabular}


На мікрофротографріях чітко помітні рівномірність поверхні покриттів сплавом Co-Mo-W з електроліту №1, а також глобулярна структура покривів, отриманих 3 розчину №2 при використанні стаціонарного режиму $j=3 \mathrm{~A} /$ дм $^{2}$ (a).

Підвищення вмісту тугоплавкого компонента завдяки збільшенню густини струму $j=6 \quad \mathrm{~A} /$ дм $^{2}$ (б) та використання імпульсного режиму $j=10 \mathrm{~A} /$ дм $^{2}$ (в) в сплавах призводить до появи мережі тріщин (№1, в) або аморфізації покриттів (№2, в), яка візуалізується як поступове зменшення розміру зерна з ростом вмісту вольфраму та молібдену в сплаві [5]. Склад та вихід за струмом сплаву, отриманого з цитратно-дифосфатного електроліту в імпульсному режимі на мідну подкладку, наведено на рисунку.

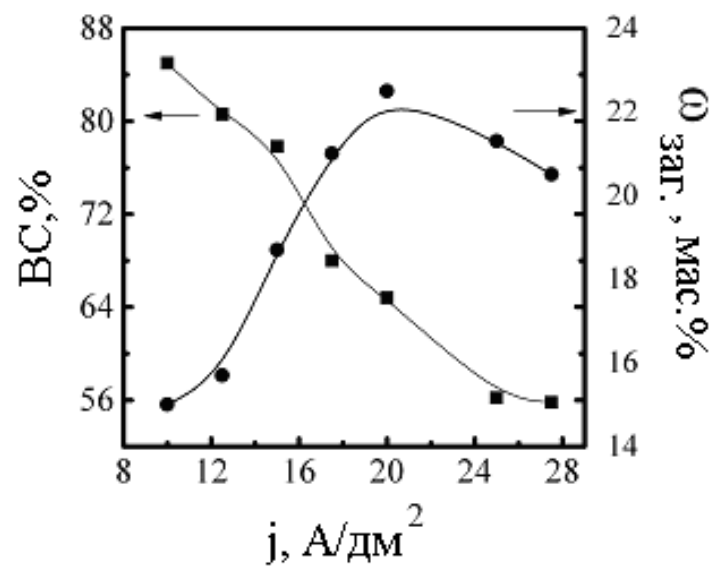

Рисунок. Залежність ВC і загального вмісту вольфраму та молібдену $\left(\omega_{\text {заг.. }}\right)$ у сплаві Co-Mo-W від густини струму (час імпульсу 2 мс, час паузи 10 мс).

Аналіз елементного складу покриттів показує, що загальний вміст сплавотвірних металів становить 83-92 мас.\%, а кисню та вуглецю, які входять також до складу сплаву - 8-18\% Логічно припустити, що отриманий сплав являє собою твердий розчин СоMo-W, який може включати різні інтерметалеві сполуки (наприклад, CoW, CoMo або $\left.\mathrm{Co}_{3} \mathrm{~W}, \mathrm{Co}_{3} \mathrm{Mo}\right)$, а також інші можливі поєднання зазначених елементів [6]. Такими потенційно можливими сполуками можуть бути карбіди вольфраму, молібдену або оксиди кобальту, молібдену і вольфраму [7]. 3 огляду на високу твердість карбідів і оксидів Со, Мо і W, можна припустити, що їх присутність в електролітичному сплаві сприятиме зміцненню одержуваних покривів.

\section{Висновки}

Досліджено процеси електроосадження багатокомпонентних сплавів на основі кобальту і встановлено, що 3 полілігандних 
електролітів можна наносити якісні покриття сплавом кобальтмолібден-вольфрам з вмістом тугоплавких металів до 21-35 мас.\%. Покриття, отримані з цитратно-дифосфатного електроліту, більш рівномірні, але вміст тугоплавких металів менший, ніж у покриттів 3 цитратно-амоніачного розчину. За результатами досліджень впливу режимів електролізу на його ефективність встановлено, що вихід за струмом сплаву, осадженого в імпульсному режимі, $\epsilon$ достатньо високим і становить 56-88 \%, що з урахуванням значно вищих, у порівнянні 3 гальваностатичним, робочих густин струму робить нестаціонарний режим більш привабливим. Доведено, що завдяки комплексу фізико-хімічних властивостей сплавотвірних елементів та їх сполук спрямований синтез сплаву Co-Mo-W є перспективним методом зміцнення поверхні і підвищення ії зносостійкості та корозійної стійкості.

\section{Перелік посилань}

[1] Ведь М.В., Сахненко Н.Д., Гапон Ю.К., Ненастина Т.А., Электроосаждение тройных сплавов кобальта с тугоплавкими металлами, Гальванотехника и обработка поверхности, №1, С.14 21, (2016).

[2] Байрачная Т.Н., Ведь М.В., Сахненко Н.Д. Электролитические сплавы вольфрама: получение и свойства, Saarbrucken: LAP Lambert Academic Publishing, 2013.

[3] Сидельникова С.П., Володина Г.Ф., Грабко Д.3., Дикусар А.И., Электрохимическое получение Co-Мо покрытий из цитратных растворов, содержащих ЭДТА: состав, структура, микромеханические свойства, Электронная обработка материалов, №6, C. 4-9, (2007).

[4] Sakhnenko N. D., Ved M. V., Hapon Yu. K., Nenastina T. A., Functional coatings of ternary alloys of cobalt with refractory metals, Russian Journal of Applied Chemistry,Vol. 88, №. 12, pp. 1941-1945, (2015).

[5] Ved M. V., Sakhnenko M. D., Bairachna T. M., Tkachenko M. V., Structure and properties of electrolytic Cobalt-Tungsten alloy coatings, Functional Materials, V.15, № 4, pp. 613 - 617, (2008).

[6] Барабаш О. М. Коваль Ю. Н., Кристаллическая структура металлов и сплавов, К. : Наук. думка, 1986.

[7] Грабко Д.3., Дикусар А.И., Петренко В.И., Харя Е.Е., Шикимака O.A., Микромеханические свойства электролитических сплавов СоW, получаемых при осаждении в импульсных условиях, Электронная обработка материалов, № 1, С. 16-23, (2007). 
УДК 540.185; 621.793

\title{
COMPOSITE NICKEL - CARBON MATERIAL COATINGS
}

\author{
BERVICKAJA O. S., POLISHCHUK YU.V. \\ SHEI «Ukrainian State University of Chemical Technology» \\ impus@ukr.net
}

Electrochemical composite coatings (ECC) with matrices of nickelcontaining particles of the carbon phase were obtained. The average particle size and bulk density of carbon were measured. was analyzed An evolution of the current-voltage dependencies of the process of composite coatings production with temperature was analyzed. Quality carbon deposits were produced at a current density of $1 \mathrm{~A} / \mathrm{dm}^{2}$.

\section{КОМПОЗИЦИОННЫЕ ПОКРЫТИЯ НИКЕЛЬ УГЛЕРОДНЫЙ МАТЕРИАЛ}

\section{БЕРВИЦКАЯ О.С., ПОЛИЩУК Ю.В.}

Государственное высшее учебное заведение "Украинский государственный химико-технологический университет», impus@ukr.net

Получены композиционные электрохимические покрытия (КЭП) с матрицами из никеля, содержащие частицы углеродной фразы. Установлены средние размеры частиц и насыпная плотность углерода. Проанализирована эволюция вольт-амперных зависимостей процесса получения композиционных покрытий при изменении температуры. Качественные осадки углерода получены при плотности тока $1 \mathrm{~A} /$ дм $^{2}$.

Важным направлением в современной гальванотехнике является создание композиционных электрохимических покрытий (КЭП). Методы получения КЭП основаны на осаждении дисперсных частиц различных размеров вместе с металлом из электролитасуспензии, в результате чего частицы дисперсной фразы включаются в металлическую матрицу. Такое модифицирование покрытия позволяет значительно влиять на его эксплуатационные свойства, а именно твердость, износостойкость, коррозионную устойчивость.

Структура и свойства КЭП зависят от природы наполнителя (порошкового материала), размера частиц, их количества в покрытии и взаимодействия с металлической матрицей. В качестве матрицы могут быть применены никель, хром, медь и другие 
металлы. В качестве дисперсной фразы - оксиды, карбиды, бориды и нитриды металлов, углеродные материалы (ультрадисперсный алмаз, графит, фруллерен).

Композиционные электрохимические покрытия с углеродными материалами представляют существенный интерес в качестве новых композиционных материалов благодаря простому составу электролита и его устойчивости во времени. Включение частиц данных материалов в металлические матрицы КЭП позволяет значительно улучшить их износостойкость, коррозионную стойкость, снизить пористость осадков. Ранее [1] нами было показано увеличение микротвердости покрытий никель-графит по сравнению с обычными покрытиями.

\section{Методология исследований}

Осаждение КЭП проводили в сульфатно-хлоридном электролите Уоттса следующего состава:

- $\mathrm{NiSO}_{4}-180$ г/л;

$-\mathrm{N}_{\mathrm{i}} \mathrm{Cl}_{2}-20 \mathrm{r} / \mathrm{s}$

$-\mathrm{H}_{3} \mathrm{BO}_{3}-30$ г/л.

В качестве дисперсной фразы использовали мелкодисперсный порошок наноуглерода марки BG-34 (Китай), который вводился в электролит в количестве 0,5 г/л.

Покрытие осаждалось на медную подложку. Катод перед применением подвергался механической обработке мелкозернистой наждачной бумагой, после чего поверхность катода обезжиривали и травили. Для корректного сопоставления результатов, нами были получены осадки чистого никеля в электролитах без и с перемешиванием, а также КЭП при постоянном перемешивании электролита магнитной мешалкой. Время электролиза соответствовало получению осадка толщиной 25 мкм.

Поляризационные кривые получали на потенциостате ПИ-501.1 с помощью регистрирующего прибора.

Фракционный состав порошка модифицированного наноуглерода определяли методом седиментации в гравитационном поле. Была получена кривая седиментации которая позволила с помощью метода касательных провести анализ дисперсионной системы. Дисперсионной средой, в ходе эксперимента, выступала дистиллированная вода.

\section{Результаты и их обсуждение}

Известно [2], чем меньше размер частиц и чем больше искажена кристаллическая решетка частиц, тем легче они захватываются неровностями поверхности металла. Приобретая 
положительный заряд, дисперсные частицы быстрее продвигаются к катоду и легче встраиваются в покрытие. Введение их в электролит может существенно влиять на кинетику осаждения металла. Полученные нами в диапазоне температур $40-60{ }^{\circ} \mathrm{C}$ вольтамперные характеристики процесса осаждения КЭП приведены на рисунках 1 - 3. Увеличение температуры приводит к смещению потенциала в более электроположительную сторону. Существенного отличия в ходе кривых не обнаружено.

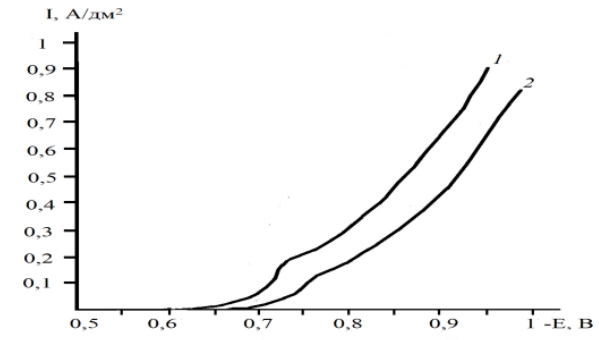

Рисунок 1. Вольт-амперные зависимости процесса осаждения чистого никеля без перемешивания: 1 - $T=333 \mathrm{~K} ; 2$ - T = 313 K

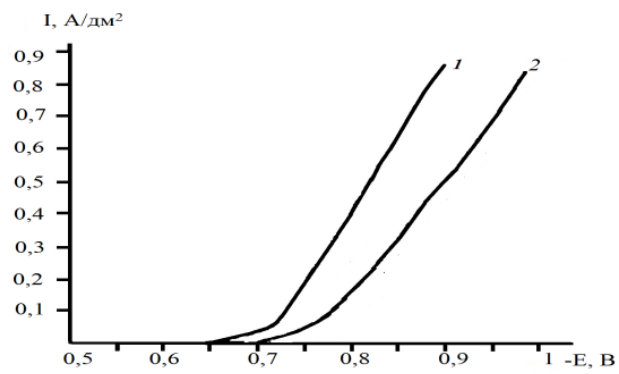

Рисунок 2. Вольт-амперные зависимости процесса осаждения чистого никеля с перемешиванием: $1-T=333 \mathrm{~K} ; 2$ - $T=313 \mathrm{~K}$

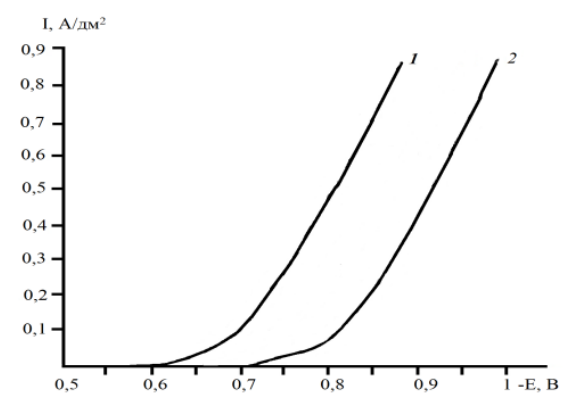

Рисунок 3. Вольт-амперные зависимости процесса осаждения КЭП на основе никеля: 1 - $T=333 \mathrm{~K} ; 2-T=313 \mathrm{~K}$

Результаты седиментационного анализа приведены ниже:

\begin{tabular}{|c|c|}
\hline Радиус частиц, $\mathbf{1 0}^{\mathbf{7}} \mathbf{~}$ & Процентное содержание частиц, \% \\
\hline $2,3-2,5$ & 14 \\
\hline $2,5-2,7$ & 24 \\
\hline $2,7-3,0$ & 21 \\
\hline $3,0-3,8$ & 18 \\
\hline $3,8-4,7$ & 13 \\
\hline $4,7-6,6$ & 10 \\
\hline
\end{tabular}


КЭП, полученные при плотности тока 2 A/дм ${ }^{2}$ и комнатной температуре имели ярко выраженную дендритообразную неравномерную структуру темного серого цвета. Повышение рабочей температуры до $50^{\circ} \mathrm{C}$ не дало существенного улучшения морфологии поверхности. Снижение рабочей плотности тока до 1 $\mathrm{A} /$ дм $^{2}$ позволило получить качественные покрытия без дендритов, серого цвета. Поверхность выглядит более плотной с незначительной шероховатостью.

Содержание углерода в электролите определялось исходя из удобства соизмерения результатов, с полученными для других графитов и приведенных, например, в [1]. Однако нами было установлено, что осадки, полученные при содержании графита меньше 0,5 г/л являются более однородными и качественными. Дальнейшие испытания направлены на определение оптимального количества графита с точки зрения морфологии поверхности и фрункциональных свойств КЭП.

\section{Выводы}

1. Введение дисперсной фразы в электролит никелировния не приводит к существенному изменению фрормы поляризационных кривых. Повышение температуры от 30 до $80^{\circ} \mathrm{C}$ приводит к смещению потенциала в более электроположительную область.

2. Средний размер (радиус) частиц углерода в полидисперсной системе колеблется в пределах $(2,5 \div 3,0) \cdot 10^{-7} \mathrm{M}$.

3. В случае модифицированного наноуглерода марки BG-34, при плотности тока $1 \mathrm{~A} /$ дм $^{2}$ получены качественные плотные осадки. Повышение плотности тока до 2A/дм² при содержании углерода 0,5 г/л приводит к ухудшению морфологии поверхности и образованию неравномерных дендритообразных осадков.

\section{Литература}

[1] Полищук Ю.В., Нефедов В.Г., Бутова Е.А., Васильева Е.А., Баскевич А.С., Захаров В.Д., Ваганов В.Е. // Вопросы химии и химической технологии. - 2013. - №4. - С. 172-174.

[2] Иванов В.В., Балакай В.И., Щербаков И.Н., Арзуманова А.В., Старунов А.В., Мурзенко К.В. // Успехи современного естествознания. - 2015. - №1. - С. 1335-1338. 


\title{
Part 3
}

\section{CORROSION PROTECTION}

\author{
Розділ 3
}

\section{ЗАХИСТ МЕТАЛІВ ВІД КОРОЗІЇ}




\title{
CORROSION-ELECTROCHEMICAL PROPERTIES OF COBALT- MOLYBDENUM-ZIRCONIUM DEPOSITS
}

\author{
KOZIAR M. A., SLAVKOVA M. A., SAKHNENKO N. D., VED' M. V. \\ National Technical University "Kharkiv Polytechnic Institute" \\ koziar.maryna@gmail.com
}

Galvanic alloy coatings of cobalt-molybdenum and cobalt-molybdenumzirconium were deposited on substrates steel 3 from a poly-ligand citrate-pyrophosphate bath at a temperature of $25-30^{\circ} \mathrm{C}$. The acidity of the electrolyte was maintained in the range $\mathrm{pH} 8-9$. The coatings were deposited using a pulsed electrolysis with current amplitude 2$20{\mathrm{~A} \times \mathrm{dm}^{-2}}^{-2}$ in the frequency range of $19-910 \mathrm{~Hz}$, pulse time $2 \times 10^{-3}-2 \times 10^{-1} \mathrm{sec}$, pause durability $2 \times 10^{-2}-2 \times 10^{-1} \mathrm{sec}$; duty cycle was $2-20$. The electrolysis parameters influence on cobalt-molybdenumzirconium alloy deposition peculiarities, composition and surface morphology has been revealed. The elevating in current density leads to a decrease in the zirconium content and cracking of deposits due to the growth of internal stresses. The effect of cobalt-molybdenum-zirconium alloys composition and topography on their corrosion resistance in acid, neutral and chloride-containing media was investigated. It was established the cobalt-molybdenum-zirconium functional alloys have a high chemical resistance in aggressive media due to the both molybdenum and zirconium trend to passivity especially for local corrosion.

In our time, the rapid development of new trends in energetics, microelectronics, creating compact equipments and appliances is impossible without using of new materials with a wide range of functional properties. One way their creating is forming of thin layers of electrolytic coatings with high corrosion resistance, hardness, heat resistance and catalytic activity on the surface of traditional structural materials [1, 2].

For expansion possibilities use of electrolytic coating alloys with two or more components are used in addition to pure metal. In recent years becomes relevant research cobalt alloys with refractory metals (molybdenum, tungsten) [3-5].This choice is primarily due to their high acceptor capacity, their ability to passivity and create multivalent oxides that causes their functional properties. Considering the growing interest in coatings with high resistance to local types of corrosion, which is provided by alloying components, special attention was paid to the alloy Co-Mo-Zr. It's known that zirconium can't be deposited from aqueous 
solutions because it have negative standard potential $-1,21 \mathrm{~V}$. However, as shown in [6], we obtained electrolytic deposits Co-Mo from polyligand electrolyte, which contain up to $4 \mathrm{wt}$. \% zirconium.

The goal of this study is to investigate the composition, morphology, and composition of the electrolytic cobalt-molybdenum-zirconium alloy coatings and to determine of their corrosion resistance in various aggressive environments.

\section{Research Methodology}

The coatings were deposited on substrates of steel 3, surface pretreatment of which was performed by standard technique.

Coatings Co-Mo- $\mathrm{Zr}$ were deposited from a poly-ligand citratepyrophosphate bath at a temperature of $25-30^{\circ} \mathrm{C}$. The acidity of the electrolyte was maintained in the range $\mathrm{pH}$ 8-9. Electrolyte was prepared of the certified reactive "pure grade" mark on the distilled water.

The coatings were obtained in unipolar pulse current with amplitude 2-20 Axdm ${ }^{-2}$ in the frequency $f$ range of $19-910 \mathrm{~Hz}$, pulse time $t_{\text {on }}$ $2 \times 10^{-3}-2 \times 10^{-1} \mathrm{sec}$, pause durability $t_{\text {off }} 2 \times 10^{-2}-2 \times 10^{-1} \mathrm{sec}$; duty cycle was 2-20. As soluble anodes were used coplanar cobalt plates with anode to cathode area ratio as $5: 1$. Electrolysis mode $\left(t_{\mathrm{on}}, t_{\mathrm{off}}\right.$, current density) set by potentiostat PI-50-1.1 with programmer PR-8 [7].

The chemical composition of the coatings was examined with X-ray photoelectron spectroscopy using energy dispersive spectrometer INCA Energy 350 and with X-ray fluorescence method using a portable spectrometer "SPRUT", the absolute error of components did not exceed 1 wt.\%. The surface morphology was evaluated from the images obtained using a scanning electron microscope (SEM) ZEISS EVO 40XVP registering secondary electrons (BSE) during scanning the patterns by electron beam. Corrosion tests were carried out in model medium of different $\mathrm{pH}$ : $3 \%$ sodium chloride solution $(\mathrm{pH} 7)$ and $1 \mathrm{M}$ solution of sodium sulfate at $\mathrm{pH} 3$ and 11 . The corrosion rate of coatings was determined by polarization resistance technique analyzing cathodic and anodic polarization dependences in semilogarithmic coordinates [8].

\section{Results and Discussion}

Results of studies showed the possibility of deposition of ternary Co-Mo-Zr alloy using pulsed electrolysis, which can not be obtained in the direct current dc mode [6]. The composition and surface topography of coatings depend on the energy parameters of electrolysis that allowing to flexibly managing the quality and properties of materials.

Doping cobalt by molybdenum and zirconium promotes the formation of globular amorphous surface. The elevating in current density leads to cracking of deposits due to the growth of internal stresses (Fig. 1). 

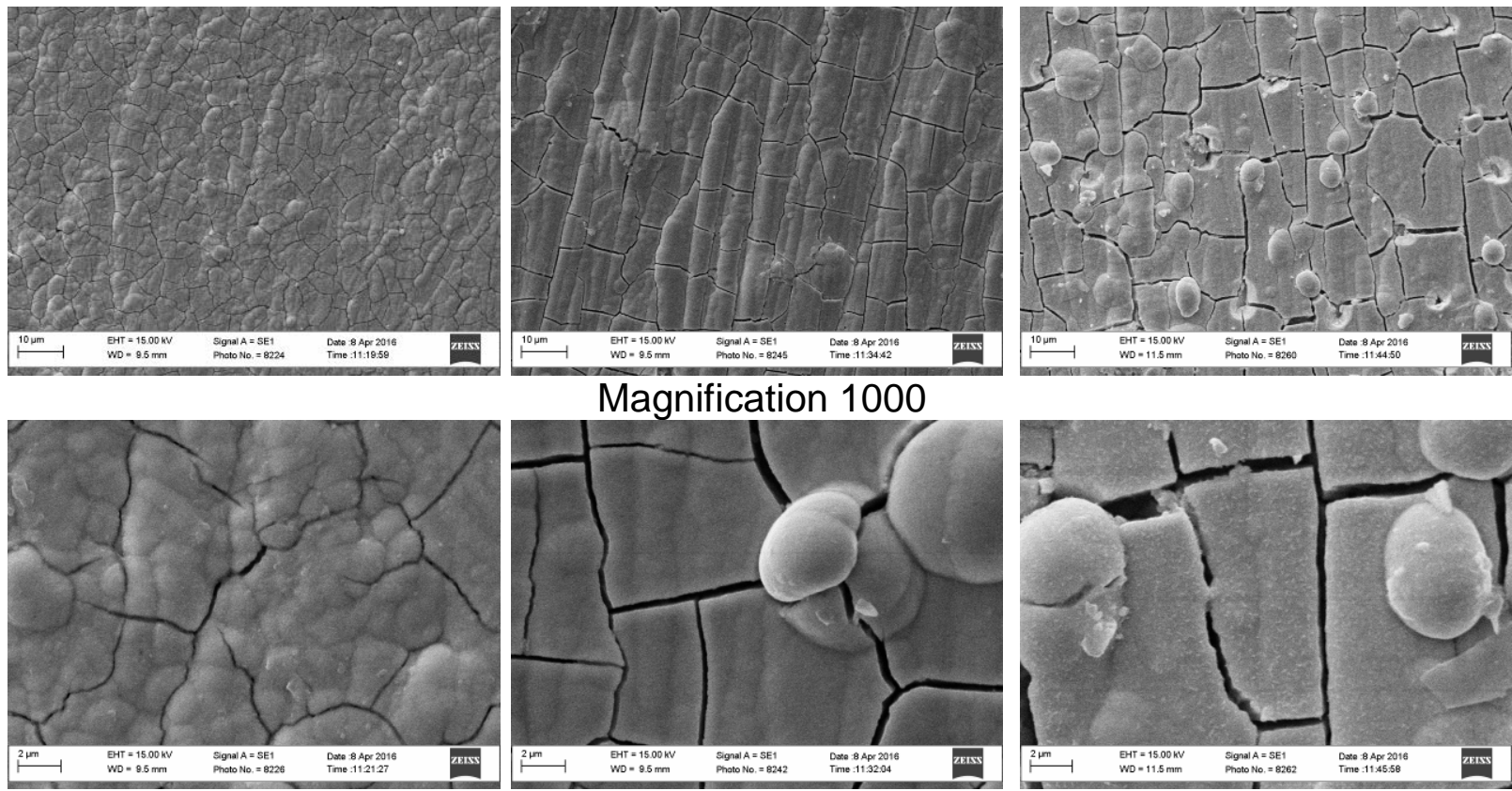

Magnification 1000
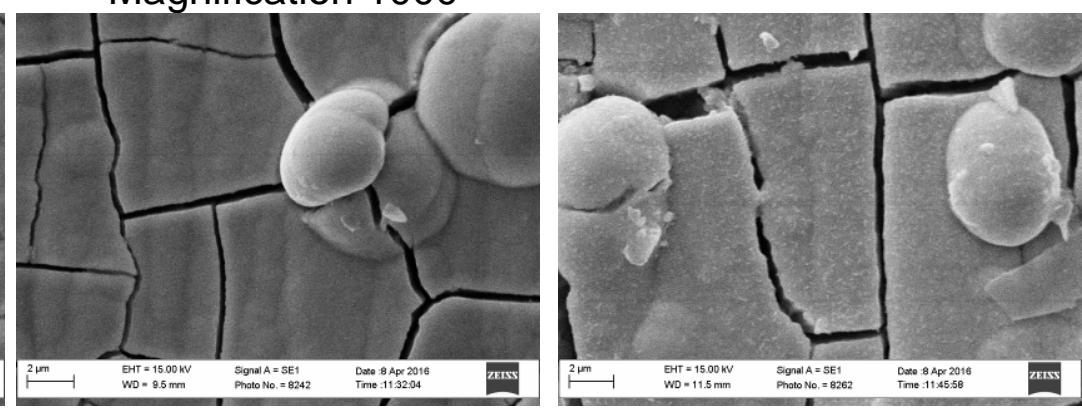
Co - 54,4; Mo - 29,1; Zr - 4,$2 ; 0-12,3$

$$
\text { Magnification } 1000
$$

$$
\begin{gathered}
\text { Co - 58,2; Mo - 29; } \\
\text { Zr - 3,4; O - 9,4 }
\end{gathered}
$$

$$
\begin{gathered}
\text { Co - 57; Mo - 28,8; } \\
\text { Zr - 2,5; O - 11,6 }
\end{gathered}
$$

a

$b$

$c$

Figure 1. Morphology and composition (wt. \%) of Co-Mo-Zr coatings deposited in pulse mode at current density, $A \cdot d m^{-2}: 4$ (a); 6 (b) and 8 (c); $t_{\text {on }} / t_{\text {off }}=2 / 10 \mathrm{msec} ; T=$ 20-25 ${ }^{\circ} \mathrm{C}$; $\mathrm{pH}$ 8; plated time $30 \mathrm{~min}$.

Composition analysis of ternary coatings revealed that content of zirconium decreases with an increase in current density. Also they contain some oxygen. This can be explained by including not completely recovered molybdenum oxides and partially hydrolyzed oxo- zirconate ions in the surface layers. It should be noted that with rising current density grid of cracks on the surface of precipitates becomes denser and branched due to increased internal stresses in the coating.

The doping of cobalt by molybdenum as it was shown in [8] leads to increased resistance to local types of corrosion - pitting and intergranular. In this study the corrosion resistance of ternary electrodeposited alloys was compared with corrosion resistance of binary Co-Mo systems [8]. The shift of the corrosion potential of coated samples in $\mathrm{NaCl}$ solution up to the negative region as compared to the same parameter in acidic solution as well as the character of anodic polarization dependences (Fig. 2, 3) testifies the cathodic control of corrosion process. The rise in corrosion potential simultaneously with the appearance of a plateau on the anode branches of voltammograms (Fig. 3) in alkali solution indicates an anode control of corrosion process, which can be explained by trend to passivity of the surface due to the formation of the oxide film [9]. 


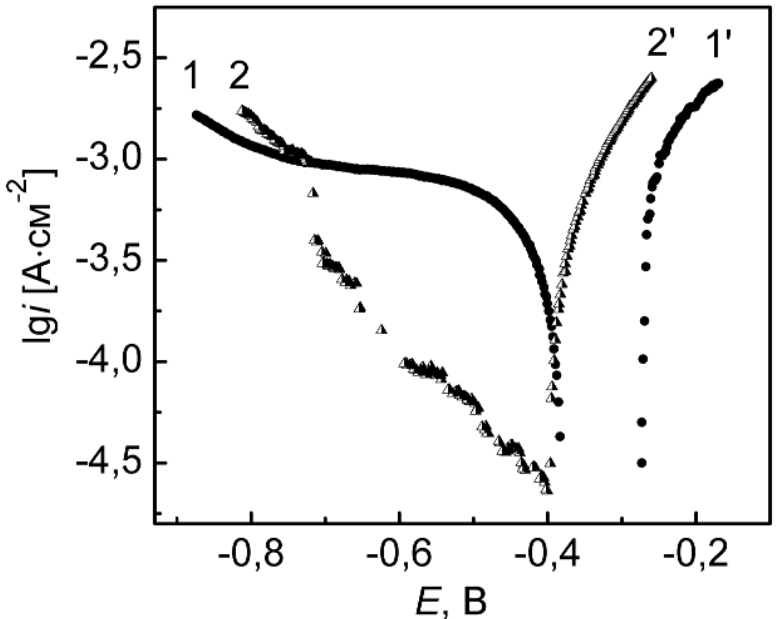

Figure 2. Corrosion diagrams for coatings Co-Mo (1) and

Co-Mo-Zr (2) in $1 \mathrm{M} \mathrm{Na}_{2} \mathrm{SO}_{4} \mathrm{pH} 3$ : cathodic plots $(1,2)$; anodic plots $(1,2)$

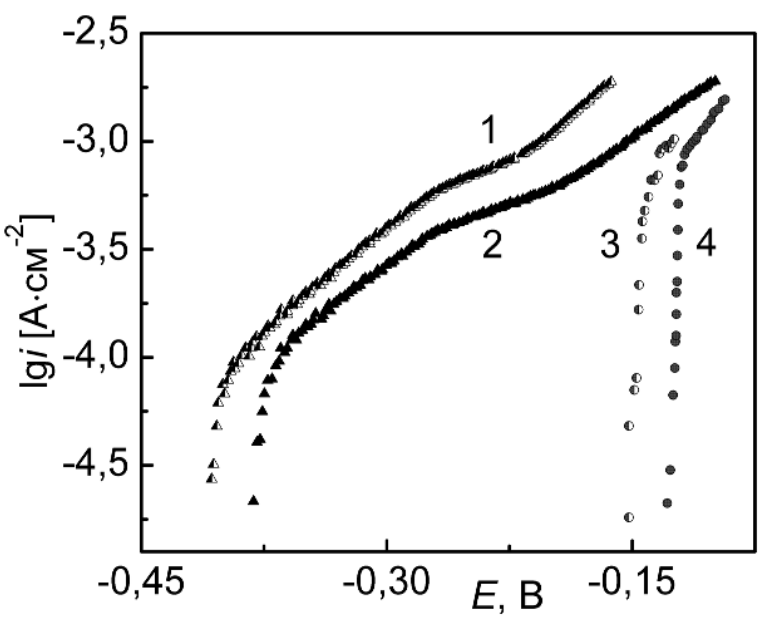

Figure 3. Anodic polarization dependences for coatings

Co-Mo-Zr (1, 2) and Co-Mo $(3,4)$ in solutions: $1 \mathrm{M} \mathrm{Na}_{2} \mathrm{SO}_{4}$ with $\mathrm{pH}$ 11(1, 3); 3 $\% \mathrm{NaCl} p \mathrm{H} 7(2,4)$

Corrosion resistance of ternary alloys with zirconium content of 3$4 \mathrm{wt} . \%$ and molybdenum up to 25-30 wt. \% proceeding from corrosion depth index in acid $\left(k_{\mathrm{h}}=3,1 \cdot 10^{-4} \mathrm{~mm} /\right.$ year $)$ and neutral chloridecontaining media $\left(k_{\mathrm{h}}=2,2 \cdot 10^{-4} \mathrm{~mm} /\right.$ year) increases practically an order of magnitude compared with a binary ones $\left(k_{\mathrm{h}}=2,3 \cdot 10^{-3} \mathrm{~mm} / \mathrm{year}\right.$, $k_{\mathrm{h}}=2,9 \cdot 10^{-3} \mathrm{~mm} /$ year respectively). Corrosion resistance in an alkaline medium in increases by three times $-k_{h}(\mathrm{Co}-\mathrm{Mo}-\mathrm{Zr})=3,1 \cdot 10^{-4} \mathrm{~mm} / \mathrm{year}$, $k_{\mathrm{h}}(\mathrm{Co}-\mathrm{Mo})=9,3 \cdot 10^{-4} \mathrm{~mm} /$ year.

Binary coatings with a molybdenum content not less than 10 at. \% and ternary zirconium containing galvanic alloys belong to the group "very resistant" by the depth of corrosion index.

\section{Conclusions}

1. The surface Co-Mo-Zr electrodeposits obtained from polyligand citrate-pyrophosphate electrolyte is uniform, bright, brilliant, but is covered by a grid of cracks. It was found that an increase in current density leads to an increase of internal stresses in the coating. Thus, it is advisable process to conduct the electrodeposition at lower current densities $\left(4-6 \mathrm{~A} \times \mathrm{dm}^{-2}\right)$.

2. Chemical stability of the electrolytic ternary coatings causes by increase tendency to passivity and resistance to pitting corrosion in the presence of molybdenum and zirconium. Ternary coatings by the corrosion depth index belong to the group "very resistant", and can be recommended as safety when working in aggressive media. 


\section{References}

[1] Mousavi R., Bahrololoom M.E., Deflorian F., Ecco L. Improvement of corrosion resistance of Ni-Mo alloy coatings: Effect of heat treatment. Appl. Surf. Sci. 2016. - V.364. - P. 9-14.

[2] Tsyntsaru N., Dikusar A., Cesiulis H. et al., Tribological and corrosive characteristics of electrochemical coatings based on cobalt and iron superalloys. Powder Metall. Met. Ceram. 2009. - 48. - P. 419-428.

[3] Gomez E, Kipervaser Z., Pellicer E., Vales E. Extracting deposition parameters for cobalt-molybdenum alloy from potentiostatic current transients. Phys. Chem. 2004. - V. 6. - P. 1340-1344.

[4] Gomez E., Pellicer E., Valles E. Intermediate molybdenum oxides involved in binary and ternary induced electrodeposition. Journal of Electroanalytical Chemistry. - 2005. - V. 580, № 2. - P. 238-244.

[5] Ведь М. В. Каталітичні та захисні покриття сплавами і складними оксидами: електрохімічний синтез, прогнозування властивостей: монографрія / М. В. Ведь, М. Д. Сахненко. - Харків: НТУ «ХП|», 2010. - 272 c.

[6] Ved M.V., Sakhnenko N.D., Glushkova M.A., Kozyar M.A. Electrodeposition of catalytic ternary cobalt based coatings // Вопросы химии и химической технологи. - 2015. - № 5. - С. 4 - 11.

[7] Ведь М.В. Влияние режимов электролиза на состав и морфологию тернарных сплавов Со-Мo-W(Zr, Ag) / М. В. Ведь, Н. Д. Сахненко, М. А. Глушкова , Ю. К. Гапон, М. А. Козяр // Вопросы химии и хим. технологии. - Днепропетровск: УГХТУ. - 2013. - № 4. C.140-143.

[8] Glushkova M. Electrodeposited Cobalt Alloys as Materials for Energy Technology / M. Glushkova, T. Bairachna, M. Ved, M. Sakhnenko / MRS Proceedings, 2013, 1491, mrsf12-1491-c08-15 doi:10.1557/opl.2012.1672.

[9] Ved M. Corrosion and catalytic properties of galvanic binary d6-8 metal alloys / M. Ved, M. Sakhnenko, T. Nenastina et al // Phys. Chem. Mech. Mater. - 2008. - no 7. - P. 346-353. 
УДК 629.1

\title{
CORROSION RESISTANCE COMPARISON OF CONVERSION COATINGS IN SALT FOG CHAMBER
}

\author{
AKULICH N.E. ${ }^{\text {a) }}$, CHERNIK A.A. ${ }^{\text {a) }}$, LOS A.I. ${ }^{\text {b) }}$ \\ a) Belarusian State Technological University \\ ${ }^{b)}$ Minsk Traktor Works \\ akulitch.nadejda@yandex.ru
}

There are a lot different chemical and electrochemical processes which allow to protect items from corrosion: phosphate and oxidation of the surface, application of galvanic and paint coatings. Corrosion resistance of conversion coatings on carbon steel in the salt fog chamber has been investigated. Comparison of the basic methods of corrosion treatment of parts Gardorol 8010 impregnation has been done. It has been found that phosphating and additional treatment with the Gardorol 8010 protecting agent 8010 as well as anodization with oiling provide temporary corrosion protection of carbon steel items during interdepartmental transportation and short-time storage.

\section{СРАВНЕНИЕ КОРРОЗИОННОЙ СТОЙКОСТИ КОНВЕРСИОННЫХ ПОКРЫТИЙ В КАМЕРЕ СОЛЕВОГО ТУМАНА}

\author{
АКУЛИЧ Н.Е. ${ }^{\text {a) }}$, ЧЕРНИК А.А. ${ }^{\text {a) }}$, ЛОСЬ А. И. ${ }^{\text {() }}$ \\ а) Белорусский государственный технологический университет

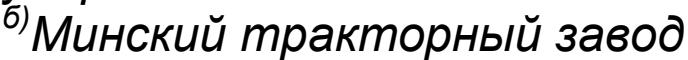 \\ akulitch.nadejda@yandex.ru
}

Существуют различного рода химические и электрохимические процессы, которые позволяют защитить деталь от коррозии: фоссратирование и оксидирование поверхности, нанесение гальванических и лакокрасочных покрытий. В камере солевого тумана оценена коррозионная стойкость конверсионных покрытий на углеродистой стали. Приведено сравнение базовых методов антикоррозионной обработки деталей с пропиткой Gardorol 8010. Установлено, что фоссратирование и дополнительная обработка в пропитке Gardorol 8010, а также оксидирование с промасливанием обеспечивают временную защиту деталей из углеродистой стали от коррозии при межцеховой транспортировке и кратковременном хранении. 
Экономический и экологический ущерб, наносимый коррозией металлических изделий, оборудования и конструкций, неисчислим. В последние годы, например, только в США ежегодные потери от коррозии составили 300 миллиардов долларов.

В Российской Федерации ежегодные потери металлов из-за их коррозии составляют до $12 \%$ общей массы металлофонда, что соответствует утрате до $30 \%$ ежегодно производимого металла. Кроме столь огромных связанных с коррозией прямых потерь, существуют еще большие косвенные потери. К ним относятся расходы, обусловленные потерей мощности металлического оборудования, его вынужденными простоями из-за аварий, а также расходы на ликвидацию последствий аварий, часто носящих характер экологических катастроф [1].

Суммарно в большинстве стран потери от коррозии составляют 4-6 \% национального дохода.

Таким образом защита металлов от коррозии является крайне актуальной задачей. Для этого могут применять различного рода химические и электрохимические процессы: фросфратирование и оксидирование поверхности, нанесение гальванических и лакокрасочных покрытий. Также возможно применение различных средств, уменьшающих или прекращающих коррозию металла [2].

В данной работе оценена коррозионная стойкость конверсионных покрытий на углеродистой стали полученных различными способами.

\section{Методология исследований}

В машиностроении защите от коррозии подвергаются не только конечные изделия, но и сборочные единицы, предназначенные для сборки и передаваемые из цеха в цех. В этом случае детали подвергают временной защите. В данной работе в качестве объектов исследования рассматривались детали сборочной единицы ходовой части автотракторной техники - опорная шайба сателлита. Данная деталь в готовом изделии эксплуатируется в масле. В качестве временной защиты использовали различные виды обработки (табл. 1).

Фосфратирование деталей проводили в растворе, приготовленном из состава фосфатирующего ЛФК-1, (производитель РБ) 95-100 г/дм³ . Общая кислотность раствора - 40-60 точек. Свободная кислотность раствора - 3-8 точек. Соотношение общей кислотности к свободной - 1:8-1:12. Температура раствора 50$60^{\circ} \mathrm{C}$, время обработки 30-40 мин.

Оксидирование деталей проводили в растворе содержащем натр едкий технический марки TP $(\mathrm{NaOH})$ в количестве 500- 
700 г/дм ${ }^{3}$. Температура раствора $135-145^{\circ} \mathrm{C}$, время обработки $15-$ 30 мин. Также для серии деталей было выполнено промасливание по технологии МТЗ ТеР21Ц - в индустриальном масле ИД20-А при температуре масла $60-100^{\circ} \mathrm{C}$ в течение 1-3 мин.

Термообработка - нитроцементация, проводили в печах для придания твёрдости 75-80 HRA при температуре $800-850^{\circ} \mathrm{C}$. Длительность процесса от 1 до 6 часов.

Gardorol 8010 является торговой маркой средств защиты от коррозии фрирмы Chemetall (Германия). Эта пропитка может быть применена к фоссратированным или не обработанным деталям. Однако эта технология обеспечивает лишь временную защиту от коррозии. Время обработки в пропитке Gardorol 8010 составляло 10 мин.

Для простоты восприятия условия получения конверсионных покрытий сведены в таблицу 1.

Таблица 1. Условия получения конверсионных покрытий на углеродистой стали

\begin{tabular}{|c|c|}
\hline № образца & Условия получения конверсионного покрытия \\
\hline 1 & Фосфатирование \\
\hline 2 & $\begin{array}{c}\text { Фосфатирование, пропитка Gardorol } 8010 . \\
\text { Сушка атмосфрерная }\end{array}$ \\
\hline 3 & $\begin{array}{l}\text { Фосфратирование, пропитка Gardorol } 8010 . \\
\text { Сушка после пропитки } \mathrm{T}=80-100^{\circ} \mathrm{C} \text {, время } 10 \text { мин }\end{array}$ \\
\hline 4 & $\begin{array}{c}\text { Фосфратирование, обработка в масле ИД20-А. } \\
\text { Сушка атмосфрерная }\end{array}$ \\
\hline 5 & Оксидирование \\
\hline 6 & $\begin{array}{c}\text { Оксидирование, пропитка Gardorol } 8010 . \\
\text { Сушка атмосфрерная }\end{array}$ \\
\hline 7 & $\begin{array}{l}\text { Оксидирование, пропитка Gardorol } 8010 \text {. } \\
\text { Сушка после пропитки } \mathrm{T}=80-100^{\circ} \mathrm{C} \text {, время } 10 \text { мин }\end{array}$ \\
\hline 8 & $\begin{array}{c}\text { Оксидирование с промасливанием по технологии МТЗ } \\
\text { ТеР21Ц }\end{array}$ \\
\hline 9 & Термообработка \\
\hline 10 & $\begin{array}{c}\text { Термообработка, обработка в масле ИД20-А. } \\
\text { Сушка } 90-100^{\circ} \mathrm{C}\end{array}$ \\
\hline 11 & $\begin{array}{c}\text { Пропитанная в масле ИД20-А. } \\
\text { Сушка после пропитки } \mathrm{T}=80-100^{\circ} \mathrm{C} \text {, время } 10 \text { мин }\end{array}$ \\
\hline
\end{tabular}

Ресурсные испытания конверсионных покрытий с определением площади поражения красной коррозией стали проводили в камере солевого тумана ASCOTT S120iS с использованием $5 \%$ раствора $\mathrm{NaCl}$. Площадь поражения образцов оценивали визуально. 


\section{Результаты и их обсуждение}

Внешний вид покрытий не зависит от условий получения конверсионного покрытия или другой обработки и представлен на рисунке 1. По истечении 6 часов в камере солевого тумана наблюдались явные следы красной коррозии на образцах $1,4,5,7$, 10, 11. На образцах 2 и 3 нет изменений. В порядке увеличения площади пора-жения поверхности образцов по истечении 6 часов образцы распо-лагаются в след ряду: 2, 3, 8, 6, 1 (6 и 1 наравне), 5, $11,4,9,10,7$.

Спустя 10 часов в камере солевого тумана образцы 4-7, 9-10 практически полностью покрыты продуктами коррозии стали (рис. 1).

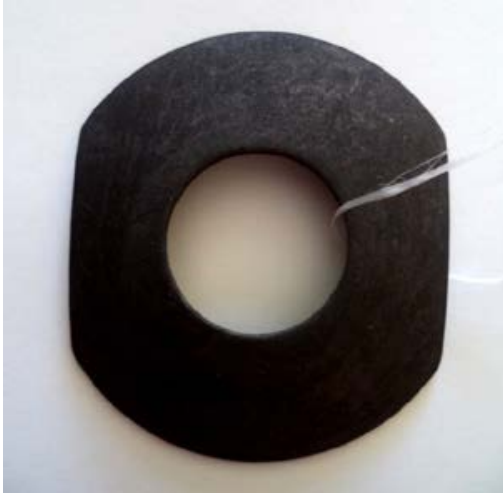

a)

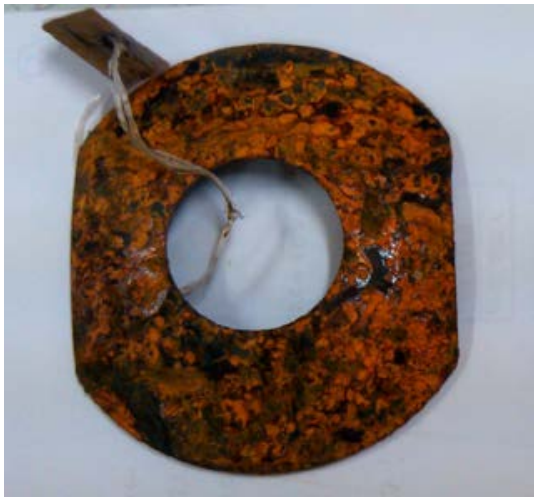

б)

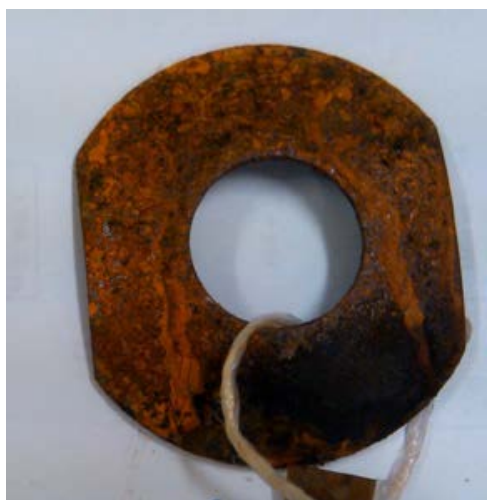

в)

Puс. 1 Внешний вид покрытий до ресурсных испытаний (а) и после 10 часов испытаний: б - 5 образец; в- 4 образец.

Площадь поражения, выраженную в процентах по истечении определенного времени нахождения в камере солевого тумана от условий обработки поверхности детали приведены в таблице 2.

Таблица 2. Зависимость площади поражения от условий обработки поверхности детали и времени коррозионного воздействия

\begin{tabular}{|c|c|c|c|c|c|c|c|}
\hline \multirow{2}{*}{$\begin{array}{c}\text { № } \\
\text { образца }\end{array}$} & \multicolumn{6}{|c|}{ Площадь поражения, \% по истечении времени т, ч } \\
\hline & 6 & 16 & 19,5 & 24,5 & 28,8 & 35,4 & 41,2 \\
\hline 1 & $5-7$ & $5-7$ & $7-10$ & $25-30$ & 30 & $35-38$ & $40-45$ \\
\hline 2 & 0 & $3-5$ & 15 & $35-40$ & $40-45$ & 60 & $60-65$ \\
\hline 3 & 0 & $2-3$ & $5-7$ & $30-35$ & $35-40$ & $43-45$ & $45-50$ \\
\hline 4 & 70 & 80 & - & - & - & - & - \\
\hline 5 & 60 & 80 & - & - & - & - & - \\
\hline 6 & $5-7$ & $35-40$ & - & - & - & - & - \\
\hline 7 & $70-75$ & $85-90$ & - & - & - & - & - \\
\hline 8 & $1-5$ & $5-7$ & 30 & $45-50$ & $50-53$ & $55-60$ & 70 \\
\hline 9 & $70-75$ & $80-85$ & - & - & - & - & - \\
\hline 10 & $70-75$ & 95 & - & - & - & - & - \\
\hline 11 & 65 & $80-85$ & - & - & - & - & - \\
\hline
\end{tabular}




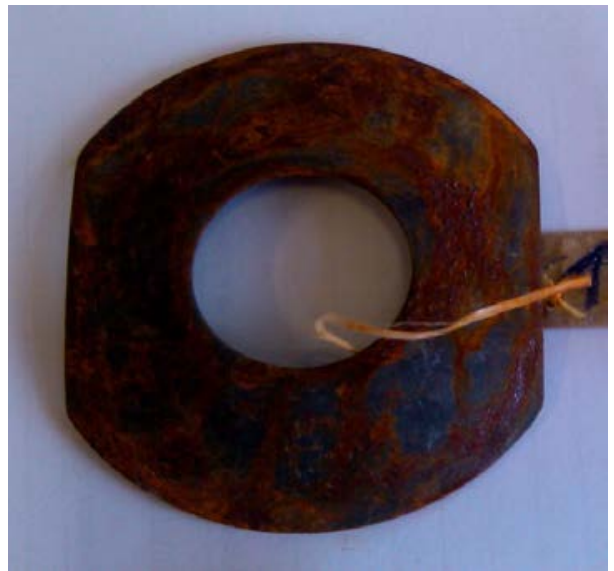

a)

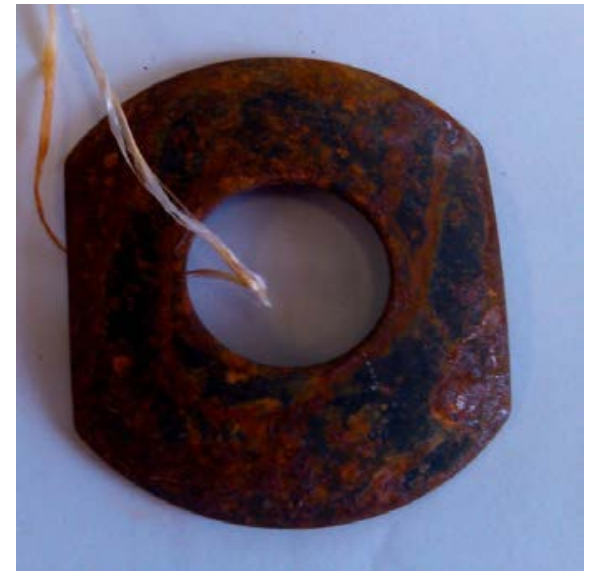

б)

Puс. 3 Внешний вид покрытий после 10 часов испытаний: а - 2 образец; б - 8 образец.

Как видно из экспериментальных исследований через 41 час нахождения в камере солевого тумана площадь поражения коррозией 8 образца составила 70\%; 2 образца - 60-65\%. Образцы 1 и 3 имеют площадь поражения до $50 \%$.

\section{Выводы}

Сравнение коррозионной стойкости полученных конверсионных покрытий в камере солевого тумана показало, что фоосфатирование является наиболее целесообразным методом антикоррозионной обработки деталей для обеспечения временной защиты от коррозии.

Детали из углеродистой стали К270B5 фосфратированные и дополнительно обработанные в пропитке Gardorol 8010 спустя 41 час нахождения в камере солевого тумана имеют площади поражения $40 \%$ и 60\% соответственно. Показано, что применение сушки после пропитки Gardorol 8010 при T=80-100 ${ }^{\circ} \mathrm{C}$ снижает площадь поражения коррозией на 15\%, чем использование атмосферной сушки.

Установлено, что детали из углеродистой стали фоссратированные и дополнительно обработанные в пропитке Gardorol 8010, а также оксидированные с промасливанием по технологии МТЗ ТеР21Ц обеспечивают временную защиту от коррозии.

\section{Литература}

[1] Семенова И.В., Флорианович Г.М., Хорошилов А.В., Коррозия и защита от коррозии, М.: ФИЗМАТЛИТ, 2002.

[2] Жарский И.М., Иванова Н.П., Куис Д.В., Коррозия и защита металлических конструкций и оборудования, Минск : Выш. шк., 2012. 
УДК 620.193.26+544.636

\title{
CORROSION PROTECTION OF AMC ALLOY IN ALKALINE MEDIUMS BY SODIUM ORTHOVANADATE
}

\author{
KHARITONOV D.S., KURILO I.I., ZHARSKY I.M. \\ Belarusian State Technological University, Minsk, Belarus \\ kharitonov@belstu.by
}

Corrosion behavior of the AMC (AA3003) alloy in $0,05 \mathrm{M} \mathrm{NaCl}$ solutions ( $\mathrm{pH} 10)$ with $0,003 \mathrm{M}$ sodium orthovanadate addition has been studied by electrochemical impedance spectroscopy (EIS). It has been found that corrosion of the AMC alloy exposed in $0,05 \mathrm{M} \mathrm{NaCl}$ solutions for 1 and 24 hours is controlled by the charge transfer stage and for 8 hours exposure is controlled by oxygen diffusion process. In alkaline solutions, containing $\mathrm{Na}_{3} \mathrm{VO}_{4}$, the corrosion process is kinetically limited. Increasing the sample's exposure time in vanadium-containing solutions from 1 to 24 hours leads to formation of protective films on their surface and increases total surface resistance by a factor of 4,3 .

\section{АНТИКОРРОЗИОННАЯ ЗАЩИТА СПЛАВА АМЦ В ЩЕЛОЧНЫХ СРЕДАХ ОРТОВАНАДАТОМ НАТРИЯ}

\author{
ХАРИТОНОВ Д.С., КУРИЛО И.И., ЖАРСКИЙ И.М. \\ Белорусский государственный технологический университет, \\ Минск, Беларусь; kharitonov@belstu.by
}

Методом электрохимической импедансной спектроскопии изучено коррозионное поведение сплава АМЦ в 0,05 М растворе хлорида натрия ( $\mathrm{pH} 10)$, содержащем 0,003 моль/дм ${ }^{3}$ ортованадата натрия. Показано, что процесс коррозии образцов сплава АМЦ, выдержанных в $0,05 \mathrm{M} \mathrm{NaCl}$ лимитируется стадией переноса заряда, а в щелочных растворах, содержащих ортованадат натрия коррозия сплава АМЦ протекает в кинетической области. Установлено, что увеличение продолжительности выдержки образцов в ванадийсодержащих растворах хлорида натрия от 1 до 24 ч приводит к формированию на их поверхности защитных пленок и увеличению общего сопротивления поверхности сплава в 4,3 раза.

Сплавы алюминия широко применяются в промышленности благодаря их относительно высоким эксплуатационным характеристикам и коррозионной устойчивости, тепло- и 
электропроводности, малому удельному весу, привлекательному внешнему виду и возможности вторичной переработки.

Гетерогенная микроструктура сплавов алюминия обусловливает их подверженность локальным видам коррозии, основной причиной которой является формирование микрогальванических пар на границе раздела фраз алюминиевая матрица - интерметаллическая частица [1].

Долгое время для защиты сплавов алюминия от коррозии применялись ингибиторы на основе соединений хрома (VI) [1, 2]. Однако их высокая экологическая опасность и канцерогенные свойства привели к ужесточению норм их промышленного использования. Ингибиторы на основе соединений ванадия могут использоваться в качестве альтернативы хроматам. В литературе описано их применение для защиты от коррозии стали, цинка, некоторых сплавов алюминия и магния [2, 3].

Целью работы было изучение коррозионного поведения марганецсодержащего сплава алюминия марки АМЦ в щелочной хлорид-содержащей среде в присутствии ортованадата натрия.

\section{Методология исследований}

Объектом исследований в данной работе являлся сплав алюминия марки АМЦ (ААЗ003). Номинальный состав сплава по ГОСТ 4784-97, \%: Si - 0,60; Fe - 0,7; Cu - 0,05-0,20; Mn - 1,00-1,50; $\mathrm{Mg}$ - 0,20; Zn - 0,1; Ti - 0,10; Al - баланс.

Используемые в экспериментах образцы сплава АМЦ предварительно полировались с последовательным использованием наждачной бумаги \#250, \#500, \#800, \#1200.

В качестве коррозионной среды использовали 0,05 М раствор $\mathrm{NaCl}$ без добавки и с добавкой ортованадата натрия в количестве 0,003 моль/дм ${ }^{3}$, поддерживая $\mathrm{pH}$ равным десяти. Корректировку $\mathrm{pH}$ проводили 0,1 М растворами $\mathrm{NaOH}$ и $\mathrm{HNO}_{3}$ (х. ч.). Рабочая концентрация ортованадата натрия выбиралась исходя из экономической целесообразности и экологической безопасности его промышленного использования в качестве ингибитора коррозии.

Импедансные спектры снимали на потенциостате Solatron 1287A в комплекте с модулем анализа импеданса Solartron 1260A. Спектры импеданса записывали при значении бестокового потенциала через 1 , 8 и 24 ч после погружения образцов сплава АМЦ в исследуемые растворы. Диапазон частот измерения составлял $10^{5}-10^{-2}$ Гц, амплитуда колебаний - $10 \mathrm{MB}$, количество точек на декаду колебаний 7. Количество параллельных опытов - не менее трех.

Анализ спектров импедансной спектроскопии проводили с использованием программного обеспечения «ZView» и «Nova 1.11». 


\section{Результаты и их обсуждение}

Для определения ионных фрорм ванадия в исследуемых растворах с помощью ПО «Medusa» построена диаграмма Пурбе, которая представлена на рис. 1.

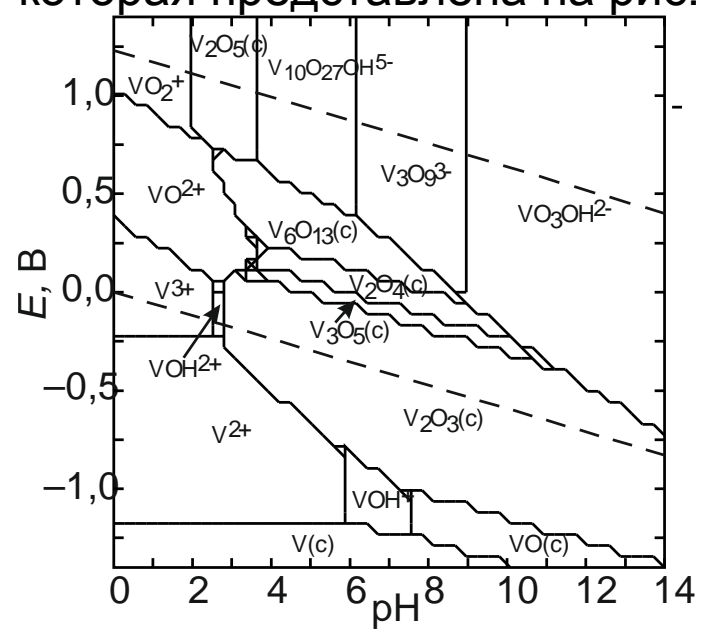

Рис. 1. Диаграмма Пурбе для соединений ванадия в растворе состава, моль/дм: $\mathrm{NaCl}-0,05$; $\mathrm{Na}_{3} \mathrm{VO}_{4}-0,003$

Начальное значение $\mathrm{pH}$ приготовленных растворов $\mathrm{NaCl}$ составляло 6,0-6,3. При введении в фоновый электролит 0,003 моль/дм ${ }^{3}$ ортованадата натрия значение $\mathrm{pH}$ увеличивалось до 11. Согласно диаграмме Пурбе в данном растворе преимущественными формами существования соединений ванадия(V) являются тетраэдрически координированные монованадат-ионы. Корректировка значения $\mathrm{pH}$ приготовленных ванадийсодержащих растворов до 10 согласно диаграмме не приводит к существенному изменению ионных форм ванадия в растворе (рис. 1).

Отсутствие окраски у содержащих ванадат-ионы растворов с рH 11, свидетельствует о существовании в растворе бесцветных соединений ванадия состава $\mathrm{VO}_{3} \mathrm{OH}^{2-}, \mathrm{V}_{2} \mathrm{O}_{7}{ }^{4-}$ и $\mathrm{VO}_{4}{ }^{3-}$ [3]. При постепенном снижении рН раствора до 10 введением 1 М раствора $\mathrm{HNO}_{3}$ наблюдается появление бледной желто-оранжевой окраски раствора, что можно объяснить значительным локальным подкислением раствора, сопровождающимся образованием устойчивых при низких значениях рН поливанадат-ионов различного строения [3]. Поскольку деполимеризация образовавшихся поливанадат-ионов протекает очень медленно, для установления в растворах химического равновесия после приготовления их выдерживали в течение 24 ч при температуре $20 \pm 1{ }^{\circ} \mathrm{C}$ до исчезновения окраски.

Результаты импедансной спектроскопии поверхности образцов сплава АМЦ после их выдерживания в исследуемых растворах с pH 10 представлены на рис. 2.

Анализ диаграмм Найквиста (рис. 2, а) показал, что для образцов сплава АМЦ, выдержанных в 0,05 M растворе $\mathrm{NaCl}$ в течение 1 ч, спектр импеданса имеет фрорму двух искаженных полуокружностей, 
что характерно для процессов с лимитирующей стадией переноса заряда. С увеличением времени выдержки образцов в растворе до 8 ч наблюдается увеличение доли активного растворения сплава (увеличение Рэндоловской части спектра) и появление прямого участка спектра под углом около $45^{\circ}$ к оси абсцисс, что свидетельствует о дифффузионном контроле процесса коррозии.

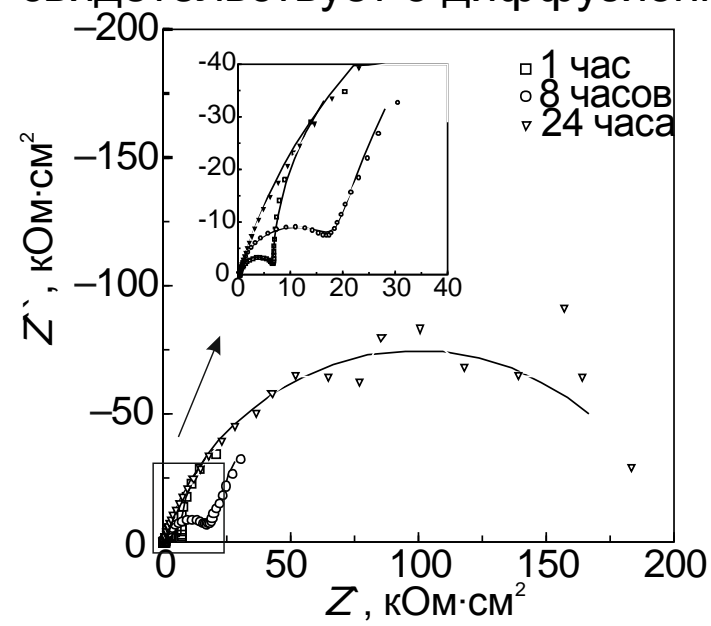

a

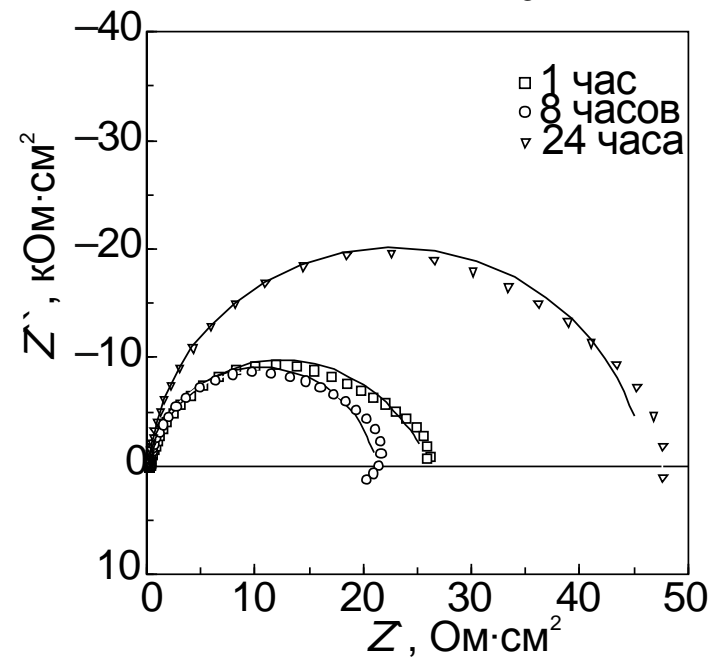

8
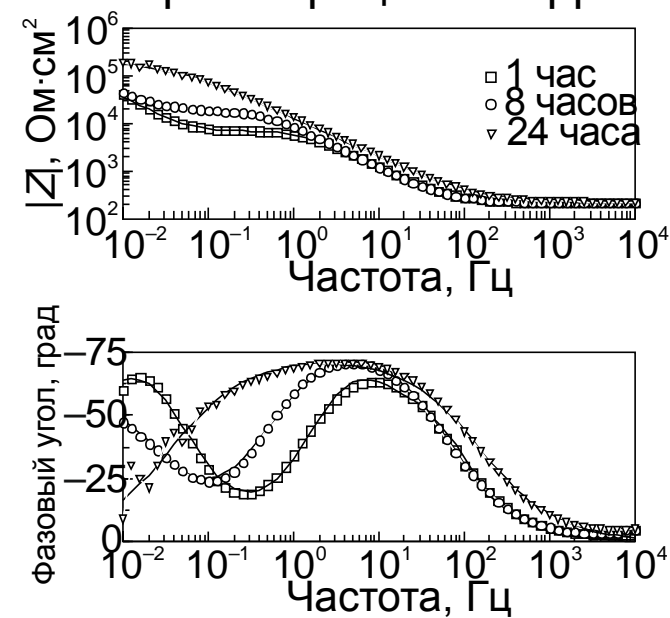

б
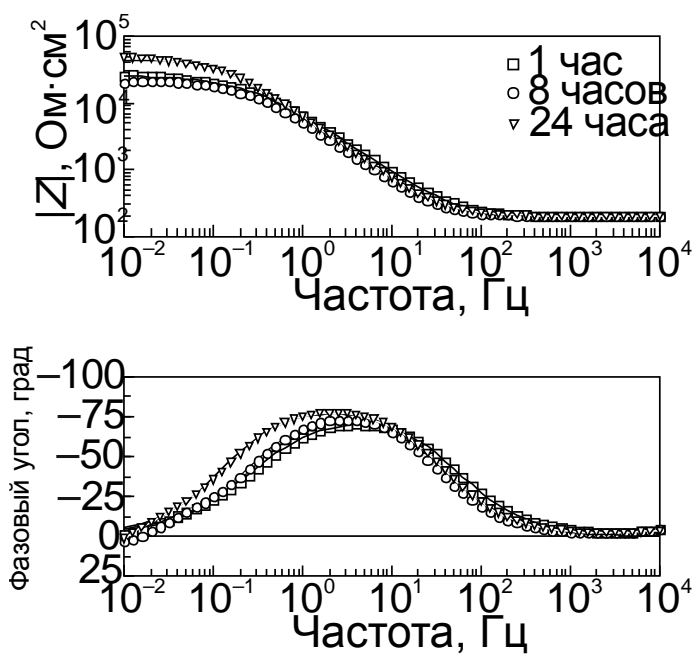

ट

Puc. 2. Результаты импедансной спектроскопии сплава АМЦ в виде диаграмм Найквиста $(a, s)$ и Боде $(\sigma, 2)$ после выдерживания в течение 1,8 и 24 ч в 0,05 M растворах $\mathrm{NaCl}$ без $\left(a\right.$, б) и с добавкой 0,003 моль/дм ${ }^{3} \mathrm{Na}_{3} \mathrm{VO}_{4}($ (в, г) при $\mathrm{pH} 10$

Наличие на спектрах импеданса одной временной константы после выдерживания образцов сплава АМЦ в исследуемом растворе в течение 24 ч, свидетельствует о протекании процесса коррозии в кинетической области и о формировании компактной защитной оксидно-гидроксидной пленки на поверхности сплава.

Анализ диаграмм Боде образцов сплава АМЦ, выдержанных в 0,05 M растворе $\mathrm{NaCl}$, показал (рис. 2, б), что при увеличении продолжительности выдержки от 1 до 24 ч общее сопротивление поверхности сплава возрастает от $10^{4}$ до $10^{5} \mathrm{Om} / \mathrm{cm}^{2}$. Диаграммы 
Найквиста для образцов сплава АМЦ, выдержанных в 0,05 М растворе хлорида натрия с добавкой 0,003 моль/дм ${ }^{3}$ ортованадата натрия, имеют вид искаженных полуокружностей (рис. 2, в). Наличие двух временных констант указывает на фрормирование на поверхности образцов пористых пленок. Анализ диаграмм показывает, что увеличение времени выдержки в растворе от 1 до 24 ч приводит к возрастанию амплитуды спектра импеданса, что указывает на увеличение коррозионной устойчивости образцов.

Анализ диаграмм Боде (рис. 2, г), показывает, что в растворах хлорида натрия, содержащих 0,003 моль/дм ${ }^{3}$ ортованадата натрия, наблюдается увеличение общего сопротивления поверхности сплава АМЦ примерно до $5 \cdot 10^{4} \mathrm{Om} / \mathrm{cm}^{2}$.

Для определения параметров двойного электрического слоя на границе электрод - электролит использовали эквивалентные схемы $[R(R Q)], \quad[R(Q[R W)]$ и $[R(Q[R(R Q)])]$. Полученные данные свидетельствуют, что для образцов сплава АМЦ, выдержанных в ванадийсодержащих растворах хлорида натрия с $\mathrm{pH} 10$ в течение 1, 8 и 24 ч, значения сопротивления переноса заряда ниже, а сопротивление пленки на поверхности сплава выше, чем у образцов, выдержанных в фоновом электролите при одинаковой продолжительности опыта. Увеличение продолжительности выдержки образцов сплава АМЦ в ванадийсодержащем электролите с 1 до 24 ч приводит к увеличению сопротивления переноса заряда в 4,3 раза.

\section{Выводы}

1. Процесс коррозии образцов сплава АМЦ, выдержанных в $0,05 \mathrm{M}$ растворе $\mathrm{NaCl}$ в течение 1 и 24 ч лимитируется стадией переноса заряда, а при выдержке в растворе в течение 8 ч наблюдается диффузионный контроль. Для образцов сплава АМЦ, выдержанных в щелочных растворах, содержащих ортованадат натрия, процесс коррозии протекает в кинетической области.

2. Увеличение продолжительности выдержки образцов в ванадийсодержащем электролите от 1 до 24 ч приводит к формированию на их поверхности компактных защитных пленок и увеличению общего сопротивления поверхности сплава в 4,3 раза.

\section{Литература}

[1] Corrosion behavior and protection of copper and aluminium alloys in seawater / Féron D. Cambridge : Woodhead Publishing Limited, 2007.

[2] An Initial Exploration of Corrosion Inhibition of AA6061 and AA7075 by Aqueous Vanadates / Ralston K. D., Buchheit R. D. // ECS Electrochem. Lett. 2013. Vol. 2, Iss. 9. P. 35-38.

[3] Corrosion Inhibition of Aluminum Alloy 2024-T3 by Aqueous Vanadium Species / Ralston K. D. [et al.] // J. Electrochem. Soc. 2008. Vol. 155, Iss. 7. P. 350-359. 
УДК 544.6.018

\title{
ELECTROCHEMICAL BEHAVIOR OF THE Fe/Fe ${ }_{3} \mathrm{O}_{4} / \mathrm{C} / \mathrm{NaCl}$ SYSTEM
}

\author{
KRAVCHENKO O.V., PERSHINA K.D. \\ Inter-Agency Department of Electrochemical Energy Systems \\ katherinepersh@gmail.com
}

\begin{abstract}
Electrochemical behavior of the $\mathrm{Fe} / \mathrm{Fe}_{3} \mathrm{O}_{4} / \mathrm{C} / \mathrm{NaCl}$ system in the exothermic redox reaction with oxygen was studied using electrochemical impedance spectroscopy. In modeling electrochemical impedance spectra of samples during the redox reaction the formation of a new phase with a low conductivity was revealed. This phase is characterized by the appearance of a constant phase element (CPE) in the equivalent circuit of the spectrum. The contacting of the $\mathrm{Fe} / \mathrm{Fe}_{3} \mathrm{O}_{4}$ / $\mathrm{C} / \mathrm{NaCl}$ system with oxygen leads to a $5{ }^{\circ} \mathrm{C}$ increase in temperature and creates conditions for the formation of a new phase with high impedance values (increased by three orders of magnitude) and capacity reduction of the shunted capacitance by 2 orders of magnitude. The conductive properties of the new oxide phases were determined by the Mott-Schottky equation, which relates the change of the space charge layer capacitance with applied potential. A relationship between increasing temperature, changing the total potential and formation of iron oxides with different compositions on the surface of iron particles was established. It was found that the formation of the new electrochemical system is possible under spatial distribution of the temperature gradient The heuristic model of the temperature gradient distribution was proposed.
\end{abstract}

\section{ЕЛЕКТРОХІМІЧНА ПОВЕДІНКА СИСТЕМИ $\mathrm{Fe} / \mathrm{Fe}_{3} \mathrm{O}_{4} / \mathrm{C} / \mathrm{NaCl}$}

\author{
КРАВЧЕНКО О.В., ПЕРШИНА К.Д. \\ Міжвідомче відділення електрохімічної енергетики НАН України \\ katherinepersh@gmail.com
}

Було вивчено електрохімічну поведінку системи $\mathrm{Fe} / \mathrm{Fe}_{3} \mathrm{O}_{4} / \mathrm{C} / \mathrm{NaCl}$ при екзотермічній окислювально-відновній реакції 3 киснем 3 використанням спектроскопії електрохімічного імпедансу. При моделюванні спектрів електрохімічного імпедансу зразків під час окислювально-відновної реакції було виявлено утворення нової фрази з низькою провідністю. Ця фраза характеризується фрактом появи елемента постійної фрази (СРЕ) в еквівалентній схемі спектру. 
Таким чином, контакт системи $\mathrm{Fe} / \mathrm{Fe}_{3} \mathrm{O}_{4} / \mathrm{C} / \mathrm{NaCl}$ з киснем призводить до підвищення температури на $5{ }^{\circ} \mathrm{C}$, а також створює умови для формування нової фази з високими значеннями імпедансу (збільшення на три порядки) і зниження ємності шунтованого конденсатора - на 2 порядки. Провідні властивості нових оксидних фаз визначали з використанням рівняння Мотт-Шотки, що пов'язує зміну ємності шару просторового заряду 3 прикладеним потенціалом. Встановлено наявність взаємозв'язку між підвищенням температури, зміною сумарного потенціалу і формуванням оксидів заліза з різними складами на поверхні часток заліза. Було встановлено, що фрормування нової електрохімічної системи можливе при просторовому розподілі температурного градієнта. Запропоновано евристичну модель розподілу температурного градієнту.

Відомо, що зміна температури електрохімічної системи супроводжується появою тепло- та масообмінних явищ, пов'язаних 3 утворенням термогальванічних елементів (ТГЕ) [1-3]. Особливий інтерес викликають системи на основі заліза і його сполук через їх низьку вартість, доступність та екологічну безпеку [3]. Тому для дослідження впливу градієнта температури на зміну електрохімічних властивостей була обрана система $\mathrm{Fe} / \mathrm{Fe}_{3} \mathrm{O}_{4} / \mathrm{C} / \mathrm{NaCl}$, що здатна до екзотермічної редокс реакцій за участю кисню повітря.

\section{Методологія досліджень}

Вплив градієнта температури редокс реакцій за участю кисню повітря на зміну електрохімічних властивостей досліджувався у термоактивній системі, що складається з порошкового металічного заліза, графріту, порошку оксиду заліза й хлориду натрію $\left(\mathrm{Fe} / \mathrm{Fe}_{3} \mathrm{O}_{4} / \mathrm{C} / \mathrm{NaCl}\right)$. Експеримент проводився у зібраних елементах формату 2032. Елементи готувалися із суміші реагентів масою 0,8 г, що була відпресована під тиском 6 атм. в атмосфері аргону (без доступу кисню). Електрохімічні виміри проводили в двохелектродній комірці на електрохімічному модулі Autolab-30 моделі Pgstat302n Metrohm Autolab, оснащеному модулем FRA (Frequency Response Analyzer) в інтервалі частот $10^{-2}-10^{6}$ Гц. Управління модулем здійснювали за допомогою програми Autolab 4.9 за стандартною процедурою з подальшою обробкою в пакеті Zview 2.0. Виміри проводили в двох режимах: 1- в герметичному; 2- у присутності кисню повітря. Контакт з повітрям здійснювався протягом 20 хвилин у комірках з перфорованими кришками, закритими герметичним покриттям, що знімається. 


\section{Результати та їх обговорення}

Аналіз спектрів імпедансу встановив, що в герметичної комірці відбувається утворення електрохімічної системи з відносно низьким активним і реактивним опором ( $Z<100$ Ом, $Z$ " $<-50$ Ом), яку можна описати моделлю, що складається з шунтованого конденсатора в області високих частот, послідовно сполученого 3 резистором. Подібна еквівалентна схема характерна для систем, що утворюють подвійний електричний шар (ПЕШ) 3 дифузійною областю. Розрахункова ємкість модельного конденсатора склала - 42,5 нФ/г в умовах високої провідності системи (рис.1, табл.1).

Моделювання спектрів електрохімічного імпедансу зразків в умовах редокс реакції виявило утворення нової фрази з низькою провідністю, що характеризується появою елементу СРЕ в еквівалентній схемі спектру. Таким чином, при контакті системи $\mathrm{Fe} / \mathrm{Fe}_{3} \mathrm{O}_{4} / \mathrm{C} / \mathrm{NaCl} 3$ киснем спостерігається не лише підвищення температури на $5{ }^{\circ} \mathrm{C}$, але і поява нової фази, яка на 3 порядки підвищує як активний, так і реактивний опір системи, з одночасним зниженням ємності шунтованого конденсатора на 2 порядки (рис.2, табл. 1).

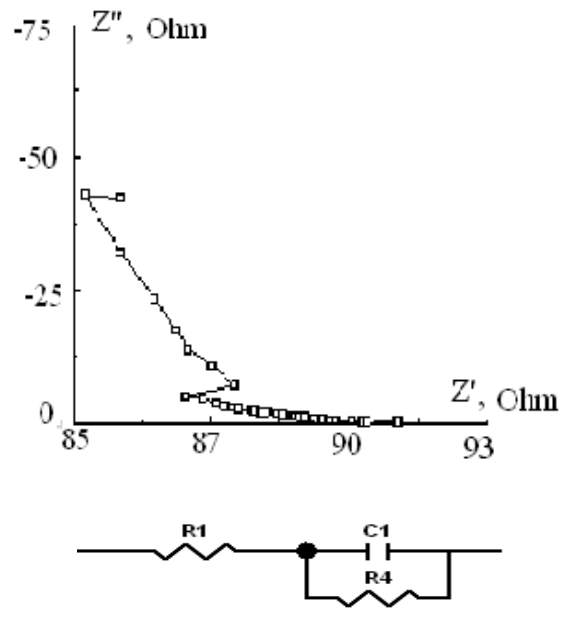

Puc.1. Спектр імпедансу системи $\mathrm{Fe} / \mathrm{Fe}_{3} \mathrm{O}_{4} / \mathrm{C} / \mathrm{NaCl}$ в герметичній коміриі

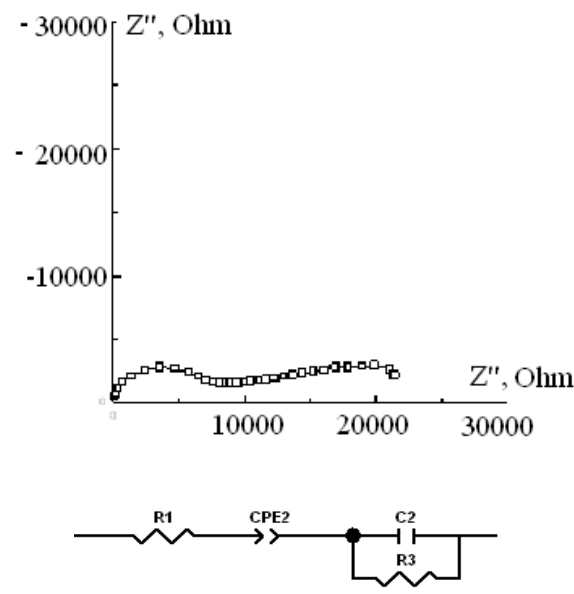

Puс.2. Спектр імпедансу системи $\mathrm{Fe} / \mathrm{Fe}_{3} \mathrm{O}_{4} / \mathrm{C} / \mathrm{NaCl}$ при контакті з повітрям

Таблиця 1. Значення елементів еквівалентних схем зразків

\begin{tabular}{|c|c|c|c|c|}
\hline Зразок & С, $\Phi$ & Похибка, \% & CPE & $\begin{array}{c}\text { Похибка, } \\
\%\end{array}$ \\
\hline Інертний & $42,5 \cdot 10^{-9}$ & 2,04 & & \\
\hline Повітряний & $1,07 \cdot 10^{-10}$ & 5,4 & $\mathrm{CPE}-\mathrm{P}-0,3$ & 8,1 \\
\hline & & & $\mathrm{CPE}-\mathrm{T}-2,5 \cdot 10^{-6}$ & 19,7 \\
\hline
\end{tabular}


Згідно з дослідженнями, проведеними в [4], при окисленні заліза можливе утворення тонких плівок $\mathrm{Fe}_{3} \mathrm{O}_{4}$ або $\mathrm{y}-\mathrm{Fe}_{2} \mathrm{O}_{3} \quad 3$ шпінелеподібною структурою. Зростання цих плівок $є$ чинником, що контролює дифузію і міграцію структурних іонних дефектів. Зміна швидкості руху цих дефектів впливає на утворення ПЕШ й його ємність, яка згідно рівнянню Мотте-Шотткі впливає на різницю потенціалів в напівпровідникової системи.

$$
1 / C^{2}=2 / \varepsilon \varepsilon_{0} e N_{D}\left(E-E_{f b}-k T / e\right),
$$

де $\varepsilon$ - діелектрична проникність середовища, $\varepsilon_{0}$ - діелектрична проникність вакууму, $N_{D}$ - щільність донорних вакансій, $E_{f b}$ потенціал плоских зон, - поляризаційний потенціал, $k$ - константа Больцмана, $T$ - абсолютна температура.

Відповідно до цього рівняння, різниця між поляризаційним потенціалом i потенціалом плоских зон напівпровідникової компоненти повинна збільшитися на 0,05 В при підвищенні температури на $5{ }^{\circ} \mathrm{C}$ при дотриманні умов постійності діелектричної проникності середовища. Експериментально встановлено, що в досліджуваній системі різниця потенціалів зростає на 0,1 В при підвищенні температури на $5{ }^{\circ} \mathrm{C}$. Це узгоджується 3 припущенням про формування складної напівпровідникової системи на поверхні часток заліза, що складається з оксидів заліза різного складу, які можуть мати різні значення діелектричної проникності.

Аналіз отриманих результатів дозволив передбачити, що в умовах доступу кисню через певні канали можливо фрормування нової системи, що володіє іншими електрохімічними властивостями. Імовірність появи такої системи регулюється градієнтами температури не лише в горизонтальному напрямі [3], але й у вертикальному (рис.3).

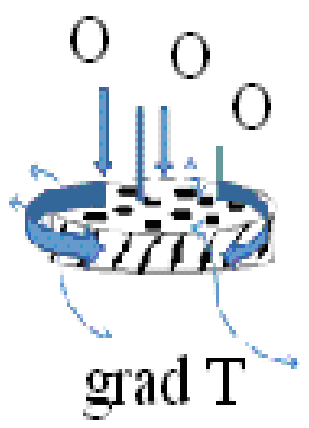

Рис. 3. Схема фоормування температурних градієнтів в системі $\mathrm{Fe} / \mathrm{Fe}_{3} \mathrm{O}_{4} / \mathrm{C} / \mathrm{NaCl}$ 


\section{Висновки}

Дослідження спектрів імпедансу системи $\mathrm{Fe} / \mathrm{Fe}_{3} \mathrm{O}_{4} / \mathrm{C} / \mathrm{NaCl}$ в інертному режимі і при доступі кисню повітря встановило появу нової фрази, яка на 3 порядки підвищує як активний, так і реактивний опір, а також змінює механізм провідності досліджуваної системи при контакті 3 киснем повітря. Порівняльний аналіз результатів експерименту з наявними літературними даними показав, що в результаті взаємодії часток заліза з киснем повітря в умовах екзотермічної редокс реакції на поверхні металу утворюються стійкі оксиди, що формують нову фазу 3 напівпровідниковими властивостями. Формування нової електрохімічної системи можливе лише в умовах об'ємного розподілу градієнта температури.

\section{Перелік посилань}

[1] J.R. Sootsman, D.Y. Chung, M.G. Kanatzidis. New and Old Concepts in Thermoelectric Materials/l Angewandte Chemie International Edition,- 2009.- 48(46).- P.8616-8639.

[2] A. J. Minnich, M. S. Dresselhaus, Z. F. Ren, G. Chen. Bulk nanostructured thermoelectric materials: current research and future prospects// Energy \& Environmental Science.- 2009.- 2(5). - P. 466 479.

[3] J. P. Heremans, B. Wiendlocha and A. M. Chamoire, Resonant levels in bulk thermoelectric semiconductors// Energy \& Environmental Science.- 2012.- 5. - P. 5510-5530.

[4] W. S. Li, J. L. Luo Electrochemical investigations on formation and pitting susceptibility of passive films on iron and iron-based alloys// Int. J. Electrochem. Sci., 2 (2007) 627 - 665 
УДК 620.197.3:547.333.4

MODELING A MECHANISM FOR INHIBITING ACID CORROSION OF STEEL BY MULTIFUNCTIONAL PYRIDINE SALTS WITH CARBONYL GROUPS

\author{
POGREBOVA I.S., PILIPENKO T.N., KOTSIUBA E.S. \\ National Technical University of Ukraine "Kiev Polytechnic Institute" \\ fakel2303@mail.ru
}

The interrelation between the inhibitory action of multifunctional quaternary pyridine salts containing carbonyl groups in acid corrosion of steel and the characteristic constants of their substitutes has been investigated. A model has been proposed for the mechanism of action of the compounds studied on the metal, and the role of various constants of the functional groups during acid corrosion inhibition of steel has been revealed.

\title{
МОДЕЛИРОВАНИЕ МЕХАНИЗМА ИНГИБИРОВАНИЯ КИСЛОТНОЙ КОРРОЗИИ СТАЛЕЙ ПОЛИФУНКЦИОНАЛЬНЫМИ ПИРИДИНОВЫМИ СОЛЯМИ С КАРБОНИЛСОДЕРЖАЩИМИ ГРУППИРОВКАМИ
}

\author{
ПОГРЕБОВА И.С., ПИЛИПЕНКО Т.Н., КОЦЮБА Е.С. \\ Национальный технический университет Украины «Киевский \\ политехнический институт»; fakel2303@mail.ru
}

Исследовалась взаимосвязь между ингибирующим действием при кислотной коррозии сталей полифункциональных четвертичных пиридиновых солей, содержащих карбонильные группировки, и характеристическими константами их заместителей. Предложена модель механизма действия исследованных соединений на металле и выявлена роль различных констант заместителей фонкциональных группировок в процессе ингибирования кислотной коррозии стали.

Полифункциональные четвертичные пиридиновые соли проявляют высокую эффрективность при кислотной коррозии металлов и благодаря наличию дешевого сырья для их производства являются основой многих промышленных ингибиторов коррозии. Ингибирующее действие таких соединений связано с их адсорбцией на поверхности корродирующего металла 
и влиянием адсорбированных частиц на кинетику парциальных реакций коррозионного процесса. Вклад в результативное действие полифункциональных ингибиторов тех или иных функциональных групп часто оказывается различным и зависит как от их адсорбционных свойств, так и от параметров протекания коррозионного процесса. Моделирование процессов адсорбции и механизма ингибирования коррозии может поэтому стать основой создания новых высокоэффективных ингибиторов различного назначения и выявления причин эффектов синергизма, наблюдаемых при их использовании.

В настоящей работе исследовалась взаимосвязь между ингибирующим действием при кислотной коррозии сталей полифункциональных четвертичных пиридиновых солей, содержащих карбонильные группировки, и характеристическими константами их заместителей.

В качестве объектов исследований были выбраны Nфенацилметилпиридиновые соли, которые проявляют высокое защитное действие при кислотной коррозии железа и углеродистых сталей [1,2]. Такие ингибиторы одновременно являются как четвертичными пиридиновыми солями, так и органическими соединениями с карбонильными группировками. Наличие в них метиленового мостика, разделяющего пиридиновый и карбонильный фрагменты, позволяет, вводя в их состав те или иные заместители, выявлять роль каждого из них в ингибировании кислотной коррозии стали.

\section{Методология исследований}

Моделирование механизма ингибирования коррозии исследованными соединениями проводили на основе данных гравиметрических исследований и измерений поляризационного сопротивления процесса коррозии автоматизированным индикатором Р 5126, разработанным на кафедре ТЭХП НТУУ «КПИ» под руководством д.т.н. Герасименко Ю.С.. Исследования проводили со стальными образцами марки 08КП, 20 в 3 М растворе $\mathrm{H}_{2} \mathrm{SO}_{4}$ и в тех же растворах, содержащих ингибиторы, при 20-80 $\mathrm{C}$. Синтез, разработка исследованных ингибиторов и обсуждение роли структурного фактора в механизме их защитного действия проводились совместно с в.н.с кафедры ОХ и ТОВ НТУУ «КПИ», д.Х.н. Юрченко Р.И. 


\section{Результаты и их обсуждение}

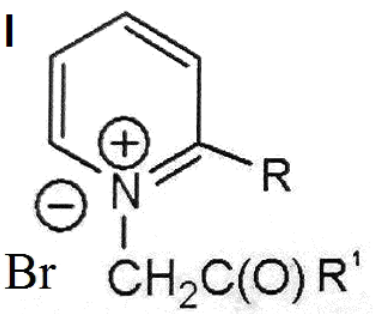

Исследованные

$\mathrm{N}$-френацилметилпиридиний бромиды (I), благодаря наличию в них пиридинового фррагмента, также как и другие четвертичные пиридиновые соли, являются поверхностно-активными веществами катионного типа, подавляющими кислотную коррозию железа при комнатной температуре по энергетическому механизму за счет возникновения положительного адсорбционного скачка потенциала. Наряду с этим они обеспечивают высокую эффрективность при повышенных температурах раствора, что обусловлено способностью кислорода карбонильной группировки насыщать незаполенные d-орбитали атомов железа [3]. Эфрфективность защитного действия этих соединений зависит от характеристических констант, входящих в их состав заместителей. Так, при введении в пиридиновое ядро электронодонорных $\left(-\mathrm{CH}_{3}\right.$, $\mathrm{NH}_{2}$ ) заместителей, а также $\mathrm{COCH}_{3}$-группы наблюдается изменение защитного действия ингибиторов, и связь между величинами Igy (где ү-коэфрфициент торможения коррозии) и их б- и Еs-константами, характеризующими, соответственно, влияние электронного и стерического эфрфектов, могут быть представлены корреляционными зависимостями:

$$
\begin{aligned}
& 20^{\circ} \mathrm{Clgy}=1,045-0,729 \sigma^{\circ} \mathrm{C}, r=0,974 \\
& 40^{\circ} \mathrm{Clgy}=1,128-0,690 \sigma^{\circ} \mathrm{C}, r=0,993 \\
& 60^{\circ} \mathrm{Clgy}=2,364+0,146 \sigma^{\circ} \mathrm{C}, r=0,903 \\
& 80^{\circ} \mathrm{Clgy}=2,225+0,214 \sigma^{\circ} \mathrm{C}, \mathrm{r}=0,888
\end{aligned}
$$

$$
\begin{aligned}
& 20^{\circ} \mathrm{Clg}=1,163-0,346 \mathrm{Es}, r=0,999 \\
& 40^{\circ} \mathrm{Clgy}=1,219-0,399 \mathrm{Es}, r=0,995 \\
& 60^{\circ} \mathrm{Clgy}=2,336+0,055 \mathrm{Es}, r=0,993 \\
& 80^{\circ} \mathrm{Clg}=2,224+0,116 \mathrm{Es}, r=0,905
\end{aligned}
$$

В меньшей степени на защитное действие этой группы соединений влияет изменение констант заместителей (Es). Эти выводы находятся в соответствии с результатами исследований, приведенных в работе [1], согласно которой ингибирующее действие $\mathrm{N}$-френацилметилпиридиний бромидов увеличивается при усилении т-электронного взаимодействия с поверхностью металла и введением в пиридиновое кольцо электронодонорных заместителей. Обращение приведенных зависимостей при повышении температуры может быть обусловлено переориентацией молекул ингибитора и их адсорбцией по фенацильному фрагменту, а также некоторым разложением исследованных соединений.

Для N-фенацилметил-пиридиний бромидов общей фрормулы (II), [2] также проявляются корреляционные зависимости между величинами Igy и ароматическими индукционными $\sigma_{1}$-константами Тафрта их заместителей $\mathrm{R}=\mathrm{C}_{6} \mathrm{H}_{5},-\mathrm{C}_{6} \mathrm{H}_{4} \mathrm{CH}_{3}-4,-\mathrm{C}_{6} \mathrm{H}_{4} \mathrm{Cl}-4$ : 


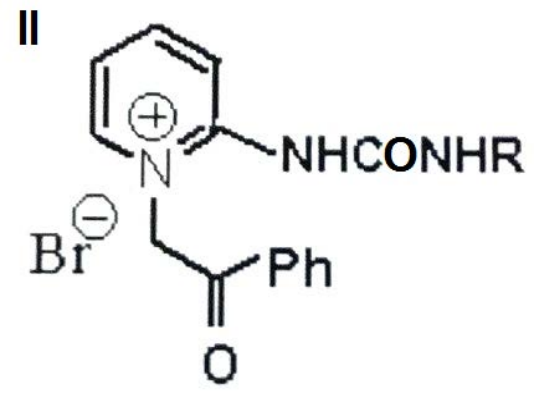

$20^{\circ} \mathrm{C} \lg \mathrm{\gamma}=1,445-0,704 \sigma_{\mathrm{l}}, \mathrm{r}=0,999$ $40^{\circ} \mathrm{Clg} \gamma=1,820-1,013 \sigma_{1}, r=0,991$

$60^{\circ} \mathrm{Clg} \gamma=2,695-0,753 \sigma_{1}, r=0,993$

что свидетельствует об участии в процессе адсорбции и ингибировании коррозии пиридинового кольца $\mathrm{N}$-френацилметилпиридиний бромидов.

Наряду с пиридиновым фррагментом при адсорбции на поверхности стали исследованных соединений также принимает участие и фенацильный фррагмент ингибиторов, о чем свидетельствует изменение их защитного действия при введении заместителей в фенацильные группировки.

Так, при введении в соединение (I), содержащее в пиридиновом цикле $\mathrm{NH}_{2}$-группу заместителей $\mathrm{R}^{1}=\mathrm{C}_{6} \mathrm{H}_{5},-\mathrm{C}_{6} \mathrm{H}_{4} \mathrm{CH}_{3}-4$, $-\mathrm{C}_{6} \mathrm{H}_{4} \mathrm{Br}-4, \quad-\mathrm{C}_{6} \mathrm{H}_{4} \mathrm{Cl}-4$ имеющих электронодонорные свойства $\left(\mathrm{CH}_{3}\right.$ группа), наблюдается повышение защитного действия ингибиторов. При наличии в молекуле електроноакцепторних заместителей атомов брома и хлора - происходит резкое уменьшение их эфрфективности. Для этой группы соединений наблюдаются корреляционные зависимости между величинами Igy $и \sigma_{1}$ константами Тафрта и стерическими Еs-константами их заместителей:

$$
\begin{aligned}
& 20^{\circ} \mathrm{Clg}=1,348-2,075 \sigma_{\mathrm{l}}, \mathrm{r}=0,972 \\
& 40^{\circ} \mathrm{Clg}=1,444-2,156 \sigma \mathrm{\sigma}, \mathrm{r}=0,986 \\
& 60^{\circ} \mathrm{Clg}=2,408-2,223 \sigma_{\mathrm{l}}, \mathrm{r}=0,982 \\
& 80^{\circ} \mathrm{Clg}=2,217-0,938 \sigma_{\mathrm{l}}, \mathrm{r}=0,972
\end{aligned}
$$

$$
\begin{aligned}
& 20^{\circ} \mathrm{Clgy}=0,982+1,809 \mathrm{Es}_{,} \mathrm{r}=0,70 \\
& 40^{\circ} \mathrm{Clgy}=1,064+1,871 \mathrm{Es}_{2} \mathrm{r}=0,70 \\
& 60^{\circ} \mathrm{Clgy}=2,008+1,753 \mathrm{Es}_{2} \mathrm{r}=0,58 \\
& 80^{\circ} \mathrm{Clg}=2,047+0,720 \mathrm{Es}_{,} \mathrm{r}=0,54
\end{aligned}
$$

Высокая эффрективность исследованных соединений при повышенных температурах и их хемосорбция на поверхности стали подтверждается данными гравиметрических исследований, а также измерениями поляризационного сопротивления и эффектами последействия. Так, в присутствии соединения (I) $\mathrm{R}=\mathrm{COCH}_{3} \mathrm{R}^{1}=\mathrm{C}_{6} \mathrm{H}_{5}$ наблюдается значительное повышение поляризационного сопротивления стали 20 по сравнению с фроновым раствором кислоты как при при 20, так и при $60^{\circ} \mathrm{C}$ (рис. 1 а). О проявлении эфрфекта последействия исследованного соединения свидетельствует сохранение его ингибирующего и защитного действия в неингибированном растворе в течение длительного времени (до одного месяца) испытаний (рис. 1 б). 


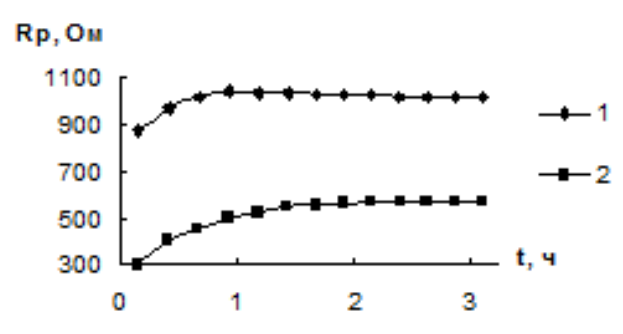

a)

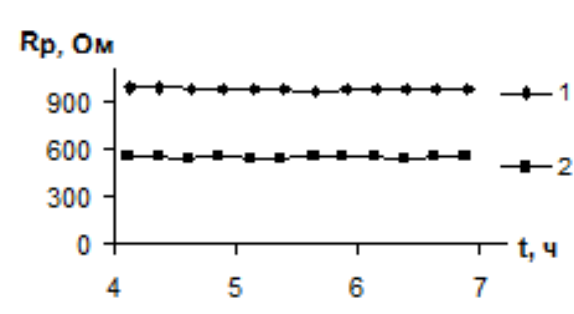

б)

Puc. 1. Зависимости поляризационного сопротивления от времени коррозионных испытаний стали 20 в $3 \mathrm{M} \mathrm{H}_{2} \mathrm{SO}_{4}$ в присутствии $1 \cdot 10^{-2}$ моль $\cdot \pi^{-1}$ соединения (I) $\left(a, 1-60^{\circ} \mathrm{C}, 2-20^{\circ} \mathrm{C}\right)$ и при последующем ее погружении в неингибированную кислоту $\left(6,1-60^{\circ} \mathrm{C}, 2-20^{\circ} \mathrm{C}\right)$.

Анализ приведенных корреляционных зависимостей свидетельствует о значительном вкладе электронного фрактора влияния заместителей в ингибирующее действие исследованных соединений и значительно меньше стерического, роль которого при хемосорбции карбонильного фрагмента практически нивелируется.

\section{Выводы}

При адсорбции молекул $\mathrm{N}$-френацилметилпиридиний бромидов на отрицательно заряженной поверхности сталей при комнатных температурах часть из них ориентируется по пиридиновому фррагменту, принимая планарное расположение, что обусловлено п-электронным взаимодействием пиридинового кольца с поверхностью металла. Фенацильная часть располагается в объеме раствора с ориентацией отрицательно заряженного кислорода карбонильной группы в сторону водной фазы. При высоких температурах раствора большинство молекул ингибитора адсорбируются по френацильному фрагменту и характерным для них является хемосорбция, обеспечивающая торможение коррозии за счет энергетически-блокировочного эффеекта ингибирования.

\section{Перечень ссылок:}

[1] Антикоррозионные свойства N-фенацилметилпиридиний бромидов / Р.И. Юрченко, И.С. Погребова, Т.Н. Пилипенко, Е.М. Красько // Журнал прикладной химии. - 2003. - Т. 76, вып. 11. - С. $1814-1818$.

[2] Антикоррозионные свойства 1-фенацилметил-2арилкарбамидо(арилтиокарбамидо)пиридиний бромидов / P.И. Юрченко, И.С. Погребова, Т.Н. Пилипенко, Т.Е. Шубина // Журнал прикладной химии.- 2006. - Т. 79, вып. 12. - С. $1993-1997$.

[3] Погребова И.С. Эфрфекты внутримолекулярного синергизма при ингибировании коррозии бифункциональными соединениями / И.С. Погребова // Украинский химический журнал. - 1982. - Т. 2, № 11. - C. $1198-1203$. 
УДК 620.193

\title{
INFLUENCE OF THE STATE OF THE B1341T ALUMINIUM ALLOY OF THE Al - Mg - Cu - Si SYSTEM ON RESISTANCE AGAINST INTERGRANULAR CORROSION
}

\author{
NURIACHMETOVA M.M., NYRKOVA L.I., LABUR T.M., \\ BORYSENKO Yu.V. \\ Kyiv National University of Technologies and Design \\ Electric Welding Institute named by Ye.O. Paton NAS of Ukaine \\ Inyrkova@gmail.com
}

The influence of the state of the B1341T aluminium alloy of the Al$\mathrm{Mg}-\mathrm{Cu}$-Si system (in the delivery state, after artificial aging, after hardening and artificial aging) on its resistance against intergranular corrosion (IGC) was investigated. It was shown that the artificial aging and hardening with artificial aging, to some extent, increase the maximum depth of grain boundary rupture, but on the whole, do not assist exceeding the criterion of resistance against IGC permissible by normative documents.

\section{ВПЛИВ СТАНУ АЛЮМІНІЄВОГО СПЛАВУ В1341Т СИСТЕМИ Al-Mg-Cu-Si HA CTІЙКІСТЬ ПРОТИ МІЖКРИСТАЛІТНОÏ КОРОЗІЇ}

\author{
НУРІАХМЕТОВА М.М., НИРКОВА Л.І., ЛАБУР Т.М., \\ БОРИСЕНКО Ю.В.
}

Київський національний університет технологій та дизайну, Інститут електрозварювання ім. Є.О. Патона НАН України Inyrkova@gmail.com

Досліджено вплив стану алюмінієвого сплаву В1341Т системи Al-Mg-Cu-Si (у стані постачання, після штучного старіння, після гартування та штучного старіння) на його стійкість проти міжкристалітної корозії (МКК). Показано, що штучне старіння та гартування з наступним штучним старінням в деякій мірі збільшують максимальну глибину руйнування границь зерен, але в цілому не сприяють перевищенню допустимого нормативними документами критерію стійкості проти МКК.

Наявність інформації щодо властивостей і корозійної стійкості конструкційних матеріалів дозволяє оцінити перспективність використання того чи іншого металу або сплаву в будь-якій області і 
створити виріб із заданими властивостями і строком експлуатації [1]. Відомо, що алюміній та його сплави широко застосовуються в різних галузях промисловості. Дослідження стійкості алюмінієвого сплаву B1341T, у тому числі, після різних методів термооброблення, проти локальної корозії на сьогодні $є$ актуальним з економічної точки зору. Отримання даних щодо властивостей цього сплаву дозволить розширити сореру його застосування і оцінити термін експлуатації виготовлених із нього виробів.

В представленому нижче матеріалі наведено результати порівняльних досліджень впливу різних методів термооброблення на стійкість алюмінієвого сплаву B1341T системи Al-Mg-Cu-Si проти міжкристалітної корозії (далі - МКК).

\section{Методологія досліджень}

Досліджування проводили на зразках алюмінієвого сплаву В1341T у різному стані: у стані поставки (без додаткового оброблення), після штучного старіння, після сумісного впливу гартування та штучного старіння. Випробування стійкості проти МКК виконували за стандартною методикою згідно з ГОСТ 9.021 [2]. Глибину руйнування границь зерен визначали на нетравлених шліфрах.

\section{Результати та їх обговорення}

На рисунку 1 представлено зовнішній вигляд площин торців зразків алюмінієвого сплаву В1341Т після випробувань.

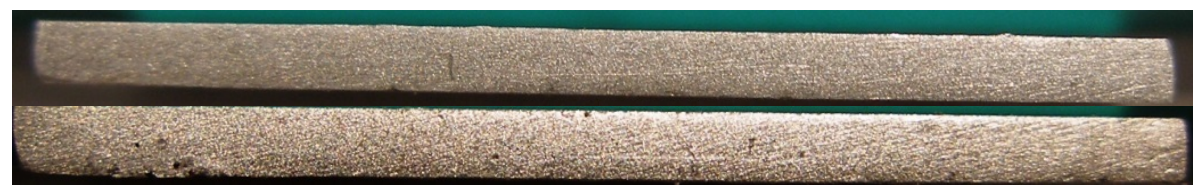

a

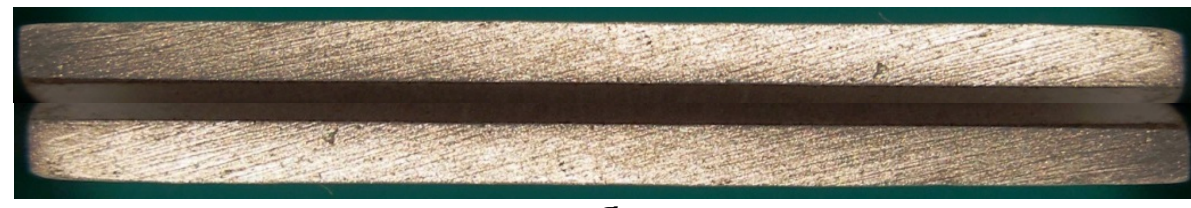

б

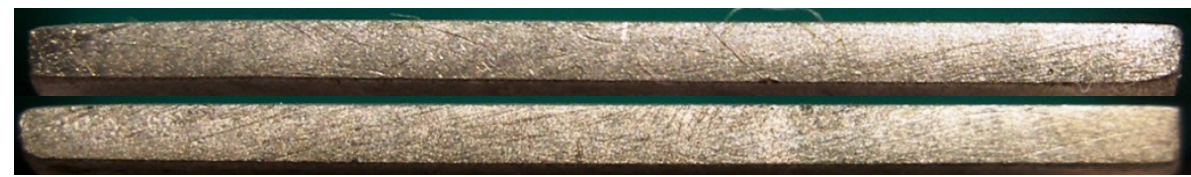

8

Puc. 1. Зовнішній вигляд площин торців зразків сплаву В1341T після випробувань стійкості проти МКК: а - у стані поставки, б - після штучного старіння, в - після гартування та штучного старіння, ×5. 
Після виготовлення шліфів за допомогою мікроскопу NEOPHOT 21 проводили їх огляд по всій довжині, визначали глибину руйнування границь зерен. Критерієм стійкості зразків $є$ руйнування границь зерен. В нормативному документі (НД), в якому сфрормульовано вимоги до сплаву В1341T, максимальна глибина руйнування границь зерен має бути не більше, ніж 0,350 мм. Оскільки ця інформація $€$ конфріденційною, повна назва НД не наведена. Результати оцінювання стійкості алюмінієвого сплаву В1341Т проти МКК наведено в табл. 1.

Таблиця 1. Результати оцінювання стійкості алюмінієвого сплаву В1341T у різному стані проти МКК

\begin{tabular}{|c|c|c|c|}
\hline \multirow{2}{*}{$\begin{array}{c}\text { Характеристика } \\
\text { зразків }\end{array}$} & \multicolumn{2}{|c|}{$\begin{array}{c}\text { Глибина руйнування границь } \\
\text { зерен, мкм }\end{array}$} & \multirow{2}{*}{$\begin{array}{c}\text { Відповідає } \\
\text { вимогам НД, } \\
\text { так/ні }\end{array}$} \\
\hline & згідно з НД & $\begin{array}{l}\text { фактичні } \\
\text { значення }\end{array}$ & \\
\hline Без термообробки & \multirow[t]{3}{*}{$\begin{array}{c}\text { не більше } \\
0,350\end{array}$} & від 0,082 до 0,086 & так \\
\hline Після штучного старіння & & від 0,074 до 0,117 & так \\
\hline $\begin{array}{l}\text { Після гартування та } \\
\text { штучного старіння }\end{array}$ & & від 0,111 до 0,209 & так \\
\hline
\end{tabular}

На рисунку 2 представлена діаграма, на якій показано, як впливає на глибину руйнування границь зерен стан сплаву В1341T ${ }^{1}$. 3 аналізу отриманих результатів випливає, що штучне старіння та гартування із штучним старінням в деякій мірі збільшує максимальну глибину МКК, але в цілому не сприяє перевищенню допустимого НД значення.

Аналіз результатів випробувань свідчить про те, що досліджувані зразки алюмінієвого сплаву B1341T системи Al-Mg-CuSi у стані поставки, після штучного старіння та після гартування i штучного старіння $є$ стійкими проти МКК та відповідають вимогам НД. Результати досліджень алюмінієвого сплаву В1341Т дозволяють розглядати його, як перспективний матеріал для заміни сталевих листів в авіабудівництві і автобудівництві [3].

\section{Висновки}

Зразки алюмінієвого сплаву B1341T системи Al-Mg-Cu-Si (у стані поставки, штучного старіння, гартування та штучного старіння) $€$ стійкими проти міжкристалітної корозії та відповідають вимогам

\footnotetext{
${ }^{1}$ На діаграмі наведено значення глибини руйнування меж зерен трьох паралельних зразків.
} 
нормативної документації. Штучне старіння та гартування і штучне старіння деякою мірою збільшують максимальну глибину МКК, але в цілому не сприяють перевищенню допустимого НД значення.

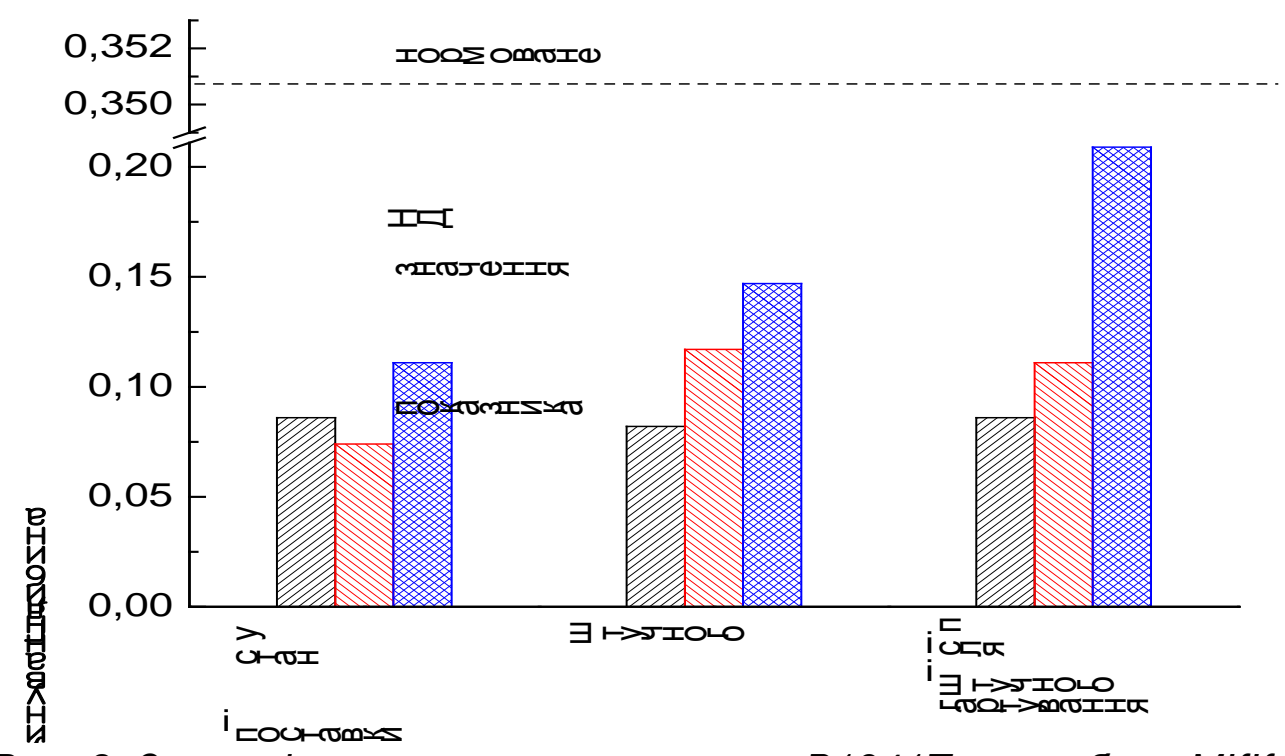

Puc. 2. Залежність впливу стану сплаву В1341Т на глибину МКК: 1 - у вихідному стані; 2 - після штучного старіння; 3 - після гартування та штучного старіння.

\section{Перелік посилань}

[1] Фридляндер И.Н. Алюминиевые сплавы - перспективный материал в автомобилестроении. [Текст] / Фридляндер И.Н., Систер В.Г., Грушко О.Е. и др.- // Металловедение и термическая обработка металлов. - М., 2002. - № 9. - С. 3-9.

[2] ГОСТ 9.021-74. «Единая система защиты от коррозии и старения. Алюминий и сплавы алюминиевые. Методы ускоренных испытаний на межкристаллитную коррозию».

[3] Радзієвський,В.М. Металознавство високотемпературної технології нерознімних з'єднань [Текст]: монографрія / В.М. Радзієвський, А.Ф. Будник, В.Б. Юскаєв. - Суми : СумДУ, 2011. $255 \mathrm{c}$. 
Удк 544.6.018 + 54-412

\title{
DEVELOPMENT OF METHODS FOR THE FORMATION OF PASSIVATION LAYERS ON ALUMINUM AND ITS ALLOYS
}

\author{
KLIMOVA E.A., KESHIN A.V., CHERNIK A.A., ZHYILINSKI V.V.
} Belarusian State Technological University, klimoma.zhen@yandex.ru

This paper deals with the conditions and procedure of aluminum passivation in titanium-based solution, and producing an anodic oxide coating modified with polyaniline on the metal surface. Anodic polarization curves have been considered corrosion currents have een compared for each of the protective coatings.

\section{РАЗРАБОТКА МЕТОДИКИ НАНЕСЕНИЯ ПАССИВАЦИОННЫХ СЛОЕВ НА АЛЮМИНИЙ И ЕГО СПЛАВЫ}

КЛИМОВА Е.А., КЕШИН А.В., ЧЕРНИК А.А. ЖИЛИНСКИЙ В.В. Белорусский государственный технологический университет, klimoma.zhen@yandex.ru

В данной работе представлена информация об условиях и методике пассивации алюминия в растворе на основе соединений титана, и получение модифицированного полианилином аноднооксидного покрытия на поверхности металла. Рассмотрены анодные поляризационные кривые и проведено сравнение токов коррозии для каждого из рассмотренных защитных покрытий.

Алюминий и его сплавы получили широкое распространение в машиностроении, приборостроение благодаря своим уникальным свойством: плотности, электропроводности, прочности, устойчивости к атмосферной коррозии в умеренном климате. Использование полимерных материалов, а также неорганических пассиваторов для повышения коррозионной стойкости конструкционных на основе алюминиевых сплавов представляет собой важное направление в инженерии поверхности.

Более высокая стойкость по отношению к атмосферной коррозии наблюдается при сочетании анодированного алюминия с наложением полианилина (ПАНИ). Данный полимер привлекает наибольшее внимание благодаря своим уникальным свойствам и доступности мономера. Электрохимические свойства ПАНИ обратимо изменяются в зависимости от состава среды. 


\section{Методология исследований}

Электропроводящий полианилин синтезируют химическим или электрохимическим методами в сильно кислой среде путем окислительной полимеризацией мономера.

Объектами исследования в данной работы выступали образцы сплава АМЦ, номинального состава по ГОСТ 4784-97, \%: $\mathrm{Si}-0,60$; $\mathrm{Fe}-0,7 ; \mathrm{Cu}-0,05-0,20 ; \mathrm{Mn}-1,00-1,50 ; \mathrm{Mg}-0,20 ; \mathrm{Zn}-0,1 ; \mathrm{Ti}-$ 0,$10 ; \mathrm{Al}$ - баланс.

Подготовка образцов включала в себя 4 операции :

- предварительную полировку для выравнивания микрорельефа образцов;

- травление в $1,5 \mathrm{M}$ растворе $\mathrm{NaOH}$ при $T 60^{\circ} \mathrm{C}$ в течение 2 мин;

- осветление в 25\% растворе $\mathrm{HNO}_{3}$ в течение1 мин при комнатной температуре.

- после каждой стадии образцы промывались дистиллированной водой.

Анодирование сплава АМЦ проводили в сернокислом электролите с концентрацией $\mathrm{H}_{2} \mathrm{SO}_{4}$ 0,5 моль/л при напряжении $30 \mathrm{~B}$ при температуре $20^{\circ} \mathrm{C}$. Продолжительность процесса анодирования составляла 20 мин. После анодирования образцы для удаления остатков электролита промывались дистиллированной водой.

Получение модифицированных полианилиномоно-оксидных покрытий на поверхности сплава проводили в электролите состава, моль/дм ${ }^{3}: \mathrm{C}_{6} \mathrm{H}_{5} \mathrm{NH}_{2}-0,3 ; \mathrm{H}_{2} \mathrm{SO}_{4}-0,5$. Процесс проводили в гальваностатическом режиме со стабилизацией по току, при плотности рабочего тока $i$ 1,25 A/дм². Время получения покрытия составляло 20 мин, температура электролита $-20^{\circ} \mathrm{C}$

Перед дальнейшим использованием полученные образцы сушились при постоянной температуре $25^{\circ} \mathrm{C}$ на воздухе в течение 24 часов. Пассивация образцов проводилась в растворе на основе солей титана при комнатной температуре в течение 1 минуты.

\section{Результаты и их обсуждение}

Исследования электрохимических свойств полученных покрытий проводили вольтамперометрически в диапазоне потенциалов от -3 до 1 В в растворе $\mathrm{NaCl}$ с концентрацией 0,05 моль/л. 


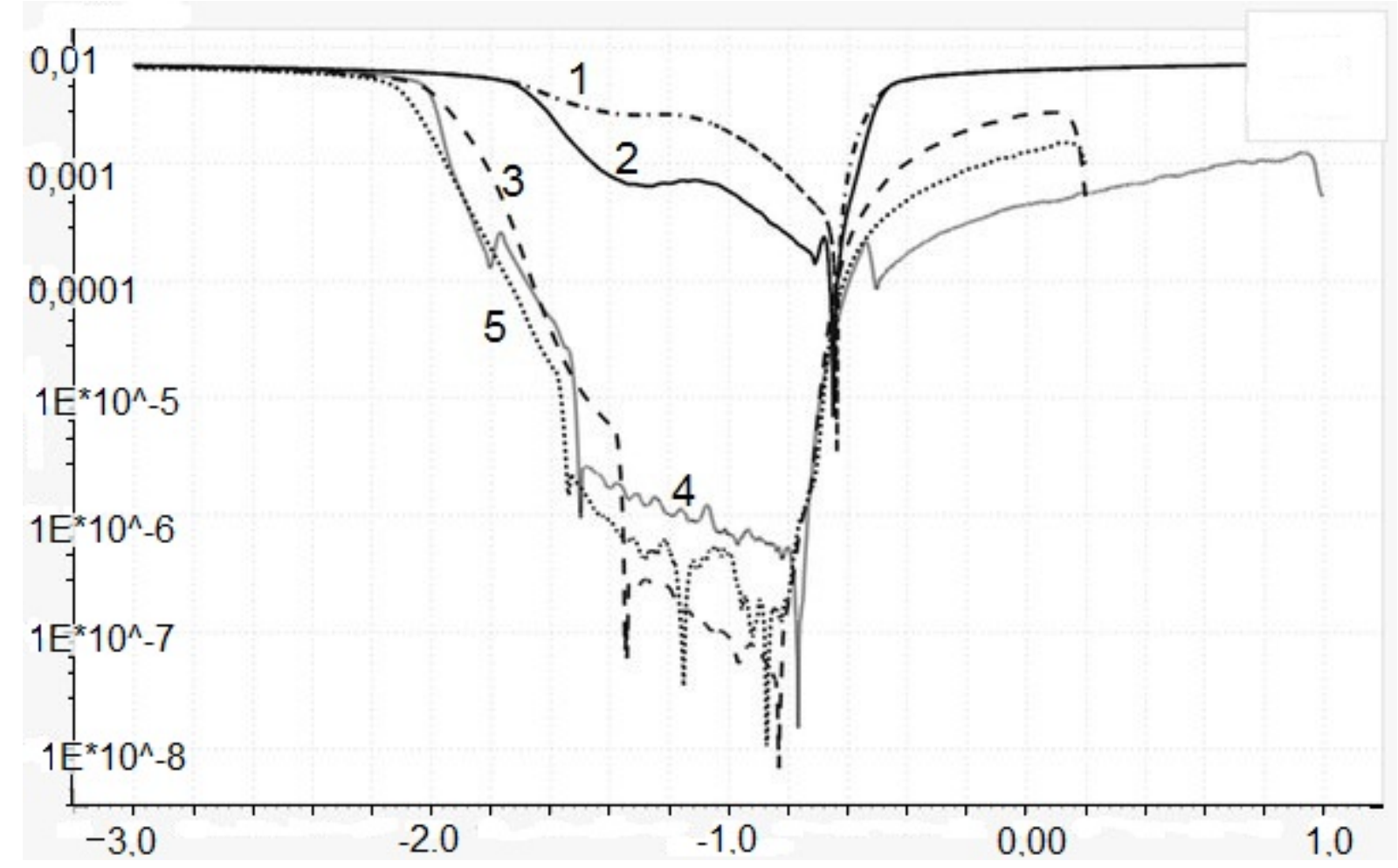

Рисунок 1. Анодные поляризационные кривые сплава АМЦ в 0,05 M NaCl в координатах логарифрм тока от потенциала.

1 - сплав АМЦ; 2 - сплав АМЦ после пассивации; 3 - сплав АМЦ+ПАНИ; 4 сплав АМЦ + ПАНИ + пассивация; 5 - анодированный сплав АМЦ

Исходя из анализа зависимостей, представленных на рисунке 1 , можно проследить влияние метода защиты на процесс протекания коррозии алюминия. Как следует из рисунка 1, введение солей пассивации алюминия в титансодержащем растворе приводит к уменьшению плотности тока коррозии в два раза в области потенциалов относительно хлор серебреного электрода от -0,7 до 1,45 B.

Наблюдается улучшение коррозионной стойкости сплава АМц при проведении осаждения ПАНИ на три порядка по сравнению с исходной металлической поверхностью.

Кривая 5, полученная на сплаве АМЦ с предварительно нанесенным анодно-оксидным покрытием показывает значительное уменьшение коррозионных токов в сравнении с чистым алюминием, что наиболее вероятно связанно с экранированием поверхности металла плотной химически стойкой пленкой оксида. Значительно большие защитные свойства показывает модифицированный полианилином оксидный слой, кривая 3 рисунок 1, полученный в ходе совместного оксидирования и окислительной полимеризацией. Подобное улучшение свойств можно объяснить тем, что в ходе образования оксидного слоя на поверхности металлаполимер 
заполняет образующиеся поры, а также полианилин за счет своих электропроводящих свойств перераспределяет заряд с активных мест по всей поверхности металла.

Кривая 4 обладает несколько меньшими в сравнении с модифицированным оксидным слоями защитными свойствами. Это объясняется химическим взаимодействием использованного пассиватора с полианилином, который под действием ионов Ti(IV) меняет свои проводящие свойства.При этом можно заметить уменьшение тока коррозии в области -1,42 - -1,56 В и -1,76 - -1,92 В вызванного более глубоким окислением полимерной пленки.

\section{Вывод}

Применение модифицированного полианилиномоно-оксидного покрытия показывает значительное повышение коррозионной стойкости, однако в сравнении с другими методами, отличается большими экономическими затратами.

\section{Литература}

[1] Абаляева В.В. Электрохимический синтез полианилина на алюминиевом электроде / Абаляева В.В., Ефимов О.Н. // Электрохимия. - 1996. - Т. 32. - № 6. - С. 728-735.

[2] Семенова И.В. Коррозия и защита от коррозии: учеб. для вузов/ И.В.Семенова, Г. М. Флорианович, А. В. Хорошилов. М: Физматлит, 2006. -376 с.

[3] Вершина А.К. Состав-структура-свойства цветных металлов и сплавов, полимерных материалов / Лабораторный практикум // А. К. Вершина, Н. А. Свидунович, Д. В. Куис. - Минск: БГТУ, 2010. - 62 C. 


\title{
Part 4 \\ ELECTROCHEMICAL SENSORS
}

\author{
Розділ 4 \\ ЕЛЕКТРОХІМІЧНІ СЕНСОРИ
}


УДК 541.136

\title{
CATHODIC REDUCTION OF NITROGEN DIOXIDE BY MEDIATOR CATALYSIS
}

\author{
POLYANICHKO O.O., BUKET O.I. \\ National Technical University of Ukraine "Kyiv Polytechnic Institute" \\ alexa.polyanichko@gmail.com
}

Cathodic reduction of nitrogen dioxide is one of the possible ways to quantify this gas in the air. The problems of cathodic reduction of nitrogen dioxide were analysed on the catalytically active electrodes in a system with aqueous solutions of electrolytes, and it was shown that the limiting stages of this process were the transport of nitrogen dioxide through a layer of electrolyte and discharge of it. Taking into account the literature data and previous research a mediator homogeneous catalysis was suggested as a method for removing these limitations. Thermodynamic calculations showed the potential use of brominebromide redox systems in aqueous solution as a mediator of the oxidative action of nitrogen dioxide on the electrode. It was experimentally established that the system was capable of removing limitations of transport and kinetic stages, due to which the speed ratio of cathodic reduction reaction of nitrogen dioxide to atmospheric oxygen reduction reaction increases by three orders of magnitude.

\section{МЕДІАТОРНИЙ КАТАЛІЗ КАТОДНОГО ВІДНОВЛЕННЯ ДІОКСИДУ A30TY}

\author{
ПОЛЯНІЧКО О.О., БУКЕТ О.І. \\ Національний технічний університет України \\ «Київський політехнічний інститут»; alexa.polyanichko@gmail.com
}

Катодне відновлення діоксиду азоту є одним з можливих шляхів реалізації процесу кількісного визначення цього газу в повітряному середовищі. Проаналізовано проблеми катодного відновлення діоксиду азоту на каталітично активних електродах у системі 3 водними розчинами електролітів та показано, що лімітуючими стадіями цього процесу $€$ транспорт діоксиду азоту через шар електроліту і розряд. 3 огляду на літературні відомості та попередні дослідження запропоновано гомогенний медіаторний каталіз як засіб зняття названих обмежень. Термодинамічними розрахунками 
показано потенційну можливість використання редокс-системи бромбромід у водному розчині як медіатору окислювальної дії діоксиду азоту на електрод. Експериментально показано здатність обраної системи знімати як транспортні так і кінетичні обмеження, завдяки чому відношення швидкості катодної реакції відновлення діоксиду азоту до реакції відновлення атмосферного кисню збільшується на три порядки.

Діоксид азоту є токсичним газом, який негативно впливає на дихальну і серцево-судинну систему людини і теплокровних тварин. Моніторинг вмісту цього газу $є$ актуальним не лише на промислових виробництвах але й у великих містах, де діоксид азоту є одним 3 основних компонентів, а за деякими даними - каталізатором утворення, так званого фотохімічного смогу [1]. Один зі способів кількісного визначення цього реакційно здатного газу базується на його електрохімічній активності й полягає в катодному відновленні на електродах у системі з водним розчином електроліту. Основною проблемою при цьому $\epsilon$ паралельне відновлення атмосфрерного кисню, концентрація якого зазвичай на кілька порядків переважає концентрацію діоксиду азоту.

Зважаючи на успіхи медіаторного каталізу при амперометричному визначенні хлору на рівні кількох ppm у повітряному середовищі [2], запропоновано використати медіаторний каталіз для прискорення катодного відновлення діоксиду азоту на фоні атмосферного кисню.

\section{Методологія досліджень}

Дозування діоксиду азоту проводили термохімічним розкладанням розрахованої кількості (кількох міліграмів) насиченого розчину нітрату мангану безпосередньо у еластичній пластиковій ємності, у якій створювали газоповітряну суміш. Методика дозування протестована на похибки, викликані адсорбцією визначуваного газу, з застосуванням генератора і сенсора озону [3], як більш реакційно здатного і нестійкого газу.

Катодне відновлення проводили в стандартній скляній триелектродній комірці з комплекту потенціостата ПИ-50-1.1. Суміш $\mathrm{NO}_{2}$ з повітрям барботували через водний розчин електроліту біля електрода з платинованого титану (20 мг Pt на 1 г пористого титану). Геометрична площа відкритої поверхні електрода складала 2,5 см². Електролітом слугував $5 \mathrm{~m} \mathrm{LiBr} 3 \mathrm{pH}$, де бромід-іон відігравав роль медіатора. Потенціали наведені відносно н.в.е., а катодний струм подано як позитивний. 


\section{Результати та їх обговорення}

Примусовий барботаж повітря через розчин викликає очікуване зростання струму відновлення атмосферного кисню на робочому електроді комірки (крива 1, рис. 1) внаслідок зняття транспортних обмежень у рідкій фразі. Стаціонарні значення швидкості відновлення кисню за даних умов барботажу наведені у вигляді вольт-амперної кривої 1 на рис. 2. При появі діоксиду азоту у барботованій повітряній суміші катодний струм на робочому електроді суттєво зростає (крива 2, рис. 1).

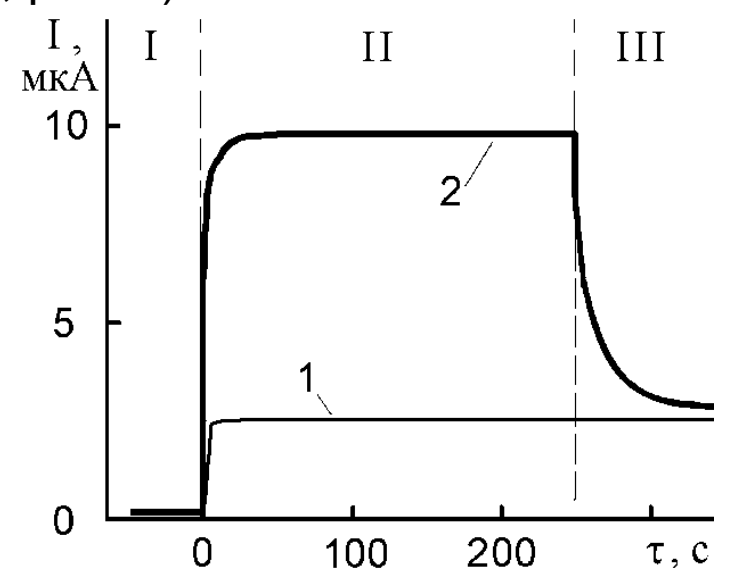

Puc. 1. Хроноамперограма пористого титанового електрода активованого 20 мг Pt на 1 г Ti у системі з водним розчином $5 \mathrm{~m} \mathrm{LiBr}$ з рH1 при потенціалі 0,5 B: I - без барботажу; II - барботаж суміші;

III - барботаж повітря; 1 - без $\mathrm{NO}_{2} ; 2$ - 5 ppm $\mathrm{NO}_{2}$.

За даними рис. 1 і додаткових дослідів при інших потенціалах робочого електрода, на рис. 2 побудовано вольт-амперну залежність для стаціонарного струму відновлення діоксиду азоту. Відхилення стаціонарних значень від апроксимації кривою 2 на рис. 2 пояснюються випадковою похибкою дозування діоксиду азоту внаслідок варіації маси краплі нітрату мангану, який піддавали термічному розкладанню.

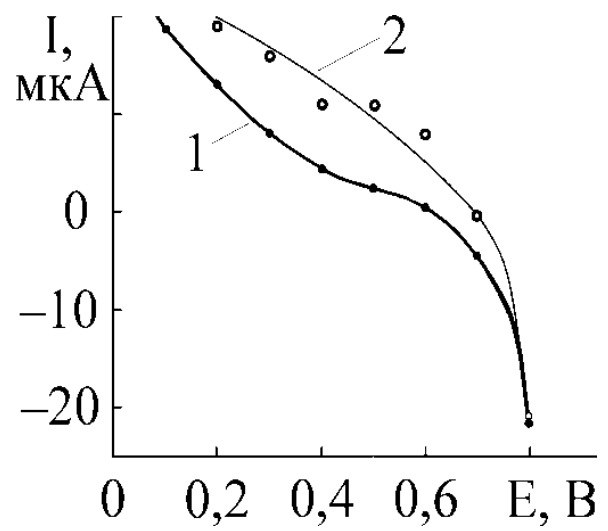

Puc. 2. Стаціонарна поляризаційна характеристика пористого титанового електрода з геометричною площею $2,5 \mathrm{~cm}^{2}$ активованого 20 мг Pt на 1 г Ti у водному розчині $5 \mathrm{~m} \mathrm{LiBr} \mathrm{при} \mathrm{pH1} \mathrm{за} \mathrm{умови} \mathrm{барботажу:}$ 1 - повітря; 2 - повітря з 5 ррт $\mathrm{NO}_{2}$. 
Ефективність медіаторного каталізу катодного відновлення діоксиду азоту слідує з порівняння співвідношень концентрацій атмосфрерного кисню i $\mathrm{NO}_{2}$ зі співвідношенням струмів їх відновлення. Так з рис. 2 слідує, що струми катодного відновлення кисню й діоксиду азоту $є$ щонайменше співмірними. При цьому, концентрація $\mathrm{NO}_{2}$ у повітряній суміші становила близько 5 ppm, тобто, була у 42000 раз меншою за концентрацію кисню, яка в атмосфрері становить 210000 ppm. Отже, з рис. 2 слідує, що медіаторний каталіз прискорює катодне відновлення діоксиду азоту на 4 порядки порівняно з паралельним відновленням кисню близько потенціалу 0,6 В. Загалом, при потенціалах нижче 0,6 В можна гарантувати прискорення катодного відновлення $\mathrm{NO}_{2}$ на три порядки. Варто відмітити, що досліди проведені 3 розчином $5 \mathrm{~m}$ $\mathrm{LiNO}_{3}$ показали цілковиту індиферентність випробуваного електрода до появи $\mathrm{NO}_{2}$ у газовій суміші. Зважаючи на потенційно низьку розчинність $\mathrm{NO}_{2}$ в концентрованих нітратних розчинах, можна стверджувати уповільненість як розряду, так і транспортної стадії.

Оборотна бром-бромідна реакція описується рівняннями [4]

$$
B r_{2}+2 e=2 B r^{-}, \quad E=1.087+0.0295 \cdot \lg \frac{\left[B r_{2}\right]}{a_{B r^{-}}^{2}},
$$

і має для кисню [4]

$$
2 \mathrm{H}_{2} \mathrm{O}=\mathrm{O}_{2}+4 \mathrm{H}^{+}+4 \mathrm{e}, \quad E=1.228-0.0591 \cdot p H+0.0147 \cdot \lg p_{O_{2}} .
$$

відігравати роль відновника при $\mathrm{pH}<7$. При цьому для реакції [4]

$$
\begin{aligned}
& \mathrm{NO}_{2}+2 \mathrm{H}^{+}+2 \mathrm{e}=\mathrm{NO}+\mathrm{H}_{2} \mathrm{O}, \\
& E=1.045-0.0591 \cdot p H+0.0295 \cdot \lg \left(p_{\mathrm{NO}_{2}} / p_{\mathrm{NO}}\right) .
\end{aligned}
$$

бром-бромідна система (1) може виступати відновником лише при $\mathrm{pH}<<7$ (5 m LiBr було доведено до pH1 введенням певної кількості $\mathrm{HBr}$ ) навіть з урахуванням низької концентрації брому, близької до $5 \mathrm{M}$ активності броміду й приблизно рівних концентрацій $\mathrm{NO}_{2}$ і $\mathrm{NO}$ в приелектродному просторі.

Проте з даних рис. 2 слідує, що кисень повітря при потенціалах нижче 0,6 В відновлюється повільніше ніж $\mathrm{NO}_{2}$ щонайменше у кілька тисяч раз. Отже, бром-бромідна система, реагуючи $3 \mathrm{NO}_{2}$ за рівнянням

$$
\mathrm{NO}_{2}+2 \mathrm{Br}^{-}+2 \mathrm{H}^{+}=\mathrm{NO}+\mathrm{Br}_{2}+\mathrm{H}_{2} \mathrm{O} \text {, }
$$


виступає у ролі селективного медіатора. Вірогідною причиною селективності $\epsilon$ відома попередня реакція $\mathrm{NO}_{2}$ з водою, яка перебігає з утворенням кислот через проміжні стадії з генерацією короткоживучих радикалів, тоді як кисень з водою у відчутну хімічну взаємодію не вступає і навіть гідрати утворює при тиску до 100 атм. Така селективна взаємодія $\mathrm{NO}_{2}$ з бромідом на фоні кисню дозволяє на порядки прискорити абсорбцію діоксиду азоту з повітряної суміші. До того ж, відновлення утвореного у реакції (4) галогену за реакцією (1) перебігає зі значно меншою перенапругою, ніж відновлення кисню. Таким чином, медіаторний каталіз знімає як транспортні, так і кінетичні обмеження з відновлення $\mathrm{NO}_{2}$, окислювальна дія якого відповідає межі відновлювальних властивостей бром-бромідної системи. Тобто, дана медіаторна система $€$ селективною до слабшого за кисень окисника.

\section{Висновки}

Показано, що взаємодія діоксиду азоту з бром-бромідною редокс-системою водного розчину електроліту відбувається незважаючи на їх практично близькі потенціали при $\mathrm{pH} 1$. При цьому, взаємодія цієї редокс-системи з киснем повітря відбувається повільніше щонайменше на три порядки.

Можлива причина селективності дослідженого медіаторного каталізу катодного відновлення $\mathrm{NO}_{2}$ на фоні кисню полягає у здатності діоксиду азоту хімічно реагувати з водою з утворенням кислот і радикалів. Результатом хімічної реакції бромідом у розчині $\mathrm{LiBr} €$ прискорення абсорбції $\mathrm{NO}_{2}$, що знімає транспортні обмеження у рідкій фразі, та утворення розчиненого у воді брому, що значно легше відновлюється на робочому електроді.

Загалом, електрод з платинованого титану у системі з водним розчином $\mathrm{LiBr}$ може бути використаний для селективного кількісного амперометричного визначення $\mathrm{NO}_{2}$ на фоні атмосфрерного кисню.

\section{Перелік посилань}

[1] Владимиров А.М., Ляхин Ю.И. Охрана окружающей среды. Л.: Гидрометеоиздат, 1991. - 422 с.

[2] Buket O., Linyucheva O., Nahorniy O., Bludenko A., Linyuchev O. Extending the range of amperometric sensors // Chemistry and Chemical Technology. - 2015. - № 9(2). - P. 251-255.

[3] Чвірук В.П., Букет О.І. Вихід за струмом озону на свинцевому аноді в ортофросфорній кислоті // Вісник Львівського університету. Серія хімічна. Частина1. - 2002. - С. 226-228.

[4] Справочник по электрохимии / Под ред. Сухотина А.М., изд. 4е, испр. и доп. - Л.: Химия, 1981. - 488 с. 
УДК 620.193 .2

\title{
THE EFFECT OF THE NUMBER OF ELECTRODE COUPLES ON THE SENSITIVITY OF ELECTROCHEMICAL SENSORS OF ATMOSPHERIC CORROSION RATE
}

\author{
OSADCHUK S.A., NYRKOVA L.I., MELNICHUK S.L. \\ PWI. Paton NASU. 03680, Kiev-150,Str. Malevich, 11. \\ svetlanaosadchuk@meta.ua
}

The influence of the number of electrode couples on the sensitivity of electrochemical sensors was investigated for the estimation of the corrosion rate of carbon steel in atmospheric conditions. It was shown that at increasing the number of electrode couples of the sensor from one to two the ratio of electrode width to the thickness of insulation layer increases by a factor of 1,75 , and at increasing the number of electrode couples from two to four the thickness increases by a factor of 1,3 . The further increasing of the number of electrode couples in the sensor will not significantly increase its sensitivity.

\section{ВЛИЯНИЕ КОЛИЧЕСТВА ЭЛЕКТРОДНЫХ ПАР НА ЧУВСТВИТЕЛЬНОСТЬ ЭЛЕКТРОХИМИЧЕСКИХ ДАТЧИКОВ СКОРОСТИ АТМОСФЕРНОЙ КОРРОЗИИ}

\author{
ОСАДЧУК С.А., НЫРКОВА Л.И., МЕЛЬНИЧУК С.Л. \\ ИЭС им. Е. О. Патона НАН Украины. 03680, г. Киев-150, \\ ул. К. Малевича, 11; svetlanaosadchuk@meta.ua
}

Исследовано влияние количества электродных пар на чувствительность электрохимических датчиков для оценки скорости коррозии углеродистой стали в атмосферных условиях. Показано, что при увеличении количества электродных пар датчика от одной до двух отношение ширины электрода к толщине электроизолирующей прослойки увеличивается в 1,75 раз, а от двух до четырех - в 1,3. Дальнейшее увеличение количества электродных пар датчика практически не будет способствовать существенному повышению его чувствительности.

\footnotetext{
* Авторы выражают искреннюю благодарность Ю.Ф. Фатееву, доценту, заслуженному преподавателю «Химико-технологического фракультета» НТУУ «КПИ» за предложения и замечания, полученные в ходе работы.
} 
Известно, что при определении мгновенной скорости коррозии одним из наиболее используемых является метод поляризационного сопротивления, рабочий инструмент которого электрохимические датчики, применяемые в электропроводящих средах: водах, обводненных нефтепродуктах, охлаждающих жидкостях, под смазочными материалами и т.д. [1]. Разнообразие конструкционных решений датчиков обусловлено требованиями объектов контроля, эксплуатирующихся в различных условиях.

Применение электрохимических методов коррозионного мониторинга для наблюдения за тонкопленочной коррозией затруднено из-за высокого омического сопротивления электролита. Для преодоления этой проблемы разработаны электрохимические ячейки с коповерхностным расположением электродов [1]. Методический подход к разработке чувствительного элемента многоэлектродного датчика скорости атмосферной коррозии в тонких пленках основывался на теоретических основах метода поляризационного сопротивления и определении оптимальных критических параметров коповерхностных электродов в соответствии с соотношением [1]:

$$
\mathrm{p}_{\text {крит. }} \approx 0,1 \mathrm{q}_{\text {крит.' }}
$$

где q - ширина электрода;

p - толщина электроизолирующей прослойки.

Отмечено [1], что при использовании датчика с коповерхностным расположением электродов с параметрами $q \leq 400$ мкм и $\mathrm{p} \leq 40$ мкм можно определять скорости коррозии сталей, в том числе, сварных соединений с погрешностями менее $10 \%$ практически в любых условиях тонкопленочной коррозии. Однако, влияние количества электродных пар на чувствительность датчиков авторами [1] не рассматривалось.

Цель работы состояла в изучении влияния количества электродных пар на чувствительность многоэлектродных коповерхностных датчиков для оценки скорости коррозии в условиях защиты от атмосферной коррозии (продувание сухим воздухом, применение ингибиторов и т.д.), в тонких фразовых и адсорбционных пленках толщиной от 0,6 до 45 мкм при $100 \%$ относительной влажности воздуха и температуре от $24{ }^{\circ} \mathrm{C}$ до $50{ }^{\circ} \mathrm{C}$.

\section{Методология исследований}

Скорость коррозии определяли двумя методами: массометрии по стандартным методикам и поляризационного сопротивления [1]. 


\section{Результаты и их обсуждение}

Характеристика разработанных датчиков с разным количеством электродных пар приведена в табл. 1, 3D схема многоэлектродного датчика - на рис. 1.

\section{Таблица 1. Характеристика исследуемых датчиков}

\begin{tabular}{|c|c|c|c|c|c|c|}
\hline \multirow{2}{*}{$\begin{array}{c}\text { Вид датчика } \\
\text { и количество } \\
\text { электродных } \\
\text { пар }\end{array}$} & \multicolumn{3}{|c|}{ Размер электродов, мм } & \multirow{2}{*}{$\begin{array}{c}\text { Максималь- } \\
\text { ная толщина } \\
\text { электроизоли } \\
\text {-рующей } \\
\text { прослойки р, } \\
\text { мм }\end{array}$} & \multirow{2}{*}{$\begin{array}{c}\text { Соот- } \\
\text { ноше- } \\
\text { ние } \\
p / q\end{array}$} & \multirow{2}{*}{$\begin{array}{c}\text { Площадь } \\
\text { чувстви- } \\
\text { тельного } \\
\text { элемента } \\
\text { S, см }{ }^{2}\end{array}$} \\
\hline & $\begin{array}{c}\text { Длина } \\
\text { I }\end{array}$ & $\begin{array}{l}\text { Шири- } \\
\text { на q }\end{array}$ & $\begin{array}{l}\text { Тол- } \\
\text { щина }\end{array}$ & & & \\
\hline $\begin{array}{l}\text { модель } 1, \\
\text { одна пара }\end{array}$ & 45 & 10 & 5,8 & 0,325 & 0,0325 & 9,0 \\
\hline $\begin{array}{l}\text { модель 2, } \\
\text { одна пара }\end{array}$ & 50 & 10 & 2 & 0,200 & 0,0200 & 5,0 \\
\hline $\begin{array}{l}\text { модель 3, } \\
\text { две пары }\end{array}$ & 50 & 2 & 10 & 0,070 & 0,0350 & 2,0 \\
\hline $\begin{array}{c}\text { модель } 4, \\
\text { четыре пары }\end{array}$ & 50 & 3 & 2 & 0,140 & 0,0467 & 6,0 \\
\hline
\end{tabular}

Для повышения чувствительности датчиков уменьшали толщину электроизолирующего слоя до значений, сопоставимых с толщиной влажной пленки и повышали его переходное электрическое сопротивление, уменьшали ширину и толщину электродов, увеличивали их количество.

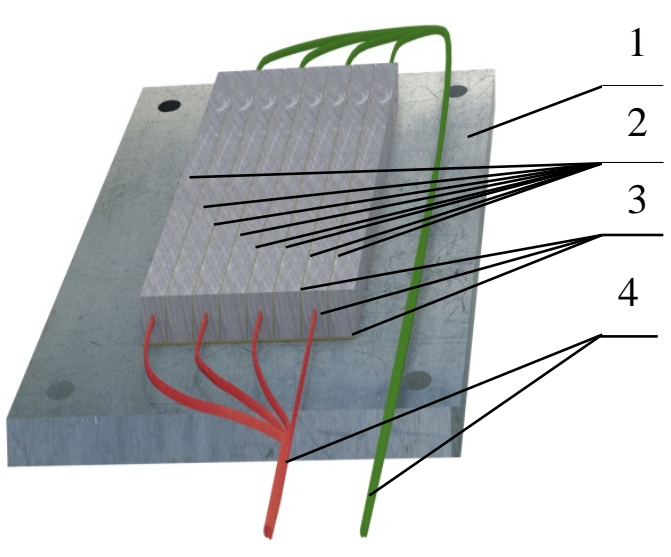

Puc. 1. Общий вид многоэлектродного датчика:

1 - металлическая основа;

2 - электроды чувствитель-ного элемента датчика;

3 - диэлектрический слой; 4- токоотвод

Для уменьшения разницы между температурой датчика и температурой среды его крепили на подложке из теплопроводного материала [2].

Важным параметром, влияющим на чувствительность электрохимических датчиков с коповерхностным расположением электродов, является соотношение ширины электродов к толщине электроизолирующего слоя. Для сравнения чувствительности датчиков с разным количеством электродов, которое определяется скоростью коррозии, это соотношение было рассчитано, 
и полученные данные представлены в табл. 1. Поскольку при увеличении количества электродных пар датчика от одной до двух отношение $\mathrm{p} / \mathrm{q}$ увеличивается в 1,75 раз, а от двух до четырех - в 1,3, то можно предположить, что дальнейшее увеличение количества электродных пар датчика не будет способствовать существенному повышению его чувствительности. Поэтому датчик с
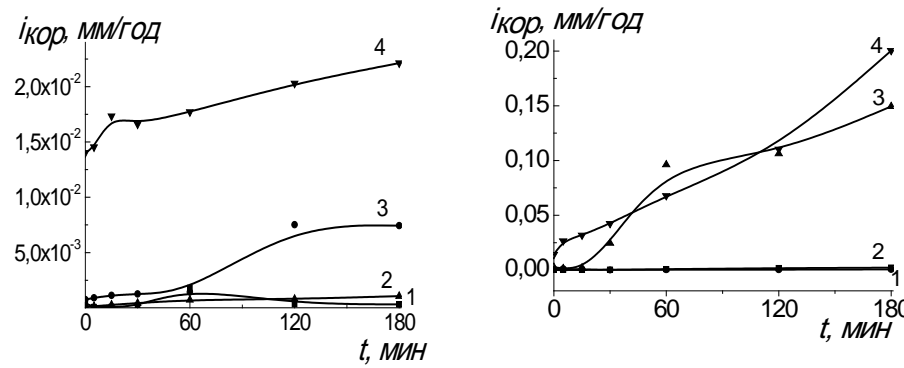

a

6

Puc. 2. Скорость коррозии, определенная с помощью датчиков с разным количеством электродных пар при относительной влажности $100 \%$ и температуре $24^{\circ} \mathrm{C}$ (a) u $50^{\circ} \mathrm{C}(6)$ :

1 - модель 1 (одна пара); 2 - модель 2 (одна пара); 3 - модель 3 (две пары); 4 - модель 4 (четыре пары) четырьмя электродными парами обеспечит определение скорости коррозии в тонких пленках с заданной точностью. Проверка чувствительности датчиков различных моделей по показателю скорости коррозии при относительной влажности воздуха $100 \%$ и температуре $24 \quad{ }^{\circ} \mathrm{C}$ (рис. 2, а) без конденсации влаги и $50{ }^{\circ} \mathrm{C}$ (рис. 2, б) с конденсацией влаги подтвердила предположение о достаточности четырех электродных пар в его конструкции для определе-ния скорости коррозии в условиях образования адсорбционных пленок. Как видно (рис. 2), при комнатной температуре, когда влага не конденсируется, наибольшую чувствительность продемонстри-ровал многоэлектродный датчик с четырьмя электродными парами (рис. 2, a, б, кривая 4). Сравнивая значения скоростей коррозии, полученные методом поляризационного сопротивления и массометрии (рис. 2 и табл. 2) установлено, что более объективные результаты получены с помощью датчика с четырьмя электродными парами (модель 4).

Таблица 2. Результаты определения скорости коррозии углеродистой стали методом массометрии и поляризационного сопротивления $c$ помощью датчиков разных моделей при различных температурах и относительной влажности воздуха $100 \%$

\begin{tabular}{|c|c|c|c|c|c|}
\hline Tемпера- & \multicolumn{5}{|c|}{ Скорость коррозии, мм/год } \\
\cline { 2 - 5 } & $\begin{array}{c}\text { Метод } \\
\text { мура }\end{array}$ & \multicolumn{4}{|c|}{ Метод поляризационного сопротивления } \\
\cline { 3 - 6 } & рии & 1 & 2 & 3 & 4 \\
\cline { 3 - 6 } & 0,005 & 0,00032 & 0,0014 & 0,0011 & 0,022 \\
\hline 24 & 0,076 & 0,0041 & 0,0039 & 0,150 & 0,20 \\
\hline
\end{tabular}


Изменение плотности тока в контролируемых атмосферных условиях при относительной влажности воздуха $100 \%$ и температуре $24{ }^{\circ} \mathrm{C}$ с периодичностью 0,25 часа, определенное при помощи датчиков с разным количеством электродных пар (рис. 3) подтверждает более высокую чувствительность датчика многоэлектродной системы в этих условиях.

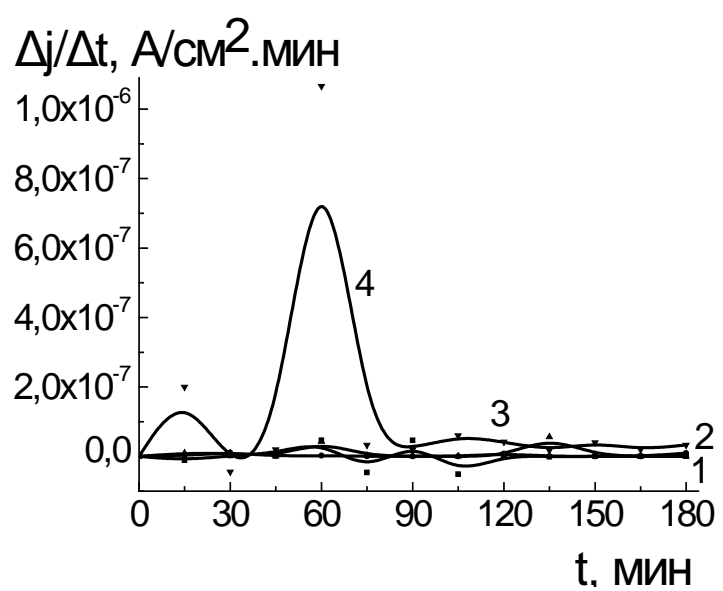

Puc. 3. Изменение плотности тока при относи-тельной влажности воздуха $100 \%$ и температуре $24^{\circ} \mathrm{C}$ с периодичностью 0,25 часа при помощи датчиков с разным количеством электродных пар: 1 - модель 1 (одна пара); 2 - модель 2 (одна пара); 3 - модель 3 (две пары); 4 - модель 4 (четыре пары)

\section{Выводы}

При увеличении количества электродных пар датчика скорости атмосферной коррозии в тонких пленках влаги от одной до двух отношение ширины электродов к ширине электроизолирующей прослойки увеличивается в 1,75 раз, а от двух до четырех - в 1,3. Дальнейшее увеличение количества электродных пар датчика, не будет способствовать существенному повышению его чувствительности. Применение датчика с четырьмя электродными парами для определения скорости атмосфрерной коррозии углеродистой стали в адсорбционных пленках продемонстрировало удовлетворительное совпадение с результатами массометрии.

\section{Лumepamypa}

[1] Чвірук В. П. Електрохімічний моніторинг техногенних середовищ / Чвірук В. П., Поляков С. Г., Герасименко Ю. С. - Київ, Академперіодика, - 2007. - 323 с.

[2] № 70510 України, МПК G 01 N 17/00, G 01 N 23/00. Давач для вимірювання швидкості корозії в тонких плівках / Ниркова Л. І., Осадчук С. О., Мельничук С. Л., Гапула Н. О., Яковенко Г. М. ; заявлювач та патентовласник IE3 ім. Є. О. Патона. - № u2011 15328 ; заявл. 26.12.2011 ; - опубл. 11.06.2012, Бюл. № 11. 
УДК 621.357.2-543.257-541.135

\title{
CHLORINE EMISSION MONITORING IN THE COPPER ELECTROWINNING PROCESS FROM LEACH SOLUTIONS OF CARBONATE ORES
}

\author{
USHCHAPOVSKYI D.YU., LINYUICHEV O.G., TSYMBALIUK A.S. \\ National Technical University of Ukraine "Kyiv Polytechnic Institute"; \\ soltdim@gmail.com
}

The process of compact copper electrowinning from chloridecontaining solutions of carbonate ores leaching was investigated. The industrial rectifier "Kraft Flex" by Kraft Powercon was used as a DC power source. The estimation of chlorine emissions at the work of a semi-industrial cell was carried out by using the NTUU "KPI" series of two-electrode amperometric sensors. It was shown that at a concentration of chloride ion in pregnant leach solution of about 0,5 $\mathrm{g} / \mathrm{dm}^{3}$ the chlorine concentration in the air stream above the electrowinning cell in electrowinning with a current density of $5 \mathrm{~A} / \mathrm{dm}^{2}$ can achieve $4 \mathrm{mg} / \mathrm{m}^{3}$ (four times higher than the MPC of working zone). Technological calculation confirms profitability of chlorine utilisation as a collateral product of the copper electrowinning process in the form of highly profitable product - sodium hypochlorite solution.

\section{МОНІТОРИНГ ВИКИДІВ ХЛОРУ ПРИ ЕЛЕКТРОЕКСТРАКЦІЙНОМУ ОТРИМАННІ МІДІ 3 РОЗЧИНІВ ВИЛУГОВУВАННЯ КАРБОНАТНИХ РуД}

УЩАПОВСЬКИЙ Д. Ю., ЛІНЮЧЕВ О. Г., ЦИМБАЛЮК А. С. Національний технічний університет України «Київський політехнічний інститут», soltdim@gmail.com

Досліджено процес електроекстракції компактної міді з хлоридвмісних розчинів вилуговування карбонатних мідних руд. Здійснено оцінку обсягів викидів хлору при роботі напівпромислової лабораторної комірки. Проведено технологічні розрахунки, що підтверджують рентабельність утилізації хлору як побічного продукту при електроекстракції міді, у вигляді високоліквідного товарного продукту - медичного розчину гіпохлориту натрію. 
Однією 3 важливих проблем, яка виникає при роботі гідрометалургійних виробництв, $€$ утилізація відходів переробки рудних матеріалів [1]. Зокрема при гідроелектрометалургійному отриманні міді 3 оксидних чи карбонатних руд на стадії вилуговування в розчин можуть переходити хлорид іони, які при подальшому електроекстракційному отримані міді будуть окислюватись на аноді з утворенням молекулярного хлору. 3 одногу боку, хлор $є$ екологічно небезпечним та має руйнівну дію по відношенню до обладнання. 3 іншого боку, хлор $\epsilon$ цінною промисловою сировиною і набув широкого застосування у багатьох галузях хімічної промисловості. Виходячи з вищенаведеного можна виділити ряд важливих прикладних завдань, вирішення яких буде наведено в даній роботі:

- визначення вмісту хлору у повітряному просторі над напівпромисловою коміркою електроекстракції міді;

- прогнозування обсягів викидів хлору та вибір способу їх утилізації.

\section{Методологія дослідження}

Для дослідження застосовувались сульфатно-кислі мідьвмісні розчини, отримані шляхом вилуговування природних карбонатних руд та модельні розчини. Вилуговування карбонатних руд здійснювали 9\% розчином сульфатної кислоти. Концентрацію хлорид іонів в розчинах визначали за допомогою потенціометричного титрування $0,01 \mathrm{M}$ розчином нітрату срібла. Розчини містили г/дм³ $: 180$ - $207 \mathrm{CuSO}_{4} \cdot 5 \mathrm{H}_{2} \mathrm{O} ; 10-100 \mathrm{H}_{2} \mathrm{SO}_{4} ; 0,4$ $0,8 \mathrm{Fe}^{3+} ; 0,4-0,5 \mathrm{Cl}^{-}$.

Для досліджень застосовувалася прямокутна напівпромислова комірка робочим об'ємом 9,6 дм³, виконана 3 пластику. В якості катода застосовувалася пластина 3 нержавіючої сталі X18H9T із робочою площею $14 \mathrm{дм}^{2}$. Торці катода ізолювались струмонепровідним захисним екраном. В якості анода використовувалась пластина із хімічно-чистого свинцю з робочою

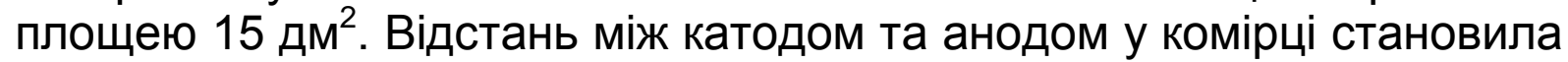
50 мм. Дзеркало електроліту, з метою зменшення випаровування та винесення електроліту, вкривалось шаром піно-полістирольних фррагментів. Над коміркою розташовувалась місцева вентиляційна система з продуктивністю $105 \mathrm{~m}^{3} /$ год.

Електроекстракцію міді здійснювали зі ступінчастим зниженням робочої густини струму в часі, відповідно до зменшення концентрації іонів міді в розчині [2]. Перед електроосадженням міді за технологічної густини струму, на катод 3 нержавіючої сталі 
нарощували первинний шар міді за густини струму 0,45 $\mathrm{A} / \mathrm{дm}^{2}$ (операція затяжки). В якості джерела постійного струму використовувався промисловий двоблоковий випрямляч Kraft Flex фрірми Kraft Powercon із паралельним з'єднанням блоків.

Визначення концентрації хлор у повітрі над коміркою здійснювали за допомогою уніфрікованої серії газових сенсорів серії НТУУ «КПІ» [3], а саме, амперометричного сенсору хлору 3 діапазоном концентрацій $0-5 \mathrm{ppm}\left(0-14 \mathrm{mг} / \mathrm{m}^{3}\right)$. Оскільки ГДК хлору у повітрі робочої зони складає $2,8 \mathrm{ppm}\left(1 \mathrm{mr} / \mathrm{m}^{3}\right)$, тому всі виробництва потребують особливих заходів щодо техніки безпеки, складовою яких $€$ постійний моніторинг повітряного середовища. Сенсор хлору на основі твердотільних систем 3 матричним електролітом придатний для використання при температурі від $-30 \div$ $+50{ }^{\circ} \mathrm{C}$, як в умовах циклічної зміни вологості, так і при стабільно низькій відносній вологості повітряного середовища (від 10 до 98 \%) [4]. Сенсор хлору НТУУ «КПІ» являє собою двоелектродну електрохімічну комірку, яка реагує на хлор, котрий $€$ у повітрі, утворюючи при цьому неперервний струмовий сигнал. Сила струм, яка генерувалася сенсором, прямо пропорційна концентрації хлору в повітрі і реєструвалася за допомогою двопозиційного координатного самописця ПДА-1. Сенсор розміщувався на відстані 7 см від дзеркала електроліту у комірці під коробом місцевої вентиляційної системи, таким чином, щоб сенсор експлуатувався в дифузійному режимі. Чутливість сенсора хлору складала 3,3 мкА / ppm (1,18 мкА / $\left.\mathrm{Mr} / \mathrm{M}^{3}\right)$.

\section{Результати та їх обговорення}

Експериментальні дані, отримані при електрохімічній екстракції міді з хлорид-вмісного розчину представлено на рис. Як видно з рис. а., на першому етапі електроосадження міді (режим затяжки катода), при накладанні сили струму 6,3 А протягом 2,05 год роботи спостерігався струмовий сигнал від сенсору, який відповідав концентрації хлору близько $1 \mathrm{mг} / \mathrm{M}^{3}$. При накладанні технологічних величин струмового навантаження 92 - 56 А, спостерігалось різке зростання та подальше зниження концентрації хлору, за 2,325 год, від 6,5 до $3,2 \mathrm{mr} / \mathrm{M}^{3}$ (рис. б, крива 3), яке можна апроксимувати наступним рівнянням:

$$
\left[\mathrm{Cl}_{2}\right]=15,57 \mathrm{e}^{-0,43 \mathrm{~T}}\left(\mathrm{R}^{2}=0,7854\right) .
$$




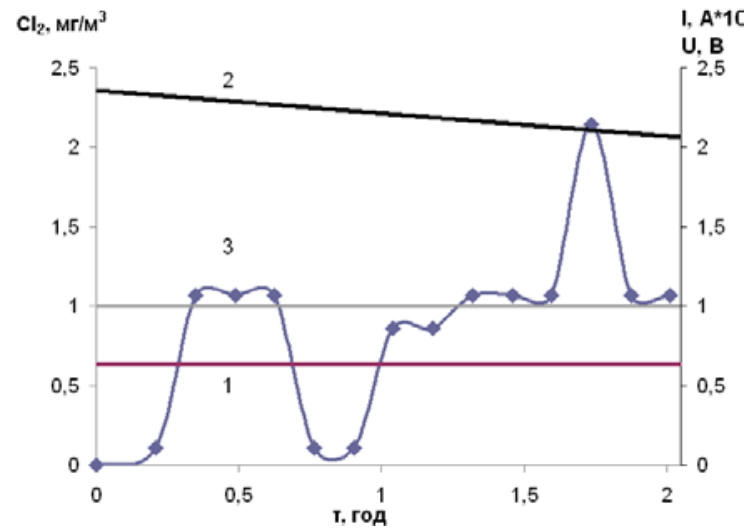

a

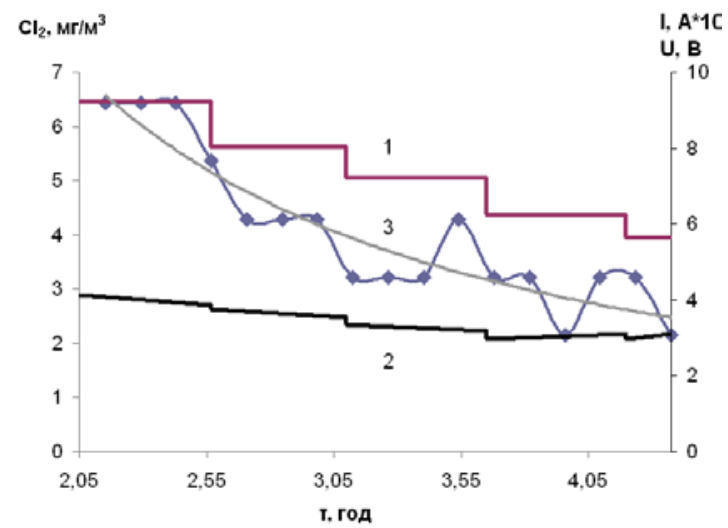

6

Puc. Зміна основних параметрів в часі процесу електрохімічної екстракції міді:

а) режим затяжки катода; б) технологічний режим електроекстракції. 1 графок зміни робочої сили струму в часі; 2 -зміна напруги в часі; 3 залежність зміни концентрації хлору в часі.

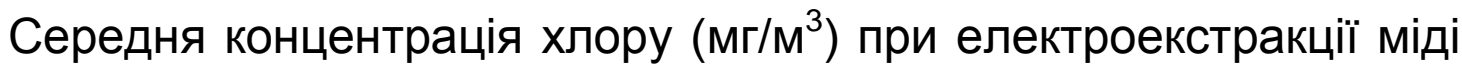
за технологічних величин густин струму може бути визначена шляхом інтегрування рівняння (1) за фрормулою трапеції. Відповідно до отриманих експериментальних та розрахункових даних можна визначити ряд основних технологічних параметрів процесу виділення хлору на аноді при електроекстракції міді, що представлені в таблиці.

\begin{tabular}{|l|c|c|}
\hline \multicolumn{1}{|c|}{ Параметри, розмірність } & $\begin{array}{c}\text { Режим затяжки } \\
\text { катода }\end{array}$ & $\begin{array}{c}\text { Технологічний режим } \\
\text { електроосадження }\end{array}$ \\
\hline $\begin{array}{l}\text { Тривалість етапу } \\
\text { електроосадження, год }\end{array}$ & 2,05 & 2,33 \\
\hline $\begin{array}{l}\text { Обсяг поглинутого повітря в } \\
\text { процесі, м }\end{array}$ & 215 & 244 \\
\hline $\begin{array}{l}\text { Середня концентрація хлору } \\
\text { у повітряному потоці, мг/м }\end{array}$ & 1,00 & 9,94 \\
\hline $\begin{array}{l}\text { Сумарна кількість виділеного } \\
\text { хлору, мг }\end{array}$ & 215 & 4,99 \\
\hline $\begin{array}{l}\text { Середня величина анодної } \\
\text { густини струму, А/дм }\end{array}$ & 0,40 & 74,84 \\
\hline $\begin{array}{l}\text { Середня величина робочого } \\
\text { струму, А }\end{array}$ & 6,30 & 174 \\
\hline Кількість електрики, А*гд & 12,9 & 0,42 \\
\hline Вихід за струмом, \% & 1,30 & 414 \\
\hline Продуктивність хлору мг/год & 105 & 4,7 \\
\hline $\begin{array}{l}\text { Питома продуктивність } \\
\text { хлору, г СІ } / \text { кг Си }\end{array}$ & - & \\
\hline
\end{tabular}


Як видно з таблиці, вихід за струмом хлору у процесі електроекстракції міді за анодної густини струму 0,4-6,1 $\mathrm{A} / \mathrm{дm}^{2} \epsilon$ дуже малим, що зумовлено відносно малим вмістом хлорид іонів у розчині $\left(0,5\right.$ г/дм $\left.{ }^{3}\right)$, і не перевищує 1,3 \%. Сумарна зміна концентрації хлорид іонів в розчині за весь час електролізу не перевищує 20 \%, а отже зменшення концентрації хлору у потоці повітря при технологічному режимі електроекстракції в основному пов'язане зі зменшенням робочої густини струму.

Концентрація хлору у повітряному потоці над коміркою при

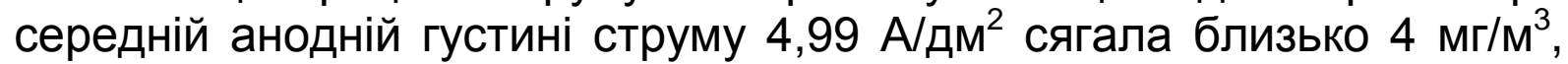
що у 4 разів вище за ГДК хлору у повітрі робочої зони. Якщо виділити замкнений об'єм робочої зони 2×2×2 м³, то за відсутності засобів вентиляції при роботі лабораторної напівпромислової комірки через 2,325 год, концентрація хлору складатиме близько 120 мг/м³, що в 120 разів вище за ГДК хлору у повітрі робочої зони.

Питома продуктивність хлору при електроекстракції міді за анодної густини струму 4,99 А/дм ${ }^{2}$ та відповідно катодної 5,3 A/дм² складає близько 4,7 г $\mathrm{Cl}_{2} /$ кг Cu. Тобто, при електроосадженні 1 т високочистої міді 3 розчинів вилуговування карбонатних руд, що містять близько 0,5 г/дм³, можна отримати близько 4,7 кг хлору. Одним з можливих шляхів утилізації хлору $€$ його поглинання в насадкових апаратах колонного типу розчинами гідроксидів натрію або кальцію, в наслідок чого можуть бути отримані розчини хлоридів та гіпохлоритів цих металів. При повному поглинанні 4,7 кг хлору 100 дм $^{3} 6$ \%-вого розчину $\mathrm{NaOH}$ можна отримати відповідний об'єм $5 \%$ розчину гіпохлориту натрію. Такий розчин $є$ технологічно придатним для використання в якості медичного дезінфікуючого засобу, ринкова вартість якого складає близько 30 грн /0,1 дм³.

\section{Висновки}

Здійснено оцінку обсягів викидів хлору при роботі напівпромислової комірки електроекстракції міді 3 хлоридвмісних сульфатно-кислих розчинів вилуговування карбонатних руд. Встановлено, що при реалізації електрохімічної екстракції міді, 3 розчинів, які містять близько 0,5 г/дм ${ }^{3}$ хлорид іонів, може бути досягнуто 120-ти кратне перевищення ГДК за концентрацією хлору у замкненому об'ємі робочої зони $8 \mathrm{~m}^{3}$.

На основі технологічних розрахунків показано, що при отриманні однієї тони високочистої катодної міді з хлоридвмісних розчинів вилуговування карбонатних руд можна отримати близько 4,7 кг хлору. Запропоновано здійснення утилізації хлору шляхом поглинання розчинами гідроксиду натрію. Процес утилізації хлору $є$ однією зі складових комплексного способу переробки багатих на 
мідь окиснених та карбонатних руд [1], реалізація якого дозволить створити рентабельне, гнучке в умовах ринку, безвідходне та екологічно-безпечне виробництво.

\section{Подяка}

Колектив авторів висловлює щиру вдячність фрірмі Kraft Powercon за надану можливість працювати 3 промисловим випрямлячем Kraft Flex.

\section{Список посилань}

[1] Комплексна переробка багатих на мідь окислених та карбонатних руд / Д.Ю. Ущаповский, О.В. Лінючева, М.І. Донченко, М.В. Бик // Сучасні проблеми електрохімії: освіта, наука, виробництво: збірник наукових праць. - Харків: НТУ «ХПІ». - 2015. С. $192-193$.

[2] Разработка высокопродуктивных токовых режимов процесса электроэкстракции меди в виде компактного металла / Д. Ю. Ущаповский, М. И. Донченко, О. В. Линючева, Д. Н. Складанный // Восточно-европейский журнал передовых технологий. - 2014. 6(72). - C. 48 - 55. DOI: 10.15587/1729-4061.2014.30660

[3] Патент України №43414 Електрохімічна комірка для визначення галогенів у повітрі / В.П. Чвірук, О.В. Лінючева, С.В. Нефьодов.17.12.2001. Бюл.№11.

[4] Чвірук В.П., Лінючева О.В. Електрохімічні газові сенсори для моніторингу повітряного середовища // Вопросы химии и химической технологии. - 1999. - №1. - С. 359 - 361. 
УДК 66.028.2+66.087+661.971.9

\title{
A CARBON DIOXIDE GENERATOR FOR CALIBRATION OF ELECTROCHEMICAL SENSORS
}

MATVEEV O.M., MAZANKA V.M., KOSOHIN O.V.

National technical university of Ukraine "Kyiv polytechnic institute"

o.kosogin@kpi.ua

Usage of modern means of monitoring the ambient air of industrial and domestic gas environments require periodic inspection of their efficiency. This can be done using the coulometric generator of gasanalyte. Coulometrically carbon dioxide can be obtained by electrolysis of carboxylic acids solutions, using electrodes with high overvoltage of secondary processes. It is shown that the production of high purity carbon dioxide (about $90 \%$ ) with stable current output (60\%) is possible during electrolysis of the oxalic acid with the dioxide lead anode. Generator may be used to periodically verify the $\mathrm{CO}_{2}$ sensors, which are used in municipal and agriculture, the food industry and for improving safety in the mines.

\section{ГЕНЕРАТОР ДІОКСИДУ ВУГЛЕЦЮ ДЛЯ КАЛІБРУВАННЯ ЕЛЕКТРОХІМІЧНИХ СЕНСОРІВ}

\author{
МАТВЄЄВ О. М., МАЗАНКА В.М., КОСОГІН О.В. \\ Національний технічний університет України «Київський \\ політехнічний інститут»; o.kosogin@kpi.ua
}

Застосування сучасних засобів моніторингу повітряного середовища промислових та побутових газових середовищ потребує періодичної перевірки їх роботоспроможності. Кулонометричне отримання діоксиду вуглецю можливе шляхом електролізу розчинів карбонових кислот 3 використанням електродів 3 високою перенапругою побічних процесів. Показано, що електролізом оксалатної кислоти 3 діоксидно-свинцевим анодом можливе отримання діоксиду вуглецю достатньо-високої чистоти (близько $90 \%$ ) із стабільним виходом за струмом $60 \%$. Створений дозатор може бути використаний для періодичної перевірки сенсорів $\mathrm{CO}_{2}$, що застосовуються у комунальному та сільському господарстві, харчовій промисловості та для підвищення безпеки праці на шахтах.

Сучасний розвиток промисловості неможливий без урахування екологічних наслідків реалізації конкретної технології, що вимагає 
застосування надійних засобів моніторингу повітряного середовища. Переважна більшість технічних засобів моніторингу повітряного середовища базується на електрохімічних сенсорах, яким притаманні висока надійність, точність, простота обслуговування, низьке енергоспоживання і доступність. В той же час, ефективність використання технічних засобів моніторингу спирається на коректність вимірювання концентрації, а отже, потребує періодичної повірки.

Повірку газоаналізаторів різних типів проводять 3 використанням стандартних газових сумішей, які можуть бути приготовлені методами статичного та динамічного дозування [1]. Статичні методи передбачають наявність еталонних газобалонних сумішей, які в заданій кількості вводять у калібровану замкнену ємність. Метод дозволяє готувати суміші з будь-якою концентрацією визначуваного компоненту, проте мало придатний для повірки великої кількості газоаналізаторів внаслідок зміни складу газоповітряної суміші, відрізняється значними габаритами газобалонної техніки та неможливістю автоматизації процесу. Динамічні методи передбачають створення газової суміші змішуванням потоків газу-розбавлювача та газу-визначуваного компонента, що дозволяє швидко змінювати концентрацію суміші у широких межах. Дозатором газу-визначуваного компонента при цьому може бути відповідний газовий балон, або, частіше, кулонометричний генератор, який відрізняється високою ефрективністю.

Діоксид вуглецю $\mathrm{CO}_{2}$ надзвичайно поширений у різних галузях промисловості та сільського і комунального господарства. Разом 3 тим, його надлишок або ж перевищення над фоновим містом може бути шкідливим, що вимагає постійного контролю, в першу чергу, у закритих приміщеннях. Визначення вмісту $\mathrm{CO}_{2}$ можливе за допомогою різних типів газоаналізаторів, в першу чергу електрохімічних сенсорів амперометричного типу, перевірка яких проводиться 3 використанням балонних сумішей та термохімічних дозаторів, які окрім громіздкості характеризуються значним енергоспоживанням та інерційністю в роботі [2, 3].

Кулонометричні генератори діоксиду вуглецю на даний момент відсутні, однак відомо, що $\mathrm{CO}_{2}$ як побічна речовина може бути отриманий при електролізі водних розчинів 3 використанням графрітових електродів, або як продукт в реакції анодного окислення карбонових кислот, а саме реакції Кольбе

де $\mathrm{R}$ - будь-який алкільний радикал.

$$
2 \mathrm{R}-\mathrm{COO}^{-}+2 \mathrm{e}^{-} \rightarrow \mathrm{R}-\mathrm{R}+2 \mathrm{CO}_{2} \uparrow,
$$


Використання для електролізу оксалатної кислоти дозволить отримати чистий діоксид вуглецю, не забруднений алканами [4]. Підбір умов електролізу та застосування електродів 3 високою перенапругою виділення кисню дозволить отримати $\mathrm{CO}_{2}$ відповідної чистоти та створити генератор діоксиду вуглецю для періодичної перевірки сенсорів в широкому діапазоні концентрацій визначуваного газу. Зокрема, було показано можливість принципової реалізації такої реакції на платинових анодах [1], однак доцільно дослідити процес електролізу оксалатної кислоти з використанням більш дешевих матеріалів, що характеризуються високою перенапругою виділення кисню.

\section{Методологія досліджень}

Електроліз проводили у гальваностатичному режимі в Uподібній комірці, що дозволяє без ускладнення конструкції забезпечити надійне розділення електродних газоподібних продуктів. Для електролізу використовували 10 \%-вий розчин оксалатної кислоти $\mathrm{H}_{2} \mathrm{C}_{2} \mathrm{O}_{4}$, концентрація якої була близька до насичення. Катоди були виготовлені з графріту. Як анодні матеріали були використані графріт та діоксид свинцю, що характеризуються високою перенапругою для реакцій виділення кисню [5]. $\mathrm{PbO}_{2}$ одержували електрохімічним осадженням на графрітову основу 3 нітратного електроліту.

Об'єм отриманого за час електролізу анодного газу приводили до нормальних умов. Оскільки на аноді одночасно перебігали два процеси

$$
\begin{aligned}
& \left(\mathrm{COO}^{-}\right)_{2} \rightarrow 2 \mathrm{CO}_{2}+2 \mathrm{e}, \\
& 2 \mathrm{H}_{2} \mathrm{O} \rightarrow \mathrm{O}_{2}+4 \mathrm{H}^{+}+4 \mathrm{e}
\end{aligned}
$$

то вміст діоксиду вуглецю визначали об'ємним методом, поглинаючи 3 відібраної у газову бюретку певної порції газу $\mathrm{CO}_{2}$ лужним розчином (15 \%-вий розчин $\mathrm{NaOH})$.

\section{Результати та їх обговорення}

Отримані результати дозволяють стверджувати (рис. 1), що для отримання діоксиду вуглецю з високим виходом за струмом доцільніше використовувати діоксидно-свинцеві матеріали завдяки їх більш високій перенапрузі в реакції виділення кисню. Чистота отриманого $\mathrm{CO}_{2}$ зростає на електродах обох типів при збільшенні густини струму внаслідок меншої поляризації реакції (1) порівняно із (2) (рис. 2). Зниження виходу за струмом $\mathrm{CO}_{2}$ на діоксиді свинцю при густині струму більше $10 \mathrm{~A} /$ дм $^{2}$ може бути пов'язано з механічним 
руйнуванням достатньо пористого шару $\mathrm{PbO}_{2}$ в результаті розігрівання електрода.

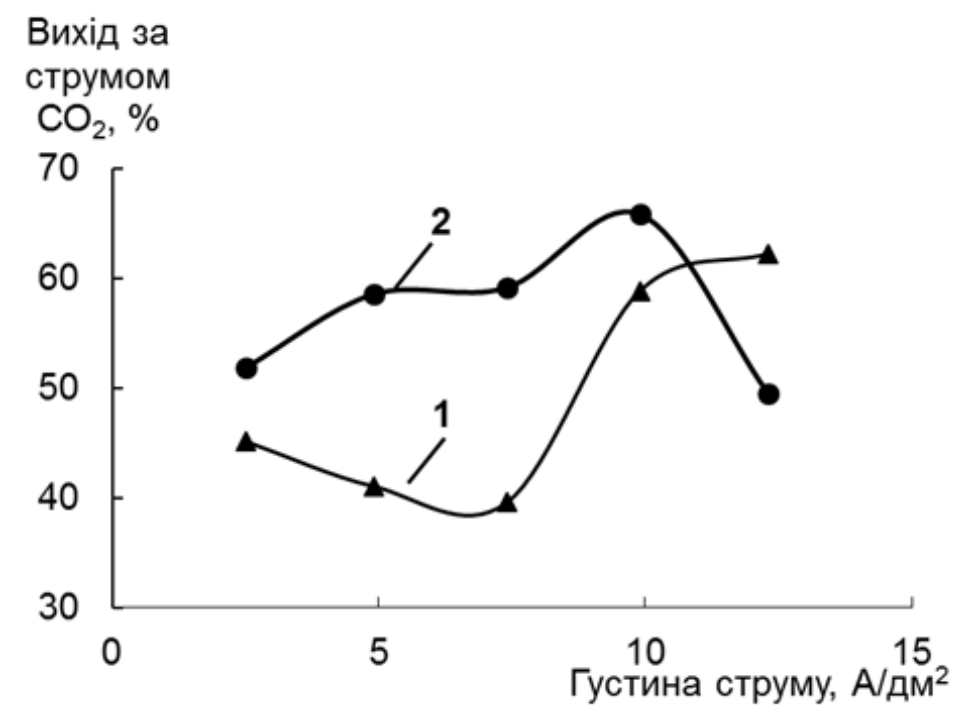

Puc.1. Вихід за струмом діоксиду карбону від густини струму на графрітових (1) та діоксидно-свинцевих (2) електродах при електролізі 10 \%-вого розчину оксалатної кислоти.

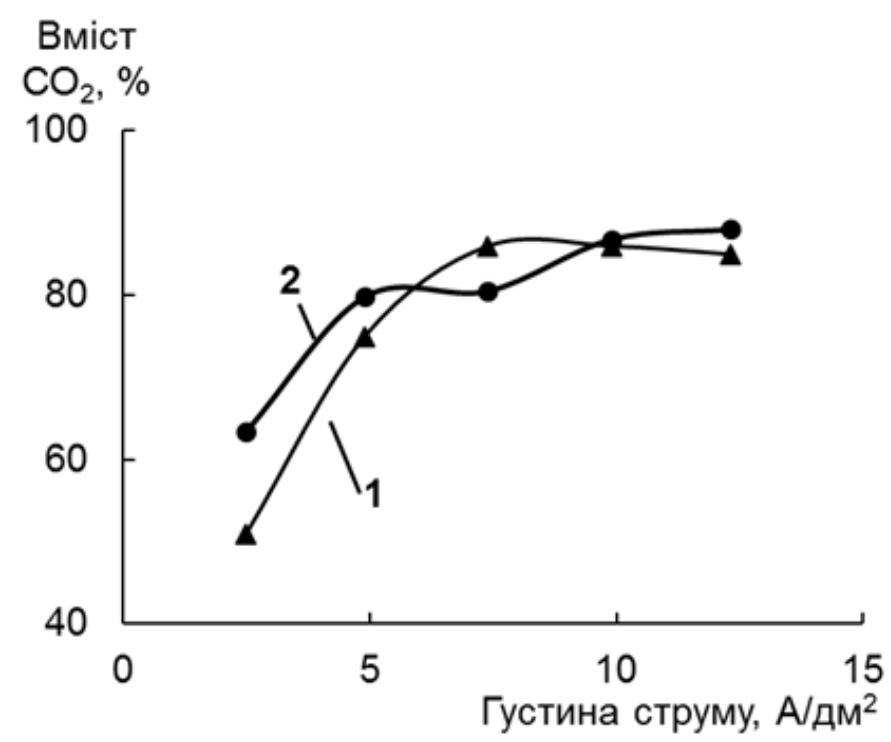

Puс.2. Вплив густини струму на чистоту отриманого діоксиду карбону при електролізі 10 \%-вого розчину оксалатної кислоти з графрітовими (1) та діоксидно-свинцевими (2) електродами.

Також була перевірена можливість використання як електрода пресованої композиції з титану та порошку графріту, оскільки чистий титан за анодної поляризації вкривається малоелектропровідними оксидними шарами. Композицію з порошку титану марки ПТЕМ 3 розміром зерна 0,05...0,10 мм та порошку графріту марки ГС-1 (масове співвідношення титану та графріту 10:1) виготовляли 
пресуванням при зусиллі $360 \mathrm{MPa}$, що перевищувало межу текучості титану. Використання такого електрода дозволило б збільшити питому продуктивність електролізера за менших габаритних розмірів (питома поверхня титанового порошку використаної марки становить $\left.0,2 \mathrm{~m}^{2} / \Gamma\right)$. Експериментально було встановлено, що застосування такого електрода дозволяє одержувати анодний газ з вмістом $\mathrm{CO}_{2}$ не нижче $65 \%$, однак вихід за струмом діоксиду вуглецю становив близько 40...45\%. Даний фракт пов'язаний із втратою частини електрики на зміну стехіометрії оксидних шарів на титані.

\section{Висновки}

Показано можливість створення електрохімічного генератора діоксиду вуглецю, в якому електролітом слугує розчин оксалатної кислоти, а анод виготовлений з діоксиду свинцю на електропровідній основі. Така конструкція генератора дозволяє отримувати $\mathrm{CO}_{2}$ зі стабільним виходом за струмом більше 60 \% та чистотою $85 . . .90 \%$. В подальшому планується дослідження систем, в яких газогенеруючий електрод являє собою пресовану композицію 3 порошків титану та $\mathrm{PbO}_{2}$.

\section{Список посилань}

[1] Агасян П. К. Кулонометрический анализ / П. К. Агасян, Т. К. Хамракулов. - М. : Химия, 1984. - 166 с.

[2] Кальвода Р. Электроаналитические методы в контроле окружающей среды / Кальвода Р., Зыка Я., Штулик К. - М. : Химия, 1990. - 240 c.

[3] Patent US7174766 B2, G12B13/00. Calibration device for carbon dioxide sensor / Eickhoff S.J., Wood R.A. - Honeywell International Inc., 13/01/2007.

[4] Свэн Ш. Электрохимические методы получения органических соединений / Под ред. А. Вайсбергера. - М. : Издательство Иностранной литературы, 1951. - 64 с.

[5] Якименко Л. М. Электродные материалы в прикладной электрохимии / Л. М. Якименко. - М. : Химия, 1977. - 264 с. 


\title{
ELECTROCHEMICAL FORMATION OF ORDERED STRUCTURES OF ALUMINUM OXIDE FOR THE ELECTRONIC INDUSTRY
}

\author{
EGOROVA YU.A., CHERNIK A.A., ZHARSKIY I.M.
} Belarusian State Technological University, Minsk; egorova.y_a@mail.ru

The results of formation of ordered structures of aluminum oxide by an electrochemical method in oxalic acid solution containing ionogenic non-isotropic surface-active substances are presented. The structure and morphology of surface films of the anodized aluminum oxide have been investigated by the method of scanning electron microscopy. It has been established that the addition of surfactants to the anodizing electrolyte leads to the change of the film structure. Thus, by varying compositions of solutions and conditions of anodizing, it is possible to change ratios of pore sizes of aluminum films

\section{ЭЛЕКТРОХИМИЧЕСКОЕ ФОРМИРОВАНИЕ УПОРЯДОЧЕННЫХ СТРУКТУР ОКСИДА АЛЮМИНИЯ ДЛЯ ЭЛЕКТРОННОЙ ПРОМЫШЛЕННОСТИ}

\author{
ЕГОРОВА Ю.А., ЧЕРНИК А.А., ЖАРСКИЙ И.М.
}

Белорусский государственный технологический университет, 2. Минск; egorova.y_a@mail.ru

Представлены результаты фрормирования упорядоченных структур оксида алюминия электрохимическим методом в растворе щавелевой кислоты, содержащей ионогенные анизотропные поверхностно-активные вещества. С помощью растровой электронной микроскопии исследована структура и морфология поверхности пленок анодированного оксида алюминия. Установлено, что добавление поверхностно-активных веществ в электролит анодирования приводит к изменению структуры пленок. Таким образом, варьируя составами растворов и условиями анодирования, можно изменять соотношения размеров пор алюминиевых пленок.

Перспективными объектами для опто-, микро- и наноэлектроники, фотокатализаторов, сенсоров, и других объектов являются микро- и нанопористые матрицы, модифицированные функциональными материалами. Например, при создании прозрачных электропроводящих наноструктур для жидкокристаллических 
устройств, используются процессы самоорганизованного роста упорядоченного анодного оксида алюминия [1].

\section{Методология исследований}

Для управления структурно-геометрическими параметрами образующейся пленки оксида алюминия в электролит щавелевой кислоты добавляли ионогенные поверхностно-активные вещества. В качестве структурообразователей использовались анизотропные поверхностно-активные вещества: додецилсульфат натрия (DSN), триметилдодециламмоний бромид (TM) и диметилбелзилдодециламмоний бромид (DMB).

Образцы представляли собой стеклянную подложку со слоем алюминия толщиной 1 мкм, нанесенного методом вакуумного напыления.

Для получения анодированных образцов применяли источник постоянного тока марки МНИПИ Б5-78/7. Для контроля значения температуры использовали терморегулятор ВАРТА. Цифровая регистрация хроноамперограмм производилась с помощью измерителя сопротивления Hantek 365-A. В качестве катода использовался титан марки ВТО.

Исследование структуры поверхности анодированных структур оксида алюминия проводилось с помощью растрового электронного микроскопа с системой микроанализа с безазотным энергодисперсионным детектором X-Act ADD + JSM-5900LV (Jeol, Япония), оснащенного системой волнодисперсионного микроанализатора, шлюзовой камерой и устройством для подавления электромагнитных помех INCA Energy 250 и INCA Wave500 (Oxford Instruments, Великобритания).

\section{Результаты и их обсуждение}

Кондуктометрическим методом были определены критические концентрации мицеллообразования (ККМ) поверхностно-активных веществ (ПАВ), которые оказывают непосредственное влияние на формирование упорядоченных структур оксида алюминия. ККМ при температуре $20{ }^{\circ} \mathrm{C}$ для DSN, TM и DMB составили соответственно, г/л: $0.74,1.54,0.55$.

На начальной стадии мицеллообразования в водном растворе, в области концентраций вблизи ККМ, образуются сферические мицеллы одинаковых размеров. При достижении ККМ сферические мицеллы начинают взаимодействовать между собой, что приводит к их деформации и дальнейшей трансформации в цилиндрическую или другую формы [2]. 


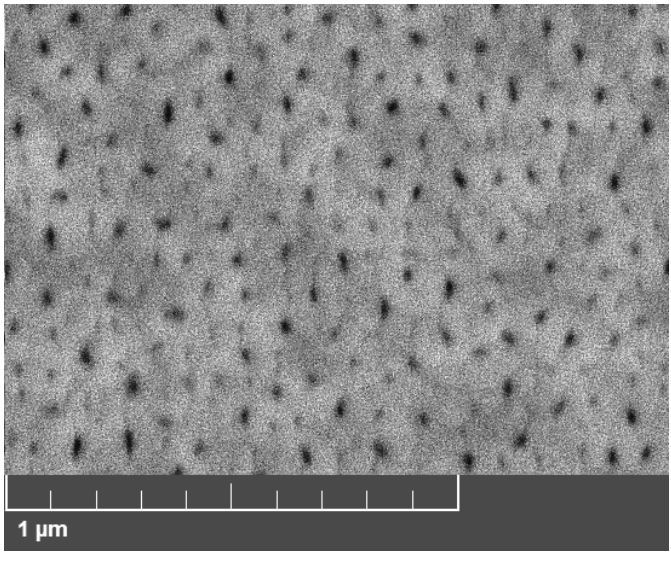

Рисунок. Микрофоотографрия поверхности оксида алюминия, полученного в щавелевой кислоте с применением DSN
Структура поверхности анодированного оксида алюминия представлена на рисунке.

На микрофротографрии отчетливо наблюдается упорядоченное расположение ячеек и геометрия пор анодированного оксида алюминия.

На основании анализа микрофотографий анодно-оксидного покрытия были определены характеристические параметры. Доля пор на поверхности оксидированного алюминия, полученного с применением поверхностно- активного вещества

DSN, больше и составляет $11 \%$, по сравнению с 9 \% долей пор на поверхности оксидированного алюминия, полученного в результате анодирования без добавки. При увеличении температуры электролита доля пор в пленке уменьшается и составляет $5 \%$. Такая же зависимость наблюдается и при переходе через критическую концентрацию мицеллообразования. Это свидетельствует о том, что средний диаметр поры с увеличением концентрации ПАВ и ее переходом через ККМ увеличивается. Данное явление объясняется явлением полиморфизма мицелл. Средний диаметр пор в аноднооксидной пленке, полученной при анодировании в щавелевой кислоте, колеблется в диапазоне от 10 до $11 \mathrm{HM}$, а в присутствии DSN - от 12 до 16 нм в зависимости от концентрации поверхностно-активного вещества. Подобная картина наблюдается и для других видов ПАВ.

\section{Выводы}

Таким образом, для получения наиболее упорядоченных, воспроизводимых и однородных по всей анодируемой площади структур оксида алюминия необходимо варьировать не только добавками и их концентрациями, но и температурой. Это позволит изменять соотношение размеров наносетки и пор наносетчатых алюминиевых пленок.

\section{Литература}

[1] Jaguiro P., Stsiapanau A., Hubarevich A., Mukha Y., Smirnov A., Selforganized nanostructured anodic oxides for display applications, Semiconductor Physics, Quantum Electronics and Optoelectronics, V. 13, N 3. P. 305-308,(2010)

[2] Мчедлов-Петросян, Н.О., Лебедь А.В., Лебедь В. И. Коллоидные поверхностно-активные вещества: Учебно-методическое пособие. Х.: ХНУ имени В. Н. Каразина, 2009. 
УДК 544.653.23 +544.654.2

\title{
THE CHEMICAL SYNTHESIS OF NANOSTRUCTURED SYSTEMS WITH CHEMOSENSITIVITY PROPERTIES
}

\author{
PYANKO A.V ${ }^{1}$, ZHYLINSKI V.V. ${ }^{1}$, GOROH G.G. ${ }^{2}$ \\ ${ }^{1}$ Belarusian State Technological University \\ ${ }^{2}$ Belarusian State University of Informatics and Radio Electronics
}

a_pyanko@mail.ru

This paper deals with the processes of electrochemical and chemical filling of anodic aluminum oxide with wide-zone metal oxide semiconductors $\left(\mathrm{SnO}_{2}, \mathrm{ZnO}\right)$ in terms of their use in gas sensors. The method of two-step anodization of aluminum on a silicon substrate was designed. Analysis of the gas sensor was carried out using a test structure.

\section{ХИМИЧЕСКИЙ СИНТЕЗ НАНОСТРУКТУРИРОВАННЫХ СИСТЕМ С ХЕМОЧУВСТВИТЕЛЬНЫМИ СВОЙСТВАМИ}

\author{
ПЯНКО А.В. ${ }^{1}$, ЖИЛИНСКИЙ В.В. ${ }^{1}$, ГОРОХ Г.Г. ${ }^{2}$ \\ ${ }^{1}$ Белорусский государственный технологический университет \\ ${ }^{2}$ Белорусский государственный университет инфрорматики и \\ радиоэлектроники; a_pyanko@mail.ru
}

В настоящей работе исследованы процессы электрохимического и химического наполнения анодно-оксидного алюминия широкозонными металлооксидными полупроводниками $\mathrm{SnO}_{2}, \mathrm{ZnO}$ для использования в газовой сенсорике. Разработана методика двустадийного анодирования алюминия на кремниевой подложке. Выполнен анализ газового сенсора с помощью тестовой структуры.

Решение проблем безопасности и активного мониторинга состояния окружающей среды может быть обеспечено системами контроля на основе сенсорных устройств. Для этих целей используются адсорбционно-полупроводниковые газовые датчики, позволяющие решить широкий круг задач и обладающие существенными достоинствами, к которым относятся высокая чувствительность, низкая стоимость, малые размеры, простота обслуживания [1]. Одним из основных типов химических сенсоров является адсорбционно-резистивный газовый сенсор, чувствительный слой которого фрормируется на основе полупроводниковых тонких пленок. Перспективным направлением в 
разработке химического сенсора является использование высокоупорядоченных нанопористых матриц для получения наноструктурированных металооксидных слоев на подложках кремния.

\section{Методика эксперимента}

Наиболее подходящим материалом для фрормирования структурированных газочувствительных слоев является пористый анодный оксид алюминия (AОА), обладающий уникальной ячеистопористой структурой, хорошей механической прочностью и высокими показателями жесткости, упругости и износостойкости [2, 3].

Объектами исследования в данной работы выступали кремниевая подложка n-типа проводимости с сорормированным слоем анодно-оксидного алюминия и хемочувствительной пленкой.

В качестве исходных образцов использовали кремниевые подложки n-типа проводимости (4,5 Ом·см) с кристаллической ориентацией (111), на которые методом магнетронного напыления в вакууме был нанесен слой Al толщиной 1,2 мкм.

Формирование АОА проводили согласно электрохимической методике [3], обеспечивающей размер и профиль пор, позволяющий равномерно заполнить матрицу газочувствительным материалом. Матрицу AOA получали методом двухстадийного электрохимического анодирования в 0,4 М водном растворе винной кислоты при плотности анодного тока 6 мА $/ \mathrm{cm}^{2}$. Схематически этапы формирования AOA показаны на рис. 1.

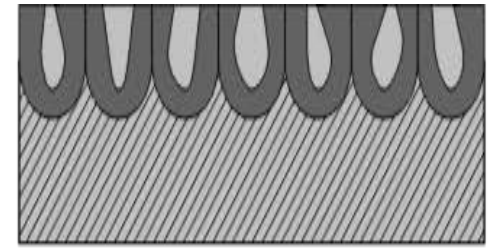

Первая стадия анодирования анодированияформирование разупорядоченного AOA

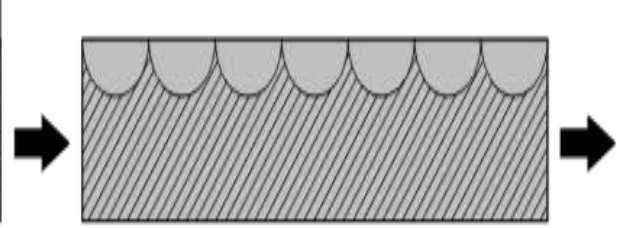

Селективная удаление АOA, сформированного на первой стадии

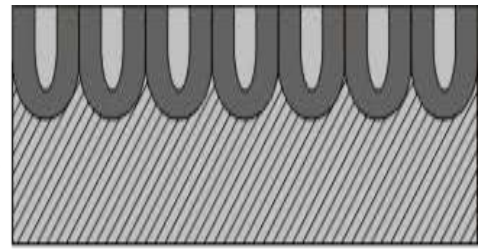

Вторая стадия формирование упорядоченного АOA

Puc.1. Формирование матрицы AOA

Напряжение роста пористого оксида алюминия составляло 200 В. Сформированный В первой стадии анодирования слой пористого оксида толщиной 0,5 мкм селективно удаляли в нагретом до $80^{\circ} \mathrm{C}$ водном растворе хромового ангидрида и ортофросфорной кислоты, в результате чего поверхность алюминия была структурирована 
структурированной поверхности алюминия формировали упорядоченный слой АОА методом повторного анодирования при условиях, аналогичных первой стадии.

Формирование хеморезистивного слоя на поверхности пористого АОА (видимая поверхность $4 \mathrm{~cm}^{2}$ ) осуществляли в две стадии. Вначале электрохимически проводили окисление Sn(II)в $\mathrm{Sn}(\mathrm{IV})$ в $1 \%$ растворе $\mathrm{SnSO}_{4}$ на поверхности пористой структуры AOA, инициируя осаждение гидроксидов олова(IV) в порах AOA (рис.2). Далее образцы отжигали на воздухе при $750^{\circ} \mathrm{C}$ в течение 30 мин. Вторая стадия заключалась в химическом осаждении гидроксида цинка на поверхность сформированного оксида олова (IV). Образцы пористого AOA с нанесенным слоем $\mathrm{SnO}_{2}$ последовательно выдерживали в течении 1 мин в 0,01 $\mathrm{M} \mathrm{ZnSO}_{4}$ и $1 \% \mathrm{KOH}$. Полученный таким образом слой гидроксида на поверхности AOA после естественной сушки подвергали отжигу при температуре $750^{\circ} \mathrm{C}$ в течение 30 мин. Полученные таким образом слои представлены на рис. 2.

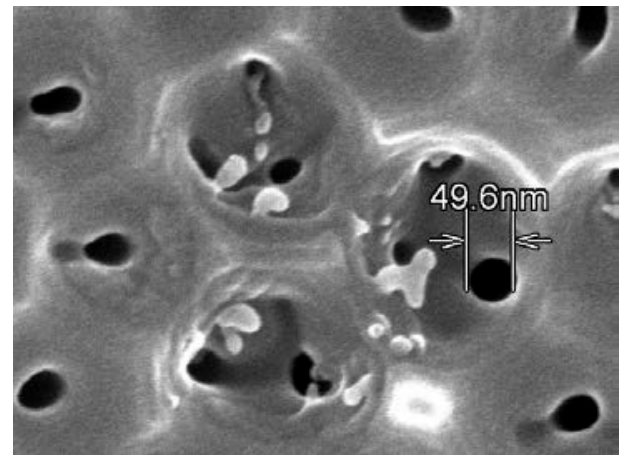

a)

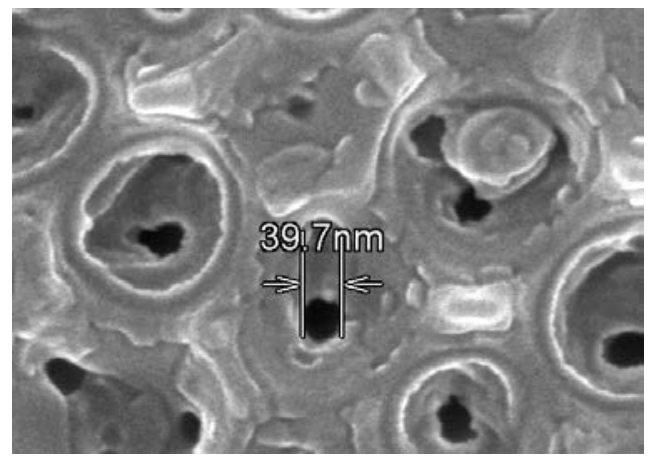

б)

Puc. 2. Микрофотографии поверхности образца $A O A$ матрицы до (а) и после (б) осаждения хеморезистивного слоя $\mathrm{SnO}_{2} \cdot \mathrm{ZnO}$

Диаметр пор сфрормированного упорядоченного слоя АОА составлял 50 нм, а диаметр пор после осаждения хеморизистивного слоя $\mathrm{SnO}_{2} \cdot \mathrm{ZnO}-40$ нм.

Для определения эффрективности работы хеморезистивной пленки в качестве пленки для газового сенсора была собрана тестовая сенсорная структура, включающая нагреватель, кремниевую подложку с АОА мембраной и газочувствительным слоем, внешние контакты.

Отклики на чувствительность пленки к $\mathrm{NO}_{2}$ получали путем нагрева кремниевой подложки до $300^{\circ} \mathrm{C}$. Электрическое сопротивление образца измерялось через внешние контакты. Результаты измерения представлены на рисунке 3. 


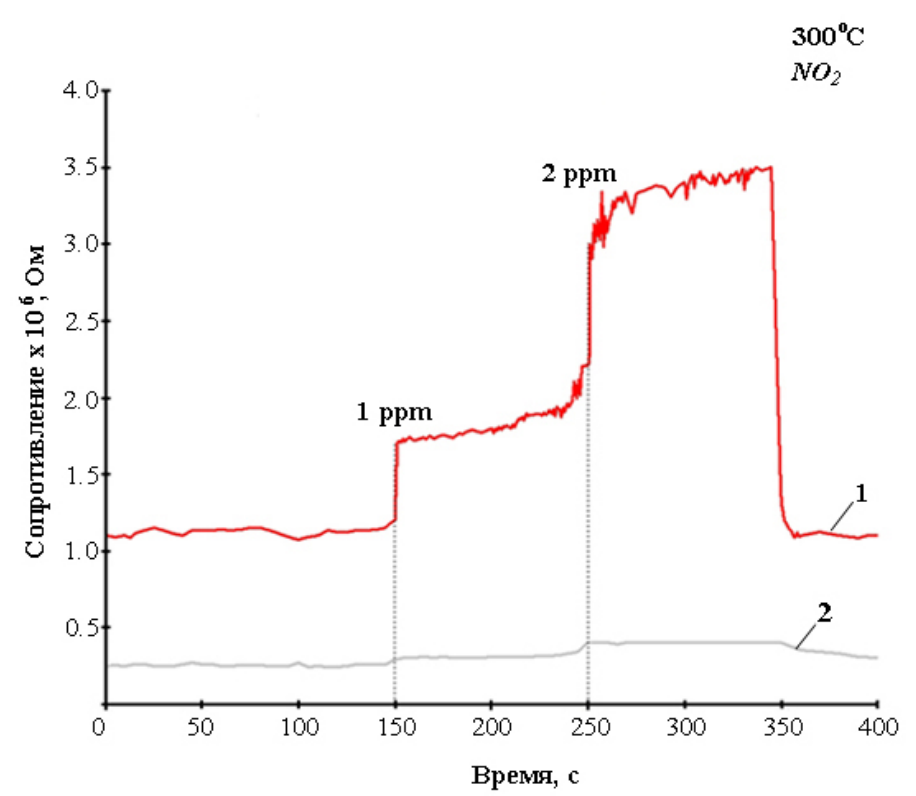

Puc. 3. Отклики на $\mathrm{NO}_{2}$ структурированных (1) и гладких (2) пленок $\mathrm{SnO}_{2} \cdot \mathrm{ZnO}$

Как следует из рис. 3 сопротивление образца восстанавливается через 350 с после подачи $\mathrm{NO}_{2}$ на поверхность хеморизистивного слоя, что свидетельствует о газочувствительности пленки.

\section{Выводы}

Определены оптимальные условия, сочетающие стабильность и достаточно высокую чувствительность полученных сенсоров. Структурированные газочувствительные пленки $\mathrm{SnO}_{2} \cdot \mathrm{ZnO}$, сформированные химическим осаждением $\mathrm{ZnO}$ и $\mathrm{SnO}_{2}$, показали приемлемые отклики на $\mathrm{NO}_{2}$ с максимальной чувствительностью при температуре $300^{\circ} \mathrm{C}$.

\section{Литература}

[1] Основы золь-гель технологии нанокомпозитов/ Максимов А.И. [и др.]// Издат. «Элмор», Санкт-Петербург, 2007. - 254 с.

[2] Tungsten trioxide sensing layers on highly ordered nanoporous alumina template/ V. Khatko [et al] // Sensor \& Actuators; B. Chemical, 2006, Vol.118, P.255-262.

[3] Evolution of surface morphology, crystallite size, and texture of WO 3 layers sputtered onto Si-supported nanoporous alumina templates N. Khatko [et al] //Journal of The Electrochemical Society, 155, 7, 2008, P. 116-123. 
УДК 544.65:544.4:661

\title{
ELECTROCHEMICAL FORMATION OF NANOSTRUCTURED ALUMINUM COATING
}

\author{
PISMENSKAYA A.S., CHERNIK A.A., ZHYLINSKI V.V., \\ BOGOMAZOVA N. V.
}

Belarusian State Technological University; as.pismenskaya@mail.ru

The article presents the results of electrochemical investigations of the oxidation process of aluminum. It has been established that for the formation of a transparent nanostructured layer of aluminum with fine porosity and good dielectric properties of the film, oxalic electrolyte $(0,3 \mathrm{M})$, high voltage $(50-80 \mathrm{~V})$ and low temperature $\left(4-20^{\circ} \mathrm{C}\right)$ should be used. To create an orderly structure and increase the dielectric properties of the nanostructured aluminum film layers were etched in a solution containing in $\mathrm{g} / \mathrm{l}$ : $\mathrm{CrO} 3$ - 18; $\mathrm{H} 3 \mathrm{PO} 4-60(\rho=1,69 \mathrm{~g} / \mathrm{cm} 3)$ at $80^{\circ} \mathrm{C}$.

\section{ЭЛЕКТРОХИМИЧЕСКОЕ ФОРМИРОВАНИЕ НАНОСТРУКТУРИРОВАННОГО АЛЮМИНИЕВОГО ПОКРЫТИЯ}

ПИСЬМЕНСКАЯ А.С., ЧЕРНИК А.А., ЖИЛИНСКИЙ В.В., БОГОМАЗОВА Н.В.

Белорусский государственный технологический университет as.pismenskaya@mail.ru

Промышленное производство всех типов дисплейных устройств с ежегодным объемом выпуска в сотни миллионов штук (активноматричные жидкокристаллические дисплеи для телевизионной и компьютерной техники, мобильные телефоны и др.) основано на использовании прозрачного проводящего оксида $\ln _{2} \mathrm{O}_{3}$, легированного оловом или цинком, с оптическим пропусканием на уровне 80 - 85\% и поверхностным сопротивлением менее 50 Ом/ $[1,2]$. Разведанные мировые запасы исходных материалов, прежде всего индия, весьма ограничены и в ближайшие несколько лет промышленность может столкнуться с их существенным десицитом.

В связи с этим поиск новых альтернативных материалов с улучшенными технологическими и эксплуатационными характеристиками, а также экономическими показателями, является 
актуальной и практически важной задачей. Одним из направлений дальнейшего развития производства дисплейных устройств является разработка технологии фрормирования прозрачного слоя наноструктурированного алюминия с использованием технологии формирования нанопористого анодного оксида алюминия на поверхности стеклянной подложки [1].

Цель исследования - изучение закономерностей фрормирования упорядоченной наноразмерной структуры на основе алюминия методом анодирования и последующего химического удаления сорормированного оксида алюминия для получения электропроводящих покрытий с улучшенным светопропусканием при производстве жидкокристаллический устройств.

\section{Методика эксперимента}

Процесс фрормирования пористого оксида алюминия осуществляли в гальваностатическом режиме в двухэлектродной термостатированной электрохимической ячейке. Катод - графит. В качестве анода использовали стеклянные пластины размером 1х2 см со слоем алюминия толщиной 1 мкм, нанесенного на поверхность магнетронным напылением. Предварительная подготовка образцов перед анодированием включала трафраретное нанесение химически стойкого лака по контуру пластины шириной 2 мм и на расстоянии 3 мм от верхнего края пластины; сушка лака в течение 30 мин; обезжиривание в $70 \%$ этиловом спирте в течение 60 с в ультразвуковой ванне (ВУ-09-“Я-ФП”-02). Анодирование образцов осуществляли в 0,3 М растворе щавелевой кислоты в интервале температур от 4 до $20{ }^{\circ} \mathrm{C}$ и напряжении $30-80$ В. Исследования морфологии поверхности анодированных образцов осуществлялись с помощью электронного микроскопа JEOL (Япония), а также электрохимического метода исследования пористых структур [3].

Сформированный анодный оксид алюминия подвергался ступенчатому растворению в растворе содержащем, г/л: $\mathrm{CrO}_{3}-18$; $\mathrm{H}_{3} \mathrm{PO}_{4}-60\left(\rho=1,69\right.$ г/см $\left.{ }^{3}\right)$ при температуре $80{ }^{\circ} \mathrm{C}$, до установления постоянной массы образцов [4].

\section{Результаты и их обсуждение}

Зависимости (рис. 1 a и b) силы тока от продолжительности анодирования содержат два пика. Первый пик обусловлен развитием поверхности Al при анодировании в результате фрормирования слоя барьерного оксида алюминия при анодной поляризации электрода. С ростом толщины барьерного анодно-оксидного слоя увеличивается электрическое сопротивление анода, что вызывает падение тока в ходе анодирования. При этом усиливается процесс выделения 
джоулевого тепла, что вызывает локальный разогрев истончающегося слоя алюминия и увеличивает скорость химического растворения оксида алюминия в щавелей кислоте.

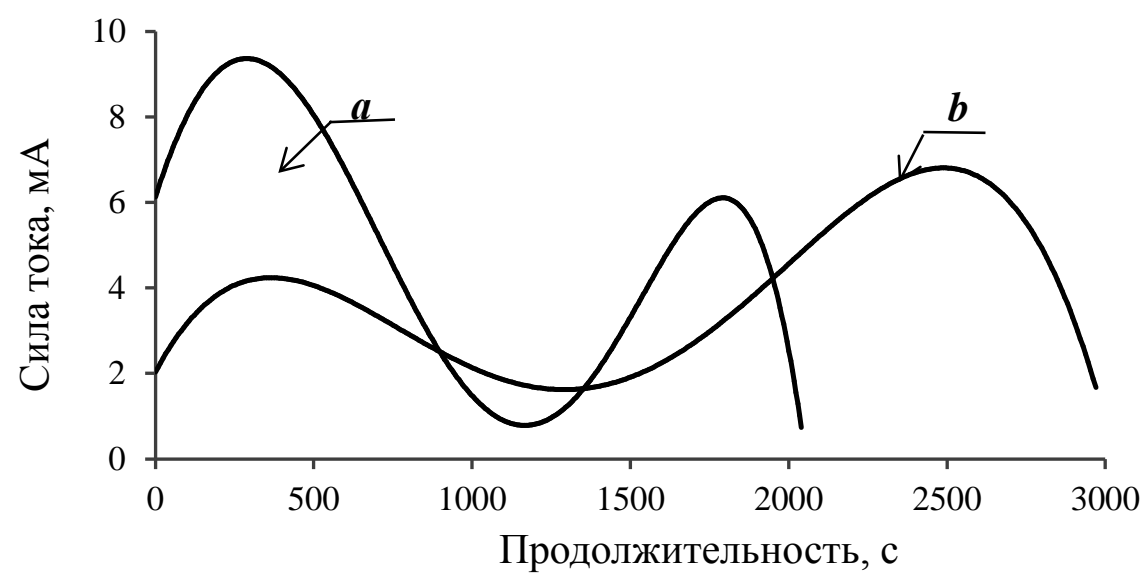

Puc.1.

Хроноамперограммы анодирования тонких пленок алюминия (1 мкм) в 0,3 М растворе щавелевой кислоты при температуре $10^{\circ} \mathrm{C}$ и напряжении 50 (a) u $60 \mathrm{~B}(\mathrm{~b})$

Наличие второго пика на хроноамперограммах может быть связано с локальным разрушением барьерного оксида при возникновении градиентов температур на поверхности аноднооксидной пленки и соответствующее увеличению тока окисления алюминия. Повышение напряжения анодирования с 50 до 60 В уменьшает высоту первого пика, что связано с повышенной скоростью анодного растворения алюминия на начальной стадии анодирования при формировании барьерного слоя и самоструктурировании пористого оксидного слоя. Дальнейшее повышение напряжения анодирования до 80 В и температуры до $15^{\circ} \mathrm{C}$ приводит к исчезновению второго пика на хроноампераграммах (рис 2 a).

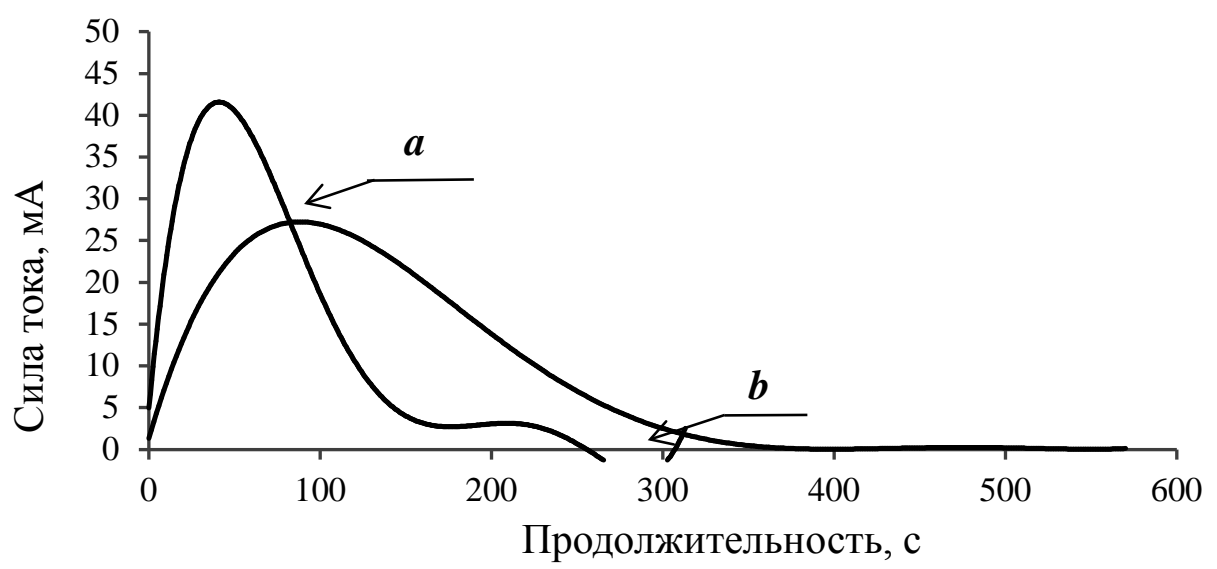

Puc.2. Хроноамперограммы анодирования тонких пленок алюминия (1 мкм) в 0,3 М растворе щавелевой кислоты при 80 В и температуре $15^{\circ} \mathrm{C}$ (a) u $10^{\circ} \mathrm{C}(\mathrm{b})$ 
Электрономикроскопические исследования слоев пористого оксида алюминия (рис. 3) показали, что с ростом температуры анодирования от 10 до $15{ }^{\circ} \mathrm{C}$ наблюдается увеличение среднего диаметра пор с 98,9 до 213 нм и уменьшение их полидисперсности, что связано с влиянием процесса химического растворения оксида алюминия в щавелевой кислоте.

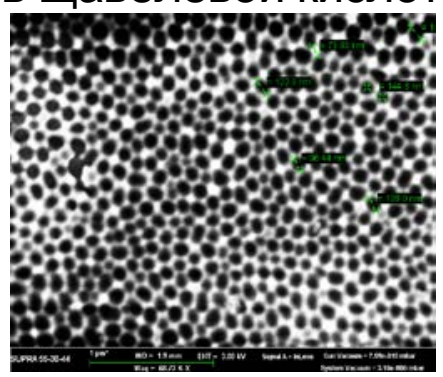

a)

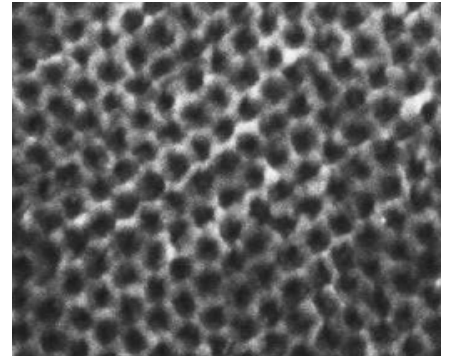

b)

Puc. 3. Микрофотографии поверхности анодированной алюминиевой пленки при напряжении $80 \mathrm{~B}$, температуре $10^{\circ} \mathrm{C}$ (a) и $15^{\circ} \mathrm{C}$ (b)

\section{Выводы}

Показано, что повышение напряжения анодирования от 50 до 80 В при повышении температуры от 10 до $15{ }^{\circ} \mathrm{C}$ приводит к увеличению характерных размеров профилированной структуры от 98,9 до 213 нм и повышению ее геометрической однородности. Наиболее благоприятные условия анодирования в 0,3 М растворе щавелевой кислоты при напряжении 80 В и температуре $10{ }^{\circ} \mathrm{C}$ обеспечивают получение нанопрофилируемой алюминиевой пленки. Полученные наноструктурированные пленки алюминия имеют перспективы использования при производстве «умных» стекол, электрооптических устройств памяти, дисплейной техники различного назначения.

\section{Литература}

[1] Мухин, И.А. Развитие жидкокристаллических мониторов / И.А. Мухин // Телевидение и радиовещание. - 2006. - № 4(48). - С. 71-73. [2] Самарин, А.В. Жидкокристаллические дисплеи: схемотехника, конструкция, применение / А.В. Самарин. - М., 2002. - 310 с.

[3] 3 . Фогель, В.А. Электрохимическмй метод контроля защитных пленок / В.А. Фогель// Электронная техника. Сер. 2, Полупроводниковые приборы. - 1971. - Вып. 1 (58). - С. 87 - 93.

[4] Письменская, А.С. Формирование пористых анодно-оксидных покрытий в щавелевокислом растворе при пониженных температурах /A.C. Письменская // 66-я студенческая научнотехническая конференция учащихся, студентов и магистрантов, Минск, 20-25 апреля 2015 г.:/ БГТУ; издат.-БГТУ. - Минск, 2015. C. 475 . 


\title{
Part 5 \\ MODERN ELECTROCHEMICAL AND RELATED TECHNOLOGIES
}

\author{
Розділ 5 \\ СУЧАСНI ЕЛЕКТРОХІМІЧНІ ТА \\ СПОРІДНЕНІ ТЕХНОЛОГIÏ
}


UDC 544.6.018.45=111

\title{
ANODIC GROWTH OF NANOPOROUS TIN OXIDE LAYERS IN ACIDIC ELECTROLYTES
}

\author{
L. ZARASKA, K. GAWLAK, A. KRZYSIK, M. JASKUŁA \\ Department of Physical Chemistry and Electrochemistry, Faculty of \\ Chemistry, Jagiellonian University in Krakow, Ingardena 3, 30-060 \\ Krakow, Poland. jaskula@chemia.uj.edu.pl
}

The aim of this work was to synthesize $\mathrm{SnO}_{2}$ nanostructures with various morphologies by simple anodic oxidation (anodization) of metallic tin in acidic electrolytes. A series of Sn foil anodizations was performed in different electrolytes (oxalic acid, citric acid, tartaric acid) with various concentrations. It was confirmed that anodic oxidation of tin in the oxalic acid results in the formation of nanoporous oxide layers with completely open pores on the surface of the electrode. On the other hand, when citric acid or tartaric acid were used as an electrolyte, porous oxide with a compact layer on the surface was formed during electrolysis.

Tin dioxide $\left(\mathrm{SnO}_{2}\right)$, a wide band gap n-type semiconductor has recently become a subject of great scientific interest as a result of its various promising electronic, optical and photoelectrochemical properties offering many potential practical applications, e.g. in solid-state gas sensors, solar cells, and catalysts [1]. Moreover, it is also widely known, that the use of nanostructured oxides instead of bulk materials can significantly improve semiconductor's functionality [2]. Unfortunately, very often the main problem that limits the practical application of such nanomaterials is a relatively high cost of fabrication process. Therefore, a further development of simple and cost-effective methods for fabrication of nanostructured tin oxides is strongly desirable. Among various methods that have been already proposed for fabrication of $\mathrm{SnO}_{2}$ nanostructures [3], anodic oxidation (anodization) proposed originally by Shin et al. in 2004, seems to be a very interesting, simple and costeffective strategy [4].

In our recent works we discussed in detail the effect of anodizing conditions on the formation and structure of anodic tin oxides formed during anodization of various $\mathrm{Sn}$ substrates in $\mathrm{H}_{2} \mathrm{C}_{2} \mathrm{O}_{4}$ [5-8] and $\mathrm{NaOH}$ electrolytes. This works aims in a brief comparison of the morphology of anodic tin oxide layers grown in various acidic electrolytes at different anodizing conditions. 


\section{Results and discussion}

Nanoporous tin oxide layers were synthesized by one-step anodic oxidation of Sn foils according to the procedure described in detail in our previous work [7]. The FE-SEM images of the typical anodic layer formed during anodization of $\mathrm{Sn}$ in oxalic acid electrolyte are shown in Figure 1 together with a schematic representation of the oxide structure. As can be seen, a completely irregular porous layer with randomly distributed nanochannels was formed during anodization. The typical layered oxide structure with a lot of internal gaps and transversal pores can be recognized in Figures $1 \mathrm{~A}$ and $\mathrm{B}$. These discontinuities, being a direct consequence of the vigorous gas evolution during anodization, can significantly affect the properties of oxide layers (e.g., electronic conductivity) and dramatically decrease their mechanical stability and integrity.

The FE-SEM images shown in Figures $1 C$ and $D$ indicate that a continuous barrier layer, similar to those observed during anodizations of other metals (e.g. Al or Ti) is also formed at the metal/oxide interface during anodic oxidation of the Sn substrate. Top-view images of the nanoporous tin oxide layer grown via one-step anodization of $\mathrm{Sn}$ foil in $0.3 \mathrm{M}$ oxalic acid at the potential of $8 \mathrm{~V}$ are shown in Figure $2 \mathrm{~A}-\mathrm{C}$. An irregular, porous structure with number of interconnections between individual nanopores can be easily seen on the oxide surface (see Figure 2A). However, it is evident that the inner oxide layer, clearly visible in Figures $2 \mathrm{~B}$ and $\mathrm{C}$, exhibits a different morphology with more defined, larger and more regular nanopores [5-7].

The FE-SEM top-view images of anodic tin oxide layers after anodization in $0.3 \mathrm{M}$ oxalic acid at various anodizing potentials are shown in Figure 2 D-F. As can be seen, an anodizing potential significantly affects the morphology of the outer oxide layer, and in general, the higher applied potential the more open porous structure is formed (compare Figures 2D and E showing anodic layers grown at the potential of 4 and $7 \mathrm{~V}$, respectively).

It should be mentioned that in our recent works we confirmed a significant increase in the average pore diameter in the outer layer with increasing potential and concentration of oxalic acid. This phenomenon can be attributed not only to the enhanced field-assisted chemical etching of anodic oxide at the oxide/electrolyte interface, but also to a more vigorous oxygen gas evolution at the anode under severe anodizing conditions. 


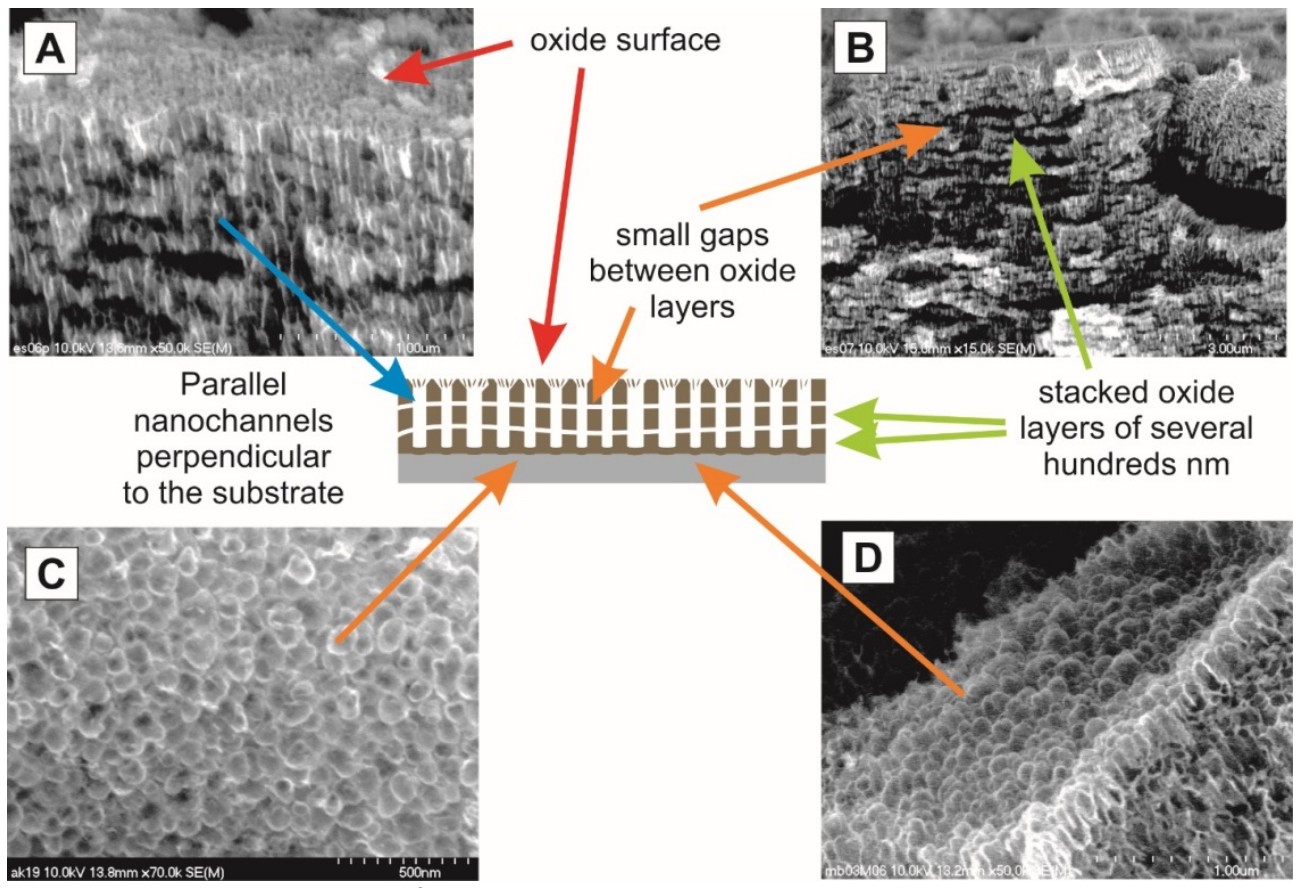

Figure 1. Typical structure of nanoporous tin oxide layers: cross sectional views ( $A$, $B, D)$ and bottom-view of the barrier-layer (C). Anodization was carried out in $0.3 \mathrm{M}$ $\mathrm{H}_{2} \mathrm{C}_{2} \mathrm{O}_{4}$
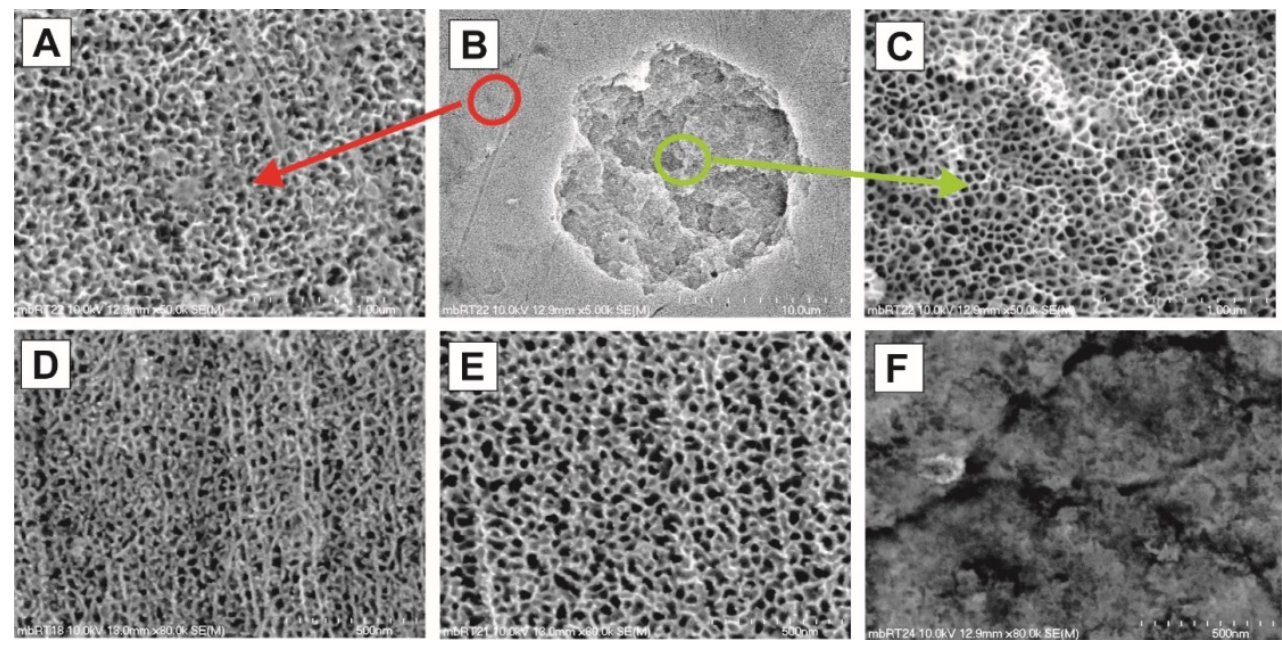

Figure 2. FE-SEM images of the nanoporous oxide layer obtained by anodizing in $0.3 \mathrm{M}$ oxalic acid at $8 \mathrm{~V}$ - outer layer $(A, B)$ and inner layer $(B, C)$ and nanoporous $\mathrm{SnO}_{x}$ grown at different anodizing potentials $(4 \mathrm{~V}-\mathrm{D}, 7 \mathrm{~V}-\mathrm{E}, 10 \mathrm{~V}-\mathrm{F})$

Contrary to this, no significant effect of anodizing parameters on the structure of the inner oxide layer was recognized [5-7]. However, it is noteworthy that anodizing of $\mathrm{Sn}$ foil at potentials of $>9 \mathrm{~V}$ results in initial formation of the dense, passive outer layer (see Figure $2 \mathrm{~F}$ ) its further breakdown, and formation of the well-defined, nanoporous inner oxide layer [6]. Anodic films with completely different morphologies were obtained on the surface of metallic Sn when anodizations were carried out in citric or tartaric acid solutions. FE-SEM images of oxide layers grown in these electrolytes are shown in Figure 3. 

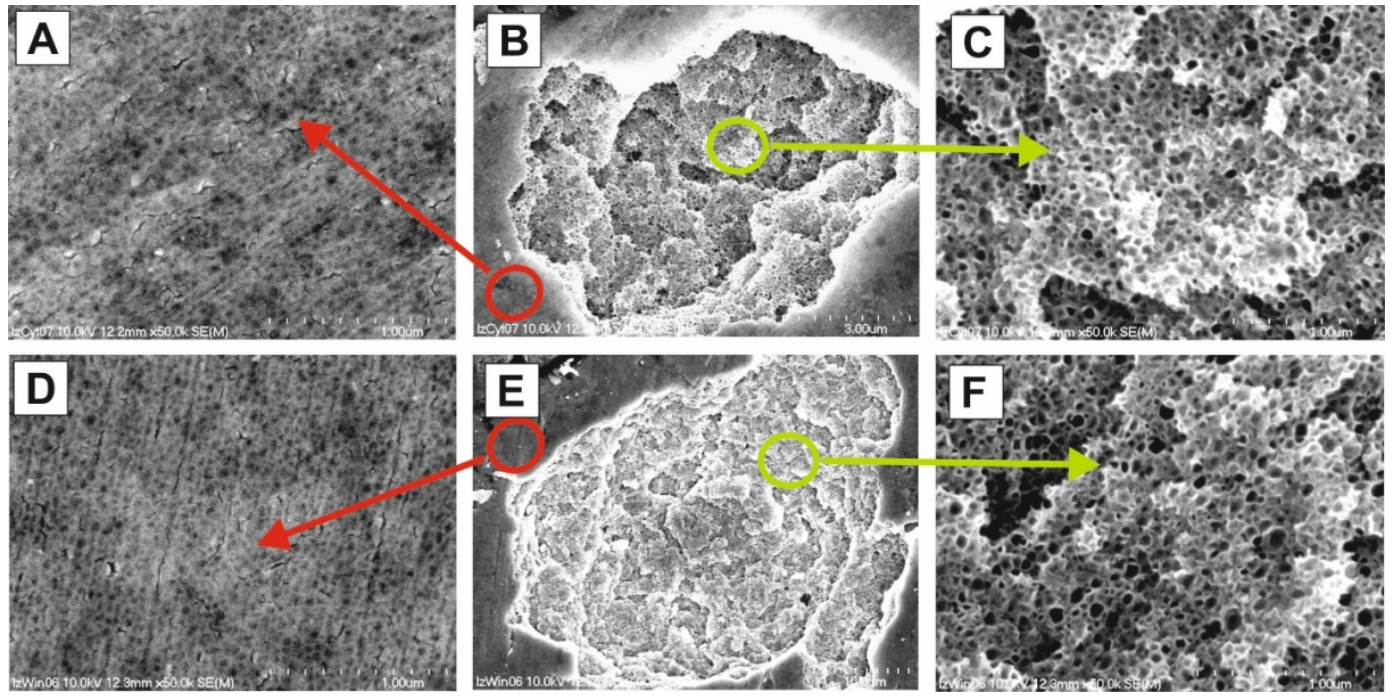

Figure 3. FE-SEM images of anodic layers on Sn foil after 30 min of anodization in $0.3 \mathrm{M}$ citric $(A-C)$ and $0.3 \mathrm{M}$ tartaric acid $(D-F)$ at the potential of 7 and $6 \mathrm{~V}$, respectively

It was confirmed, that almost a compact passive layer was initially created on the surface of metallic substrate and further anodization did not lead to the pore opening. In consequence, the pores were still completely closed at the oxide surface even after $30 \mathrm{~min}$ of anodic oxidation (see Figures $3 \mathrm{~A}$ and $\mathrm{D}$ ). On the other hand, it is evident that the inner oxide layer exhibits the porous morphology and consists of quite well defined nanochannels (see Figure $3 \mathrm{C}$ and $\mathrm{F}$ ), however an average pore diameter $(-30 \mathrm{~nm})$ is still much lower from that observed in anodic layers grown in oxalic acid $(-50 \mathrm{~nm})$. We also confirmed that the surface area of nanoporous inner anodic layer exposed to the electrolyte increases with increasing anodizing duration.

However, this can be attributed not to the enhanced field-assisted etching of the passive layer, but rather to the peeling of the outer part of the film as a result of vigorous oxygen evolution and formation of internal cracks and transversal pores in the anodic layer. It should be also mentioned that even if anodization was carried out in more concentrated electrolytes (up to $1 \mathrm{M}$ ) and higher anodizing potentials (to $20 \mathrm{~V}$ ) as created anodic films still exhibited a non-porous morphology of the outer layer. It is obvious that this phenomenon hinders the potential application of such kind of porous anodic tin oxides.

Since the species cannot access the internal pores of oxide layers, its application to functional devices is limited. Taking above into consideration it should be stated that citric and tartaric acid solutions are not very promising electrolytes within the context of fabrication of nanoporous tin oxide layers. 


\section{Conclusions}

In summary, nanoporous tin oxide layers can be easily obtained via extremely simple one-step anodic oxidation carried out in acidic electrolytes. However, the character of the electrolyte strongly affects the morphology of anodic tin layers. Nanoporous films with well-defined and open pores can be obtained when anodization is carried out in oxalic acid at the potentials $<9 \mathrm{~V}$. On the contrary, the use of weaker acids as electrolytes (citric acid, tartaric acid) results in formation of anodic oxides with a completely compact outer layer and nanoporous inner structure.

\section{Acknowledgements}

This work was partially supported by the Polish Ministry of Science and High Education (Project luventus Plus No. IP2012 057372) and National Science Centre, Poland (Project no. 2014/13/D/ST5/02750).

\section{References}

[1] Batzill M. The surface and materials science of tin oxide / M. Batzill, U. Diebold // Prog. Surf. Sci.- 2005. - V. 79. - P. 47-154.

[2] Wang $\mathrm{H}$. Hierarchical $\mathrm{SnO}_{2}$ nanostructures: recent advances in design, synthesis, and applications / H. Wang, A.L.Rogach // Chem. Mater. - 2014.-V.26. - P.123-133.

[3] Pan J. One-Dimensional $\mathrm{SnO}_{2}$ Nanostructures: Synthesis and Applications / J. Pan, H. Shen, S. Mathur // J. Nanotechnol.- 2012. Article ID 917320, P. 1-12.

[4] H-Ch. Shin Porous tin oxides prepared using an anodic oxidation process / H-Ch. Shin, J. Dong, M. Liu // Adv. Mater. - 2004. - V. 16. - P. 237-240.

[5] Zaraska L. Synthesis of nanoporous tin oxide layers by electrochemical anodization / L. Zaraska, N. Czopik, M. Bobruk, G.D. Sulka, J. Mech, M. Jaskuła // Electrochim. Acta. - 2013. - V. 104. - P. 549-557.

[6] Zaraska L. Growth and complex characterization of nanoporous oxide layers on metallic tin during one-step anodic oxidation in oxalic acid at room temperature / L. Zaraska, M. Bobruk, M. Jaskuła, G.D. Sulka // Appl. Surf. Sci. - 2015. - V. 351. - P. 1034-1042.

[7] Zaraska L. Formation of Nanoporous Tin Oxide Layers on Different Substrates during Anodic Oxidation in Oxalic Acid Electrolyte / L.

Zaraska, M. Bobruk, G.D. Sulka // Adv. Cond. Matter Phys. - 2015. Article ID 302560, - P. 1-11.

[8] Zaraska L. Nanoporous tin oxides synthesized via electrochemical anodization in oxalic acid and their photoelectrochemical activity / L. Zaraska, K. Syrek, K. Hnida, M. Bobruk, A. Krzysik, T. Łojewski, M. Jaskuła, G.D. Sulka // Electrochim. Acta [in press]. 


\title{
THE INFLUENCE OF IONIC DOPANTS ON INITIAL STAGES OF LEAD DIOXIDE ELECTROCRYSTALLIZATION
}

\author{
O. SHMYCHKOVA, T. LUK'YANENKO, A. VELICHENKO \\ Ukrainian State University of Chemical Technology \\ o.shmychkova@hotmail.com
}

Electrocrystallization of $\mathrm{PbO}_{2}$ begins with the formation of a monolayer on the electrode surface, then the formation and growth of three-dimensional nuclei take place. The formation of one phase is noticeably lagged behind the other. In the layer-by-layer crystallization and significant lagging of one of phases there may occur ingesting of growing centres of one phase by another. The type of lagging phase depends on the nature of electrolyte: for nitrate bath it is $\beta$, for methanesulfonate $-\alpha$.

It has been determined that the crystallization of lead dioxide from methanesulfonate electrolytes proceeds through the progressive mechanism. A preferred form of formed crystals at 2D nucleation in the case of electrolytes, based on nitric acid is a cone, and electrolytes, based on methanesulfonic acid is a cylinder. The process of coating formation of lead dioxide begins with the formation of $\alpha$-phase crystals. After a certain period of time, the formation of $\beta$-phase crystals takes place. Thus, the $\alpha$ - and $\beta$-phases can be formed simultaneously. Predominance in the growth of one or the other phase is determined by the ratio between the kinetic constants of the crystal growth of $\alpha$ - and $\beta$ phases. The coatings obtained from methanesulfonate bath are almost entirely composed of $\alpha$-phase. It was found for the first time that addition of dopants in deposition electrolytes leads to growth of $\beta$-phase content in deposits. The latter suggests that the phase composition is largely influenced not by the nature of the substrate but by kinetic difficulties in initial stages of crystallization depending on the composition of deposition electrolyte.

Electrodes based on lead dioxide doped by ionic additives are known to be of great interest for investigation owing to tailoring solid state properties as well as electrocatalytic activity of $\mathrm{PbO}_{2}$ [1-3]. Particular attention should be paid to ionic additives in high oxidation states +3 , and +4 (compared to places of cation vacancies of lead dioxide, in which $\mathrm{Pb}^{2+}$-ions are known to be localized). It is recognized [4, 5], that there are two zones on the lead dioxide surface: crystal $\left(\mathrm{PbO}_{2}\right)$ and hydrated $\left[\mathrm{PbO}(\mathrm{OH})_{2}\right]$, that are in equilibrium and are capable to 
exchange cations and anions with the ions present in the bulk. Lead ions replacement both in hydrated and crystal zone would cause not only the change of amount of oxygen-containing particles in each zone, but their binding energies, that in turn will change the electrocatalytic activity of materials.

In the present work we examine early stages of electrocrystallization of $\mathrm{PbO}_{2}$ from methanesulfonate/nitrate electrolytes that contain various ionic additives and surfactants $\left.\left(\mathrm{Bi}^{3+}, \mathrm{Ce}^{3+}, \mathrm{Sn}^{4+},\left[\mathrm{NiF}_{6}\right]^{2-},[\mathrm{SnF}]_{6}\right]^{2-}, \mathrm{SDS}\right)$ and estimate rate constants of crystallization of $\alpha$ - and $\beta$ - phases.

\section{Research Methodology}

Electrodeposition regularities of lead dioxide both in nitrate and methanesulfonate electrolytes were studied on $\mathrm{Pt}$ disk electrode by steady-state voltammetry, chronoamperometry. Voltammetry measurements were carried out in a standard temperature-controlled three-electrode cell. All potentials were recorded and reported vs. Ag I $\mathrm{AgCl} / \mathrm{KCl}$ (sat.).

\section{Results and Discussuon}

Current transients for $\mathrm{PbO}_{2}$ deposition on $\mathrm{Pt}$ disk electrode were obtained for investigation of initial stages lead dioxide electrodeposition from methanesulfonate electrolytes (Fig. 1). The type of transient is determined by the electrode potential. At low polarizations $(E=1.55 \mathrm{~V})$ the biggest induction period with a further stretched maximum of current is observed. Increasing the anodic polarization leads to a substantial decreasing the induction period and the increasing of current maximum.

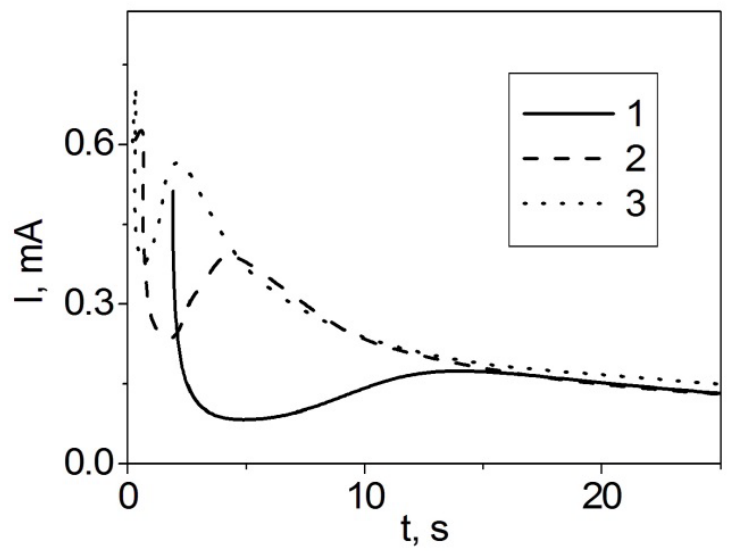

Fig. 1. Current-time transients for $\mathrm{PbO}_{2}$ deposition on $\mathrm{Pt}$ disk electrode from $0.01 \quad \mathrm{M}$ $\mathrm{Pb}\left(\mathrm{CH}_{3} \mathrm{SO}_{3}\right)_{2}+1 \quad \mathrm{M} \mathrm{CH}_{3} \mathrm{SO}_{3} \mathrm{H}$ at different deposition potentials, $\mathrm{mV}$ : 1 - 1550; 2 - 1600; 3 - 1620

A linear relationship between the natural logarithm of the induction time of crystallization and the applied potential with negative slope is observed both for nitrate and methanesulfonate electrolytes. Such dependence shows that the electrocrystallization of $\mathrm{PbO}_{2}$ begins with the formation of a monolayer on the entire surface of the electrode, and then the formation and growth of nuclei occurs. Growth of lead dioxide 
occurs through layer-by-layer crystallization, so each following layer is formed on the renewed surface $[6,7]$.

An increase of a current delay corresponding to the induction time can be observed if ionic dopants are present in the deposition bath. This indicates difficulties in the initial stages of the phase formation of lead dioxide (Figs. 2, 3).

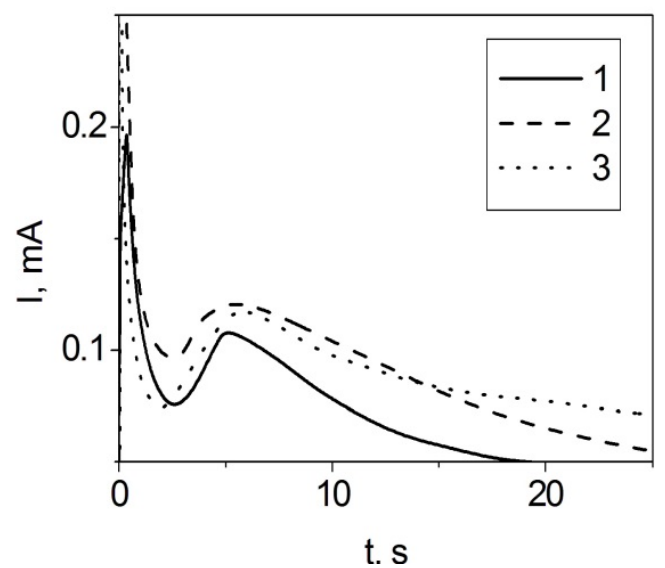

Fig. 2. Current-time transients for $\mathrm{PbO}_{2}$ deposition on Pt disk electrode at 1620 $\mathrm{mV}$ from $0.01 \mathrm{M} \mathrm{Pb}\left(\mathrm{CH}_{3} \mathrm{SO}_{3}\right)_{2}+1 \mathrm{M}$ $\mathrm{CH}_{3} \mathrm{SO}_{3} \mathrm{H}+\mathrm{X}$, where $\mathrm{X}$ is $1-0.01 \mathrm{M} \mathrm{Bi}^{3+}$; $2-0.001 \mathrm{M} \mathrm{Ce}^{3+} ; 3-0.01 \mathrm{M} \mathrm{Sn}^{4+}$

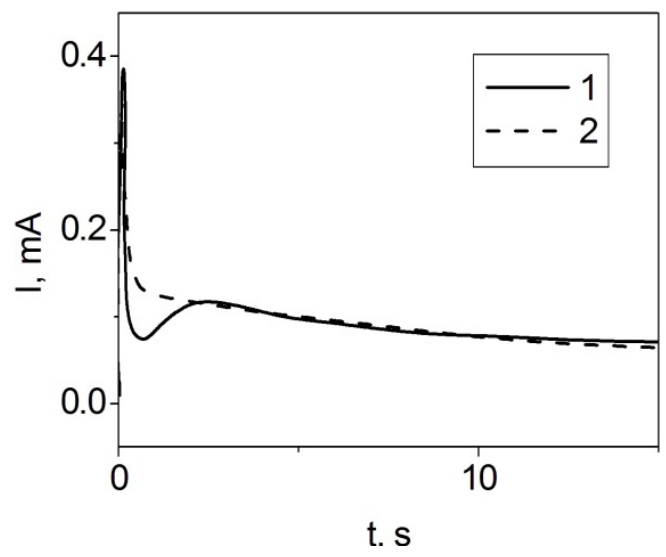

Fig. 3. Current-time transients for $\mathrm{PbO}_{2}$ deposition on $\mathrm{Pt}$ disk electrode at 1620 $\mathrm{mV}$ from $0.01 \mathrm{M} \mathrm{Pb}\left(\mathrm{CH}_{3} \mathrm{SO}_{3}\right)_{2}+1 \mathrm{M}$ $\mathrm{CH}_{3} \mathrm{SO}_{3} \mathrm{H}+\mathrm{X}$, where $\mathrm{X}$ is $1-\left[\mathrm{NiF}_{6}\right]^{2-} ; 2-$ $0.01 \mathrm{M}\left[\mathrm{SnF}_{6}\right]^{2-}$

For the analysis of obtained transients we used the model, described in [8], and calculated rate constants for instantaneous and progressive nucleation.

For all the above cases, the crystallization occurs through the progressive mechanism. The preferred geometric shape of formed crystals at 2D nucleation from electrolytes containing cationic additives is cone. And upon crystallization from electrolytes containing complex ions additives geometric shape changes on a cylinder. The main parameters of the crystallization of lead dioxide from electrolytes containing ionic additives are presented in the Table 1.

Table 1. Parameters of initial stages of lead dioxide electrocrystallization

\begin{tabular}{|l|c|c|c|c|}
\hline $\begin{array}{c}\text { Deposition electrolyte } \\
\mathbf{0 . 0 1 ~ M ~ P b ( M S )} \mathbf{~}_{\mathbf{2}}+\mathbf{1 M} \text { MSA }\end{array}$ & $\mathbf{t}_{\boldsymbol{\alpha}}$ & $\mathbf{K}_{\boldsymbol{\alpha}}$ & $\mathbf{t}_{\boldsymbol{\beta}}$ & $\mathbf{K}_{\boldsymbol{\beta}}$ \\
\hline$+0.01 \mathrm{M} \mathrm{Bi}^{3+}$ & 2.17 & $9.20 \times 10^{-6}$ & 4.71 & $4.1 \times 10^{-6}$ \\
\hline$+0.001 \mathrm{M} \mathrm{Ce}^{3+}$ & 2.40 & $2.12 \times 10^{-6}$ & 4.40 & $8.95 \times 10^{-8}$ \\
\hline$+0.01 \mathrm{M} \mathrm{Sn}^{4+}$ & 1.56 & $2.06 \times 10^{-5}$ & 4.41 & $6.28 \times 10^{-7}$ \\
\hline$+0.01{\left.\mathrm{M} \mathrm{NiF}_{6}\right]^{2-}}^{+}$ & 0.02 & $4.61 \times 10^{-5}$ & 0.05 & $9.78 \times 10^{-7}$ \\
\hline$+0.01{\mathrm{M}\left[\mathrm{SnF}_{6}\right]^{2-}}_{+3 \times 10^{-5} \mathrm{SDSS}}^{0.64}$ & $3.92 \times 10^{-6}$ & 1.99 & $5.32 \times 10^{-5}$ \\
\hline$+7 \times 10^{-5} \mathrm{SDS}$ & 1.50 & $6.38 \times 10^{-6}$ & 2.80 & $1.04 \times 10^{-5}$ \\
\hline
\end{tabular}


As one can conclude from obtained data, the presence of cations in the deposition electrolyte alters the ratio between $\alpha$ - and $\beta$-phase crystallization constants in different amount. Thus, in the presence of the complex ion $\left[\mathrm{SnF}_{6}\right]^{2-}$ the growth of $\beta$-phase dominates. For other cationic additives the prevalence of $\alpha$-phase growth is observed. It should also be noted, that the presence of complex nickel and tin fluoride ions reduces the beginning of nucleation. Most clearly this effect is observed for $\left[\mathrm{NiF}_{6}\right]^{2-}$ ion.

It is known [9], that the surfactant additive has a significant effect on the kinetics of lead dioxide electrodeposition, without changing the mechanism of the process. It has been also found that it is incorporated into the growing coating through adsorption on $\mathrm{PbO}_{2}$ crystals. That in turn will lead to changes in initial stages of the crystallization. Surfactant additives selectively adsorbed on certain faces, usually parallel to faces, reducing the growth rate of these faces, and thereby altering the shape of growing crystals. For more detailed analysis of surfactant additives influence on the initial stages of the crystallization current-time transients from electrolytes, containing sodium dodecyl sulfate (SDS) of two different concentrations $3 \times 10^{-5}$ and $7 \times 10^{-5} \mathrm{~mol} \mathrm{dm}^{-3}$ were obtained (Fig. 4).

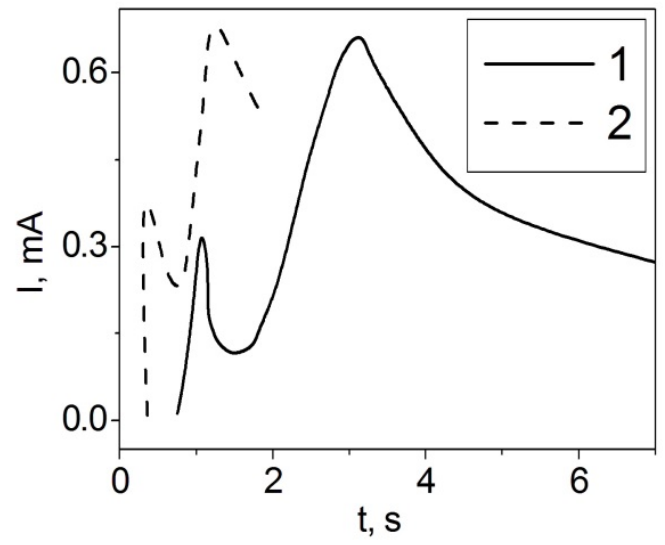

Fig. 4. Current-time transients obtained at $\mathrm{PbO}_{2}$ deposition on $\mathrm{Pt}$ electrode at $1620 \mathrm{mV}$ from next solutions: $0.1 \mathrm{M}$ $\mathrm{Pb}\left(\mathrm{CH}_{3} \mathrm{SO}_{3}\right)_{2}+0.1 \mathrm{MCH}_{3} \mathrm{SO}_{3} \mathrm{H}+3 \times 10^{-5}$ $\mathrm{SDS} ; 2-0.1 \mathrm{M} \mathrm{Pb}\left(\mathrm{CH}_{3} \mathrm{SO}_{3}\right)_{2}+0.1 \mathrm{M}$ $\mathrm{CH}_{3} \mathrm{SO}_{3} \mathrm{H}+7 \times 10^{-5} \mathrm{SDS}$

The analysis of obtained transient revealed that in the case of methanesulfonate electrolytes the crystallization proceeds according to the progressive mechanism. For nitrate electrolytes there is a change in the mechanism from progressive on instantaneous at high concentrations of surfactants. The preferred form of crystals at 2D nucleation in the presence of additives in nitrate electrolytes is semispheroid, and in the case of methanesulfonate electrolytes cylinder becomes the preferred form of crystals (see Table 1). 


\section{Conclusions}

The nature of depositing electrolyte considerably influences on the phase composition of lead dioxide coatings and on crystallographic orientations of individual faces. The coatings obtained from methanesulfonate bath are almost entirely composed of $\alpha$-phase. It was found for the first time that addition of dopants in deposition electrolytes leads to growth of $\beta$-phase content in deposits. This in turn suggests that the phase composition is largely influenced not by the nature of the substrate but by kinetic difficulties in initial stages of crystallization depending on the composition of the deposition electrolyte. Predominance in the growth of one or the other phase is determined by the ratio between the kinetic constants of the crystal growth of $\alpha-$ and $\beta$ phases.

\section{References}

[1] Li X. Electrodeposited lead dioxide coatings / X. Li, D. Pletcher, F.C. Walsh // Chem. Soc. Rev. 2011. - Vol. 40. - P. 3879-3894.

[2] Chaplin B. P. Critical review of electrochemical advanced oxidation processes for water treatment applications / B. P. Chaplin // Environ. Sci.: Processes Impacts. - 2014. - Vol. 16. - P. 1182-1203.

[3] Low C. T. J. The electrodeposition of highly reflective lead dioxide coatings / C. T. J. Low, D. Pletcher, F. C.Walsh // Electrochem. Commun. - 2009. - Vol. 11. - P. 1301-1304.

[4] Ruetschi $\mathrm{P}$. On the presence of $\mathrm{OH}^{-}$ions, $\mathrm{Pb}^{2+}$ ions and cation vacancies in $\mathrm{PbO}_{2}$ / P. Ruetschi, R. Giovanoli // Power Sources. - 1991. - Vol. 13. - P. 81-97.

[5] Pavlov D. The $\mathrm{PbO}_{2}$ Particle: exchange reactions between ions of the electrolyte and the $\mathrm{PbO}_{2}$ particles of the lead-acid battery positive active mass / D. Pavlov, I. Balkanov // J. Electrochem. Soc - 1992. - Vol. 139. - P. 1830-1835.

[6] Electrocrystallization of lead dioxide: influence of early stages of nucleation on phase composition / O. Shmychkova, T. Luk'yanenko, A. Piletska [et al.] // J. Electroanal. Chem. - 2015. - Vol. 746. - P. 57-61.

[7] The influence of deposition conditions on phase composition of lead dioxide-based materials / O. B. Shmychkova, T. V. Luk'yanenko, A. B. Velichenko [et al.] // Prot. Met. Phys. Chem. Surf. - 2015. - Vol. 51. - P. 593-599.

[8] Electrocrystallization of lead dioxide: Analysis of the early stages of nucleation and growth / M. Y. Abyaneh, V. Saez, J. Gonzalez-Garcia [et al.] // Electrochim. Acta. - 2010. - Vol. 55. - P. 3572-3579.

[9] Nafion effect on the lead dioxide electrodeposition kinetics / A. B. Velichenko, T. V. Luk'yanenko, N. V. Nikolenko [et al.] // Russ. J. Electrochem. - 2007. - Vol. 43. - P. 118-120. 


\title{
THE EFFECT OF WATER ADDITION ON PHYSICOCHEMICAL PROPERTIES OF ELECTROCHEMICAL SYSTEMS BASED ON DEEP EUTECTIC SOLVENTS
}

\author{
BOBROVA L.S., SHAIDEROV D.A., KITYK A.A., PROTSENKO \\ V.S., DANILOV F.I \\ Ukrainian State University of Chemical Technology \\ bobrova.lina@yandex.ru
}

We investigated the effect of water addition on physicochemical properties of ionic liquids containing (i) chromium chloride, choline chloride and water in the molar ratio of 1:0.5:x, and (ii) choline chloride, ethylene glycol, nickel chloride and water in the molar ratio of 1:2:1: $x,(x$ $=6,9,12,15$ or 18) for the temperatures between 25 and $80^{\circ} \mathrm{C}$. An increase in the water content resulted in decreasing density, viscosity and surface tension and increasing conductivity. The obtained results were interpreted in terms of hole theory. The introduction of water was stated to have a beneficial effect on the electrodeposition of chromium and nickel coatings.

Electrochemical systems based on deep eutectic solvents (DESs) are now considered as a promising alternative to common aqueous electrolytes [1]. DESs have an ionic character and may be considered as a new class of ionic liquid analogues; they consist of a eutectic mixture of compounds having a melting point significantly lower than that of either individual component $[1,2]$. Commonly, DESs consist of quaternary ammonium salt such as choline chloride (2-hydroxy-ethyl-trimethyl ammonium chloride) and a hydrogen bond donor species such as amides, glycols or carboxylic acids). Similarly to usual ionic liquids, DESs have relatively wide potential electrochemical window, the high solubility of metal salts, negligible vapor pressures and high conductivity compared to non-aqueous solvents [1].

Electrodeposition of various metals and alloys using DESs have been received significant attention as deep eutectic solvents are cheap, easy to synthesize, easily biodegradable and not harmful for the environment compared to most other ionic liquids [1, 3].

It is known that electrodeposition processes from DESs based systems may be sufficiently improved by the introduction of water additives into electroplating baths $[4,5]$. In this context, water molecules added to DESs can be considered as a special hydrogen bond donor. This study was aimed to ascertain the effects of extra water addition on 
the main physicochemical properties of ionic liquids containing $\mathrm{CrCl}_{3} \cdot 6 \mathrm{H}_{2} \mathrm{O}$ or $\mathrm{NiCl}_{2} \cdot 6 \mathrm{H}_{2} \mathrm{O}$ and on the electrodeposition of chromium and nickel films.

\section{Research Methodology}

Choline chloride was recrystallized from isopropanol then filtered and dried under vacuum. Chromium(III) and nickel(II) chlorides were used as they were received. The ionic liquids were prepared by mixing choline chloride and $\mathrm{CrCl}_{3} \cdot 6 \mathrm{H}_{2} \mathrm{O}$ or $\mathrm{NiCl}_{2} \cdot 6 \mathrm{H}_{2} \mathrm{O}$ in a thermostatic heater at $70{ }^{\circ} \mathrm{C}$ by stirring until a homogenous liquids had formed. Then a required amount of extra bidistillate water was added to the mixture and stirred at the same elevated temperature in order to obtain a homogenous liquid mixture. Density measurements were performed using a glass specific gravity bottle. The surface tension was determined by means of Wilhelmy plate method. Viscosity measurements were performed with a glass Ubbelohde type viscometer. Conductivity measurements were performed by means of usual ac Wheatstone bridge.

Electrodeposition experiments were carried out in a thermostated glass cell. Chromium and nickel were deposited at a constant value of current density on the disc electrode of copper foil fixed in a plastic holder. Platinum gauze and nickel plate were used as anodes without separation of anodic and cathodic compartments for $\mathrm{Cr}$ and Ni plating, respectively.

\section{Results and Discussion}

Chromium(III)-containing systems

The effect of water addition on physicochemical properties of liquid mixtures was investigated for the systems containing $\mathrm{CrCl}_{3}$, choline chloride and water in the molar ratio of 1:0.5: $x$ (where $x=6,9,12,15$ or 18). As expected, density, surface tension and viscosity decrease with increasing temperature and water content in the liquid mixtures. On the contrary, conductivity increases with temperature and water content. Some of the obtained results are shown in Figures 1 and 2.

It is well-known that hole theory can be used to explain the mobility of particles in deep eutectic solvents. According to this concept [1], ionic liquids (including DESs) contain empty spaces arising from thermally generated fluctuations in local density. The vacancies are of a random size and position; they are in constant motion. An ion can only move through an ionic liquid if it is adjacent to a hole of equal or greater size. 
The average hole size $(r)$ in an ionic liquid is given by the following relationship [1]

$$
\left.4 \pi r^{2}\right\rangle=3.5 \frac{k T}{\gamma}
$$

where $\gamma$ is the surface tension, $k$ is the Boltzmann constant and $T$ is the absolute temperature.

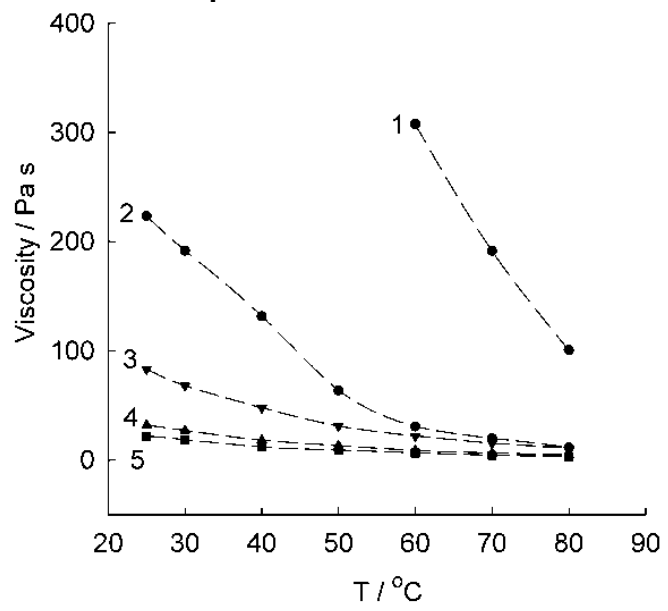

Fig. 1. Viscosity of $2 \mathrm{CrCl}_{3}+\mathrm{ChCl}+$ $\mathrm{xH}_{2} \mathrm{O}$ mixtures as a function of temperature.

$x=6(1), 9$ (2), 12 (3), 15 (4), 18 (5)

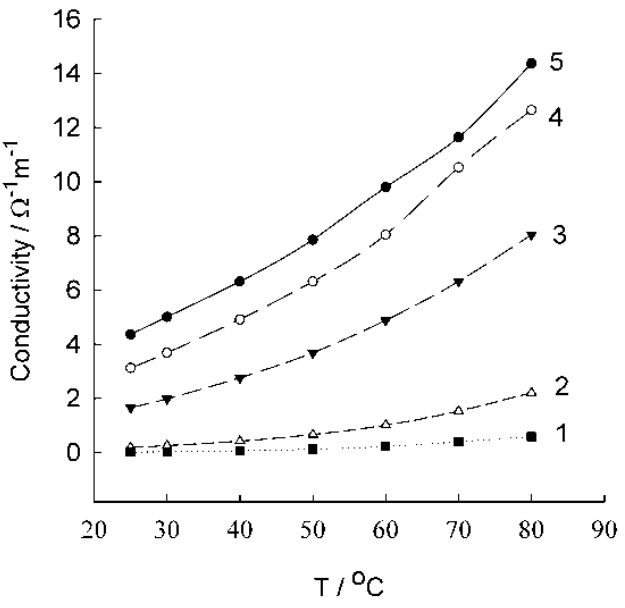

Fig. 2. Conductivity of $2 \mathrm{CrCl}_{3}+\mathrm{ChCl}+$ $\mathrm{xH}_{2} \mathrm{O}$ mixtures as a function of temperature.

The calculated average void radii for the systems under consideration are shown in Table 1. As can be seen, increasing both temperature and water content leads to an appreciable increase in average void radius. As the natural result, this will promote decreasing viscosity and increasing conductivity.

Table 1. Calculated average void radii for $2 \mathrm{CrCl}_{3}+\mathrm{ChCl}+\mathrm{xH}_{2} \mathrm{O}$ mixtures

\begin{tabular}{cccccc}
\hline \multirow{2}{*}{$T\left({ }^{\circ} \mathrm{C}\right)$} & \multicolumn{5}{c}{$r(\AA)$} \\
\cline { 2 - 6 } & $x=6$ & $x=9$ & $x=12$ & $x=15$ & $x=18$ \\
\hline 25 & 0.732 & 1.254 & 1.287 & 1.315 & 1.509 \\
30 & 0.741 & 1.268 & 1.306 & 1.332 & 1.530 \\
40 & 0.765 & 1.304 & 1.343 & 1.374 & 1.583 \\
50 & 0.788 & 1.340 & 1.389 & 1.428 & 1.648 \\
60 & 0.811 & 1.383 & 1.437 & 1.481 & 1.714 \\
70 & 0.839 & 1.424 & 1.488 & 1.536 & 1.773 \\
80 & 0.866 & 1.482 & 1.550 & 1.602 & 1.832 \\
\hline
\end{tabular}

The temperature dependences of viscosity and conductivity were processed using logarithmic form of Arrhenius equation and the corresponding values of activation energies were calculated. Both activation energy for viscous flow and activation energy for conductivity diminish with increasing water content in liquid mixtures. Lower activation energies correspond to more mobile ions within the melt. Therefore, the obtained results are in good agreement with the estimation of average hole sizes: an increase in $r$ makes ionic motion considerably easier. 
Thus, the introduction of extra water into the systems results in an appreciable improvement in some properties of liquid mixtures: a decrease in viscosity and an increase in conductivity are observed. This feature is important and favorable in terms of the possible practical application of plating baths containing DESs. However, the results of electrodeposition experiments reveal that an increase in extra water concentration leads to a decrease in current efficiency due to the acceleration of competitive hydrogen evolution reaction. Taking into account these considerations, we conclude that the chromium electroplating should be performed from liquid mixtures of $2 \mathrm{CrCl}_{3}+\mathrm{ChCl}$ $+x \mathrm{H}_{2} \mathrm{O}$ with intermediate water content $(x=9$ or 12$)$.

Nickel(II)-containing systems

The effect of water addition on the physicochemical properties of liquid mixtures was investigated for the systems containing choline chloride, ethylene glycol, nickel chloride and extra water in the molar ratio of 1:2:1: $x$ (i.e. ethaline $+\mathrm{NiCl}_{2}+x \mathrm{H}_{2} \mathrm{O}$ ) where $x=6,9,12$ or 18 .

Analogous to chromium-containing ionic liquids, an increase in the water content $(x)$ results in decreasing density, viscosity and surface tension and increasing conductivity (see Figures 3 and 4 for references).

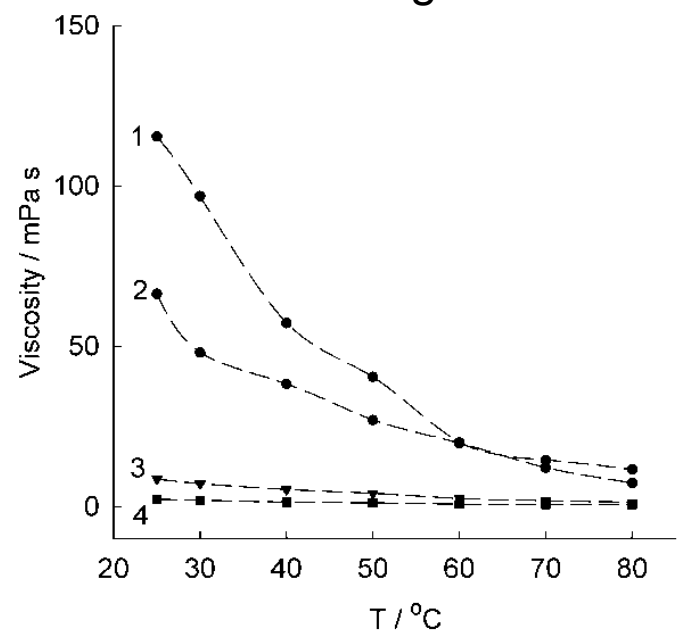

Fig. 3. Viscosity of ethaline + $\mathrm{NiCl}_{2} \cdot \mathrm{xH}_{2} \mathrm{O}$ mixtures as a function of temperature.

$x=6$ (1), 9 (2), 12 (3), 18 (4)

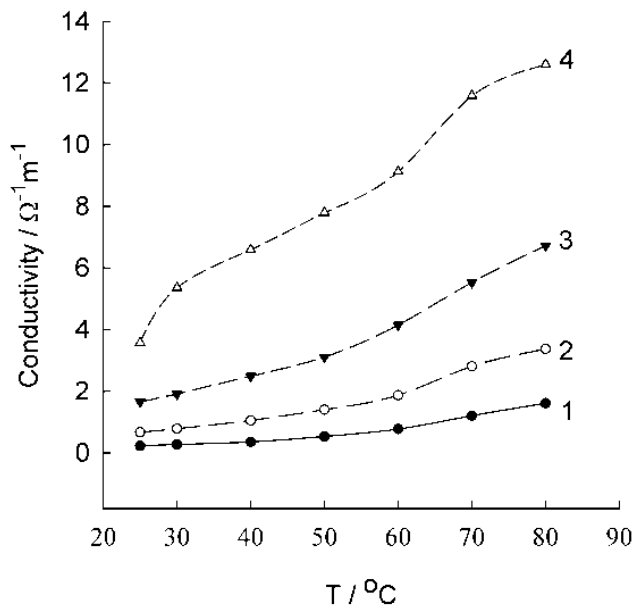

Fig. 4. Conductivity of ethaline + $\mathrm{NiCl}_{2} \cdot \mathrm{xH}_{2} \mathrm{O}$ mixtures as a function of temperature.

$x=6$ (1), 9 (2), $12(3), 18$ (4)

The calculated average hole sizes in the liquid systems under study are summarized in Table 2, the value of $r$ being increased with increasing both temperature and water content. This means that ionic motion becomes easier.

Nickel electrodeposition experiments showed that high-quality nanocrystalline Ni deposits can be obtained from the electroplating bath on the basis of DESs with water addition. The current efficiency of $\mathrm{Ni}$ electrodeposition reaction reaches $95-100 \%$. The coatings morphology 
becomes finer at higher water concentrations. Our preliminary results showed that the microhardness and corrosion resistance of $\mathrm{Ni}$ coatings can be enhanced with an increase in water content in the plaiting bath.

Table 2. Calculated average void radii for ethaline $+\mathrm{NiCl}_{2} \cdot \mathrm{XH}_{2} \mathrm{O}$ mixtures

\begin{tabular}{ccccc}
\hline \multirow{2}{*}{$T\left({ }^{\circ} \mathrm{C}\right)$} & \multicolumn{4}{c}{$r(\AA)$} \\
\cline { 2 - 5 } & $x=6$ & $x=9$ & $x=12$ & $x=18$ \\
\hline 25 & 1.207 & 1.220 & 1.234 & 1.248 \\
30 & 1.223 & 1.236 & 1.251 & 1.265 \\
40 & 1.256 & 1.270 & 1.285 & 1.300 \\
50 & 1.289 & 1.295 & 1.314 & 1.336 \\
60 & 1.325 & 1.332 & 1.347 & 1.370 \\
70 & 1.356 & 1.372 & 1.393 & 1.406 \\
80 & 1.391 & 1.410 & 1.425 & 1.444 \\
\hline
\end{tabular}

\section{Conclusions}

1. The introduction of extra water into the ionic liquids containing $2 \mathrm{CrCl}_{3}+\mathrm{ChCl}+\mathrm{xH}_{2} \mathrm{O}$ or ethaline $+\mathrm{NiCl}_{2} \cdot \mathrm{xH}_{2} \mathrm{O}$ has a beneficial effect on the physicochemical properties of the plating bath: an increase in conductivity and a decrease in viscosity are observed.

2. High-quality $\mathrm{Cr}$ and $\mathrm{Ni}$ coatings with a relatively high current efficiency can be electrodeposited from the plating bath based on DESs with extra water addition.

\section{References}

[1] Smith E.L., Abbott A.P., Ryder K.S., Deep eutectic solvents (DESs) and their applications, Chem. Rev., 114, 11060-11082, (2014).

[2] Abbott A.P., Capper G., Davies D.L., Rasheed R.K., Tambyrajah V., Novel solvent properties of choline chloride/urea mixtures, Chem. Commun., 70-71, (2003).

[3] Abbott A.P., Ryder K.S., König U., Electrofinishing of metals using eutectic based ionic liquids, Trans. Inst. Met. Finish., 86, 196-204, (2008).

[4] McCalman D.C., Sun L., Zhang Y., Brennecke J.F., Maginn E.J., Schneider W.F., Speciation, conductivities, diffusivities, and electrochemical reduction as a function of water content in mixtures of hydrated chromium chloride/choline chloride, J. Phys. Chem. B, 119, 6018-6023, (2015).

[5] Protsenko V.S., Kityk A.A., Shaiderov D.A., Danilov F.I., Effect of water content on physicochemical properties and electrochemical behavior of ionic liquids containing choline chloride, ethylene glycol and hydrated nickel chloride, J. Mol. Liq., 212, 716-722, (2015). 


\title{
THE KINETICS OF WATER TRANSFER THROUGH CATION EXCHANGE MEMBRANES
}

\author{
B. PAVLOV, G. TULSKIY \\ National Technical University «Kharkiv Polytechnical Institute», \\ Pavlov6993@i.ua
}

The purpose of this work is to research the kinetics transfer of proton water through the membrane and to evaluate the influence of technological options of electrolysis on this process.

The values of the ions streams through the membrane were determined by measuring the quantity of substance in electrode cameras, separated from each other by membrane, after putting the known quantity of electricity through.

In order to simplify the technological scheme of membrane electrolysis to get the $\mathrm{NaClO}$ «A», the conditions of electrolysis which exclude the circulation of electrolyte were proposed. High concentration of $\mathrm{NaCl}$ in anolit will be provided by transfer of proton water through the membrane from the anode camera to the catode camera.

Experimental measurements of transfer numbers were carried out by the Hittorf method.

The results of calculations according to the Breslau and Miller model, for the Nafion 125 - solute $\mathrm{NaCl}$ system shows that with decreasing $\mathrm{NaCl}$ concentration the numbers of proton water transfer grows from $t_{w}=4,3 \mathrm{~mol} \cdot \mathrm{F}^{-1}$ with $\mathrm{c}=5 \mathrm{~mol} \cdot \mathrm{dm}^{-3}$ to degree $\mathrm{t}_{\mathrm{w}}=7,8 \mathrm{~mol} \cdot \mathrm{F}^{-1}$ with $\mathrm{c}=2 \mathrm{~mol} \cdot \mathrm{dm}^{-3}$.

It was found that with increasing amperage density more $100 \mathrm{~A} \cdot \mathrm{m}^{-2}$ influence on electrolysis chloride solutes make the ohmic component of amperage decreasing. Increasing of ohmic amperage leads to local increasing of temperature of anode and negatively affect the solutes stability of $\mathrm{NaClO}$. So, if the main purpose is to get the $\mathrm{NaClO}$, it's important to foresee the possibility of decreasing temperature of anode.

Decreasing of anode potential is possible at the expense of decreasing of $\mathrm{Ph}$ of electrolite solute. However decreasing of $\mathrm{Ph}$ lower than 2,5 leads to excess of critical anode potential, decreasing the persistence $\mathrm{RuO}_{2}$ - catalycity active component of low vanishing anode.

Achieving of critical potential DSA with low temperatures $(288 \mathrm{~K}$ and lower) reflects the decreasing of electrode activity DSA when electrochemical getting of $\mathrm{Cl}_{2}$. 
Last years a lot of researches are aiming on developing of membrane way of electrolyses of water chlorides solutes. Technological process of production of $\mathrm{NaClO}$ with using of membrane technologies composed in getting $\mathrm{Cl}_{2}$ and $\mathrm{NaOH}$ in cameras of membrane electroliser, their cooling and the next cooperation in reactor with next getting of $\mathrm{NaClO}[1-3]$.

\section{Research Methodology}

With electrochemical synthesis of concentrated solutes "active chlore" as a membrane we used MФ-4CK, Nafion-125.

For tests the membrane setting was investigated, which helps to get concentrated solutes "active $\mathrm{Cl}_{2}$ ".

Common view on the setting is on picture 1.

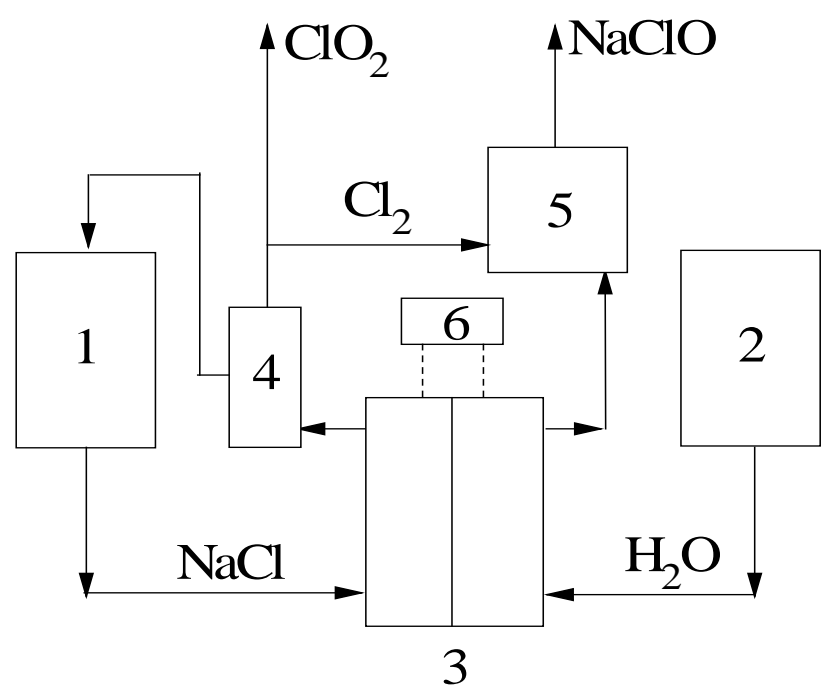

Fig. 1. Scheme of electrolyses membrane setting work

Solute of Chloride $\mathrm{Na}$ given $\mathrm{pH}$ from streaming tank 1 goes to the lowest part of anode camera of electrolyses 3. Using of streaming tank lets us use the expend calculator, which provides smooth, self flowing transmission of electrolyte to electroliser with set speed and keeps in this cameras concentration of electrolyte in exact determined interval $280 \ldots 310 \mathrm{~g} \cdot \mathrm{dm}^{-3}$. Self flowing transmission of $\mathrm{NaCl}_{2}$ solute to electroliser and flowing mode heads to installing stationary more of electrolyze.

To catode camera the flow of distilled water was organized from flowing tank 2 through union in the lower part. Before start of electroliser catode camera was filled $1,5 \mathrm{~mol} \cdot \mathrm{dm}^{-3}$ of $\mathrm{NaOH}$ solute.

The speed of flows in catode and anode cameras was determined by expend calculator and was regulated by crane.

Exiting the electroliser anode products of electroliser were headed to gas bleeder 4. In which $\mathrm{Cl}_{2}$ separated from $\mathrm{NaCl}$ solute. Depleted on $\mathrm{Cl}^{-}$ 
solute of $\mathrm{NaCl}$ was headed to additional saturation and then goes back to electrolyze. Thus, this way let us to realize wasteless technology of getting solutes of "active Cl". Also to gas bleeder mercury thermometer was put, which helped to watch the temperature of formatted in electrochemical generator products.

Catode products of electrolise in form of $\mathrm{NaOH}$ and carbon was headed to reactor of blending. 5 . In reactor of blending worked catolite with gas $\mathrm{Cl}$ in result of Chemical reaction forming the concentrate solute of $\mathrm{NaClO}$. Presence of reactor of electrolise product blending levels the danger of blowout of $\mathrm{Cl}_{2}$ to the atmosphere, because it combines with alkali which increases the level of installation work in general.

With a view to simplify the technological scheme of membrane electrolyses for getting $\mathrm{NaClO}$ "A" we proposed such conditions of electrolise when the circulation of anolite will be absent. High concentration of $\mathrm{NaCl}$ in anolite will be provided by transfer of protone water through membrane from anode camera to catode.

Set the dependency of coefficients of ions diffusion in cations from the temperature. With increasing of temperature (with decreasing of $1 / T$ ) the effective energy of activation decreases. This fact can be explained by changing the mechanism of water replacement. With increasing of water temperature increases the level of ions dissociation and increases the role of solvation mechanism in ions transfer. Worth noting that energy of activation decreases with increasing of electrolyte solute concentration (4).

Adding the electric field the charged water moves in direction of anions move, at that working on it force is proportional to charge of matrix and the voltage of electric field, and force of movement resistance - versus proportional to hydraulic penetration of membrane.

\section{Results and Discussion}

The experimental results of membrane electrolise work without of electrolyte flow in anode camera are shown on pic. 2 like dotted line and changed from $t_{w}=4,3 \mathrm{~mol} \cdot \mathrm{F}^{-1}$ при $\mathrm{c}=5,13 \mathrm{~mol} \cdot \mathrm{dm}^{-3}$ to point $t_{\mathrm{w}}=9,6 \mathrm{~mol} \cdot \mathrm{F}^{-1}$ with $\mathrm{c}=2 \mathrm{~mol} \cdot \mathrm{dm}^{-3}$. Comparison of experimental and calculation results shows that model proposed by authors (4), adequately describes the process of transfer of hidrate water in investigated by ours field of concentration $\mathrm{NaCl}\left(4 \ldots 5 \mathrm{~mol} \cdot \mathrm{dm}^{-3}\right)$. Differences of experimental and calculative data with concentration $\mathrm{NaCl}$ less than $4 \mathrm{~mol} \cdot \mathrm{dm}^{-3}$ related to part hydratation of ions in membrane with decreasing of $\mathrm{pH}$ anolite in electrolise process.

But for investigated, and moreover for working range concentration of $\mathrm{NaCl}$ using of model is permissible. Using in quality of anolite water solute of $\mathrm{NaCl}$ with concentration $280 \mathrm{~g} \cdot \mathrm{dm}^{-3}$ through the surface of 
membrane $0,05 \mathrm{~m}^{2}$ when flows $100 \mathrm{~A}$-hour of electricity will be transferred $300 \pm 0,5 \mathrm{~g} \mathrm{H}_{2} \mathrm{O}$.

With chosen concentration $280 \mathrm{~g} \cdot \mathrm{dm}^{-3}\left(\rho=1,178 \mathrm{~g} \cdot \mathrm{sm}^{-3}\right)$ in $900 \mathrm{sm}^{3}$ will be $254 \mathrm{~g} \mathrm{NaCl}$ and $806 \mathrm{~g} \mathrm{H}_{2} \mathrm{O}$.

In accordance to Faraday law when flows $100 \mathrm{~A}$-hour voltage mass $\mathrm{NaCl}$ will decrease on $206 \mathrm{~g}$ (BT $\approx 95 \%$ ). After one hour of electrolyze with voltage density $2000 \mathrm{~A} \cdot \mathrm{m}^{-2}$ in anode camera of membrane electroliser will still be $254-206=48 \mathrm{~g} \mathrm{NaCl}$. During the same time in accordance with investigated numbers of water transfer from outputing $806 \mathrm{~g} \mathrm{H}_{2} \mathrm{O}$ through membrane wil be transferred $302 \mathrm{~g} \mathrm{H}_{2} \mathrm{O}$, another words, there will be only $504 \mathrm{~g} \mathrm{H}_{2} \mathrm{O}$ left. Thus in the result of electrolise anolite contain only $8 \%$ solute $\mathrm{NaCl}$, that match the concentration of $\mathrm{NaCl} 85 \mathrm{~g} \cdot \mathrm{dm}^{-3}$.

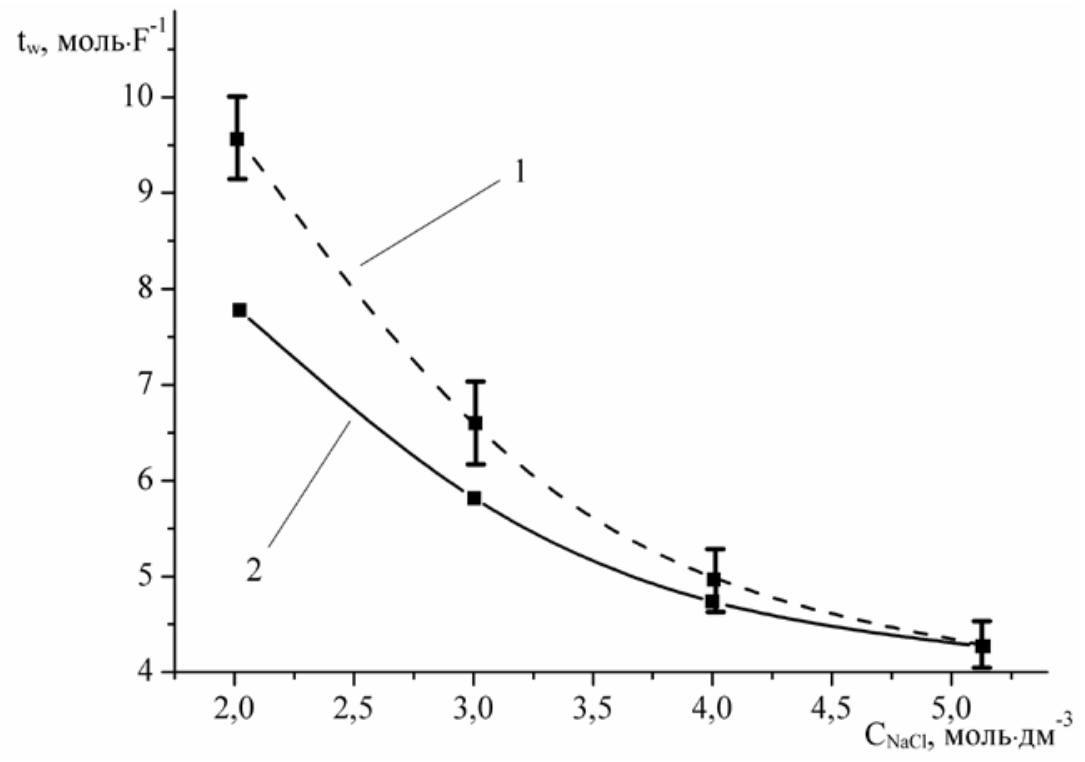

Fig. 2. Dependence of numbers of transfer water from concentration of solute $\mathrm{NaCl}$, which is in contact with membrane: 1 - experimental. 2 - calculative

Made calculation was confirmed with the results of recourse tests of laboratory setting, which confirmed the hypothesis about possibility of technical scheme of membrane electrolyses without of using the stage of analite additional saturation of solid $\mathrm{NaCl}$ qualification.

Based on made investigations of the different factor's influence on kinetics of anode process, we can make the next conclusions:

- increasing of thickness of voltage more than $100 \mathrm{~A} \cdot \mathrm{m}^{-2}$ great influence on $\mathrm{Cl}$ solute electrolise makes the Ohm component of the voltage falling. Increasing of Ohm component makes the local heat up of anode surface and makes the negative influence on stability of $\mathrm{NaClO}$. That's why if the final product foresees getting of $\mathrm{NaClO}$, in the construction of electroliser is important to foresee the possibility of cooling anode. 
- decreasing of anode potential is possible through decreasing of $\mathrm{pH}$ of electrolite solute. However decreasing lower than 2,5 leads to excess of critical anode potential, decreasing of $\mathrm{RuO}_{2}$ resistance - katolit active component low damaging anode.

- gaining the critical of potential OPTA with decreasing temperatures (288 K and lower) reflects the decreasing of electrode DSA activity with electrochemical getting of $\mathrm{Cl}$.

- Oxide ruthenium-titanium anode cover holds katalit activity in electrochemical synthesis of $\mathrm{Cl}$ and dioxid $\mathrm{Cl}$. However in the conditions of low temperatures in order to increase the working thicknesses of voltage was proposed the using of more stable anode material $-\mathrm{IrO}_{2}$.

- Comparing of experimental and calculative results shows that used model describes adequately the process of transfer proton water through membrane in range of working $\left(4 \ldots 5 \mathrm{~mol} \cdot \mathrm{dm}^{-3}\right)$ concentration of $\mathrm{NaCl}$.

\section{References}

[1] Бахир В.М. Дезинфекция питьевой воды: анализ и перспективы / В.М. Бахир // Питьевая вода. - 2007. - № 3. - С. 11 - 18.

[2] Баштан С.Ю. Електрохімічна очистка води в апаратах 3 розділювальною керамічною мембраною : автореф. дис. на здобуття наук. ступеня канд. техн. наук : спец. 05.17.21 «Технологія водоочищення» / Софрія Юріївна Баштан. - К., 2009. - 20 с.

[3] Гончарук В.В. Электрохимическое обеззараживание морской воды в плавательном бассейне / В.В. Гончарук, С.Ю. Баштан, Р.Д. Чеботарева // Химия и технология воды. - 2003. - Т. 25, № 4. - С. $334-341$.

[4] Breslau B.R. A hydrodynamic model for electroosmosis / B.R. Breslau, I.F. Miller // Industr. and Eng. Chem. Fundam. - 1971. - Vol. 10. - № 4. - P. 554 - 558. 


\title{
WHEY ELECTRODIALYSIS USING ORGANIC-INORGANIC MEMBRANES
}

\author{
ZMIEVSKII YU.G. ${ }^{\text {a) }}$, ROZHDESTVENSKA L.M. ${ }^{\text {b) }}$, ZAKHAROV V.V. ${ }^{\text {a) }}$, \\ DZYAZKO YU.S. ${ }^{\text {b) }}$, MYRONCHUK V.G. ${ }^{\text {b) }}$ \\ a) National University of Food Technologies of the MES of Ukraine, \\ b) V.I. Vernadskii Institute of General and Inorganic Chemistry \\ of the NAS of Ukraine; zaharoff.911@yandex.ua
}

Organic-inorganic membranes based on heterogeneous ion exchange polymer supports, which were modified with hydrated zirconium dioxide (anion exchange membrane) and zirconium hydrophosphate (cation exchange separator), were used for whey desalination as well as for concentrate and permeate of whey nanofiltration. Comparing with pristine polymer membranes, the composite materials are characterized by stability against fouling inside pores. The membranes were applied to desalination of whey and products of its baromembrane treatment. Exponential decay of electrical conductivity over time has been found for the solutions being purified. The membrane resistance grew simultaneously.

Large amounts of liquid wastes produced by dairy industry are dropped into rivers and lakes resulting in deterioration of water quality due to occurrence of turbidity and unpleasant odor, development of pathogens and so on. Recycling of milky whey allows one to solve not only ecological but also economical problems, since the end products (protein supplements or infant formula) can be sold. However, deep desalination of whey is needed to obtain these products [1]. Since milky whey contains high amount of inorganic salts (the order is $1 \mathrm{~g} \mathrm{dm}^{-3}$ ), electrodialysis (ED) is attractive for this purpose [2].

As a rule, polymer membranes are used for the ED processes, however they accumulate organic and inorganic matters not only on their outer surface, but also inside pores [3]. Thus, a durable procedure, which involves large amount of aggressive reagents and deionized water, is needed for regeneration of the membrane system. However, polymer material containing intraporous active layer of inorganic ion-exchanger is stable against fouling during baromembrane separation [4]. A similar approach could be applied to ion exchange membranes [5]. Before ED treatment, whey proteins are concentrated by means of nanofiltration, this process gives both concentrate and permeate [6]. After desalination, the concentrate is used for manufacture of valuable products. Salts are 
removed from the concentrate, which is used further for manufacture of valuable products. Desalinated permeate can be returned to fresh whey in order to enrich it with lactose. The aim of the investigation is application of organic-inorganic membranes to desalination of whey and products of its baromembrane treatment.

\section{Research Methodology}

The ion exchange separators were obtained by modification of heterogeneous CM-40 cation exchange and AM-40 anion exchange polymer supports (Schekinoazot, RF) with zirconium hydrophosphate (ZHP) and hydrated zirconium dioxide (HZD) respectively [5]. These membranes were manufactured from $\mathrm{CU}$ 2-8 cation-exchange resin and EDE-10P anion-exchanger. The resins were modified by similar manner for visualization of small incorporated particles using a JEOL JEM 1230 transmission electron microscope (Jeol) and a scanning electron microscope JEOL JSM $6700 \mathrm{~F}$ (Jeol).

Experimental set-up involves seven-compartment cell, power supplier, measuring instrumentations and three independent liquid lines [10]. The first line provides circulation of whey $\left(300 \mathrm{~cm}^{3}\right)$ throw three desalination compartments with a flow velocity of $0.3 \mathrm{~cm}^{3} \mathrm{~s}^{-1}$, the second line was through two concentration chambers filled with a $0.1 \mathrm{M} \mathrm{HCl}$ solution $\left(1 \mathrm{dm}^{3}\right)$. The electrode compartments were filled with a $0.05 \mathrm{M}$ $\mathrm{Na}_{2} \mathrm{SO}_{4}$ solution. A thickness of each compartment was $6 \mathrm{~mm}$, the desalination compartments contained turbulators for intensification of mass transport.. Only composite membranes (further $\mathrm{CM}$ ) or only pristine membranes (PM) were used for separation of the compartments from each other.

Milky whey and products of its nanofiltration (NF) treatment (concentrate and permeate) were purified from inorganic ions. The ED processes were performed at $15 \mathrm{~V}$.

\section{Results and Discussion}

Both single nanoparticles (4-20 nm in the case of ZHP and 3-6 nm fo HZD) are visible in TEM image of ion exchange resins. Aggregates of the nanoparticles $(\approx 300 \mathrm{~nm})$ have been also found (Fig. 1). Single nanoparticles are placed in clusters and channels of the polymers and improve ion transport [5]. The aggregates are placed in pores outside clusters and channels, where hydrophobic parts of the polymer chains are located. The aggregates prevent adsorption of organics (fouling). 

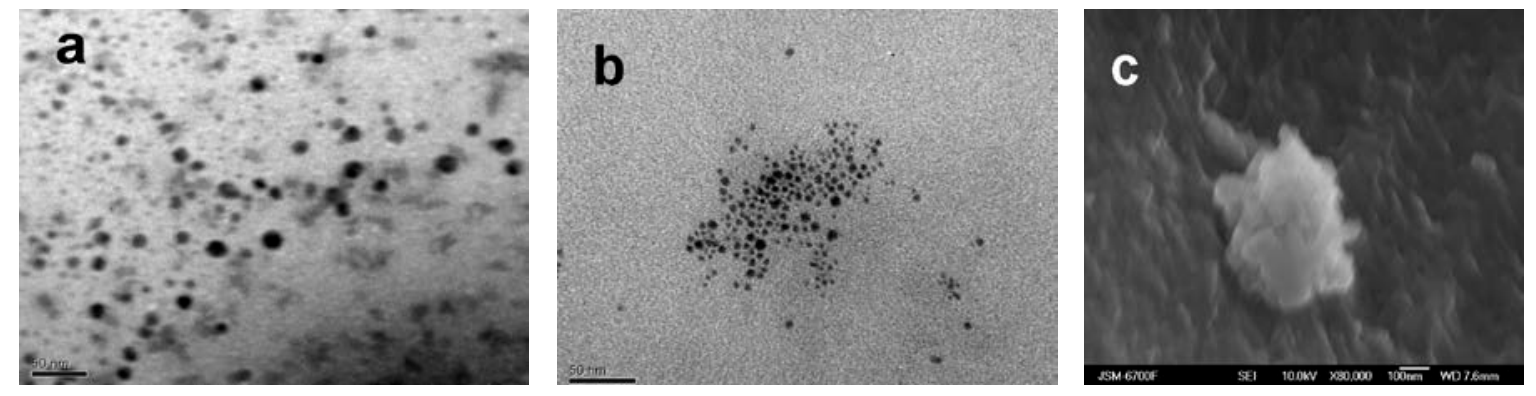

Fig. 1. TEM and SEM images of ZHP (a, c) and HZD (b) particles in cation-(a, c) anion-(b) exchangers contain.

During electrodialysis using PM and CM, the whey conductivity $(\kappa)$ decreased over time ( $\tau$ ) due to removal of mineral components (Fig. 2). The conductivity changed according to the relation:

$$
\kappa=10^{a-b \tau},
$$

where $a$ (initial conductivity) and $b$ (related to desalination rate) are the empirical coefficients. The $b$ parameter corresponds to slope of the $\kappa-$ $\tau$ curve, which is plotted in semi-logarithmic coordinates, i.e. $b=d(\log \kappa) / d \tau$. Modified membranes demonstrate higher rate of desalination than PM (Table 1$)$. The cell voltage $\left(U_{c}\right)$ is determined as:

$$
U_{c}=E_{c a t h}+E_{a n}+I\left(\sum_{i} R_{s, i}+\sum_{j} R_{m, j}\right) .
$$

Here $E_{\text {cath }}$ and $E_{a n}$ are the electrode potentials, $I$ is the current, $R$ is the resistance, the $s$ and $m$ indexes correspond to solutions and membranes, $i$ and $j$ are the numbers of compartments and membranes. Since $U_{c}$ is the constant, the current is determined by a resistance of the membranes and solutions, $R=p \frac{l}{S}=\frac{1}{\kappa} \frac{l}{S}$ (here $\rho$ is the specific resistance, $l$ is the thickness, $S$ is the area), it is possible to write:

$$
I=\frac{S\left[U_{c}-\left(E_{c}+E_{a}\right)\right]}{l_{\text {comp }}\left[3 \rho_{s, \text { des }}+2\left(\rho_{s, \text { conc }}+\rho_{s, e l}\right)\right]+l_{m} \sum_{j} \rho_{m, j}} .
$$


Here the des, conc and el indexes correspond to the desalination, concentration and electrode compartments (comp) respectively. The terms of $2\left(\rho_{s, \text { conc }}+\rho_{s, e l}\right)$ and $\frac{3 l_{\text {comp }}}{S\left[U_{c}-\left(E_{c}+E_{a}\right)\right]}$ can be neglected, thus:

$$
\frac{\rho_{s, d e s}}{I}=S\left[U_{c}-\left(E_{c}+E_{a}\right)\right] \sum_{j} \rho_{m, j} .
$$

In other words, the $\rho_{s, d e s} / I-\tau$ plot reflects a change of the membrane resistance (due to depletion of whey and fouling) over time. As seen, PM are characterized by higher $\rho_{s, \text { des }} / I$ value despite lower desalination degree of whey. Thus, the composite membranes demonstrate higher stability against fouling than PM. ED process involving CM requires also lower energy consumptions (see Table 1).
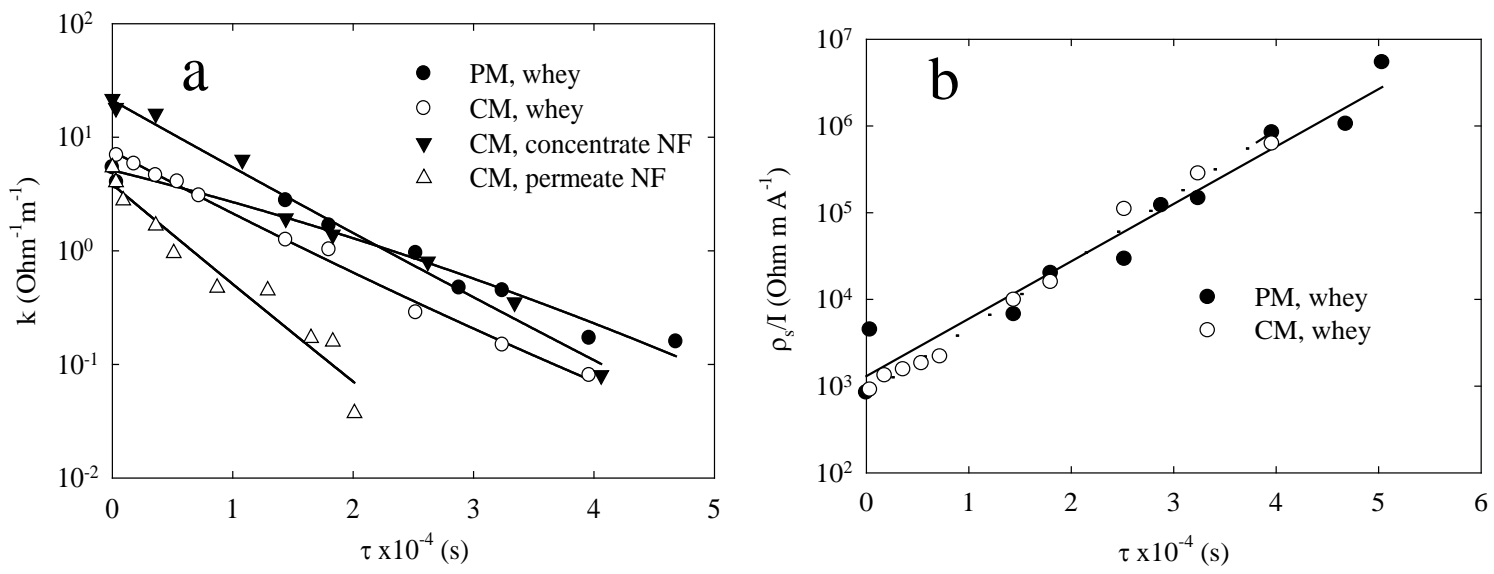

Fig. 2. Conductivity of liquid through desalination compartments (a) and $\rho_{s} / I$ ratios (b) as functions of time.

Table 1. Electrodialysis of biological liquids

\begin{tabular}{|c|c|c|c|}
\hline \multirow{2}{*}{ Liquid } & Membranes & $\begin{array}{c}d(\log \kappa) / d \tau \\
\left(\mathbf{O h m} \mathbf{m}^{-1} \mathbf{~}^{-\mathbf{- 1}}\right.\end{array}$ & $\begin{array}{c}\text { Energy consumptions for } \\
\mathbf{1} \text { kg salts } \mathbf{~ k W h}\end{array}$ \\
\hline \multirow{2}{*}{ whey } & $\mathrm{PM}$ & $-3.8 \times 10^{-10}$ & 3.8 \\
\cline { 2 - 4 } & $\mathrm{CM}$ & $-5.1 \times 10^{-10}$ & 1.7 \\
\hline NF concentrate & $\mathrm{CM}$ & $-5.7 \times 10^{-10}$ & 1.5 \\
\hline NF permeate & $\mathrm{CM}$ & $-8.7 \times 10^{-10}$ & 2.4 \\
\hline
\end{tabular}


The modified membranes were also applied to desalination of NF concentrate and permeate. Higher rate of desalination was found for the permeate evidently due to an absence of proteins, which form precipitation on outer surface of the membranes. However, the precipitate can be easy removed by polarity reversal or by hydrodynamical pulsations.

\section{Conclusions}

Modified separators demonstrate higher stability against fouling evidently due to nanoparticle aggregates, which prevent penetration of organics inside the membranes. Higher desalination rate and lower energy consumptions were found for these materials than for pristine membranes evidently due to this stability and improved ion transport, which is provided by single nanoparticles. Normally $\approx 1 \mathrm{kWh}$ is necessary per $1 \mathrm{~kg}$ salts, needed decrease of the consumptions could be provided by optimization of the cell geometry.

\section{References}

[1] Fomon S. J. Infant Feeding in the 20th Century: Formula and Beikost / S. J. Fomon // J. Nutr. - 2001. - V. 131, N 2. - P. 409-420.

[2] Greiter M. Desalination of whey by electrodialysis and ion exchange resins: analysis of both processes with regard to sustainability by calculating their cumulative energy demand / M. Greiter, S. Novalin, M. Wendland [et al.] // J. Membr. Sci. - 2002. - V. 210, N 1. - P. 91-102.

[3] Lin Teng Shee F. Microscopic approach for the identification of cationic membrane fouling during cheddar cheese whey electroacidification / F. Lin Teng Shee, P. Angers, L. Bazinet // J. Colloid Interface Sci. - 2008. - Vol. 322, N 2. - P. 551-557.

[4] Dzyazko Yu. S. Organic-inorganic materials containing nanoparticles of zirconium hydrophosphate for baromembrane separation / Yu. S. Dzyazko, L. M. Rozhdestvenskaya, Yu. G. Zmievskii [et al.] // Nanoscale Res. Lett. - 2015. - V. 10. - P. 64.

[5] Dzyazko $\mathrm{Yu}$. Heterogeneous membranes modified with nanoparticles of inorganic ion-exchangers for whey demineralization / Yu. Dzyazko, L. Rozhdestvenskaya, Yu. Zmievskii [et al.] // Mater. Today: Proc. - 2015. - V. 2, N 6. - P. 3864-3873.

[6] Bazinet L. Electrodialytic phenomena and their applications in the dairy industry: a review / L. Bazinet // Crit. Rev. Food Sci. Nutr. -2004. V. 44, N 7-8. - P. 525-544. 
УДК 678.011:544.6

\title{
ELECTROMAGNETIC LOSSES IN CARBON/POLYMER COMPOSITES WITH COPPER NANORODS ADDITIVES
}

\author{
SHPAK YU.V, DRAGAN D.R., SENYK I.V., BARSUKOV V.Z. \\ Kyiv National University of Technologies and Design \\ Ilona_Senyk@i.ua
}

The work is devoted to investigating the influence of some nanometal additives on shielding properties of graphite-carbon-polymer composites against electromagnetic radiation (EMR).

It was shown that due to addition of as much as $3 \%$ of electrochemically synthesized copper nanorods into the graphite-carbonpolymer composite it is possible to achieve a decrease in EMR up to 1000 times in the 17-27 GGz microwave frequency range.

It is planned to use the electrochemically synthesized copper nanorods as effective additives to the graphite-carbon-polymer coatings, which can increase their shielding effectiveness to protect personnel and equipment from EMR.

\section{ЕЛЕКТРОМАГНІТНІ ВТРАТИ В КОМПОЗИТАХ ВУГЛЕЦЬ/ПОЛІМЕР 3 ДОМІШКАМИ НАНО-СТЕРЖНІВ МІДІ}

\author{
ШПАК Ю.В., ДРАГАН Д.Р., СЕНИК І.В., БАРСУКОВ В.З. \\ Київський Національний університет технологій та дизайну \\ Ilona_Senyk@i.ua
}

Робота присвячена дослідженню впливу деяких нано-металевих включень на екрануючі властивості графіт-вуглець-полімерних композитів від електромагнітного випромінювання (EMB).

Показано, що введенням до складу вуглецевого композиту наностержнів міді, отриманих електрохімічним шляхом, в кількості 3\% можна досягти зменшення EMВ до 1000 разів в СВЧ діапазоні 17-27 ГГц. Планується використання електрохімічно-синтезованих мідних наностержнів як ефективних добавок до графіт-вуглецьполімерних покриттів, що може підвищити екрануючі властивості для захисту персоналу та обладнання від впливу EMB.

Проблема захисту персоналу та обладнання від електромагнітного випромінювання (EMB) набуває все нових аспектів, що пов'язано з бурхливим розвитком різноманітних технологій та сорер діяльності людини. 
Найлегше здійснити захист від ЕМВ шляхом його екранування. Поглинаючі екрани (покриття) застосовують у тих випадках, коли відбита електромагнітна енергія від внутрішніх поверхонь суцільних металевих екранів може суттєво порушувати режим роботи НВЧ генератора. Тому поглинаючі покриття повинні по можливості повністю поглинати енергію. Цього досягають підбором діелектричних та магнітних проникностей поглинаючого матеріалу. Проте, існує ряд недоліків таких матеріалів: вузька робоча частота, необхідність забезпечення великих товщин покриття (від 1 мм та вище), що в свою чергу веде до збільшення масогабаритних параметрів, тощо.

Ефективність використання наночасток металів в великій мірі залежить від застосовуваного методу синтезу. Найбільш доступним методом $€$ формування в об'ємі матеріалу упорядкованих структур (шарів, пор) з подальшим їх заповненням металом. Для цієї мети широке поширення отримали плівки анодного оксиду алюмінію (AOA), що характеризуються високоупорядкованим розташуванням гексагональних пор, розміщених перпендикулярно до поверхні [1]. В роботі [2] відзначено вплив морфології деяких металів на захисні властивості композитних матеріалів, виготовлених на їх основі.

У зв'язку з цим була поставлена задача розробити покриття, здатне до блокування EMB від працюючого обладнання 3 максимальними втратами при мінімальних товщинах (до 200 мкм). Вивчалась можливість та ефективність включення до складу композитів металевих часточок, синтезованих електрохімічними та хімічними методами.

\section{Методика експерименту}

Металеві нано-частинки вирощували в матриці $\mathrm{Al}_{2} \mathrm{O}_{3}$. Оксидну матрицю електрохімічно синтезували за методикою [3] з алюмінієвої фольги чистотою $99,5 \%$ в 0,3 М розчині щавлевої кислоти при прикладеній напрузі $45 \mathrm{~B}$ та температурі $20{ }^{\circ} \mathrm{C}$. Вирощування мідних нано-волокон (нано-стержнів) здійснювали з електроліту, який містив в своєму складі $\mathrm{CuSO}_{4}$ 0,9 M та $\mathrm{H}_{2} \mathrm{SO}_{4}$ 0,6 M [1].

Зразки композитних графріт-вуглець-мідь-полімерних фрарб готували шляхом змішування сухих компонентів, які потім вводили в заздалегідь приготовлений розчин полімеру. Плівку формували методом нанесення пензликом на субстрат, висушували при температурі склування полімеру $50-60{ }^{\circ} \mathrm{C}$. Електропровідність оцінювали за методом вимірювання питомого опору 3 використанням чотирьох-електродної комірки. Електромагнітні втрати визначали за допомогою автоматичного вимірювача згасання в діапазоні частот 17-27 ГГц за стандартною схемою вимірювання мікрохвильового згасання в чотирьохполюсниках. 


\section{Результати та обговорення}

Оксидований алюміній використовувався як матриця для вирощування нановолоконних мідних структур [3, 4]. В роботах [5-6] детально досліджено різноманітні параметри та умови електрохімічного синтезу оксидної матриці. В результаті двостадійного електрохімічного оксидування металевого алюмінію (рис. 1) утворюється упорядкована пориста структура, з рівномірним розподілом пор, товщинами стінок та внутрішнього діаметру пор.

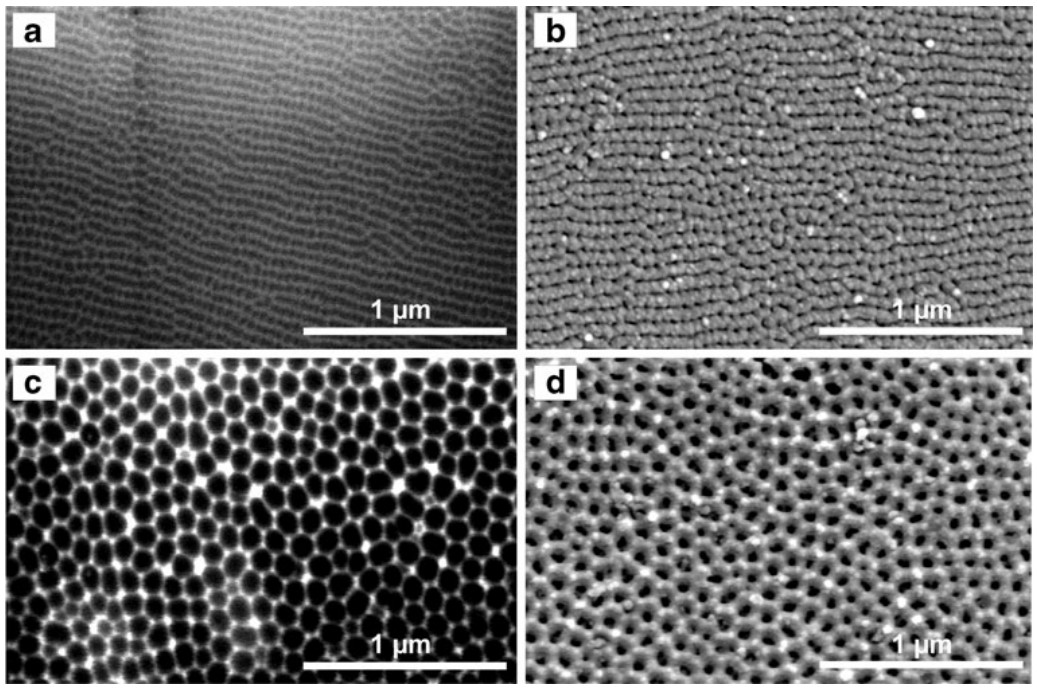

Puc. 1.CЕМ зображення поверхні алюмінієвого зразка після електрополірування (а), шару оксиду алюмінію після першого кроку анодизації

(б), поверхня металу після оксидного відновлення (c) та пориста матриця $\mathrm{Al}_{2} \mathrm{O}_{3}$ після другого кроку анодизації (d)

Матеріали, отримані в результаті електрохімічного синтезу в таких матрицях, відрізняються високою чистотою, контрольованістю форм та розмірів часточок.

В даній роботі порівняні вклади в екранування від ЕМВ нановолокон міді з порошковою міддю марки ПМВ-С 0045 К з розміром часточок 45-63 мкм та базовою графіт-вуглець-полімерною фарбою.

Отримані результати досліджень (рис. 2) відображають загальні втрати EMB, які вносить зразок. Так, базова графріт-вуглецьполімерна фрарба вносить втрати на рівні -23 dB при товщині зразка не більше 160 мкм, що відповідає подавленню сигналу більше ніж в 100 разів. Включення до складу фрарби навіть невеликої кількості металевих часточок (3\%) дозволяють покращити ці результати (рис. 2) адже вони підвищують електропровідність системи і не впливають суттєво на масогабаритні показники. 
$L, d B$

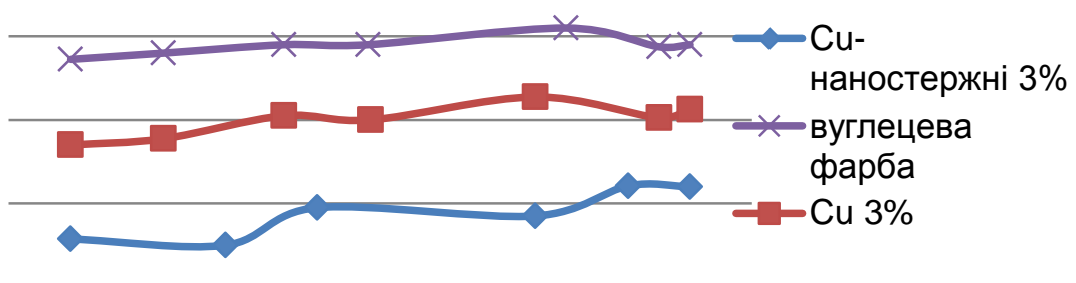

f, ГГц

Puc. 2. Частотні характеристики втрат зразків графріт-вуглецевих фрарб з вмістом 3\% часточок міді в різній формі

Введення порошкових металевих часточок міді (3\% за масою) безумовно привело до збільшення втрат, проте введення волокнистих структур міді в такій самій кількості дозволяє покращити результат екранування в середньому аж до -27 dB (майже в 1000 разів).

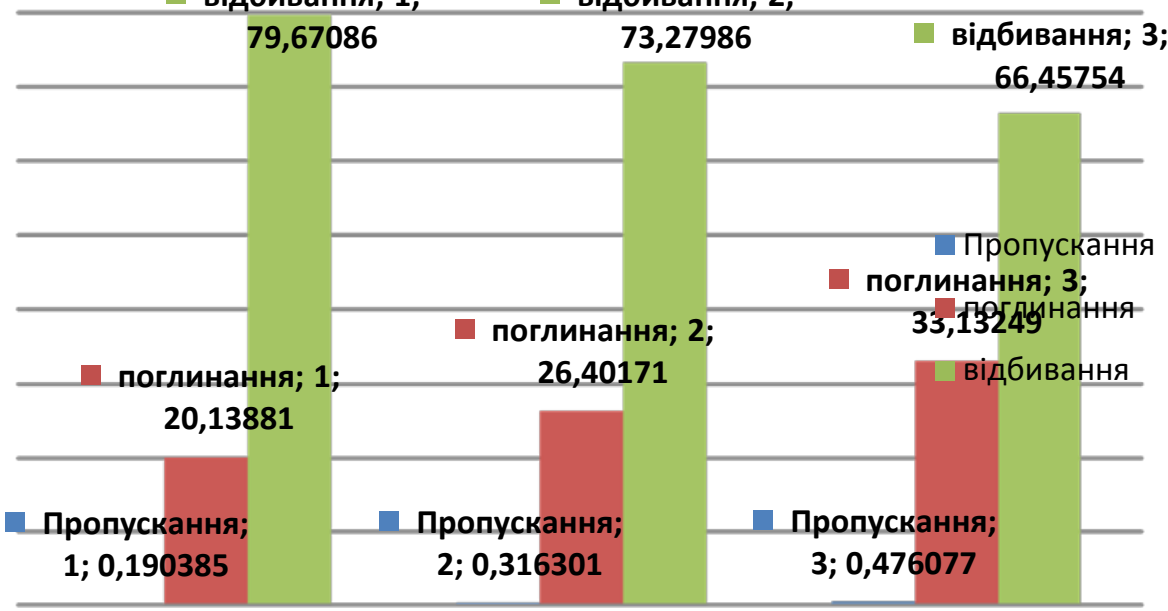

Puc. 3. Діаграма розподілу електромагнітних втрат в середині композиту, де 1 - вуглецева фрарба з Си-волокнами (3\%), 2 - вуглецева фрарба з порошковою Си (3\%), 3 - вуглецева фрарба

При проектуванні захисних покриттів від електромагнітного випромінення важливо враховувати область його використання. Для вирішення задачі «узгодженості» роботи обладнання, яке генерує електромагнітне випромінення, необхідно не тільки запобігти його впливу на інше обладнання та обслуговуючий персонал, але й не створити умови «концентрування» електромагнітного поля в середині прибору. Тому використання тільки металевих покриттів часто не достатьно для вирішення цих проблем і необхідно створювати багатошарові покриття з різними 
електричними та магнітними проникностями, чи градієнтні структури, що безумовно підвищує кошторис та ускладнює технологію виготовлення таких матеріалів. Вуглецева фарба може застосовуватись як основа для створення гібридних захисних покриттів, оскільки третина електромагнітного потоку втрачається в процесі поглинання при проходженні через зразок (рис. 3). Звичайно, внесення до складу металевих включень дещо змінює картину розподілу електромагнітних втрат в сторону збільшення коефіцієнту відбиття, але такі композитні матеріали зберігають здатність до поглинання EMB. Картину розподілу електромагнітних втрат можна змінювати підбираючи оптимальні склади компонентів.

\section{Висновки}

Таким чином, в роботі досліджено вплив металічних включень на втрати в структурах композитів. Доведено перевагу електрохімічно синтезованих волокнистих структур перед порошковими матеріалами на прикладі міді. Запропоновані матеріали можуть бути використані в проектуванні захисних та блокуючих екранів від НВЧ випромінювань.

\section{Список посилань}

[1] Семкина Е.В. Синтез медных нановолокон в матрице пористого анодного оксида алюминия / Е. В. Семкина, Б. И. Байрачный, Л. В. Ляшок, О. В. Борзенко // Вісник НТУ «ХПІ». - 2011. - С. 65-69.

[2] Елсуков Е. П. Влияние формы, химического и фазового состава частиц на основе $\mathrm{Fe}$ на СВЧ-характеристики композитов с диэлектрической матрицей / Е. П. Елсуков, К. Н. Розанов, С. Ф. Ломарев, А. В. Осипов, Д. А. Петров и др. // Журнал технической физики. - 2009. - Т. 79 (4). - С. 125-130.

[3] Zaraska L. The effect of anode surface area on nanoporous oxide formation during anodizing of low purity aluminum (AA1050 alloy) / $\mathrm{L}$. Zaraska, E. Kurowska, G. Sulka, I. Senyk, M. Jaskula // J. Solid State Electrochem. - 2013. - V. 18. - P. 361-368.

[4] Losic D. Nanoporous Alumina: fabrication, structure, properties and application / editors D. Losic, A. Santos // Springer series in Materials Science. - 2015. \# 219- P. 360

[5] Zaraska L. Analysis of nanopore arrangement and structural features of anodic alumina layers formed be two-step anodizing in oxalic acid using the dedicated executable software / L. Zaraska, W. J. Stepniowski, M. Jaskula et. al. // Appl. Surf. Sci. - 2014. - V. 305. - P. 650-657.

[6] Zaraska L. Properties of nanostructures obtained by anodization of aluminum in phosphoric acid at moderate potentials / L. Zaraska, G. D. Sulka, M. Jaskula // J. Phys: Conf.Ser. - 2009. - V. 146. - ID 012020. 


\title{
SMART WINDOWS: CATION INTERNAL AND ANION EXTERNAL ACTIVATION FOR ELECTROCHROMIC FILMS OF NICKEL HYDROXIDE
}

\author{
KOTOK V.A. ${ }^{(1,2)}$, MALAHOVA E. $V^{(2)}$. KOVALENKO V.L. ${ }^{(1,2)}$, \\ BARAMZIN M.N. ${ }^{(3)}$ KOVALENKO P.V. ${ }^{(2)}$ \\ ${ }^{1}$ SHEI "Ukrainian State University of Chemical Technology" \\ ${ }^{2}$ FSBEI HE "Vyatka State University" \\ ${ }^{3}$ Lyceum of informational education at Vyatka State University \\ Valeriy_e-ch@ukr.net
}

Two methods - internal and external - were used for improving the electrochemical activity and electrochromic properties of $\mathrm{Ni}(\mathrm{OH})_{2}$ films. In the case of internal activation, $\mathrm{Al}^{3+}$ ions were added to the electrolyte composition during the electrochemical precipitation process. In the case of external activation, $\left[\mathrm{Fe}(\mathrm{CN})_{6}\right]^{4-}$ ions were used in the electrolyte during the cycling process. In all the experiments there were used $\mathrm{Ni}(\mathrm{OH})_{2}$ films synthesized by the electrochemical template method with polyvinyl alcohol (PVA) addition to the electrolyte composition. It was shown that the addition of $\left[\mathrm{Fe}(\mathrm{CN})_{6}\right]^{4-}$ ions into the electrolyte for cycling leads to significant improvement of electrochemical and electrochromic (colorization-bleaching) properties. At the same time, the addition of $\mathrm{Al}^{3+}$ ions into the electrolyte for $\mathrm{Ni}(\mathrm{OH})_{2}$ films precipitation leads to drastic worsening of their properties. Also, possible mechanisms of $\mathrm{Al}^{3+}$ and $\left[\mathrm{Fe}(\mathrm{CN})_{6}\right]^{4-}$ ions influence were considered in this work.

Electrochromic devices are capable of changing their transparency under applied voltage, thus controlling heat and light transmittance. The state can be changed between bleached, colored or semi-colored. Color can vary from intense to barely noticeable. The voltage supply is only necessary for adjusting the degree of transparency, and after that, the power supply is almost unnecessary for maintenance of required state.

The electrochromic devices are based on redox reactions occurring in an electrochemical cell. Two processes occur:

- reduction of an oxidized form (the reduced form is colored):

oxidized form + electron(s) $\rightarrow$ reduced form,

- oxidation of a reduced form (the oxidized form is colored):

reduced form - electron(s) $\rightarrow$ oxidized form. 
The described reactions are responsible for changes in optical properties. When voltage is turned off the system maintains its altered state. This is called "memory effect".

The design is composed of two glasses covered with conducting films that also act as a frame, electrochromic film and an electrolyte. A polyethylene terephthalate (PET) can be used instead of glass, to design flexible devices. In most cases, the tin-doped indium oxide is used as a transparent conducting film. For modulation of incident radiation, at least one electrochromic film must be utilized in the devices' design. A second electrochromic film can be employed to improve color intensity.

$\mathrm{Ni}(\mathrm{OH})_{2}$ is one of the studied electrochromic materials. In order to employ nickel hydroxide as an electrochromic material, it's deposited on a glass substrate covered with a conductive support. When current is applied the following reversible topochemical reaction occurs:

$$
\mathrm{Ni}(\mathrm{OH})_{2 \text { (transparent) }} \leftrightarrow \mathrm{NiOOH}_{\text {(colored) }}+\mathrm{H}^{+}+\overline{\mathrm{e}}
$$

Thin films of $\mathrm{Ni}(\mathrm{OH})_{2}$ change their color from transparent to darkbrown and backwards. The mechanism of electrochromic process depends on structure, presence of water in material's pores and impurities.

\section{Investigation methodology}

The hydroxide films were cathodically electrodeposited from $1 \mathrm{M}$ nitrate solutions of nickel with 5\% wt. PVA. In case of the internal cation activation in solution for precipitation $\mathrm{Al}(\mathrm{NO})_{3}$ was added. The molar ratio between $\mathrm{Ni}$ and $\mathrm{Al}$ ions was $\mathrm{Ni}$ : $\mathrm{Al}-4: 1$ [1]. Electropolished nickel plates with working are of $\mathrm{S}=4 \mathrm{~cm}^{2}$ was used as a substrate. The deposition was carried out galvanostatically at current density of 0.625 $\mathrm{mA} / \mathrm{cm}^{2}$.

The hydroxide film deposition occurs according to following reactions:

$$
\begin{aligned}
& \mathrm{NO}_{3}^{-}+6 \mathrm{H}_{2} \mathrm{O}+8 \overline{\mathrm{e}}=\mathrm{NH}_{3}+9 \mathrm{OH}^{-} \\
& \mathrm{Me}^{2+}+2 \mathrm{OH}^{-}=\mathrm{Me}(\mathrm{OH})_{2}
\end{aligned}
$$

where $\mathrm{Me}^{2+}=\mathrm{Ni}^{2+}, \mathrm{Co}^{2+}$.

Electrochemical measurements were performed using Elins $\mathrm{P}-8$ potentiostat. The change of film transparency was measured as a change in voltage drop of photoresistor that was recorded with help of analog-to-digital converter. The films were cycled in range $0-550 \mathrm{mV}$ (201-751 vs. NHE) at $1 \mathrm{mV} / \mathrm{s}$ in $0.1 \mathrm{M} \mathrm{KOH}$ electrolyte. For the external activation by anions for cycling $0.1 \mathrm{M} \mathrm{KOH}$ electrolytes with addition of 1.6 or $3.2 \mathrm{mg} / \mathrm{l} \mathrm{K}{ }_{4}\left[\mathrm{Fe}(\mathrm{CN})_{6}\right]$ were used [2]. 


\section{Results and discussion}

In figures 1-4 cyclic voltammograms and colorization-bleaching curves of all samples are shown. As it seen from fig.1 the film which was precipitated from nickel nitrate solution with PVA has good reversibility and high depth of colorization (fig.1b). Here upper point of the colorization-bleaching curve is bleached state. Gradual decreasing of bleached state caused by nickel substrate using. Since metallic nickel has on the surface nickel oxides, the substrate can show weak electrochromic properties [3].

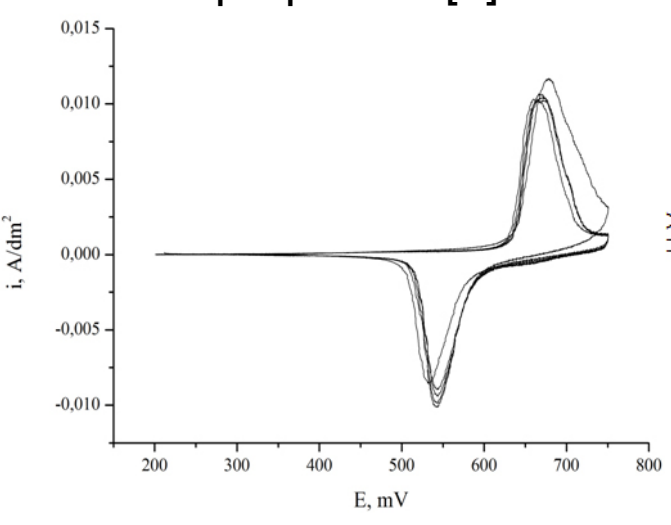

a

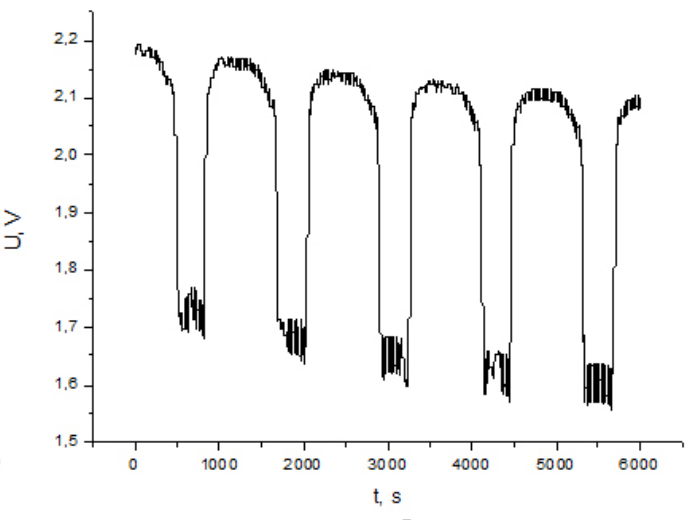

b

Fig.1. Cyclic voltammetry (a) and colorization-bleaching (b) curves of $\mathrm{Ni}(\mathrm{OH})_{2}$ deposited from: $1 \mathrm{M} \mathrm{Ni}\left(\mathrm{NO}_{3}\right)_{2}+5 \%$ PVA. Solution for cycling: $0.1 \mathrm{M} \mathrm{KOH}$

The main idea of aluminum ions addition was in a possibility of the precipitation of the layered double hydroxides (LDHs) based on Al with higher electrochromic and electrochemical properties. However, addition of $\mathrm{Al}^{3+}$ in precipitation electrolyte leads to drastic worsening of both electrochemical and electrochromic properties. In the fig. 2 it is seen oxidation-reduction peaks absence as well as any colorization process. Probably, the electrochemical method not fits for LDHs precipitation due to small electrogeneration speed for $\mathrm{OH}^{-}$ions during the process. Thus, aluminum ions results to $\mathrm{Ni}(\mathrm{OH})_{2}$ poisoning, that is well known phenomena described in a literature.

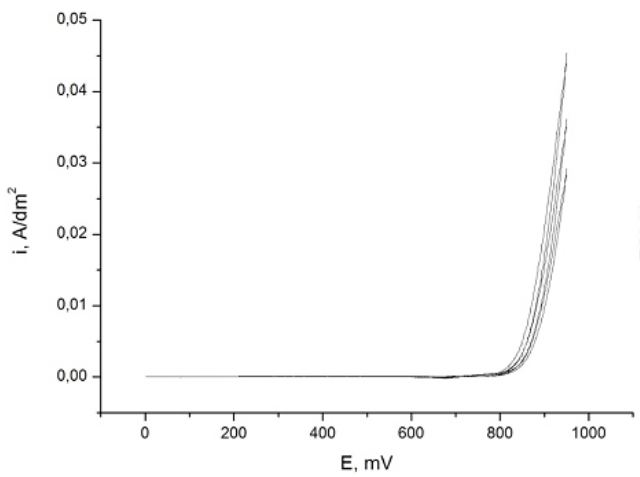

a

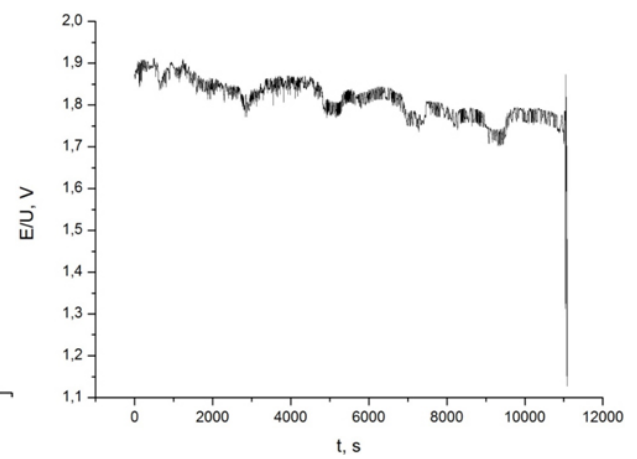

b

Fig.2 Cyclic voltammetry (a) and colorization-bleaching (b) curves of $\mathrm{Ni}(\mathrm{OH})_{2}$ deposited from: $1 \mathrm{M} \mathrm{Ni}\left(\mathrm{NO}_{3}\right)_{2}+0,25 \mathrm{M} \mathrm{Al}\left(\mathrm{NO}_{3}\right)_{3}+5 \% \mathrm{PVA}$.

Solution for cycling: $0.1 \mathrm{M} \mathrm{KOH}$ 
For activation by $\left[\mathrm{Fe}(\mathrm{CN})_{6}\right]^{4-}$ ions, $\mathrm{K}_{4}\left[\mathrm{Fe}(\mathrm{CN})_{6}\right]$ salt was added to $0.1 \mathrm{M} \mathrm{KOH}$ solution, which was used for cycling. $\mathrm{K}_{4}\left[\mathrm{Fe}(\mathrm{CN})_{6}\right]$ concentration in $1.6 \mathrm{mg} / \mathrm{l}$ is not lead to significant changes in depth of colorization and in electrochemical properties - fig.3, but in case of higher concentration (3.6 mg/l, fig.4) properties are increased. The depth of colorization and current peaks considerably higher than they are for $\mathrm{Ni}(\mathrm{OH})_{2}$ precipitated from $\mathrm{Ni}\left(\mathrm{NO}_{3}\right)_{2}$ with PVA (fig.1) and for $\mathrm{Ni}(\mathrm{OH})_{2}$ precipitated from $\mathrm{Ni}\left(\mathrm{NO}_{3}\right)_{2}$ with PVA and $1.6 \mathrm{mg} / \mathrm{K} \mathrm{K}_{4}\left[\mathrm{Fe}(\mathrm{CN})_{6}\right]$ (fig.3). The mechanism of such effect can lie in ions intercalation which open intercrystalline space for electrochemical process.

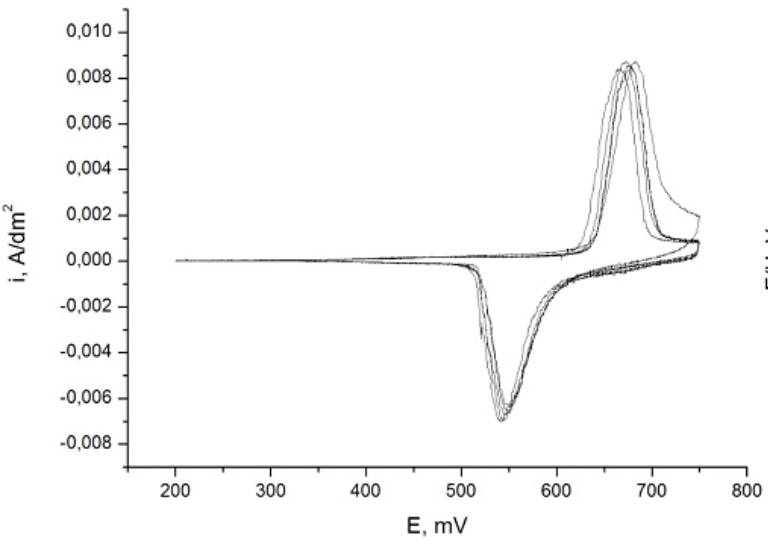

a

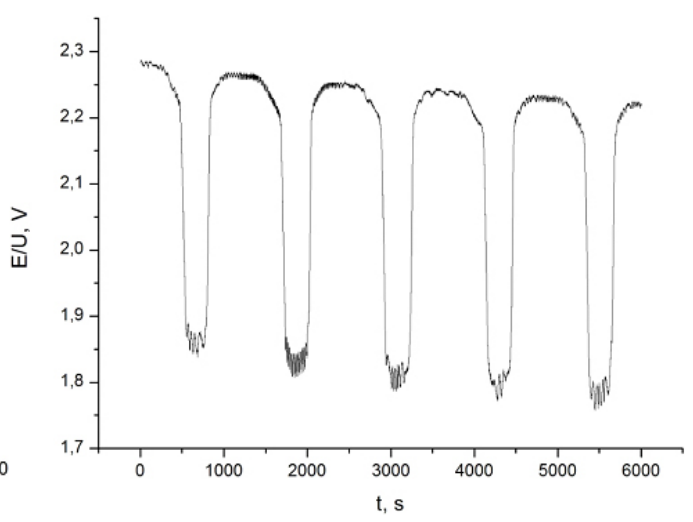

b

Fig.3. Cyclic voltammetry (a) and colorization-bleaching (b) curves of $\mathrm{Ni}(\mathrm{OH})_{2}$ deposited from: $1 \mathrm{M} \mathrm{Ni}\left(\mathrm{NO}_{3}\right)_{2}+5 \%$ PVA. Solution for cycling: $0.1 \mathrm{M} \mathrm{KOH}+\left[\mathrm{Fe}(\mathrm{CN})_{6}\right]^{4-}$ $1,6 \mathrm{mg} / \mathrm{l}$

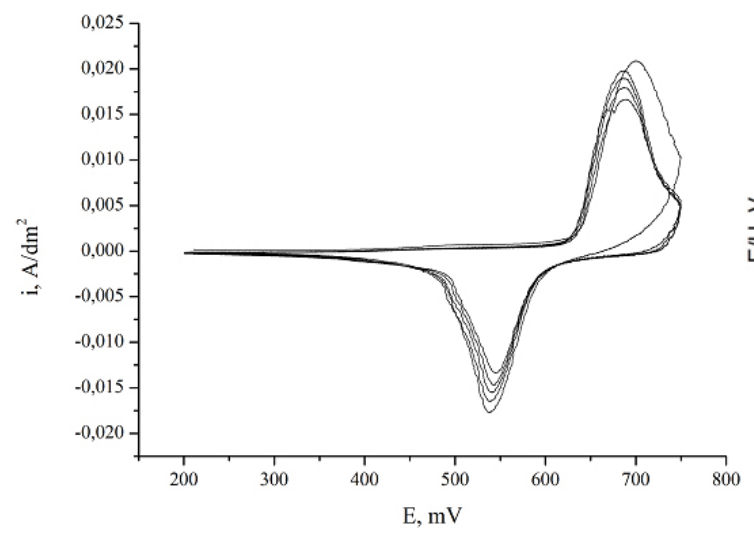

a

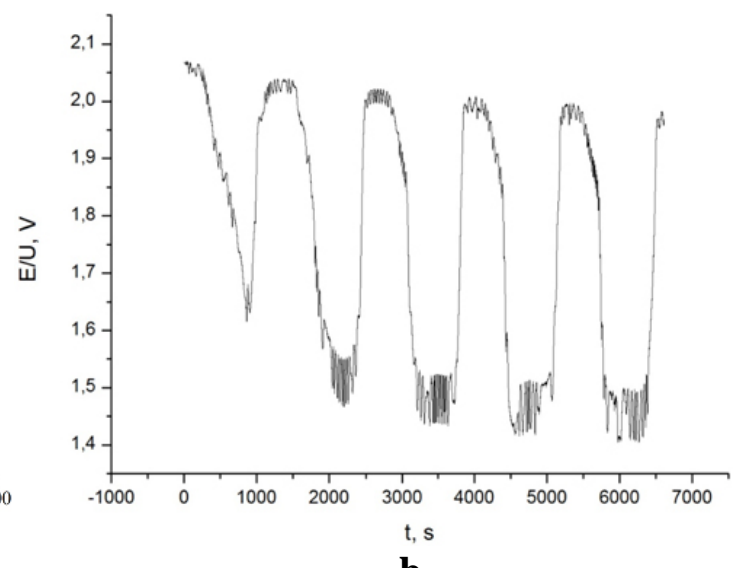

b

Fig.4. Cyclic voltammetry (a) and colorization-bleaching (b) curves of $\mathrm{Ni}(\mathrm{OH})_{2}$ deposited from: $1 \mathrm{M} \mathrm{Ni}\left(\mathrm{NO}_{3}\right)_{2}+5 \%$ PVA. Solution for cycling: $0.1 \mathrm{M} \mathrm{KOH}+\left[\mathrm{Fe}(\mathrm{CN})_{6}\right]^{4-}$ $3,2 \mathrm{mg} / \mathrm{l}$ 


\section{Conclusions}

It were shown effects of addition of $\mathrm{Al}^{3+}$ in electrolyte for films $\mathrm{Ni}(\mathrm{OH})_{2}$ precipitation and $\mathrm{K}_{4}\left[\mathrm{Fe}(\mathrm{CN})_{6}\right]$ ions in electrolyte for cycling. It was found two contrary effects: $\mathrm{Al}^{3+}$ conducts to $\mathrm{Ni}(\mathrm{OH})_{2}$ poisoning, in contrary $\mathrm{K}_{4}\left[\mathrm{Fe}(\mathrm{CN})_{6}\right]$ addition leads to significant properties increasing. Activation mechanism by $\left[\mathrm{Fe}(\mathrm{CN})_{6}\right]^{4-}$ ions can lie in intercalation process of ions into intercrystalline space with simultaneous opening inner surface for electrochemical process.

\section{References}

[1] B. Liu, X.Y. Wang, H.T. Yuan, Y.S. Zhang, D.Y. Song, Z.X. Zhou. Physical and electrochemical characteristics of aluminium-substituted nickel hydroxide. Journal of Applied Electrochemistry July 1999, Volume 29, Issue 7, pp 853-858.

[2] Carpani, I. Berrettoni, M. Ballarin, B. Giorgetti, M. Scavetta E., Tonelli, D. Study on the intercalation of hexacyanoferrate (II) in a Ni, Al based hydrotalcite. Solid State Ionics. Volume 168, Issues 1-2, 15 March 2004, Pages 167-175.

[3] Kotok, V.A. Kovalenko, V.L. Ananchenko, B.A. Levko, E.N. The deposition of electrochromic film based on nikel hydroxide by electrochemical method. XV International scientific conference «New Technologies and achievements in metallurgy, materials engineering and production engineering». Materials Engineering, Czestochowa, Poland, Collective Monografie, 2014. - P. 448 - 452. 
Удк 541.135

\title{
GAS BUBBLE SIZE PREDICTION IN CONCENTRATED ALKALINE SOLUTIONS USING THE THEORY OF PLANAR NUCLEUS
}

\author{
ATAPIN A.G., NEFEDOV V.G. \\ Ukrainian State University of Chemical Technology, \\ assai02@yandex.ru
}

The theory of planar nucleus has been used in order to calculate a theoretical size of tear-off gas bubbles formed during the electrolysis. The possibility of predicting the bubble size was demonstrated. The calculated numbers have a good correlation with the experimental data and do not contradict the classical ideas.

\section{ПРОГНОЗИРОВАНИЕ РАЗМЕРОВ ГАЗОВЫХ ПУЗЫРЕЙ В КОНЦЕНТРИРОВАННЫХ ЩЕЛОЧНЫХ РАСТВОРАХ С ПОМОЩЬЮ ТЕОРИИ ПЛОСКОГО ЗАРОДЫША}

\author{
АТАПИН А. Г., НЕФЕДОВ В. Г. \\ Украинский государственный химико-технологический \\ университеm, assai02@yandex.ru
}

\begin{abstract}
В работе для теоретического расчета отрывных размеров газовых пузырей, выделяющихся при электролизе воды, использовалась теория плоского зародыша. Показана возможность прогнозирования размеров пузырей, величины которых, имеют хорошую корреляцию с экспериментальными данными и не противоречат классическим представлениям.
\end{abstract}

Согласно классическим представлениям, отрывные размеры выделяющихся при электролизе газовых пузырей определяются равенством сил прилипания (1) и отрывных, определяемых законом Архимеда (2):

$$
\begin{gathered}
F_{\Pi P}=\Pi \cdot d \cdot \sigma_{2 \varkappa} \cdot \sin \theta, \\
F_{A P X}=V \cdot g \cdot \rho,
\end{gathered}
$$

Из равенства этих сил определяется отрывной диаметр (3)

$$
d=\sin \theta \cdot \sqrt{\frac{\sigma_{2 \varkappa}}{g \cdot \rho}},
$$

где

$\sigma-$ поверхностное натяжение жидкости на границе раздела фраз газ-жидкость, НІм; 
$\theta$ - краевой угол смачивания, град.;

$\mathrm{g}$ - ускорение свободного падения м/с;

$\rho-$ плотность жидкости кг/м³.

Величина краевого угла смачивания определяется из соотношения величин поверхностных натяжений на границе трех фраз, по формуле (4):

$$
\cos \theta=\frac{\sigma_{z m}-\sigma_{m \varkappa}}{\sigma_{m \varkappa}}
$$

где $\sigma_{\text {пт }} \sigma_{\text {тж }}-$ поверхностное натяжение на границе раздела фраз газ-твердое тело и твердое тело - жидкость соответственно, $\mathrm{H} / \mathrm{M}$

Абсолютные значения поверхностных натяжений $\sigma_{\text {п }}$ и $\sigma_{\text {тж }}$ обычно неизвестны, поэтому $\cos \theta$ теоретически рассчитать невозможно. Измерить его в процессе роста пузыря также нельзя, поскольку он меняется во времени. Диаметр основания пузыря определяется как соотношение отрывного диаметра пузыря к синусу угла смачивания

$$
d_{\text {осн }}=d_{\text {отр }} \cdot \sin \theta \text {, }
$$

В этом уравнении неизвестные две величины: диаметр основания пузырька и синус угла смачивания. Для решения этой проблемы диаметр основания пузырька рассчитывали с помощью теории плоского зародыша [1] (6):

$$
d_{\text {och }}=\left(\frac{32 \cdot \sigma \delta^{2}}{\varepsilon \varepsilon_{0} \cdot(\Delta \varphi)^{2}+2 \rho \delta^{2} g h}-4 \delta^{2}\right)^{1 / 2},
$$

где $\delta$ - толщина плоского зародыша, м; $\varepsilon \varepsilon_{0}$ - диэлектрическая проницаемость раствора, $\Delta \varphi$ - разница потенциалов поверхностей раздела фраз, $\rho$ - плотность жидкости, g- ускорение силы тяжести, $\mathrm{h}$ - толщина слоя жидкости над электродом.

\section{Методология проведения экспериментов}

Определение отрывных размеров кислородных пузырей при электролизе производилось в 8-16 М растворах гидроксида натрия методами дисперсионного микрофотоанализа. Микрофотосъемка газовых пузырьков проводилась по методу светлого поля через окуляр микроскопа МБС-9 с использованием компактной цифровой фотокамеры Canon A570IS. Камера и микроскоп устанавливались соосно. Электрохимическая ячейка, изготовленная из кварцевого фротостекла, устанавливалась на двухкоординатном монтажном микрометрическом столике, обеспечивающем наведение резкости на электрод или прилегающий к нему слой электролита. 
Источником освещения служила импульсная лампа-вспышка Sigma EF500S.

Во всех экспериментах использовались только полированные электроды. Полировка осуществлялась при помощи алмазной пасты ACM 1/0 НОМ с зерном до 1 мкм, на фретровых и замшевых дисках. После полировки электроды промывались этиловым спиртом, водой и раствором щелочи. В работе нами использовались электроды, изготовленные из никеля

Для оценки размеров газовых пузырьков использовались отпечатки при 50-кратном увеличении и шаблон для измерения размеров пузырей от 20 до 500 мкм с шагом 20 мкм. Набирался статистический ансамбль из 300-500 пузырей и рассчитывались их средние диаметры (7)

$$
d_{M}=\frac{\sum\left(n_{i} d_{i}\right)}{N_{\tilde{I}}},
$$

где: $\mathrm{n}_{\mathrm{i}}$ - число пузырьков диаметром $\mathrm{d}_{\mathrm{i}} ; \mathrm{N}_{\text {п }}$ - общее число пузырей в статистическом ансамбле.

Поляризационные кривые выделения кислорода снимались с помощью потенциостата ПИ-50-1 при скорости развертки потенциала $1 \mathrm{mB} / \mathrm{c}$.

\section{Экспериментальная часть}

Зависимость средних диаметров кислородных пузырей от концентрации растворов приведена на рис. 1.

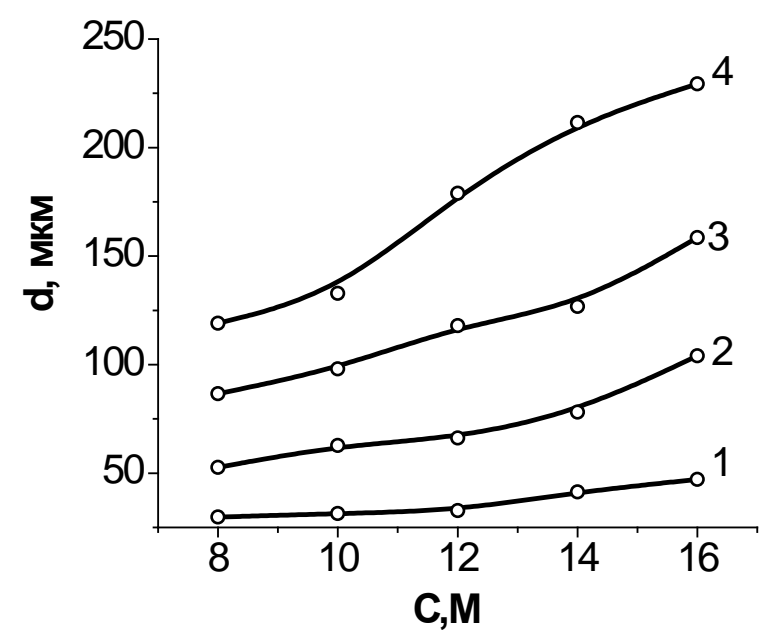

Puc.1. Зависимость среднего диаметра пузырька кислорода от концентрации раствора $\mathrm{NaOH}$, при различных плотностях тока: 1-10 мA/см², 2-30мA/ $\mathrm{Cm}^{2} ; 3-50 \mathrm{MA} / \mathrm{CM}^{2}, 4-70 \mathrm{MA} / \mathrm{cm}^{2}$. Ni электрод 
Из рисунка видно, что с ростом концентрации раствора и плотности тока размеры пузырей увеличиваются. Полученные данные противоречат экспериментам Кабанова и Фрумкина [2], которые установили, что максимальный размер пузырей наблюдается при потенциале электрода, равном потенциалу нулевого заряда и резко снижаются при анодной или катодной поляризации электрода. Это указывает на ограниченную применимость указанной теории для условий реального электролиза.

На первом этапе по (6) были рассчитаны диаметры основания пузыря. Для растворов гидроксида натрия концентрацией от 8 до 16 моль/л , плотность и поверхностное натяжение которых приведены в табл.1.

Таблица 1.Свойства растворов гидроксида натрия

\begin{tabular}{|c|c|c|c|c|c|}
\hline $\begin{array}{c}\text { Концентрация } \\
\text { моль/л }\end{array}$ & $\mathbf{8}$ & $\mathbf{1 0}$ & $\mathbf{1 2}$ & $\mathbf{1 4}$ & $\mathbf{1 6}$ \\
\hline Плотность кг/см & 1275 & 1330 & 1380 & 1425 & 1465 \\
\hline $\begin{array}{c}\text { Поверхностное } \\
\text { натяжение Н/M }\end{array}$ & 0,086 & 0,091 & 0,0943 & 0,0975 & 0,086 \\
\hline
\end{tabular}

Аналогичные расчеты были проведены для плотностей тока от 100 до 700 A/m². При этом принималось во внимание, что локальные плотности тока в центрах роста пузырей превышают габаритные плотности тока обратно пропорционально степеням экранирования поверхности электрода, то есть, количеству центров роста пузырей. Для этих условий величина поляризации электродов повышалась как с ростом плотности тока, так и с увеличением концентрации и достигала $1 \div 1,2 \mathrm{~B}$.

\section{Обсуждение результатов}

Результаты расчетов показывают, что диаметры плоских зародышей, которые являются основанием растущих пузырей, уменьшаются с ростом концентрации (рис. 2А), Подставив (6) в (5) мы получили синусы краевого угла смачивания(рис. 2Б), которые по расчетам так же уменьшаются с ростом концентрации электролита, плотности тока и поляризации электрода, что не противоречит суждениям Кабанова - Фрумкина о зависимости размеров пузырей от потенциала электрода. 

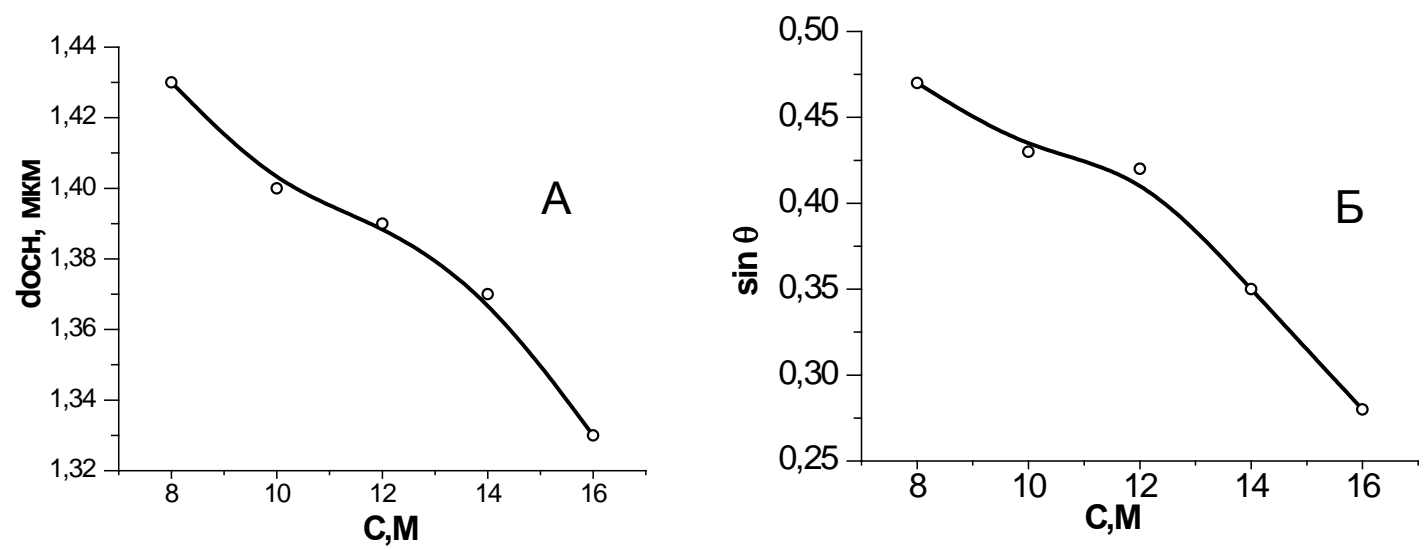

Puc. 2. Зависимость диаметра основания пузырька по ТПЗ (А) и синуса угла смачивания (Б) от концентрации раствора

Используя (5) были рассчитаны теоретические отрывные диаметры пузырей кислорода выделяющегося при электролизе $\mathrm{NaOH}$ при плотности тока $100 \mathrm{Alm}^{2}$. Сопоставив их с экспериментально полученными данными, наблюдается удовлетворительная корреляция теоретических значений с экспериментальными данными, рис.3.

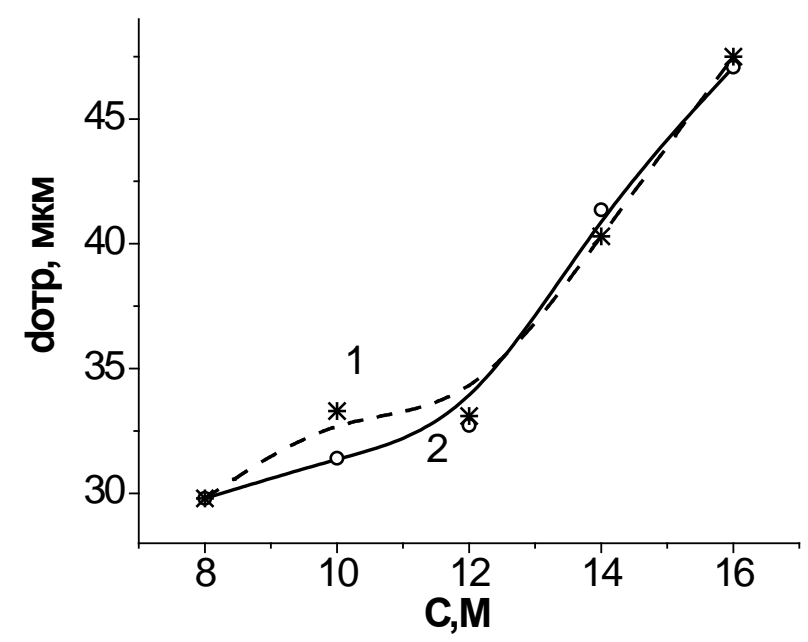

Puс.3. Сравнение теоретического (1) и экспериментально измеренного (2) отрывного диаметра пузырька кислорода от концентрации раствора $\mathrm{NaOH}$, при плотности тока $100 \mathrm{~A} / \mathrm{M}^{2}$

\section{Литература}

[1] Нефедов В.Г. Исследование влияния гравитации и негравитационных фракторов на образование ,рост и отвод от электрода газовых пузырей при электролизе воды // дис. ... д-ра хим. наук. УГХТУ, Днепропетровск, 1997.

[2] Кабанов Б.Н., Фрумкин А.Н. // Журн. фриз. химии. -1933. -4. -С. $538-549$. 


\title{
THE EFFECT OF DEHYDRATION OF MANGANESE NITRATE ON THE QUALITY OF MANGANESE DIOXIDE COATING ON TITANIUM ANODES
}

\author{
BUTENKO O.S., BUKET O.I. \\ National Technical University of Ukraine "Kyiv Polytechnic Institute" \\ a.bos007@gmail.com
}

The problems of production and exploitation of titanium anodes coated with manganese dioxide were analysed. Attention was focused on the complexity of multilayer deposition of the oxide coating by successive operations of applying manganese nitrate to the titanium base and its burning. The cause of the deteriorating quality of the coating while trying to increase its thickness in one work cycle was found out. It is a dramatic increase in water loss by crystalline manganese nitrate that occurs during the formation of manganese dioxide crystals in the $100 \ldots$ $150{ }^{\circ} \mathrm{C}$ temperature range. It was proved that in this temperature range it was necessary to remove the limits at the stage of formation of a new manganese dioxide phase and simultaneously to slow down the removal of water in the gas phase. To do this, it was proposed to introduce a solid phase of fine inorganic composition capable of retaining water in the crystalline form in the $100 \ldots 220^{\circ} \mathrm{C}$ temperature range into the layer of liquid manganese nitrate, after its application to the titanium base. It was established that the use of gypsum-cement composition in an amount of about $1 \%$ by weight of manganese dioxide deposited enables one to apply a coating by an order of magnitude thicker in one work cycle without significant loss of its strength and resistance to erosion during subsequent operation.

\section{ВПЛИВ ПРОЦЕСУ ДЕГІДРАТАЦІЇ НІТРАТУ МАНГАНУ НА ЯКІСТЬ ДІОКСИДНО-МАНГАНОВОГО ПОКРИТТЯ ТИТАНОВИХ АНОДІВ}

\author{
БУТЕНКО О.С., БУКЕТ О.І.
}

Національний технічний університет України «Київський політехнічний інститут»; a.bos007@gmail.com

Проаналізовано проблеми виготовлення та експлуатації титанових анодів з покриттям із діоксидом мангану. Акцентовано увагу на трудомісткості багатошарового осадження оксидного покриття шляхом послідовних операцій нанесення нітрату мангану на титанову основу та його обпалення. Встановлено причину 
погіршення якості покриття при спробі збільшити його товщину, що наноситься за один технологічний цикл. Причиною $\epsilon$ різка інтенсифікація втрати води кристалогідратами нітрату мангану саме у процесі утворення зародків кристалів діоксиду мангану у діапазоні температур $100 \ldots 150{ }^{\circ} \mathrm{C}$. Доведено, що у названому діапазоні температур необхідно зняти обмеження на стадії утворення нової фрази діоксиду мангану і одночасно уповільнити видалення води у газову фразу. Для цього запропоновано ввести у шар рідкого нітрату мангану, після його нанесення на титанову основу, тверду фразу дрібнодисперсної неорганічної композиції, яка здатна утримати воду у формі кристалогідратів у діапазоні температур $100 \ldots 220{ }^{\circ} \mathrm{C}$. Встановлено, що використання гіпсово-цементної композиції у кількості близько $1 \%$ від маси нанесеного діоксиду мангану дозволяє за один технологічний цикл нанести покриття на порядок більшої товщини без суттєвої втрати його міцності та стійкості до ерозії у процесі подальшої експлуатації.

Електроди 3 покриттям із діоксиду мангану широко використовуються у різноманітних галузях технічної електрохімії від електролізу з метою одержання різноманітних речовин до вторинних хімічних джерел струму. Основна методика одержання діоксидно-манганових електродів на інертній струмопровідній основі лишається незмінною 3 часі їх винайдення до сьогодні багаторазове пошарове нанесення розчину нітрату мангану на поверхню струмопровідної основи 3 наступним піролізом при температурах близько $200^{\circ} \mathrm{C}$ [1]. Такий метод відрізняється надзвичайною тривалістю, трудомісткістю та надвисокими витратами енергоносіїв, оскільки для одержання якісного покриття необхідно виконати одержання кількох десятків шарів послідовним нанесенням розчину та його наступного піролізу. У даній роботі проаналізовано причини, що не дозволяють наносити якісні $\mathrm{MnO}_{2}$ покриття за меншу кількість технологічних операцій (по-можливості, одним шаром, товщина якого відповідає традиційному багатошаровому покриттю) та запропоновано спосіб усунення цього недоліку.

\section{Методологія досліджень}

Насичений розчин нітрату мангану, який відповідає складу близько 1 моль $\mathrm{Mn}\left(\mathrm{NO}_{3}\right)_{2}$ на 6 моль $\mathrm{H}_{2} \mathrm{O}$ [2], наносили на основу у вигляді пластини 3 титану марки ВТ-1-0 і обпалювали при температурі до $200 \pm 20{ }^{\circ} \mathrm{C}$ протягом півтори години. Розчин наносили без розведення одним товстим шаром, який тримався на поверхні титанової пластини за рахунок в'язкості й поверхневого натягу. Для 
утримання зв'язаної води від закипання у розчин перед його нанесенням запропоновано вносити порошкову гіпсово-цементну композицію. Для порівняння використовували титан-діоксидноманганові аноди вкриті багатошаровим покриттям на серійному виробництві, де нітрат мангану наносили 3 більш розведеного розчину й потім обпалювали послідовно 10 раз. Випробовування електродів проводили в стандартній скляній триелектродній комірці потенціостату ПИ-50-1.1 у розчині 0,5 $\mathrm{M} \mathrm{Na}_{2} \mathrm{SO}_{4}$. Всі потенціали наведені відносно н.в.е.

\section{Результати та їх обговорення}

Електрод 3 багатошаровим діоксидно-мангановим покриттям відрізняється матовим чорним кольором, місцями з антрацитовим блиском. Покриття рівне й не відшаровується. При спробі одержати одношарове покриття 3 товщиною рівною багатошаровому у результаті спостерігали здуття шару діоксиду мангану у вигляді пухирів. Покриття погано зчеплене 3 основою й легко відшаровується, особливо після анодної поляризації у розчині мало агресивної до електрода $0,5 \mathrm{M} \mathrm{H}_{2} \mathrm{SO}_{4}$.

Послідовне нагрівання зразків електродів 3 товстим рідким шаром нітрату мангану до температур 100, 150 і $200{ }^{\circ} \mathrm{C}$ показало, що термічне розкладання нітрату мангану починається вже при $100{ }^{\circ} \mathrm{C}$. Причому, цей процес супроводжується різким вивільненням i випаровуванням зв'язаної води. Внаслідок цього, утворювані при $100 \ldots 150{ }^{\circ} \mathrm{C}$ зародки кристалів діоксиду мангану відриваються від поверхні титанової основи й подальший їх ріст часто відбувається у спіненому киплячому розчині. Тому спроби ступінчатим нагрівом 3 витримкою при 100 і $150{ }^{\circ} \mathrm{C}$ перед обпаленням при $200{ }^{\circ} \mathrm{C}$ усунути скипання й неконтрольоване розкладання розчину позбавлені сенсу.

Зважаючи на утворення нової твердої фази у розчині вже при температурах $100 \ldots 150{ }^{\circ} \mathrm{C}$, запропоновано ввести у рідку фразу тверді центри кристалізації, які одночасно зможуть утримувати зв'язану воду хоча б протягом утворення і початкового росту зародків кристалів діоксиду мангану на поверхні титанової основи.

Відомо, що гіпс $\mathrm{CaSO}_{4} \cdot 0,5 \mathrm{H}_{2} \mathrm{O}$ швидко зв'язується з водою в гіпсовий камінь складу $\mathrm{CaSO}_{4} \cdot 2 \mathrm{H}_{2} \mathrm{O}$, який поступово може втрачати воду при температурах від 100 до $180{ }^{\circ} \mathrm{C}$. Цементи здатні утримувати зв'язану воду при температурах до $600{ }^{\circ} \mathrm{C}$ [3]. Тому доцільним $\epsilon$ введення у розчин нітрату мангану порошкової композиції із гіпсу і цементу. 
Досліди показали, що введення сторонніх порошкових матеріалів у розчин у кількості більше 5 \% від маси нанесеного розчину різко погіршує як адгезію, так і електропровідність діоксидно-манганового покриття. Покриття має темно сірий колір й відносно легко відкришується при надавлюванні пластиковою лопаткою. Проте у кількостях до 1 \% композиція з порошків цементу i гіпсу покращує зовнішній вигляд покриття після обпалення (зменшується відносна площа здутого покриття), а також зчеплення 3 основою та зменшує анодну перенапругу, у т.ч. і внаслідок зростання електропровідності на межі $\mathrm{MnO}_{2}-\mathrm{Ti}$ (рис. 1). При цьому покриття має практично матовий чорний колір і не викришується при надавлюванні пластиковою лопаткою.

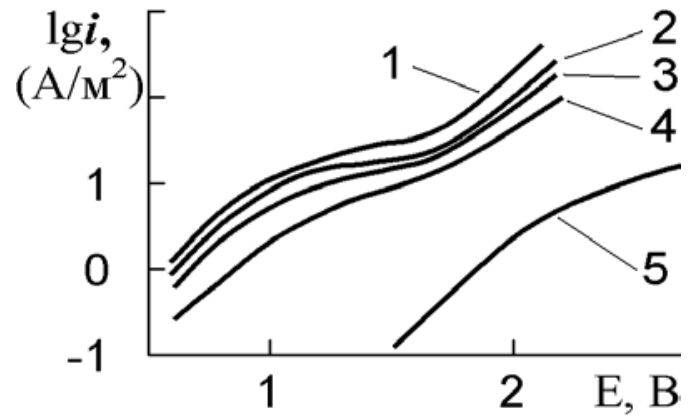

A)

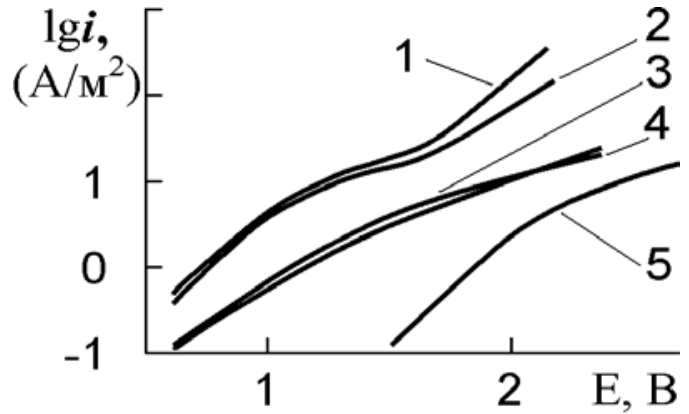

Б)

Puc. 1. Анодні поляризаційні криві одержані на анодах з однаковою масою $\mathrm{MnO}_{2}$ на титановій основі одразу після виготовлення (А) та після 10 діб анодної поляризації (Б) струмом $30 \mathrm{~A} / \mathrm{M}^{2}$ у розчині 0,5 $\mathrm{M} \mathrm{Na}_{2} \mathrm{SO}_{4}$.

Кількість шарів $\mathrm{MnO}_{2}$ :

$1-10$

$2-4-1$

5 - без покриття.

Добавка 1\% гіпсово-цементної суміші до розчину нітрату мангану перед виготовленням анодів:

1 - без добавки;

2 - суміш $75 \%$ гіпсу і $25 \%$ цементу;

3- гіпс;

4-цемент.

Встановлено, що окреме використання цементу або гіпсу не дає повного усунення явища здуття покриття у вигляді погано зчеплених 3 титановою основою пухирів. При цьому аноди, виготовлені 3 застосуванням нітратного розчину 3 добавкою $1 \%$ гіпсу, відрізняються швидким зносом покриття - через 10 діб впливу анодним струмом $30 \mathrm{~A} / \mathrm{M}^{2}$ їх поляризованість наближається до такої у титану ВТ-1-0 (крива 3, рис. 1). Аноди, виготовлені з нітратного 
розчину з добавкою лише цементу, від початку мають вищу поляризованість (криві 4, рис. 1), а їх функціонування під струмом $30 \mathrm{~A} / \mathrm{m}^{2}$ протягом 10 діб дає результат аналогічний такому для застосування гіпсової добавки.

Виконанням ряду експериментів 3 гіпсово-цементною композицією різного складу було встановлено, що співвідношення 75 \% гіпсу і 25 \% цементу є оптимальним для введення у нітратний розчин у кількості 1 \% від його маси перед обпаленням. Такі аноди не змінюють своїх властивостей при тривалій експлуатації, хоча й відрізняються більшою поляризацією ніж титанові аноди 3 багатошаровим $\mathrm{MnO}_{2}$-покриттям (криві 1 і 2, рис. 1). Більший нахил кривої 2, порівняно з кривою 1, при високих поляризаціях, де механізм анодного процесу ідентичний і відповідає лише виділенню кисню, вказує на збільшення омічних втрат у шарі $\mathrm{MnO}_{2}$ внаслідок введення гіпсово-цементної суміші.

\section{Висновки}

Показано, що проблема щільності й адгезії до титанової основи при нанесенні одного товстого шару діоксиду мангану пояснюється, у першу чергу, утворенням зародків кристалів $\mathrm{MnO}_{2}$ у рідкій фразі нітрату мангану при температурах близько $100{ }^{\circ} \mathrm{C}$. У другу чергу відшаруванням зародків $\mathrm{MnO}_{2}$ від титанової основи внаслідок скипання розчину при вивільненні зв'язаної води із гідратних оболонок іонів мангану й нітрату при температурах $100 \ldots 150{ }^{\circ} \mathrm{C}$.

Запропоновано ввести у нітратний розчин порошкову гіпсовоцементну композицію, частинки якої виступають центрами кристалізації й здатні швидко вступати в хімічну взаємодію 3 вивільненою водою при температурах близько $100{ }^{\circ} \mathrm{C}$ (гіпс) й частково утримувати її у процесі обпалення до $220^{\circ} \mathrm{C}$ (цемент).

Показано, що введення $1 \%$ суміші 75 \% гіпсу з $25 \%$ цементу у насичений розчин нітрату мангану дозволяє за одне обпалення нанести покриття, що за товщиною відповідає десятишаровому традиційному $\mathrm{MnO}_{2}$-покриттю на титані, а за електрохімічними властивостями мало йому поступається.

\section{Перелік посилань}

1. Якименко Л. М. Электродные материалы в прикладной электрохимии. - М.: Химия, 1977. - 264 с.

2. Химическая энциклопедия: В 5 т.; т. 2. - М.: Сов. энцикл., 1990. -671 c.

3. Волженский А.В. Минеральные вяжущие вещества / Учебн. Изд. 4-е, перераб. и дополн. - М.: Стройиздат, 1986 - 320 с. 


\title{
ELECTROLYTE EFFECT ON THE ELECTROCHEMICAL PROPERTIES OF POLY(3-METHYLTHIOPHENE) THIN FILMS
}

\author{
KOZLOVA T.B. ${ }^{1}$, MOTRONYUK T.I. ${ }^{1}$, SYDOROV D.O. ${ }^{2}$ \\ ${ }^{1}$ National Technical University of Ukraine «Kyiv Polytechnic Institute» \\ ${ }^{2}$ Institute of Bioorganic Chemistry and Petrochemistry \\ of the National Academy of Sciences of Ukraine; bilobog@mail.ru
}

In this work the P3MT was synthesized electrochemically on transparent conductive substrates of indium-tin oxide (ITO) using the 0,5 $\mathrm{M}$ electrolyte $\mathrm{MClO}_{4}\left(\mathrm{M}=\mathrm{Li}^{+}, \mathrm{Na}^{+}, \mathrm{Bu}_{4} \mathrm{~N}^{+}\right)$in acetonitrile. Electrochemical characterization of these films using the same electrolyte as that used for synthesis shows that their electrochemical properties are controlled mainly by the nature of cation. The discussion of the results suggests an idea that the nature of the cation affects essentially the behaviour of the polymer films during the charge-discharge processes.

\section{ВПЛИВ ПРИРОДИ ЕЛЕКТРОЛІТУ НА ЕЛЕКТРОХІМІЧНІ ВЛАСТИВОСТІ ТОНКИХ ПЛІВОК ПОЛІ(З-МЕТИЛТІОФЕНУ)}

\author{
КОЗЛОВА Т.Б. ${ }^{1}$, МОТРОНЮК Т.І. ${ }^{1}$, СИДОРОВ Д.О. ${ }^{2}$ \\ ${ }^{1}$ Національний технічний університет України «Київський \\ політехнічний інститут» \\ ${ }^{2}$ Iнститут біоорганічної хімії та нафотохімії національної академії \\ наук України; bilobog@mail.ru
}

У цій роботі ПЗМТ був синтезований шляхом електроосадження на прозорих струмопровідних підложках з оксиду індію та олова (ITO) з використанням 0,5 $\mathrm{M}$ розчинів $\mathrm{MClO}_{4}\left(\mathrm{M}=\mathrm{Li}^{+}\right.$, $\mathrm{Na}^{+}, \mathrm{Bu}_{4} \mathrm{~N}^{+}$) в ацетонітрилі (AН). Електрохімічні дослідження цих плівок з використанням того ж електроліту, який використовувався для синтезу показують, що їх електрохімічні властивості залежать головним чином від природи катіона. Обговорення результатів наштовхує нас на думку, що природа катіона має істотний вплив на поведінку полімерних плівок під час процесів заряду-розряду.

Політіофени $є$ важливими представниками класу електропровідних полімерів. Висока електропровідність, хімічна, електрохімічна і термічна стійкість політіофенів та їх похідних дозволяють використовувати їх в різноманітних галузях сучасної техніки - сенсорних пристроях, фотоелектричних перетворювачах, 
електрохромних пристроях та ін. Найбільш ефективним методом формування тонких шарів політіофену та його похідних на поверхні електроду $є$ електрохімічне окиснення мономеру безпосередньо на поверхні електроду. Проте на властивості полімерів, що утворюються в процесі електрохімічного синтезу може впливати цілий ряд чинників - густина струму синтезу, температура, катіонноаніонний склад електроліту та інші.

\section{Методологія досліджень}

В представленій роботі проведено дослідження впливу катіонного складу електроліту на електрохімічні властивості шару полімеру на прикладі полі(3-метилтіофену), синтезованого в присутності тетрабутиламоній перхлорату, перхлорату натрію та перхлорату літію.

Методом циклічної вольтамперометрії проведено дослідження процесу електрохімічної полімеризації $3 \mathrm{MT}$ у 0,5 $\mathrm{M}$ розчинах $\mathrm{MClO}_{4}$ $\left(\mathrm{M}=\mathrm{Li}^{+}, \mathrm{Na}^{+}, \mathrm{Bu}_{4} \mathrm{~N}^{+}\right)$в ацетонітрилі (АН).

Дослідження електрохімічної полімеризації полімеру проводили за допомогою потенціостата ПІ - 50 - 1 з програматором ПР-8 в трьохелектродній електрохімічній комірці 3 нероздільними католітом та анолітом.

Як електрод порівняння використовували електрод $\mathrm{Ag} / \mathrm{Ag}^{+}$, заповнений розчином 0,5 $\mathrm{M} \mathrm{AgNO}_{3}$, як робочий електрод (анод) скло, вкрите оксидом олова, як допоміжний електрод (катод) платинова дротинка. Потенціал електроду порівняння дорівнює $\mathrm{E}=$ 0,2224 В відносно насиченого водневого електроду (н.в.е.).

Електрохімічний синтез ПЗМТ та дослідження електрохімічних властивостей на робочому електроді проводили в режимі циклювання потенціалу.

\section{Результати та їх обговорення}

\section{$1,4 \mathrm{~B}$.}

Електрохімічний синтез ПЗМТ протікає при потенціалах до

Базуючись на літературних даних [1] було встановлено, що АН, $\mathrm{LiClO}_{4}, \mathrm{NaClO}_{4}$ та $\mathrm{Bu}_{4} \mathrm{NClO}_{4} €$ стабільними при таких значеннях потенціалів, що дозволяє використовувати їх для проведення електрохімічного синтезу ПЗМТ. Проте існує ряд побічних процесів, що погіршують якість полімеру та зменшують його вихід за струмом, а саме: розкладання залишкової води та відновлення розчиненого кисню. Тому, щоб переконатись в чистоті приготованих електролітів попередньо знімали фонові циклічні вольтамперограми (рис 1). 
a)

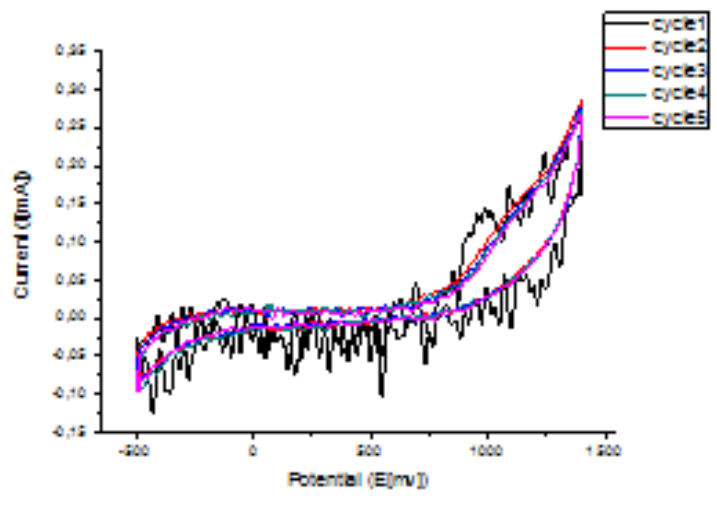

б)

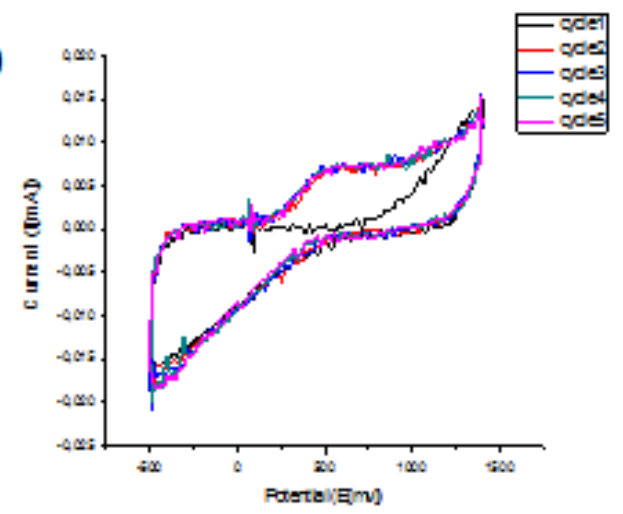

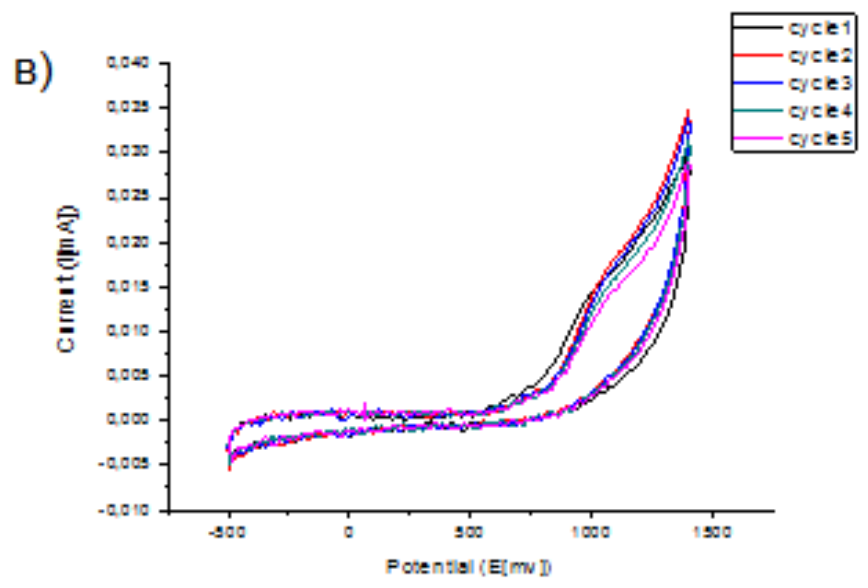

Puc. 1. Циклічні вольтамперограми фронових розчинів 0,5 M a) LiClO4 б) $\mathrm{NaClO} 4$ в) Bu4NClO4 в АН на скляному електроді при швидкості розгортки потениіалу $50 \mathrm{mB} / \mathrm{c}$

Як видно з представлених ЦВА при $E=1400$ мВ фоновий струм не перевищує 50 мкА, а при $E=-500$ мВ - 25 мкА відповідно, що свідчить про чистоту приготовлених електролітів та можливість їх використання для електрохімічного синтезу ПЗМТ в даному діапазоні потенціалів.

Формування політіофенового шару на поверхні робочого електроду та його дослідження здійснювали за допомогою методу циклічної вольтамперометрії. Вибір такого методу отримання модифікованих електродів пов'язаний 3 тим, що політіофенові покриття, сформовані в процесі циклювання потенціалу, $є$ більш однорідними і містять менше десектів, ніж плівки, синтезовані потенціостатичних умовах [2]. Потенціодинамічні криві (рис.2) знімали зі швидкістю $\mathrm{v}=50 \mathrm{mB} / \mathrm{c}$ в діапазоні потенціалів від $-0,5 \mathrm{~B}$ до 1,4 В. Обмеження робочого діапазону потенціалів значенням 1,4 B обумовлено тим фактом, що при циклюванні до більших значень потенціалу відбувається незворотня деструкція утвореного ПТ шляхом його переокиснення. 

$\left.{ }^{0} \mathrm{C}\right)$.

Всі дослідження проводили при кімнатній температурі (+ 20

Опрацювання отриманих експериментальних даних здійснювали на комп'ютері за допомогою програми Origin.

Циклічні вольтамперограми (перші цикли) процесу електрохімічного синтезу ПЗМТ на скляному електроді в 0,5 М розчинах електролітів $\mathrm{MClO}_{4}\left(\mathrm{M}=\mathrm{Li}^{+}, \mathrm{Na}^{+}, \mathrm{Bu}_{4} \mathrm{~N}^{+}\right)$в $\mathrm{AH}$ приведена на рис.2.

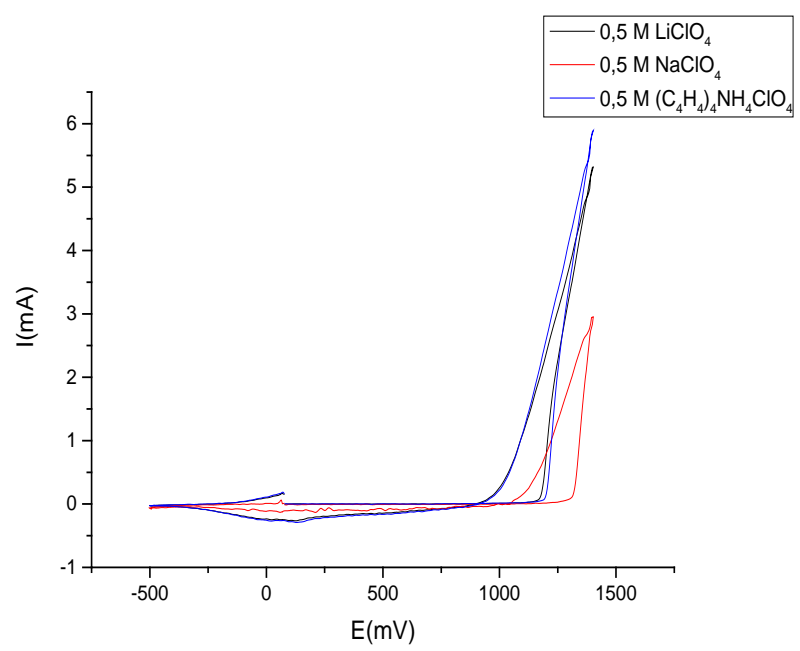

Puc.2. Циклічні вольтамперограми росту плівок ПЗМТ на скляному електроді в 0,5 $\mathrm{M} \mathrm{MClO}_{4}\left(\mathrm{M}=\mathrm{Li}^{+}, \mathrm{Na}^{+}, \mathrm{Bu}_{4} \mathrm{~N}^{+}\right)$в $\mathrm{AH}$, концентрація 3-метилтіофрену 0,05 $M ; v_{\text {розгортки }}=50 \mathrm{MB} / \mathrm{c} ; 1$-ий цикл для кожного з електролітів

Таблиця 1. Потенціал окиснення ЗМТ в 0,5 $\mathrm{M} \mathrm{MClO}_{4}$ в $\mathrm{AH}\left(\mathrm{M}=\mathrm{Li}^{+}\right.$, $\left.\mathrm{Na}^{+}, \mathrm{Bu}_{4} \mathrm{~N}^{+}\right) ; v_{C K}=50 \mathrm{MB} / \mathrm{c}$

\begin{tabular}{|c|c|}
\hline $\begin{array}{c}\text { Фонова сіль електросинтезу } \\
\text { ПзМт }\end{array}$ & $\mathbf{E}_{\mathbf{p a}}, \mathbf{B}$ \\
\hline $\mathrm{LiClO}_{4}$ & $+1,18$ \\
\hline $\mathrm{NaClO}_{4}$ & $+1,31$ \\
\hline $\mathrm{Bu}_{4} \mathrm{NClO}_{4}$ & $+1,2$ \\
\hline
\end{tabular}

Для кожного електроліту на анодній гілці циклічної вольтамперограми спостерігається різке зростання струму при потенціалах позитивніше 1,2 В відносно $\mathrm{Ag} / \mathrm{Ag}^{+}$, що відповідає початку окиснення 3-метилтіофену та його олігомерів за схемою (1) [3].

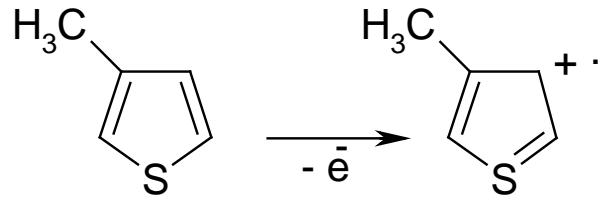


Далі відбувається зменшення перенапруги процесу завдяки утворенню шару полімеру на поверхні електроду. За рахунок утворення плівки, а також за рахунок того що окрім окиснення мономеру на поверхні скла відбувається також окиснення димеру, тримеру та інших олігомерів.

Різна перенапруга процесу окиснення 3-метил тіофену може бути пояснена конкуренцією катіон радикалів 3 катіонами електроліту при формуванні іонних пар з аніоном. Зважаючи на те, що підвищення перенапруги процесу електрохімічного окиснення мономеру може призводити до деградації полімеру, що утворюється на поверхні електроду, варто обирати електроліт з найменшою перенапругою окиснення мономеру.

\section{Висновки}

У роботі розглянуто особливості електрохімічного синтезу ПЗМТ на поверхні оптично прозорих електродів, покритих електропровідним сплавом оксидів індію та олова (ITO, $\ln _{2} \mathrm{O}_{3}: \mathrm{SnO}_{2}$ ), у 0,5 $\mathrm{M}$ розчинах $\mathrm{MClO}_{4}\left(\mathrm{M}=\mathrm{Li}^{+}, \mathrm{Na}^{+}, \mathrm{Bu}_{4} \mathrm{~N}^{+}\right)$в ацетонітрилі $(\mathrm{AH})$.

Знайдено, що потенціал окиснення $\left(\mathrm{E}_{\mathrm{pa}}\right)$ ЗМТ залежить від природи катіона фронового електроліта електросинтезу. Було визначено потенціал початку осадження полімеру для кожного електроліту (табл.1). В процесі електросинтезу плівок ПЗМТ можливе здійснення взаємодії між катіоном фронового електроліта і молекулою мономера, що спричиняє вплив на величину потенціала окиснення мономера, а також на властивості утворюваних плівок.

Відповідно, 3 досліджених електролітів, $\mathrm{LiClO}_{4} €$ найкращим для ефективного формування ПЗМТ шару на поверхні електроду оскільки у даному випадку перенапруга процесу електрохімічного окиснення мономеру $є$ найменшою. Таким чином, шляхом вибору оптимального іонного складу фонового електроліту можна підвищити вихід цільового полімеру на поверхні електроду та підвищити якість утворюваних полімерних плівок.

\section{Перелік посилань}

[1] Афранасьев В. Л., Назарова И. Б., Хидекель М. Л. Политиофен проводящее органическое соединение // Изв. АН СССР. Сер. хим. 1980. - № 7. - C. 1687 - 1688.

[2] Skotheim, T.A; Elsenbaumer, R.L.;Reynolds, J.R.; Handbook of Conducting Polymers, 2nd Ed. Marcel Dekker, New York, 1998.

[3] Waltman R. J. Electroactive properties of polyaromatic molecules/ R. J. Waltman, A. F. Diaz, G. Bargon // J. Electrochem. Soc. 1984. Vol. 131. N 6. p. $1952-1956$. 
УДК 66.091.3

\title{
KINETICS OF ANODIC PROCESSES IN ACETIC ACID SOLUTIONS
}

\author{
BILOUS T.A., TULSKY G.G. \\ National Technical University "Kharkiv Polytechnical Institute" \\ beloystany@yandex.ru
}

Anodic processes in the solutions of acetic acid without additives and with additives of potassium thiocyanate have been investigated by the voltammetry method at high potential on a platinum electrode. The role of potassium thiocyanate additive in acetic acid solution as a promoter in the electrochemical synthesis of peroxyacetic acid has been shown.

Kinetics of the anode process has been investigated in the acetic acid solutions in the concentration range of $1 . . .9 \mathrm{~mol} \cdot \mathrm{dm}^{-3}$. It has been shown that increasing the acetic acid concentration up to $6 \mathrm{~mol} \cdot \mathrm{dm}^{-3}$ promotes achieving the electrochemical potential of peroxyacetic acid synthesis.

Keywords: acetic acid, peroxyacetic acid, potassium thiocyanate.

\section{КИНЕТИКА АНОДНЫХ ПРОЦЕССОВ В РАСТВОРАХ УКСУСНОЙ КИСЛОТЫ}

\author{
БЕЛОУС Т.А., ТУЛЬСКИЙ Г.Г. \\ Национальный Технический Университет "Харьковский \\ Политехнический Институm"; beloystany@yandex.ru
}

Методом снятия вольт-амперных кривых исследованы анодные процессы в растворах уксусной кислоты в области высоких потенциалов без добавки и с добавкой роданида калия на платиновом электроде. Установлена роль добавки роданида калия в растворах уксусной кислоты как промотора в электрохимическом синтезе пероксиуксусной кислоты.

Исследована кинетика анодного процесса в растворах уксусной кислоты в диапазоне концентраций 1...9 моль-дм ${ }^{-3}$. Показано, что увеличение концентрации уксусной кислоты до 6 моль-дм ${ }^{-3}$ способствует достижению потенциалов электрохимического синтеза пероксиуксусной кислоты.

Ключевые слова: уксусная кислота, пероксиуксусная кислота, роданид калия. 
При электролизе растворов карбоновых кислот и их солей на аноде возможно протекание нескольких конкурирующих реакций: выделение кислорода; реакция Кольбе; образование пероксидных соединений. На механизм анодных реакций существенное влияние оказывают концентрация ионов $\mathrm{CH}_{3} \mathrm{COO}^{-}$и наличие добавок, которые, встраиваясь в двойной электрический слой, меняют механизм и кинетику электродного процесса.

Известно, что роданиды тормозят процесс выделения кислорода [1] и в их присутствии полностью подавляется реакция Кольбе [2], что облегчает электрохимический синтез пероксиуксусной кислоты [3]. Применение электрохимических технологий для получения пероксиуксусной кислоты непосредственно на месте применения исключает потери целевого продукта в результате его хранения.

\section{Методика эксперимента}

Вольт-амперные зависимости получали с помощью импульсного потенциостата ПИ-50-1 с программатором ПР-8. Скорость развертки потенциала $10 \mathrm{mB} / \mathrm{c}$.

Электролиты готовили из концентрированной уксусной кислоты марки «хч». $\mathrm{pH}$ растворов уксусной кислоты определяли путем измерения на приборе $\mathrm{pH}-150 \mathrm{M}$.

Поляризационные исследования проводили в электрохимической ячейке при температуре 18-22 ${ }^{\circ} \mathrm{C}$. Анод платиновая пластина с рабочей поверхностью $1,32 \mathrm{~cm}^{2}$. В качестве вспомогательного электрода использовали платину. Электрод сравнения - хлорид-серебряный. Все значения потенциалов пересчитаны относительно водородного электрода.

\section{Результаты эксперимента и их обсуждение}

Поляризационные исследования проводили на плоском платиновом аноде с изолированной тыльной стороной. Платиновый анод был выбран из-за высокого перенапряжения протекания побочного процесса - выделения кислорода.

На рис. 1 представлены анодные потенциодинамические зависимости, снятые на платиновом электроде в растворах уксусной кислоты.

Подъём тока начинается при потенциалах выше 1,7 В и сопровождается выделением кислорода. Учитывая значения потенциалов при выделении кислорода можно предположить, что протекание этого процесса происходит через образование пероксида водорода: 


$$
\begin{aligned}
& 2 \mathrm{H}_{2} \mathrm{O}=\mathrm{H}_{2} \mathrm{O}_{2}+2 \mathrm{H}^{+}+2 \mathrm{e}, \mathrm{E}_{\mathrm{p}}=1.776-0.0591 \mathrm{pH} \\
& 2 \mathrm{H}_{2} \mathrm{O}_{2}=\mathrm{O}_{2}+2 \mathrm{H}_{2} \mathrm{O}, \mathrm{E}_{\mathrm{p}}=0.682-0.0591 \mathrm{pH} .
\end{aligned}
$$

Расчетные значения равновесных потенциалов с учетом соответствующих значений $\mathrm{pH}$ исследуемых растворов уксусной кислоты приведены в табл. 1.

Таблица 1. Значения равновесных потенциалов с учетом $\mathrm{pH}$

\begin{tabular}{|c|c|c|c|c|}
\hline $\begin{array}{c}\text { Концентрация } \\
\mathbf{C H} \mathbf{H}_{3} \mathbf{C O O H}, \\
\text { моль } \mathbf{A M}^{-3}\end{array}$ & $\mathbf{p H}$ & $E_{\mathrm{H}_{2} \mathrm{O} / \mathrm{H}_{2} \mathrm{O}_{2}}^{p}, \mathbf{B}$ & $E_{\mathrm{O}_{2} / \mathrm{H}_{2} \mathrm{O}_{2}}^{p}, \mathbf{B}$ & $E_{\mathrm{H}_{2} \mathrm{O} / \mathrm{O}_{2}}^{p}, \mathbf{B}$ \\
\hline 9 & 1,91 & 1,663 & 0,569 & 1,116 \\
\hline 6 & 2,00 & 1,658 & 0,564 & - \\
\hline 3 & 2,14 & 1,650 & 0,555 & - \\
\hline 1 & 2,38 & 1,635 & 0,541 & - \\
\hline
\end{tabular}

Известно, что платина является катализатором разложения пероксида водорода [1]. Поэтому единственным продуктом анодной реакции является кислород. С целью торможения реакции выделения кислорода целесообразно проводить процесс электролиза в концентрированных растворах уксусной кислоты с добавкой промоторов образования перекисной группы. Так же целесообразно исследовать кинетику анодных процессов в растворах уксусной кислоты на не платиновом аноде. В качестве альтернативного анодного материала перспективно исследовать диоксид свинца.

На рис. 2 представлены анодные потенциодинамические поляризационные зависимости, снятые на платиновом электроде в растворах уксусной кислоты с добавкой промотора - роданида калия.

Сравнив рис. 1 и рис. 2 можно утверждать, что скорость электрохимического процесса с добавлением в раствор роданида калия возрастает. Известно, что роданид калия тормозит процесс выделения кислорода, адсорбируясь на поверхности электрода. Соответственно, скорость процесса должна была снизиться. Поскольку этого не наблюдается, можно утверждать, что добавление в раствор роданида калия облегчает протекание другого электрохимического процесса, предположительно образования пероксида водорода.

Анодная потенциодинамическая поляризационная зависимость для раствора 9 моль-дм ${ }^{-3} \mathrm{CH}_{3} \mathrm{COOH}$ с добавкой роданида калия существенно отличается от остальных на рис. 2 наличием начала подъёма тока при потенциале примерно 1..1,1 В (связанного, вероятно, с встраиванием роданида в структуру двойного 
электрического слоя), а затем подъема тока при потенциалах более 2,0 В. Этот подъем тока связан с совместным протеканием процессов (1) и (2), но соотношение долей тока на выделение пероксида возрастает за счет снижения выхода по току кислорода.

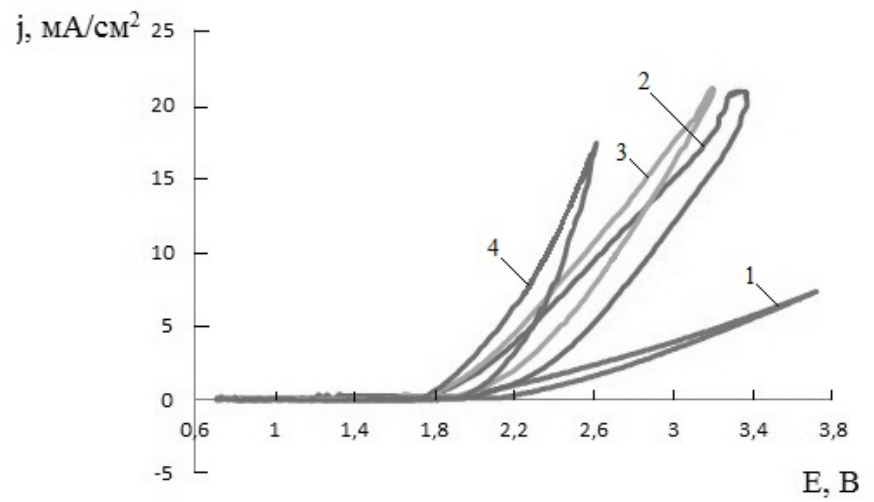

Puc.1. Анодные поляризационные зависимости на платине в растворах $\mathrm{CH}_{3} \mathrm{COOH}$ (моль $\left.\cdot \partial \mathrm{M}^{-3}\right): 1$ - 9; 2 - 6; 3 - 3; 4 - 1

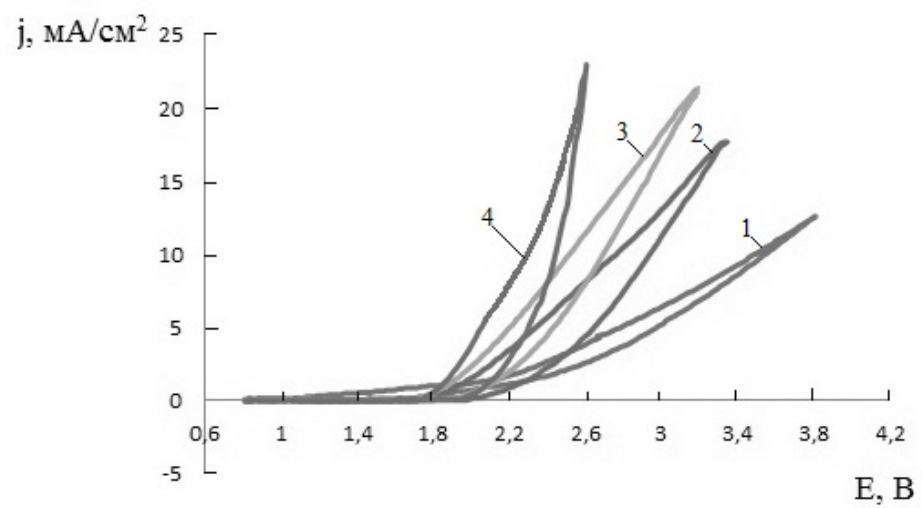

Puc.2. Анодные поляризационные зависимости на платине в растворах $\mathrm{CH}_{3} \mathrm{COOH}$ (моль $\cdot$ дм ${ }^{-3}$ ) с добавкой роданида калия: 1 - 9; 2 - 6; 3 - 3; 4 - 1

Для понимания механизма электрохимических реакций на рис. 3 приведены полулогарифмические зависимости для растворов 9 моль.дм ${ }^{-3} \mathrm{CH}_{3} \mathrm{COOH}$ без добавки (линия 1) и с добавкой роданида калия (линия 2). Линия 1 характеризуется одним тафеелевским участком с $b=60$ мВ. При потенциалах более 2,0 В участок с электрохимическим контролем заканчивается и начинается переходная область.

Первый прямолинейный участок кривой 2 на рис. 3, приходящийся на области потенциалов $1 \ldots 1,2$ В, соответствует выделению кислорода:

$$
2 \mathrm{H}_{2} \mathrm{O}=\mathrm{O}_{2}+4 \mathrm{H}^{+}+4 \mathrm{e}, \mathrm{E}_{\mathrm{p}}=1.228-0.0591 \mathrm{pH} .
$$

Следует отметить, что прямолинейный участок кривой 2 характеризуется тафрелевским участком $\mathrm{c} b=60 \mathrm{MB}$, что соответствует процессу выделения кислорода. 


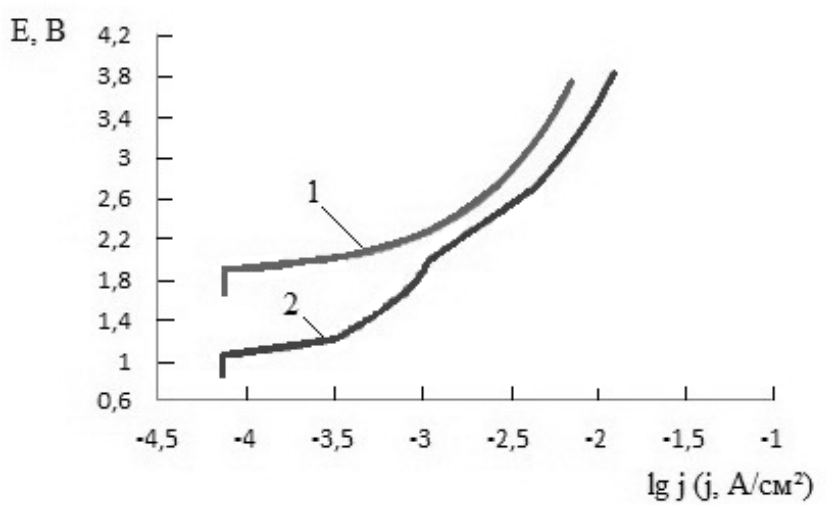

Puс.3. Вольт-амперные зависимости на платиновом аноде в 9 моль $\cdot{ }^{-3}$ $\mathrm{CH}_{3} \mathrm{COOH}: 1$ - без добавки KCNS; 2 - с добавкой KCNS
Второй прямолинейный участок на кривой 2 (рис. 3), который находится промежутке потенциалов $1,8 \ldots 2,6 \quad B, \quad$ соответствует электрохимическому процессу образования пероксида водорода. Рабочие плотности тока при этом составляют порядка $10^{2} \mathrm{~A} \cdot \mathrm{M}^{-2}$.

В области более высоких плотностей тока и потенциалов возможно протекание еще одного совмещенного

процесса - образования озона и побочных реакций - синтез Кольбе и деструкция уксусной кислоты.

Следующим этапом исследований, направленных на увеличение рабочих плотностей тока, является исследование влияния температуры на выход по току целевого продукта и замена платинового анода.

\section{Выводы}

Методом вольтамперометрии исследованы анодные процессы в растворах уксусной кислоты без добавки и с добавкой роданида калия на платиновом электроде. В растворах $\mathrm{CH}_{3} \mathrm{COOH}$ без добавки роданида калия наблюдается подъем тока при потенциалах выше 1,7 В в результате выделения кислорода через образование пероксида водорода. Добавление в растворы $\mathrm{CH}_{3} \mathrm{COOH}$ роданида калия приводит к торможению процесса выделения кислорода и облегчает протекание процесса образования пероксиуксусной кислоты. Обоснованы технологические показатели электросинтеза пероксиуксусной кислоты.

\section{Список литературы}

[1] Фиошин М.Я., Смирнова М.Г. Электросинтез окислителей и восстановителей. - 2-е изд., перераб. и доп. - Л.: Химия, 1981. - 212 с., ил.

[2] Хидиров Ш.Ш. Вольтамперометрическое исследование электродных процессов в ацетатных растворах на платиновом электроде / Ш.Ш. Хидиров // Электрохимия. - 1992. - Т.28. - №2. C. 158-164.

[3] Пат. 2216537 Россия, МПК ${ }^{7}$ С 07 С 409/24. Способ получения пероксиуксусной кислоты. 
УДК 621.357.12

\title{
ELECTROCHEMICAL DISINFECTION OF WATER WITH A NATURAL CONTENT OF SALTS
}

\author{
E.B.BASHMAKOV, V.B.BAYRACHNYI, DIAB HASSAN \\ National technical university "Kharkov polytechnic institute" \\ baric1303@yandex.ua
}

Electrochemical synthesis has been investigated for sodium hypochlorite water solution during the electrolysis of sodium chloride solutions with low concentration. Limiting densities of current have been determined depending on the concentration of sodium chloride and the temperature of electrolysis. The design of electrode block of a flowing cell for disinfection of water that allows one to minimize Ohm losses and to reach flow turbulization has been proposed. The choice of the cobalt titanium oxide anode with natural content of sodium chloride in the range from 0,01 to $0,05 \mathrm{~g}$ per $\mathrm{dm}^{3}$ for electrolysis of water has been justified.

\section{ЭЛЕКТРОХИМИЧЕСКОЕ ОБЕЗЗАРАЖИВАНИЕ ВОДЫ С ПРИРОДНЫМ СОЛЕСОДЕРЖАНИЕМ}

\author{
БАШМАКОВ Е.Б., БАЙРАЧНЫЙ В.Б., ДИАБ ХАССАН \\ Национальный технический университет "Харьковский \\ политехнический институт"; baric1303@yandex.ua
}

\begin{abstract}
Исследован электрохимический синтез водного раствора гипохлорита натрия при электролизе водных растворов хлорида натрия с низкой концентрацией. Установлены предельные плотности тока в зависимости от концентрации хлорида натрия и температуры электролиза. Предложена конструкция электродного блока для проточной ячейки для обеззараживания воды, которая позволяет минимизировать омические потери напряжения и турбулизировать поток жидкости. Обоснован выбор оксидного кобальтового титанового анода для электролиза воды с природным солесодержанием хлорида натрия от 0,01 до 0,05 г.экв дм $^{-3}$. Показално, что ОКТА, с содержанием 21..30 мол. \% $\mathrm{Co}_{3} \mathrm{O}_{4}$ практически не уступает покрытию из индивидуального $\mathrm{Co}_{3} \mathrm{O}_{4}$ по каталитической активности в реакции выделения хлора и имеет более высокую износостойкость.
\end{abstract}


Для решения проблем водоснабжения в Украине большой интерес вызывает возможность использования природного солесодержания воды для проведения процессов электрохимического обеззараживания, умягчения и дезодорирования. В настоящее время широко применяемым методом обеззараживания воды является использование «активного хлора» полученного путем прямого электролиза. Учитывая нестабильность растворов «активного хлора», электрохимический метод позволяет создавать установки различной производительности непосредственно на месте потребления дезинфектанта с использованием местного исходного сырья. В качестве последнего могут выступать морская вода, естественные рассолы, минерализированные или промышленные стоки и т.д., которые содержат хлорид натрия. В этом случае эксплуатационные затраты определяются в основном затратами электроэнергии, поэтому с целью снижения энергетических затрат процесс целесообразно вести в направлении получения слабоконцентрованных растворов гипохлорита натрия с содержанием активного хлора до $2 r \cdot \mathrm{gm}^{-3}$. При реализации такой схемы на практике электролит без какой-либо предварительной обработки с заданным расходом подается на электролизную установку, а потом в бак - накопитель гипохлорита натрия, или непосредственно в обрабатываемые системы.

$\mathrm{Ha}$ сегодняшний день бездиафрагменные установки периодического действия работают на растворах с содержанием хлорида натрия не менее 50 г·дм ${ }^{-3}[1-4]$. Их недостатком является низкое содержание гипохлорита натрия из-за процессов восстановления целевого продукта на катоде. Альтернативными являются установки с использованием керамической фрильтрующей диафрагмы [5 - 6]. Применение диафрагмы позволяет повысить выход по току по гипохлориту натрия. Однако такая технологическая схема требует высокой степени очистки рассола, что делает процесс электрохимического обеззараживания больших объемов воды сложно реализуемым и весьма затратным.

Широкое использование электролиза тормозится из-за несовершенства анодных материалов и конструкции электролизных установок.

\section{Конструкция электролизера}

Разработана конструкция электродного блока, состоящего из двух плоскопараллельных водопроницаемых пористых электродов, прижатых друг к другу через тонкую сетчатую разделительную перегородку. Это позволяет минимизировать омические потери 
напряжения в электродном блоке вследствие низкого солесодержания, обрабатываемого раствора. А структура пористых электродов турбулизирует поток проходящего через него раствора для устранения концентрационных затруднений. Поток обрабатываемой воды подается перпендикулярно на электродный блок и проходит сквозь него со стороны катода, что позволяет избежать катодного восстановления образовавшегося активного хлора.

Для эфффективной работы предложенной конструкции в качестве анодного материала был выбран ОРТА. Аноды на основе $\mathrm{RuO}_{2}$ применяются для промышленного электролиза концентрированных растворов хлоридов. При концентрации хлоридов менее 5 г·дм ${ }^{-3}$ они подвержены значительному износу.

\section{Результаты исследования и их обсуждение}

Основными показателями, определяющими эфффективность процесса электрохимического обеззараживания воды, является концентрация хлорид ионов, температура электролиза и ионный состав. Содержание хлорид ионов в природных водах находится в очень широком диапазоне. Предельно допустимое содержание хлорид ионов в питьевой воде составляет 70 мг·дм ${ }^{-3}$, в воде плавательных бассейнов - не более $350 \quad г \cdot \mathrm{gm}^{-3}$. Содержание хлоридов в природных водах, используемых для хозяйственнобытовых нужд предприятий Украины, может достигать $5-10$ г·дм ${ }^{-3}$. Обеззараживание всех перечисленных категорий вод путем добавления растворов гипохлорита натрия неизбежно приводит к увеличению содержания хлоридов, что ограничивает применение этого метода обработки. Поэтому были проведены исследования по изучению использования природного солесодержания хлорида натрия от 0,01 до 0,05 г·экв·дм ${ }^{-3}$.

Результаты исследования показывают значительное влияние концентрации хлорида натрия на кинетику анодного процесса. Увеличение концентрации хлорида натрия приводит к снижению перенапряжения анодного процесса и увеличению прямолинейного участка поляризационной зависимости, на котором лимитирующей стадией анодного процесса является стадия электрохимического разряда. Область окончания электрохимического контроля анодного процесса переходит в область, в которой лимитирующим процессом является диффузионный контроль по хлорид ионам. Зона перехода определяет максимально возможную плотность тока выделения хлора в этих условиях. Значения плотности тока для исследуемых концентраций хлорида натрия и температур от 283 К до 308 К приведены в табл. 1. 
Из приведенных, в табл. 1, данных можно говорить о существенном влиянии хлорид ионов на процесс образования хлора, который в результате гидролиза образует соединения активного хлора. Также данные таблицы 1 позволяют установить скорость протекания процесса обработки для каждого конкретного случая содержания хлорид ионов в обрабатываемой воде.

Альтернативной заменой ОРТА в низко - концентрированных хлоридных растворах являются электроды с активным слоем на основе оксидов кобальта. Исследования кинетики совмещенных анодных процессов на оксидном кобальтовом титановом аноде (ОКТА) при электролизе водных растворов $\mathrm{NaCl}$ показали, что ОКТА, с содержанием 21...30 мол. \% $\mathrm{Co}_{3} \mathrm{O}_{4}$ практически не уступает покрытию из индивидуального $\mathrm{Co}_{3} \mathrm{O}_{4}$ по каталитической активности в реакции выделения хлора при более высокой износостойкости. Увеличение содержания $\mathrm{TiO}_{2}$ в ОКТА приводит к снижению количества активных центров $\mathrm{Co}_{3} \mathrm{O}_{4}$ на поверхности композиционного покрытия. Это, в свою очередь, является причиной значительного роста реальной плотности тока на активных $\mathrm{Co}_{3} \mathrm{O}_{4}$ участках. Уменьшение содержания $\mathrm{Co}_{3} \mathrm{O}_{4}$ приводит к увеличению омических потерь напряжения. Значительные омические потери напряжения на ОКТА объясняются обеднением каталитического покрытия носителями заряда.

Таблица 1. Предельная анодная плотность тока $\left(A \cdot M^{-2}\right)$ в зависимости от содержания хлорид ионов и температуры электролиза

\begin{tabular}{|c|c|c|c|}
\hline \multirow{2}{*}{$\begin{array}{l}\text { Содержание } \\
\mathrm{Cl}^{-}, \text {г·экв-дм }\end{array}$} & \multicolumn{3}{|c|}{ Температура электролиза, `K } \\
\hline & 283 & 298 & 308 \\
\hline 0,01 & 5,7 & 9,1 & 14,0 \\
\hline 0,02 & 6,5 & 11,7 & 16,1 \\
\hline 0,03 & 9,2 & 14,8 & 18,1 \\
\hline 0,05 & 12,4 & 25,4 & 30,1 \\
\hline
\end{tabular}

По величине перенапряжения (45...60 мВ) ОКТА является каталитически активным в реакции выделения хлора. Более высокая каталитическая активность ОКТА позволяет проводить электролиз разбавленных хлоридных растворов при более высоких, чем в случае применения ОРТА, плотностях тока. Уже при плотности тока $100 \mathrm{~A} \cdot \mathrm{M}^{-2}$ в 0,04 моль дм $^{-3}$ водном растворе $\mathrm{NaCl}$ анодный потенциал на ОРТА приближается к критическому для $\mathrm{RuO}_{2}-1,65 \mathrm{~B}$. 
Достижение критического для $\mathrm{Co}_{3} \mathrm{O}_{4}$ потенциала, равного $1,70 \mathrm{~B}$ происходит при плотности тока более $300 \mathrm{~A} \cdot \mathrm{m}^{-2}$. Влияние температуры на скорость анодного процесса при значении анодного потенциала 1,5 В показано в табл. 2.

Таблица 2. Влияние температуры электролиза на анодную плотность тока $\left(A \cdot M^{-2}\right)$ при обеззараживании воды $\left(E_{a}=1,5 B\right)$

\begin{tabular}{|c|c|c|}
\hline \multirow{2}{*}{ Температура, `K } & \multicolumn{2}{|c|}{ Концентрация хлорида натрия, г·экв·дм } \\
\hline & 0,01 & 0,05 \\
\hline 283 & 3,7 & 9,4 \\
\hline 298 & 5,1 & 15,3 \\
\hline 308 & 6,9 & 23,9 \\
\hline
\end{tabular}

Повышение температуры обрабатываемой воды не является однозначным, так как нагрев воды выше $313{ }^{\circ} \mathrm{K}$ приводит к разложению гипохлорита натрия $[5,6]$. Снижение температуры, с одной стороны делает растворы более стабильными и тормозит побочный процесс - выделение кислорода, но с другой стороны увеличивает удельное сопротивление электролита, что приводит к увеличению омической составляющей падения напряжения в электролизере и таким образом способствует разложению гипохлорита натрия.

Однако, как видно из табл. 2, повышение температуры (не превышающей $\left.313 \quad{ }^{\circ} \mathrm{K}\right)$ позволяет скомпенсировать концентрационные ограничения и за счет этого повысить рабочие плотности тока.

\section{Выводы}

Предложена конструкция электродного блока проточного типа для обеззараживания воды. Показана возможность проведения процесса обеззараживания воды путем электролиза за счет природного солесодержания. В исследуемом диапазоне температур $\left(283 \ldots 308{ }^{\circ} \mathrm{K}\right)$ и концентраций хлорид иона $\left(0,01 \ldots 0,05\right.$ г·экв·дм $\left.{ }^{-3}\right)$ определены предельно допустимые рабочие плотности тока. Показано, что использование ОКТА позволяет повысить анодную плотность тока на порядок в разбавленных хлоридных растворах по сравнению с ОРТА.

Разработаны технологические параметры обеззараживания природной воды в зависимости от солесодержания и температуры прямым электролизом с использованием без диафрагменного проточного электродного блока. 


\section{Литература}

[1] Гринберг В.А. Электрохимическое получение в проточном электролизере растворов гипохлорита натрия медицинского назначения / В.А. Гринберг, А.М. Скундин, Е.К. Тусеева // Электрохимия. - 2001. - Т. 37, № 4. - С. $500-504$.

[2] Баштан С.Ю. Електрохімічна очистка води в апаратах 3 розділювальною керамічною мембраною : автореф. дис. на здобуття наук. ступеня канд. техн. наук : спец. 05.17.21 «Технологія водоочищення» / Софрія Юріївна Баштан. - К., 2009. - 20 с.

[3] Гончарук В.В. Электрохимическое обеззараживание морской воды в плавательном бассейне / В.В. Гончарук, С.Ю. Баштан, Р.Д. Чеботарева // Химия и технология воды. - 2003. - Т. 25, № 4. - C. $334-341$.

[4] Гончарук В.В. Умягчение воды в електролизере с керамической мембраной / В.В. Гончарук, Р.Д. Чеботарева, В.А. Багрий, С.Ю. Баштан, С.В. Ремез // Химия и технология воды. - 2005. - Т. 27, № 5. - С. $460-470$.

[5] Тульский Г.Г. Совершенствование технологии электрохимического синтеза растворов "активного хлора" / Г.Г. Тульский, О.О. Смирнов, О.Ю. Бровін // Вопросы химии и химической технологии. -Днепропетровск: УГХТУ, - 2011. - № 4(2). С $236-238$.

[6] Смирнов О.О. Вплив рН на кінетику анодного процесу при електролізі водного розчину хлориду натрію / О.О. Смирнов, О.Ю. Бровін, Г.Г. Тульский // Вісник Національного технічного університету “ХПІ". -Харків: НТУ “ХПІ”, 2011. - № 27. - С 42 - 47. 
УДК 531.138

\title{
ELECTROCATALYTIC ACTIVITY OF COMPOSITE MATERIALS $\mathrm{PbO}_{2}-\mathrm{TiO}_{2}$ DEPOSITED FROM SUSPENSION ELECTROLYTES
}

\author{
KNYSH V.A., VELICHENKO A. B. \\ Ukrainian State University of Chemical Technology \\ valja-k67@yandex.ru
}

Electrocatalytic activity of composite materials $\mathrm{PBO}_{2}-\mathrm{TiO}_{2}$ for oxygen-transfer reactions (oxygen evolution and electrochemical incineration of p-nitroaniline) was studied. It was shown that increasing the content of $\mathrm{TiO}_{2}$ in the composite leads to an increase in both oxygen.overpotential and oxidation rate of $p$-nitroaniline.

\section{ЭЛЕКТРОКАТАЛИТИЧЕСКАЯ АКТИВНОСТЬ КОМПОЗИЦИОННЫХ МАТЕРИАЛОВ $\mathrm{PbO}_{2}-\mathrm{TiO}_{2}$, ОСАЖДЕННЫХ ИЗ СУСПЕНЗИОННЫХ ЕЛЕКТРОЛИТОВ}

\author{
КНЫШ В.А., ВЕЛИЧЕНКО А.Б.
}

ГВУЗ «Украинский государственный химико-технологический университеm», valja-k67@yandex.ru

В работе исследована электрокаталитическая активность композиционных материалов $\mathrm{PbO}_{2}-\mathrm{TiO}_{2}$ по отношению к реакциям выделения кислорода, а также процессам электрохимического разрушения п-нитроанилина. Показано, что с увеличением содержания $\mathrm{TiO}_{2}$ в композиционных материалах возрастает как перенапряжение выделение кислорода, так и скорость разрушения п-нитроанилина в композите.

Диоксид свинца, является одним из перспективных и широко применяемых на практике электрокатализаторов [1, 2]. Электрокаталитическая активность анодов на основе диоксида свинца, может быть существенно увеличена за счет их модифицирования [3 - 6]. Известно, что реакции, протекающие при высоких анодных потенциалах, в частности, выделение кислорода и разрушение токсичных органических веществ, протекают через начальную стадию образования кислородсодержащих частиц радикального типа, адсорбированных на поверхности электрода [3]. При этом электрокаталитическая активность материалов данного типа зависит от природы хемосорбированных 
кислородсодержащих частиц [3]. В зависимости от прочности связи с поверхностью электрода различают "инертные" и "лабильные" частицы. В конечном итоге их соотношение и определяет каталитическую активность электродов по отношению к тем или иным процессам. В данной работе исследовали влияние состава композиционных материалов $\mathrm{PbO}_{2}-\mathrm{TiO}_{2}$ на электрокаталитическую активность по отношению к реакциям выделения кислорода, а также процессам электрохимического разрушения п-нитроанилина.

\section{Методология исследований}

Для получения композиционных материалов на основе диоксида свинца были использованы метансульфонатные суспензионные электролиты с концентрацией кислоты и ионов $\mathrm{Pb}^{2+}$ равной 0,1 М, которые обладают агрегативной устойчивостью, а размер частиц дисперсной фразы составляет в среднем 14 нм. Выбор п-нитроанилина в качестве модельной реакции был обусловлен возможностью проводить кинетические исследования по исходному веществу, так как его раствор окрашен. Для него выполняется закон Бугера-Ламберта-Бера, а график зависимости оптической плотности от концентрации представляет собой прямую линию, проходящую через начало координат $(y=0,1068 x+0,0864$; $r=0,998)$.

\section{Результаты и их обсуждение}

Как было показано ранее [7, 8], при электроосаждении диоксида свинца из суспензионных электролитов формируются композиционные материалы, которые существенно отличаются от $\mathrm{PbO}_{2}$ по составу, фризико-химическим свойствам и электрокаталитической активности. Согласно полученным данным (рис. 1), перенапряжение кислорода на композиционных $\mathrm{PbO}_{2}-\mathrm{TiO}_{2}$ материалах значительно выше, чем на $\mathrm{PbO}_{2}$ электроде. Это является положительным моментом в тех случаях, когда анод работает в водных растворах при высоких поляризациях, а реакция выделения кислорода не является целевым процессом. При использовании композиционных анодов данного типа выход по току целевой реакции может возрасти за счет ингибирования РВК. Следует отметить, что увеличение содержания диоксида титана в композите ведет к росту перенапряжения РВК, вероятно, за счет увеличения поверхностной концентрации оксида вентильного металла. При этом центры данного типа обладают более высоким сродством к кислороду, что приводит к изменению соотношения лабильных и инертных форм кислородсодержащих частиц в сторону последних. Поскольку лимитирующей стадией РВК является 
электрохимическая десорбция (перенос второго электрона), это вызывает закономерное увеличение перенапряжения выделения кислорода.

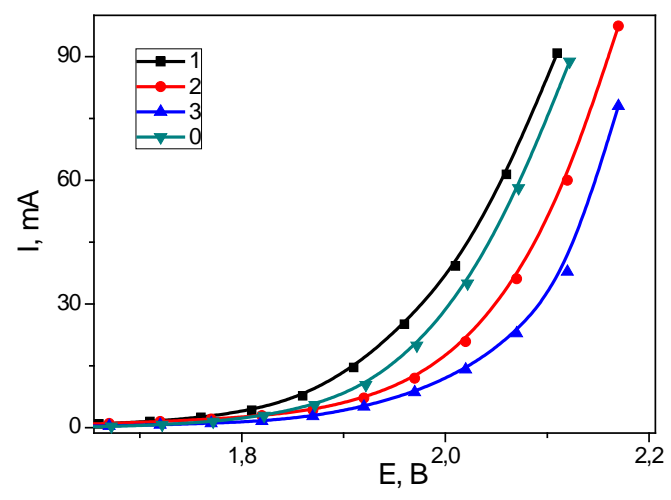

Puc. 1. Квазистационарные поляризационные кривые выделения кислорода в $1 \mathrm{MHClO}_{4}$ для электродов на основе диоксида свинца, полученных из

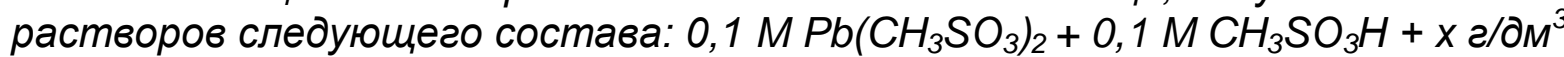
$\mathrm{TiO}_{2}: 1-1,0 ; 2-2,0: 3-5,0$

Согласно [9], общенный механизм окисления органических соединений ароматической природы включает в себя первичную трассрормацию до промежуточных продуктов хиноидной структуры, реакции раскрытия ароматического кольца и образования алифатических продуктов (в основном карбоновых кислот), а в предельном идеальном случае - полную минерализацию до $\mathrm{CO}_{2}$ и $\mathrm{H}_{2} \mathrm{O}$. В конкретном случае анодного окисления п-нитроанилина, образуется довольно большое число промежуточных продуктов. При этом основными являются бензохинон и малеиновая кислота [10]. При длительном электролизе в растворе обнаруживаются только алифатические кислоты.

Время исчезновения промежуточных ароматических продуктов и изменение концентрации исходного вещества определяли из электронных спектров поглощения растворов при различном времени электролиза. Следует отметить, что процессы электроокисления п-нитроанилина на немодифицированном и модифицированных диоксидносвинцовых электродах протекают качественно одинаково и отличаются только скоростью. Это указывает на неизменность механизма окисления п-нитроанилина на различных материалах, что дает возможность проводить корректное сопоставление их электрокаталитической активности.

Интересные результаты получены для композиционных электродов на основе диоксида свинца, полученных из суспензионных метансульфонатных электролитов, содержащих в качестве дисперсной фазы наноразмерные частицы диоксида 
титана. Как следует из табл. 1, скорость разрушения пнитроанилина возрастает с увеличением содержания $\mathrm{TiO}_{2}$ в композите, превышая, в предельном случае, до 1,8 раза лучшие показатели, полученные в метансульфонатных электролитах, не содержащих добавок $\left(1,68^{*} 10^{-2}\right.$ мин $\left.^{-1}\right)$. Перемешивание суспензионного электролита в процессе получения композиционного материала $\left(0,1 \mathrm{MPb}\left(\mathrm{CH}_{3} \mathrm{SO}_{3}\right)_{2}+0,1 \mathrm{MCH}_{3} \mathrm{SO}_{3} \mathrm{H}+5\right.$ г/л $\mathrm{TiO}_{2} 30$ мин, 10 $\left.\mathrm{mA} / \mathrm{cm}^{2}, \mathrm{t}=25^{0} \mathrm{C}\right)$, приводящее к дополнительному росту содержания $\mathrm{TiO}_{2}$, позволяет достигнуть большего значения константы скорости п-нитроанилина, которая составляет $3,56 * 10^{-2}$ мин $^{-1}$, а снижение плотности тока осаждения до $5 \mathrm{MA} / \mathrm{cm}^{2}-4,45^{\star} 10^{-2} \mathrm{Mnн}^{-1}$. В последнем случае полученная константа скорости в 2,4 раза превышает лучшее значение, достигнутое в метансульфонатных электролитах, не содержащих добавок.

Таблица 1. Константа скорости реакции к электрохимического разложения п-нитроанилина на различных $\mathrm{PbO}_{2}-\mathrm{TiO}_{2}$ анодах

\begin{tabular}{|c|c|}
\hline 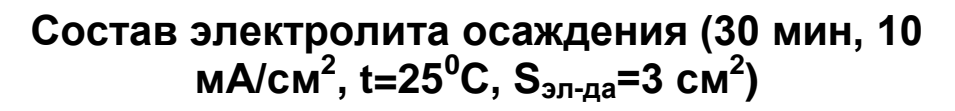 & $\begin{array}{l}\text { Константа скорости } \\
k^{*} 10^{2}, \text { мин }^{-1}\end{array}$ \\
\hline $0,1 \mathrm{MPb}\left(\mathrm{CH}_{3} \mathrm{SO}_{3}\right)_{2}+0,1 \mathrm{M} \mathrm{CH}_{3} \mathrm{SO}_{3} \mathrm{H}+0,5$ г/л $\mathrm{TiO}_{2}$ & 2,32 \\
\hline $0,1 \mathrm{MPb}\left(\mathrm{CH}_{3} \mathrm{SO}_{3}\right)_{2}+0,1 \mathrm{M} \mathrm{CH}_{3} \mathrm{SO}_{3} \mathrm{H}+1$ г/л $\mathrm{TiO}_{2}$ & 2,33 \\
\hline $0,1 \mathrm{MPb}\left(\mathrm{CH}_{3} \mathrm{SO}_{3}\right)_{2}+0,1 \mathrm{M} \mathrm{CH}_{3} \mathrm{SO}_{3} \mathrm{H}+2$ г/л $\mathrm{TiO}_{2}$ & 2,76 \\
\hline $0,1 \mathrm{MPb}\left(\mathrm{CH}_{3} \mathrm{SO}_{3}\right)_{2}+0,1 \mathrm{M} \mathrm{CH}_{3} \mathrm{SO}_{3} \mathrm{H}+5$ г/л $\mathrm{TiO}_{2}$ & 3,02 \\
\hline
\end{tabular}

Увеличение скорости окисления п-нитроанилина на композиционных анодах $\mathrm{PbO}_{2}-\mathrm{TiO}_{2}$ обусловлено, предположительно, ростом количества кислородсодержащих частиц с высокой прочностью связи, в том числе и за счет их генерации по фотохимическому механизму.

\section{Выводы}

Таким образом, на композиционных материаллах $\mathrm{PbO}_{2}-\mathrm{TiO}_{2}$, наблюдается увеличение перенапряжения РВК, обусловленное ростом прочности хемосорбированного кислорода. Композиционные аноды данного типа представляют интерес для использования в тех случаях, когда возникает необходимость в подавлении нежелательного процесса выделения кислорода.

Показано, что электрокаталитическая активность композиционных материалов диоксид свинца - оксид вентельного металла $\left(\mathrm{TiO}_{2}\right)$ зависит от содержания последнего в композите. Использование материалов $\mathrm{PbO}_{2}-\mathrm{TiO}_{2}$ позволяет существенно увеличить скорость электрохимического окисления п-нитроанилина.

Таким образом, полученные композиционные материалы могут быть рекомендованы в качестве электрокатализаторов для 
различных электрохимических процессов, в том числе электрохимического разрушения токсичных органических веществ и других процессов, где требуются аноды с высоким перенапряжением выделения кислорода.

\section{Литература}

[1] Sandro Cattarin, Marco Musiani. //Electrochimica Acta 2006. Vol. 52. № 4. P. 1339-1348.

[2] Guoting Li, Jiuhui Qu, Xiwang Zhang, Jiantuan Ge. //Water Reserch 2006. Vol. 40. - №4. P.213 - 220.

[3] Trasatti S. Oxygen and chlorine evolution at conductive metallic oxides / S. Trasatti, G. Lodi // Electrodes of conductive metallic oxides. Part B. - Amsterdam: Elsevier. - 1981. - P. 521-626.

[4] А.Б. Величенко Композиционные материалы на основе диоксида свинца: получение, фризико-химические свойства и электрокаталитическая активность / А.Б. Величенко, Л.В. Дмитрикова, В.А. Книш, Д. Девильи // Вопр. химии и хим. технологии. - 2011. - №4(1). - С. 110 - 112.

[5] A. B. Velichenko Electrodeposition $\mathrm{PbO}_{2}-\mathrm{TiO}_{2}$ and $\mathrm{PbO}_{2}-\mathrm{ZrO}_{2}$ and its physicochemical properties / A. B. Velichenko, V. A. Knysh, T. V.Luk'yanenko, D Devilliers // Materials Chemistry and Physics. - 2012. - Vol. 131, № 3. - P. 686-693.

[6] Т.В. Лукьяненко Электрохимическая конверсия салициловой кислоты и ее производных на модифицированных ионами $\mathrm{Bi}^{3+}$ и $\mathrm{Ce}^{3+}$ диоксидносвинцовых анодах / Т.В. Лукьяненко, В. А. Книш, О.Б. Шмычкова Л.В. Дмитрикова, К.Ю. Калинина, А.Б. Величенко // Вопр. химии и хим. технологии. - 2014. - № 2. - С. 34-40.

[7] Velichenko A. B. Kinetics of lead dioxide electrodeposition from nitrate solutions containing colloidal $\mathrm{TiO}_{2} / \mathrm{A}$. B. Velichenko , R. Amadelli, V. A. Knysh , T. V. Luk'yanenko, F. I. Danilov // Journal of Electroanalytical Chemistry. - 2009. - Vol. 632. - P. 192-196.

[8] Velichenko A. B. $\mathrm{PbO}_{2}-\mathrm{TiO}_{2}$ Composites: Electrosynthesis and Physicochemical Properties / A. B. Velichenko , V. A. Knysh , T. V. Luk'yanenko, D. Devilly, F. I. Danilov // Russian Journal of Applied Chemistry. - 2008. - Vol. 81. - № 6. - P. 994-999.

[9] Study of the oxidation of solutions of $p$-chlorophenol and $p$ nitrophenol on Bi-doped $\mathrm{PbO}_{2}$ electrodes by UV-Vis and FTIR in situ spectroscopy / C. Borras, T. Laredo, J. Mostany [et al.] // Electrochim. Acta. - 2004. - Vol. 49. - P.641-648.

[10] Jimenez Jado N. E. Electrochemical degradation of nitroaromatic wastes in sulfuric acid solutions: Part I / N. E. Jimenez Jado, C. Fernandez Sanchez, J. R. Ochoa Gomez // J. Appl. Electrochem. 2004. Vol. 34. - P. 551-556. 
УДК $66.01: 579.6 .08$

\title{
USING ELECTROCHEMICAL METODS FOR DETERMINING THE DEGREE OF DEACETYLATION OF CHITOSAN
}

\author{
SLIS A.A., REDKA K.V., SOLODOVNIK T.V. \\ Cherkassy State Technological University
}

The degree of deacetylation of chitosan by conductometric titration was analyzed. The values were compared with the results of spectroscopic analysis and technical characteristics specified by the manufacturer. It was found that this method is simpler and faster to determine the amino groups in chitosan, so it is more appropriate than other methods.

\section{ВИКОРИСТАННЯ ЕЛЕКТРОХІМІЧНИХ МЕТОДІВ ДЛЯ ВИЗНАЧЕННЯ СУПЕНЯ ДЕАЦЕТИЛЮВАННЯ ХІТОЗАНУ}

СЛІСЬ А.А., РЕДЬКА К.В., СОЛОДОВНІК Т.В. Черкаський державний технологічний університет

Було проаналізовано ступінь деацетилювання хітозану методом кондуктометричного титрування. Отримані значення були порівняні 3 результатами спектрофотометричного аналізу та технічних характеристик, зазначених виробниками.Було встановлено, що даний метод простіший і швидший для визначення аміногруп в хітозані, тому є більш доцільним ніж інші методи.

Останнім часом широкого застосування у багатьох галузях та виробництвах набув природний амінополісахарид - хітозан, який виявляє унікальні сорбційні властивості до іонів важких металів, барвників, нафртопродуктів, а також $є$ нетоксичним і легко піддається біодеградації. Отримують хітозан 3 хітину за допомагаю реакції деацетилювання (Рис.1).

В залежності від ефективності реакції деацетилювання одержують хітозани з різним значенням ступеню деацетилювання (СД). Ступінь деацетилювання $€$ важливим параметром для хітозану, який характеризує концентрацію аміногруп та визначає його фрізико-хімічні властивості. 


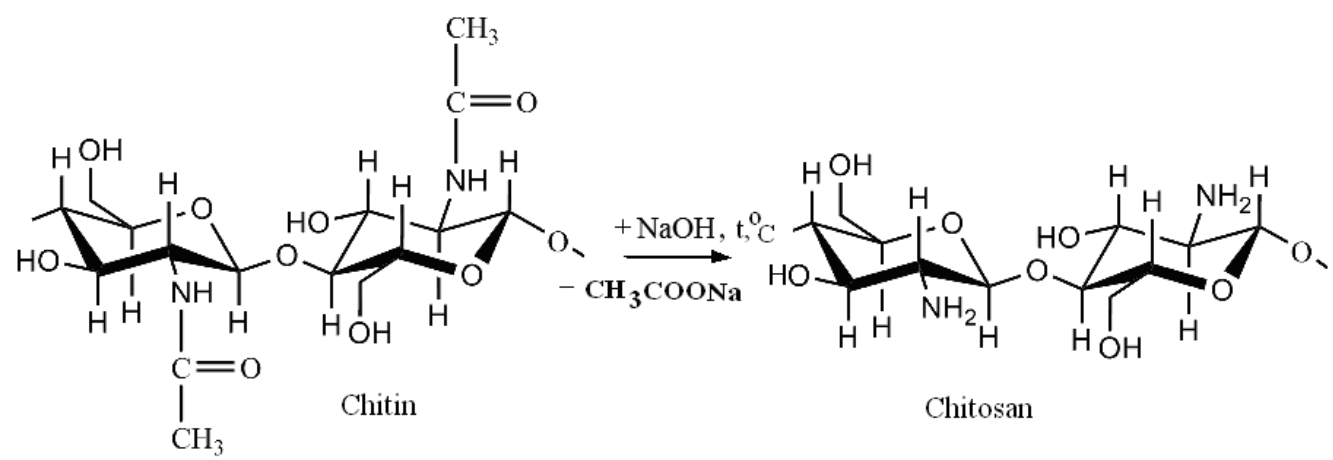

Puс. 1. Реакція деацетилювання

Відомо декілька методів визначення ступеня деацетилювання, а саме: потенціометричний метод, кондуктометричний, спектрофотометричний, метод ІЧ-спектроскопії [1,2]. В нашій роботі для визначення СД різних зразків хітозану було використано кондуктометричний метод, оскільки він $€$ найбільш доступним та простим для використання в звичайних хімічних лабораторіях. Метою роботи було визначення СД різних зразків хітозану та порівняння отриманих даних 3 результатами, одержаними відповідно інших методик.

\section{Методологія досліджень}

Для дослідження СД хітозану в роботі використовувались наступні зразки:

- хітозан ЗАО «Біопрогрес»-1;

- хітозан ЗАО «Біопрогрес»-2;

- хітозан фрірми Aldrich.

Визначення ступеня деацетилювання В природних амінополісахаридах методом кондуктометричного титрування ґрунтується на аналізі солянокислих розчинів хітозану. Для вимірювання опору розчинів використовували спеціальні датчики у вигляді скляної посудини (2) з двома електродами (4) рівної площі. Електроди були виготовлені з інертного матеріалу (платина). Датчик увімкнено в лабораторний кондуктометр КФ-1 (1), який був сконструйований студентами кафедри хімії та хімічної технології неорганічних речовин Черкаського державного технологічного університету в рамках науково-дослідної роботи студентів, схему якого подано на рис. 2.

Для приготування розчинів хітозану використовували 0,1 M розчин $\mathrm{HCl}$. Титрування проводили $0,33 \mathrm{M}$ розчином $\mathrm{NaOH}$. Точну наважку сухого матеріалу $(0,2$ г) розчинили у відповідному розчиннику впродовж 2 годин при перемішуванні. Титрування 
проводили поступовим додаванням розчину $\mathrm{NaOH}$ (по 0,5 $\mathrm{cm}^{3}$ ). Після кожного додавання титранту очікували 1 хвилину а потім фріксували покази кондуктометру [3]. Розрахунки проводили за відповідними формулами $[4,5]$.

$$
N_{a n}=\frac{V(\mathrm{NaOH}) \cdot \mathrm{C}(\mathrm{NaOH}) \cdot 1,4}{m}, \%,
$$

де $\mathrm{V}(\mathrm{NaOH})$ - об'єм лугу, який пішов на титрування аміногруп, $\mathrm{cm}^{3} ; \mathrm{C}(\mathrm{NaOH})$ - нормальна концентрація лугу, моль/дм³; $\mathrm{m}$ - наважка сухого матеріалу, г; 1,4 - коефріцієнт перерахунку на азот.

$$
\begin{gathered}
\varphi_{\mathrm{NH}_{2}}=\frac{N_{a n} \cdot 203}{14 \cdot 100+42 \cdot N_{a \mu}} . \\
C Д=\varphi_{\mathrm{NH}_{2}} \cdot 100 \% .
\end{gathered}
$$

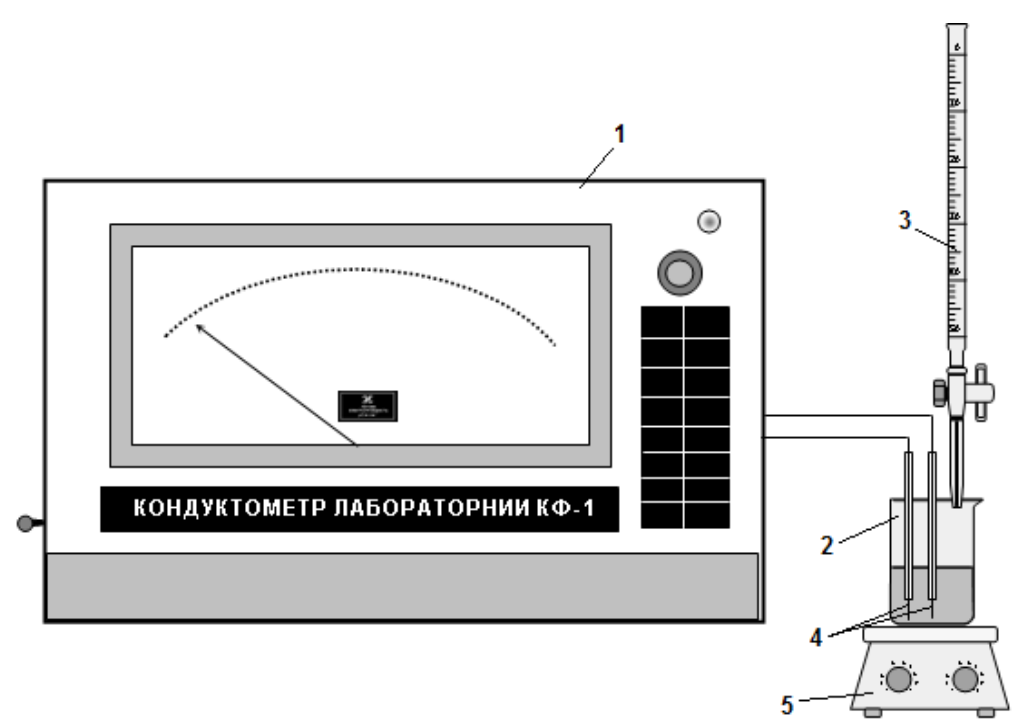

Puc. 2. Схема кондуктометра КФ-1: 1 - кондуктометр лабораторний; 2 кондуктометрична комірка; 3 - бюретка з розчином титранту; 4 електроди платинові; 5 - магнітна мішалка

\section{Результати та їх обговорення}

За даними кондуктометричного титрування для всіх зразків були побудовані криві титрування, які наведені на рис.3. Аналіз отриманих кривих показує, що на початку титрування покази пристрою зменшувались, і на нашу думку, це відбувалось в наслідок зменшення провідності при нейтралізації кислоти, потім зменшення проходило повільніше (оскільки в зразках були присутні карбоксильні групи), після чого спостерігалася ділянка сталих показів (титрування аміногруп), далі відбувалось збільшення провідності за рахунок 
надлишку лугу. За допомогою кривих титрування був визначений об'єм $\mathrm{NaOH}$, який пішов на титрування аміногруп і проведені відповідні розрахунки, результати яких наведені в таблиці. Для порівняння різних методів, в таблиці також представлені значення СД для тих само зразків хітозану, отримані спектрофоотометричним методом в попередніх дослідженнях. 3 таблиці видно, що середнє значення трьох паралельних кондуктометричних дослідів для кожного зі зразків хітозану добре узгоджується з результатами спектрофотометричного аналізу та даними технічної документації виробників.

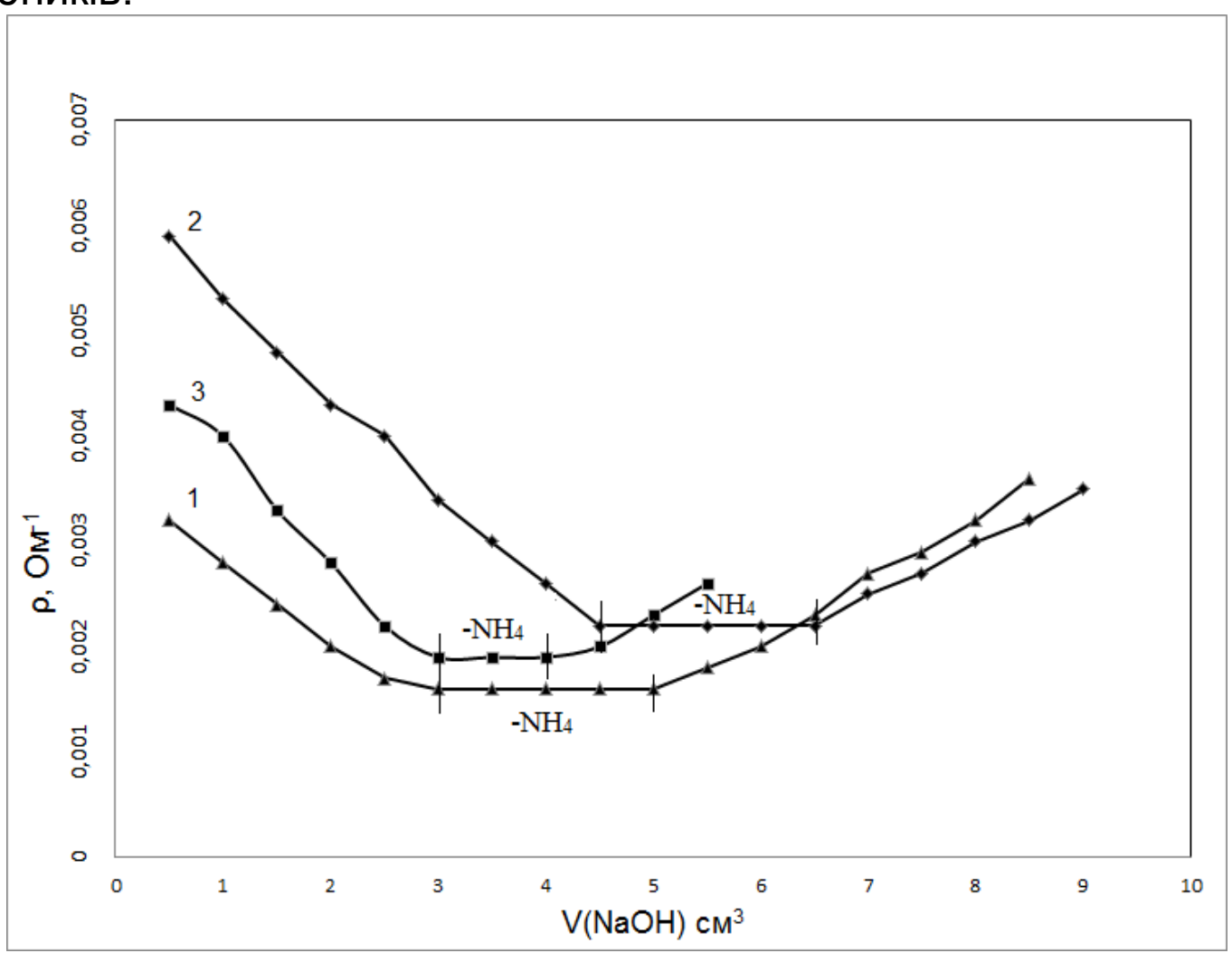

Рис.3. Графрічна залежність питомого опору розчинів хітозану від об'єму доданого титранту NaOH: 1 - хітозан ЗАО «Біопрогрес»-1; 2 хітозан ЗАО «Біопрогрес»-2; 3 - хітозан фрірми Aldrich

Встановлено, що розбіжність у результатах для різних методів знаходиться у межах 1-10,6\%. Результати ступеня деацетилювання, отримані спектрофотометричним і кондуктометричним методами $€$ доволі достовірними, добре узгоджуються 3 технічною документацією на хітозан, але, на нашу думку, кондуктометричний метод $є$ більш простий у використанні, легко відтворюваний і не потребує роботи у спеціалізованих хімічних лабораторіях. 
Таблиця. Результати визначення СД методами спектрофотометрії та кондуктометрії

\begin{tabular}{|c|c|c|c|c|c|c|c|c|c|}
\hline \multirow[b]{2}{*}{ Назва зразка } & \multirow{2}{*}{$\begin{array}{c}\text { СД за } \\
\text { ТУ } \\
\text { вироб } \\
\text { ника, } \\
\%\end{array}$} & \multicolumn{4}{|c|}{ Спектрофотометрія, \% } & \multicolumn{4}{|c|}{ Кондуктометрія, \% } \\
\hline & & 1 & 2 & 3 & cep & 1 & 2 & 3 & cep \\
\hline $\begin{array}{c}\text { Хітозан 3АО } \\
\text { «Біопрогрес»-1 }\end{array}$ & 82 & 66,7 & 73,8 & 70,1 & 70,2 & 71,5 & 70,9 & 71,8 & 71,4 \\
\hline $\begin{array}{c}\text { Хітозан ЗАО } \\
\text { «Біопрогрес»-2 }\end{array}$ & - & 57,9 & 64,2 & 60,9 & 61 & 58,4 & 59,4 & 58,6 & 58,8 \\
\hline $\begin{array}{l}\text { Хітозан фірми } \\
\text { Aldrich }\end{array}$ & 45 & 47,3 & 43,8 & 44,5 & 45,2 & 35,9 & 52,4 & 49,7 & 46 \\
\hline
\end{tabular}

\section{Висновки}

Проведено визначення СД різних зразків хітозану методом кондуктометричного титрування, отримані дані порівняно 3 результатами спектрофотометричного методу. Встановлено, що кондуктометричний метод є простим, швидким та досить точним для визначення аміногруп в хітозані, а також не потребує приготування калібрувальних графріків, на відміну від спектрофотометрії та ІЧспектроскопії. В зв'язку з цим, даний метод можна рекомендувати для дослідження хітозану та хітозанвмісних з метою визначення основної їх характеристики - ступеня деацетилювання.

\section{Перелік посилань}

[1] J. Brugnerottoa, J. Lizardib, F.M. Goycooleab, W. ArguhellesMonalc, J. Desbriebresa, M. Rinaudoa An infrared investigation in relation with chitin and chitosan characterization// Polymer 42 (2001) 3569-3580.

[2] Ю.А. Кучина, Н.В. Долгопятова, В.Ю. Новиков, В.А. Сагайдачный, Н.Н. Морозов Инструментальные методы определения степени деацетилирования хитина //Вестник ГТУ, том 15, №1, 2012. стр.107-113

[3] Солодовнік Т.В. Кондуктометричний метод визначення ступеню деацетилювання хітинвмісних сполук // Праці та повідомлення третього міжнародного симпозіуму „Методи хімічного аналізу” Севастополь - 2008. С.45.

[4] Zotkin M.A., Vihoreva GA., Smotrina T.V., Derbenev M.A. Thermal modification and study of the structure of chitosan films. Fibre Chem. 2004, 36(1), pp.16-20.

[5] Arzamastsev O.S., Artemenko S.E., Abdullin V.F., Arzamastsev S.V. (2008). Features extraction process when removing the biopolymer chitin crustaceans. Fibre Chem., - 2008, pp. 21-24. 


\title{
THE INFLUENCE OF CONDUCTIVE FILLERS ON PROPERTIES OF POLYETHYLENE-BASED COMPOSITIONS
}

\author{
KURIPTYA Y., NOVAK D., SAVCHENKO B., PLAVAN V. \\ Kyiv National University of Technologies and Design
}

It was shown that carbon particles and metallic fillers of different nature and their mixtures have great impact on the conductivity and strength properties of polyethylene compositions. Polyethylene was selected as a matrix, while carbon fibers, carbon black, nickel powder and copper fibers were used as fillers. It was established that the ratio of fillers of different nature in the polymer has a great impact on conductivity and strength characteristics of compositions. Usage of filler mixtures can improve the above characteristics. Binary fillers can increase the conductivity of polymer compositions due to a lower percolation threshold. The scope of possible applications of filled flexible conducting plastic electrodes in electrochemistry could be batteries, metal plating, etc.

\section{ВПЛИВ ВМІСТУ СТРУМОПРОВІДНИХ НАПОВНЮВАЧІВ НА ВЛАСТИВОСТІ ПОЛІЕТИЛЕНОВИХ КОМПОЗИЦІЙ}

\author{
КУРИПТЯ Я.А., НОВАК Д.С., САВЧЕНКО Б.М., ПЛАВАН В.П.
} Київський національний університет технологій та дизайну

Наведено результати дослідження впливу часток вуглецевих та металевих наповнювачів різної природи, а також їх сумішей, на струмопровідність та міцністні властивості поліетиленових композицій. В якості матриці в цих композиціях взято поліетилен, а як наповнювачі вибрано вуглецеве волокно, графітизовану сажу, нікелевий порошок та мідне волокно. Встановлено, що співвідношення в полімері вмісту наповнювачів різної природи значно впливає на струмопровідність та міцністні властивості композицій, а використання сумішей наповнювачів призводить до їх покращення. Бінарне наповнення підвищує струмопровідність полімерних композицій через зниження порогу перколяції.

Галузями застосування наповнених гнучких електропровідних полімерних електродів в електрохімії можуть бути батареї, електроосадження металів та ін. 
Сучасний розвиток техніки вимагає створення нових струмопровідних полімерних композиційних матеріалів. Зокрема, це стосується галузей промисловості, пов'язаних 3 використанням антистатичних матеріалів, напівпровідників і екрануючих матеріалів від електромагнітних випромінювань, а також струмопровідних композиційних матеріалів в низьковольтних нагрівальних елементах. Для створення таких матеріалів в полімер вводять або наносять на поверхню спеціальні добавки, які утворюють струмопровідну структуру [1]. В даній роботі визначено вплив часток вуглецевих та металевих наповнювачів різної природи, а також їх сумішей, на такі властивості поліетиленових композицій, як струмопровідність та міцність.

\section{Методологія досліджень}

Для досліджень було обрано поліетилен (ПЕ) LLDPE марки M3804RWP (SCG Chemicals) в якості матриці та такі наповнювачі: вуглецеве волокно (BB) марки ВMH-4 довжиною 1-2 мм та діаметром 5 мкм, графітизована сажа (ГС) марки PUREBLACK SCD-205 i PowCarbon 3200F, нікелевий порошок (НП) марки ПНК-УТ1 ГОСТ 9722-97, мідне волокно (МВ) марки М1 (електротехнічне) ГОСТ 8592001 з діаметром волокна 60 мкм та довжиною 1-2 мм.

Технологія отримання струмопровідних композицій включає наступні стадії: підготовка компонентів, змішування всіх компонентів композицій, отримання дослідних зразків методом спікання у формі.

Наповнювачі попередньо висушують у вакуумній шафі при температурі $80^{\circ} \mathrm{C}$ протягом 5 годин для видалення залишкової вологи. Змішування компонентів проходить в два етапи: спочатку матрицю у вигляді порошку змішують 3 наповнювачами на одностадійному лопатевому турбозмішувачі періодичної дії типу Henschel протягом 5 хвилин, після змішування отриману суміш екструдують на одношнековому екструдері ( $D=27$ мм, $L / D=30)$ зі статичним змішувачем. Спікання отриманих композицій проводилося при температурі $190^{\circ} \mathrm{C}$ протягом 2 хвилин.

Вимірювання струмопровідності композицій проводилося за ГОСТ 6433.2-71 [2], вимірювання міцності при розриві та відносного видовження - за ГОСТ 11262-80 [3].

\section{Результати та їх обговорення}

Результати визначення струмопровідності композицій на основі ПЕ наведено на рисунку 1. Із аналізу залежностей, наданих на рисунку 1a, випливає, що для композицій, наповнених ВB, струмопровідність зі збільшенням вмісту наповнювача різко зростає. При вмісті ВВ 0,0045 об. част. спостерігається значне підвищення струмопровідності композиції, тобто поява порогу перколяції [4]. Подальше збільшення вмісту наповнювача не приводить до суттєвих 
змін струмопровідності. Таке різке збільшення струмопровідності при такій малій концентрації наповнювача можна пояснити особливостями геометричної будови наповнювача. Співвідношення довжини ВВ до його діаметру I/d значно впливає на максимально можливий ступінь наповнення (пакінг-фрактор $F$ ). Як відомо пакінг-фрактор $F \in$ параметром, що дозволяє оцінити величину порогу перколяції [5]. Оскільки у волокнистих наповнювачів в порівнянні з дисперсними $F$ менший, то відповідно потрібна менша об'ємна концентрація наповнювача для утворення провідних структур у полімерній композиції.
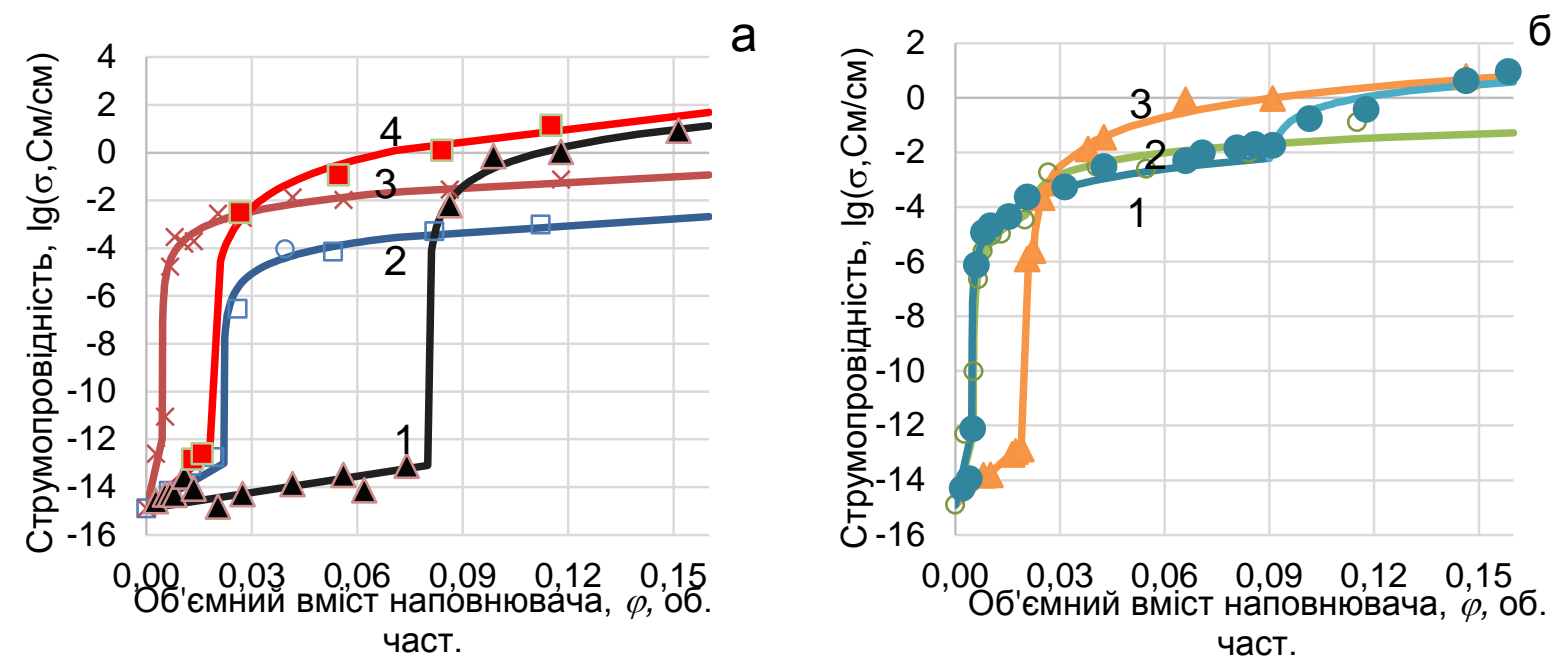

Puc. 1. Залежність струмопровідності композицій на основі ПЕ від вмісту наповнювача: а) 1 - НП, 2 - ГС, 3 - ВВ, 4 - МВ; б) 1 - НП/ВВ, 2 - ГC/BВ, 3 - ГС/MB

Для композицій, наповнених ГС, поява порогу перколяції спостерігається при вмісті ГС - 0,022 об. част. Оскільки сажа дисперсний наповнювач, то має більше значення $F$ у порівнянні $з$ волокнистим наповнювачем і для досягнення порогу перколяції потрібна більша об'ємна концентрація. У композиціях, наповнених НП та МВ, залежність струмопровідності від вмісту наповнювача характеризується появою порогу перколяції при значно вищих концентраціях наповнювача, порівняно з ВВ та ГС, що можна пояснити високою густиною НП та МВ $\mathrm{i}$ більшим значенням співвідношення I/d. Поява порогу перколяції відбувається при вмісті НП 0,008 об. част. та МВ - 0,018 об. част., але значення струмопровідності для цих композицій значно вищі за рахунок власної високої струмопровідності наповнювачів. Із рисунка 16 випливає, що для бінарнонаповнених ГС/ВВ композицій значення струмопровідності суттєво відрізняється від струмопровідності мононаповнених композицій. Для даної системи характерний подвійний поріг перколяції. Перший виникає при загальному вмісті наповнювача 0,0047 об. част., а наступний при 0,02 об. част. Дане явище можна пояснити наявністю синергічного ефректу при взаємодії компонентів між собою. Перший поріг виникає за рахунок структури утвореної ВВ, а далі, при збільшенні концентрації бінарного наповнювача, даний наповнювач відіграє роль структуроутворювача провідної сітки в композиції. 
Проте при збільшенні об'ємної концентрації бінарного наповнювача близької до концентрації порогу перколяції для сажонаповнених композицій з'являється наступний поріг, пов'язаний із значним збільшенням концентрації ГС, що утворює більш розгалужену провідну сітку разом з ВВ. Таким чином, бінарне наповнення ВВ/ГС має кращий результат, ніж мононаповнення. При наповненні $\mathrm{H} / \mathrm{BB}$ та сажа/MB перший поріг перколяції наближається до 0,0047 об. част. та 0,018 об. част., а другий до 0,09 об. част. та 0,021 об. част., відповідно і практично не відрізняється від значення для мононаповнювача. Бінарне наповнення дає можливість зменшити вміст більш струмопровідного, але економічно невигідного наповнювача - BВ, за рахунок введення більш дешевого наповнювача - ГС, несуттєво впливаючи на поріг перколяції композицій у порівнянні 3 композиціями, наповненими мононаповнювачем. Результати визначення вимірювання міцності при розриві та відносного видовження композицій на основі ПЕ наведено на рисунку 2.
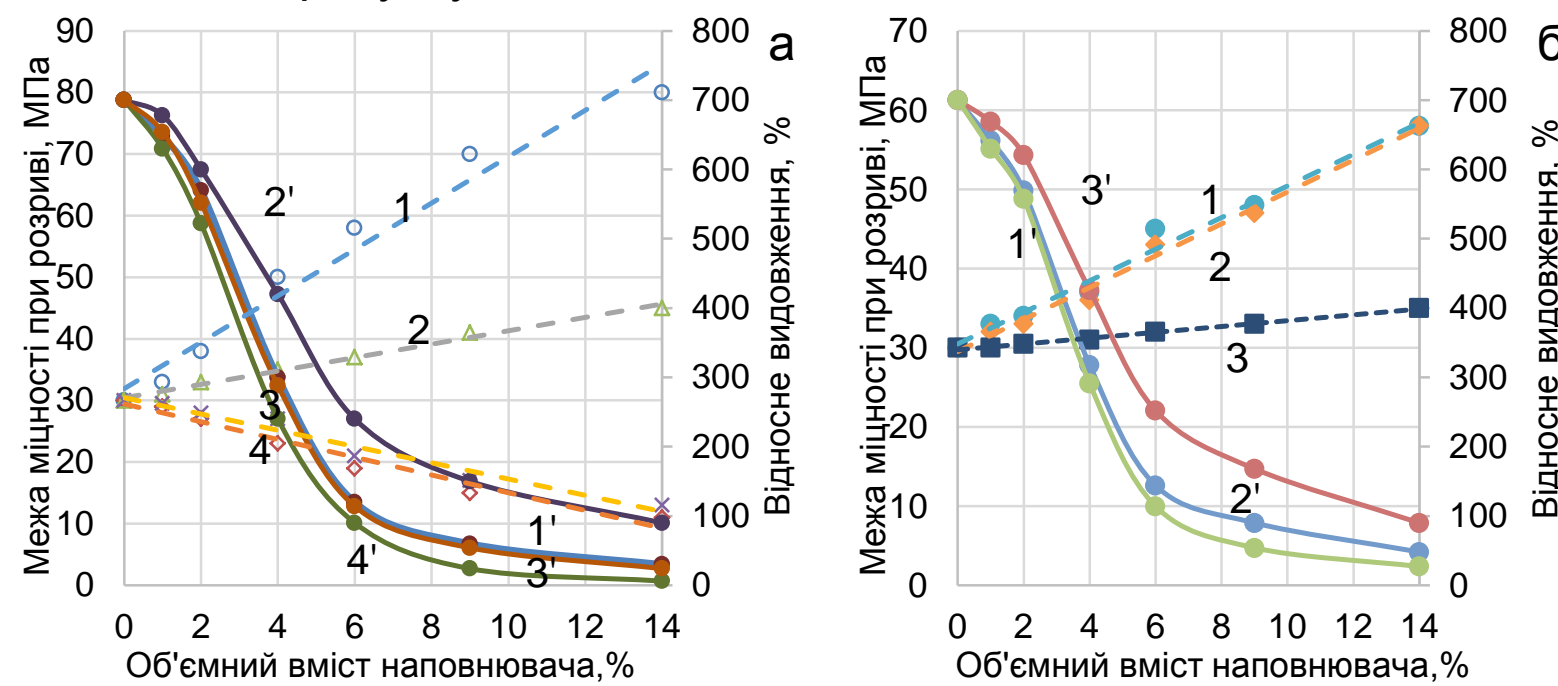

Puc. 2. Залежність міцності при розриві та (---) та відносного видовження (-) полімерних композицій на основі LLDPE від вмісту наповнювача: а) 1, 1' BB, 2, 2' - MB, 3, 3' - HП, 4, 4' - сажа; б) 1, 1' - HП/BB, 2, 2' -ГC/BB, 3, 3' - ГC/MB

Із аналізу залежностей, наданих на рисунку 2, випливає, що вуглецеві волокна в порівнянні з мідними мають вищу анізотропію та міцнісні властивості, що покращує механічні властивості композицій. Композиції, наповненні BB, мають найвищу межу міцності при розриві. Найнижчі значення даного показника мають композиції, наповнені дисперсними наповнювачами - НП, ГС. Відносне видовження монотонно зменшується при збільшенні концентрації наповнювача. МВ в порівняні з ВВ мають значно меншу межу міцності. Тому композиції, наповненні BВ/HП, мають вищу межу міцності при розриві у порівняння з композиціями, наповненими 
ГC/MВ. Відносне видовження зменшується 3 наповненням волокнистими наповнювачами, особливо ВВ, а також з введенням великою кількістю дисперсного наповнювача - ГС.

3 урахуванням вищенаведених результатів, можна встановити таку сфреру можливого застосування полімерних композицій залежно від значення їх струмопровідності. При вмісті бінарного наповнювача ГС/ВВ від 4 до $16 \%$ об. значення струмопровідності композицій змінюється в діапазоні від $10^{-2}$ до $10^{-1} \mathrm{Cm} / \mathrm{cm}$, ці композиції можна використовувати для виготовлення екрануючих матеріалів від електромагнітного випромінювання. Композиції з вмістом гібридного наповнювача НП/ВВ від 9 до $16 \%$ об. мають значення струмопровідності близьке до $10^{1} \mathrm{Cm} / \mathrm{cm}$.

Передбачається, що основними галузями застосування наповнених гнучких електропровідних полімерних електродів в електрохімії можуть бути батареї, електроосадження металів, електроліз без виділення металів.

\section{Висновки}

За результатами проведених досліджень встановлено, що бінарне наповнення дає покращення струмопровідних властивостей полімерних композицій, а саме зниження порогу перколяції, але в кожному випадку треба враховувати особливості кожного матеріалу, його природу, фрізичні властивості, структурні і розмірні характеристики. Визначено сфреру можливого застосування полімерних композицій залежно від значення їх струмопровідності та міцності.

\section{Перелік посилань}

[1] Гуль В.Е. Электропроводящие полимерные композиции / В.Е. Гуль, Л.3. Шенфиль.- М.: Химия, - 1984. - 240 с.

[2] ГОСТ 6433.2-71 Материалы электроизоляционные твердые. Методы определения электрического сопротивления при постоянном напряжении. - Взамен ГОСТ 6433-65; Введ. 01.07.72.М.: Изд-во стандартов, 1971.- 23 с.

[3] ГОСТ 11262-80. Пластмассы. Метод испытания на растяжение. - Взамен ГОСТ 11262-76; Введ. 01.12.80.- М.: Изд-во стандартов, 1980.- 14 с.

[4] Мамуня Є.П. Вплив різних фракторів на перколяційні характеристики двофразної системи провідник ізолятор / Є.П. Мамуня, М.В. Юрженко, Є.В. Лебедєв та ін. // Електроактивні полімерні матеріали. - Київ: Альфа Реклама, 2013. - С. 28.

[5] Мамуня Є.П. Електроактивні полімерні матеріали / Є.П. Мамуня, М.В. Юрженко, Є.В. Лебедєв та ін. - Київ: Альфа Реклама, 2013. -402 c. 


\title{
BIOIMPEDANCE ANALYSIS OF THE HUMAN BODY: HISTORY, CLASSIFICATION , BIOPHYSICAL FUNDAMENTALS OF THE METHOD
}

\author{
CHEREVACH Ya.F., BORYSENKO YU.V. \\ Kiev National University of Technologies \& Design, \\ boria95@ukr.net
}

This work deals with the history, benefits and biophysical basics of the bioimpedance analysis method for studying the composition of human body. It was shown that various tissues of the body have different conductivity values. This is associated with a different content of fluid and electrolytes in the tissues. The method is based on a high correlation between the values of the impedance magnitude and the total water content, fat and lean body mass. Dependence of the human body impedance values on the frequency of the current. The fields of medicine where the bioimpedance analysis is applicable were shown.

\section{БИОИМПЕДАНСНЫЙ АНАЛИЗ СОСТАВА ТЕЛА ЧЕЛОВЕКА: ИСТОРИЯ, КЛАССИФИКАЦИЯ И БИОФИЗИЧЕСКИЕ ОСНОВЫ МЕТОДА}

\author{
ЧЕРЕВАЧ Я.Ф., БОРИСЕНКО Ю.В. \\ Киевский национальный университет технологий и дизайна \\ boria95@ukr.net
}

Рассмотрены история, преимущества и биофизические основы биоимпедансного метода анализа состава тела человека. Показано, что различные ткани тела имеют разные значения электропроводности. Это связано с различным содержанием жидкости и электролитов в тканях. Метод основан на высокой корреляции между величиной импеданса и величинами общего содержания воды, безжировой и жировой массы в организме. Приведена зависимость величины импеданса тела человека от частоты зондирующего тока. Указаны области медицины, где применяется биоимпедансный метод анализа. 
Современный этап развития науки о составе тела характеризуется увеличением роли новых технологий и методов исследования in vivo. Наряду с традиционно используемыми для оценки состава тела методами антропометрии, калиперометрии и подводного взвешивания, получили развитие биофизические методы, самым распространённым из которых является биоимпедансный анализ (БИА) - оперативный, неинвазивный и надёжный метод, используемый в клинических, амбулаторных и домашних условиях [1]. БИА широко применяется в медицине качестве диагностического метода и для мониторинга, позволяющего получить оперативную информацию о состоянии пациента, что важно для правильного выбора и корректировки лечения.

\section{История}

Начало применения биоимпедансного анализа для изучения состава тела человека связывают с работами фрранцузского анестезиолога А.Томассета, выполненными в начале 1960-х годов [2]. Метод основан на измерении импеданса всего тела или отдельных сегментов тела (Z) с использованием специальных приборов - биоимпедансных анализаторов. Величина импеданса имеет две компоненты - активное $(R)$ и реактивное сопротивление $(\mathrm{Xc})$, которые связаны следующим соотношением:

$$
Z^{2}=R^{2}+X c^{2}
$$

Субстратом активного сопротивления $\mathrm{R}$ в биологическом объекте являются жидкости (как вне-, так и внутриклеточные), обладающие ионным механизмом проводимости. Субстратом реактивного сопротивления Хс (диэлектрический компонент импеданса) являются клеточные мембраны.

По величине активного сопротивления рассчитывается общее содержание воды в организме (ОВО), высокая удельная проводимость которой обусловлена наличием в ней электролитов. Электрическое сопротивление жировой ткани примерно в 20 раз выше, чем основной массы тканей, составляющих безжировую массу тела (БМТ). Так как гидратация безжировой массы составляет в норме около 73\% (Heymsfield et al., 2005, [3]), то безжировая масса может быть оценена как

$$
\mathrm{EMT}=\mathrm{OBO} / 0,73 \text {. }
$$

Hoffer и соавт. (1969, [4]) показали наличие высокой корреляции между величиной импеданса и величинами ОВО, БМТ и жировой массы тела (ЖМТ), и построили регрессионные 
зависимости, связывающие эти величины с параметрами импеданса. Houtkooper и соавт. (1996) [5] систематизировали опубликованные к тому времени 55 формул для оценки показателей состава тела биоимпедансным методом: 18 для расчета ОВО, 29 для БМТ, 8 для \%ЖМТ. В указанной работе сообщалось, что точность приведенных оценок составляет 0,9-1,8 кг для ОВО и 2,53,5\% для ЖМТ.

По величине реактивной составляющей импеданса рассчитываются величины основного обмена (OO) и активной клеточной массы (АКМ) - массы мышц и внутренних органов.

\section{Классификация}

Имеется несколько разновидностей биоимпедансного анализа, которые классифицируют по следующим признакам: по частоте зондирования (одно-, двух-, многочастотные), по участкам измерений (локальные, региональные, интегральные, полисегментные), по тактике измерений (однократные, эпизодические, мониторные). Наиболее часто используемая (90\% всех измерений в мировой практике) и полноверифицированная разновидность биоимпедансного анализа - одночастотные интегральные эпизодические измерения с расположением электродов на щиколотке и запястье с зондирующим током на частоте 50кГц [1].

\section{Биофизические основы метода}

Биоимпедансный анализ состава тела основывается на различиях электропроводности составляющих его тканей ввиду различного содержания в них жидкости и электролитов (см. таблицу).

Таблица. Типичные значения удельного электрического сопротивления биологических тканей (1980) [6]

\begin{tabular}{|l|c|}
\hline \multicolumn{1}{|c|}{ Биологическая ткань } & Удельное сопротивление, Ом × $\mathbf{~}$ \\
\hline Кровь & 1,5 \\
\hline Спинномозговая жидкость & 0,65 \\
\hline Нервно-мышечная ткань & 1,6 \\
\hline Легкие без воздуха & 2,0 \\
\hline Скелетные мышцы & 3,0 \\
\hline Печень & 4,0 \\
\hline Кожа & 5,5 \\
\hline Легкие при выдохе & 7,0 \\
\hline
\end{tabular}


Использование биоимпедансного анализа для оценки состава тела основано на устойчивом соотношении между содержанием воды в организме и безжировой массой тела (1969, [4]). Результаты биоимпедансного анализа зависят от некоторого набора допущений относительно электрических свойств тела, его состава, гидратации, и плотности, а также возраста, пола, расовой принадлежности и фризического состояния обследуемого (1988, [7]). Термин «биоэлектрический импеданс» стал общепринятым в зарубежных публикациях второй половины 20 века для характеристики электрических свойств биологических объектов, имеющих клеточную структуру. Импеданс измеряется при пропускании через биологический объект переменного тока в соответствии с законом Ома:

$$
\mathrm{Z}=\mathrm{U} / \mathrm{I} \text {, }
$$

где U - разность потенциалов, а I - сила тока.

Первая электрическая модель клетки была предложена Фрике (1924), который описал и объяснил зависимость импеданса от частоты тока (см. рисунок). В области низких частот импеданс практически совпадает с величиной активного сопротивления, а реактивное сопротивление близко к нулю. При увеличении частоты тока реактивное сопротивление возрастает до определенного максимума, соответствующего характеристической частоте $\mathrm{f}_{\mathrm{c}}$. При дальнейшем увеличении частоты реактивное сопротивление уменьшается, и в пределе импеданс будет снова равен активному сопротивлению. На рисунке видно, что при изменении частоты тока меняется угол между векторами импеданса и активного сопротивления.

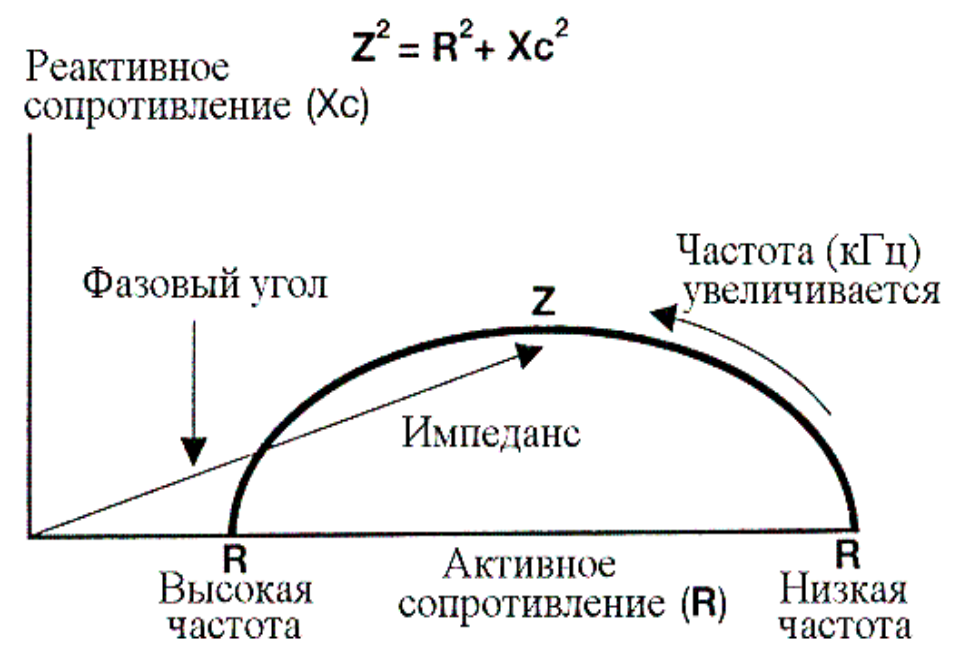

Puc. Зависимость величины импеданса от частоты зондирующего тока $(2005,[3])$ 
Он имеет название фразового угла, и определяется как арктангенс отношения реактивного и активного сопротивлений:

$$
\varphi=\operatorname{arctg}(\mathrm{Xc} / \mathrm{R}) \text {. }
$$

Для практического применения биоимпедансного метода к задачам оценки состава тела существенной является взаимосвязь геометрической формы исследуемого объекта и величины импеданса биологического объекта: величина импеданса пропорциональна длине измеряемого участка тканей и обратно пропорциональна площади его поперечного сечения.

Для однородного изотропного проводника постоянного сечения, поперечные размеры которого много меньше его длины, справедливы следующие соотношения:

$$
\mathrm{V}=\mathrm{L} \times \mathrm{S}, \quad \mathrm{R}=\rho \times \mathrm{L} / \mathrm{S},
$$

где $\rho$ - удельное электрическое сопротивление, L - длина, S площадь поперечного сечения, a V - объем проводника.

Если выразить S из второго соотношения и подставить в первое, то:

$$
V=\rho L^{2} / R \text {. }
$$

В биоимпедансных анализаторах используется зондирующий ток очень низкой, безопасной амплитуды, что обеспечивает возможность не ограничивать количество и длительность измерений.

Реактивное сопротивление и фазовый угол также характеризуют свойства биологических тканей (1988, [7]). Исследования показали взаимосвязь Хс и фазового угла с параметрами фризиологического состояния и режима питания пациентов. Удельное сопротивление в выражении $\rho L^{2} / R$ принято постоянным для тела в целом; однако, каждая ткань имеет свое удельное сопротивление, и наблюдаемое удельное сопротивление это среднее удельное сопротивление всех проводящих тканей.

Опубликованы результаты верификации методов биоимпедансного анализа оценки жировой и безжировой массы тела с результатами подводного взвешивания, для костной массы рентгеновской денситометрии, для общей, вне- и внутриклеточной жидкости организма - методами разведения индикаторов, а для определения основного обмена - с методом Фика, в том числе для различных возрастных и нозологических групп [1].

Один из вариантов методики одночастотного БИА заключается в следующем: биоадгезивные электроды устанавливаются: на руке середина первого электрода крепится над сочленением костей предплечья и кисти, а другой располагается на 3-4 см дистальнее; 
на ноге - один серединой над сочленением костей голени и стопы, другой дистальнее на 3-5 см. Зажимы электродного кабеля крепятся к свободным от проводящего геля концам электродов, красные - к дистальным, черные - к проксимальным электродам. Дистальные электроды служат для подключения к пациенту цепи пропускания зондирующего тока, проксимальные - для подключения измерительной цепи анализатора. Измерение выполняется в течение 20-40 с и считается завершенным, если в последние 4-5 с значения величин активного и реактивного сопротивлений менялись не более чем на 2 единицы последней значащей цифры [1].

Выходные протоколы методики содержат оценки следующих параметров: основного обмена (ОО), индекса массы тела (ИМТ), жировой массы тела (ЖМТ), безжировой массы тела (БМТ), активной клеточной массы (массы мышц и внутренних органов) (АКМ), процентного содержания активной клеточной массы в безжировой массе (\%АКМ), объема воды в организме (ОВО), индекса талия-бедра (ИТБ), а также процентного содержания жира в организме (\%ЖМТ).

\section{Применение}

Биоимпедансометрия, как быстрый, неинвазивный и безопасный диагностический метод, имеет широкие клинические приложения. Он применяется для оценки ожирения и избыточной массы тела, в медицине критических состояний, для планирования трансфузионной терапии для больных с большими кровопотерями, для оценки гидратации организма у хирургических больных и при отеке мозга, в диагностике и лечении сердечно-сосудистых и желудочно-кишечных заболеваний, при отравлениях с нарушением водного баланса организма, для оценки состояния органов для трансплантации, в урологии, стоматологии, в спортивной медицине.

\section{Выводы}

К середине 90-х годов 20 века методы и аппаратура биоимпедансного анализа состава тела по частоте применения в клинической практике превзошли все известные технологии оценки состава тела. Анализ состава тела стал производиться не по антропометрическим индексам, а на основе аппаратных методов, использующих биофизические свойства различных тканей организма. Биоимпедансный анализ состава тела является быстрым, неинвазивным, безопасным и имеет широкие клинические приложения. 


\section{Литература}

[1] Николаев Д.В. Биоимпедансный анализ состава тела человека / Д.В. Николаев, А.В. Смирнов, И.Г. Бобринская, С.Г. Руднев. - М.: Наука, 2009 - 392 с.

[2] Thomasset A. Bio-electrical properties of tissue impedance measurements // Lyon Med. 1962. V. 207. P. 107-118.

[3] Heymsfield S.B., Lohman T.G., Wang Z., Going S.B. (eds.) Human body composition (2nd ed.). Champaign, IL: Human Kinetics, 2005. 533 p.

[4] Hoffer E.C., Meador C.K., Simpson D.C. Correlation of whole-body impedance with total body water volume // J. Appl. Physiol. 1969. V. 26. P. 531-534.

[5] Houtkooper L.B. Assessment of body composition in youths and relationship to sport // Int. J. Sport Nutr. 1996. V. 6, № 2. P. 146-164.

[6] Шван Х.П., Фостер К.Р. Воздействие высокочастотных полей на биологические системы: Электрические свойства и биофизи-ческие механизмы // ТИИЭР. 1980. Т. 68, № 1. С. 121-132.

[7] Baumgartner R.N., Chumlea W.C., Roche A.F. Bioelectric impedance phase angle and body composition // Am. J. Clin. Nutr. 1988. V. 48, № 1. P.16-23. 


\title{
BIOELECTRIC POTENTIALS: MECHANISMS OF EMERGENCE AND FUNCTIONING; BIOLOGICAL ROLE
}

\author{
PATLUN D.V., KISLOVA O.V. \\ Kyiv National University of Technologies and Design \\ m-sharingan1@mail.ru
}

The emergence of bioelectric potentials is the basis of the normal life of any cell and is particularly important for the excitation and inhibition processes in living organisms. Biopotentials are caused by the motion of ions (sodium, potassium, calcium, chlorine) through special hardorganized ion channels in the membrane, and the diffusion of ions in the intercellular and intracellular environments. At the excitation time the cell membrane becomes permeable to sodium ions, rapidly entering the cell, and the cell membrane recharges. Disorders of cell membranes conductivity can lead to serious organism pathologies (including death). Studies of bioelectric potentials are widely used in electrophysiology for testing potential drugs and also in medicine for diagnostic purposes.

\section{БІОЕЛЕКТРИЧНІ ПОТЕНЦІАЛИ: МЕХАНІЗМ ВИНИКНЕННЯ ТА ФУНКЦІОНУВАННЯ; БІОЛОГІЧНА РОЛЬ}

\author{
ПАТЛУН Д.В., КИСЛОВА О.В. \\ Київський національний університет технологій та дизайну \\ m-sharingan1@mail.ru
}

Виникнення біопотенціалів лежить в основі нормальної життєдіяльності будь-якої клітини та $є$ особливо важливим для процесів збудження і гальмування у живих організмах. Біопотенціали і біоструми обумовлені рухом не електронів, а іонів (переважно натрію, калію, кальцію, хлору) через спеціальні складно організовані іонні канали в мембрані, а також дифузією іонів в міжклітинному та внутрішньоклітинному середовищах. Механізм перезарядження полягає в тому, що в момент збудження мембрана клітини стає на короткий час проникною для іонів натрію, які швидко входять в клітину та перезаряджають мембрану. Порушення провідності клітинних мембран може призводити до серйозних патологій організму. Дослідження біоелектричних потенціалів широко застосовують в електрофрізіології для тестування потенційних ліків, а також в медицині з діагностичними цілями. 
Живі організми, включаючи організм людини, $€$ виключно складними системами, діяльність яких забезпечується різноманітними процесами - фрізичними, хімічними, біологічними, які регулюють внутрішні умови фрункціонування організмів, їх відтворення, розумову діяльність людини і багато іншого. В основі реалізації цих процесів лежать електричні явища на молекулярному та клітинному рівні [1,2].

\section{Відкриття клітинних потенціалів}

Уявлення про ісування зв'язку між електрикою та живою природою з'явились набагато раніше винайдення першого джерела струму. I відбулося це, зокрема, завдяки рибам, що виробляють електричний струм. Ще в трактаті античного фрілософра Платона знаходяться перші згадки про вироблення скатами електричного розряду. Але справжній розвиток електричного вчення відбувся дуже пізно - в кінці XVIII ст., коли фрранцузький вчений Луїджі Гальвані випадково винайшов першу гальванічну систему, яку помилково прийняв за м'язову електричну роботу. Через деякий час його співвітчизник Алессандро Вольта прийшов до думки, що в основі «живої електрики» лежать хімічні процеси, і створив прообраз звичних для нас батарейок $[1,3]$.

Роботи англійського зоолога Джона Юнга та його послідовників - профресора Ендрю Хакслі і його учня Алана Ходжкіна довели, що електричний заряд сконцентрований на неушкодженій клітині в стані спокою. Для цього вони помістили один електрод всередину нервового волокна головоногого молюска, а інший залишили на його поверхні. Вже через 0,0003 секунди було зареєстровано електричний імпульс з живої клітини. Згодом виявилося, що всі клітини заряджені і заряд мембрани є невід'ємним атрибутом іiї життя. Поки клітина жива, у неї є заряд [1].

\section{Сучасна теорія біоелектричних потенціалів}

Як відомо, наш організм складається на $70 \%$ з води, а точніше, з розчину солей і білків. Всередині клітини міститься приблизно в 50 разів більше іонів $\mathrm{K}^{+}$, ніж за її межами. В міжклітинному просторі переважають іони $\mathrm{Na}^{+}$(тут їх приблизно в 20 разів більше, ніж в клітині). Такий нерівномірний розподіл підтримується клітинною мембраною. Вона складається з двох фосфоліпідних шарів, товщу яких пронизують білки, що виконують різноманітні функції та, зокрема, є високоспецифічними каналами для кожного типу іонів. 
Коли клітина знаходиться в стані спокою, іони $\mathrm{K}^{+}$здатні безперешкодно виходити за межі клітини через свої канали. Іони $\mathrm{Na}^{+}$не мають такої можливості, оскільки всі мембранні канали $є$ закритими [4].

У живих організмах іони $\mathrm{K}^{+}$або $\mathrm{Na}^{+}$завжди знаходяться 3 аніонами кислот $-\mathrm{SO}_{4}{ }^{2-}, \mathrm{Cl}^{-}, \mathrm{PO}_{4}{ }^{3-} \mathrm{i}$ т. д. В звичайних умовах мембрана $€$ непроникною для негативно заряджених частинок. Це означає, що коли іони $\mathrm{K}^{+}$рухаються через свої канали, пов'язані 3 ними аніони скупчуються на внутрішній поверхні мембрани. Оскільки в міжклітинному просторі переважають іони $\mathrm{Na}^{+}$та до них постійно просочуються іони $\mathrm{K}^{+}$, на зовнішній поверхні мембрани концентрується надлишковий позитивний заряд, а на їі внутрішній поверхні - негативний. Клітинна мембрана поляризується за рахунок різниці зарядів по обидві її сторони. Заряд в стані спокою клітини називають мембранним потенціалом спокою, який дорівнює приблизно -70 мВ [2].

Після з'ясування механізму виникнення клітинного потенціалу постало питання використання цієї електрики при функціонуванні організму. Коли клітина реагує на зовнішні або внутрішні подразнення, блискавично відкриваються мембранні канали і позитивні іони спрямовуються всередину клітини. А аніони, що перебували всередині клітини, - за її межі. Таким чином, в збудженій клітині іони дифундують, врівноважуючи свою концентрацію по обидві сторони мембрани. Тепер вже всередині клітини, а саме на внутрішній поверхні мембрани, концентрується надлишковий позитивний заряд, а на її зовнішній поверхні буде сконцентрований негативний заряд. В момент порушення клітини спостерігається реверсія заряду, тобто зміна його знаку на протилежний. Частину свого заряду клітина втрачає і під час роботи.

Отже, заряд існує тільки тоді, коли $\epsilon$ різниця між концентраціями іонів $\mathrm{Na}^{+} / \mathrm{K}^{+}$. При збудженні клітини чисельність іонів $\mathrm{Na}^{+}$по обидві сторони мембрани однакова, до цього ж стану прагне і $\mathrm{K}^{+}[4]$.

Згодом постало питання, як клітина відновлює свій стан. 3'ясували, що існує спеціальний білок, вбудований в мембрану. Він використовував для здійснення роботи певну кількість енергії, яка накопичувалась у вигляді молекул АТФ (аденозинтрифоосфатної кислоти). Ці молекули спеціально синтезуються в «енергетичних станціях» клітини - мітохондріях, дбайливо там зберігаються і при необхідності за допомогою спеціальних переносників доставляються до місця призначення. Енергія з цих молекул вивільняється при їх розпаді і витрачається на різні потреби клітини. 
Зокрема, в нашому випадку, ця енергія потрібна для роботи білка - $\mathrm{Na}^{+} / \mathrm{K}^{+}$- АТФази, основна функція якого полягає в тому, щоб переміщувати іони $\mathrm{Na}^{+}$назовні 3 клітини, а $\mathrm{K}^{+}$- в зворотному напрямку. Отже, коли клітина працює, то на рівні клітинної мембрани цей процес протікає пасивно, а для того, щоб відпочити, їй потрібна енергія [4].

Подібним чином відбувається і передача нервових імпульсів у організмі. Збудження, яке виникає у місці подразнення, поширюється далі по ланцюжку, але тепер подразником для сусідніх ділянок буде не зовнішня дія, а внутрішні процеси, викликані потоками іонів $\mathrm{Na}^{+}$i $\mathrm{K}^{+} \mathrm{i}$ зміною заряду мембрани. Біоструми по мембрані нервового волокна поширюються круговими хвилями, викликаючи збудження все більш віддалених ділянок [2]. Передача нервових імпульсів здійснюється однонапрямленно через велику витрату енергії на відновлення заряду.

\section{Біологічна роль клітинних потенціалів}

Загалом величина електричних зарядів в організмі, як і їх походження, нерозривно пов'язана 3 обміном речовин, 3 інтенсивністю окисно-відновних процесів. Окремі ділянки органів i тканин можуть набувати різних зарядів. Пошкоджені ділянки бувають заряджені негативно щодо неушкоджених. Такий заряд має сухожилля по відношенню до м'язів, корінь - по відношенню до стебла і листя.

Біоелектричні струми виявлені в усіх органах і тканинах людини. Вони виникають в серці при скороченні і розслабленні м'язів. Скорочене серце має негативний потенціал, розслаблене позитивний. В одному з останніх досліджень були виявлені п'єзоелектричні властивості кісткової тканини, тобто генерації в ній електрики при механічному впливі (наприклад, при навантаженні під час ходіння). Відомо, коли кісткова тканина не відчуває регулярного навантаження, то її механічні властивості втрачаються [2].

Такі електричні імпульси майже не помітні у навколишньому середовищі. Але існує значна кількість організмів, які здатні генерувати струми з великою силою. Нині відомо близько 300 видів риб, що здатні виробляти сильні електричні розряди. Так, американські електричні вугрі генерують розряди напругою до 600 В, африканські електричні соми - близько 350 В. Напруга великих морських скатів порівняно невисока, проте оскільки морська вода $€$ гарним провідником, то сила струму в такому середовищі може сягати іноді 60 А. Причиною виникнення такого сильного розряду $\epsilon$ наявність у згадуваних організмів специфічних електричних органів. Це парні видозмінені м'язи. У різних видів риб вони сильно 
відрізняються розташуванням, формою і внутрішньою будовою. Maca їх може досягати від 1/6 до 1/4 всієї маси тіла. Кожен електричний орган складається з численних зібраних в стовпчики електричних пластинок - видозмінених м'язових або нервових клітин - електроцитів. Кожна така клітина з однієї сторони з'єднана 3 нервовим каналом, а 3 іншої - 3 іонним каналом. Завдяки цьому клітина виявляється зарядженою лише однією частиною. Пластинки електроцитів впорядковані за своїми полюсами: синапси з одного боку, а поверхні з численними іонними каналами - 3 іншого. Виходить батарея з'єднаних клітин з упорядкованою полюсністю, тому їх струми додаються. В результаті при проходженні нервового сигналу електричний орган видає розряд певної величини, яка визначається видоспецифічними властивостями і безпосередніми життєвими завданнями власника батареї [2].

Цікавим фрактом також $€$ те, що електричні розряди, які виробляють вже згадані нами тварини, зовсім не діють на них самих. Однозначної відповіді на це питання поки не знайдено, але $є$ кілька гіпотез. По-перше, життєво важливі органи таких тварин зазвичай зміщені в одну частину тіла, де ізолюються додатковими шарами жирової тканини, що погано проводить струм. По-друге, весь створений струм повністю витрачається на знищення жертви [3].

Але на виробленні електричних розрядів унікальні властивості водних жителів не закінчуються. Риби не гірше, а часом і краще найчутливіших приладів реєструють електричне поле і помічають найменшу зміну його напруженості. За допомогою електричних сигналів риби можуть навіть особливим чином "перемовлятися". Риби - суперники визначають силу свого супротивника за величиною випромінюваних ними сигналів. Скати можуть виявляти крабів за їх електричними полями, а соми здатні відчувати навіть електрополя, створювані черв'яками [3].

\section{Висновки}

Вивчення електричних імпульсів у тілах живих істот $\epsilon$ важливим завданням. За відкриття у цій сфрері було присуджено сім Нобелівських премій. Наука, що вивчає ці електричні явища, дістала назву електрофрізіології. На ії працях побудовані значні підрозділи різноманітних галузей науки і техніки.

Електрофрізіологічні дослідження широко використовуються в медицині. Новітні методи, які фріксують потенціали тканин, дозволяють діагностувати або попередити різноманітні патології. Відомо також, що загальний наркоз, втрату свідомості і больової чутливості можна викликати, пропускаючи через мозок людини 
імпульси змінного струму. Цей спосіб знеболення під час операцій широко використовується за кордоном.

Сьогодні значна частка фрармакологічних досліджень побудована на фундаментальних відкриттях електрофрізіології, які застосовуються для скринінгу нейролептичних та знеболюючих препаратів, що блокують певні мембранні функції. Значні перспективи «жива електрика» має в енергетичній галузі, тому що добування дешевої, екологічно чистої енергії - це, мабуть, одна 3 основних цілей людства на найближчі роки.

\section{Перелік посилань}

[1] Дмитрієва Н. В. Системна електрофрізіологія / Н.В. Дмитрієва. М.: Сайнс-Пресс, 2008. - 256 с.

[2] Костюк П.Г. Біофрізика / П.Г. Костюк, В.Л. Зима, І. С. Магура, М.С. Мірошниченко, М.Ф. Шуба. - К.: ВПЦ КНУ, 2008. — 567 с

[3] Allaby M. A. Dictionary of Zoology (Oxford Quick Reference). 4th Edition/ M. A. Allaby. - Oxford, 2014. - 704 p.

[4] Jensen M.O. Principles of conduction and hydrophobic gating in $\mathrm{K}^{+}$ channels / M.O. Jensen, D.W. Borhani, D.E. Shaw. - Proc. Natl. Acad. Sci. USA. 2010. - 126 p. 
Scientific issue

Barsukov Viacheslav Z.

Borysenko Yulia V.

Buket Olexander I.

Khomenko Volodymyr G.

\title{
PROMISING MATERIALS AND PROCESSES IN TECHNICAL ELECTROCHEMISTRY
}

Monograph

\author{
Editor N.P. Mazur \\ Responsible person for issue printing T.A. Nazarevich \\ Proofreader N.P. Bilanyuk \\ Computer design N.P. Mazur
}


Наукове видання

Барсуков В'ячеслав Зіновійович Борисенко Юлія Володимирівна

Букет Олександр Іванович

Хоменко Володимир Григорович

\section{ПЕРСПЕКТИВНІ МАТЕРІАЛИ ТА ПРОЦЕСИ В ТЕХНІЧНІЙ ЕЛЕКТРОХIMIÏ}

Монографрія

Редактор Н. П. Мазур

Відповідальний за поліграфрічне видання Т. А. Назаревич

Коректор Н. П. Біланюк

Комп'ютерний дизайн Н. П. Мазур 